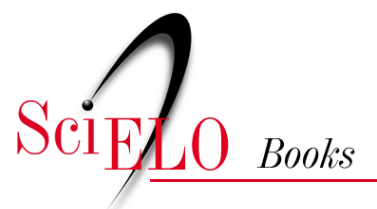

\title{
Fazer-se no "Estado" \\ uma etnografia sobre o processo de constituição dos "LGBT" como sujeitos de direitos no Brasil contemporâneo
}

\author{
Silvia Aguião
}

\section{SciELO Books / SciELO Livros / SciELO Libros}

SILVA, A. Fazer-se no "Estado": uma etnografia sobre o processo de constituição dos "LGBT" como sujeitos de direitos no Brasil contemporâneo [online]. Rio de Janeiro: EdUERJ, 2018, 391 p. Sexualidade, gênero e sociedade. Sexualidades e cultura collection. ISBN 978-85-7511-489-6. https://doi.org/10.7476/9788575115152.

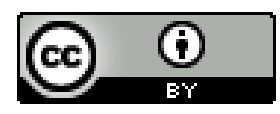

All the contents of this work, except where otherwise noted, is licensed under a Creative Commons Attribution 4.0 International license.

Todo o conteúdo deste trabalho, exceto quando houver ressalva, é publicado sob a licença Creative Commons Atribição 4.0.

Todo el contenido de esta obra, excepto donde se indique lo contrario, está bajo licencia de la licencia $\underline{\text { Creative Commons }}$ Reconocimento 4.0. 


\section{FAZER-SE NO “ESTADO”}

Silvia Aguião
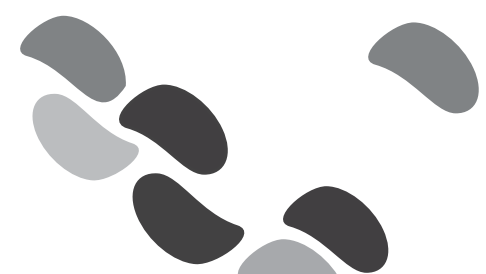

Uma etnografia sobre o processo de constituição dos "LGBT" como sujeitos de direitos no Brasil contemporâneo 
Reitor

Ruy Garcia Marques

Vice-reitor

Maria Georgina Muniz Washington

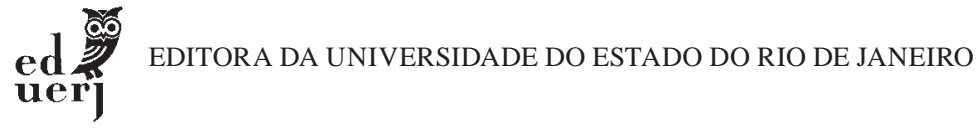

CONSELHO EDITORIAL

Glaucio José Marafon (presidente) Luciano Rodrigues Ornelas de Lima

Henriqueta do Coutto Prado Valladares Maria Cristina Cardoso Ribas

Hilda Maria Montes Ribeiro de Souza Tania Maria Tavares Bessone da Cruz Ferreira

Italo Moriconi Junior Anibal Francisco Alves Bragança (EDUFF)

José Ricardo Ferreira Cunha Katia Regina Cervantes Dias (UFRJ)

Lucia Maria Bastos Pereira das Neves

COLEÇÃo sexualidade, gênero e sociedade

Dirigida por Maria Luiza Heilborn e Sérgio Carrara

Coordenação Editorial

Jane Russo

Anna Paula Uziel

Bruno Zilli

CONSELHO EDITORIAL Parry Scott

Albertina Costa

Peter Fry

Daniela Knauth

Regina Barbosa

Leila Linhares Barsted

Richard Parker

Maria Filomena Gregori

Roger Raupp Rios

Mariza Correa 
Fazer-se no “Estado": uma etnografia sobre o processo de constituição dos "LGBT" como sujeitos de direitos no Brasil contemporâneo

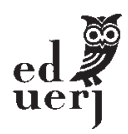

Rio de Janeiro 2018 
Copyright (C) 2018, Silvia Aguião.

Todos os direitos desta ediçấo reservados à Editora da Universidade do Estado do Rio de Janeiro. É proibida a duplicação ou reprodução deste volume, ou de parte do mesmo, em quaisquer meios, sem autorização expressa da editora.

\section{EdUERJ}

Editora da UNIVERSIDADE DO ESTADO DO RIO DE JANEIRO

Rua Sáo Francisco Xavier, 524 - Maracanã

CEP 20550-013 - Rio de Janeiro - RJ - Brasil

Tel./Fax: 55 (21) 2334-0720 / 2334-0721

www.eduerj.uerj.br

eduerj@uerj.br

Editor Executivo

Coordenadora Administrativa

Coordenadora Editorial

Assistente Editorial

Coordenador de Produção

Assistente de Produção

Supervisor de Revisão

Revisão

Capa

Diagramaçăo
Glaucio Marafon

Elisete Cantuária

Silvia Nóbrega

Thiago Braz

Mauro Siqueira

Érika Neuschwang

Elmar Aquino

Elmar Aquino

Iuri Pavan

Júlio Nogueira

Editora Morandi de constituição dos "LGBT" como sujeitos de direitos no Brasil contemporâneo / Silvia Aguião. - Rio de Janeiro : EdUERJ, 2018. 396 p. - (Sexualidade, gênero e sociedade. Sexualidades e cultura)

ISBN 978-85-7511-489-6

1. Homossexualidade. 2. Direitos sexuais. 3. Direitos humanos. I. Título. II. Série. 


\section{AGRADECIMENTOS}

Este livro é oriundo da tese defendida em fevereiro de 2014 no Programa de Doutorado em Ciências Sociais da Universidade Estadual de Campinas (Unicamp). Os anos que separam a defesa da tese e a sua transformação em livro tornam ainda mais difícil a já praticamente inexequível tarefa de agradecer a contento a todas as pessoas fundamentais para que o trabalho fosse realizado. Mas, como sempre vale tentar, começo pela família. A minha avó, minha mãe, meu pai, minha irmã, minhas tias e tios, agradeço por atenderem a todos os meus chamados e também por compreenderem os momentos em que eu deixei de chamar.

A minha orientadora, Maria Filomena "Bibia" Gregori, agradeço por toda a gentileza com que me recebeu na Unicamp, pela generosidade com que partilha ideias e pela paciência e compreensão com os meus caminhos tortos. Preciso também agradecer pela delícia do tempo compartilhado no seu grupo de estudos, "Prazer e Perigo", espaço fundamental para, junto aos colegas de orientação, amadurecer ideias, dividir impasses de pesquisa, dar risadas e aprender. Por isso, um agradecimento especial para Ana Laura Lobato, Camilo Braz, Carol Parreiras, Fabiana de Andrade, Giovana Lopes Feijāo e Larissa Nadai. Ainda na Unicamp, é preciso agradecer pelos ricos espaços de debate ocasionados tanto por 
disciplinas cursadas quanto pelos mais incríveis Seminários de Área, nos quais pude testar elaborações preliminares e receber invariavelmente valiosas contribuiçōes para a pesquisa. Agradeço a todas e todos com quem tive a oportunidade de trocar ideias e, sobretudo, ouvir. Agradeço especialmente às professoras e pesquisadoras do PAGU: Maria Filomena Gregori, Mariza Correa (in memoriam), Guita Grin Debert, Angela Araújo, Adriana Piscitelli, Karla Bessa, Heloisa Pontes, Maria Conceição da Costa, Regina Facchini e Iara Beleli.

A Adriana Vianna, Antônio Carlos de Souza Lima e Laura Moutinho, pelos diálogos que possibilitaram o alinhavo das primeiras ideias do projeto que deu origem à tese que agora se torna livro. Especialmente a Antônio e Adriana, é necessário agradecer imensamente também por terem me recebido como aluna-ouvinte em suas disciplinas, em diferentes momentos. No mesmo sentido, agradeço a Sérgio Carrara por ter permitido que, em várias oportunidades, eu participasse dos seminários de orientação junto com os seus alunos.

São muitos os colegas, amigas e amigos cujas trocas estabelecidas ao longo do período de formação e pesquisa do doutorado desembocaram neste trabalho, dos mais antigos aos mais recentes: Isadora Lins França, Glaucia Destro, Carolina Branco, Natália Padovani, Cadu Henning, Thiago Duque, Marcelo Perilo, Guilherme Passamani, Roberto Efrem Filho, Andrea Lacombe, María Elvira Díaz Benítez, Laura Lowenkron, Bruno Cesar Barbosa, Cabelo Jorge Leite Jr. Fundamentais na vida em São Paulo foram (são) Laura Moutinho, Marcia Lima, Emília Feitosa, Igor Torres, Thiago Pinheiro.

Ao longo do doutorado participei de variados GTs em ABAs, RAMs, SBSs, LASAs etc. Todos foram muito importantes para testar ideias, receber contribuiçōes e conhecer novas referências. Agradeço, em particular, a alguns dos coordenadores desses grupos: Maria Gabriela Lugones, Adriana Vianna, Laura Moutinho, Fabiano Gontijo, Regina Facchini, Miguel Vale de Almeida, Mario Pecheny, Horacio Sívori, Luiz Mello, Cristian Paiva, Berenice Bento.

Aos companheiros de Laboratório Integrado em Diversidade Sexual e de Gênero, Políticas e Direitos (Lidis-UERJ), agradeço pela alegria de trabalhar só com quem a gente gosta: Aureliano Lopes, Anna Uziel, 
Adriana Balthazar, Guilherme Almeida, Vanessa Leite e Sérgio Carrara. Ao Centro Latino-Americano em Sexualidade e Direitos Humanos (CLAM/UERJ), é necessário agradecer não apenas pelos aprendizados dos mais diversos ao longo da minha formação (desde a graduação), mas também pela construção de relaçôes de amizade das mais arrebatadoras e imprescindíveis para a vida. No fim das contas, à UERJ devo muito. O começo de tudo e encontros para sempre. É em grande parte de lá que, de um jeito ou de outro, ou puxados uns pelos outros, vêm as amigas e os amigos que tornam o meu mundo habitável de diferentes formas: Juliana Farias, Raíza Siqueira, Lia Rocha, Vanessa Leite, Bruno Zilli, Camilinha Sampaio, Igor Torres, Negra Lugones, Federico Lavezzo, Antoniene, Laurita Navallo, Laura Moutinho, Horacio Sívori, Hernán Ulm, Paula Lacerda, Letícia Carvalho, Paulo Victor Leite Lopes, Fabiene Gama, Carla Gomes, Anelise Guterres, Adriana Vianna, Ana Cunha, Tadeu Capistrano, Guilherme Silva, Aline Paiva, Andrea Resende. E, às amigas da vida toda, grata por continuarem aqui há trinta ou vinte $\mathrm{e}$ poucos anos: Maitê Carmo, Roberta Pisco, Elaine Dali, Juana Alvim.

Às amigas leitoras, agradeço pela revisão das diversas versōes "quase lá" do texto e a Malu Resende pela preciosa revisão final.

Se a tese - e, com sorte, a sua publicação - representa o fim de um longo ciclo de formação, é fundamental mencionar as orientadoras que, desde a graduação, fizeram com que eu persistisse e me divertisse durante todo esse processo. Por isso, um agradecimento mais do que especial para Clarice Peixoto, Laura Moutinho e Maria Filomena Gregori. Aos professores Sérgio Carrara e Guita Grin Debert, agradeço pela leitura atenciosa e pelas sugestôes recebidas por ocasião da qualificação de doutorado. E, também, aos professores e às professoras que aceitaram compor a banca de defesa como titulares e suplentes: Antônio Carlos de Souza Lima, Sérgio Carrara, Julio Simões, Guita Grin Debert, Adriana Vianna, Adriana Piscitelli e Regina Facchini.

Agradeço ao Grupo Arco-Íris, do Rio de Janeiro, espaço no qual comecei a pensar algumas das questôes que deram origem a este trabalho. Agradeço à equipe da SuperDir/SEASDH-RJ e muito especialmente à equipe dos Centros de Cidadania LGBT do Rio de Janeiro pela oportunidade de troca e aprendizado. 
Agradeço, por fim, ao CNPq e à FAPESP pela concessão das bolsas que permitiram a realização desta pesquisa e especialmente à Maria Filomena Gregori o apoio para a sua publicação através do Processo FAPESP 2016/05820-4.

Quando eu ainda estava escrevendo a dissertação de mestrado, disseram-me que tese é um trabalho que não se conclui sem duas coisas: amigos e dívidas contraídas. Se a tese que agora se transforma em livro se tornou possível, é porque eu tenho a sorte de ter belíssimas amizades e dívidas imensas e eternas. 
SUMÁRIO

APRESENTAÇÃO:

FAZER(-SE) (NA) PESQUISA, FAZER(-SE) (NA) POLÍTICA

LISTA DE CENAS

INTRODUÇÃO

-19-

PARTE I - A DELEGAÇÃO E A CRENÇA NO ESTADO:

TECENDO UMA NARRATIVA POSSÍVEL SOBRE A CONSTITUIÇÃO DE "SUJEITOS LGBT"NO BRASIL

CAPÍTULO 1 - AS CONFERÊNCIAS E A PRODUÇÃO

DE UM CAMPO DE "DIREITOS LGBT"

CAPÍTULO 2 - PERCORRENDO DOCUMENTOS:

UMA LEITURA ATRAVÉS DOS "PAPÉIS"

PARTE II - SUJEITOS EM PROCESSO E ARGUMENTOS

EM CIRCULAÇÃO

CAPÍTULO 3 - ESTRATÉGIAS DE VISIBILIDADE E

TENTATIVAS DE REGULAÇÃO

CAPÍTULO 4 - OS DESAFIOS DOS ENQUADRAMENTOS

ADMINISTRATIVOS E DAS CLASSIFICAÇÕES IDENTITÁRIAS 
PARTE III - DA PROPOSIÇÃO À EXECUÇÃO OU

DOS APRENDIZADOS DA GESTÃO

CAPÍTULO 5 - SOBRE UMA POLÍTICA

(QUE SE QUER) MODELO

CONSIDERAÇÕES FINAIS OU NOTAS SOBRE

UMA SITUAÇÃO ELOQUENTE

REFERÊNCIAS

309

ANEXO A - LINHA DO TEMPO “EM

CONSTRUÇÃO" (1993-2013)

ANEXO B - PRINCIPAIS EVENTOS OBSERVADOS

ENTRE 2008 E 2011

ANEXO C - ALGUNS DOCUMENTOS (DECRETOS,

PORTARIAS E MATERIAL VEICULADO PELA MÍDIA) 


\section{APRESENTAÇÃO}

FAZER(-SE) (NA) PESQUISA, FAZER(-SE) (NA) POLÍTICA

Como se constituiu uma população LGBT no Brasil e como essa, de marginalizada e desviante, viria a se tornar sujeito de direitos e objeto de políticas públicas? Partindo dessa questão, Silvia Aguião nos conduz aos cenários movediços em que se realizaram duas "conferências nacionais LGBT": a primeira, em 2008, e a segunda, em 2011. Nelas, entreteceram-se e decantaram-se os processos sociais que também forjaram políticas governamentais de combate à homofobia e de defesa de direitos relativos à diversidade sexual e de gênero, seja no plano federal, seja no do estado do Rio de Janeiro (além de outras unidades da federação), articulando agências da administração pública e da sociedade civil.

Nesse percurso tenso, os agentes e agências da "sociedade civil", do "Estado" e da "universidade" associam-se, entrecruzam-se, superpõem-se e distanciam-se, constituindo-se como forças, a um tempo distintas e embaralhadas, na imaginação de uma "coletividade LGBT". Ao mesmo tempo, essa população se estatiza, inscrevendo-se como parte do espectro de políticas em luta pelo reconhecimento da "diversidade" que, muito distintas em sua sociogênese, acabaram por compartilhar esquemas de pensamento e ação quando (se) fazem "Estado". 
Ao abordar tais processos, este livro nos apresenta, de modo denso e claro, aspectos do fazer político na vida pública brasileira que estão para muito além da questão específica focalizada.

Aguião trilha a formação da ideia de "direitos LGBT", recuperando os estudos sobre a história da militância homossexual desde 1970 até o período abordado mais intensamente neste trabalho, de modo a ver a paulatina inflexão entre identidades, direitos e formas de ação governamental. Para tanto, parte da perspectiva de que "O Estado" não está dado de uma vez por todas em um sistema de agências e agentes dito "público", nem corresponde a uma ideia que pode ser subsumida a priori de textos legais e normativos. Ao contrário, é por uma análise fina e minuciosa das práticas e enunciações que a pesquisa desentranha os múltiplos modos de se presentificar a fluidez do "Estado" a partir da cena "LGBT", que aqui é abordada como resultante da trama complexa entre "marcadores sociais da diferença" atualizados em sistemas de classificação supostamente objetivos. Aos poucos, emergem no texto categorias, estratégias e morfologias, dizeres e fazeres, vocabulários e performances que atravessam a ação de movimentos sociais tanto quanto a de agências do governo, assim como, de algum modo, estão presentes na reflexão (e na ação) "acadêmica".

Para chegar a tais resultados, Silvia Aguião se baseou na análise de documentos públicos que, tomados como repositórios de fluxos de relaçôes e tensões, revelam-nos os contornos do que seja a população $L G B T$. Dois outros movimentos metodológicos foram essenciais à sua pesquisa: a observação direta de eventos de variado escopo e a observação a partir de sua presença no processo de implantação do Programa Rio Sem Homofobia, ligado à Superintendência de Direitos Individuais, Coletivos e Difusos (SuperDir), na Secretaria de Assistência Social e Direitos Humanos do Estado do Rio de Janeiro, e, em particular, no estabelecimento dos Centros de Referência de Promoção da Cidadania LGBT.

E esse é um dos ganhos deste trabalho exemplar: a reflexão densa e nada ingênua sobre a impossibilidade de se esquivar de certo envolvimento, bem como a necessidade de não assumir qualquer "portavozismo", ultrapassando quer as ilusōes da neutralidade, quer um 
certo heroísmo acadêmico. Ser afetada é aqui condição e pressuposto de qualquer tentativa inicial de "entrar em campo" e uma construção que não poderia ser obtida meramente no tempo formal de um doutorado, mas que se fez desde a graduação até o estágio da pesquisadora no Centro Latino-Americano em Sexualidade e Direitos Humanos (CLAM), cujo nome carrega em si todo o largo investimento que é matéria de análise e ponto de partida da pesquisa aqui dada a público. Pesquisar e atuar, fazer-se na pesquisa e na ação política são movimentos tomados em sua abrangência, sem ingenuidade ou autocomplacência. Os aspectos éticos de um trabalho dessa natureza estão claramente colocados. Não há jogos de sombras, retóricas elusivas ou citaçōes desnecessárias.

O resultado é uma singular etnografia das relações pelas quais se forjam sujeitos - e formas de assujeitamento/subjetivação - no cotidiano de uma política de identidades de cunho "participativo", compondo um panorama dos processos de formação do Estado que, como a autora destaca, são também processos de formação de subjetividades, de afetos e de redes. Tão importante quanto o conteúdo etnográfico e a análise do "campo" LGBT é a construção teórica rigorosa, em especial, mas não só, no uso dos textos, uma antropologia sobre/do Estado, testando-a, operacionalizando-a de modo argumentativo. E tudo isso nos chega por meio de um texto claro, direto e enxuto, tanto quanto denso, reflexivo e inquietante.

Terminamos o texto com um panorama de aspectos ainda pouco elaborados da história do Brasil recente, por essa via pouco usual da translação entre sexualidades e direitos. Além disso, vemo-nos retirados de qualquer zona de conforto em que "reflexão científica" ou "militância" sejam depuradas da presença estatal. Longe disso, Fazerse no "Estado" coloca a todos os seus leitores o desafio de se olharem tão incisivamente quanto sua autora o faz e de retirarem dessa visada lúcida e implacável as consequências das escolhas teóricas, éticas e associativas, todas necessariamente políticas.

Antonio Carlos de Souza Lima LACED/DA-Museu Nacional-UFRJ 
Um crente

Ao cair da tarde, dois desconhecidos se encontram nos corredores escuros de uma galeria de quadros. Com um leve calafrio, um deles diz: - Este lugar é sinistro. Você acredita em fantasmas? - Eu, não - respondeu o outro. - Evocê?

- Eu, sim - disse o primeiro, e desapareceu.

George Loring Frost*

* O conto faz parte de uma antologia organizada por Adolfo Bioy Casares, Jorge Luis Borges e Silvina Ocampo, cuja primeira edição data de 1940 (Casares et al., 2013). Diz-se que George Loring Frost, assim como o conto a ele atribuído na coletânea, são invenções de J. L. Borges. 


\section{LISTA DE CENAS}

Cena 1 - Noite de cinco de junho de dois mil e oito

Cena 2 - Noite de quinze de dezembro de dois mil e onze

Cena 3 - Madrugada do dia dezenove de dezembro de dois mil e onze

Cena 4 - Dia dezessete de maio de dois mil e dez

Cena 5 - Maio de dois mil e onze

Cena 6 - Vinte e nove de outubro de dois mil e onze

Cena 7 - Trinta de outubro de dois mil e onze

Cena 8 - Dia primeiro de julho de dois mil e dez

Cena 9 - Dezesseis de maio de dois mil e onze 
INTRODUÇÃO

\section{PERCURSOS E BIFURCAÇÕES}

Esta pesquisa debruçou-se sobre o processo de construção da população designada, no momento do estudo, LGBT como sujeitos de direitos no Brasil contemporâneo. Dei início à investigação seguindo a perspectiva de que a sigla LGBT (Lésbicas, Gays, Bissexuais, Travestis e Transexuais) recobriria uma espécie de "coletividade imaginada", parafraseando Benedict Anderson (2008 [1983]), produto e produtora de diversos feixes de relações sociais que perpassam políticas de governo, movimentos sociais, a produção acadêmico-científica sobre o tema e os seus idiomas específicos, como, por exemplo, o dos direitos humanos. ${ }^{1}$

1 Guardados os devidos distanciamentos entre a conceituação de Anderson (2008) e o que me proponho a fazer aqui, utilizo a paráfrase das "coletividades imaginadas" de maneira livre. Penso em uma aproximação com as "comunidades imaginadas" do autor em relação a três sentidos: i) a "criação imaginativa" de um nós comum; ii) no sentido de que a essa imaginação não se opõe uma comunidade "verdadeira“; e iii) no sentido de que, ao ser imaginada, é iniciado um processo de produção de fronteiras, limites e adaptações de significados que virão a conformar a aparência natural dessa imaginação. Para pensar o movimento social, considero interessante retomar um aspecto do balanço crítico da abordagem dos "movimentos sociais na América Latina” realizado por Cardoso (1987). Naquele momento, a autora apontava para uma tendência das análises da área a não mencionarem aspectos como "o desenrolar do processo de negociação com as instâncias governamentais, os mecanismos internos de formação de opinião, os conflitos quanto às táticas de ação etc.”. Nesse sentido, chama a atenção para o fato de que os movimentos sociais só 
Isso implicou voltar a atenção não apenas para o processo de legitimação da identidade coletiva LGBT e para os processos e as gramáticas sociais e políticas que a tornam possível no cenário atual, mas também para as dinâmicas de especificação dos segmentos que a compõem: Lésbicas, Gays, Bissexuais, Travestis e Transexuais. Invisto em uma análise que, a partir das estratégias políticas dos atores envolvidos nos debates em torno dos “direitos LGBT" ou "direitos da pessoa LGBT" (Rios, 2008), considera processos de criação e recriação de morfologias de Estado, mantendo como pano de fundo a questão de como certos "direitos" corporificam certas "identidades", e vice-versa.

O desenvolvimento da pesquisa esteve sempre alicerçado em minha trajetória de formação acadêmica e profissional. Desde a graduação venho trabalhando com questóes relacionadas à (homo)sexualidade, ao gênero, à cor/raça e à mestiçagem. Analisar o entrecruzamento de diversas marcas de diferenciação social - e possíveis eixos constituintes de desigualdades ${ }^{2}$ - tem se mostrado uma tarefa bastante complexa. Por ocasião de minha dissertação de mestrado, conduzida em uma favela do Rio de Janeiro, ${ }^{3}$ busquei indicar alguns caminhos de reflexão a partir de uma análise etnográfica dessas questôes. Investi em explorar usos, sentidos e manipulações de categorias referentes à cor/raça e à homossexualidade presentes nas relaçôes da vida cotidiana da localidade.

Ao observar as formas como homossexualidade e cor/raça apareceram durante o trabalho realizado no mestrado, uma das hipóteses apresentadas foi a de que, na adaptação do discurso de certas

formam uma impressão de unidade quando olhados de fora; se o foco for colocado em suas diferenças, essa aparência de objeto uniforme se fragmenta. A partir daí, a autora aborda a necessidade de "uma análise mais cuidadosa das relaçôes entre Estado e Sociedade nos nossos países" e indica que "não são os fenômenos singulares que devem ser comparados, mas sim os processos".

2 Sigo a perspectiva de que "estruturas de classe, racismo, gênero e sexualidade não podem ser tratadas como 'variáveis independentes' porque a opressão de cada uma está inscrita dentro da outra - é constituída pela outra e é constitutiva dela” (Brah, 2006, p. 351).

${ }^{3}$ A pesquisa foi conduzida na favela de Rio das Pedras, zona oeste da cidade do Rio de Janeiro. A localidade apresenta certas características particulares, como a ausência do tráfico armado de drogas e a intensa migração nordestina, fatores que contribuem para a conformação de configuraçôes específicas no que tange a questões relacionadas a (homo)sexualidade, gênero, cor/raça e mestiçagem (Aguião, 2004, 2007, 2011). 
políticas de identidade - veiculado por instâncias como o governo, movimentos sociais e, de outro modo, a academia - às práticas da vida diária, firmava-se uma dissonância, pois eram formulaçōes que surgiam no campo da pesquisa um tanto desconcertadas em relação à sua construção original. Assim, a intenção inicial do projeto que originou a presente pesquisa foi deslocar o foco etnográfico de um campo microlocalizado para um campo político mais amplo de análise.

Durante a graduação e o mestrado, trabalhei como assistente de pesquisa do Centro Latino-Americano em Sexualidade e Direitos Humanos (CLAM/IMS-UERJ), em projetos que olhavam para os mesmos temas em diferentes escalas (nacionais e internacionais). ${ }^{4}$ Após a conclusão do mestrado, participei de uma pesquisa ${ }^{5}$ voltada para a reflexão acerca da constituição de políticas governamentais direcionadas à concretização e à regulação dos "direitos culturalmente diferenciados" e dos direitos especiais ${ }^{6}$, a partir da Constituição de 1988. Pouco tempo depois, passei a trabalhar também em dois projetos de pesquisa e desenvolvimento de ações de prevenção ao HIV/Aids do Grupo Arco-Íris de Cidadania LGBT. ${ }^{7}$ Por meio desse grupo, passei a ter contato com a Superintendência de Direitos Individuais, Coletivos e Difusos (SuperDir), ${ }^{8}$ que compõe hoje a estrutura da Secretaria de Assistência

4 Projeto "Relations among 'race', sexuality and gender in different local and national contexts", coordenação de Laura Moutinho; projeto "Heterossexualidades: contracepção e aborto", coordenaçāo de Maria Luiza Heilborn; projeto "Razão, afetividade e desejo: uma análise dos relacionamentos afetivo-sexuais inter-raciais entre homossexuais no Rio de Janeiro", coordenação de Laura Moutinho; projeto "Dados sobre comportamentos sexuais no Brasil", coordenação de Laura Moutinho e Sérgio Carrara.

${ }^{5}$ Projeto "Políticas para a diversidade e os novos sujeitos de direitos: estudos antropológicos das práticas, gêneros textuais e organizações de governo". Laced/MN-UFRJ e PPGA/UFF. Coordenação de Antonio Carlos de Souza Lima, Adriana Vianna, Eliane Cantarino O’Dwyer. O projeto foi desenvolvido entre os anos de 2006 e 2013. Disponível em: http://www.laced.etc.br/projetos_politicas_diversidade.htm.

${ }^{6}$ Tomo de empréstimo a definição de Rios (2006, p. 91), segundo a qual direitos especiais "seriam todas as previsōes protetivas de discriminação elaboradas pela legislação ordinária e não previstas expressamente na Constituição". Nesse sentido, o estabelecimento de tais direitos seria uma forma de concretizar o princípio geral de igualdade em situações sócio-históricas de existência de grupos privilegiados e oprimidos em uma mesma sociedade.

${ }^{7} \mathrm{O}$ grupo foi fundado em 1993 e é registrado como uma associação civil sem fins lucrativos, com o nome de Grupo Arco-Íris de Conscientização Homossexual. Entretanto, em meados da primeira década dos anos 2000, adotou como nome fantasia Grupo Arco-Íris de Cidadania LGBT.

${ }^{8}$ Segundo um boletim divulgado em 2007, a "Superdir iniciou suas ações de combate à discriminação e à promoção da cidadania junto à população GLBT (gays, lésbicas, bissexuais, travestis e transexuais); pessoas discriminadas por estado de saúde (HIV-Aids, tuberculose e hepatites); comunidades de religiôes de 
Social e Direitos Humanos do estado do Rio de Janeiro, e cujo superintendente, durante todo o período da pesquisa, seria integrante e ex-presidente do Grupo Arco-Íris e ex-diretor da Associação Brasileira de Gays, Lésbicas, Bissexuais, Travestis e Transexuais (ABGLT).

O período em que me aproximei do trabalho da SuperDir coincidiu com a mobilização provocada por um decreto presidencial de novembro de 2007, que convocou a I Conferência Nacional de Gays, Lésbicas, Bissexuais, Travestis e Transexuais. Esse decreto expunha como objetivos da conferência: "I - propor diretrizes para a implementação de políticas públicas e o plano nacional de promoção da cidadania e direitos humanos de Gays, Lésbicas, Bissexuais, Travestis e Transexuais - GLBT; e II - avaliar e propor estratégias para fortalecer o Programa Brasil Sem Homofobia". Além disso, estabelecia uma data em 2008 para a realização da reunião e, ainda, que a eleição dos delegados participantes seria conduzida durante conferências estaduais e regionais ocorridas antes da nacional.

A partir de então, comecei a acompanhar mais sistematicamente as etapas que antecederam a I Conferência Nacional GLBT - que, no estado do Rio de Janeiro, foram organizadas pela SuperDir - e a mapear outras açōes localizadas nas (ou propostas por) esferas governamentais que se referissem ou tivessem como público principal a chamada "população LGBT". A primeira conferência do estado do Rio de Janeiro foi antecedida por nove conferências regionais, organizadas de acordo com a subdivisão por região geopolítica do estado. Nessas conferências, foram discutidas e definidas propostas para cada sub-região, assim como eleitos - em número proporcional à população da região - os delegados que participariam da etapa estadual. Ainda em 2008, estive como observadora da pré-conferência da capital do Rio de Janeiro, assim como da etapa estadual e, finalmente, da nacional, ${ }^{9}$ que teve

matrizes africanas; comunidade judaica e outras populações discriminadas em razão de sua nacionalidade, origem, religiosidade, além das intolerâncias correlatas e das múltiplas formas de discriminação”.

9 Pré-Conferência de Políticas Públicas para GLBT da Capital da Cidade do Rio de Janeiro, realizada na Universidade do Estado do Rio de Janeiro em 5 de abril de 2008; I Conferência de Políticas Públicas para GLBT do Estado do Rio de Janeiro, realizada na Universidade do Estado do Rio de Janeiro em maio de 2008; I Conferência Nacional de Políticas Públicas para Gays, Lésbicas, Bissexuais, Travestis e Transexuais, realizada no Centro de Eventos Brasil 21, em Brasília, em junho de 2008. 
como tema "Direitos Humanos e Políticas Públicas: o caminho para garantir a cidadania de Gays, Lésbicas, Bissexuais, Travestis e Transexuais (GLBT)”. Foi por conta da experiência em acompanhar essas conferências que construí o projeto inicial que deu origem à minha tese de doutorado, agora transformada neste livro.

Explicitar a minha trajetória anterior ao início da pesquisa justifica-se não apenas no sentido de retomar o processo que originou a sua proposta, mas também por reconhecê-lo e incorporá-lo como parte da reflexão desenvolvida. Essa experiência inscreve-se em um campo ético-político complexo e profundamente desafiador. Não se trata exatamente de refletir sobre os modos de representação etnográfica - embora seja de grande rendimento heurístico a ideia de que os textos etnográficos compõem "um sistema complexo de relações" ${ }^{10}$ O lugar que venho ocupando como pesquisadora se inscreve em um momento histórico específico para o qual confluem diversos fenômenos que espero poder colocar em perspectiva ao longo do texto.

De fato, conta nesse sentido a angústia que ronda os pesquisadores que se propõem a estudar a dinâmica do campo político e adquirem, de súbito, a consciência das ambiguidades de suas descriçôes em relação à imagem e aos objetivos do grupo pesquisado. ${ }^{11}$ Anos atrás, Gregori (1993a) já chamava a atenção para a complexidade da posição ou do lugar militante/pesquisador. Se, por um lado, a inserção no movimento enriquece o trabalho etnográfico, por outro, a tradicional identificação do antropólogo com seu objeto de estudo pode nublar a riqueza etnográfica do processo. Fundamental, nesse sentido, é "ler, reler, cruzar informaçôes, suspeitar dos detalhes que nos parecem óbvios, observar gestos aparentemente banais e interpretar a cadeia de significados que se situa no imbricamento entre 'falas', discursos, gestos e ações" (Gregori, 1993a, pp. 17-8).

De forma mais tangencial, chamo a atenção, desse modo, para a minha experiência de trabalho no CLAM, ${ }^{12}$ uma das instituições

\footnotetext{
${ }^{10}$ Cf. Clifford (1998).

11 Ver, sobre o tema, Brites e Fonseca (2006).

${ }^{12}$ Nos países em que atua, o Centro Latino-Americano em Sexualidade e Direitos Humanos (CLAM) vem se firmando como um centro de pesquisa cujo esforço é o de estabelecer redes de diálogo
} 
colaboradoras na elaboração do programa federal Brasil Sem Homofobia (BSH) e onde, entre os outros projetos mencionados, trabalhei como pesquisadora e coordenadora de campo dos surveys sobre vitimização e discriminação realizados na Parada do Orgulho LGBT do Rio (2003 e 2004). ${ }^{13}$ Como será visto, ambas as iniciativas têm papel bastante significativo na produção de dados que são apresentados como legitimadores de políticas especiais ou diferenciadas para LGBT. Cabe referir, no mesmo sentido, ter trabalhado para dois projetos do Grupo Arco-Íris, que concentra grande parte das lideranças do movimento LGBT carioca e que, em algumas situaçōes, opera em estreita articulação com um órgão do aparelho administrativo do estado do Rio de Janeiro. Meu trabalho nessa organização trazia desconforto para alguns pelo fato de eu não possuir uma identidade coincidente com nenhum dos "segmentos LGBT". Por esse motivo, eu era apresentada publicamente como uma "técnica" qualificada para o trabalho de pesquisa, não como uma ativista. Sendo assim, é possível afirmar que a minha própria inserção é representativa também de um movimento crescente de maior circulação de atores entre ativismo, academia e governo, ou do embaralhamento de posições, já que muitos ativistas vêm sendo absorvidos por novas esferas de participação. ${ }^{14} \mathrm{E}$ grande parte da produção acadêmica tem sido articulada como instrumento de reivindicação política por esse ativismo.

Por conta dessa trajetória pregressa de algum grau de envolvimento com organizaçóes e sujeitos que compóem parte do campo das “políticas LGBT" no Brasil e, em especial, no estado do Rio de Janeiro, o percurso metodológico trilhado pela investigação também traz essa marca. O trabalho de campo realizado, particularmente o que privilegia uma política conduzida na cidade do Rio de Janeiro, como será visto

entre pesquisadores, ativistas e gestores públicos, conectando agendas políticas - especialmente do movimento feminista e do movimento LGBT. Como será visto, ele tem papel bastante significativo no processo que me proponho a analisar neste livro. Carrara (2010) reflete sobre o papel do Centro nesse sentido.

13 Além do Rio de Janeiro, a pesquisa já foi realizada em São Paulo, Pernambuco, Porto Alegre e outras cidades da América Latina (Carrara et al., 2003, 2005, 2006, 2007).

14 Souza Lima (2007) identifica a alta circulação de quadros da academia, da administração pública e do movimento social em "processos contemporâneos de formação de Estado". 
mais adiante, esteve marcado pelo imbricamento de posições entre pesquisar e atuar no campo de produção de "sujeitos LGBT" no Brasil.

Em resumo, trata-se de considerar os sentidos que o tipo de debate que as pesquisas nas quais tenho trabalhado suscitam e a pertinência de certas categorias de reflexão e da experiência em diferentes contextos, como na academia, no ativismo e no governo.

\section{DA EMERGÊNCIA DE UMA “POPULAÇÃO LGBT"}

A pesquisa que deu origem a este livro teve início em um momento em que algo como uma "população LGBT" ainda soava estranho, e os seus contornos provocavam muitas dúvidas. Se as margens do que exatamente delimita os sujeitos que podem ou não ser incluídos nesse enquadramento continuam pouco claras - e, com sorte, nunca estarão -, o vocabulário, por sua vez, foi estabelecido. Creio que, ao final do livro, será possível perceber essa estabilização por meio da multiplicação de iniciativas e de políticas de governo que assumiram a "população LGBT" como o seu objeto de mobilização e intervenção nos últimos anos. Nesse sentido, cabe olhar para alguns antecedentes que podem lançar luz sobre o modo como se conformou o terreno sobre o qual essas políticas e iniciativas estão sendo desenvolvidas.

Da leitura extensa apresentada por Simões e Facchini (2009) dos processos de incorporação de "identidades" que desembocaram na atual denominação "Movimento LGBT", para designar o que um dia já foi chamado "Movimento Homossexual Brasileiro", ou "MHB", podemos abstrair uma marcação temporal sucinta. Por meio de uma releitura do histórico dos encontros da militância, os autores percebem que, até 1992, eles eram chamados de "Encontro de Homossexuais". Em 1993, o termo "lésbicas" foi incorporado; em 1995, a denominação utilizada foi "Encontro de Gays e Lésbicas"; e a reunião de 1997 ganhou a adesão do termo "travestis". Apenas em 2005 os termos "transexuais" e "bissexuais" foram incorporados, e também nesse ano foram formadas "redes de associações nacionais" para esses "segmentos". Vemos então, nessa trajetória, um movimento 
que começou majoritariamente composto por homens "gays" e que, ao longo da década de 1990, foi acrescentando e multiplicando o seu alfabeto de "identidades".

Obviamente, todo esse processo é marcado por conflitos e contestações e apresenta muitas nuances que merecem ser acompanhadas. Entretanto, uma vez que já existe um conjunto de trabalhos que se debruçam sobre essa trajetória e que o foco desta pesquisa são os processos que viabilizaram a assunção de uma coletividade como uma "população" (Foucault, 2008) a ser administrada pelo governo brasileiro, não retomarei aqui um histórico pormenorizado do percurso de formação desse Movimento. Assim, recorro à periodização traçada por Facchini (2003, 2005), destacando aqui os momentos que mais nos interessam, quais sejam: aqueles indicados pela bibliografia como pontos de inflexão para a aproximação entre "movimento social" e "Estado".

O final da década de 1970 é o período marcado pela bibliografia para a emergência do Movimento Homossexual Brasileiro, estando essa data associada ao surgimento daquela que é considerada como a sua primeira organização política: o Somos - Grupo de Afirmação Homossexual, fundado em São Paulo em 1978. ${ }^{15}$ Outro marco apontado para o mesmo ano é o lançamento do jornal O Lampião da Esquina, "que teria um importante papel de articulação das primeiras iniciativas do movimento" (Facchini, 2003, p. 88). ${ }^{16}$

Facchini chama esse momento de "primeira onda", quando as iniciativas do movimento político concentravam-se no eixo Rio-São Paulo e estavam bastante associadas ao contexto histórico-político da ditadura. A autora ressalta que a bibliografia que analisa esse período retrata uma ênfase "antiautoritária e comunitarista" presente nesses grupos, determinando o seu caráter "alternativo" e "libertário". O início da década de 1980 é marcado, para alguns, pelo "declínio do movimento". ${ }^{17}$

\footnotetext{
${ }^{15}$ Para uma leitura do surgimento do MHB, feita particularmente por meio da trajetória do Grupo Somos, ver MacRae (1990). Já para um percorrido histórico mais amplo sobre a trajetória da "homossexualidade no Brasil do século XX", ver Green (2000).

${ }^{16}$ Para mais detalhes sobre a trajetória de $O$ Lampiäo da Esquina, que encerrou as suas atividades em junho de 1981, além de Facchini (2005), ver Silva (1998).

${ }^{17}$ De acordo com a bibliografia percorrida por Regina Facchini (2005), no início dos anos 1980 teriam sido identificados 22 grupos existentes no Brasil. Já em 1984 esse número teria caído para sete.
} 
Esse esvaziamento teria sido provocado pelo surgimento da epidemia de Aids, que fez com que "as propostas de liberação sexual" fossem desmobilizadas e que muitas lideranças migrassem para a atuação na luta contra a doença, "criando as primeiras respostas da sociedade civil à epidemia” (Facchini, 2005, p. 102). Há que se considerar ainda, naquele trágico período, o impacto da morte de figuras importantes desse movimento.

No entanto, a autora desloca esse tipo de afirmação sobre "o declínio do movimento" ao demonstrar que a diminuição do número de grupos esteve associada a uma profunda transformação condicionada pelo "período da abertura". Em um momento inicial - a "primeira onda" - havia, antes de tudo, um inimigo comum: o ambiente repressor e autoritário ocasionado pela "ditadura". O novo contexto colocado pela redemocratização exigiria que os grupos adaptassem o seu ideário e o estilo de sua militância. A essa mudança seria correlata uma passagem para a "ênfase na garantia do direito à diferença e para uma tendência a estabelecer organizaçóes de caráter mais formal que comunitário" (Facchini, 2005, p. 107). Essa nova ênfase marca uma alteração da compreensão sobre o que conta como atuação política: da aposta em uma "transformação social ampla, construída a partir da intimidade e do cotidiano", passa-se à valorização de uma atuação mais pragmática, centrada na garantia de direitos civis e no combate à discriminação e à violência voltadas a homossexuais.

Segundo a autora, há também um foco crescente na institucionalização das atividades e preocupações, tais como "ter uma sede, bem como o registro oficial do grupo e o estabelecimento de uma diretoria, com cargos e funções claramente definidos" (Facchini, 2005, p. 115), e ainda um progressivo envolvimento com organizações do movimento em âmbito internacional. Esses aspectos prenunciariam as características distintivas que viriam a configurar a "segunda onda" do movimento. Então, apesar do número reduzido de grupos na segunda metade dos anos 1980, os que permaneceram atuando lograram mobilizar recursos fundamentais para o que viria a ser a nova fase de "reflorescimento" do movimento. Segundo Facchini (2003, p. 104), entre esses recursos estava "o apoio de diversos atores sociais, principalmente de associaçôes 
científicas, partidos políticos, parlamentares, juízes, exatamente num momento em que a associação de caráter negativo entre Aids e homossexualidade ainda era muito grande" ${ }^{18}$

Nessa "segunda onda" emergente predominou ainda a tendência a afastar o caráter de marginalidade da homossexualidade, que, de certa forma, era valorizada na "primeira onda" devido ao seu então atribuído caráter "revolucionário" e "transformador" mais amplo. A preocupação agora seguiria mais na direção de afirmar uma imagem pública de legitimidade para a homossexualidade.

Facchini marcou o início dos anos 1990 como o período de reflorescimento do Movimento. A quarta e a quinta edições do Encontro Brasileiro de Gays e Lésbicas, realizadas, respectivamente, em 1990 e 1991, contaram com a participação de apenas seis grupos, mas, na edição de 1992, foram 11 grupos. Em 1993, na sétima edição do evento, o número de grupos participantes subiu para 21, e, em 1995, no VIII Encontro Brasileiro de Gays e Lésbicas e I Encontro Brasileiro de Gays e Lésbicas que Trabalham com Aids, realizado em Curitiba, esse número saltou para 84. Naquele ano, os Encontros começaram a contar com o financiamento de programas governamentais de combate à Aids, e foi também essa edição do encontro que marcou a fundação da Associação Brasileira de Gays e Lésbicas (ABGLT). Ainda


Internacional da International Lesbian and Gay Association (ILGA), o que marcou a inserção do movimento brasileiro em uma rede de circulação internacional. A partir daí, a autora destaca os efeitos do início do financiamento oriundo do combate à epidemia de Aids: a multiplicação de grupos e novas formas de organização e atuação.

Em 1992, o governo brasileiro firmou com o Banco Mundial um acordo para o desenvolvimento do Projeto de Controle da Aids, conhecido como AIDS I. Uma das orientações explícitas desse projeto

\footnotetext{
${ }^{18}$ A partir da leitura dos trabalhos de Câmara (2002) e Silva (1998), Facchini aponta que algumas das bases constituintes das características principais de uma segunda fase, ou "segunda onda", do Movimento começaram a ser delineadas ainda no início dos anos 1980, marcadas principalmente pela atuação do Grupo Gay da Bahia, liderado por Luiz Mott, e pelo Grupo Triângulo Rosa, liderado por João Antonio Mascarenhas.
} 
era condicionar o desenvolvimento de suas ações à "parceria com a sociedade". Esse momento marcou a multiplicação de investimentos na formação de quadros para atuar em ações de prevenção e assistência ao HIV/Aids, envolvendo atores da "sociedade civil".

Das relações estabelecidas com as políticas de Aids, Facchini (2005, p. 165) destaca um aspecto bastante interessante:

Do ponto de vista do movimento homossexual, foi muito importante em todo esse processo o fato de que a classificação de 'grupos de risco', que incluia homossexuais, profissionais do sexo e usuários de drogas injetáveis, há muito questionada por ser discriminatória, acabou se revertendo em justificativa da importância de traçar estratégias especificas para essas populaçóes. Nesse sentido, o uso da noção de 'educação por pares' possibilitou que grupos com dificuldades de obtenção de recursos passassem a ser financiados por agências de cooperaçáo internacional e por organismos governamentais. ${ }^{19}$

Temos então que os desdobramentos das respostas à epidemia não só significaram o fortalecimento do movimento e a formação de novos grupos, mas também alimentaram a segmentação das identidades, uma vez que os financiamentos exigiam a definição de públicos-alvo bem delimitados. ${ }^{20}$ Essa perspectiva colaborou para a definição dos "homossexuais" como uma "população" específica para a incidência de políticas.

\footnotetext{
${ }^{19}$ Galvão (2000) identifica a repercussão internacional dessa visão dos "grupos de risco" a partir da ótica da violação de direitos humanos. Para a autora, foi esse tipo de identificação que fez com que grupos gays e redes de trabalhadoras do sexo se unissem à "ONG/Aids estrito senso" para a produção das "primeiras respostas" à epidemia (p. 84). A autora também analisa a importância da cooperação internacional para esse período não só alimentando e dando sustentação para a formação de grupos e ONGs, mas também introduzindo "prioridades e linhas de atuação" imiscuídas em noçôes sobre "desenvolvimento, saúde e direitos humanos". Especialmente para as formas de atividades de enfrentamento da Aids no Brasil, a autora destaca, além do Banco Mundial, o papel da Fundação Ford.

20 A respeito da "segmentação de identidades", é importante ressaltar a influência do mercado especializado, que também empreendeu, a partir da década de 1990, uma expansão considerável que contribuiu para o efeito de produção e diferenciação de identidades e estilos. Para uma análise específica sobre essa dimensão, ver França $(2006,2012)$.
} 
Como muito autores apontam, uma característica que marca o campo da Aids no Brasil é a circulação de atores entre diferentes esferas. As políticas de governo financiam iniciativas não governamentais, atores ligados a esses grupos e também a universidades, que são incorporados como quadros de agências de governo e de organismos internacionais.

A bibliografia que trata do assunto mostra que a epidemia de Aids marcou o cenário de aprendizado de certo fazer políticoadministrativo, tendo os grupos que se ajustar ao formato de ONG, trabalhar por projetos, disputar financiamentos e buscar recursos e canais de interlocução no interior dos governos. Em um sentido mais amplo, o impacto da Aids e a maneira como as respostas foram construídas transformaram profundamente o cenário das relações entre movimentos sociais e políticas governamentais. ${ }^{21}$

Outra dimensão significativa na virada dos anos 1990, que aparece na esteira da redemocratização notada por Simōes e Facchini (2009), é a intensificação da aproximação e da "construção da legitimidade das temáticas LGBT" junto a partidos políticos. Os autores destacam que nos anos 1990 já existiam "setoriais LGBT" no PT e no PSTU, e que "nos anos 2000 começaram a se organizar setoriais e açôes de políticas públicas e de parlamentares, bem como candidaturas LGBT, em vários outros partidos" (p. 139). Ainda na década de 1990, os autores ressaltam a proposição do projeto de lei sobre a união civil entre pessoas do mesmo sexo como um resultado positivo dessa articulação $0^{22}$.

Facchini e França (2009) indicam que esse cenário de mudanças iniciado na década de 1990 está relacionado a um contexto mais amplo de alteração das formas de "operar políticas públicas no Brasil". Essa dimensão será discutida na Parte I deste livro, na qual veremos que, em relação às conexões entre movimento LGBT e esferas governamentais, houve um progressivo deslocamento da ênfase nas questões de saúde para

\footnotetext{
${ }^{21}$ Para algumas das reflexões que traçam esse panorama e, entre outros aspectos, realizam uma discussão aprofundada sobre o campo de respostas à Aids no Brasil, ver Parker (1994, 1997), Villela (1999), Galvāo (2000), Ramos (2004), Castro e Silva (2005), entre outros.

${ }^{22}$ O Projeto de Lei n. ${ }^{\circ} 1.151$ foi proposto pela então deputada federal Marta Suplicy (PT-SP) em outubro de 1995 .
} 
a expansão em outras direções ligadas à garantia de direitos humanos em sentido mais amplo. Cabe considerar que esses desenvolvimentos estão vinculados também à emergência de uma concepção dos direitos sexuais como direitos humanos. Embora uma dimensão comparativa de análise internacional desse processo pudesse ser incorporada, restrinjo-me, no escopo deste livro, às discussōes suscitadas no interior do governo brasileiro, remetendo a esse plano quando for diretamente pertinente à análise ${ }^{23}$. Gostaria apenas de pontuar uma observação feita por Carrara (2010). Ao considerar o processo de desvinculação da sexualidade de questôes relativas à saúde ou à demografia, em correlação à sua autonomização como um plano específico de exercício de direitos, o autor destaca como a luta pelos chamados "direitos LGBT" no Brasil tem se dado em relação a esse plano: "Conforme construídos contemporaneamente no Brasil, direitos sexuais se referem a prerrogativas legais relativas ou à sexualidade ou a grupos sociais cujas identidades foram forjadas sobre formas específicas de desejos e de práticas sexuais" (Carrara, 2010, p. 135).

Nesse sentido, o autor nota que muitas das principais pautas de reivindicação da atualidade guardam pouca relação direta com sexualidade e concentram-se em questôes como direitos previdenciários, adoção e mudanças de registro civil. A inclusão desses direitos sob o guarda-chuva dos direitos sexuais vincula-se a uma interpretação segundo a qual processos sociais e políticos de discriminação privam determinados sujeitos de acessá-los. Esse quadro poderá ser notado ao longo das próximas páginas.

\footnotetext{
${ }^{23}$ Vianna e Lacerda (2004) apresentam um panorama dos direitos e das políticas relacionadas à sexualidade no Brasil e, entre outros aspectos, fornecem uma síntese que reflete parte da trajetória dos direitos humanos e dos direitos sexuais no plano internacional. Corrêa (2006) aponta os reveses e os contrassensos inscritos na discussão teórica e política a respeito dos chamados "direitos sexuais", expondo enfaticamente a resistência no debate internacional no sentido de que, no âmbito de tratados e convençôes internacionais (em especial, Cairo e Pequim), o avanço dos "direitos sexuais" das mulheres não resultou em "avanços equivalentes no que se refere aos direitos da diversidade sexual (homossexuais, lésbicas, bissexuais, transexuais, transgêneros, trabalhadoras e trabalhadores do sexo)" (p. 103). Parte da discussão contemporânea que se dedica a analisar os impasses, os avanços e as contradiçōes do que se convencionou chamar de "direitos sexuais" e seus desdobramentos, como os "direitos da diversidade sexual" ou os "direitos da pessoa LGBT", nesse plano, pode ser encontrada em Rios $(2008,2010)$ e Szasz e Salas (2008).
} 
O período de análise coberto pela investigação mais sistemática teve início no ano de 2008, a partir da convocação da I Conferência Nacional LGBT, e final em dezembro de 2011, data em que ocorreu a II Conferência Nacional LGBT. Partindo do entendimento de um campo em processo, a pesquisa se desenvolveu em torno de dois eixos de questionamento derivados de um objetivo geral mais amplo: analisar alguns dos processos sociais e políticos que tornam possível a construção da população designada, no momento, LGBT como sujeitos de direitos no Brasil contemporâneo.

Para o desenvolvimento de tais eixos, é preciso estabelecer a concepção de estado por meio da qual a investigação foi estruturada, pois a proposta conceitual assumida de princípio foi fundamental para determinar os modos de fazer da etnografia. Sendo assim, trabalho com uma abordagem que prevê o "Estado" não como uma dada unidade coesa, mas que busca justamente investir na análise de processos de criação e recriação de morfologias do estado-governo, ou seja, "recuperar a dimensão de representação no sentido performático e figurativo da administração pública" (Souza Lima, 2002); e indagar como certos "direitos" corporificam certas "identidades" e vice-versa e quais as formas de administração pública acionadas para determinados segmentos em detrimento de outras.

Essa perspectiva está ancorada na proposta de Elias (2006) ao tratar do caráter inacabado e contínuo dos processos sociais e, necessariamente, dos "processos de formação de Estado". Isso implica uma aproximação dinâmica do sistema estado-governo de seus processos e regimes de produção e funcionamento, de forma que permita olhar para "relações de poder mutantes entre diferentes grupos sociais".

Assumo a perspectiva de não encarar o "Estado" como dado, mas, a cada passo da pesquisa, procurar o sentido imiscuído em práticas e enunciados nos quais este apareça encarnado. Como espero que fique claro ao longo do livro, o estado pode significar e estar significado em múltiplos lugares, objetos e pessoas. Sigo as proposições de Abrams (1988 [1977]), nas quais uma conceituação instrumental postula um 
"estado-sistema”, significando a prática e a estrutura institucional, que pode ser compreendida como a administração. De acordo com Abrams, o estado reificado ganha progressivamente uma identidade abstrata desvencilhada da prática:

I'm proposing only that we should abandon the state as a material object of study whether concrete or abstract while continuing to take the idea of state extremely seriously. The internal and external relations of political and governmental institutions (the state-system) can be studied effectively without postulating the reality of the state (1988, p. 75).

O esforço empreendido por Philip Abrams oferece um conjunto sofisticado de provocações para uma análise do estado. Mais do que apenas afirmar a sua dimensão ideológica ou ilusória, sua proposta é a de manter a atenção para esse aspecto como foco de uma interrogação profunda a partir não da busca de uma estrutura fundamental oculta, mas da compreensão das práticas políticas por meio das quais o estado é forjado como tal. O estado como prática, o "estado-sistema”, seria a forma por meio da qual o "estado-ideia" é construído ${ }^{24}$.

Seguir essa abordagem significa compreender o "Estado", com letra maiúscula, como o efeito de uma imaginação compartilhada. Nenhuma aproximação teórica pode desconsiderar a eficácia dessa imaginação. O "Estado" como substância dotada de coerência e unidade conforma uma poderosa abstração com efeito de aparato externo à sociedade (Mitchell, 2006) ${ }^{25}$.

Nesse sentido, o fazer-se no Estado de que fala o título deste livro procura chamar a atenção não só para as formas por meio das quais o estado produz os sujeitos que governa (administra), mas também para o processo de constituição desses sujeitos como parte de um fluxo

\footnotetext{
24 "In sum: the state is not the reality which stands behind the mask of political practice. It is itself the mask which prevents our seeing political practice as it is" (Abrams, 1988, p. 82).

25 "We must analyse the state as such a structural effect. That is to say we should examine it not as an actual structural, but as the powerful, apparently metaphysical effect of practices that make such structures appear to exist" (Mitchel, 2006, p. 180).
} 
contínuo de produção do próprio estado ${ }^{26}$. A perspectiva adotada foi a de olhar para açôes da administração pública praticadas por governos específicos, mas sem perder de vista a dimensão do "Estado" como ideia e ideal totalizante e sempre inconcluso.

Atentar para a dimensão ilusória do estado não significa que desempenhos e aparatos institucionais da administração governamental não possam ser investigados e analisados, mas o oposto disso. Nesse sentido, procuro seguir a proposição de Antonio Carlos de Souza Lima, segundo a qual olhar para o "fazer do Estado" é encarar "as dimensões de processo, fluxo e performance, não apenas aquelas apreensíveis pela via das análises dos grandes rituais e eventos, mas também a da sua atualização cotidiana numa miríade de ações estereotipadas e rotinizadas [...]" (Souza Lima, 2012, p. 561)27.

O primeiro dos dois eixos de questionamento que orientaram o desenvolvimento da pesquisa voltou-se para a dinâmica própria de constituição de direitos para determinados sujeitos. Em torno desse eixo da investigação articulam-se algumas questôes: Quem são os sujeitos desses direitos? Como diferenças múltiplas podem ser articuladas em termos de reivindicação de direitos? Por meio de que mecanismos certas marcas sociais são reconhecidas como tendo mais relevância do que outras ou em detrimento de quais outras? Como o entrecruzamento complexo de marcadores da diferença que perpassam os sujeitos (Brah, 2006) é convertido em sistemas de classificação objetivos ou que se pretendem objetivos? Ou como eixos de classificação sempre contingentes, contextuais e relacionais são produzidos, objetivados e cristalizados na produção governamental de políticas direcionadas para determinados sujeitos? Aqui coube investigar como se dá a manipulação de certas

${ }^{26}$ Para uma série de reflexōes que adotam essa perspectiva, ver o dossiê organizado por Antonio Carlos de Souza Lima, "Fazendo o Estado", publicado na Revista de Antropologia, USP, v. 55, n. 2, 2012. As leituras de alguns desenvolvimentos anteriores também foram fundamentais para desenhar a perspectiva adotada neste livro: além da coletânea já citada, organizada por Souza Lima (2002), destaco Vianna (2002) e Lugones (2009).

${ }^{27}$ Tal concepção permite uma abordagem em que "os centros simbólicos e de exercício de poder não necessariamente coincidem e operam racionalmente, e toda a panóplia dos múltiplos exercícios de poder contidos num certo território definido como soberano tem tanta importância quanto os pequenos rituais, os jogos linguísticos cotidianos, as crenças pelas quais a cives se faz polis" (Souza Lima e Castro, 2008, p. 371). 
categorias, assim como as figuras sociais que funcionam como escape, ou que escapam, dos enquadramentos mais simples.

É também pertinente analisar a dinâmica entre demandas por reconhecimento - com foco em políticas de identidade - como uma iniciativa do movimento social e, ao mesmo tempo, o quanto essa demanda é provocada pelas próprias morfologias e rotinas administrativas de governo. Falando de outra forma, podemos pensar que, por vezes, certas estratégias de ação incorporam determinadas identidades como figuras legítimas de reivindicação; outras vezes, cria-se uma reivindicação legítima, e procuram-se identidades a ela adequadas.

Entrando no âmbito das políticas governamentais direcionadas para determinadas populações, cabe atentar para a imposição de "categorias de pensamento" e compreensão imiscuídas em rotinas administrativas de governo ${ }^{28}$. A dimensão performativa envolvida em processos de formação de estado é explorada de maneira bastante elucidativa por Blázquez (2012). O autor recorre a Judith Butler $(1997)^{29}$ ao elaborar uma abordagem que compreende o estado como o "efeito performativo de um conjunto de práticas repetidas e repetíveis, citadas e citáveis, que através de sua interação criariam tanto as redes cooperativas que fariam o trabalho administrativo do Estado como a ficção de sua existência" (Blázquez, 2012, p. 740). ${ }^{30}$ A proposta é tomar a fabricação de identidades como efeito de práticas discursivas. E parte dos processos de estado é justamente apagar os traços dessa fabricação.

\footnotetext{
${ }^{28}$ Bourdieu (1996) lembra que um dos principais poderes do estado é a capacidade de produção das "categorias de pensamento que utilizamos espontaneamente para todas as coisas do mundo": "Tentar pensar o Estado é expor-se a assumir um pensamento de Estado, a aplicar ao Estado categorias de pensamento produzidas e garantidas pelo Estado [...]" (p. 91). "[P]orque as coisas da cultura, particularmente as divisōes e hierarquias sociais a elas associadas, são constituídas como natureza pela ação do Estado que, instituindo-se ao mesmo tempo nas coisas e nos espíritos, confere todas as aparências do natural a um arbitrário cultural” (p. 95).

${ }^{29}$ A dimensão performativa citacional é acionada por Butler (1997), a partir de uma leitura de Austin (1962), na qual essa dimensão significa que a emissão do enunciado não é apenas dizer algo, mas também a realização de uma ação. A repetição estilizada de discursos e enunciados performáticos tem o efeito de produzir sentidos, ainda que contingenciais, práticas discursivas que produzem um efeito de verdade.

${ }^{30}$ Tradução minha.
} 
Nesse sentido, as provocaçóes elaboradas por Judith Butler (2008 [1990]) a respeito da categoria "mulheres" como "o sujeito" do feminismo oferecem expressivos aportes para a compreensão de formas de construção de sujeitos políticos. A autora indaga se haveria uma forma política de sujeito que preceda a elaboração de seus interesses ou que anteceda as "práticas que estabelecem os termos de inteligibilidade pelos quais ele pode circular" (Butler, 2008, p. 207). As afirmaçôes de Butler nos permitem olhar para as "identidades" que conformam "sujeitos inteligíveis" não como fixas ou fundantes, mas como o efeito resultante de práticas culturais e políticas configuradas por meio de regras determinadas.

Nesse ponto está situado o segundo eixo de questôes da presente investigação, que se detém sobre táticas e estratégias de organização e performances do fazer politico, envolvendo a replicação de formatos desse mesmo fazer entre movimentos sociais, disputas internas aos próprios movimentos e circulação desses formatos para os cenários governamentais. Nesse trajeto, cabe indagar a respeito da formulação de linguagens e desempenhos específicos, tidos como mais estratégicos e eficazes, a serem manejados pelos atores em distintos momentos e de acordo com cada contexto e interlocutor. Cunhar um vocabulário próprio, a ser compreendido como legítimo para tratar as "especificidades" e dominar o seu correto manejo, cria um espaço negociado que orienta a constituição de alianças e a produção de diferenças, indicando quais são os atores que estão mais ou menos inseridos no jogo político de disputas representacionais do campo dos direitos.

Procuro assim acompanhar como certos sujeitos são forjados no entrelaçamento de determinados direitos e vice-versa. A produção da representação de uma coletividade como sujeito político relaciona-se ao acionamento da polissemia de linguagens que compõe "o fazer e o desfazer dos direitos", para usar a expressão de Vianna (2013). ${ }^{31}$

\footnotetext{
${ }^{31}$ Com "o fazer e o desfazer", Vianna (2013, p. 15) procura chamar a atenção tanto para "a dimensão de ação social dos 'direitos' - seja como normativas legais, como tradiçōes administrativas ou como forma de construção de posicionamentos de sujeitos morais e políticos - quanto para sua dimensão processual e dinâmica".
} 
Uma das proposições que orientam as análises empreendidas a partir de um campo que mobiliza a construção de direitos relacionados à sexualidade e ao gênero é bem resumida por François Ewald (1993). Ao analisar o trabalho de Foucault (1988), o autor expõe um de seus postulados relativos aos enunciados discursivos presentes nos emaranhados da articulação poder-resistência: "a propósito das lutas de liberação sexual, estas são de fato lutas, mas cujos temas, objetivos e alvos estão pendentes das relações de poder em que se encontram enredadas e que elas combatem" (Ewald, 1993, p. 13).

Assim, dispositivos e formatos administrativos de operação acionados para a legitimação de direitos específicos para a "população LGBT" são compreendidos a partir desse pano de fundo. A fim de olhar para um campo em processo de constituição e de categorias dinâmicas em desenvolvimento, algumas escolhas metodológicas foram sendo produzidas ao longo da investigação. Uma delas foi a de enfocar pontos de interseção entre sujeitos localizados em diversas instâncias, buscando igualmente acessar diferentes níveis de compreensão de relações que se desenvolvem, por sua vez, em planos distintos.

Ao enfatizar as relaçóes entre os elementos que compõem o campo da pesquisa, buscou-se perceber como o "Estado" se movimenta e se produz, as formas por meio das quais a burocracia se organiza e como categorias são negociadas em diferentes contextos no interior de um processo dinâmico. Trata-se, enfim, de tomar como espaço de pesquisa a interseção entre os próprios elementos que transitam pelo campo que vem legitimando a coletividade LGBT, incluindo não apenas pessoas, mas também documentos e outros elementos como agentes que circulam na trama. Nesse sentido, a abordagem metodológica foi pensada de maneira a envolver diferentes entradas de análise. A proposta foi a de abarcar algumas das formas e expressóes das políticas de visibilidade inerentes a determinados mecanismos de afirmação de uma coletividade e as estratégias de argumentação circuladas por diferentes sujeitos envolvidos na trama processual de forjar uma população determinada. Por fim, buscou-se compreender algumas formas efetivas por meio das quais a gestão dessa população é levada a cabo. 
Cabe ressaltar que olhar para tramas de relaçóes nas quais circulam pessoas, ideias, conceitos e objetos não significa olhar para tramas estabilizadas, mas o oposto disto. As tramas enfocadas aqui são compreendidas como móveis e mutantes, abarcando distintos modos e tipos de sedimentação. Sendo assim, foram eleitas três entradas de análise para o desenvolvimento da pesquisa.

A primeira entrada baseou-se no levantamento de documentos relevantes para o processo de construção da "população LGBT" para o governo brasileiro. Fazem parte do conjunto de documentos percorridos ao longo da pesquisa: programas e planos de governo, anais de eventos, decretos, portarias, normativas, ofícios e cartilhas. Desse conjunto, alguns foram considerados mais centrais para a análise, concentrando-se no período delimitado para a investigação - 2008 a 2011. Entretanto, algumas peças exteriores a esse marco temporal funcionam como contraposição e contextualização fundamental, como, por exemplo, as três versōes do Programa Nacional de Direitos Humanos (PNDH) e o programa federal Brasil Sem Homofobia (2004).

Considero os documentos como peças de "precipitação de relações" (Ferreira, 2011) estabelecidas entre os atores e os elementos que constituem o campo dos "direitos LGBT". Assim, interesso-me por buscar os sentidos imiscuídos em documentos institucionalizados pelo governo, bem como alterações, inclusões e exclusōes de conteúdo e forma ocorridas ao longo do tempo. $\mathrm{Na}$ análise dos documentos, a proposta foi percorrer o processo de formatação da chamada "população LGBT" no decorrer dos anos, especialmente no período pós-I Conferência Nacional LGBT, quando a formulação e a implantação de políticas se intensificam.

A segunda entrada de análise teve como foco a observaçáo de eventos como seminários, congressos, conferências, encontros, reuniōes e palestras, além de audiências públicas levadas a cabo no Congresso Nacional. Um dos objetivos de olhar para eventos desse tipo foi perceber atores e redes em interação e tramas em formação. Em geral, foram selecionados espaços onde estavam representados "academia/ universidade", "ativismo/militância" e "governo/estado". Muitas vezes, esses termos não funcionam como categorias nas quais possamos 
enquadrar de maneira simples os atores desse campo, que amiúde circulam e são forjados nessas diferentes instâncias. No entanto, ou justamente por isso, são categorias que podem ser utilizadas para compreender e problematizar as relações estabelecidas entre esses domínios e como eles próprios se constituem, ou se constituem uns aos outros.

Essa entrada também trouxe rendimento para a compreensão, como exposto anteriormente, das táticas e estratégias de organização e performances do fazer politico. Tais estratégias envolvem o manejo de concepções a respeito de gênero, sexualidade, raça, etnia e outros marcadores sociais de diferença como formas de legitimação de reivindicações. Nesse âmbito, há uma dupla inscrição a ser avaliada: o irredutível das experiências particulares e a lógica pragmática subjacente a formatos de funcionamento de estado que geralmente exigem enquadramentos bastante específicos para o direcionamento de ações e políticas.

Finalmente, a terceira entrada de análise concentrou-se na observação detida da implantação de um serviço e do esforço de construção de uma política de governo. Trata-se do acompanhamento da implantação do programa Rio sem Homofobia, uma espécie de versão estadual do programa federal Brasil sem Homofobia.

Durante essa observação, acompanhei, entre outras ações, parte do processo de implantação de Centros de Referência de Promoção da Cidadania LGBT, processo coordenado pela já citada SuperDir, da estrutura da Secretaria de Assistência Social e Direitos Humanos do Estado do Rio de Janeiro, por meio de um convênio com a Universidade do Estado do Rio de Janeiro.

Em consonância com a proposição mais geral de refletir sobre "processos de formação de Estado", um dos rendimentos desse foco de atenção abarca a ideia do quanto certas demandas são provocadas pelas próprias rotinas administrativas de governo e permite pensar em formatos de administração acionados para gerir determinadas "populações". Aqui, retóricas e ações políticas, bem como protocolos de funcionamento burocrático, podem ser "estranhadas" de maneira a tornar possível a reflexão sobre as relações que são estabelecidas com 
aquilo que se costuma chamar de "Estado". Além disso, a noção de "trama institucional" desenvolvida por Gregori (2000) nos ajuda a perceber "uma rede formada por uma gama de instituições e atores, cuja trama, por sua vez, também revela a existência de conflitos" (p. 166).

Vale destacar que foi uma opção não privilegiar a realização de entrevistas formais para o desenvolvimento da investigação e que a maior parte do trabalho reflexivo aqui apresentado está ancorada na experiência em campo. Nesse sentido, esta é uma etnografia afetada desde o princípio pela inserção da pesquisadora no campo e por relações pessoais e profissionais que, obviamente, dizem sobre aquilo que pode ser visto e compreendido a partir de um lugar bastante específico e, logicamente, também traz a marca de todos os não vistos, não ditos e inobserváveis desse mesmo posicionamento.

\section{ESTRUTURA DO LIVRO}

O que aqui se apresenta está estruturado em três partes. Alguns parágrafos acima, anunciei que esta pesquisa teve início com a mobilização criada em torno da realização da I Conferência Nacional LGBT, e este é o ponto de partida da Parte I: "A delegação e a crença no Estado". Após a realização dessa primeira conferência, um ativista declarou em uma lista de discussão: "É aquela coisa, mesmo a primeira conferência nacional tendo ficado $96 \%$ no papel, se fará a segunda e já se fala na terceira. Não sei pra quê". Procurei indicar situações como as das conferências como um evento-ritual de produção de uma imagem de "Estado" que necessariamente também é produtora dos elementos e dos sujeitos que a compõem. Assim, no capítulo 1, exploro esses eventos por meio de uma análise comparativa interessada, ressaltando questōes que me chamaram a atenção durante essas ocasiōes e que funcionaram como um norte tanto para as questóes iniciais que mobilizaram a pesquisa - quando ainda em formato de projeto - quanto para a estrutura de redação final da tese que deu origem a este livro. No capítulo 2, percorro alguns documentos produzidos pelo governo 
federal que elegi como peças fundamentais para a compreensão do contexto que tornou possível a mobilização desses eventos.

A Parte II, "Sujeitos em processo e argumentos em circulação", trata de acompanhar a produção discursiva que envolve a constituição de uma "população" específica como sujeitos de direitos. Assim, no capítulo 3, são exploradas algumas das estratégias de visibilidade forjadas com o objetivo de emprestar legitimidade para tais sujeitos e também algumas das principais tentativas de regulação de "direitos LGBT" acompanhadas durante a pesquisa de campo. Procuro, dessa forma, explorar as argumentaçôes que as justificam, bem como aquelas veiculadas por seus opositores. O capítulo 4 divide-se em três seções. A primeira trata da relação entre diferentes demandas e formatos administrativos forjados para encaminhá-las; a segunda se volta para as inflexões particularmente relacionadas ao "T" da coletividade "LGBT", procurando destacar algumas "perturbações de gênero" desestabilizadoras de convençôes que percorrem determinadas "tramas institucionais"; a terceira seção do capítulo aborda alguns dos conflitos e das disputas internas aos diferentes "segmentos" reunidos sob a "população LGBT" e que nos permitem refletir sobre dinâmicas de produção e afirmação de identidades políticas.

A Parte III, “Da proposição à execução”, volta-se para a contextualização e a descrição de parte do processo de implantação de uma política específica voltada para a "população LGBT". Destaco, especialmente, as relações que envolveram atores ligados à "academia”, ao "ativismo" e à "gestão pública", no processo de construir as rotinas administrativas necessárias à gestão cotidiana desses "novos" sujeitos.

Ao longo do texto são feitas referências a eventos e à publicação de documentos tidos como marcos para o processo de consolidação da "política LGBT" no Brasil. No Anexo A, encontra-se uma linha do tempo na qual esses "marcos" podem ser visualizados em sequência. O Anexo B apresenta uma tabela com os principais eventos observados durante a pesquisa de campo, no período entre 2008 e 2011. Já o Anexo $\mathrm{C}$ traz alguns dos documentos selecionados para a análise e referenciados no corpo do texto.

Para a redação deste livro, poderia ter sido feita a escolha de utilizar termos que sugerissem ao leitor a relativização de identidades absolutas, 
como "sexualidades ou expressões de gênero não normativas". No entanto, resolvi me ater aos próprios termos circulados pelo campo. Uma vez que a pesquisa se debruçou justamente sobre a eficácia da produção de uma categoria particular de sujeitos, gostaria que o leitor tivesse em mente que, quando no texto surgem expressões como "população LGBT", "pessoas LGBT", "política LGBT" ou "direitos LGBT", não as estou assumindo como categorias absolutas, mas seguindo os termos circulados ao longo do processo de legitimação política desses sujeitos.

Este livro é uma versão pouco modificada da tese de doutorado defendida em fevereiro de 2014. Algumas informações foram atualizadas, mas, em geral, o texto se refere a açōes e eventos sistematizados até dezembro de 2013. 


\section{PARTE I \\ A DELEGAÇÃO E A CRENÇA NO ESTADO: TECENDO UMA NARRATIVA POSSÍVEL SOBRE A CONSTITUIÇÃO DE "SUJEITOS LGBT" NO BRASIL}

Cena 1 - Noite de cinco de junho de dois mil e oito

Cheguei ao centro de convenções, um prédio vistoso no plano piloto de Brasília, mais um entre os muitos feitos para se destacar na arquitetura de largas avenidas. Notei um esquema de segurança inusitado sendo montado, incluindo algo que me pareceu um detector de metais. Fui perguntar. Disseram que "aquilo tudo" era por causa da possível presença do presidente Lula. Já dentro do salão lotado, cerca de mil pessoas talvez, me acomodei onde foi possível, um lugar quase na última fileira. À entrada de Lula seguiram-se muitas palmas, gritos e urros de saudação e contentamento. Lá na frente do salão, de pé atrás de um púlpito coberto com a bandeira do arco-íris, o presidente iniciou o pronunciamento oficial na abertura da I Conferência Nacional GLBT. Durante o discurso do presidente, cerca de 20 minutos, foram vários os momentos de aplauso em cena aberta. Ao final, as pessoas subiram nas cadeiras 
para ver melhor, fiz o mesmo. Lula pegou uma criança no colo, que se aproximou do microfone e puxou: "Brasil Sem Homofobia! Brasil Sem Homofobia! Brasil Sem Homofobia...”. No que foi acompanhada pelo presidente e todos os demais presentes.

Iniciei o projeto que deu origem à minha tese de doutorado, agora transformada neste livro, a partir da convocação da I Conferência Nacional LGBT, ${ }^{1}$ e realizei uma pesquisa de campo de forma mais ou menos contínua desde o acompanhamento dessa primeira conferência, em 2008, até a realização de sua segunda edição, em dezembro de 2011.

Nessa primeira parte, proponho uma análise comparativa, mas sem realizar um cotejamento exaustivo termo a termo. Procuro desenhar o cenário no qual a pesquisa teve início e levantar algumas das principais questôes que são aprofundadas ao longo do texto por meio da apresentação de cenas e conteúdos expostos nesses eventos e documentos.

Parte do que é apresentado aqui reflete um processo contrastivo da minha percepção do campo no tempo, ou traz a marca do desenvolvimento do próprio campo no tempo. Como será visto no material selecionado para montar esta seção, é perceptível, e não irrelevante, que na primeira conferência eu dedique mais ênfase ao que é dito e feito nos discursos de abertura e nas falas de painéis expositivos. Já na segunda conferência, o que aparece com mais destaque são falas e cenas dos debates ocorridos na plenária final. Essa diferenciação pode ser considerada segundo dois planos de interpretação. Um deles está diretamente relacionado à minha percepção do campo da pesquisa. Três anos e seis meses separam uma conferência da outra, e, em 2011, na segunda edição do evento, pude olhar e reconhecer processos que só se colocam a descoberto para aqueles que são um pouco mais entendidos no "jogo político" do campo, nos termos de Bourdieu. A dificuldade

1 A conferência foi convocada com a sigla GLBT, mas, posteriormente, convencionou-se que a sigla padrão a ser utilizada, ao menos até o presente momento, seria LGBT. Portanto, adoto essa ordem ao longo do livro, a não ser em momentos em que justamente a alteração das letras da sigla ganha relevância para a análise em curso. 
de compreensão que, numa mirada mais rápida, poderia denotar a complexidade da linguagem expressa, em verdade seria aquilo que não poderia adquirir sentido ou tornar-se inteligível para aqueles que, por não participarem do jogo, não são capazes de dar conta das relações travadas em determinado campo político:

[...] menos inteligivel do que desprovida de razão de ser aos que, não participando no jogo, 'não veem nele interesse' e não podem compreender que este ou aquele distinguo entre duas palavras ou entre dois rodeios de frase de um discurso-jogo, de um programa, de uma plataforma, de uma moçâo ou resolução, dê lugar a tais debates, visto que não aderem ao principio das oposiçóes que suscitam os debates geradores desses distinguos (Bourdieu, 1989, p. 178).

Algumas (ou muitas) nuanças de significado dos discursos, disputas e performances dos participantes das conferências jamais poderiam ser alcançadas por mim, ainda em 2008, quando dava meus primeiros passos nesse campo de pesquisa e ignorava as relações entre grupos, pessoas, partidos e seus interesses particulares. Já em 2011, deixei de registrar nos meus cadernos de campo, mais ou menos conscientemente, aquilo que eu costumava minutar nos primeiros anos da pesquisa: falas protocolares e lugares comuns no discurso de representantes institucionais, recorrências reivindicativas de lideranças da militância e dinâmicas ritualísticas de funcionamento de eventos. Ou seja, aquilo que já estava saturado pela minha percepção do campo foi perdendo espaço nas minhas anotaçóes. Na segunda conferência, detive-me em elementos "observáveis" na plenária final, lugar em que conflitos e diferenças aparecem com mais vigor, menos controlados por discursos pré-rascunhados, ou onde os “imponderáveis" se mostram com mais relevo.

Se os jogos da plenária são menos reconhecíveis para não entendidos nas relações travadas no campo, num outro plano, podemos considerar que eu não fui a única a adquirir competência nesse jogo político. Se agucei minha percepção como observadora e eventual participante dessa cena, em três anos e seis meses, os seus protagonistas igualmente 
aprimoraram técnicas de discurso, adquiriram mais competência em códigos e linguagens e aperfeiçoaram o manejo do capital pessoal, político e partidário disponível.

A partir desse pano de fundo e buscando puxar alguns fios da trama que vêm construindo os "sujeitos LGBT" no Brasil, nesta primeira parte, discuto as conferências como um ritual de delegação, no sentido de que as encaro como eventos de produção da representação, ao mesmo tempo que produzem justamente aquilo que precisa ser representado. Em seguida, trabalho com documentos que preparam o campo para aquilo que precisa ser delegado, ou que institucionalizam o que foi produzido pelo ritual de delegação. Como será desenvolvido adiante, utilizo como referências principais para essa reflexão o trabalho de Mariza Peirano (2001) sobre a abordagem antropológica de eventos como rituais, ${ }^{2}$ o de Bourdieu a respeito da delegação e da representação política (1989 e 2004) e os desenvolvimentos deAbrams (1988) e Mitchell (2006) para uma visão do estado-ideia e dos efeitos de Estado, respectivamente.

2 Essa abordagem vem sendo amplamente explorada pelo grupo de pesquisadores reunidos no Núcleo de Antropologia da Política (NUAP), coordenado pelos professores Mariza Peirano (UnB) e Moacir Palmeira (MN-UFRJ), e de diversas instituiçōes, dedicando-se a explorar significados culturais e sociais de processos da política no Brasil por meio da etnografia de eventos, rituais, entre outras situaçôes consideradas estratégicas. 


\section{CAPÍTULO 1 AS CONFERÊNCIAS E A PRODUÇÃO DE UM CAMPO DE “DIREITOS LGBT"}

Portanto, essa espécie de ato original de constituiçáo, no duplo sentido, filosófico e político, que a delegação representa é um ato de magia que permite fazer existir o que não passava de uma coleção de pessoas plurais, uma série de individuos justapostos, sob a forma de uma pessoa fictícia [...] (Bourdieu, 2004, p. 194).

Em 28 de novembro de 2007, um Decreto da Presidência da República convocou a I Conferência Nacional de Gays, Lésbicas, Bissexuais, Travestis e Transexuais. Esse decreto determinou que a realização da conferência, em data ali estipulada, estava sob os auspícios da então chamada Secretaria Especial de Direitos Humanos, a partir de uma comissão organizadora constituída por meio de uma portaria, e que 
a reunião nacional teria a participação de "delegados representantes da sociedade civil", eleitos em conferências estaduais, e "delegados do poder público, na proporção sessenta e quarenta por cento, respectivamente". ${ }^{1}$

Ainda de acordo com o decreto, os trabalhos da conferência deveriam se dar em torno do tema "Direitos Humanos e Políticas Públicas: o caminho para garantir a cidadania de Gays, Lésbicas, Bissexuais, Travestis e Transexuais" e teriam como objetivos: “i) propor as diretrizes para a implementação de políticas públicas e o plano nacional de promoção da cidadania e direitos humanos de Gays, Lésbicas, Bissexuais, Travestis e Transexuais - GLBT; e ii) avaliar e propor estratégias para fortalecer o Programa Brasil Sem Homofobia”.

No início de 2008, fui convidada a participar de uma das primeiras reuniōes preparatórias do processo de organização das conferências no Rio de Janeiro. Uma situação presenciada naquela reunião despertou meu interesse e provocou algumas das ideias iniciais que deram origem a esta pesquisa.

Naquela ocasião, foi apresentado o Regimento da conferência, elaborado pela Comissão Organizadora Nacional, contendo algumas regras para a organização das etapas estaduais e a metodologia de participação. Para o que viso ressaltar aqui, são dois os pontos relevantes desse documento: o artigo 8. ${ }^{\circ}$ - "A realização da Conferência Estadual é fator indispensável para escolha dos delegados da Conferência Nacional GLBT" - e o artigo 28 - "A delegação a ser eleita nas Conferências Estaduais para a Conferência Nacional deverá ser composta por, no mínimo, $50 \%$ de pessoas com identidade de gênero feminina (mulheres, lésbicas, bissexuais, transexuais e travestis)". ${ }^{2}$

1 PRESIDÊNCIA DA REPÚBLICA. Casa Civil. Subchefia para assuntos jurídicos. Decreto de 28 de novembro de 2007. Convoca a I Conferência Nacional de Gays, Lésbicas, Bissexuais, Travestis e Transexuais e dá outras providências (não numerado). Ver anexo C1, p. 339. Disponível em: http://www.planalto.gov.br/ccivil_03/_Ato2007-2010/2007/Dnn/Dnn11426.htm. Acesso em: 5 fev. 2013.

2 Regimento da Conferência Nacional de Gays, Lésbicas, Bissexuais, Travestis e Transexuais: "Direitos Humanos e Politicas Públicas: o caminho para garantir a cidadania de Gays, Lésbicas, Bissexuais, Travestis e Transexuais". Aprovado pela Comissāo Organizadora em 10 de janeiro de 2008. A Comissão Organizadora responsável pela elaboração do regimento foi constituída a partir de uma portaria da 
Após a leitura do regimento, notei um pequeno alvoroço entre algumas mulheres, integrantes de movimentos de lésbicas, perto de mim e me aproximei para perguntar o que estava acontecendo. Escutei uma dizer para a outra: "Precisamos ficar atentas, senão elas vão pegar o nosso lugar", e o "elas", aqui, referia-se principalmente a travestis e mulheres transexuais. Fiquei sabendo depois que estas últimas poderiam ocupar as cotas de "identidade de gênero feminina", diminuindo as vagas para mulheres lésbicas.

Ainda pouco experimentada nas dinâmicas do campo de pesquisa, o que mais me chamou a atenção na cena foi a explicitação da disputa entre as identidades agregadas então sob a sigla GLBT e o quanto isso era um reflexo dos limites ou um efeito das políticas calcadas justamente em identidades. Mais tarde, durante a pesquisa, percebi que as disputas entre o "L" e o "T" da sigla eram frequentes, mas não só, como será visto adiante. Num outro plano, comecei a refletir sobre como um documento - no caso, um regimento - resultante de uma iniciativa cristalizada em outro documento - um decreto presidencial de abrangência nacional - reverberava no plano local. Um decreto estipulou uma situação nova, provocou a formação de uma comissão organizadora que, por sua vez, estabeleceu mais uma série de critérios e condiçōes, instando pessoas a se mobilizarem para realizar um evento com prazos, método e formatos específicos de participação preestabelecidos.

Ainda sobre critérios de participação, impressionou-me a inserção de cotas de gênero como condição necessária para a formação da delegação, com o estabelecimento de quais sujeitos poderiam ser incluídos ou se incluírem nas cotas de identidade de gênero feminina (repito: "mulheres, lésbicas, bissexuais, travestis e transexuais") e o que isto queria dizer sobre as concepçōes a respeito de gênero e sexualidade que ali estavam sendo operadas. Então, um homem gay não poderia se identificar com o gênero feminino? Por que não? Então, o que exatamente definiria gênero nessa situação senão a autoclassificação? Apenas aqueles

Secretaria de Direitos Humanos (Portaria no 260, de 21 de dezembro de 2007, publicada no Diário Oficial da Uniāo n. ${ }^{\circ} 246$, de 24 de dezembro de 2007). 
que se identificam como travestis e transexuais poderiam dispor da dissociação entre identidade de gênero e sexo anatômico? Uma mulher que se identificasse com o gênero masculino seria compulsoriamente computada nas cotas de gênero feminino independentemente disso? ${ }^{3}$

Ao me sentir intrigada com esse tipo de disputa e de diferenciações institucionalizadas em decretos e regimentos, entre outras questóes, comecei em 2008 a observar e a participar das etapas no Rio de Janeiro que antecederam a I Conferência Nacional LGBT.

Compreendo as conferências como eventos-chave para a produção não só do que se convencionou chamar "população LGBT" para o governo brasileiro, mas também do campo mais amplo que envolve o que poderíamos denominar de "políticas LGBT" no Brasil. Esse conjunto de relações abarca organizações não governamentais, movimentos sociais estruturados em diferentes formatos, o campo acadêmico que se dedica à reflexão sobre o tema e uma série de atores e objetos multifacetados. Encaro-os como espaços privilegiados para perceber como esse universo é produzido relacionalmente e como conflitos, embates e disputas funcionam para constituir e continuamente definir os limites e as fronteiras do próprio campo.

Outra determinação da comissão organizadora da I Conferência Nacional foi a de que a realização das conferências estaduais ficaria a cargo de comissões organizadoras a serem estabelecidas localmente. ${ }^{4}$ No Rio de Janeiro, a conferência foi convocada por decreto do governador, em 28 de fevereiro de 2008. Segundo este, antes do encontro estadual, nove pré-conferências regionais abrangendo todos os municípios do estado deveriam ser realizadas com a "finalidade de discutir a interiorização e a ampliação da participação do Movimento LGBT local e gestores públicos locais e eleição de delegados para a conferência estadual". O decreto ainda apontou os objetivos da

3 Cabe notar aqui que, nessa época, início de 2008, a presença de homens transexuais era rara nessa cena política.

4 Deixando claro que a prerrogativa de convocar e promover as conferências nos estados seria dos governos estaduais. De fato, a realização de conferências no nível estadual depende da vontade dos governos executivos locais, uma vez que o governo federal não pode desrespeitar a autonomia dos estados estabelecida pela Constituição Federal. 
conferência: “i) discutir e propor as diretrizes para a implementação de políticas públicas e o plano nacional e estadual de promoção da cidadania e direitos humanos de Gays, Lésbicas, Bissexuais, Travestis e Transexuais (GLBT); ii) avaliar e propor estratégias para implantar o Programa Estadual Rio Sem Homofobia; iii) avaliar e propor estratégias para fortalecer o Programa Brasil Sem Homofobia; iv) eleger os delegados do estado do Rio de Janeiro para a Conferência Nacional".

As pré-conferências previstas pelo decreto, segundo relatório elaborado pela Superintendência de Direitos Individuais, Coletivos e Difusos (SuperDir) da Secretaria de Estado de Assistência Social e Direitos Humanos (SEASDH-RJ), reuniram cerca de 1.200 pessoas. Já para a Conferência Estadual, o relatório aponta cerca de 600 participantes. Não me atenho aqui aos eventos estaduais, apresento apenas alguns dados mais gerais para dar uma noção da série de conferências que ocorreram antes da nacional e do tipo de mobilização que provocaram. ${ }^{6}$

De fato, causava impressão a quantidade de pessoas que pareciam subitamente mobilizadas politicamente em torno da reivindicação de "direitos LGBT". Segundo uma das pessoas envolvidas na organização dos eventos, a mobilização foi possível por conta de diversas articulações e parcerias feitas com prefeituras, secretarias, ONGs e todo tipo de lideranças locais (não necessariamente envolvidas de forma direta com grupos LGBT). E, assim, um dos objetivos apresentados pela organização - o de fortalecer "redes de articulação e mobilização do movimento social LGBT no estado" - parece ter sido logrado. Onde não havia qualquer tipo de movimento organizado, a partir daquele momento, passava a existir.

Acredito que a pergunta pode ser expandida: O quanto de movimento social foi criado e quantas demandas foram provocadas a partir do

5 Decreto n. ${ }^{\circ} 41.196$, de 28 de fevereiro de 2008. Publicado no Diário Oficial do Estado do Rio de Janeiro. Ver anexo C1 (p. 339). No capítulo 5, detenho-me no processo de implantação da política Rio Sem Homofobia.

6 Acompanhei no Rio de Janeiro a Pré-Conferência de Políticas Públicas para GLBT da Capital da Cidade do Rio de Janeiro e a I Conferência de Políticas Públicas para GLBT do Estado do Rio de Janeiro, ambas realizadas na Universidade do Estado do Rio de Janeiro, de 15 a 18 de maio de 2008. 
decreto da I Conferência Nacional e da consequente mobilização de pessoas para participarem segundo critérios predefinidos? Todos os 27 estados da federação realizaram conferências estaduais e enviaram "delegados" para a etapa nacional, que enfim ocorreu em junho de 2008. A I Conferência Nacional de Gays, Lésbicas, Bissexuais, Travestis e Transexuais (GLBT) aconteceu em um imenso centro de convençōes em Brasília. Ao todo, foram 1.118 participantes, distribuídos entre "delegados" (569), "observadores" (441) e convidados (108).?

Com o tema "Direitos Humanos e Políticas Públicas: o caminho para garantir a cidadania GLBT", como citado anteriormente, o objetivo da conferência era sugerir propostas e açōes para a elaboração do Plano Nacional de Promoção da Cidadania e Direitos Humanos LGBT. Para cumprir esse objetivo, as atividades de discussão de propostas foram divididas em dez grupos de trabalho. ${ }^{8}$ Todos os participantes receberam o texto-base ${ }^{9} \mathrm{da}$ conferência e um caderno de propostas consolidadas, que consistia em uma condensação dos relatórios finais das conferências estaduais.

De maneira geral, a metodologia das conferências segue um mesmo modelo. Após a solenidade de abertura, há uma primeira plenária que visa à aprovação do regulamento da reunião. Com o regulamento aprovado, seguem-se alguns painéis expositivos, e depois os participantes se dividem em grupos para discutir e compor propostas. Findo o trabalho nos grupos, as propostas aprovadas vão para apresentação na plenária final, na qual poderão ser suprimidas, alteradas ou aprovadas em caráter definitivo para inclusão no relatório final do evento.

7 PRESIDÊNCIA DA REPÚBLICA. Secretaria Especial de Direitos Humanos. Anais da Conferência Nacional de Gays, Lésbicas, Bissexuais, Travestis e Transexuais. Brasil, 5 a 8 de junho de 2008.

8 Grupos de Trabalho da I Conferência LGBT 2008: 1-direitos humanos; 2-saúde; 3-educação; 4-justiça e segurança pública; 5-cultura; 6-comunicação; 7-turismo; 8-trabalho e emprego; 9-previdência social; 10-cidades e esportes.

9 O conteúdo do texto-base tratava de um apanhado da história do movimento LGBT, um panorama breve da conjuntura internacional e de iniciativas legislativas nacionais, "Princípios e diretrizes do evento", uma revisão de iniciativas de políticas públicas para o tema, um "diagnóstico" e "estratégias de gestão e de ação" para cada um dos temas dos grupos de trabalho, um item versando sobre açôes governamentais desenvolvidas com o foco em "mulheres", um item sobre "temas transversais", a saber: "idosos", "pessoas com deficiência", "infância, adolescência e juventude" e mais dois itens versando sobre o Ministério Público e o Poder Judiciário 
A programação da I Conferência se estendeu por uma noite e três dias inteiros. A primeira noite foi tomada pela solenidade de abertura, uma "palestra magna" e a presença, não anunciada quando da divulgação da programação do evento, do presidente Lula.

Como fiquei sabendo depois, a presença do presidente era uma possibilidade, mas causava desconfiança em muitos, ainda poucos minutos antes do início da cerimônia de abertura. Embora breve, a sua fala se estendeu para além do que exigiria o protocolo, surpreendendo até mesmo os mais otimistas presentes. Apesar de certos deslizes no discurso terem causado incômodo inicial a alguns ativistas (como o uso da palavra "homossexualismo" e do termo "opção sexual" sua presença foi o ponto alto do evento. Conversando com vários participantes na época, ouvi que ter o presidente discursando na conferência significava o "reconhecimento pelo Estado" da legitimidade das demandas LGBT. Ao longo dos dias que sucederam a abertura, também era comum ouvir nos bastidores que só o fato de a conferência estar acontecendo já era uma enorme vitória.

Em seu discurso, Lula fez comparaçōes com a Conferência da Igualdade Racial e citou o projeto do Estatuto da Igualdade Racial como exemplo de que, se não houvesse um consenso nas proposiçôes a serem encaminhadas para o Congresso Nacional, estas não poderiam ser votadas, caso do referido Estatuto naquele momento. O presidente garantiu que: "[...] o tratamento que vocês terão, com o documento que apresentarem, será igual ao tratamento que nós demos às 49 conferências que aconteceram antes da de vocês. Se não for assim, nós estaremos fazendo apenas uma meia democracia $[. .$.$] ".$

\footnotetext{
10 “[...] ninguém pergunta a opção sexual de vocês na hora de pagar Imposto de Renda, ninguém pergunta quando vai pagar qualquer tributo nesse país. Por que discriminar na hora em que vocês, livremente, escolhem o que querem fazer com o seu corpo?”. O termo “opção sexual” é profundamente rechaçado pelo movimento organizado, pois denotaria uma questão de escolha pessoal consciente, o que, politicamente, por exemplo, poderia dar abertura para iniciativas como o Projeto de Lei 717/2003, de autoria de um deputado religioso, que previa a destinação de verbas públicas para "curar" homossexuais. Já "homossexualismo" é uma palavra rechaçada por ter um sufixo que traria referenciais relacionados à doença e não a dimensōes mais amplas da sexualidade. Sendo assim, os termos tidos como corretos politicamente são "orientação sexual" e "homossexualidade".
} 
Respondendo a uma brincadeira feita pelo então presidente da Associação Brasileira de Gays, Lésbicas, Bissexuais, Travestis e Transexuais - ABGLT, ${ }^{11}$ Toni Reis, em fala que o antecedeu, o presidente se disse orgulhoso do fato de que "nunca antes na história do planeta um presidente convocou uma conferência como esta", e afirmou: "estamos vivendo no Brasil um momento de reparação". Encerrou a sua explanação ressaltando o marco que representava aquele evento: "Então, eu acho que esse dia é realmente histórico. Eu penso que vocês não têm ainda a dimensão do que este dia pode causar como efeito multiplicador de quebra de preconceitos e de conquista de direitos".

O discurso do presidente encerrou a solenidade de abertura após as exposiçôes de algumas outras "autoridades". O então ministro da Secretaria Especial de Direitos Humanos da Presidência da República, Paulo Vanucchi, afirmou que a conferência fazia parte da revisão do Plano Nacional de Direitos Humanos, que em 2008 passava por um "debate inédito":

[...] no cômputo das muitas conferências já realizadas [...] o PNDH náo deveria ser mais do que a junçáo da conferência da mulher, da conferência da igualdade racial, da conferência da saúde, das conferências de cada um dos segmentos [...]. Nesse encontro, o Brasil cresce mais um pouco como exemplo de democracia [...] democracia que avança em direitos humanos pouco a pouco, mesmo sobre a base de quatro séculos de escravidão [...] a criação da Seppir, a política de cotas representam a sustentação da equidade [...] Não é um fenômeno meramente substantivo de igualdade. Equidade é mais preciso e mais concreto. É justiça no caso concreto. Equidade é tratar desigualmente os desiguais, para produzir justiça.

Traçando um paralelo com a declaração do racismo como incompatível com a democracia, o ministro afirmou que "o que

${ }^{11}$ Associação criada em 1995 que, à época da pesquisa, agregava mais de 280 organizaçōes filiadas em todo o Brasil, sendo, de acordo com o seu site, a maior rede LGBT na América Latina. É a instância que costuma responder nacionalmente pela "população LGBT". 
queremos hoje é declarar a homofobia como incompatível com a democracia" e que ali o Brasil declarava ser "o lugar sim da convivência na diferença”. E encerrou sua fala dizendo que, por meio de estratégias de "enfrentamento" e "convencimento", deveríamos nos ver como parte da luta em "defesa dos direitos da criança, da igualdade de gênero, da igualdade racial", que "é a mesma luta dos índios, das pessoas portadoras de deficiência". ${ }^{12}$

O discurso de Paulo Vanucchi chama a atenção também pela forma e pelo número de vezes com que se dirige retoricamente ao presidente da República. Em oito páginas de transcrição, o "presidente" é pontuado 17 vezes durante o seu pronunciamento, como exemplifica o trecho: "o nosso enorme agradecimento, presidente, a todo o apoio, a toda a força que nos deu em momentos de hesitação", ou "eu me perguntava hoje, presidente, se este encontro celebra mais a liberdade ou mais a igualdade", ou "Presidente, nosso planeta ainda tem países onde a homossexualidade é punida com pena de morte". Este é um recurso retórico comum de técnicas de oratória, mas também representa uma estratégia de chamamento e comprometimento do presidente ali presente, tendo sido utilizada ainda com mais ênfase pelo presidente da ABGLT, que, em cinco páginas de transcrição, invocou o "presidente" 19 vezes: "É isso que nós queremos, presidente Lula. E nós colocamos nas suas mãos o nosso futuro para a questão da discriminação".

$\mathrm{Na}$ intervenção do então ministro da Saúde, reverberou como destaque o anúncio da realização de cirurgias de transgenitalização pelo Sistema Único de Saúde (SUS). O ministro também ressaltou a possibilidade do uso do nome social por travestis e transexuais usuárias/os do SUS e comentou sobre a "resposta brasileira à epidemia de AIDS”, reconhecendo o papel do ativismo LGBT na construção de um embasamento na defesa dos direitos humanos.

$\mathrm{O}$ segundo dia foi ocupado por painéis temáticos. $\mathrm{O}$ painel de abertura "Introdução à orientação sexual e identidade de gênero" consistiu em uma exposição didática que pareceu uma tentativa de

\footnotetext{
${ }^{12}$ Como será visto, a comparação insistente e a inserção da "luta" LGBT no bojo da luta de outras "minorias" são constantes.
} 
estabelecer ali um consenso sobre como definir conceitualmente os termos que davam título à apresentação. Em seguida, o painel "Conjuntura internacional - contextualização e perspectivas" contou com a participação de representantes de outros países da América Latina e da África, em exposiçōes que fizeram referência a tratados e convenções internacionais de direitos, manifestaram ausências de marcos regulatórios de direitos relacionados à orientação sexual e à identidade de gênero, e, algumas vezes, mencionaram o quanto o Brasil tinha "avançado" em relação às ações (ou não açōes) de governos de outros países.

Após esses dois primeiros painéis, os quatro seguintes se dedicaram, respectivamente, ao "Poder Legislativo", ao "Poder Judiciário e Ministério Público", ao "Poder Executivo" e ao "Poder Público Federal". Destaco aqui apenas alguns pontos levantados nessas exposições.

O painel sobre o Poder Legislativo ressaltou justamente a falta de legislação federal relativa aos "direitos LGBT" e a inércia do Legislativo quanto aos variados casos de ações favoráveis envolvendo tais direitos no Judiciário. A explicação para o não andamento dos projetos no Legislativo foi creditada à "falta de articulação", à necessidade de localizar "aliados" e de reavaliar "táticas" de incidência política e à "reação fundamentalista" de determinados "segmentos religiosos" do Congresso Nacional. Como prioridades da "agenda Legislativa LGBT" foram destacadas: a regulação da união civil entre pessoas do mesmo sexo, a criminalização da homofobia e a mudança de prenome para transexuais (não necessariamente nesta ordem).

As exposições do painel do Judiciário deram certo destaque para a atuação do Ministério Público. Alguns expositores ressaltaram a possibilidade de obter resultados por meio da judicialização de demandas, como forma indireta de pressionar o Legislativo, ${ }^{13}$ enquanto outros criticaram esse tipo de estratégia. Para alguns, o Judiciário representa um espaço importante de visibilidade para determinadas demandas, ao

\footnotetext{
${ }^{13}$ Fala de uma procuradora: "Eu acho que a gente tem muito para conquistar. Mas é a atuação no dia a dia, judicializando ao máximo as demandas que forem possíveis, porque se cria uma situação prática que o legislador vai ter que enfrentar".
} 
passo que outros fizeram referência a decisóes favoráveis de juízes apenas como vitórias isoladas.

O último bloco abordou açôes previstas no programa Brasil Sem Homofobia. Expositores ligados ao governo buscaram apontar ações realizadas ou a realizar, e expositores que representavam de algum modo o movimento social cobraram ações não cumpridas. ${ }^{14}$

O terceiro dia do encontro foi aberto com a votação do regulamento da conferência, que se estendeu por uma longa votação na plenária repleta de destaques e disputas. Tiveram, então, início os grupos de trabalho, que se seguiram até a noite. Divididos por temas, os grupos se constituíram como espaços de discussão, elaboração e aprovação de propostas. E o último dia do evento foi todo reservado para a plenária final, com apresentação e discussão das propostas aprovadas nos grupos, e também de votação de moções e da "carta de Brasília". A plenária final, palco de muitos conflitos e debates, só terminou na madrugada, por volta das $2 \mathrm{~h} 30$. O tempo para discussão parece nunca ser suficiente, porque todos precisam falar e ser ouvidos para que a plenária se constitua de fato como "um espaço democrático". ${ }^{15}$ Apresentarei mais adiante um pouco do formato e do conteúdo das propostas debatidas, percorrendo os documentos produzidos como resultado do evento.

Assim, o que sobressaiu da I Conferência foi que, embora denúncias de violação de direitos tenham sido recorrentes e, consequentemente, tenha havido a chamada de responsabilização do "Estado" para essa situação, o clima geral foi de celebração de "um marco histórico". O "reconhecimento pelo Estado" foi a tônica predominante.

Uma resolução marcante do evento foi a aprovação da alteração da sigla que representa a coletividade. Se até aquele momento a ordem das

\footnotetext{
${ }^{14}$ Após as exposições dos painéis, que tomaram a manhã e a tarde do segundo dia do evento, a noite ainda reservou espaço para o lançamento de livros, exposiçōes e outras "atividades culturais".

${ }^{15}$ Ao se dedicar à análise de reuniōes de formatos diversos entre trabalhadores rurais, Comerford (1999, 2002) destrincha alguns dos elementos precípuos que, de modo geral, as compõem: um objetivo, uma pauta, uma programação, uma coordenação, o uso da palavra falada e escrita e elementos de conclusão, como propostas e definição de ações. Entre os procedimentos esperados, consta a fala de todos, ou seja, que as reuniōes sejam de fato um espaço de que todos participem. E, ao falar, é preciso demonstrar o domínio do bom uso da palavra, incluindo convencimento e persuasão de quem ouve.
} 
letras que a compõem era GLBT, o "L” (relacionado a lésbicas) passou a ser usado no início da sigla: LGBT. A justificativa da alteração foi dar mais "visibilidade" ao "segmento" de lésbicas. Como resultado consolidado do encontro, foi lançado o Plano Nacional de Promoção da Cidadania e Direitos Humanos de LGBT em maio de 2009.

A I Conferência, como o nome indica, trazia no seu horizonte a realização de outras ediçóes. A expectativa era de que um processo contínuo de produção e avaliação de diretrizes para a implementação de políticas públicas se iniciasse ali. Passados pouco mais de três anos, entre os dias 15 e 18 de dezembro de 2011, aconteceu em Brasília a II Conferência Nacional de Políticas Públicas e Direitos Humanos de LGBT, com o tema "Por um país livre da pobreza e discriminação: promovendo a cidadania de lésbicas, gays, bissexuais, travestis e transexuais".

Cena 2 - Noite de quinze de dezembro de dois mil e onze

É anunciada a formação da mesa de abertura, e seus componentes são chamados a subir ao palco. Auditório lotado. Vemos e ouvimos o público de pé, com faixas e bandeiras em punho, algumas vaias, vociferando repetidamente: "Ô Dilma, que papelão, não se governa com religião!"; "A Dilma pisou na bola, a homofobia continua na escola!”. O Hino Nacional começa a ser cantado pela travesti Valéria Houston, cortando a gritaria da plenária. Alguns ainda resistem um pouco, mas acabam aderindo ao hino, de pé. Ao término, a audiência prossegue repetindo: "Ô MEC, sai do armário, o kit homofobia é prioritário!”. A mesa dá continuidade aos trabalhos como se nada incomum estivesse acontecendo. O cerimonial cita as "autoridades" presentes, e, em seguida, a travesti Keila Simpson é chamada para recitar um poema. Faz-se silêncio novamente.

O clima da abertura de 2011 foi bastante diferente daquele a que assistimos na primeira edição da Conferência, na qual o presidente 
Lula e os demais representantes do governo foram efusivamente ovacionados. $\mathrm{Na}$ abertura da II Conferência, com o auditório lotado, ouvimos vaias, gritos de protesto, cartazes e palavras de ordem que criticavam diretamente a presidente Dilma e a sua gestão e denotavam uma atmosfera de insatisfação geral.

Os protestos direcionavam-se primordialmente ao veto do kit anti-homofobia nas escolas, decisão que teria sido tomada pela presidente sob pressão de lideranças religiosas. ${ }^{16}$ Alguns cartazes faziam referências e cobravam a necessidade de criminalização da homofobia, numa alusão bastante clara ao projeto de lei que tramitava desde 2006 no Congresso Nacional. ${ }^{17}$ Três enviados do governo federal compuseram a mesa de abertura representando a presidente: a ministra Maria do Rosário (Secretaria de Direitos Humanos - SDH), a ministra Luiza Bairros (Secretaria de Políticas de Promoção da Igualdade Racial - SEPPIR) e o ministro Gilberto Carvalho (Secretaria-Geral da Presidência da República). Diante das vaias, a ministra da SDH procurou reverter a situação, dizendo estar presente como ministra da presidente Dilma: “orientada diretamente pela presidente Dilma

\footnotetext{
${ }^{16} \mathrm{O}$ kit foi um material educativo de combate à homofobia nas escolas, elaborado pelo Ministério da Educação, que deveria ser distribuído nas escolas de ensino médio da rede pública. Entretanto, em maio de 2011, a distribuição do material foi suspensa pela presidente Dilma sob a alegação de que parte do material traria conteúdo não adequado para distribuiçăo nas escolas e deveria ser reformulado. Já a acusação do movimento social e as versões que circulavam na imprensa denunciavam que a decisão teria sido tomada pela presidente sob pressão de lideranças religiosas. Dilma teria negociado com a bancada parlamentar evangélica o veto ao kit anti-homofobia em troca da garantia de que o ex-ministro Palocci não seria chamado a depor no Congresso para dar explicaçōes sobre o crescimento de seu patrimônio durante o período de sua atuação no ministério. Ver "Para salvar Palocci, Dilma cede e suspende kit anti-homofobia", publicado em 25 de maio de 2011, Estadão.com. br (http://www.estadao.com.br/noticias/nacional,para-salvar-palocci-dilma-cede-e-suspende-kit-antihomofobia,724005,0.htm). Disponível também o anexo C2 (p. 340-341); "Após pressão, governo irá reavaliar kit anti-homofobia", em 19 de maio de 2011, Folha.com (http://www1.folha.uol.com. br/cotidiano/917690-apos-pressao-governo-ira-reavaliar-kit-anti-homofobia.shtml); "Militantes pretendem vaiar Dilma por veto ao kit anti-homofobia", em 11 de julho de 2011, Portal Terra Notícias (http://noticias.terra.com.br/educacao/noticias/0,,OI5236200-EI8266,00-Militantes+pr etendem+vaiar+Dilma+por+-veto+ao+kit+antihomofobia.html); "Um ano após veto, MEC diz que não desistiu de kit anti-homofobia" (http://noticias.terra.com.br/educacao/um-ano-apos-veto-mecdiz-que-nao-desistiu-de-kit-anti-homofobia,677a42ba7d2da310VgnCLD200000bbcceb0aRCRD. Html). Para uma análise minuciosa e sofisticada do Projeto Escola sem Homofobia, ver Leite (2014).

17 O PLC 122/2006 é um projeto de lei, originado na Câmara dos Deputados, que propõe a criminalização da discriminação baseada em orientação sexual e identidade de gênero.
} 
para estar aqui, trabalhando pela superação da homofobia". Disse ainda considerar e respeitar as reclamações anunciadas e que estava ali para "reacender a chama da confiança no governo da presidente Dilma". Grande parte da insatisfação manifestada pelos presentes nessa solenidade de abertura se devia justamente à ausência da presidente, o que refletiria diretamente o não comprometimento do seu governo com a "causa LGBT". Outra grande reclamação se direcionava também à ausência do ministro da Educação e do ministro da Saúde, presentes na reunião de 2008.

Durante a II Conferência Nacional LGBT, o ponto alto de comemoração foi a decisão do Supremo Tribunal Federal que garantiu o direito de união estável aos casais de mesmo sexo em maio daquele ano. ${ }^{18} \mathrm{~A}$ ministra da $\mathrm{SDH}$ ressaltou a importância histórica dessa decisão por seu papel na introdução de um novo conceito de família e exaltou a figura do ministro Ayres Britto, relator da ação no Supremo, que, em seguida, faria a palestra magna de abertura, intitulada "Reconhecimento de LGBT como sujeitos de direitos".

As falas na abertura de 2011 certamente não causaram o mesmo impacto das de 2008, possivelmente porque não estavam envolvidas na mesma aura de "marco histórico". Além das ministras, compuseram a "solenidade de abertura" um deputado federal, Jean Wyllys ${ }^{19}$ (PSOL-

\footnotetext{
${ }^{18} \mathrm{O}$ julgamento teve origem na Ação Direta de Inconstitucionalidade (ADI) 4277 e na Arguição de Descumprimento de Preceito Fundamental (ADPF) 132. A ADI 4277 foi ajuizada pela Procuradoria Geral da República e pediu o reconhecimento da união entre pessoas do mesmo sexo como entidade familiar, e que os direitos e os deveres previstos na Constituição para uniōes estáveis fossem equiparados às uniōes estabelecidas entre pessoas do mesmo sexo. A ADPF 132, apresentada pelo governador do Rio de Janeiro, Sergio Cabral, alegou que a não aplicação às "uniōes homoafetivas do mesmo regime jurídico das uniōes estáveis" feria o princípio da dignidade da pessoa humana e os princípios da igualdade, da liberdade e da segurança jurídica, todos explicitados na Constituição Federal. As duas açōes foram votadas em conjunto e aprovadas por unanimidade. A partir da publicação do acórdão do STF, todos os tribunais do Brasil devem seguir o mesmo entendimento (O documento referente ao acórdão pode ser encontrado no endereço: http://www.stf.jus.br/portal/ autentica- cao/, através do número '1319706'. Acesso em: abr. 2013).

${ }^{19}$ Com formação em Jornalismo e Letras, Jean Wyllys ficou famoso em 2005 depois de ganhar uma edição do reality show Big Brother Brasil. Atuou como professor em universidades particulares e como articulista de revistas de grande circulação. Foi eleito deputado federal pelo Rio de Janeiro para o mandato 2011-2015. Segundo o seu site: "Jean Wyllys tem uma história de envolvimento com trabalhos em favor da justiça social, de uma educação para a cidadania e para a valorização da vida, e em favor das liberdades civis que remonta à sua adolescência, quando pertencia às pastorais
} 
$\mathrm{RJ})$, e mais cinco representantes do movimento social. Entre estes últimos, algumas falas se referiram ao presidente Lula, lamentando a sua ausência ou novamente exaltando a importância de sua presença na primeira edição do evento. Todos fizeram menção à garantia da laicidade do estado, em face da presença dos "fundamentalistas", ou "ditadura evangélica", ou "ditadura religiosa", no Congresso.

O segundo dia da conferência foi dedicado à plenária inicial de discussão e aprovação do "Regimento Interno" e aos painéis "Poder Legislativo e direitos da população LGBT", "Políticas públicas e direitos da população LGBT" e "Políticas de inclusão social e cidadania da população LGBT". Os painéis foram montados de maneira que as exposiçôes ficassem a cargo de representantes do governo (de secretarias e ministérios), e o debate e a coordenação das mesas couberam a pessoas ligadas ao movimento social e à universidade. Após a noite de abertura e um dia inteiro de painéis expositivos, o terceiro dia da conferência foi dedicado aos grupos de trabalho, organizados em torno de nove eixos. ${ }^{20}$

Como resultado consolidado da I Conferência, realizada em 2008, foi lançado o Plano Nacional de Promoção da Cidadania e Direitos Humanos de LGBT em maio de 2009. A II Conferência seria o momento de avaliar a execução desse plano e aperfeiçoar propostas. Mas isso não foi feito. Os grupos de trabalho tiveram como tarefa formular cinco grandes diretrizes orientadoras. Essas diretrizes, discutidas e aprovadas em plenária no quarto dia do evento, teriam o propósito de servir de base para que o Conselho Nacional LGBT elaborasse um novo plano ou uma nova versão do Plano Nacional de Promoção da Cidadania e Direitos Humanos de LGBT. Mas essa dinâmica não ficou bem esclarecida entre os participantes, e o

da Juventude Estudantil e da Juventude do Meio Popular, e atuava nas comunidades eclesiais de base da Igreja Católica. Parceiro dos movimentos LGBT, negro e de mulheres, Jean Wyllys participa de ações que combatem a homofobia, a intolerância e o fundamentalismo religioso, a discriminação contra o povo de santo, o trabalho escravo, a exploração sexual de crianças e adolescentes e as violências contra a mulher" (http://jeanwyllys.com.br/wp/bio. Acesso em: abr. 2013).

20 1. Poder Legislativo e direitos humanos da população LGBT; 2. Cultura, turismo, esporte e comunicação social; 3. Saúde; 4. Educação; 5. Combate à miséria, desenvolvimento social, trabalho, geração de renda e previdência social; 6 . Sistema de justiça, segurança pública e combate à violência; 7. Enfrentamento do machismo e do racismo, promoção da igualdade racial e políticas de juventude; 8. Pacto federativo e articulação orçamentária; 9. Direitos humanos e participação social. 
resultado disso foi que alguns grupos se dedicaram de fato à elaboração de grandes diretrizes, enquanto outros se concentraram em avaliar propostas passadas ou formular novas propostas.

A partir daqui me detenho na plenária final, mas antes é necessário escrever uma pequena nota sobre esse momento do evento. Para quem nunca esteve em uma conferência, grande assembleia, reunião ou um evento correlato, alguns dos termos repetidos aqui podem soar estranhos. Plenária se refere tanto a um momento específico quanto a um espaço fisicamente delimitado desse tipo de reunião. De preferência, deve ser um espaço amplo, no qual todos os participantes da reunião possam estar ao mesmo tempo. As plenárias são essencialmente um espaço de deliberação em que todas as decisōes que necessitem ser tomadas coletivamente o serão por meio do voto dos delegados aqueles que estão credenciados para votar - e a decisão da maioria será acatada. Como esperado de uma arena de decisão que se pretende democrática, muitas votaçôes envolvem longos debates e embates. Para o caso da conferência que nos interessa, quase toda votação tornou-se também um espaço de debate. O que e quais decisões devem ou não ser submetidas à plenária são pontos definidos por meio do Regimento da conferência, no qual devem constar todas as regras referentes à metodologia de funcionamento do evento. O Regimento é a primeira coisa a ser alvo de votação na plenária, geralmente na manhã do primeiro dia, antes do início do trabalho nos grupos.

Segundo a metodologia previamente definida para o funcionamento da plenária final da conferência, os presentes podiam se dirigir à mesa diretora em três circunstâncias para solicitar a palavra: colocar uma questão de ordem; pedir um esclarecimento; e fazer um destaque sobre algum ponto, proposta ou diretriz que estivesse sendo colocada em votação. Os destaques poderiam ser de supressão (quando alguém discorda totalmente de algum item e deseja que ele seja excluído), de alteração (quando alguém considera que, com algumas modificaçôes, o item pode ser aprovado) e de inclusão (quando alguém quer incluir mais algum termo ao item). Ainda de acordo com a metodologia acordada pela e para a plenária, feito um destaque, a pessoa pleiteante (da alteração, 
supressão ou inclusão) deve expor a sua justificativa para a plenária, e, em seguida, outra pessoa defenderá ou não a manutenção do texto original.

Temos então que a razão prática de uma plenária é ser um espaço de deliberação e votação, mas há uma outra razão que ultrapassa as motivações meramente instrumentais: plenárias são espaços de manifestação de grupos, afirmação de identidades, construções pessoais e coletivas de legitimidade política, entre outras questões. Há um modo de se comportar em plenária, uma etiqueta que envolve não só o conhecimento das regras formais de funcionamento, mas também saber fazer piadas e injetar ironias nos momentos corretos, confabular, incitar ou induzir sutil ou explicitamente, gritar, abraçar e beijar "companheiros e companheiras", enfim, saber como se movimentar e proceder no jogo. Elas são, portanto, espaços privilegiados para perceber sujeitos em relação e para as construções do jogo político do campo.

Para citar algumas situaçóes: é comum que as pessoas circulem pela plenária portando ou mesmo vestindo bandeiras de seus grupos, camisetas e cartazes de manifestação. $\mathrm{Na}$ plenária em questão, uma personagem andava com um volume da Constituição brasileira e, por vezes, durante exposiçóes ou falas da mesa diretora, jogava-o para o alto. Muitos gritam, vaiam, urram, repetem palavras de ordem, vários fazem questão de se manifestar, ter voz na plenária, de acordo com o que estipula a metodologia ou usando alguma outra estratégia para tal. Esse tipo de atitude pode conferir status e visibilidade (negativa ou positiva) para o próprio campo. É comum que, em alguns momentos, a mesa que conduz os trabalhos peça calma ou silêncio e se dirija à plenária, cujos “ânimos estão exaltados" ou "à flor da pele”. Um caso de piada ou ironia colocada publicamente: duas mulheres, ambas ativistas, velhas conhecidas, uma negra e outra branca, sentadas distantes uma da outra. Eis que, em plenária aberta, enquanto uma terceira pessoa fazia um pronunciamento ao microfone, a branca gritou para que a negra fizesse silêncio. Então, a negra retrucou: “a companheira está 
denegrind ${ }^{21}$ a minha imagem" e, ato contínuo, abriu uma sonora gargalhada, no que foi acompanhada pelos demais que assistiam à cena.

A plenária final da II Conferência, que teve início às $9 \mathrm{~h}$ da manhã do dia 18 de dezembro e término por volta de $01 \mathrm{~h} 40$ da madrugada do dia 19 de dezembro de 2011, foi um momento bastante interessante para perceber os conflitos e os impasses presentes no campo dos “direitos LGBT" na atualidade. Destaco a seguir algumas situaçôes.

Uma novidade da II Conferência foi a utilização de um mecanismo para votação eletrônica. Cada delegado recebeu uma espécie de controle remoto, no qual devia digitar um número, de acordo com o seu voto. As alegadas vantagens dessa tecnologia seriam o fato de que a votação poderia ser secreta e não haveria dúvidas na contagem de votos, o que, por vezes, acontece quando a votação se dá por contraste visual de crachás. De fato, o uso desse mecanismo pareceu especialmente impressionante quando da votação de uma diretriz do eixo "Direitos Humanos e Participação Social”:

Cena 3 - Madrugada de dezenove de dezembro de dois mil e onze

Uma mulher lésbica e negra fez um destaque de alteração visando à subtração do sublinhado no seguinte trecho do texto: "[...] dando ênfase às políticas afirmativas voltadas para a transformação da realidade da população LGBT, em especial as travestis e transexuais" (grifo meu). ${ }^{22}$ Então o que se seguiu foi o seguinte.

\footnotetext{
${ }^{21}$ Talvez seja necessário explicar a piada aqui. "Denegrir" é uma palavra considerada preconceituosa para uma parcela dos que militam no movimento negro e foi, de certa forma, banida de discursos politicamente corretos.

${ }^{22}$ Trecho completo: "Os planos municipais, estaduais e nacionais cumprem importante papel na formulação de políticas públicas. Tendo em vista a transversalidade do tema, torna-se necessário discutir o plano de Promoção da Cidadania e Direitos Humanos LGBT, as três esferas governamentais, como também os planos de saúde, justiça, segurança pública, trabalho e renda, educação e assistência social, considerando as populaçôes urbanas e rurais, dando ênfase às políticas afirmativas voltadas para a transformação da realidade da população LGBT, em especial as travestis e transexuais" (parte da diretriz 4 do eixo Direitos Humanos).
} 
A justificativa de subtração, feita pela mulher-lésbica-negra, pautava-se no fato de que, sempre que se faz referência a um grupo "em especial", implicitamente se está excluindo outros e que "não só travestis são mortas, lésbicas também são estupradas e esfaqueadas, principalmente as mais masculinizadas". Em seguida à sua fala, ouviu-se um grito de uma travesti da plenária: "Mas a gente morre mais!". Então, uma mulher-lésbica-branca se levantou para defender a manutenção do texto original. Seu argumento foi o de que todos sofrem violência, mas é preciso reconhecer que as travestis e transexuais sofrem mais e algumas pesquisas existentes comprovariam isso. A tréplica que se seguiu da mulher-lésbica-negra, na tentativa de um acordo, propunha que fosse acrescentado ao texto "em especial, travestis, transexuais e lésbicas masculinizadas", pois, segundo ela, as masculinizadas sofreriam tanta violência quanto as travestis.

Foi chamada a votação, entre a manutenção do texto original (proposta 1) ou o acréscimo: "travestis, transexuais e lésbicas masculinizadas" (proposta 2). A contagem dos votos resultou em empate: $48,9 \%$ a favor da proposta 1 e $48,9 \%$ a favor da proposta 2 , com 2,04\% de abstençóes.

Uma segunda rodada de defesas foi aberta. A favor da proposta 1, uma mulher-transexual-branca defendeu que "lésbicas que não aparentam ser" não sofrem a mesma violência que travestis e transexuais, que "carregam no rosto a marca do que são". E a favor da proposta 2 falou outra mulher-lésbica-branca. Segundo ela, as lésbicas não aparecem nas estatísticas justamente porque são "invisibilizadas pelo machismo e pela lesbofobia”. Seu argumento foi o de que os crimes contra a mulher seriam usualmente classificados como crimes passionais, tendo a dimensão da orientação sexual ofuscada. E, ainda, quando uma travesti ou transexual morre, "é pelo peito, pelo que tem em comum conosco [mulheres lésbicas], não pelo pinto”. 
Novamente foi chamada a votação eletrônica. Dessa vez, foram 60 votantes, ${ }^{23} 70,97 \%$ dos votos pela inclusão de "travestis, transexuais e lésbicas”, 25,81\% pela manutenção de apenas "travestis e transexuais" e 3,23\% de abstenções. Ao final da apuração, uma delegada pediu declaração de voto de abstenção e disse estar impressionada com o que tinha acabado de ver ali, pois todo aquele processo apontava para os limites da política de identidade, que seria uma política que hierarquiza, e "todos nós sofremos".

Umas das questôes que subjazem a essa cena é: Qual a medida do sofrimento a ser colocada como parâmetro para a criação de mecanismos de proteção e garantia de direitos? Essa pequena situação explicita um conflito antigo entre as letras "T" e "L" do coletivo $L G B T$. E falo mesmo em letras porque, antes de ser uma disputa tangível entre sujeitos encarnados, é uma disputa entre identidades abstraídas de seus contextos e que reverbera provocações interessantes envolvendo a interseção entre cor/raça, classe, orientação sexual e performances de gênero. ${ }^{24}$

Mesmo que, na fala das personagens envolvidas na cena, a cor/raça não tenha sido verbalizada como um dos elementos que matizavam a disputa, este era, sem dúvida, um dos componentes que estava em jogo. Quem chamou a atenção sobre o "destaque" do texto foi uma lésbica, negra e de performance estético-corporal mais masculinizada, que contrastava com a estilização mais feminina das outras participantes da disputa. Nesse sentido, essa cena aponta para o que Gregori (2011, p. 31) destaca em diálogo com as elaborações de Judith Butler: "ninguém faz o gênero sozinho, ele implica uma relação, uma socialidade”. 25

\footnotetext{
${ }^{23}$ Vale apontar que essa cena ocorreu em momento avançado, na madrugada do dia 19/11, e a plenária já se encontrava bastante esvaziada.

${ }^{24}$ Sigo a proposta de Judith Butler (2008 [1990]), na qual o gênero é compreendido como um efeito de atos performatizados: "o gênero é a estilização repetida do corpo, um conjunto de atos repetidos no interior de uma estrutura reguladora altamente rígida, a qual se cristaliza no tempo para produzir a aparência de uma substância, de uma classe natural de ser" (Butler, 2008, p. 59).

25 Trecho completo: "Gênero, nesse sentido, é um aparato construído nas práticas sociais que materializam os corpos e que instituem constrangimentos, estando longe de ser algo que conduz
} 
Ao discutirem o percurso de formação da "identidade lésbica" e as nuanças implicadas na sua mobilização política, Guilherme Almeida e Maria L. Heilborn (2008) tecem consideraçôes fundamentais a respeito da relação entre cor/raça, classe e performances de gênero nas trajetórias de mulheres integrantes de movimentos de lésbicas. Para tratar dos estereótipos sexuais associados à "mulher-negra-lésbica", os autores acionam alguns dos desenvolvimentos de Laura Moutinho (2004) a respeito de como o vetor "cromático" que se articula com as assimetrias de gênero pode imprimir sentidos particulares aos trânsitos "libidinais" envolvidos em relações heterocrômicas (ou interraciais). Esses estereótipos sexuais associados à exotização racial são refletidos nas figuras da "mulata lésbica" - "constituída nos moldes dos atributos de gênero feminino" e da "fancha negra" - "comumente constituída nos moldes do homem negro" (Almeida e Heilborn, 2008, p. 245). Nesse sentido, os autores argumentam que raça, gênero e classe social são aspectos inseparáveis da discussão sobre maneiras e modos de engajamento político acionados pelos atores desse campo. ${ }^{26}$ Considerar as maneiras como se interseccionam contextualmente é fundamental para a compreensão de formas de produção das diferenças e de sua hierarquização. ${ }^{27}$

A Cena 3 permite vislumbrar o quanto a interseção de diferentes marcadores sociais sempre opera de maneira relacional não só no cotidiano das vidas dos sujeitos, mas também na constituição do próprio campo dos "direitos LGBT".

Outro ponto interessante da plenária final foi o momento da discussão de uma diretriz que trazia o trecho "garantir a

a uma estabilidade definitiva. Tal aparato, neste mesmo sentido, deve ser visto como um conjunto de dispositivos que criam desigualdades de poder, mas também é, simultaneamente, uma estrutura aberta às transformaçōes. Como bem assinala Butler, gênero é uma prática de improvisação em um cenário de constrangimentos. Além disso, não há risco nessa formulação às tentações modernas que conduzem ao substantivismo e aos essencialismos: ninguém faz o gênero sozinho, ele implica uma relação, uma socialidade" (Gregori, 2011, p. 31).

${ }^{26}$ Para uma abordagem mais detalhada das relaçōes de engajamento mobilizadas por sexualidade, gênero e raça entre ativistas lésbicas, ver Almeida (2005).

${ }^{27}$ Para uma análise acerca das dinâmicas envolvendo o cruzamento entre (homos)sexualidade, cor/raça, classe, ver Moutinho (2006). A autora demonstra como o cruzamento de diferentes marcadores sociais da diferença não pode ser compreendido apenas segundo a lógica da simples soma de subjugações. 
interseccionalidade de gênero". Uma transexual fez um destaque nesse ponto. Pedindo esclarecimento, disse: "As pessoas estão querendo colocar intersex dentro da sigla, e alguém aqui vai ter que me explicar se intersex está dentro da homossexualidade ou da heterossexualidade", e então pediu a retirada do termo. Buscando esclarecer a confusão, uma mulher, que se apresentou como "militante e acadêmica", disse que a palavra "não tem nada a ver com intersexualidade, tem a ver com o entrecruzamento. A gente vai falar da trans negra, da lésbica negra. $E$ as pessoas que vão executar a política têm esse entendimento do significado do termo". Ao que a transexual replicou: "A palavra é um termo acadêmico, e a maioria das pessoas aqui não entende o que quer dizer, entendem como intersex". Uma outra mulher gritou da plenária: "É uma questão semântica; se fosse intersex, estaria escrito com ' $x$ '”.

Após esse pequeno debate, a mesa que coordenava os trabalhos no momento interveio: "Entendemos que essa palavra, 'interseccionalidade', não funciona porque a sociedade civil não a entende, ainda que acadêmicos a expliquem". Então, alguém sugeriu que o termo fosse trocado por "entrecruzamento", mas a plenária não concordou. Por fim, surgiu outra sugestão: "transversalizando as questões de gênero, raça e etnia" e, por consenso, esta foi aprovada. ${ }^{28}$

O debate ocasionado em razão da interseccionalidade, "um termo acadêmico" e "desconhecido da sociedade civil", leva à outra questão que chamou a atenção na II Conferência: a maneira como a "academia" esteve presente e participou. Convidados com acúmulo de experiência acadêmica no tema já haviam sido convidados para a I Conferência,

\footnotetext{
${ }^{28}$ É interessante notar que a "transversalidade" parece ser compreendida perfeitamente por todos como um conceito que já estaria nas pautas das políticas públicas. De fato, há alguns anos, a inclusão de "temas transversais" ganhou força nas políticas de educação. E a "orientação sexual" é um desses temas, destacados nos Parâmetros Curriculares Nacionais (PCN) desde 1997. No entanto, "orientação sexual" nos PCN funciona como um sinônimo para "educação sexual" e enfatiza questôes relacionadas à abordagem da "gravidez indesejada" e da prevenção de doenças sexualmente transmissíveis. Altman (2001) destaca que a sexualidade compreendida como um "problema de saúde pública" fez com que a escola fosse vista como um espaço privilegiado para a abordagem da questão, e daí se justifica a sua inclusão como um "tema transversal" que perpassa o currículo pedagógico. Para uma análise mais detalhada do que significa e dos conteúdos presentes na inclusāo da "orientação sexual" como um "tema transversal" nos currículos escolares, ver Daniliauskas (2011).
} 
o que ocorreu novamente em 2011. Todos os grupos de trabalho contaram com pelo menos dois "especialistas" convidados. A diferença é que, dessa vez, havia também mais delegados e observadores relacionados à "academia". Isso pode ser explicado pelo fato de ter havido um crescimento significativo nos últimos anos na área de estudos em gênero e sexualidade de maneira mais geral e também pelo incentivo e financiamento da própria Secretaria de Direitos Humanos, direcionados para a formação de grupos de pesquisa relacionados à "diversidade sexual" e à temática "LGBT" nas universidades. Que lugar tem exatamente a "universidade" nesse processo parece ser um ponto ainda em negociação. Por vezes, é chamada para produzir avaliações, respaldar demandas ou animar debates, entretanto segue sendo acusada de produtora de uma linguagem não compreensível para os demais integrantes da "sociedade civil" e pouco efetiva na produção de respostas políticas mais pragmáticas. ${ }^{29}$

Como mencionado, na Conferência de 2008 foi decidida em plenária a alteração da sigla para "LGBT". Novas convençōes políticas terminológicas também foram acrescentadas pela Conferência de 2011. Na plenária final, ficou decidido que sempre que os textos resultantes do processo de discussão fizessem menção à discriminação desagregada por identidades, usando os termos "lesbofobia" e "transfobia", deveria também ser feita menção à "bifobia", termo relativo a bissexuais não muito utilizado até então. Outra inclusão foi "expressões de gênero", que, a partir dali, deveria ser acrescentado sempre que se fizesse referência a "orientação sexual e identidade de gênero". Foi acrescentado "identidade de gênero", pois orientação sexual não contemplaria travestis e transexuais. Agora o termo "expressões de gênero" deveria contemplar sujeitos que vivenciam outras expressões de gênero não convencionais. Por fim, a nova inclusão que apareceu na plenária foi "capacitismo". Essa palavra seria um neologismo criado para significar o estigma que recai sobre pessoas com deficiência, tidas como não capazes. Seria, então,

\footnotetext{
${ }^{29}$ Este ponto voltará a ser discutido mais detidamente na Parte III.
} 
uma expressão para dar conta do preconceito contra pessoas com deficiência, um termo análogo a "machismo" e "sexismo", por exemplo.

Dois outros pontos de conflito e disputa que pairaram durante toda a conferência referem-se ao Estatuto da Diversidade Sexual - anteprojeto elaborado por integrantes da Comissão da Diversidade Sexual da Ordem dos Advogados do Brasil (OAB) - e ao PLC 122/2006 - mais conhecido como o projeto de lei que criminaliza a homofobia.

A proposta do Estatuto da Diversidade Sexual segue os moldes de outros estatutos já existentes e pretende reunir em uma legislação única "todas as questôes envolvendo diversidade sexual" ${ }^{30}$ Em 2008, na abertura da I Conferência, dirigindo-se ao presidente Lula, que estava na mesa, o presidente da ABGLT já havia proposto a criação de um "Estatuto GLBT", "como existe o da igualdade racial e o do idoso". Naquele momento, a plateia reagiu entusiasticamente, entretanto, durante os dias que se seguiram, presenciei a questão sendo rejeitada em discussōes nos grupos de trabalho. Em 2011, apesar de a ABGLT apresentar a questão como um consenso para o ativismo $L G B T$, foram muitos os que se opuseram ao anteprojeto. Uma das principais críticas se referia ao fato de o Estatuto não ter sido amplamente discutido até então por grupos e lideranças do movimento social ou junto aos integrantes da "população LGBT". Diante dessas críticas, durante a plenária final, um representante da $\mathrm{OAB}$ garantiu que o Estatuto estaria disponível para consultas e encaminhamentos de sugestões durante dois meses, a partir daquela data, em um site da internet.

Em relação ao PLC 122/2006, é importante destacar que uma parte considerável da frente de esforços da militância se direciona, já há alguns anos, para a criminalização da homofobia. Pauta prioritária para a ABGLT, a demanda pela criminalização da homofobia opera no sentido de reconhecer lésbicas, gays, bissexuais, travestis e transexuais como vítimas históricas em busca de reparação e proteção estatal. Daí a analogia com dispositivos legais antidiscriminação existentes, como os relacionados à raça, à população indígena ou a pessoas com deficiência.

\footnotetext{
${ }^{30}$ Entrevista com a desembargadora aposentada e presidente da Comissão da Diversidade Sexual da OAB, Maria Berenice Dias, publicada em 23 de agosto de 2011. Disponível em: http://www.ibdfam. org.br/?clippings\&clipping=5053. Acesso em: dez. 2013.
} 
A estratégia de pressão por essa pauta é a de denunciar casos de violação de direitos e apontar estatísticas de assassinatos por meio de dados produzidos pelas poucas pesquisas existentes e por depoimentos-testemunhos. A resistência à aprovação de qualquer legislação federal referente à criminalização vem sendo creditada aos políticos conservadores e, principalmente, à bancada religiosa evangélica no Congresso Nacional. E aqui é necessário fazer menção à querela envolvendo o PLC 122/2006, que estava em evidência no momento da II Conferência. Esse projeto de lei originou-se na Câmara dos Deputados a partir de um projeto de autoria da deputada Iara Bernardi (PT-SP), de 2001. A primeira proposição estabelecia sanções administrativas a pessoas jurídicas por práticas discriminatórias por motivo de orientação sexual. Somente após sucessivos apensamentos e alterações substitutivas, o projeto ganhou uma forma que propunha tornar crime a discriminação e o preconceito por orientação sexual e também por identidade de gênero, alterando os artigos $1 .^{\circ}$ e 20 da Lei n. ${ }^{\circ} 7.716,{ }^{31}$ de 1989 , conhecida como Lei Caó, e o $\$ 3 .^{\circ}$ do artigo 140 do Código Penal, de modo a incluir a punição por esse tipo de crime. Com a tramitação estacionada no Senado, no fim da legislatura, em 2010, o PLC 122 foi arquivado e ficou “à espera” de que algum senador o desarquivasse, o que foi feito em janeiro de 2011 pela senadora Marta Suplicy (PT-SP)..$^{32}$

O projeto seria posto em votação no mês de novembro de 2011, porém, com o texto "flexibilizado" no formato de um substitutivo fruto de acordo entre a senadora Marta Suplicy e alguns representantes religiosos do Senado, como o senador Marcelo Crivella (PRB-RJ) e o presidente da ABGLT, Toni Reis. ${ }^{33}$ Esse acordo não foi discutido

\footnotetext{
${ }^{31}$ A Lei 7.716 dispõe sobre a punição de crimes resultantes de discriminação ou preconceito de raça, cor, etnia, religiāo ou procedência nacional.

32 Para o percurso de tramitação do projeto, ver Leite et al. (2011).

${ }^{33}$ Toni Reis é integrante do Grupo Dignidade, de Curitiba. Durante o período de realização desta pesquisa, ocupava a presidência da ABGLT. De acordo com o seu perfil do Facebook, é "professor, formado em letras pela UFPR, especialista em sexualidade, mestre em filosofia, doutor em educação. Ativista pelos direitos civis LGBT" (Acesso em: out. 2013).
} 
com a Frente Parlamentar Mista pela Cidadania LGBT ${ }^{34}$ ou com o deputado federal Jean Wyllys (um dos líderes da Frente), que, segundo sua exposição em um dos painéis da Conferência, já havia se colocado à disposição para trabalhar no texto em questão. Por fim, em virtude das divergências prevalecentes, o texto substitutivo produzido pelas tentativas de acordo da senadora nunca foi efetivamente posto em pauta de votação.

Mas, ainda que não tenha entrado em votação, durante toda a Conferência ficou claro que grande parte das pessoas ali presentes era contrária ao encaminhamento do PLC 122 com o texto do substitutivo que alterava a proposição no sentido de não sancionar expressões contrárias à homossexualidade proferidas em cultos religiosos. Foram feitas algumas propostas, diretrizes e moções que pediam explicitamente a aprovação do PLC 122/2006, entretanto não eram específicas quanto a que texto se referiam: ao original de 2006 ou ao substitutivo de 2011. Devido às controvérsias que gravitavam em torno do projeto, a plenária final decidiu então substituir todas as menções ao projeto específico por um texto que falava genericamente em "criminalizar a homofobia nas mesmas bases da lei do racismo".

No painel que tratou do "Poder Legislativo", Jean Wyllys comentou a questão ao abordar o papel da Frente Parlamentar:

[A] Frente tem esse papel de discutir uma politica pública e tem papel de discutir as proposiçóes legislativas, como o PLC 122, que foi recentemente objeto de muita polêmica e de muito debate dentro do próprio movimento. De alguma maneira, expôs ali uma fraturinha do movimento. Não digo uma fratura, mas uma fraturinha, e foi saudável essa fratura, porque, de fato, a gente pôde debater o que nos interessa, não é? Qual é a proposição que a gente quer?

\footnotetext{
${ }^{34}$ A Frente Parlamentar Mista pela Cidadania LGBT é composta oficialmente por 171 parlamentares. Mas Jean Wyllys, coordenador da Frente pela Câmara dos Deputados, explica que esse é um número apenas formal, pois é a quantidade de assinaturas necessárias para criar uma frente. Na prática, não são todos os 171 que atuam, sendo essa uma característica comum a outras frentes do Parlamento. Marta Suplicy era a coordenadora da Frente pelo Senado.
} 
E ai, quando a Frente soube que a senadora Marta Suplicy, que é membro da Frente, estava desenvolvendo uma negociação com a bancada evangélica do Senado - a bancada conservadora, não só evangélica - nós nos preocupamos, porque nós acreditávamos que esse fórum tinha o papel, inclusive, de dar o pontapé inicial nesse debate. Claro que ela sendo a protagonista, porque ela é a relatora, óbvio. Mas a Frente precisava ser ouvida e, junto com a Frente, o próprio movimento na sua diversidade. Porque a gente náo pode desconsiderar que o movimento é diverso [...]. E, nesse primeiro momento, quando a gente fez a reuniáo com a senadora, uma reunião bastante tensa-mas, como sempre, dentro do tempo da democracia - nós concordamos que aquele não era o substitutivo que nós queríamos. Não só nós, da Frente, mas também o movimento, na sua diversidade, não queria.

Segundo o deputado, de todo modo, o projeto não seria aprovado naquele momento, mesmo que fosse apresentado o texto do substitutivo negociado com lideranças religiosas. A colocação na pauta seria uma "armadilha" para que o projeto fosse "derrubado" e saísse de vez da pauta da Comissão de Direitos Humanos:

A gente só avança se a gente dialogar com essa Frente [evangélica]. Mas o diálogo e a construção da estratégia têm que ser dentro da Frente [Parlamentar Mista pela Cidadania LGBT] e ouvindo os diferentes setores do movimento. [...] Ai, a gente pensa qual é a melhor estratégia e até onde a gente pode ceder [...]. As mulheres batalharam, demoraram o tempo necessário para aprovar a Lei Maria da Penha da maneira que elas queriam [...]. Porque quem pode dizer, legitimamente, somos nós, ou os homossexuais mesmo, ou aqueles aliados [...]. Somos nós que podemos dizer o que é possivel negociar e o que não é. [...] Negociação tem que haver sim, porque é parte do conflito, é parte do papel da politica mediar conflito. Mas existem pontos inegociáveis para todos os segmentos vitimados ou difamados. Os negros, as mulheres, os idosos, as crianças e os adolescentes, todos esses grupos vulneráveis, têm pontos inegociáveis. Porque náo interessa para nenhum de nós a letra morta. 
[...] A gente quer uma lei que cumpra, pelo menos, o papel pedagógico de inibir. Pelo menos isso.

O deputado se coloca a favor da criminalização da homofobia, porém se diz também um militante do direito penal mínimo, no qual penas de reclusão poderiam ser substituídas por multas ou prestação de serviços. Apesar de apoiar o PLC 122, o deputado declarou que a pauta de seu mandato é outra, o "casamento civil igualitário". Essa pauta seria mais estratégica, pois estenderia a muitos um conjunto de direitos relacionados ao direito da família:

O casamento civil tem um efeito ordenador, institui a entidade familiar. A gente precisa aprovar como lei. Não podemos nos contentar com a decisão do STF, porque a gente sabe que a ampla maioria da populaçáo não tem acesso à justiça. Não tem Defensoria Pública na maioria dos estados e municípios deste pais. Os pobres não têm acesso à justiça. A gente vê pela maneira como eles são tratados. Portanto, não vamos nos contentar com uma decisão do Judiciário.

Essas disputas em torno do PLC 122 apontam para o embate ocorrido em outro âmbito envolvendo estratégias políticas mais amplas utilizadas para a proposição de regulaçôes jurídicas de direitos $L G B T$, embate esse que se dá entre diferentes representaçôes do movimento social e entre distintas estratégias de reivindicação de direitos. Nesse sentido, a figura do deputado federal Jean Wyllys vem se destacando. Segundo suas próprias palavras, "o primeiro deputado gay fora do armário" da história do país, que, como vimos, além de criticar os encaminhamentos dados ao PLC 122 no Congresso, aproveitou o painel em que esteve presente para falar sobre a Proposta de Emenda Constitucional (PEC) de sua autoria, que trata do casamento entre pessoas do mesmo sexo. ${ }^{35}$

Voltando-me para outro plano da análise, gostaria de ressaltar que é bastante significativo ter ressoado da II Conferência - em marcante

\footnotetext{
${ }^{35}$ Outros aspectos relacionados às estratégias envolvendo essas proposiçōes serão retomados de maneira mais aprofundada no capítulo 3 .
} 
contraste com a repercussão da primeira - a insatisfação com as políticas em curso e a acusação feita por alguns de que a conferência servia apenas para legitimar "o que eles quiserem fazer", sendo "eles" um sujeito não muito claro que pode apontar ora para o governo, ora para determinados setores partidários, ou para alguma liderança do movimento social. Isso porque a conferência não foi um espaço de discussão aprofundada de propostas, mas apenas de deliberação de grandes diretrizes orientadoras para o grupo de pessoas que em outro momento seria o responsável pela elaboração de um plano de açóes. ${ }^{36}$ Ao mesmo tempo, ficou clara a preocupação crescente em elaborar diretrizes exequíveis dentro dos parâmetros apresentados pelo governo.

As conferências produzem uma plataforma legitimada de reivindicações, mas a grande eficácia do processo se dá na direção de agitar articulações e movimentações políticas, no sentido da construção de laços e rupturas, da consolidação de arranjos, da reorganização de conexôes intramovimento e de negociações partidárias consideradas estratégicas. Operam para a ostentação de conquistas de determinados agrupamentos e, por vezes, para o oposto, o desmantelamento de redes e associações de aliança e pactos com esferas governamentais. São também um grande espaço de aprendizado, e a formulação de propostas e diretrizes por certo é apenas uma dimensão dessa cena. Esse tipo de evento trabalha essencialmente para a construção da trama de atores e relações que sustentam o próprio campo dos "direitos LGBT".

Souza Lima e Castro (2008) propõem suspender o qualificativo "públicas" das políticas e tratá-las como "governamentais". Políticas governamentais seriam, assim,

entendidas como planos, açóes e tecnologias de governo formuladas não só desde organizaçóes administrativas de Estados Nacionais, mas também a partir de diferentes modalidades de organizaçôes não redutiveis

\footnotetext{
${ }^{36}$ Ainda que não fosse desprezível a presença de militantes, agora inseridos na estrutura do governo (em coordenação de centros de referência, secretarias, coordenadorias, superintendências, entre outros aparatos administrativos), que se esforçavam em relatar avanços e apontar feitos bem-sucedidos.
} 
àquelas que estäo definidas em termos jurídicos e administrativos enquanto partícipes de administraçôes públicas nacionais (p. 369).

Isso implica considerar não só movimentos sociais e as ONGs, mas também organismos multilaterais de cooperação técnica internacional e, ainda, que

a identificação de problemas sociais e a formulação de planos de ação governamental, sua implementação e a avaliaçâo de seus resultados se dão em múltiplas escalas espaciais, com temporalidades variáveis, no entrecruzamento de amplos espaços de disputa, muitas vezes desconectados entre si na aparência (p. 369).

Seguindo esse raciocínio, poderíamos dizer que grandes eventos "exibicionistas", como os observados aqui, servem também a propósitos distintos do seu declarado objetivo, operando não para (re)formular "políticas públicas", mas para (re)formatar o campo de determinadas ações governamentais.

Para Bourdieu (1989), um campo se define justamente ao determinar o que está em jogo e os interesses específicos que são irredutíveis ao que está em jogo em outros campos. É ainda essencial para que exista o jogo ter gente disposta a participar e ciente das regras, dos comportamentos esperados e, mais uma vez assumindo o risco da redundância, do que está em jogo.

Esses espaços de construção de representantes e representações são ocupados por poucos sujeitos, e essas disputas são feitas por meio da mobilização de diferentes capitais, fazem-se com o corpo, com a cor/ raça, com diferentes performances de gênero (como na Cena 3), com relaçôes pessoais, trajetórias profissionais, acadêmicas e militantes. Encontros como as Conferências são espaços privilegiados para a emergência desses diferentes marcadores, um caldeirão propício à efervescência de disputas de poder. São ao mesmo tempo espaços fundamentais para a enunciação de identidades e demandas que 
aparecerão decantadas mais tarde nos documentos construídos como corolários desses encontros/confrontos. ${ }^{37}$

Documentos, cartas de intenções, acordos, comprometimentos, construção de laços e grupos, formação e reatualização de lideranças, são todos produtos da conferência ou relações nela sedimentadas. Além disso, o evento público, promovido pelo governo federal, resulta em diversas eficácias: a produção do "Estado" que reconhece, que se compromete e que se faz mais "Estado" nesse jogo; a produção (ou o reconhecimento) de lideranças, de novos problemas sociais a serem combatidos; e o "reconhecimento da homofobia" pelo "Estado" brasileiro. Reconhecimento que produz (mais) uma população historicamente discriminada e negligenciada até então, pois "um ato público constitui por si um ato de instituição e representa por isso uma forma de oficialização, de legitimação" (Bourdieu, 1989, p. 165). As conferências e todo o processo de delegação que as sustenta simulam uma espécie de "ato original de constituição" da população LGBT nos termos em que vem sendo gestada e gerida (Souza Lima, 2002) pelo governo brasileiro na atualidade.

O evento fabula a passagem do individual ao coletivo, "a transcendência do grupo em relação ao indivíduo singular":

Portanto, essa espécie de ato original de constituição, no duplo sentido, filosófico e político, que a delegação representa é um ato de magia que permite fazer existir o que não passava de uma coleção de pessoas plurais, uma série de individuos justapostos, sob a forma de uma pessoa ficticia [...] (Bourdieu, 2004, p. 194).

\footnotetext{
${ }^{37}$ Essa interpretação sobre o papel das conferências se assemelha às consideraçōes tecidas por John Comerford (1999) a respeito de reuniōes de organizaçōes de trabalhadores rurais. O autor analisa que, "para além de sua dimensão instrumental de simples meios de tomar decisões ou discutir assuntos do interesse dos membros das organizações, as reuniôes podem ser vistas também como um elemento importante na construção desse processo social, na medida em que criam um espaço de sociabilidade que contribui para a consolidação das redes de relaçôes que atravessam a estrutura formal das organizaçôes, possuem uma dimensão de construção ritualizada de símbolos coletivos e colocam em ação múltiplas concepçôes ou representações relativas à natureza das organizaçôes de trabalhadores e ao papel de seus dirigentes e membros, bem como sobre a natureza da própria categoria que essas organizaçōes se propõem a representar" (p. 47).
} 
Retomando o estado-ideia postulado por Philip Abrams (1988), Timothy Mitchell (2006) chama a atenção para a separação entre estado e sociedade, ou para o desenho desses espaços como distintos por definição. Para o autor, o estado moderno aparece como um aparelho destacado do resto do mundo social e, desse modo, questiona onde estariam as fronteiras entre estado, sociedade e economia e se estas de fato não existem apenas como um efeito de processos de representação, regulação, práticas e técnicas burocráticas que criam a aparência do "Estado" como uma entidade abstrata e apartada. A esse processo o autor chama "efeito de estado". 38

Os episódios de abertura das conferências aqui relatados encenam ritualisticamente a separação entre estado e sociedade. Ao estabelecerem limites entre "Estado" e o que não é "Estado", delineiam a substancialização de categorias que corroboram tais limites, como "movimento social" ou "sociedade civil". Na primeira conferência, a sociedade (civil) deposita a sua crença no estado e confiança no governo - "Nós colocamos nas suas mãos o nosso futuro para a questão da discriminação" 39 - e celebra o reconhecimento e o comprometimento do estado encarnado em eloquências, tais como:

Eu posso dizer a vocês, no que depender do apoio do governo, no que depender do apoio do Poder Executivo e dos ministros, que nós iremos trabalhar para que o Congresso Nacional aprove o que precisar aprovar nesse pais. [...] obviamente que nós seremos honestos [...] aquilo que não puder ser feito, a gente vai dizer com o mesmo companheirismo, isso aqui não dá, isso aqui não passa [...] se não estabelecermos essa relação

\footnotetext{
38 "We should address the state as an effect of mundane processes of spatial organization, temporal arrangement, functional specification, supervision and surveillance, and representation that create the appearance of a world fundamentally divided into state and society or state and economy. The essence of modern politics is not policies formed on one side of this division being applied to or shaped by the other, but the producing and reproducing of these lines of difference" (Mitchell, 2006, p. 185).

39 Trecho do discurso do presidente da ABGLT, por ocasião da abertura da I Conferência Nacional LGBT, em 2008.
} 
companheira entre nós, terminaremos a Conferência e voltaremos a ter as desconfianças que tinhamos antes de entrar aqui. ${ }^{40}$

Na II Conferência, a sociedade (civil) insatisfeita ameaça com descrença e desconfiança quando, na solenidade de abertura, os participantes se dirigem com vaias, gritos, cartazes e palavras de ordem que criticam a atuação do governo. E, como resposta, recebe mais um voto de compromisso:

Considero essenciais as palavras que o nosso governo escutou na abertura dessa conferência. [...] A nossa missáo é superarmos a homofobia. A nossa missão é construirmos um Brasil pelos direitos humanos. [...] É um compromisso de vida que está empenhado na ação do governo da presidenta Dilma, no seu programa e nas açóes dos seus ministros, como o que desenvolvo para honrar a missáo que me foi conferida por ela [...] Dirijo-me a vocês, portanto, com compromissos de trabalho de cada ministério, de cada pasta, para afirmar que nós ouviremos, nessa conferência, muitas questóes, mas que vocês não sairão desta conferência com os braços vazios. Vocês sairão dessa conferência com firmes compromissos, assinados pelo nosso governo [...] olhar para vocês, reacender a chama da confiança de que o governo da presidenta Dilma defenderá intransigentemente os direitos humanos de cada brasileiro, de cada brasileira, e se posicionará claramente com açóes concretas contra toda violência torpe, contra todo assassinato, contra toda discriminação. ${ }^{41}$

De uma conferência à outra, da expressão de fé inconteste, o governo passa a receber a ameaça da desconfiança. E apenas a ameaça, porque a desconfiança ou a descrença total seriam o equivalente a

\footnotetext{
40 Trecho do discurso do presidente Lula, por ocasiāo da solenidade de abertura da I Conferência Nacional LGBT, em 2008.

41 Trecho do discurso da ministra dos Direitos Humanos durante a solenidade de abertura da II Conferência Nacional LGBT (Anais da II Conferência Nacional LGBT, pp. 21-24).
} 
abandonar o jogo. Reconhecimento em troca de crença e confiança. ${ }^{42}$ Eventos como as conferências atualizam a separação entre estado e sociedade, reatualizam a crença no estado-ideia e reforçam o efeito de estado, ao mesmo tempo que habilitam a possibilidade de a desconfiança ameaçar administraçōes e administradores (ou governos) em particular.

É preciso haver concordância entre as partes envolvidas a respeito dos termos do jogo, e essa relação ritualizada entre compromissos/ comprometimentos e (des)confianças produz a substancialização da "sociedade civil" e do "Estado". E é a possibilidade da desconfiança por um governo ou por um governante em particular que, paradoxalmente, permite que a crença no "Estado" seja mantida e reforçada. Embora entre uma conferência e outra tenha havido a ameaça de quebra de um pacto de confiança, ao fim e ao cabo, percebe-se o reforço da crença nos modos de funcionamento das institucionalidades estatais.

Nesse contexto, é relevante pontuar que, em oito anos de gestão, o governo Lula promoveu 74 conferências versando sobre 40 temas diferentes. Segundo pesquisa realizada em parceria pelo Inesc-Pólis, $70 \%$ desses eventos foram a respeito de temas inéditos, cuja primeira edição aconteceu entre 2003 e 2010, caso da conferência LGBT. ${ }^{43}$

$\mathrm{Na}$ conferência de 2011, um representante do ministro Gilberto Carvalho, da Secretaria-Geral da Presidência da República, declarou que, entre as linhas de atuação dessa secretaria, a principal era a "participação social". Mais do que isso, afirmou que a "participação social" era o seu "método de gestão". Entre os "instrumentos de participação" elencados estão: conferências, ouvidorias, conselhos

42 "O poder simbólico é um poder que aquele que está sujeito dá àquele que o exerce um crédito com que ele o credita, uma fides, uma auctoritas, que ele lhe confia pondo nele a sua confiança. É um poder que existe porque aquele que está sujeito crê que ele existe" (Bourdieu, 1989, p. 188).

${ }^{43}$ Também segundo a pesquisa, os objetivos das conferências foram agrupados em quatro categorias: "proposição, como já era esperado, mas também tinham outras finalidades, como fortalecer a participação, analisar situações e agendar assuntos". Relatório final do projeto/pesquisa: "Governança democrática no Brasil contemporâneo: estado e sociedade na construção de políticas públicas". Arquitetura da participação no Brasil: avanços e desafios. Agosto de 2011. Disponível em: http:// www.inesc.org.br/noticias/biblioteca/textos/rela-torio-arquitetura-da-participacao-social-no-brasil. Acesso em: fev. 2012. 
de direitos, canais de internet e outros mecanismos de "interação com o Estado".

O governo entende, prezados amigos, a democracia como um processo politico e social, em que a participação dos cidadãos é essencial para definir a prática democrática. Assim, não é por acaso que a interação democrática entre o Estado e a sociedade civil é um dos eixos orientadores do terceiro Programa Nacional dos Direitos Humanos do Governo Federal, o PNDH-3. O crescente numero de pessoas e organizaçóes envolvidas nos espaços de interação com o Estado confere ao Brasil maior possibilidade de encontrar soluçóes para os problemas que enfrentamos, corresponsabilizando todos os atores envolvidos.

Não é por acaso que os discursos de representantes governamentais a todo momento ressaltam o envolvimento e a parceria com a sociedade civil como um signo de sucesso da gestão, corroborando um determinado modelo almejado de estado democrático.

No próximo capítulo, volto-me para alguns dos documentos - como as diferentes versões do Programa Nacional de Direitos Humanos que, de certa forma, provocaram a realização de conferências, e outros que foram produzidos a partir delas. Viso não a uma análise exaustiva, mas a percorrer alguns fios da trama que vem constituindo "sujeitos LGBT" e progressivamente moldando novos repertórios de sentido e de reconhecimento de sujeitos e suas "especificidades". Procuro deslindar algumas questôes: Como as conferências surgiram e quais são os seus antecedentes? O que as torna possíveis e desejáveis? E por que esse foi o formato escolhido? 


\section{CAPÍTULO 2 \\ PERCORRENDO DOCUMENTOS: UMA LEITURA ATRAVÉS DOS "PAPÉIS"}

Alguns documentos podem ser compreendidos como peças-chave para o processo de constituição do que hoje se convencionou chamar população LGBT. Com a proposta de acompanhar as mudanças de vocabulário, como as identidades aparecem nos papéis ou como a "população" aparece por escrito, percorro alguns documentos buscando ainda destacar como são estruturados. Apesar do marco temporal da pesquisa estar localizado entre os anos de 2008 e 2011, faz-se necessário percorrer algumas produções anteriores a esse período, a começar pelas duas primeiras versóes do Programa Nacional de Direitos Humanos. Sendo assim, os principais documentos aqui são: as três versōes do Programa Nacional de Direitos Humanos (1996, 2002 e 2009); o relatório da participação do Brasil na Conferência de Durban (2001); o programa federal Brasil Sem Homofobia (2004); o Plano Nacional de Promoção da Cidadania e Direitos Humanos de LGBT (2009); e os relatórios finais das duas conferências nacionais LGBT realizadas até o momento de finalização da pesquisa (2008 e 2011). 
O primeiro Programa Nacional de Direitos Humanos, de 1996, incluiu a temática da homossexualidade no eixo "Proteção do direito à vida - segurança das pessoas" em um item que tratava de apoio a programas para prevenção da "violência contra grupos em situação mais vulnerável, caso de crianças e adolescentes, idosos, mulheres, negros, indígenas, migrantes, trabalhadores sem-terra e homossexuais" (PNDH I). Apesar de reconhecer os sujeitos, o programa não foi propositivo em relação ao tema. Já no PNDH II, de 2002, o tema ganhou muito mais espaço. No eixo "Garantia do Direito à Liberdade", aparece o item "orientação sexual", em que cinco propostas são apresentadas. Mas não só, como veremos adiante.

A conferência realizada em Durban, em 2001, significou um marco para essa ampliação temática do primeiro para o segundo PNDH. No relatório do Comitê Nacional para a Preparação da Participação Brasileira na III Conferência Mundial das Nações Unidas contra o Racismo, Discriminação Racial, Xenofobia e Intolerância Correlata, entre as 14 propostas apresentadas constavam uma que trata da "criaçãoo de uma fundação ou Secretaria de Governo dirigida aos GLTTB, como as que existem para mulheres, negros e índios", e outra que propunha a "destinação, no orçamento federal, de recursos para açôes afirmativas contra práticas discriminatórias à comunidade GLTTB".

O Brasil teve uma participação de destaque nos trabalhos da Conferência de Durban. Apesar de não ter sido aprovada, a delegação brasileira propôs a inclusão de "orientação sexual" como uma forma de discriminação correlata ao racismo. Ainda em 2001, após a Conferência, foi criado o Conselho Nacional de Combate à Discriminação (CNCD $)^{1}$ como parte da estrutura do Ministério da Justiça. Mais tarde, o Conselho,

1 O CNCD foi criado pelo Decreto n. ${ }^{\circ}$ 3.952, de 4 de outubro de 2001. O decreto definia a seguinte composição básica para o conselho: o secretário de Estado dos Direitos Humanos, como seu presidente, e um representante de cada uma das seguintes instâncias: Assessoria Especial do Gabinete da Presidência da República; Ministério das Relaçôes Exteriores; Ministério da Educação; Ministério da Saúde; Ministério do Trabalho e Emprego; Ministério do Desenvolvimento Agrário; Secretaria de Estado de Assistência Social; Instituto de Pesquisa Econômica Aplicada; Fundação Cultural Palmares; Fundação Nacional do Índio; e mais "onze representantes de movimentos sociais e organizaçōes não governamentais, com especial ênfase na participação de entidades da comunidade negra que se ocupem de temas relacionados com a promoção da igualdade e com o combate a todas as formas de discriminação". 
localizado na então Secretaria de Estado de Direitos Humanos, ${ }^{2}$ incluiria entre os seus integrantes uma liderança gay, uma lésbica e uma travesti. ${ }^{3}$ Avançando para o ano de 2004, temos o que é considerado o grande marco para a construção de "políticas LGBT" no Brasil, o lançamento do programa federal Brasil Sem Homofobia. O BSH foi organizado pela Secretaria Especial de Direitos Humanos da Presidência da República com a perspectiva de envolvimento interministerial. Pequenas iniciativas vinham sendo conduzidas desde o primeiro Programa Nacional de Direitos Humanos do governo FHC, entretanto, o programa BSH aparece como o empreendimento de maior vulto até então capitaneado pelo governo federal. No Brasil Sem Homofobia, com grande destaque, há a realização de colaboração com a "Sociedade Civil Organizada", com o objetivo de "promover a cidadania de gays e lésbicas, travestis, transgêneros e bissexuais, a partir da equiparação de direitos e do combate à violência e à discriminação homofóbicas, respeitando a especificidade de cada um desses grupos populacionais" (Brasil, 2004).

A iniciativa que envolveu os PNDHs, a experiência da delegação brasileira para a Conferência de Durban, a criação do Conselho Nacional de Combate à Discriminação e o processo que levou à criação do Brasil Sem Homofobia estão intimamente relacionados e encadeados. Poranto, antes de olhar para o conteúdo desses documentos, cabe uma pequena contextualização.

2 Em 1997, a Secretaria dos Direitos da Cidadania foi substituída pela Secretaria Nacional de Direitos Humanos, tendo entre as suas atribuiçōes monitorar as ações do Programa Nacional de Direitos Humanos, ainda compondo a estrutura do Ministério da Justiça. Em 1999, a secretaria foi transformada em Secretaria de Estado de Direitos Humanos e ganhou assento nas reuniōes ministeriais. Em 2003, a Lei n. ${ }^{\circ}$ 10.683, de 28 de maio, criou a Secretaria Especial de Direitos Humanos, e o Conselho Nacional de Combate à Discriminação passou a fazer parte da sua estrutura. A mesma lei também instituiu a Secretaria Especial de Políticas para as Mulheres e a Secretaria Especial de Políticas de Promoção da Igualdade Racial. Em 2010, a Secretaria deixa de ter caráter especial. Uma medida provisória presidencial (de 25 de março de 2010) "transforma a secretaria em órgão essencial da Presidência”, passando a ser chamada apenas de Secretaria de Direitos Humanos da Presidência da República - SDH (http://www.presidencia.gov.br/estrutura_presidencia/sedh/ sobre/historico/).

3 A partir do Decreto 5.397, de 22 de março de 2005, o CNCD passou a integrar "quinze representantes de entidades e organizaçōes não governamentais das populaçôes negra, indígena e do segmento de 'Gays', Lésbicas, Transgêneros e Bissexuais - GLBT'. 


\section{O PROGRAMA NACIONAL DE DIREITOS HUMANOS}

A conjunção de esforços entre "governo e sociedade civil" é um ponto de investimento enfatizado desde a primeira versão do Programa Nacional de Direitos Humanos instituído pelo Decreto n. ${ }^{\circ} 1.904$, de 13 de maio de 1996. Diz o prefácio do então presidente Fernando Henrique Cardoso: "Iniciamos juntos, governo e sociedade, uma caminhada para pregar os direitos humanos, como um direito de todos, para proteger os excluídos e os desamparados". A introdução do documento esclarece que a publicação do Programa segue a recomendação da Conferência Mundial de Direitos Humanos realizada em Viena, em 1993; ${ }^{4}$ destaca a inserção do Brasil em determinada ordem internacional, a partir daquele momento, por meio da adesão a tratados internacionais de direitos; e reforça igualmente o novo "quadro normativo" de promoção e proteção dos direitos humanos estabelecido pela Constituição de 1988. Ainda no texto da introdução do PNDH I, ficamos sabendo que seis seminários regionais (nas cidades de São Paulo, Rio de Janeiro, Recife, Belém, Porto Alegre e Natal), envolvendo 334 participantes e representando 210 entidades, fizeram parte da elaboração do Programa, que foram "realizadas consultas, por telefone e fax, a um largo espectro de centros de direitos humanos e personalidades" e que seu conteúdo também foi debatido na I Conferência Nacional de Direitos Humanos, realizada em abril de 1996.

4 A introdução menciona o protagonismo de FHC, então chanceler, ao reunir no Ministério das Relaçōes Exteriores um grupo formado por "representantes do Ministério da Justiça, da Procuradoria Geral da República, além de parlamentares, e as mais importantes organizaçôes não governamentais de direitos humanos" para discutir qual seria a agenda brasileira para a Conferência de Viena em 1993. Após a conferência, o ministro da Justiça Maurício Correia novamente teria reunido um grupo de gestores e entidades de direitos humanos a fim de elaborar a Agenda Nacional de Direitos Humanos (Brasil, 2009, p. 188 do anexo do PNDH III). Mais adiante, o PNDH I - primeiro programa desse tipo na América Latina e o terceiro no mundo (atrás da Austrália e das Filipinas apenas) - teria a sua articulação conduzida por José Gregori, então chefe de gabinete do ministro da Justiça Nelson Jobim e futuro secretário de Direitos Humanos, quando da criação dessa Secretaria em 1997. Já, durante a elaboração do PNDH II, a Secretaria estaria sob a gestão de Paulo Sergio Pinheiro. 
De acordo com Paulo Sergio Pinheiro e Paulo de Mesquita Neto (1997), responsáveis pela relatoria do Programa, sua publicação apresentou um "quadro de referência para a concretização de garantias do estado de direito e para a ação em parceria do Estado e da sociedade civil" (p. 123). Em outro artigo, Mesquita Neto (1997) ressalta que, "ao invés de convocar um grupo de juristas e técnicos", a coordenadoria criada pelo Ministério da Justiça especialmente para a elaboração do Programa - e capitaneada pelo então chefe de gabinete do ministério, José Gregori - estabeleceu um convênio de assessoria com o Núcleo de Estudos da Violência da Universidade de São Paulo (NEV-USP). O NEV-USP, sob a coordenação de Paulo Sergio Pinheiro, elaborou o anteprojeto do Programa entre outubro de 1995 e maio de 1996 . Ainda segundo o autor, aquele era um contexto favorável de transição da herança autoritária do período da ditadura para a democracia, de internacionalização da política e da economia brasileiras e um momento em que "o governo federal e as organizações não governamentais substituíram a relação de antagonismo e conflito, característica da década de 70, por uma relação de diálogo e cooperação na década de 90" (s/p).

Para a segunda edição do Programa, lançada em 2002, novamente sob a coordenação do NEV-USP, o documento contou com recomendações de vários seminários regionais, da IV Conferência Nacional de Direitos Humanos, sendo o texto disponibilizado para consulta pública via internet.

Ao realizar uma análise comparativa entre as três versões do Programa, Sergio Adorno (2010, p. 12) avalia que, diante das críticas recebidas pelo primeiro Programa, a segunda versão incorporou "direitos de livre orientação sexual" e de "proteção dos ciganos". Outro enfoque destacado do segundo documento é o reconhecimento do racismo e a proposição de políticas de ação afirmativa visando à "reparação diante da violação sistemática de direitos humanos". Sobre o PNDH III, publicado pelo Decreto n. ${ }^{\circ}$ 7.037, de 21 de dezembro de 
2009,5 o autor destaca o aprofundamento e a ampliação do seu "elenco de direitos", resultado das demandas oriundas da XI Conferência Nacional de Direitos Humanos - que contou com a participação de cerca de 2.000 pessoas, entre delegados, convidados e observadores - e das diversas conferências com temáticas específicas convocadas pelo governo federal entre os anos de 2003 e 2009. Entre estas, a apresentação do PNDH III, assinado pelo presidente Luiz Inácio Lula da Silva, reitera a importância da realização da "I Conferência Nacional de Gays, Lésbicas, Bissexuais, Travestis e Transexuais, em 2008, marco histórico na caminhada para construirmos um país sem qualquer tipo de intolerância homofóbica" (Brasil, 2009, p. 13). ${ }^{6}$ As três versões do PNDH o ressaltam como uma "política de Estado" não vinculada à gestão de governos específicos, o seu caráter suprapartidário e a responsabilidade para com os tratados internacionais de direito dos quais o Brasil é signatário.

Como notam Vianna e Lacerda (2004) sobre as duas primeiras versões do PNDH, a incorporação da participação de organizações não governamentais, tanto na elaboração dos programas quanto na previsão do seu envolvimento na execução das diretrizes neles contidas, reverbera as regulações acordadas no plano internacional. Para essa dimensão, as autoras destacam especialmente a II Conferência Mundial de Direitos Humanos, ocorrida em Viena em 1993. O preâmbulo e outras passagens do texto final dessa conferência concedem particular destaque "não aos indivíduos portadores de direitos em geral, mas a sujeitos específicos - compreendidos como minoritários, seja pelo sexo ou pela idade, raça ou religião" (Vianna e Lacerda, 2004, p. 19). Nesse sentido, a Conferência de Viena representa um marco para a consolidação do "processo de desdobramento e diferenciação

5 A elaboração do documento foi conduzida por um grupo de trabalho coordenado pela Secretaria de Direitos Humanos, já com status de ministério e sob a gestão de Paulo Vanucchi.

6 Cabe notar que a publicação do PNDH III sofreu fortes críticas devido a algumas proposições consideradas como demais arrojadas. Dentre os temas que provocaram "ruidosa polêmica", Adorno (2010, p. 14) destaca: "a criação da Comissão Nacional de Verdade, a descriminalização do aborto, a união civil entre pessoas do mesmo sexo, o direito à adoção por casais homoafetivos, a interdição à ostentação de símbolos religiosos em estabelecimentos públicos da União, o 'controle da mídia' e a adoção de mecanismos de mediação judicial nos conflitos urbanos e rurais". 
sofrido pela concepção inicial de indivíduo, que deu lugar a uma multiplicação dos direitos humanos em corpos de regulação destinados a sujeitos específicos” (p. 19). Assim, o ímpeto voltado à especificação progressivamente substitui a "pretensão universalizadora" dos direitos humanos, baseando-se em uma concepção ancorada na fragilidade ou na "vulnerabilidade" atribuída a certos sujeitos e em maneiras de adequar-se a diferentes contextos locais. ${ }^{7}$

Olhar para os PNDH e os seus processos de elaboração é relevante por revelar o apelo à conjunção entre "Estado" e "sociedade civil" como o caminho para a consolidação democrática, caminho esse a ser trilhado sobre um solo de direitos humanos ou por meio da assunção de uma "gramática de direitos humanos" como o vocabulário progressivamente privilegiado para reivindicar direitos ou denunciar a sua violação. Esses documentos ainda revelam o esforço do estado brasileiro em inserir-se em um sistema internacional como uma nação que alia democracia, participação e desenvolvimento.

Planos e programas não têm força de lei. São diretrizes, sugestões, indicativos que devem orientar a promoção de políticas e outras ações. São documentos institucionalizados pelo governo federal, mas não há como ter gerência sobre o que de fato é efetivado em âmbitos estaduais e municipais, ou mesmo sobre as diferentes gestões da própria estrutura federal. Nesse sentido, o seu formato de produção e constituição pressupõe um espaço político de disputa.

A contextualização dos PNDH nos permite antever não só uma concepção de direitos humanos que tem por base a participação da sociedade organizada, mas também o fato de que, desde a sua primeira versão, referendava a busca de direitos de diversos "segmentos"

7 Seguindo uma leitura da periodização proposta por Norberto Bobbio, Vianna e Lacerda (2004) notam a inflexão provocada pela chamada segunda geração dos direitos humanos, especialmente em áreas onde a sexualidade pode ser inscrita, como, por exemplo, a saúde. Se, em um primeiro momento, a defesa da liberdade do indivíduo diante do Estado soberano é o principal foco, passa-se a uma concepção de que o Estado deve promover direitos fundamentais e garantir o livre desenvolvimento das individualidades. "Nesse sentido, a transformação provocada pela chamada segunda geração de direitos humanos vem do fato de que certas responsabilidades individuais e/ou coletivas passam a ser representadas como direitos, recaindo sobre os Estados o peso de sua provisão" (p. 17). Os Pactos Internacionais de Direitos Civis e Políticos e o de Direitos Econômicos, Sociais e Culturais, datados de 1966, são indicados como um "momento-chave" dessa torção. 
organizados, em uma perspectiva progressivamente mais inclusiva e específica. Essa "representação" dos grupos e dos movimentos foi sendo intensificada programa a programa, dando cada vez mais espaço para a validação de "novas" temáticas e "novos" sujeitos.

\section{O BRASIL SEM HOMOFOBIA E ALGUNS DESDOBRAMENTOS}

O Brasil Sem Homofobia foi também um programa de governo lançado sob os auspícios da Secretaria de Direitos Humanos, em 2004. Cláudio Nascimento, ${ }^{9}$ coordenador dos trabalhados de elaboração do $\mathrm{BSH}$ e, naquele momento, representante da ABGLT no Conselho Nacional de Combate à Discriminação, conta que, no fim do ano de 2003, a representação do movimento social no CNCD propôs ao governo federal que fosse criado um programa de combate à homofobia e aponta o Encontro da ABGLT realizado em Manaus em outubro daquele ano como um dos antecedentes fundamentais desse processo. ${ }^{10}$

Em pesquisa que trata das políticas de combate à homofobia implementadas pelo Ministério da Educação, Felipe Fernandes (2011) procura traçar um histórico de criação do Brasil Sem Homofobia pontuando quatro momentos. O "primeiro momento" estaria relacionado ao insucesso do movimento LGBT em inserir-se como pauta prioritária de políticas públicas de combate à violência. Por meio de material coletado durante sua pesquisa de campo e

8 A progressiva autonomização da Secretaria de Direitos Humanos, de instância subordinada a um ministério até chegar ao estatuto de ministério (retirado o seu caráter "especial" desde 2010) e de como "populaçôes específicas" ganharam instâncias administrativas destacadas de sua estrutura, como a SEPPIR e a SPM (como anteriormente indicado na nota 2 deste capítulo), pode ser lida como um indicativo da maneira como essa perspectiva foi ganhando espaço.

9 Cláudio Nascimento foi um dos fundadores da Parada do Orgulho do Rio de Janeiro, em 1995, e integrante do Grupo Arco-Íris de Cidadania LGBT, cuja presidência ocupou por dois mandatos. Cláudio integrou o comitê de preparação para a Conferência de Durban, tendo participado, durante o período de 1999 a 2000, de várias conferências e reuniōes internacionais preparatórias para essa Conferência, realizada na África em 2001. Atuou também como secretário-geral da ABGLT e, desde 2007, ocupa o cargo de superintendente de Direitos Individuais, Coletivos e Difusos na Secretaria de Assistência Social e Direitos Humanos do estado do Rio de Janeiro.

${ }^{10}$ Entrevista realizada por mim em outubro de 2011, no âmbito do projeto Retratos da Política LGBT no estado do Rio de Janeiro, coordenada pelo Lidis-UERJ (Carrara et al., 2017). 
do depoimento de ativistas, indica que uma política chamada "Balcão de Direitos" do Ministério da Justiça era a ação privilegiada de combate à discriminação no governo. A política oriunda do governo FHC ainda estava em implementação durante o primeiro ano do governo Lula (seguindo o PPA 2000-2003 ${ }^{11}$ ) e, de acordo com Caio Varela, ativista entrevistado por Fernandes (2011), "era então a única rubrica possível para a implementação de uma política LGBT" dentro do orçamento planejado para direitos humanos naquele período. "Então todas as populações minoritárias brigavam pelo 'Balcão de Direitos' e os LGBT ficavam de fora". ${ }^{12}$

De acordo com a descrição de Fernandes, essa situação marcaria um "segundo momento", quando um grupo de ativistas do movimento LGBT percebeu que era preciso entender como o plano orçamentário governamental era organizado e definido e aprender com ele, a fim de que fosse possível incidir politicamente a favor da agenda LGBT nesse planejamento. Então, um grupo de ativistas, por meio de um contato de Caio Varela, naquele momento militante do Grupo Atitude de Brasília, participou de um curso sobre "Orçamento da União" promovido pelo Instituto de Estudos Socioeconômicos (Inesc). ${ }^{13}$ Em nota de rodapé, Fernandes expóe uma fissura interna do ativismo LGBT ao nos explicar que o grupo ao qual Caio era ligado não era um dos afiliados da ABGLT. Logo, o grupo de pessoas que participou dessa formação figurava como "oposição" à referida associação. Durante o curso, esse grupo "elaborou um texto no qual propunha açôes para diversas agências governamentais”, compondo uma pauta "pró-LGBTTT", nas palavras do autor (2011, p. 93). $\mathrm{O}$ grupo teria decidido submeter esse texto ao XI Encontro Brasileiro

\footnotetext{
${ }^{11}$ PPA é a sigla para Plano Plurianual, o planejamento de gestão governamental que deve estabelecer "objetivos, diretrizes e metas" para um período de quatro anos de administração. Ver http://www. orcamentocidadao.df.gov.br/ppa.php.

${ }^{12}$ Fragmentos do diário de campo de 02/06/2010, de Felipe Bruno Martins Fernandes (2011, p. 92).

${ }^{13}$ Instituto de Estudos Socioeconômicos, organização não governamental, "não partidária e com finalidade pública. Tem por missão: contribuir para o aprimoramento da democracia representativa e participativa, visando à garantia dos direitos humanos, mediante a articulação e o fortalecimento da sociedade civil para influenciar os espaços de governança nacional e internacional" (http://www.inesc. org.br/quem-somos).
} 
de Gays, Lésbicas e Transgêneros, em novembro 2003, o que marca para o autor o "terceiro momento" do percurso que desemboca no Brasil Sem Homofobia.

O XI EBGLT é destacado por ter sido um episódio de tensão no qual o movimento social direcionou duras críticas ao governo e por ter sido marcado por disputas internas ao movimento. Nesse encontro, por exemplo, houve a decisão controversa de trocar a significação do " $T$ " de travestis para transgêneros, com a justificativa de que seria um termo "mais inclusivo". Contudo, o evento também é apontado como bastante propositivo. Continuando a seguir a pesquisa de Fernandes (2011), verificamos que o momento foi bastante produtivo no sentido de ampliar "a pauta homossexual, incluindo uma série de múltiplas demandas a serem enviadas ao governo federal" (p. 94). Logo, apesar das críticas, esse encontro foi considerado um espaço privilegiado para o diálogo com o governo. Conforme Cláudio Nascimento indica para o autor, o XI EBGLT foi marcante no primeiro mandato do governo Lula, quando a possibilidade de criação de um programa de políticas para o "segmento" foi colocada. O encontro contou com a participação de Ivair Augusto, representante da então Secretaria Especial de Direitos Humanos e também integrante do Conselho Nacional de Combate à Discriminação, que apresentou uma proposta de cartilha contra o preconceito a ser distribuída pela SDH, o que gerou forte reação dos participantes do evento, interessados não apenas em "cartilhas", mas também em "políticas públicas" (pp. 94-5). ${ }^{14}$

Por fim, o "quarto momento" delineado por Fernandes dedicou-se à elaboração de fato do Brasil Sem Homofobia. No XI EBGLT, foi acordado que as propostas registradas no relatório final do encontro funcionariam como base para a elaboração de um programa de governo.

Cláudio Nascimento relata que, depois do "encontro radicalizado em Manaus", foi chamado para uma audiência com o então secretário especial de Direitos Humanos, Nilmário Miranda, na qual propôs a criação de um programa. A resposta do secretário teria sido que, primeiramente, era importante fortalecer o debate dentro do CNCD,

${ }^{14}$ Momento também destacado por Daniliauskas (2011). 
"inclusive para que ele [o ministro] tivesse legitimidade para tratar o assunto com outros ministérios e secretarias". ${ }^{15}$ Essa audiência aconteceu na véspera de uma reunião do Conselho, quando, seguindo a recomendação recebida na audiência do dia anterior, Cláudio, Yone Lindgren e Janaina Dutra ${ }^{16}$ apresentaram uma resolução tratando do assunto. Esta foi aprovada, e, ainda naquele novembro de 2003, foi formado o comitê de elaboração do Programa Brasileiro de Combate à Violência e à Discriminação contra GLBT e de Promoção da Cidadania Homossexual, ${ }^{17}$ que teria o objetivo de "prevenir e reprimir a discriminação com base na orientação sexual, garantindo ao segmento GLTB o pleno exercício de seus direitos humanos fundamentais". ${ }^{18}$

Novamente de acordo com Cláudio Nascimento, esse comitê fez duas grandes reuniōes de consulta pública em Brasília:

Grande parte da militância foi para lá, tudo por conta própria, cartazes, bolas, uma loucura, uma mobilização bem bacana. E eu lembro que foi um periodo muito interessante [...] eu lembro que a gente fez de dezembro até maio mais de quarenta encontros com os ministérios, para ouvir os ministérios, para falar com eles. Eu coordenei isso pela sociedade civil, na verdade, eu acabei ficando como coordenador geral, junto com o Ivair Augusto na equipe, e essas foram as bases. E ai lançamos em 25 de maio de 2004 o programa Brasil sem Homofobia, em Brasilia. ${ }^{19}$

Para Cláudio, com a entrada de um ministro do PT, Nilmário Miranda, o diálogo com a Secretaria foi facilitado, pois eram setores

\footnotetext{
${ }^{15}$ Entrevista realizada por mim em outubro de 2011, no âmbito do projeto Retratos da Política LGBT no estado do Rio de Janeiro, coordenada pelo Lidis-UERJ (ver Carrara et al., 2017).

${ }^{16}$ Representantes do movimento de lésbicas e de travestis e transexuais, respectivamente.

17 O programa só ganhou seu nome definitivo mais tarde. Para consideraçôes sobre o processo de atribuição do título Brasil Sem Homofobia e sua relação com a direção priorizada em outros programas contemporâneos das campanhas vigentes durante o primeiro ano do governo Lula, ver Fernandes (2011).

${ }^{18}$ Excerto de Brasil (2004, p. 13).

${ }^{19}$ Entrevista realizada por mim em outubro de 2011, no âmbito do projeto Retratos da política LGBT no estado do Rio de Janeiro, coordenada pelo Lidis-UERJ (ver Carrara et al., 2017).
} 
com os quais ele já tinha uma relação. ${ }^{20}$ Nessa época, Cláudio já se colocava como uma figura central para as articulações. Entre 1999 e 2001, ele esteve nas atividades que antecederam a participação do Brasil na Conferência de Durban, integrando o Comitê Nacional para a Preparação da Participação Brasileira na Conferência Mundial das Nações Unidas contra o Racismo, Discriminação Racial, Xenofobia e Intolerância Correlata. O comitê tinha em torno de vinte nomes, e ele era, "infelizmente, o único gay", como me contou.

Nove anos depois, em dezembro de 2010, por decreto presidencial, a estrutura e a composição do CNCD, espaço fundamental dessas articulaçôes, foram alteradas. $\mathrm{O}$ conselho passou a ter por finalidade "formular e propor diretrizes de ação governamental, em âmbito nacional, voltadas para o combate à discriminação e para a promoção e defesa dos direitos de Lésbicas, Gays, Travestis e Transexuais LGBT" ${ }^{21}$ tendo recebido o nome fantasia de Conselho Nacional de Combate à Discriminação e Promoção dos Direitos de LGBT.

Cabe citar, por fim, que o texto introdutório do $\mathrm{BSH}$ indica que o Plano Plurianual - PPA 2004-2007 - incluiu uma ação que versava sobre a "Elaboração do Plano de Combate à Discriminação contra Homossexuais". Assim, o planejamento orçamentário do governo previa a criação de ações específicas para "homossexuais". E o texto introdutório do BSH indica a efetivação desse compromisso "com o objetivo de promover a cidadania de gays, lésbicas, travestis, transgêneros e bissexuais, a partir da equiparação de direitos e do combate à violência e à discriminação homofóbicas, respeitando a especificidade de cada um desses grupos populacionais" (Brasil, 2004, p. 11).

Segundo o Relatório de Avaliação do PPA para os anos de 2004 e 2007, entre as açóes governamentais relacionadas com "direitos LGBT"

20 Cláudio Nascimento relembrou um momento importante que, em sua opinião, não costuma ser considerado. Em 21 de setembro de 1999, foi realizado o I Seminário Direitos Humanos e Cidadania Homossexual da Câmara dos Deputados, pela Comissão de Direitos Humanos, que então era presidida pelo deputado Nilmário Miranda (PT-MG). A segunda edição do seminário ocorreria em 2005, e, em maio de 2013, houve a décima edição.

${ }^{21}$ Decreto n. ${ }^{\circ}$ 7.388, de 9 de dezembro de 2010. Presidência da República. Casa Civil. Subchefia de Assuntos Jurídicos. 
constam, além da realização do Brasil Sem Homofobia, a "instalação de 47 Centros de Referência contra a homofobia em todas as capitais e Municípios-polo no interior e a instalação de sete Núcleos de Estudo para a Prevenção e Combate à Homofobia junto a universidades" (Brasil, 2008, p. 241).22

Programas e planos muitas vezes apontam para ações que dependem de mudanças legislativas ou que necessitam de iniciativas em estados e municípios. Logo, a maior parte de um programa federal só pode trazer recomendações, uma vez que também precisa respeitar o "pacto federativo". ${ }^{23}$ Entretanto, isso não impede que esse tipo de iniciativa produza outras eficácias.

Um programa ou plano "amplamente discutido com a sociedade civil" e publicado com a chancela do governo federal funciona como um poderoso instrumento de abertura de diálogo e pressão que pode ser manejado pela "sociedade civil organizada". Além disso, o processo de elaboração desses documentos muitas vezes tem um efeito de eficácia interna.

No caso do Brasil Sem Homofobia, por exemplo, Daniliauskas (2001) reconhece algo que chama de "trajetória de reconhecimento mútuo". Em entrevista concedida ao autor, Cláudio Nascimento destaca que, ao percorrerem ministérios e secretarias para apresentar e discutir o programa, tinham a oportunidade de "sensibilizar" para a questão, ao mesmo tempo que aprendiam como se relacionar com aqueles espaços:

Nós fizemos muitos encontros com ministérios, com secretarias, com órgãos federais com três objetivos principais: o primeiro era tentar nivelar as informaçóes, porque havia mesmo muito preconceito, muita desinformaçâo, muita ignorância dos próprios gestores públicos dos diversos ministérios [...]. O segundo passo era a partir dai estabelecer

\footnotetext{
${ }^{22}$ Para mais sobre a inserção da "agenda anti-homofobia" nos PPA do governo Lula, ver Fernandes (2011, pp. 156-7).

${ }^{23} \mathrm{O}$ PNDH III procura uma estratégia que cause maior comprometimento; para cada "açāo programática", aponta um "responsável” (instâncias do governo federal), "parceiros" e ainda indica "recomendações" que muitas vezes se dirigem a estados e municípios.
} 
um lugar de diálogo e de interação com esses espaços. Primeiro, para conhecer esses órgãos, como eles funcionavam por dentro, quais eram os programas existentes, as politicas que eles já estavam fazendo, como a gente poderia fazer um link entre as reivindicaçóes que a gente fazia e a politica daquele ministério [...] Em uma terceira fase, conhecer um pouco também os aliados e os possiveis adversários dentro dos próprios ministérios. A gente precisava saber com quem a gente podia contar dentro dos ministérios [...] (Daniliauskas, 2011, p. 84).

\section{Percebemos que o Brasil Sem Homofobia funcionou como um} importante instrumento para a incidência política. $\mathrm{O}$ programa não tinha orçamento próprio, e, por essa razão, o ativismo se organizou para pressionar a alocação de recursos para a realização de suas ações. Muitas dessas atividades se organizavam apoiadas por um projeto chamado Aliadas. Uma pequena publicação, "Guia de Advocacy no Legislativo para Lésbicas, Gays, Bissexuais, Travestis e Transexuais”, organizada pela ABGLT e pelo Grupo Dignidade, com o apoio da Secretaria de Direitos Humanos, indica que a ideia do projeto Aliadas nasceu em um seminário realizado em maio de $2004 .^{24}$

Segundo um release de divulgação, o projeto Aliadas tinha como objetivo mobilizar ações de "promoção dos direitos humanos de GLBT" no Congresso Nacional, nos legislativos estaduais, municipais e distrital, e garantir "orçamento para a efetiva implantação do Programa Brasil Sem Homofobia e outras ações afirmativas para GLBT". A pesquisa de Fernandes (2011) registra o ano de 2006 como o momento da "primeira grande ação de ativismo sobre o orçamento da União"

\footnotetext{
${ }^{24}$ Seminário de advocacy do projeto Somos: desenvolvimento institucional, advocacy e intervenção para ONGs que trabalham com gays e outros HSH. O projeto Somos, realizado pela ABGLT em parceria com o então chamado Programa Nacional de DST/Aids, foi iniciado em 1999 com o objetivo de fortalecer e "capacitar" organizaçôes não governamentais para a promoção de direitos humanos e a prevenção de DSTs/Aids. As três grandes linhas de ação do projeto baseavam-se em "desenvolvimento organizacional, advocacy e intervenção". De acordo com a introdução de uma cartilha do projeto, o seu conceito norteador era: "em termos simples, à medida que os grupos se desenvolvem, tornam-se capazes de realizar açōes de advocacy, contribuem para mudanças sociais favoráveis aos gays e outros $\mathrm{HSH}$ e também se tornam aptos a intervir na comunidade local, promovendo a prevenção e a cidadania". A cartilha é assinada por Marcelo Nascimento, então presidente da ABGLT, e Toni Reis, coordenadorgeral do projeto Somos (Brasil [MS], 2005).
} 
conduzida pela ABGLT, justamente para mobilizar recursos para ações do Brasil Sem Homofobia. O autor conta que, em novembro desse mesmo ano, a associação organizou uma ação nacional, dentro do Aliadas, chamada "Brasil Sem Homofobia e Orçamento da União”. Nessa ocasiāo, respondendo ao chamado da ABGLT, um grupo pequeno de ativistas de entidades filiadas foi até Brasília visitar os gabinetes de todos os deputados durante dois dias. O objetivo era conseguir a alocação de mais recursos por meio da apresentação de "emendas individuais ao orçamento da União" para a execução do Brasil Sem Homofobia, pois, em análise prévia, a associação teria avaliado que a dotação orçamentária então existente seria insuficiente (p. 175).

$\mathrm{O}$ advocacy $^{25}$ era feito por meio de reunióes com deputados, senadores, secretarias e ministérios, audiências públicas, entre outras estratégias, como envio de cartas para parlamentares. Uma das açôes do Aliadas tratava também de arregimentar parlamentares para que se comprometessem com a então chamada Frente Parlamentar pela Livre Expressão Sexual do Congresso Nacional. ${ }^{26}$

O projeto Aliadas, portanto, parece significar uma inflexão bastante relevante no repertório de estratégias de atuação política do movimento LGBT, que passou a considerar como centrais o monitoramento de políticas, lobby junto a parlamentares, entre outras açôes tidas como eficazes na influência de decisões favoráveis à "causa". Um informe do projeto que circulou em listas de discussão por e-mail em 26 de outubro de 2007 anunciava que a realização da Conferência Nacional LGBT havia sido garantida como uma ação a constar do PPA 20082011, assim como outras ações do Brasil Sem Homofobia. A inclusão

${ }^{25}$ O Manual de Comunicação LGBT, publicação lançada pela ABGLT em 2010, voltada para instrumentalizar profissionais, estudantes e professores da área de comunicação sobre questôes, temas e termos correntes relacionados à política LGBT, define na página 30: "ADVOCACY: Palavra inglesa definida formalmente como 'argumentar em defesa de uma causa ou alguém"”. No movimento LGBT, consiste em uma estratégia de ação para a conquista de direitos e o desenvolvimento de políticas públicas em diversas áreas relacionadas às temáticas LGBT, como união estável, leis de combate à homofobia, prevenção de DSTs e Aids, atendimento à comunidade LGBT etc. (Disponível em: http://www.abglt.org.br/docs/ManualdeComunicacaoLGBT.pdf. Acesso em: jan. 2013).

${ }^{26}$ Que mais tarde seria relançada como Frente Parlamentar Mista pela Cidadania LGBT, mencionada no capítulo anterior. 
teria sido resultado das articulações promovidas pelo Aliadas junto à Comissão de Direitos Humanos. ${ }^{27}$

Para complementar esta pequena contextualização, o texto-base da I Conferência Nacional, que representaria a "coroação" das "importantes iniciativas anteriores" já citadas, ${ }^{28}$ explica que um dos seus objetivos é a construção do Plano Nacional de Promoção da Cidadania e Direitos Humanos de Lésbicas, Gays, Bissexuais, Travestis e Transexuais (PNLGBT), que seria uma espécie de consolidação das discussões e das propostas destinadas a orientar "as diretrizes para a elaboração de políticas voltadas ao segmento GLBT, mobilizando tanto poderes públicos quanto a sociedade civil organizada", diretrizes estas debatidas durante a reunião. O PNLGBT, lançado em maio de 2009, foi desenvolvido por uma comissão técnica interministerial, e entre os objetivos que enuncia está "o fortalecimento do Programa Brasil Sem Homofobia”. No mesmo ano, foi criada a Coordenação Nacional LGBT como parte da estrutura da Secretaria de Direitos Humanos.

Uma conferência, um plano, um programa, muitas vezes tidos como a "coroação" de um processo, têm um efeito de "sucesso" ou "avanço" encerrado em si mesmos que não precisam necessariamente passar pela efetiva realização de ações descritas em seu conteúdo. Reforçam a existência de uma "população" e funcionam como instrumento de pressão e visibilidade, mesmo que seja para cobrar o que foi prometido e nunca efetivado.

\footnotetext{
${ }^{27} \mathrm{O}$ informe pode ser encontrado no anexo C3 (p. 342-346). A cobrança para que o governo federal convocasse a "I Conferência Nacional de Cidadania GLBT, com a ampla participação da sociedade civil" já havia sido uma das propostas aprovadas no XII Encontro Brasileiro de Gays, Lésbicas e Transgêneros Adamor Guedes, realizado de 8 a 11 de novembro de 2005, em Brasília. E o programa de governo 2007-2010 de Lula apresentava três açōes referentes à "Cidadania LGBT", entre elas "incentivar a participação, realizando a I Conferência Nacional de Políticas para GLBT". As outras eram: "Desenvolver e aprofundar as açōes de combate à discriminação e promoção da cidadania GLBT (gays, lésbicas, bissexuais, travestis e transexuais), nos marcos do programa Brasil Sem Homofobia, que será ampliado e fortalecido"; e "Desenvolver políticas afirmativas e de promoção de uma cultura de respeito à diversidade sexual, favorecendo a visibilidade e o reconhecimento social" (Disponível em: http://bvsms.saude.gov.br/bvs/publicacoes/plano_governo.pdf. Acesso em: jan. 2013).

${ }^{28} \mathrm{O}$ texto-base da conferência nacional é o documento pré-elaborado, em geral, pela comissão organizadora da reuniāo, que orienta o enfoque que o evento terá como base (Texto-base da I Conferência Nacional LGBT. Secretaria de Direitos Humanos. Presidência da República. Apresentação do secretário de Direitos Humanos Paulo Vanucchi).
} 
De volta ao conteúdo dos documentos, percorro-os de modo a colocar o seu teor "programático" em perspectiva por meio das propostas e das ações que enunciam. Aqui cabe uma pequena nota introdutória sobre o vocabulário mobilizado e os termos frequentes nesses "papéis". Adorno (2010, p. 13) destaca o "universo léxico" em torno do qual as "açôes programáticas" do PNDH gravitam: "apoiar, fomentar, criar (mecanismos), aperfeiçoar, estimular, assegurar e garantir, articular e integrar, propor, elaborar, definir, ampliar, expandir, avançar, incentivar, fortalecer, erradicar, promover, adotar (medidas), desenvolver, produzir (informaçôes, pesquisas), instituir (código de conduta), incluir, implementar". São esses os verbos que em geral projetam a realização plena de direitos humanos. Mas, podemos ainda localizar outras expressōes recorrentes, como "enfrentamento", "transversalidade", "sensibilização", "intersetorialidade", "avanços" ou "retrocessos", entre outros quase lugares-comuns desse tipo de construção política que visa formalizar ou institucionalizar determinadas demandas por direitos. ${ }^{29}$

Seria quase possível abstrair uma formulação padrão de propostas ou ações que vão se desenvolvendo ao longo do tempo. Algo de acordo com os seguintes parâmetros: "Apoiar/incentivar/estimular a implantação/promoção/incentivo de , no âmbito de levando em consideração as dimensões de ___. Essa última lacuna pode ser preenchida por orientação sexual, gênero, raça ou geração, por exemplo, como em uma das propostas contidas no PNDH III:

- Estimular programas de atenção integral à saúde das mulheres, considerando suas especificidades étnico-raciais, geracionais, regionais, de orientação sexual, de pessoa com deficiência, priorizando as moradoras do campo, da floresta e em situação de rua.

\footnotetext{
29 Felipe Fernandes (2011), ainda que não desenvolva sua argumentação nesse sentido, nota certo vocabulário recorrente presente nas políticas que analisa. Pensando nos termos "recorte" e "transversalizar", chama a atenção para a utilização do "recorte de gênero" como forma de operacionalizar a "transversalização" da temática nas políticas de governo.
} 
Podemos dizer que esses termos compõem o vocabulário algo padronizado que precisa ser compartilhado por aqueles que compreendem/dominam a morfologia dessas políticas de estado.

\section{"AMPLIANDO O ELENCO": PROPOSIÇÕES E SUJEITOS AO LONGO DO TEMPO}

A progressiva "ampliação do elenco de direitos humanos" é outro destaque da análise de Adorno (2010) ao cotejar as três versōes do Programa Nacional de Direitos Humanos. Vejamos quanto dessa ampliação reflete os interesses desta pesquisa.

Como já mencionado acima, no PNDH I (1996), de um total de 238 propostas distribuídas entre 19 subtemas, pela primeira vez "homossexuais" aparecem em uma menção que os arrola entre outros sujeitos "em situação mais vulnerável", ${ }^{30} \mathrm{e}$ também em outra menção relacionada que propõe regulação legislativa proibindo todo tipo de discriminação "com base em origem, raça, etnia, sexo, idade credo religioso, convicção política ou orientação sexual'.

Na segunda versão do Programa (PNDH II, 2002), o total de propostas aumentou para 518, arroladas por meio de 29 subtemas. Dentro do subtema "Garantia do Direito à Liberdade, Opinião e Expressão", o item "Orientação Sexual" apresenta cinco propostas; o subtema "Crianças e Adolescentes" traz uma que versa sobre a garantia de tratamento não discriminatório de pleiteantes à adoção, na qual se especifica "gênero, raça e orientação sexual". No subtema específico "Gays, Lésbicas, Travestis, Transexuais e Bissexuais GLTTB", aparecem dez propostas, e mais outra no subtema "HIV/ AIDS". Temos então, na menção a sujeitos específicos "GLTTB", sigla utilizada na época, ou à "orientação sexual", um conjunto de 17 propostas. Constam do documento: a proposição de legislação contra a discriminação por orientação sexual e a regulamentaçẫo de "parceria

\footnotetext{
${ }^{30}$ Como na proposta de ação 5: "Apoiar programas para prevenir a violência contra grupos em situação mais vulnerável, caso de crianças e adolescentes, idosos, mulheres, negros, indígenas, migrantes, trabalhadores sem-terra e homossexuais" (PNDH I).
} 
civil registrada entre pessoas do mesmo sexo"; o incentivo à produção de levantamentos de dados demográficos sobre "GLTTB" e também a pesquisas sobre violência e discriminação motivadas por orientação sexual; a promoção de campanhas e um conjunto de ações destinadas a formar e/ou "capacitar" sobre "o tema da livre orientação sexual e da cidadania dos GLTTB" ou sobre "violência contra GLTTB", voltadas para profissionais da educação, operadores do direito, agentes da segurança pública, profissionais da saúde e da comunicação; "estimular" a realização de "políticas públicas para a promoção social e econômica da comunidade GLTTB”; e especificamente para "transexuais", o apoio "à lei de redesignação de sexo e mudança de registro civil". ${ }^{31}$

No PNDH III, a estrutura de apresentação das propostas é diferente das duas ediçôes anteriores. O Programa foi organizado em torno de seis “eixos orientadores”, contendo 25 "diretrizes”, 82 “objetivos estratégicos" e 521 “ações programáticas”. Entre os "eixos orientadores”, três deles fazem referência direta ou indireta a "LGBT", distribuídos por seis "objetivos estratégicos", compondo mais de vinte "ações programáticas". Inclui-se aí o "objetivo estratégico - Garantia do direito à livre orientação sexual e identidade de gênero", alocado no "Eixo Orientador III: Universalizar direitos em contexto de desigualdade", sob a "Diretriz 10: Garantia da igualdade na diversidade", reunindo um conjunto de oito "ações programáticas". Além de compor um "objetivo estratégico" específico, o tema ainda aparece pontualmente em outras ações inseridas em diferentes "eixos" do Programa. Por exemplo, no Eixo IV, que trata de estratégias de segurança pública, uma das açōes propostas é: "Elaborar diretrizes para as políticas de prevenção à violência com o objetivo de assegurar o reconhecimento das diferenças geracionais, de gênero, étnico-racial e de orientação sexual". Já no "Eixo 5 - Educação e Cultura em Direitos Humanos", duas açóes chamam a atenção pelo esmero em arrolar "especificidades" e "grupos historicamente vulnerabilizados":

\footnotetext{
${ }^{31}$ No anexo da publicação Brasil [PNDH III], de 2010, encontram-se reproduzidos na íntegra os textos do PNDH I e do PNDH II.
} 
- Estabelecer diretrizes curriculares para todos os niveis e modalidades de ensino da educação básica para a inclusão da temática de educação e cultura em Direitos Humanos, promovendo o reconhecimento e o respeito das diversidades de gênero, orientação sexual, identidade de gênero, geracional, étnico-racial, religiosa, com educação igualitária, não discriminatória e democrática (Diretriz 19, Objetivo Estratégico I, Ação a. PNDH III, 2010, p. 155).

- Promover campanhas e pesquisas sobre a história dos movimentos de grupos historicamente vulnerabilizados, tais como o segmento LGBT, movimentos de mulheres, quebradeiras de coco, castanheiras, ciganos, entre outros (Diretriz 20, Objetivo Estratégico II, Ação a. PNDH III, 2010, p. 161).

Desse modo, é perceptível que, na terceira versão do Programa, os "LGBT" apareçam como uma "população" com maior número de açôes direcionadas do que nas versôes anteriores, assim como é notável que "orientação sexual e identidade gênero" surjam imiscuídas nas ações voltadas para outros sujeitos merecedores de atenção especial. Como na "ação programática" abaixo, que trata de "saúde das mulheres": "Estimular programas de atenção integral à saúde das mulheres, considerando suas especificidades étnico-raciais, geracionais, regionais, de orientação sexual, de pessoa com deficiência, priorizando as moradoras do campo, da floresta e em situação de rua" (Diretriz 7 , Objetivo Estratégico IV. PNDH III, 2010, p. 60). Ou em outra ação alocada em diretriz que trata da proteção de "direitos de crianças e adolescentes com mais vulnerabilidade":

Exigir em todos os projetos financiados pelo governo federal a adoçâo de estratégias de não discriminação de crianças e adolescentes em razão de classe, raça, etnia, crença, gênero, orientação sexual, identidade de gênero, deficiência, prática de ato infracional e origem (Diretriz 8, Objetivo Estratégico III. PNDH III, 2010, p. 80). 
O interessante de se olhar para as três versões do Programa Nacional de Direitos Humanos é que, por serem documentos abrangentes e com o pretenso foco no conjunto da "população brasileira", elas permitem uma apreciação no tempo. É possível localizar o momento em que "populaçôes específicas" são incorporadas ou "transmutadas". Por exemplo, o termo "terceira idade" aparece no PNDH I e desaparece nas duas versóes posteriores do Programa. Já o termo "quilombola" só aparece a partir do PNDH II. E os "portadores de deficiência" são transmutados em "pessoas com deficiência” a partir do PNDH III.

Ainda nessa versão do Programa, entre os movimentos e grupos que "demandam políticas de inclusão social”, figuram: "adolescentes, mulheres, pessoas idosas, lésbicas, gays, bissexuais, travestis, transexuais, pessoas com deficiência, povos indígenas, populações negras e quilombolas, ciganos, ribeirinhos, varzanteiros, pescadores, entre outros". E as políticas precisam ser efetivadas para "valorizar a diversidade presente na população brasileira para [...] sempre sob o foco dos Direitos Humanos, [...] assegurar o respeito às diferenças e o combate às desigualdades, para o efetivo acesso aos direitos". As identidades " $L$ ", "G", "B" e "T", reunidas em uma mesma "população" ou significadas no composto "identidade de gênero e orientação sexual", surgem definitivamente assimiladas como objeto de um "recorte" merecedor de especial atenção para a consolidação do "Estado Democrático" projetado:

A formação e a educação continuadas em Direitos Humanos, com recortes de gênero, relaçóes étnico-raciais e de orientação sexual, em todo o serviço público, especialmente entre os agentes do sistema de Justiça e segurança pública, são fundamentais para consolidar o Estado Democrático e a proteçâo do direito à vida e à dignidade, garantindo tratamento igual a todas as pessoas e o funcionamento de sistemas de Justiça que promovam os Direitos Humanos (PNDH III, 2010, p. 151).

A alteração dos termos ao longo do tempo, a definição de áreas de incidência e a multiplicação de ações e propostas, além de outras concepções sobre "populações" ou "direitos", interseções ou 
"transversalidades", podem ser perscrutadas à medida que percorremos os documentos. Com as diferentes versōes do PNDH, fica clara a progressiva incorporação de distintos sujeitos de direitos - aludindo à retórica de um modelo de nação democrática e que preza a diversidade - que se quer construir ou "consolidar". Performativamente, esses documentos podem ser lidos como parte de um processo contínuo de "formação de Estado", conforme Elias (2006). ${ }^{32}$

Entre o PNDH II e o PNDH III, temos um programa e um plano específico: o Brasil Sem Homofobia, de 2004, no qual constam sessenta açôes, e o Plano Nacional de Promoção da Cidadania e Direitos Humanos de LGBT, de 2009, com 180 ações. Este último, como dito, é a condensação do resultado de uma conferência, cujo relatório final listou 569 resoluçóes. Nos documentos produzidos particularmente para a "população LGBT", podemos perscrutar a marcação das "especificidades" desses sujeitos já específicos, ou seja, a enunciação de diferenciaçôes internas ao coletivo forjado.

\section{“DANÇA DAS LETRINHAS” E ESPECIFICIDADES DE SUJEITOS JÁ ESPECÍFICOS}

Uma rápida mirada sobre as discussões e as propostas presentes no documento de 2004, Brasil Sem Homofobia, e no formato da Conferência Nacional realizada em 2008 indica algumas mudanças significativas. A primeira é a multiplicação de classificaçôes identitárias e sua conversão em siglas consideradas suficientemente abrangentes e ao mesmo tempo específicas para a tentativa de criação de uma identidade coletiva. Algumas páginas atrás, vimos

\footnotetext{
${ }^{32}$ Nesse ponto, cabe chamar a atenção para a dimensão performativa como referida nos desenvolvimentos de Peirano (2002), que, por sua vez, retoma o trabalho de Austin (1962, p. 10): "palavras são atos e podem ser referenciais - como nosso senso comum pressupõe - mas também fazer coisas por meio de seu próprio pronunciamento. Desse ângulo, Austin recorta atos performativos, que são aqueles nos quais a enunciação já constitui sua realização: 'Eu prometo' é um exemplo. Trata-se de expressão que não apenas exprime algo no presente ou no futuro, mas é um compromisso, uma ação, com uma força intrínseca que o autor chama de 'ilocucionária”. Essa dimensão já havia sido também trabalhada por Butler (1997), como apontado na introdução deste livro.
} 
o uso da sigla GLTTB em 2002; dois anos depois, no Brasil Sem Homofobia, a sigla utilizada foi GLTB; já a I Conferência foi convocada como GLBT. Além da alteração da ordem das letras, o "T" não mais designa transgêneros, mas travestis e transexuais. Após plenária realizada na conferência de Brasília em 2008, aparece outra inversão, e o "L" é trazido para frente com a justificativa de dar mais visibilidade para as lésbicas, resultando então no conjunto de letras utilizado predominantemente até esse momento: LGBT. Alguns trabalhos, como os de Câmara (2002), Facchini (2005), Carrara e Vianna (2007), Carrara e Simões (2007), Simões e Facchini (2009), indicam os processos de identificação e diferenciação que envolvem a produção da identidade coletiva do que se convencionava chamar de movimento homossexual brasileiro. Algumas hipóteses correlacionadas podem ser arroladas para a explicação desses processos: a busca pelo estabelecimento de identidades mais substancializadas, intensificada pela necessidade de percorrer e manejar um arsenal de reivindicações cada vez mais adequado às gramáticas e às retóricas do campo político; pode também ser o resultado de uma série de fatores relacionados ao formato dos grupos e à busca e à disputa por recursos financeiros que exigem a determinação de "público-alvo" específico; bem como podemos pensar que são fruto de disputas internas ao próprio movimento. ${ }^{33}$

Além disso, é fácil notar como os usos de conceitos como os de "identidade sexual", "identidade de gênero" e "orientação sexual" se alternam e são arranjados de forma diferente na construção de conteúdos

\footnotetext{
33 Golin (2004) se apresenta como "militante" de uma parte do "movimento homossexual brasileiro", de certa forma dissidente em relação ao que ganhou maior notoriedade nos últimos anos. Ele se coloca de modo contrário a muitas bandeiras consideradas "do movimento homossexual brasileiro", como se tal existisse como uma unidade consensual. Sua fala apresenta uma série de questôes que são deixadas numa zona de sombra, uma vez que se pretende constituir um grupo coeso que possa ser beneficiado por políticas governamentais especificamente direcionadas: "A gente fica pensando: o que a gente quer com um grupo, como uma ONG, que se pretende trabalhar com os direitos humanos de gays, lésbicas, travestis, transexuais? Eu vou usar essas palavras e acho que daria uma grande discussão só essa questão de identidade político-sexual e esses termos que a gente utiliza para ser reconhecido. Não concordamos com nenhum deles, acho todos limitados, uma limitação total [...] é um equívoco pensar que uma identidade sexual possa se transformar em uma identidade política. $\mathrm{O}$ que existe são práticas sexuais, são pessoas que sentem atração por pessoas do mesmo sexo" (Golin, 2004, pp. 233-7).
} 
e propostas. É significativo, nesse sentido, pensar que o primeiro painel da I Conferência Nacional, como já mencionado, foi "Introdução à orientação sexual e identidade de gênero" e buscava conformar que sentido seria dado a cada um desses conceitos ao longo do evento. ${ }^{34}$

Dos documentos mais abrangentes percorridos, é somente a partir dos que foram produzidos para e pela Conferência de 2008 que a homossexualidade deixa de ser o termo mais englobante utilizado para dar lugar a duas expressões conjugadas: "orientação sexual e identidade de gênero". Essa mudança ocorre por conta da reivindicação de travestis e transexuais, que não estariam contempladas pela homossexualidade, uma vez que o que definiria as suas identidades não estaria necessariamente relacionado à orientação sexual, mas aos atributos de gênero incorporados e experienciados. ${ }^{35}$ Antes da assunção da "identidade de gênero" como uma categoria-chave para o engendramento de proposiçóes específicas, "gênero" já aparecia em todos os documentos, mas subsumido ao que se refere exclusivamente às mulheres. Podemos dizer então que as reivindicações de travestis e transexuais contribuíram para ampliar os sentidos de "gênero" como categoria para a implementação de políticas.

A partir do PNDH III (2009), os "homossexuais" somem, dando lugar à "comunidade LGBT", "população LGBT", "segmento LGBT" ou "direitos LGBT" em planos e programas de governo. Em várias partes dos textos, as propostas não identificam um grupo de pessoas, mas se referem apenas a "orientação sexual e identidade de gênero". O termo "orientação sexual" já era utilizado desde o PNDH I, mas a expressão "identidade de gênero" só foi incorporada no PNDH III. Já os termos "casais homoafetivos" e "diversidades de gênero" aparecem

\footnotetext{
${ }^{34}$ Trecho da apresentação transcrita do painel de abertura: "E aí, o que é identidade de gênero? [...] A diferença de eu falar identidades de gênero significa que cada pessoa, a partir da sua sexualidade, pode construir a maneira como ela se vê e como ela se comporta. Isto é identidade de gênero; é como eu me sinto, é como eu me comporto e sou visto pelas outras pessoas. [...] Ninguém pode determinar a orientação sexual de ninguém. Só a pessoa pode dizer se ela é homo, se ela é hetero ou se ela é bissexual, que são as possibilidades que nós temos em relação à orientação sexual, o que faz com que a gente perceba uma coisa interessante, que é o fato de uma transexual ser heterossexual, por quê? Porque ela se sente mulher e ela se sente atraída pela identidade masculina" (Brasil, 2008).

${ }^{35}$ A discussão sobre a emergência da "identidade de gênero" politicamente ressignificada nesse campo retorna no capítulo 4.
} 
pela primeira vez no PNDH III, em uma "ação programática" que trata da garantia à adoção e em outra que versa sobre a educação, respectivamente.

Pelo relatório da I Conferência Nacional (2008), vemos como as propostas foram divididas em subtemas: Direitos Humanos; Saúde; Educação; Justiça e Segurança Pública; Cultura e Turismo; Trabalho, Emprego e Previdência Social; Cidades, Comunicação e Esportes; e Igualdade Racial e Mulheres. Os "temas transversais” envolvidos foram: idosos; pessoas com deficiência física; infância; adolescência e juventude; e Legislativo. Nas propostas discutidas, gênero, raça, etnicidade e geração apareciam como uma coleção de variáveis que não poderiam deixar de ser citadas, apesar de, por vezes, alguma ser deixada de fora. Dois exemplos de propostas que tentam dar conta das diversas "especificidades" e "temas transversais" no eixo "Direitos Humanos":

Assegurar a inserção da defesa dos direitos humanos da população GLBT na luta dos demais grupos historicamente estigmatizados em função de sua origem geográfica, etnia, raça, condição física, idade.

Produzir e sistematizar dados e indicadores relativos à realidade e à diversidade da população negra, indigena, cigana e ribeirinha GLBT com ênfase nas mulheres, travestis e transexuais negras. ${ }^{36}$

Em relação ao documento de 2004, Brasil Sem Homofobia, no qual existem seçôes específicas para "juventude” e "mulheres”, enquanto "racismo e homofobia" aparecem juntos em uma seção à parte, percebemos que, progressivamente, outras populações reconhecidas como alvo de políticas especiais ou como sujeitos de direitos já reconhecidos pelo governo brasileiro começam a emergir de maneira mais marcante. Esse é o caso de "idosos" e "pessoas com deficiência", e a dimensão de enfrentamento da discriminação racial ganha mais ênfase gradativamente. $\mathrm{Na}$ introdução do Plano Nacional LGBT de

\footnotetext{
${ }^{36}$ Relatório Consolidado das Conferências Estaduais de Gays, Lésbicas, Bissexuais, Travestis e Transexuais. Secretaria Especial de Direitos Humanos, 2008.
} 
2009, temos os "recortes" que devem ser considerados em todas as suas açôes:

Garantir os recortes de gênero, orientação sexual, raçaletnia, origem social, procedência, nacionalidade, atuação profissional, religião, faixa etária, situação migratória, especificidades regionais, particularidades da pessoa com deficiência é uma preocupação que perpassa todo o Plano e será levada em conta na implementação de todas as suas açóes (Brasil, 2009, p. 9).

Nas diretrizes do Plano, podemos localizar como são priorizados os "recortes" que procuram dar conta das "especificidades". Alguns exemplos:

Diretriz 5.11. Adoção de estratégias diferenciadas para grupos em situação de risco social e para grupos com histórico de estigma social: recorte étnico-racial da politica LGBT.

[...]

Diretriz 5.20. Proteção da universalidade, integralidade e acessibilidade na atençâo básica à pessoa idosa LGBT.

[...]

Diretriz 5.34. Inserção da temática LGBT nos meios e veículos de comunicação pública para promover a visibilidade dos direitos humanos e da cultura da(o)s cidadã(o)s LGBT, com uso de uma linguagem sem cunho discriminatório, que respeite as identidades de gênero, orientação sexual, raça e etnia, religião, ideologia, jovens, adolescentes, idosos e pessoas com deficiência.

O Plano segue dois "eixos estratégicos"37 que se desdobram em um conjunto de propostas e açóes. Estas, por sua vez, são apresentadas

\footnotetext{
37 "Eixo Estratégico I - Promoção e socialização do conhecimento; formação de atores; defesa e proteção dos direitos; sensibilização e mobilização; Eixo Estratégico II - Formulação e promoção da cooperação federativa; Articulação e fortalecimento de redes sociais; Articulação com outros poderes; Cooperação internacional; Gestão da implantação sistêmica da política para LGBT" (Brasil, 2009, p. 20).
} 
indicando-se a área de "competência" ou os ministérios que seriam responsáveis por sua efetivação. Outra preocupação indicada no plano é o orçamento. Além da área da administração governamental à qual caberia cada proposta, também há indicação de um prazo classificado como "curto" para execuções que deveriam ser previstas no orçamento de 2009, ou "médio" para o orçamento de 2010-11.

A preocupação com o orçamento foi um ponto que ganhou progressivamente mais espaço durante o período em que desenvolvi a pesquisa de campo e passou a ser central nas discussões, geralmente acompanhada de alguma variação da máxima: "não há política sem orçamento".

Em 2011, para a II Conferência LGBT, o orçamento ganhou um grupo de trabalho específico para a formulação de diretrizes. ${ }^{38}$ Além disso, no relatório final dessa conferência, vemos como a estrutura do documento foi organizada de maneira mais próxima das áreas da administração governamental. As propostas deixaram de tratar de ações e propostas específicas e passaram a observar "diretrizes" mais abrangentes. É claramente perceptível o esforço de investir em formulações mais exequíveis e adequadas aos formatos administrativos estabelecidos - ou de buscar adequação a determinados modos de "fazer-se Estado". Nas diretrizes destacadas a seguir, de acordo com os seus respectivos "eixos", é notável outro efeito relativo ao tempo: na diretriz de Saúde, por exemplo, temos a menção de uma política que já foi uma pauta de reivindicação na I Conferência, a Política Nacional de Saúde Integral de LGBT.

Enfrentamento ao sexismo e ao machismo

Diretriz 2 - Intersetorialidade das politicas públicas $L G B T$ e demais politicas de governo para combate ao machismo, sexismo, racismo, lesbofobia, bifobia, transfobia e homofobia, em todas as esferas de

\footnotetext{
${ }^{38}$ Os anais da II Conferência LGBT, de 2011, apresentam as diretrizes aprovadas, ordenadas pelos seguintes eixos: Educação; Enfrentamento ao Sexismo e ao Machismo; Enfrentamento ao Racismo e Promoção da Igualdade Racial; Poder Legislativo e Direitos da População LGBT; Saúde; Políticas de Juventude e de Recorte Intergeracional; Sistema de Justiça, Segurança Pública e Combate à Violência; Direitos Humanos e Participação Social; Trabalho, Geração de Renda e Previdência Social; Cultura; Turismo; Desenvolvimento Social e Combate à Miséria; Comunicação Social; Pacto Federativo e Articulação Orçamentária; Esporte.
} 
governo; transversalizando as questóes de gênero, raça e etnia, orientaçâo sexual, expressão e identidade de gênero, geracional, mulheres, travestis e transexuais, pessoas com deficiência, povos indígenas e comunidades tradicionais (p. 113).

Enfrentamento ao racismo e a promoção da igualdade racial Diretriz 1 - Garantia aos povos indigenas e comunidades tradicionais dos direitos ao território, à diversidade religiosa e cultural, considerando a dimensão étnico-racial, de gênero, de orientação sexual e de expressóes e identidade de gênero, respeitando suas formas de organização familiar.

\section{Saúde}

[Considerando] a Política Nacional de Saúde Integral de Lésbicas, Gays, Bissexuais, Travestis e Transexuais, publicada por meio da Portaria MS n. ${ }^{\circ}$ 2.836, de 01 de dezembro de 2011, considera a orientaçáo sexuale a identidade de gênero como determinantes sociais e culturais da saúde e destaca a importância de se levarem em conta as desfavoráveis condiçóes de saúde de Gays, Lésbicas, Bissexuais, Travestis e Transexuais (LGBT) agravadas pelo preconceito e discriminação existentes ainda na sociedade. [...] É uma política transversal, com gestão e execução compartilhadas entre as três esferas de governo, que deverá atuar articulada às demais politicas do Ministério da Saúde.

Diretriz 1 - Garantia de acesso universal, integral e equânime, com qualidade à saúde integral para lésbicas, gays, bissexuais, travestis e transexuais, no âmbito do SUS público estatal e de qualidade, considerando o recorte étnico/racial, geracional e de gênero para as açóes de promoção, prevenção, tratamento, com ênfase nas ações no campo da resposta às DST/HIVIAIDS e Hepatites Virais, HPV, processo transexualizador, saúde lésbica e cuidado dos agravos decorrentes da discriminação e preconceito. 
Politica de juventude e de recorte intergeracional

Diretriz 4 - Garantia das demandas e dos direitos da população LGBT na Agenda Nacional do Trabalho Decente para a Juventude (ANTDJ), com qualificação profissional, emprego, geração de renda, pautado no empreendedorismo da juventude e na economia solidária, uso do nome social nos ambientes de trabalho em todos os setores, inclusão dessa população nos programas do governo (como Projovem, Prouni, Pronatec, Ciência sem Fronteiras) com foco nas pessoas trans, respeitando questöes de gênero, orientação sexual, identidade de gênero, étnicas, de cor/raça e juventude do campo, pessoas com deficiência, classe, regiäo, grupos historicamente vulneráveis no que tange à qualificação e à inserção no mercado de trabalho.

Desenvolvimento social e combate à miséria

Diretriz 1 - Garantir o reconhecimento e a inclusão de novas configuraçôes familiares no CAD Único da Assistência Social, com a criação dos campos: orientação sexual, identidade de gênero e o nome social para que a população LGBT tenha acesso aos programas que utilizam os dados do CAD Único como base.

Pacto federativo e articulação orçamentária

Diretriz 4 - Criar e efetivar um plano estratégico pactuando com todos os entes federados com previsäo orçamentária, monitoramento e avaliação, sendo seus resultados divulgados durante a 3. ${ }^{a}$ Conferência Nacional de Políticas Públicas e Direitos Humanos LGBT. Essas ações serão articuladas por uma Comissão Intersetorial Nacional de Gestoras e Gestores estaduais e municipais que atuem em politicas da diversidade sexual e cidadania LGBT.

\section{Direitos Humanos e Participação Social}

Diretriz 5 - Garantia da plena cidadania da população LGBT mediante: aprovação da criminalização da homofobia, lesbofobia, bifobia e da transfobia nas mesmas bases da Lei de Racismo; reconhecimento do casamento civil igualitário para as pessoas LGBT; inclusão de questóes antidiscriminatórias em certames públicos 
que combatam a discriminaçâo em geral, em especial aquela por orientação sexual e por identidade de gênero; fomentar a criação, a implantação e a efetividade de órgãos estaduais e municipais que atuem em politicas para diversidade sexual e cidadania LGBT, bem como de centros de referência em direitos humanos de prevenção e combate à homofobia, atentos às especificidades da população LGBT e considerando os recortes étnico-racial, de gênero, classe, deficiência e região; efetivação da laicidade do Estado, não permitindo que decisóes governamentais sejam influenciadas por qualquer religião.

Nos trechos selecionados, podemos notar a continuidade do esforço em apontar o "recorte" das "especificidades". ${ }^{39}$ Ao mesmo tempo, algumas diretrizes procuram incluir a atenção para "orientação sexual e identidade de gênero" ou "população LGBT" em outras políticas consolidadas, como nas diretrizes reproduzidas anteriormente para os eixos de "Políticas para a juventude..." e "Desenvolvimento social...".

As pequenas alterações percebidas nos documentos produzidos entre 2004 e 2011 nos falam sobre as dinâmicas de um campo em constante movimentação, mas são, sobretudo, uma expressão do aprendizado de (ou adequação a) determinados formatos esperados ou tidos como mais eficazes. Demonstram a incorporação de certa - e correta - linguagem não só no sentido morfológico e conotativo, mas também em termos da utilização de um determinado vocabulário, compreendendo palavras como "intersetorialidade", "transversalização", "pacto federativo" etc.

Por fim, outro aspecto interessante desses tipos de planos e programas é o fato de explicitarem uma espécie de Estado em múltiplos níveis. Volto aos "princípios" do Plano Nacional LGBT, de 2009 (p. 11), para ilustrar esse ponto:

\footnotetext{
${ }^{39}$ Ainda sobre as "especificidades", durante o trabalho de campo, pude observar a realização de eventos particularmente a elas dedicados, como um encontro de "LGBT moradores de favela", a formação da "Rede de Negros e Negras LGBT", um encontro de "surdos LGBT", e, em abril de 2013, noticiou-se a realização do primeiro encontro de "Travestis e Transexuais Negras da Região Nordeste". Alguns desses eventos aparecerão nos capítulos a seguir.
} 
Um Estado democrático de direito não pode aceitar práticas sociais e institucionais que criminalizam, estigmatizam e marginalizam as pessoas por motivo de sexo, orientação sexual elou identidade de gênero. Diante disto, o Estado assume a responsabilidade de implementar políticas públicas que tenham como foco a população LGBT, a consolidação da orientação sexual e identidade de gênero, com vistas a romper com essa lógica injusta. A atuação do Estado, especialmente por meio da formulação e implementação de políticas, interfere na vida das pessoas, ao determinar, reproduzir ou alterar as relaçóes de gênero, raça e etnia e o exercício da sexualidade. O Plano Nacional de Promoção da Cidadania e Direitos Humanos LGBT tem como compromisso e desafio interferir nas ações do Estado, de forma a promover a cidadania, com respeito às diversidades.

Essas disposições expõem uma conformação particular de estado que, em certo nível, intervém e "interfere na vida das pessoas" por meio de políticas de gênero e sexualidade, e o Plano seria uma maneira de incidir sobre essa mesma "interferência" por meio de outro nível de atuação. Em suma, um plano de estado que "assume a responsabilidade de implementar políticas" e "interferir", ou talvez corrigir, a atuação do próprio estado.

\section{"DIREITO A TER DIREITOS":}

\section{UMA LINGUAGEM DE ACESSO À "CIDADANIA"}

O objetivo desta primeira parte foi versar sobre a delegação e a crença no "Estado", considerando que a delegação envolve tanto produzir representantes legitimados para uma determinada coletividade ou "população" quanto delegar ao estado a responsabilidade de resolução das questôes colocadas por tais coletividades. Desse modo, pretendeu-se expor algo da relação produtiva e mutuamente dependente entre "Estado" e "sociedade civil" - concebidos como entidades apartadas - e sobre a institucionalização de demandas e a produção de sujeitos. Por meio 
das conferências e dos documentos, selecionados entre 1996 e 2011, procurou-se uma maneira de contextualizar as dinâmicas que produzem o estado (e uma imagem determinada e desejada de estado) ao mesmo tempo que fabricam as populações possíveis ou desejadas para o efeito de estado que se pretende atingir.

Olhando para outro plano de análise, o percurso aqui delineado para a "política LGBT" segue um determinado roteiro de gestão governamental que se fia no envolvimento de organizaçóes não governamentais, entre outros atores da chamada "sociedade civil", para a discussão de políticas. Esse formato de operação acontece desde o início dos anos 1990 e parece ganhar ainda mais ênfase na lógica de realização de conferências e consultas na última década à "sociedade civil organizada”. Nas conferências LGBT e em outras convocadas nesse período, subjaz a lógica de operação do conceito de "participação democrática”. ${ }^{40}$

A criação de "espaços de participação", por meio dos quais a "sociedade civil" deve cumprir o papel de "monitorar" e "avaliar" as políticas governamentais, seria um tipo de interação pretendida, tido como garantia de promoção do desenvolvimento da democracia e da diversidade em uma sociedade igualitária. ${ }^{41}$ Essa retórica traz embutida uma imagem de estado-nação inserido em determinada

${ }^{40}$ Um exemplo, nesse sentido, é o Portal da Transparência da Presidência da República, "iniciativa inédita do governo brasileiro", criado para garantir "que cada cidadão passe a ser um fiscal da correta aplicação dos recursos públicos, sobretudo no que diz respeito às ações destinadas à sua comunidade". A página esclarece: "A participação contínua da sociedade na gestão pública é um direito assegurado pela Constituição Federal, permitindo que os cidadãos não só participem da formulação das políticas públicas, mas também fiscalizem de forma permanente a aplicação dos recursos públicos. Assim, o cidadão tem o direito não só de escolher, de quatro em quatro anos, seus representantes, mas também de acompanhar de perto, durante todo o mandato, como esse poder delegado está sendo exercido, supervisionando e avaliando a tomada das decisōes administrativas" (Disponível em: http://www. portaltransparencia.gov.br/controleSocial/. Acesso em: mar. 2013).

${ }^{41}$ No campo das políticas voltadas para o combate ao HIV/Aids, esta perspectiva foi claramente incorporada por meio dos acordos de empréstimo junto ao Banco Mundial, que garantiram o financiamento de ações capitaneadas pelo PN DST/Aids, desde 1994. A negociação desses acordos trazia certas recomendaçôes, ou "oferta de ideias" (Mattos et al., 2001) de como gestar políticas de enfrentamento, e a participação da "sociedade civil organizada" era um dos componentes de suma importância (Moutinho et al., 2005). Em outro sentido, mais especificamente sobre a retórica propagada a respeito da sexualidade pelo Banco Mundial e sua influência sobre uma visão conservadora na arena das políticas relacionadas aos direitos sexuais, ver Camargo Jr. e Mattos (2007). 
ordem internacional de direitos democráticos. De outra parte, oferece munição para que movimentos sociais e outros atores "civis" apontem para a democracia sempre inconclusa, que promete, mas não efetiva canais de participação ou não garante o exercício pleno de direitos. O Plano Nacional LGBT expõe essa concepção do estado de democracia incompleta. O texto que trata dos "princípios" do documento diz:

\section{O Plano Nacional de Promoção da Cidadania e Direitos Humanos} $L G B T$ parte da certeza de que um maior acesso e participação social nos espaços de poder é um instrumento essencial para democratizar o Estado e a sociedade. Dessa forma, é uma estratégia de longo alcance, no sentido de democratização do Estado, sendo de responsabilidade do conjunto de governo, e não de uma área específica (Brasil, 2009, p. 12). ${ }^{42}$

Pirez e Vaz (2012), em levantamento intitulado "Participação social como método de governo?", realizado no âmbito do Ipea, ${ }^{43}$ debruçam-se sobre o que chamam de "interfaces socioestatais" em programas do governo federal. O estudo se dedica a mapear açôes que vão desde "a participação social em fóruns coletivos e deliberativos, como os conselhos e as conferências nacionais, às formas mais restritas e individualizadas de contato, como ouvidorias, serviços de atendimento ao cidadão etc.". Os autores indagam sobre a relação entre "tipos de política" e "tipos de interface" e encontram diferentes modos de institucionalidade para o tratamento de determinadas áreas. Os tipos de interface propiciados pelos formatos de "conselhos e conferências" estão associados a políticas e programas da área de

\footnotetext{
${ }^{42}$ Para consideraçôes sobre o estudo de políticas públicas a partir do ângulo da antropologia, com ênfase nas dinâmicas que relacionam políticas governamentais e processos de formação de Estado, ver Souza Lima e Castro (2008).

${ }^{43}$ Nas publicações mais recentes do Ipea consta a seguinte autodefinição: "Instituto de Pesquisa Econômica e Aplicada (Ipea): fundação pública vinculada à Secretaria de Assuntos Estratégicos da Presidência da República, o Ipea fornece suporte técnico e institucional às ações governamentais possibilitando a formulação de inúmeras políticas e programas de desenvolvimento brasileiro - e disponibiliza, para a sociedade, pesquisas e estudos realizados por seus técnicos".
} 
"promoção e proteção social", enquanto "consultas públicas, audiências e reuniōes com grupos de interesse" estariam mais ligadas a temas de "desenvolvimento econômico e infraestrutura". A análise empreendida cobre o período 2002-10, e os autores argumentam que nos últimos anos teria emergido no Brasil algo que chamam de "uma ecologia da participação social, em que diferentes interfaces viabilizam o contato entre Estado e sociedade em diferentes políticas públicas para o cumprimento de diferentes objetivos e papéis" (Pirez e Vaz, 2012, p. 53).

Dagnino (2004) discute os desafios para um "projeto político democratizante" no Brasil e afirma que a década de 1990 foi marcada por uma inflexão "nas relaçóes entre o Estado e os setores da sociedade civil comprometidos com o projeto participativo democratizante, onde estes últimos substituem o confronto aberto da década anterior por uma aposta na possibilidade de uma atuação conjunta com o Estado" (p. 99). Em sua abordagem, as noçōes de "sociedade civil, participação e cidadania" aparecem como centrais nas disputas que se desenvolvem em torno desse projeto.

A autora explora a noção de "nova cidadania ou cidadania ampliada" para tratar da emergência de novos direitos, mobilizando três elementos basilares. O primeiro seria justamente a concepção de direito que "não se limita a provisões legais, ao acesso a direitos definidos previamente ou à efetiva implementação de direitos formais abstratos": o "direito a ter direitos". O segundo elemento dessa "nova cidadania" pressupóe "sujeitos sociais ativos (agentes políticos)" que definem quais são os seus direitos e lutam para o seu reconhecimento. Correlato aos dois primeiros, o terceiro elemento aponta para uma ruptura com a perspectiva de inclusão em um "sistema político já dado". Ao invés disso, o que estaria em jogo seria justamente galgar o direito de participar da invenção ou da definição desse sistema. Ainda de acordo com a autora, tal projeto democrático, que se desenrola em disputa com outros, desde a Constituição de 1988, implicaria uma "reforma moral e intelectual" envolvendo a aprendizagem e a composição de 
novos tipos de relações sociais dadas por meio de "sujeitos sociais ativos" (Dagnino, 2004, pp. 104-5). ${ }^{44}$

É a partir dessas novas configurações que emergem novos sujeitos políticos. Carrara e Vianna (2008) abordam as particularidades do período de redemocratização no Brasil desde o final dos anos 1970 e a sua relação com os sujeitos políticos que se constituíram em torno de questôes relacionadas a gênero e sexualidade. Os autores discutem a Constituição de 1988 como um "marco fundamental a partir do qual a sexualidade e a reprodução se instituíram como campo legítimo de exercício de direitos no Brasil" (p. 335), apesar de a tentativa de inclusão da "orientação sexual" no artigo que trata da proibição de discriminação com base em "origem, raça, sexo, cor e idade" não ter logrado êxito. ${ }^{45}$ Os autores destacam as "políticas de corte identitário" que ganharam terreno progressivamente pós-Constituição, processo correlato à "reelaboração dos Direitos Humanos no século $\mathrm{XX}$, [que] tem seu lugar no texto de 1988 em diversos momentos, indicando a necessidade de se reconhecer a qualidade diferenciada dos problemas que atingem 'segmentos' diversos (mulheres, crianças, povos indígenas etc.)” (p. 353). Portanto, tal disposição seria reflexo de certa concepção internacional a respeito dos direitos humanos e teria como desdobramento uma determinada maneira de articulação política que confere um lugar de destaque aos "sujeitos" nessa cena.

Tais análises oferecem elementos reflexivos que remetem ao surgimento ou ao acionamento de uma determinada "linguagem dos direitos", um vocabulário compartilhado, eivado de implicações específicas e que alimenta o campo que produz sujeitos para determinados direitos e vice-versa. Dizendo de outro modo, o "direito a ter direitos" trata não apenas de buscar a garantia de mecanismos formais de direitos, mas também passa pelo acionamento de uma

\footnotetext{
${ }^{44}$ Há um vasto e consolidado campo de estudos que vem se dedicando a analisar o projeto democrático brasileiro. Para alguns desses investimentos, ver Tatagiba (2002), Jaccoud (2005), Teixeira (2005), Feltran (2007), entre outros.

${ }^{45}$ A tentativa de inclusão da "orientação sexual" no texto constitucional foi liderada pelo Grupo Triângulo Rosa do Rio de Janeiro. Para uma análise desse processo e da conjuntura que envolvia o então chamado Movimento Homossexual Brasileiro, ver Câmara (2002), Facchini (2005), Simōes e Facchini (2009).
} 
linguagem específica, que tem como uma das suas funções produzir os sujeitos socialmente legitimados para exercerem os direitos dispostos por tais mecanismos.

Vianna (2013) destaca a "ação social dos 'direitos' - seja como normativas legais, como tradiçôes administrativas ou como forma de construção e posicionamento de sujeitos morais e políticos" ao mesmo tempo que aponta para a sua "dimensão processual e dinâmica". A autora propóe que a pluralidade de sentidos que circunda os "direitos" deve ser encarada justamente por sua produtividade, conferida pela "heterogeneidade e variabilidade morfológica" dessa arena de discursos. Em sua reflexão, desenvolvida por meio da realização e do acompanhamento de diferentes campos etnográficos de pesquisas que lidam com aparatos e agentes distintos que compõem a trama do "Estado", aborda alguns pontos nodais extremamente fecundos para a tarefa de descortinar tais dinâmicas institucionais. Por ora destaco apenas um deles, aquele que, em diálogo com as formulaçóes de Abrams (1988) e Mitchell (2006), a autora chama de "dentro e fora do Estado":

$O$ 'dentro' e o 'fora' do Estado, como expus, não se referem a localizaçôes ou estatutos precisos, mas a possibilidades de nomeação, qualificação, aliança e oposição entre atores diversos. $O$ acionamento de determinadas estratégias argumentativas é fundamental para que se produza, em niveis e contextos variados, a credibilidade dos atores sociais como estando comprometidos com o fazer direito' que pleiteiam, tenha este 'fazer direito' a forma de denúncia, reivindicação, protesto ou projeto (Vianna, 2013, p. 21).

A análise de Vianna enfatiza as interações cotidianas, a tensão positiva que pode ser encontrada entre "as práticas ou materialidades criticadas por diferentes atores sociais e essa espécie de centro nunca plenamente atingido, mas também nunca totalmente desacreditado do Estado ou da lei como 'deveriam ser"' (p. 18).

Instrumentalizando tais conceitualizações, na próxima parte, dedico-me a discutir algumas das principais tensões e disputas 
envolvidas na produção dos sujeitos específicos “LGBT". Poderíamos dizer que a linguagem operada nessas tensões e disputas é, sobretudo, moral e pretende estabelecer como social e institucionalmente inaceitáveis a "homofobia" ou a discriminação por orientação sexual elou identidade de gênero. 


\section{PARTE II \\ SUJEITOS EM PROCESSO E ARGUMENTOS EM CIRCULAÇÃO}

Nesta segunda parte, por meio de situações e falas registradas em caderno de campo entre 2008 e 2011 e outros materiais acumulados durante a pesquisa, procuro indicar alguns dos principais conflitos e disputas envolvidos no processo de forjar uma população específica como sujeitos de direitos. Os eventos selecionados para observação reuniam, em geral, atores e elementos do ativismo, do governo e das universidades e tinham o formato de reunióes, encontros, atos públicos, como caminhadas e marchas, seminários e congressos. ${ }^{1}$ Os capítulos a seguir são compostos por subtítulos que representam enunciados recorrentes em falas presenciadas durante esse tipo de atividade. Tais expressões integram um conjunto de frases de efeito - ou "atos de fala" (Austin, 1962) - que, pela repetição, performatizam e reúnem significados que condensam algumas das estratégias argumentativas da luta por direitos.

Nos próximos capítulos, percorro retóricas e estratégias políticas de visibilidade e mobilização. Volto-me para algumas das argumentações veiculadas, favoráveis e contrárias, a respeito da afirmação dessa

1 A lista dos principais eventos observados encontra-se na tabela do Anexo B (p. 333). 
população específica e procuro descortinar alguns dos efeitos pedagógicos dessas articulaçōes entre os próprios "sujeitos LGBT" e suas reverberaçôes fora do campo: Como se constituem as identidades eficazes como aglutinadoras de demandas? Quais são as operações que tornam as identidades eficazes nesses termos? Quais são os principais argumentos utilizados para a proposição de políticas públicas governamentais e por quais caminhos as demandas são feitas? 


\section{CAPÍTULO 3 \\ ESTRATÉGIAS DE VISIBILIDADE E TENTATIVAS DE REGULAÇÃO}

Cena 4 - Dia dezessete de maio de dois mil e dez

Brasília. Esplanada dos Ministérios. Saindo do metrô localizado na rodoviária, vejo pequenos grupos de pessoas caminhando. Usam camisetas com frases de protesto, outros vestem preto, alguns carregam bandeiras e faixas. Andamos na mesma direção, a Catedral de Brasília, local escolhido para a concentração da I Marcha Nacional pela Cidadania LGBT e contra a Homofobia. Já na concentração, um carro de som aguarda a reunião de manifestantes para dar início à caminhada, que seguiria até o gramado localizado em frente ao Congresso Nacional. Quando do início da Marcha, um conjunto de travestis e transexuais, algumas com longos vestidos pretos, como num luto de gala, se posiciona atrás de uma grande faixa, também preta e pintada com letras brancas: "De Luto pela Transfobia, e você????"

A convocação para a Marcha Nacional contra a Homofobia foi feita pela ABGLT, e um encarte distribuído durante o evento esclarecia: 
“será a primeira vez que a militância LGBT brasileira estará em uma grande manifestação política para denunciarmos os descasos diante da efetivação da nossa cidadania e exigirmos que nossas reivindicações históricas sejam imediatamente atendidas" (grifo meu). ${ }^{1}$ Os e-mails que circularam durante o período de convocação enfatizavam o seu caráter eminentemente político, buscando se distanciar do caráter mais festivo presente no tom das Paradas do Orgulho. Em algumas mensagens, chegou-se a sugerir que todos os participantes deveriam estar vestidos de preto, para propositalmente contrastar com a colorida e purpurinada estética presente nas Paradas que se realizam por todo o Brasil.

De fato, a I Marcha não teve carros de som entoando músicas festivas ou personagens "fantasiados". Muito material impresso foi distribuído; várias bandeiras, faixas e camisetas de diferentes organizaçóes de todo o Brasil. O carro de som serviu basicamente para discursos e palavras de ordem. Desde o início do percurso até a chegada ao gramado do Congresso, mais de vinte parlamentares proferiram discursos de apoio à "causa LGBT", do alto do carro de som. Ainda durante o trajeto, foi anunciado que o presidente Lula oficializaria, por decreto, o dia 17 de maio como o Dia Nacional de Combate à Homofobia. ${ }^{2}$ Segundo organizadores, a mobilização reuniu cerca de três mil pessoas; ônibus foram fretados de todos os estados do Brasil para levar a militância para a Marcha.

1 Encarte distribuído durante o evento intitulado "Jornal da I Marcha Nacional contra a Homofobia”, executado por um conjunto de ONGs e associaçóes e que contou com o apoio do Conselho Regional de Psicologia de São Paulo e do Conselho Regional de Serviço Social de São Paulo.

2 A data remete ao dia em que a homossexualidade foi retirada da lista de doenças da Organização Mundial da Saúde, em 1990. O decreto presidencial foi publicado no Diário Oficial da Uniáo no mês seguinte, no dia 7 de junho de 2010. 


\section{"CONTRA A HOMOFOBIA A NOSSA LUTA É TODO DIA": OS EVENTOS-ATO E OS APELOS DE LEGITIMIDADE E SOLIDARIEDADE}

A I Marcha Nacional contra a Homofobia foi antecedida por outros eventos organizados em Brasília em razão da comemoração do 17 de maio, Dia Internacional de Combate à Homofobia. Estive presente no Seminário UnB Fora do Armário: Rumo à I Marcha Nacional LGBT e na Câmara dos Deputados, onde teve lugar o VII Seminário de Lésbicas, Gays, Bissexuais, Travestis e Transexuais no Congresso Nacional, com o tema "Direitos humanos de LGBT: cenários e perspectivas". ${ }^{3}$

De uma maneira geral, os dois seminários percorreram pontos mais ou menos semelhantes, sendo que o da $\mathrm{UnB}$ procurou trabalhar a articulação da temática junto aos movimentos estudantis/universitários e de juventude, e o realizado na Câmara dos Deputados priorizou a abordagem dos temas no Poder Legislativo e no Judiciário. Ambos ressaltaram os avanços representados pelo programa Brasil Sem Homofobia, pela I Conferência Nacional LGBT e pelo Plano Nacional de Promoção da Cidadania e Direitos Humanos de LGBT.

Detenho-me no relato do seminário realizado no Congresso Nacional por considerá-lo representativo das discussões predominantes naquele período em conferências. $\mathrm{O}$ evento foi composto por uma longa mesa de abertura que precedeu duas outras. A primeira mesa teve como tema "Análise da situação dos direitos humanos das pessoas LGBT no Brasil", e a segunda, "União estável, Estado laico e fundamentalismo religioso". Destaco a seguir algumas das falas articuladas no evento. ${ }^{4}$

$\mathrm{Na}$ mesa de abertura, Eduardo Barbosa, representando o Departamento de DST/Aids e Hepatites Virais, falou sobre o

3 O primeiro evento, sediado na Universidade de Brasília, foi organizado em parceria pela Juventude da ABGLT, a UNE e o DCE UnB. O seminário da Câmara dos Deputados foi organizado em parceria pela Comissão de Legislação Participativa, a Comissão de Direitos Humanos e Minorias e a Comissão de Educação e Cultura.

4 Reproduzo as falas a partir de notas feitas em caderno de campo e também da publicação do seminário, disponibilizada pela Câmara dos Deputados (Centro de Documentação e Informação. Ediçôes Câmara 2011. Disponível em: http://bd.camara.gov.br/bd/handle/bdcamara/5984. Acesso em: jan. 2013). 
lançamento da campanha "Sou Travesti", com os objetivos de promover a prevenção das DSTs/HIV/Aids e também das hepatites virais; promover a inserção das travestis, com uma imagem positiva, no contexto da sociedade; por último, combater a violência e a exclusão a que as travestis ainda são submetidas.

Foi destacado por ele o fato de a campanha ter sido feita em colaboração com travestis de vários estados do Brasil e de a prevenção estar relacionada a "questóes de direitos humanos e promoção da igualdade". O palestrante exemplificou com a sua trajetória pessoal: "[...] se na minha vida pessoal eu tivesse podido modificar algumas coisas da clandestinidade do viver a homossexualidade, possivelmente, hoje, eu não seria soropositivo para o HIV". Por fim, Eduardo Barbosa ressaltou que travestis significam um grande desafio para o Departamento de DST/Aids, pois "ainda continuam sendo uma das populaçôes que mais sofrem com a violência e a exclusão".

Em seguida, a palavra foi concedida a Fernanda Benvenutty, uma importante liderança travesti, integrante da Associação Nacional de Travestis e Transexuais (Antra), que começou dizendo:

Tirando um pouco o foco dessa discussäo, apenas para mostrar uma outra realidade das travestis e transexuais de todo o Brasil, informo que, nos uiltimos quarenta dias, mais de vinte travestis foram assassinadas no Brasil. Este pode parecer um número pequeno, mas não é. Em cerca de vinte anos, 3.268 homossexuais foram assassinados em todo o Brasil. Desse número, $27 \%$ eram travestis. Nos últimos quarenta dias, mais de vinte travestis foram assassinadas. ${ }^{5}$

5 Apesar de não ter feito essa menção durante a apresentação, os dados citados têm origem nos levantamentos do Grupo Gay da Bahia (GGB), computados a partir de assassinatos veiculados pela mídia (Mott e Cerqueira, 2001). Para uma análise a respeito dos assassinatos de gays e travestis veiculados pela imprensa carioca, ver Lacerda (2006). Atualmente existe um blog na internet inspirado nos relatórios do GGB chamado "Quem a HOMOTRANSFOBIA matou hoje?". Nesse sítio, são reproduzidas, quase diariamente, notícias de assassinatos cometidos em todo o Brasil. O critério para a republicação das notícias no blog é a compreensão de seus moderadores de que se trata de um crime relacionado à orientação sexual ou à identidade de gênero da vítima. As notícias são utilizadas para organizar planilhas com os dados disponíveis sobre os envolvidos nos crimes, e essa contabilização é divulgada anualmente (Disponível em: http://homofobiamata.wordpress.com. Acesso em: jan. 2014). 
Durante a exposição, foram projetadas fotos do corpo de uma travesti assassinada dias antes. Fernanda não fez nenhum comentário a respeito da campanha de prevenção exibida antes da sua apresentação e, por fim, pediu palmas para saudar as companheiras assassinadas, ao que a plateia reagiu não só com palmas, mas também entoando: "Não, não, não à discriminação. Atrás do silicone também bate um coração”.

O próximo a falar foi Pedro Chequer, coordenador do Programa Conjunto das Naçóes Unidas sobre HIV/Aids (UNAIDS), no Brasil. O mais interessante em sua fala foi o destaque dado ao Brasil como um "país de contradiçôes", que "tem uma agenda bastante avançada", uma vez que nenhum outro lugar do mundo teve uma conferência LGBT convocada pela Presidência da República. Entretanto, trazendo dados produzidos pela ILGA - International Lesbian, Gay, Bissexual, Trans and Intersex Association, Chequer lembrou que, "entre os países que registram crimes homofóbicos, o Brasil é o campeão” seguido, de longe, por México e Estados Unidos. Como "pano de fundo" dessa situação, o expositor mencionou que

o fato de determinados grupos [religiosos] construirem uma agenda na qual a homossexualidade e a diversidade de orientação sexual sáo consideradas pecado e abominação com certeza estimula a existência do crime homofóbico, do crime de ódio, levando à construção de uma agenda adversa.

Ainda na continuação dos trabalhos de abertura do seminário, o próximo a falar foi Toni Reis, então presidente da ABGLT. Toni Reis mencionou a Marcha que seria realizada no dia seguinte: "Amanhã, vamos ter a primeira marcha LGBT do Brasil. Vai ser um divisor de águas no nosso movimento. Temos hoje duzentas paradas LGBT - é a comemoração e a festa da cidadania -, mas amanhã queremos uma marcha política de envolvimento".

Durante a sua fala, ainda destacou que o manifesto produzido para a Marcha havia coletado assinaturas de 535 organizações e movimentos sociais e teve a adesão de alguns partidos políticos: PT, PSDB, PSOL e PPS. Sobre o antagonismo religioso, Toni Reis declarou: 
Eu solicitei agora a palavra para dizer: Xô, homofobia do Congresso Nacional; xô, homofobia deste Congresso! Nós queremos que a Constituição Federal seja cumprida. É isso que nós queremos, pessoal. Nós não queremos privilégio nenhum, nós não queremos destruir a familia de ninguém. Nós queremos construir a nossa familia e da nossa forma. Queremos respeito, pessoal. E queremos respeitar todos os religiosos, sejam evangélicos, sejam católicos. Mas nós não podemos admitir o fundamentalismo neste país.

A fala da então vice-presidente da ABGLT, Keila Simpson, também procurou destacar os valores voltados ao esforço e ao "comprometimento" que se buscava atrelar à realização da I Marcha:

A ABGLT está extremamente feliz com o chamado que as afiliadas receberam para essa mobilização aqui em Brasília. As caravanas, que passaram 12, 36, 48 horas viajando, estão alojadas no Parque da Cidade. Essas pessoas, que estão dormindo mal, só mostram o comprometimento que têm com a causa. São caravanas de todos os estados do Brasil. Há ainda delegaçôes vindas pela estrada para chegar aqui hoje, dormir no Parque da Cidade e amanhã estar conosco na marcha nacional. Isto só demonstra o comprometimento que têm com essa nossa rede nacional, que éa $A B G L T$.

O último a se pronunciar na abertura do evento, "em reconhecimento a todas as entidades dos movimentos sociais organizados que se associam a essa luta", foi Augusto Chagas, então presidente da União Nacional dos Estudantes (UNE). Para ele, a realização da Marcha marcaria "um momento de maturidade do movimento, de convicção de que só a luta muda a vida e de que nós precisamos lutar para conquistar as transformaçôes que são tão necessárias ao nosso país". $\mathrm{O}$ convidado associou a superação do preconceito às características intrínsecas ao "povo brasileiro":

Algumas pessoas, Toni, dizem que no Brasil o preconceito não existe. Vemos muito esse discurso quando se trata de preconceito racial, por 
exemplo. Isto não é verdade. Existe muito preconceito no Brasil, e nós vamos precisar lutar muito ainda para derrotar essas ideias. Mas eu tenho a impressáo também, e esta é uma característica positiva, que o povo brasileiro é tolerante. Esta caracteristica é natural porque vem da miscigenação.

A escolha de fazer um relato mais alongado desses eventos está baseada nas características e nos encadeamentos comuns a muitos dos que observei durante a pesquisa de campo. O formato de abertura, a sequência da apresentação de expositores, o tipo de retórica articulada e de interpelação acionada por seus participantes conformam certos aspectos, quase roteirizados, que observei reiteradas vezes no decorrer da investigação. Isso inclui os argumentos, os fatos históricos, os dados e os bordões políticos enunciados. Alguns deles até aqui foram: a "luta" contínua e o esforço de comprometimento do movimento LGBT, a denúncia da violência e dos assassinatos, o horizonte internacional de garantia de direitos e, como continuaremos a ver, a linguagem dos direitos humanos e o posicionamento do Brasil nessa cena.

A primeira mesa de debates do seminário teve como tema "Direitos humanos LGBT no Brasil”. A preleção da coordenadora da mesa, deputada Manuela D’Ávila (PCdoB-RS), destacou o contraste entre o crescimento econômico, a geração de empregos e a não diminuição do preconceito:

O Brasil está melhorando muito, e nós precisamos mostrar que desenvolvimento de verdade é desenvolvimento com respeito aos direitos humanos, à diversidade. Precisamos mostrar que este país é rico porque cresce sua economia, mas é mais rico ainda porque é um continente diverso, de homens, mulheres, lésbicas, gays, travestis, negros, brancos; é um Brasil enorme em diversidade.

$\mathrm{O}$ primeiro convidado a falar foi Pedro Chequer. O expositor comentou a Declaração Universal dos Direitos Humanos, considerando que, à época de sua discussão, "não se poderia imaginar que deveria estar registrado explicitamente o respeito à diversidade sexual, 
à orientação sexual", mas que o princípio da equidade embutido na Declaração o garantia, independentemente de "raça, cor, sexo, língua, religião, opinião política de qualquer natureza, origem nacional, social e riqueza, nascimento ou qualquer outra condição".

O convidado teceu um panorama de disposiçôes internacionais que incluem o direito à livre orientação sexual e o respeito à identidade de gênero no rol de direitos humanos fundamentais, destacando o fato de aABGLT ter alcançado o status consultivo no Conselho Econômico e Social (Ecosoc) da ONU: "do ponto de vista que envolve o Estado nacional, o Brasil, temos a primeira organização dos países do sul a obter esse status". Pedro Chequer ainda apresentou a campanha da Unaids "Igual a você", contra a violação de direitos humanos e desigualdades, ${ }^{6}$ e discorreu sobre o modo como o preconceito e a discriminação podem estar relacionados à infecção pelo HIV/Aids:

A homofobia e a transfobia geram negação, medo, estigma, discriminação, dificuldade de acesso à informação, acesso reduzido a insumos de prevenção, menor acessibilidade a testagem e a aconselhamento, diagnóstico tardio da infecção pelo HIV, início tardio do tratamento e redução da sobrevida.

A Unaids considera fundamental a perspectiva de lutar pelos direitos humanos da população LGBT e implantar efetivamente açóes que visem ao acesso dessa populaçâo à informação, ao diagnóstico e ao tratamento do HIV.

A convidada seguinte foi a então subprocuradora-geral da República, Deborah Duprat, que destacou a mudança de paradigma que a Constituição de 1988 significou para o Direito:

6 "A campanha chama a atenção para o preconceito que estudantes, gays, lésbicas, pessoas vivendo com HIV, população negra, profissionais do sexo, refugiados, transexuais e travestis e usuários de drogas vivenciam todos os dias no Brasil. O preconceito se manifesta por meio de atitudes e práticas discriminatórias, tais como humilhaçōes, agressōes e acusaçōes injustas pelo simples fato de as pessoas fazerem parte de um grupo social específico" (Disponível em: http://www.unaids.org.br/campanhas/ igual_voce.asp. Acesso em: 18 jan. 2013). 
Tenho uma atuação de muitos anos na área de indios e outras minorias étnicas. O fundamento acaba sendo o mesmo para todas essas questóes de diversidade. O nosso Direito passou, com a Constituição de 1988, por uma transição, de uma sociedade hegemônica para uma sociedade plural, sem que as politicas e as leis pré-constitucionais ou infraconstitucionais tivessem seguido essa alteração.

A subprocuradora se disse surpresa com os dados de mortalidade de gays, lésbicas e travestis ali apresentados e com o fato de não existir "até hoje" uma lei definindo "como crime hediondo a homofobia". Segundo a expositora, a partir de 1988, os que estavam "nas bordas da sociedade foram incluídos" na letra constitucional. Entretanto, o Legislativo estaria se omitindo da função de editar leis que dessem significado a esse novo paradigma e, assim, também se omitindo "da sua função pedagógica de mostrar" essa mudança para a sociedade. ${ }^{7}$

A deputada Fátima Bezerra (PT-RN), que falou em seguida, também mencionou o caráter pedagógico e didático que ações do "Legislativo" poderiam assumir ao se referir a um projeto de lei de sua autoria que visava a instituir o Dia Nacional de Combate à Homofobia. O projeto passou por uma comissão e depois ficou "trancado". Por isso, foi necessário recorrer ao "Executivo", para que o presidente Lula instituísse o dia por decreto. A deputada reforçou a leitura de que o Congresso Nacional seria "hostil" e fechado a pautas ligadas à "cidadania da comunidade LGBT".

Por sua vez, Leo Mendes, outro expositor e então secretário de finanças da ABGLT, incumbiu-se de uma preleção didática, na qual explicou o uso correto de alguns termos, adotados pelo "movimento". Começando por "opção sexual”, o expositor ensinou que "não há como hoje ser gay, amanhã ser bissexual e depois de amanhã ser heterossexual

7 Na Procuradoria-Geral da República, Deborah Duprat foi a responsável por dar entrada na ADI (Ação Direta de Inconstitucionalidade) 4.275, que trata do direito de transexuais trocarem o prenome e o sexo no registro civil, independentemente de cirurgia de transgenitalização, e também na ADI 4.277, que foi julgada pelo Supremo Tribunal Federal junto com a ADPF (Arguição de Descumprimento de Preceito Fundamental) 132, impetrada pelo então governador do estado do Rio de Janeiro, Sérgio Cabral. O julgamento resultou favorável ao reconhecimento das uniōes estáveis entre pessoas do mesmo sexo como entidade familiar em 5 de maio de 2011. 
[...] pode até ser que alguém tenha essa opção [...] mas a grande maioria, se não a totalidade dos que estão no movimento, sabe que nós não temos essa opção [...]. As pessoas têm orientação sexual”. Em seguida, falou sobre o termo "homossexualismo", explicando que a OMS retirou o conceito do rol de doenças em 1990, logo "o que existe é a homossexualidade, que é tão natural quanto a heterossexualidade". E mais:

São três orientaçóes: hétero, bi e homo. Identidades de gêneros: travestis e transexuais. Quando estivermos falando de orientaçóes, estaremos falando das três e, quando estivermos falando de identidade, estaremos falando das travestis e transexuais.

E utilizamos o artigo feminino " " porque as travestis são maioria, $e$ elas são femininas.

Leo Mendes mencionou a Declaração Universal dos Direitos Humanos, a Declaração Conjunta da ONU sobre Orientação Sexual e Identidade de Gênero aprovada pelos países da América em 2008, discutiu a laicidade do estado brasileiro e destacou artigos e trechos da Constituição Federal que, por extensão, deveriam proteger os "LGBT". Por fim, o expositor declarou que o "Executivo está agindo", citando como exemplos o programa Brasil Sem Homofobia e o terceiro Programa Nacional de Direitos Humanos. "O Judiciário" foi mencionado como instância bastante atuante, com decisões favoráveis em relação a questôes como uniāo estável, direito à herança e adoção por pessoas do mesmo sexo. E o "Legislativo" continuou sendo apontado como espaço onde "há uma verdadeira ditadura de meia dúzia de fundamentalistas que se dizem religiosos e nos impedem de conquistar direitos civis".

A próxima convidada foi Tathiane Araújo, então secretária de Direitos Humanos da ABGLT e secretária de Articulação Política da Antra. A convidada anunciou que iria falar sobre "como os direitos humanos no Brasil precisam avançar, principalmente no que diz respeito à violência" e apresentou dados do Grupo Gay da Bahia de assassinatos motivados 
por homofobia. Enfatizando os números relativos à morte de travestis, justificou:

A nossa população é mais vulnerável e merece uma atenção especial porque nos ceifaram o direito à família, quando a família não nos compreende, nos expulsa de casa. Em contrapartida, não temos direito de ser travesti ou transexual dentro de uma escola, entäo tiram um segundo seio de formação para a vida, que é a escola. E só nos sobra a esquina da rua, que é perversa. O mesmo que paga à noite o programa com a gente recrimina de dia, não dá emprego, não dá oportunidade e, diante disso, somos os mais vulneráveis.

Além dos dados, a exposição contou também com a projeção de imagens de pessoas espancadas e assassinadas. E a convidada reforçou a denúncia contra "os fundamentalistas" e "pastores" que tratam a homossexualidade como doença e a associam com pedofilia.

Em seguida, a então representante da Coordenação LGBT da Secretaria de Direitos Humanos da Presidência da República, Mitchelle Meira, comentou sobre o programa Brasil Sem Homofobia, o Plano Nacional de Promoção da Cidadania e Direitos Humanos de LGBT e algumas ações do III PNDH, destacando certas controvérsias relacionadas às "questóes LGBT" contidas neste último. A partir de um levantamento realizado pelo governo, a coordenadora apresentou críticas que teriam sido direcionadas ao Programa no que tange à "questão LGBT": a garantia do direito de uma população historicamente discriminada seria "incentivo à homossexualidade", e a uniāo entre pessoas do mesmo sexo seria "contra a vontade de Deus" e poria em risco "a sobrevivência da espécie". A expositora ressaltou que, apesar das reações contrárias, o texto foi mantido na íntegra: "não recuamos um item sequer sobre os direitos LGBT. Este é um instrumento de participação social, de legitimidade".

Para finalmente fechar a primeira mesa, o deputado Iran Barbosa (PT-SE) foi chamado a se pronunciar. Ele usou seus antecedentes como participante do movimento social sindical para dar uma espécie de conselho para o público presente: 
Quero chamar a atenção para outro aspecto. [...] Se é verdade que precisamos insistir na formulação de legislação que contemple a luta $L G B T$, é verdade que não podemos arrefecer em momento algum. Há outras trincheiras em que temos que atuar. [...] a lei éo marco, mas não é a única garantia. [...] É preciso criar um sentimento além da lei.

O deputado ficou impressionado com os dados divulgados sobre violência - "são alarmantes!" - e traçou um paralelo com o reconhecimento dos homossexuais como vítimas do nazismo:

Fico a me perguntarse, de fato, às vezes a identidade, o reconhecimento, a expressäo forte de algo como foi o nazismo e o Holocausto na Europa facilitam mais o reconhecimento da barbárie, do cometimento de crime, do que a pseudodemocracia que vivemos aqui no Brasil. Os dados apresentados mostram que precisamos fazer um movimento para que se reconheça que as populaçóes de LGBT no Brasil são vítimas de uma violência direcionada.

E concluiu dizendo que, para "enfrentar a violência diária e cotidiana”, é preciso que se produzam dados mais específicos sobre a situação.

A segunda mesa do evento tratou de "união estável, Estado laico e fundamentalismo religioso". Naquele momento, dava-se atenção a um projeto em tramitação que propunha alterar o art. 1.727 do Código Civil, que trata da união estável "entre homem e mulher". Um dos proponentes desse projeto foi o deputado José Genoíno (PT-SP), e foi dele a primeira fala da mesa. $\mathrm{O}$ deputado recorreu à filosofia e citou autores como Bauman para discutir a relação entre estado e religião e defender a laicidade do estado brasileiro.

Outro convidado foi o pastor da Igreja Presbiteriana do Brasil Marcos Alves da Silva, que se valeu de argumentos que caminharam pela interpretação de premissas jurídicas e filosóficas para também tratar da relação entre religião, estado e homofobia: 
O Estado Democrático de Direito, que encontra seu desenho jurídico na Constituição de 1988, não é um dado, não está pronto como que por declaração do constituinte. O Estado Democrático de Direito se faz à medida que a Constituição, em sua dimensão prospectiva, concretiza-se historicamente na dialética entre os embates das diversas forças organizadas da sociedade civil. A reflexão que proponho sobre o fundamentalismo religioso e a intolerância no Estado Democrático de Direito tem como partida essas premissas e os principios constitucionais que asseguram a democracia não apenas como limitação ao poder estatal em face das liberdades individuais. O Estado Democrático de Direito somente será efetivo se o princípio da democracia tiver reverberação também nas relaçôes interprivadas.

Jean Wyllys, naquele momento apresentado como professor e jornalista, ${ }^{8}$ iniciou dizendo que sua formação era na área de estudos culturais e que sua atuação profissional, havia muitos anos, percorria as áreas de "direitos humanos e questões sociais". O futuro deputado fez uma explanação sobre mitos como narrativas organizadoras de culturas e explicativas da constituição de sujeitos como tais e discorreu sobre a pluralidade das "homossexualidades". Disse não ser por acaso que as letras que representam o coletivo aumentam, "confundindo aqueles que querem nos aprisionar em estereótipos definitivos”, pois a "identidade homossexual” seria "múltipla”, “em aberto”, "sem essência”. Apesar dessa "não identidade", Jean Wyllys localizou onde estaria a experiência comum que permite a formação de um "coletivo": "As injúrias de que somos vítimas [...] nos constituem como um coletivo que preexiste e nos unem mesmo que alguns homossexuais não queiram ou recusem ou dele [coletivo] não tenham consciência”.

Para Jean Wyllys, essa injúria teria como fundo a "mitologia judaico-cristâ", que culpabiliza e aponta a homossexualidade como pecado, anormalidade e antinatural. Os produtores desse tipo de mito e, portanto, produtores de significados "nefastos e letais" seriam os "fundamentalistas".

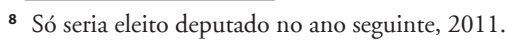


A convidada seguinte foi Rosa Oliveira, advogada e pesquisadora, que apresentou alguns resultados da sua pesquisa de doutorado sobre acórdãos judiciais relacionados a uniōes entre pessoas do mesmo sexo. ${ }^{9}$ $\mathrm{E}$ os dois últimos convidados foram integrantes da ABGLT naquele momento, Irina Bacci e Carlos Magno, respectivamente. Ambos saudaram as delegações de vários estados presentes. Irina destacou a "invisibilidade" de mulheres lésbicas e bissexuais até mesmo no cômputo de casos de assassinatos:

Não é que somos menos assassinadas porque somos mais aceitas, mas porque até para morte somos invisiveis, até para os dados não aparecemos. Isso é muito importante e muito dificil de dizer, porque até quando morremos náo somos lembradas. Esses fatos, essa raiz da invisibilidade das mulheres, especialmente de nós lésbicas e mulheres bissexuais, vêm do sexismo, do machismo.

Irina Bacci apontou a importância do PLC 122 e do Projeto de Lei de União Estável para a provocação de "debates públicos pela conquista da cidadania plena LGBT". E lembrou a Lei Maria da Penha como um "marco político", pois "é nesta lei que temos a nossa cidadania citada e lembrada pela primeira vez, ainda que seja pelo dever de manter um relacionamento saudável". ${ }^{10}$ Por fim, a convidada questionou "o modelo de Estado que estamos construindo", marcado pela "fragilidade na garantia do Estado laico", o que interferiria na "construção da cidadania LGBT".

Se esta Casa queria pressão, como sempre nos rogou Maria do Rosário, Fátima Cleide, estamos aqui, estamos fazendo pressão. Queremos uma resposta desta Casa, com a aprovação dos nossos projetos, do PLC

9 Ver Oliveira (2009).

${ }^{10}$ O Artigo 2. ${ }^{\circ}$ da Lei 11.340/2006, mais conhecida como Lei Maria da Penha, define: "Toda mulher, independentemente de classe, raça, etnia, orientação sexual, renda, cultura, nível educacional, idade e religião, goza dos direitos fundamentais inerentes à pessoa humana, sendo-lhe asseguradas as oportunidades e facilidades para viver sem violência, preservar sua saúde física e mental e seu aperfeiçoamento moral, intelectual e social". 
n. 122 e do Projeto de Lei de Uniāo Estável. Quero perguntar aos nobres deputados e deputadas quando vão colocar 'a cara a tapa' e dizer se aprovam ou náo os nossos projetos?

Já Carlos Magno relacionou o preconceito contido em "argumentos religiosos, científicos, morais" com a "despolitização" da opressão e da injustiça.

$[P]$ reconceito social é um dos principais fatores de manutenção das hierarquias e da legitimação da inferioridade. Esse preconceito é muito bem elaborado [...] levando para o campo pessoal, individual e privado uma questão de injustiça: a negação dos direitos dos homossexuais. Qual é a nossa tarefa? Politizar essa injustiça que foi despolitizada. Toda vez que usam o termo homossexual com argumentos de status morais dizem que o homossexual é pecador, que o homossexual é perverso, que o homossexual é promiscuo, que o homossexualismo é pecado. Isto fortalece outra sexualidade que foi construida como norma, que é a heterossexualidade.

Para encerrar a sua apresentação, o convidado falou sobre o sentido da Marcha que aconteceria no dia seguinte. Mencionando a visibilidade proporcionada pela enorme quantidade de Paradas do Orgulho que acontecem no Brasil anualmente, ${ }^{11}$ Carlos Magno disse:

Temos o titulo de primeiro lugar de ação e de visibilidade. Mas nós, da ABGLT, chegamos à conclusão de que só visibilidade não é suficiente. Temos de ocupar as ruas para mostrar a este Congresso que somos muitos e merecemos direitos. [...] A sociedade diz que os homossexuais gostam é de parada, de go-go boy, de música eletrônica, de oba-oba e não vêm para a luta "fazer carão". Nós gostamos de tudo isso, mas também somos de luta! Por isso mostramos que mobilizamos todos os estados deste pais! Essa é uma nova forma de criatividade, é uma nova forma de mobilização!

\footnotetext{
${ }^{11}$ Um calendário divulgado no site da ABGLT contabilizava mais de 260 paradas a serem realizadas em todo o Brasil naquele ano de 2009.
} 
E assim, com convidados de origem, formação e experiências diversas, o seminário oscilou entre apresentar um panorama dos "avanços" em relação aos "direitos LGBT" até aquele momento, localizar e apontar os entraves para a aprovação de leis e denunciar as violências sofridas. O evento foi pontuado pelo registro de "presenças parlamentares". Em todos os intervalos entre as falas, deputados e senadores que passavam pelo auditório tinham a presença anunciada pela mesa e às vezes tomavam o microfone para declarar o seu "apoio à causa" com pronunciamentos bastante semelhantes entre si. Além dos já ressaltados, outros aspectos foram recorrentes: explanações didáticas e teorias explicativas para a homossexualidade e a evocação de experiências comuns que confeririam unidade ao "coletivo".

O caráter repetitivo e de natureza redundante é notado por Maria Claudia Coelho (2009) durante a observação de um encontro de mulheres organizado com o objetivo de reunir "diagnósticos" sobre violência para os debates da I Conferência Nacional de Segurança Pública. ${ }^{12} \mathrm{~A}$ autora percebe que entre as falas das participantes havia pouca discordância e que, em geral, repetiam-se sucessivamente: "Cada participante parecia fazer do microfone o seu bilhete de entrada para um pequeno palanque, repetindo, com mínimas variações, protestos, acusaçōes e demandas já inúmeras vezes mencionados" (Coelho, 2009, p. 127). A antropóloga "confessa" que, restando ainda muito encontro pela frente, "já achava tudo extremamente repetitivo e enfadonho" (p. 126). No entanto, utiliza o seu incômodo para reorganizar as questôes pertinentes à observação que conduzia: "Por que estas mulheres não parecem entediadas?"; "O que faz com que elas sustentem o interesse em um debate que, para outros observadores, é extremamente repetitivo quanto ao conteúdo do que está sendo dito?"; "O que elas estão fazendo ao repetir?”. A análise de Coelho lança hipóteses bastante persuasivas para essas questôes. Recorrendo ao trabalho de Bruno Latour e Steve Woolgar (1997) sobre "a produção retórica dos fatos científicos", recupera a argumentação de que "hipóteses tentativas" são transformadas em

\footnotetext{
${ }^{12} \mathrm{O}$ encontro, financiado pela Secretaria Especial de Políticas para as Mulheres, foi realizado em Belém e fazia parte da iniciativa "Mulheres: Diálogos sobre Segurança Pública" (ver Brasil, 2009a).
} 
verdades por meio do gradativo apagamento do seu lugar de enunciação. Se, na repetição, o enunciado é sempre o mesmo, o sujeito que o enuncia não o é, e progressivamente o enunciado é apropriado como uma afirmação que não necessita ter a sua autoria mencionada.

A explicação encontrada por Coelho para esse "gozo repetitivo" é que aquilo que conta não é proferir "novas verdades", mas apropriarse do que é proferido:

$O$ sentido último deste aparente discurso da redundância emerge aqui: ao decidir repetir, o sujeito faz algo de novo, em seu duplo sentido: ao fazer algo 'de novo' (no sentido de fazer outra vez), ele faz algo 'de novo' (no sentido de 'inédito'). E este algo inédito é a instauração de si como sujeito dessa verdade (2009, p. 131).

Admito que a mesma sensação de enfado me ocorreu em algumas ocasiōes durante os diversos eventos que acompanhei ao longo da pesquisa. Mas, como depreende Maria Claudia Coelho, a repetição é importante por dar um lugar aos sujeitos da enunciação. Além disso, fazer sempre as mesmas denúncias e reforçar reiteradamente as mesmas faltas emprestam legitimidade e estabelecem o caráter moral de resistência não só ao que é enunciado, mas também a quem enuncia.

Nesse conjunto de eventos ocorridos em Brasília em maio de 2010, “as verdades" enunciadas pelos sujeitos versaram a maior parte do tempo sobre violência e homofobia, sobre a necessidade de leis "pró-LGBT", paralelamente à dificuldade de aprová-las. A maior dificuldade apontada para a aprovação de leis "pró-LGBT", como visto, foi repetida como um mantra por diversos expositores: o "fundamentalismo religioso", particularmente atribuído a evangélicos. Por vezes, "os fundamentalistas" a quem os protestos se dirigiam naquele momento foram citados nominalmente, caso dos senadores Magno Malta (PR-ES) e Marcelo Crivella (PRB-RJ).

Um manifesto divulgado durante os eventos afirmava que vinha sendo enfrentada "a homofobia feroz dos setores conservadores e dos fundamentalistas religiosos", apresentando alguns "resultados" desse fundamentalismo: 
- o assassinato de um LGBT a cada dois dias no Brasil (dados do Grupo Gay da Bahia - GGB) por conta da orientação sexual (bi ou homossexual) ou identidade de gênero (travestis ou transexuais);

- o Congresso Nacional não aprova nenhuma lei que garanta a igualdade de direitos entre cidadãos(âs) heterossexuais e homossexuais no Brasil;

- o Supremo Tribunal Federal não julga as Arguições de Descumprimento de Preceitos Fundamentais e Açôes Diretas de Inconstitucionalidade que favoreçam a igualdade de direitos de pessoas LGBT no Brasil;

- o Executivo Federal não implementa na sua totalidade o Plano Nacional de Promoção da Cidadania e Direitos Humanos de LGBT;

- centenas de adolescentes e jovens LGBT são expulsos diariamente de suas casas;

- milhares de LGBT são demitidos ou perseguidos no trabalho por discriminação sexual;

- travestis, transexuais, gays e lésbicas abandonam as escolas por falta de uma política de respeito à diversidade sexual nas escolas brasileiras;

- os orçamentos da União, estados e municípios nada ou pouco contemplam recursos para açóes e políticas públicas LGBT;

- o Ministério da Saúde, as secretarias estaduais e municipais precisam pactuar e colocar em prática a Política Integral da Saúde LGBT;

- as Secretarias de Justiça, Segurança Pública, Direitos Humanos e Guardas Municipais não possuem uma política permanente de respeito ao público vulnerável LGBT, agredindo nossa comunidade, não apurando os crimes de homicídio e latrocínio contra LGBT nem prendendo seguranças particulares que espancam e expulsam LGBT de festas, shoppings e comércio em geral. ${ }^{13}$

${ }^{13}$ Manifesto divulgado pela ABGLT, por ocasiāo da I Marcha Nacional contra a Homofobia, em maio de 2010 . 
A I Marcha, diversas vezes indicada como "um divisor de águas” por seu caráter político "reivindicativo", trazia entre as suas "exigências": a "garantia do Estado laico", o "combate ao fundamentalismo religioso", o "cumprimento do Plano Nacional LGBT em sua totalidade", a "aprovação imediata do PLC 122/2006 (Combate a toda discriminação, incluindo a homofobia)" e decisões favoráveis do Judiciário "sobre união estável entre casais homoafetivos, bem como a mudança de nome de pessoas transexuais". ${ }^{14}$

Desde essa primeira edição, em 2010, a Marcha entrou para o repertório de mobilização LGBT, acontecendo sempre em conjunto com um seminário na Câmara dos Deputados, entre outras atividades organizadas na capital federal. ${ }^{15}$

Estive presente também na segunda edição da Marcha, em 2011. Nessa ocasião, foi perceptível o aumento de participantes em relação ao ano anterior. Segundo a organização, foram 5.000 pessoas. Notei também mais gente "montada" - além das personagens trans de costume - e alguns ambulantes vendendo cerveja. Nada que chegasse a ser comparável com a irreverência das Paradas, mas um tom geral menos exasperadamente contido do que em 2010. O trajeto da caminhada novamente partiu da Catedral, porém foi acrescentado um desvio de percurso até o Supremo Tribunal Federal, que naquele ano ganhou um "abraço simbólico". O gesto foi organizado em agradecimento à decisão favorável ao reconhecimento da união estável entre pessoas do mesmo sexo, ocorrida no início daquele mesmo mês. O manifesto divulgado em 2011 trazia novamente as reivindicações por "igualdade de direitos", "reconhecimento" e "cidadania plena" e chamava a atenção para "o recrudescimento da violência homofóbica em todas as Unidades da Federação", indicando que "muitos dos agressores não pertencem a grupos de extermínio ou estão envolvidos em crimes de ódio, mas são jovens de classe média, o que demonstra como a homofobia está amplamente difundida em toda a sociedade".

\footnotetext{
${ }^{14}$ Manifesto divulgado pela ABGLT, por ocasião da I Marcha Nacional contra a Homofobia, em maio de 2010.

${ }^{15}$ A quarta edição da Marcha contra a Homofobia aconteceu em Brasília, em 15 de maio de 2013, com o tema "Laicidade, Democracia e Estado".
} 
Entre as "exigências", quatro pontos que não foram lembrados no manifesto de 2010:

- que todos os governos estaduais e municipais instituam coordenadorias LGBT, conselhos LGBT e Planos de Combate à Homofobia;

- que as instituições nacionais ou locais de saúde pública estabeleçam ou fortaleçam regulamentações que retirem dos sistemas de saúde públicos ou privados as pessoas que pratiquem ou promovam práticas de cura da homossexualidade;

- que os governos municipais, estaduais e federal acelerem a implementação dos Planos Nacionais de Enfrentamento da AIDS para gays e outros $\mathrm{HSH}$, travestis, lésbicas e transexuais, garantindo recursos orçamentários e o necessário controle social na sua execução, promovendo a diminuição da infecção do HIV em nossa comunidade;

- que sejam tomadas medidas concretas pelas autoridades competentes para diminuir os casos de assassinato e violência contra as pessoas LGBT.

A menção ao "recrudescimento da violência" naquela ocasião reverberava uma série de casos que ganharam espaço nos jornais a partir do final do ano de 2010 . O primeiro a repercutir nacionalmente aconteceu em 14 de novembro de 2010, em São Paulo. Um grupo de jovens que caminhava pela Avenida Paulista foi agredido com lâmpadas fluorescentes por outro grupo de cinco jovens. A motivação do ataque foi compreendida como homofobia. ${ }^{16}$ No mesmo dia, após a Parada LGBT do Rio de Janeiro, um jovem foi baleado por um soldado do Exército, e a motivação atribuída ao ocorrido também foi homofobia. ${ }^{17}$ Essas e outras ocorrências - como a divulgação, pela

\footnotetext{
16 "Grupo usou barra de lâmpadas em agressão a jovens na Avenida Paulista". Folha de São Paulo, 14/11/2010. Disponível em: http://www1.folha.uol.com.br/cotidiano/830530-grupo-usou-barrade-lampadas-em-agressao-a-jovens-na-avenida-paulista.shtml. Ver anexo C4 (p. 347-8).

17 "Jovem é baleado após Parada Gay no Rio e acusa militares". Estadão.com.br, 16/11/2010. Disponível em: http://www.estadao.com.br/noticias/impresso,jovem-e-baleado-apos-parada-gay-do-
} 
Universidade Presbiteriana Mackenzie de São Paulo, de uma nota com posicionamento contrário ao projeto de lei que visava a tornar crime "manifestaçōes contrárias à homossexualidade" - foram alardeadas como uma "onda homofóbica". ${ }^{18}$ Como resposta a esses eventos, no dia 21 de novembro de 2010, foram organizados atos públicos de protesto no Rio de Janeiro e em São Paulo. ${ }^{19}$

Ainda em novembro de 2010, um outro conjunto de iniciativas ocorreu no espaço de dois dias em Brasília. Foram eles, nessa ordem: o Seminário Escola Sem Homofobia, sediado na Câmara dos Deputados; a entrega do prêmio Educando para a Diversidade Sexual, também na Câmara; a audiência pública Bullying Homofóbico nas Escolas, ocorrida no Senado; e o Seminário sobre os Assassinatos de LGBT, novamente na Câmara dos Deputados. Esses eventos foram realizados a partir de uma parceria da ABGLT com a Frente Parlamentar Mista pela Cidadania LGBT, a Comissão de Educação, Cultura e Esporte do Senado Federal, a Comissão de Legislação Participativa e a Comissão de Direitos Humanos e Minorias da Câmara dos Deputados. O primeiro seminário foi composto de falas de deputados, representantes do movimento social e do Ministério da Educação.

As discussões nos dois dias giraram em torno do projeto Escola Sem Homofobia - e do material educativo que deveria ser lançado em

rio-e-acusa-militares, 640486,0.htm. Ver anexo C5 (p. 349).

${ }^{18}$ Trecho da nota divulgada: "A Igreja Presbiteriana do Brasil manifesta-se contra a aprovação da chamada lei da homofobia, por entender que ensinar e pregar contra a prática do homossexualismo não é homofobia [...]". Disponível em: http://educacao.uol.com.br/noticias/2010/11/16/mackenzie-divulganota-contra-lei-da-homofobia-oab-fala-em-postura-da-idade-media.htm. Ver anexo C6 (p. 350-1).

19 Por meio da minha participação na manifestação em São Paulo e das descriçōes sobre o que ocorreu no Rio de Janeiro circuladas em listas de e-mail, foi interessante notar como a conformação político-partidária das cidades se reflete na organização dos movimentos sociais. A convocação para o ato de São Paulo pedia que "convicçôes partidárias" fossem deixadas de lado para que estivessem presentes, em conjunto, filiaçôes de diferentes partidos. E, de fato, durante o ato na Avenida Paulista, registrei no caderno de campo representantes ativistas do PSTU, PSOL, PT, CUT e da Diversidade Tucana do PSDB, e ainda a participação de dois deputados do PSOL. Em manifestações do mesmo tipo no Rio de Janeiro, a maioria dos presentes, ao menos até aquele momento, não ostentava vinculações partidárias, e, quando isso ocorria, existia um predomínio do PT. Outro ponto notado parecia ser uma maior diversidade de iniciativas de organizaçōes políticas em São Paulo, como a presença de movimentos estudantis de mulheres e outras movimentaçōes autodenominadas anarquistas. 
breve pelo governo federal ${ }^{20}$ - e da necessidade de aprovação do projeto de lei, já muitas vezes aqui mencionado, que propunha criminalizar a discriminação em razão de orientação sexual e identidade de gênero (PL 122/2006), justificado pelos números alarmantes e os relatos de violência brutal apresentados por diferentes expositores. Repetidas vezes foi ressaltada a resistência encontrada para as "questōes LGBT" no Congresso Nacional, protagonizada pelos parlamentares "fundamentalistas religiosos".

No primeiro seminário, ocorrido no dia 22 de novembro de 2010, foram divulgados resultados da pesquisa Escola Sem Homofobia, um estudo qualitativo conduzido em escolas de ensino fundamental da rede pública em 11 capitais do Brasil. ${ }^{21}$ Após a execução do Hino Nacional pela cantora Jane di Castro, começaram os pronunciamentos de parlamentares e membros da ABGLT. O teor das falas ressaltava a importância daquele momento e a relevância da pesquisa ao abordar o tema nas escolas e tratá-lo no campo da educação. Um dos responsáveis pelo projeto explicou o histórico da pesquisa, o contexto de sua realização e alguns resultados. A audiência pública realizada no dia seguinte no Senado Federal tratou novamente de alguns dados da pesquisa e contou com outras apresentaçôes, que discutiram de maneira mais ampla o papel das escolas e o tema da homofobia na educação.

\footnotetext{
${ }^{20}$ Por encomenda do Ministério da Educação, a pesquisa Escola Sem Homofobia foi realizada pela Reprolatina - Soluçôes Inovadoras em Saúde Sexual, em parceria com a Pathfinder do Brasil, a ABGLT e ECOS - Comunicação em Sexualidade. O levantamento de dados sobre a percepção de alunos e funcionários das escolas a respeito da "homofobia no ambiente escolar" serviria como subsídio para, entre outras açôes, elaborar um material para trabalhar a "diversidade sexual" em contextos educativos. Mais tarde (em maio do ano seguinte), esse material educativo seria pivô do polêmico veto da presidente Dilma àquele que ficou vulgar e pejorativamente conhecido como "kit gay", mencionado no capítulo 1 deste livro. Análises detalhadas da agenda "anti-homofobia" na educação podem ser encontradas em Daniliauskas (2011) e Fernandes (2011). Especificamente para a polêmica que eclodiu em torno do "kit anti-homofobia", ver Vital e Leite Lopes (2013) e Leite (2014).

${ }^{21}$ Relatório de pesquisa disponível em: http://www.reprolatina.org.br/site/html/atividades/homofobia. asp. Acesso em: jan. 2013. As notas taquigráficas do seminário realizado na Câmara dos Deputados podem ser encontradas em: http://pfdc.pgr.mpf.mp.br/informacao-e-comunicacao/eventos/ direitos-sexuais-e-reprodutivos/audiencia-publica-avaliacao-programas-federais-respeito-diversidadesexual-nas-escolas/projeto-escola-sem-homofobia/notas-taquigraficas-sobre-o-projeto-escola-semhomofobia. Acesso em: maio de 2013.
} 
O último evento dessa série, o Seminário sobre os Assassinatos de LGBT, foi iniciado com o depoimento de mães que tiveram os filhos vitimados por violência homofóbica. ${ }^{22} \mathrm{Em}$ seguida, muitos se pronunciaram ainda na mesa de abertura, como representantes do movimento LGBT e parlamentares. Por fim, na mesa principal, os convidados expuseram alguns levantamentos sobre violência e assassinatos. Destaco alguns trechos a seguir.

Referindo-se aos dados apresentados no seminário anterior e aos depoimentos "alarmantes" das mães presentes, ainda na mesa de abertura, o deputado Paulo Pimenta (PT-RS) falou que era preciso "mobilizar a sociedade para que o projeto que criminaliza a homofobia fosse aprovado". Comparando-o com a lei que tornou o racismo crime, disse:

Quero repetir: com certeza, aprovando a criminalização da homofobia, não vamos, num primeiro momento, mudar a cabeça das pessoas, não vamos mudar a sua cultura, mas vamos reduzir, sim, e de maneira muito sensivel, a impunidade. Vejam que, antes de termos no Brasil uma lei que criminaliza o preconceito racial, era comum, em delegacias de policia, em salas de aula etc., que a pessoa, por ser negra, fosse tratada com desrespeito. Isso continua acontecendo? Com certeza, mas hoje um policial, um delegado, um professor pensa duas vezes.

O deputado não foi o único a fazer essa associação durante o conjunto de eventos que tomou o Congresso durante aqueles dias.

Toni Reis, naquele momento, presidente da ABGLT, mencionou os "avanços" conquistados, como a realização da Conferência Nacional LGBT e a criação da Coordenação Nacional LGBT. Aproveitou também para, de modo irônico, fazer uma cobrança e enviar um "pedido" para o presidente Lula por meio do diretor do Departamento de Promoção e Defesa dos Direitos Humanos da SDH, Erasto Fortes, que havia estado ao microfone pouco antes dele:

\footnotetext{
${ }^{22}$ Detenho-me especificamente neste ponto no próximo item.
} 
O que está faltando, Erasto, é só um chamegão do nosso querido amigo Lula ao Conselho Nacional contra a Discriminação LGBT. Precisamos dessa assinatura. Então, gostariamos que o senhor levasse... Acho superbonito esse seu brochinho. Significa que o senhor tem acesso ao presidente. [Risos] [Palmas]. Então, gostaria que o senhor levasse o pedido do Toni Reis, das 237 organizaçóes, da Frente Parlamentar, de que queremos estabelecer o Conselho antes que Lula saia. Inclusive, a ABGLT já quer condecorar o presidente Lula como nosso grande embaixador contra a homofobia no mundo. Hoje, em 75 paises é crime ser homossexual; e em sete países ainda existe pena de morte. Então, peço ao Erasto para dar uma articuladinha nesse pedido com a nossa querida Lena [Peres], com o Paulo Vanuchi, para estabelecermos o Conselho Nacional.

Os convidados da mesa principal, como apresentados na ocasião, foram: Cláudio Nascimento, superintendente de Direitos Individuais, Coletivos e Difusos da Secretaria de Assistência Social e Direitos Humanos do Estado do Rio de Janeiro; Osvaldo Francisco Ribas Lobos, coordenador da pesquisa Crimes Homofóbicos no Brasil: Panorama e Erradicação de Assassinatos e Violência contra LGBT; Érico Nascimento, urbanista e pesquisador associado ao NUGSEX Diadorim; Luiz Mott, antropólogo e historiador, professor da Universidade Federal da Bahia e fundador do Grupo Gay da Bahia.

Nessa mesa, foram apresentados levantamentos de violência contra LGBT por meio de notícias na imprensa, utilizando-se os dados coletados pelo GGB, complementados por clipagens compradas de jornais de todo o país, com ênfase nos números de assassinatos. As apresentações expuseram, ainda, dados particularmente referentes às cidades do Rio de Janeiro e Salvador. Após a exposição das pesquisas, foi aberto o debate com o público presente.

Um dos pontos levantados foi o número reduzido de casos de violência contra lésbicas que aparecem nos dados reunidos. Um dos expositores declarou que a hipótese para tal não é o fato de que as lésbicas sofram menos discriminação, mas que "a sexualidade da mulher é tão violentada que, até quando a lésbica sofre uma 
violência, um assassinato, isso não é registrado [...], não é respeitado nem reconhecido como violência”. Na outra ponta desse ranking de violações, estão as travestis e transexuais, apontadas como as mais discriminadas e vítimas dos crimes letais mais cruéis, em sua maioria, ocorridos nas ruas. Durante os debates, uma questão considerável foi destacada na fala de uma trans presente:

[...] no caso de travestis e transexuais, nós acabamos sendo sempre subestimados, porque, se é travesti ou transexual, o Estado brasileiro ainda se nega a reconhecer a identidade de gênero do individuo. Se eu sofrer violência, no boletim de ocorrência, lá, vai constar 'sexo masculino' [...] Eu não sou homem! As travestis e transexuais do gênero feminino não são homens [...]. As minhas companheiras travestis, quando são mortas e são levadas para o IML [...], eles dizem: 'Há um homem aqui, morto'.

Quase todos os que falaram pediram a aprovação do PLC 122, que propõe a criminalização da homofobia. Alguns exemplos:

Eu acho que há um compromisso do Estado brasileiro. Chega a ser até indigno nós chegarmos a uma Casa de Leis e pedirmos que se cumpra a Constituição, não é? Nós nem precisaríamos do PLC 122 se se cumprisse a Constituição brasileira, reconhecendo-nos como cidadãs de fato, sujeitos de direito (movimento LGBT).

Temos o PLC n.o 122. Neste momento é importante falar dele. Nós não queremos prender nenhum pastor, não queremos prender padres. Simplesmente queremos uma lei que criminalize atos homofóbicos. Queremos que as pessoas não incentivem a violência; não usem a televisâo, os púlpitos para semear ódio e preconceito; não se sirvam da internet para usar a Biblia, um livro sagrado - temos aqui, inclusive, pessoas extremamente religiosas - para incentivar o preconceito e a discriminação (movimento LGBT). 
Peço aos nossos deputados e senadores que entendam que a aprovação do PLC 122 é uma questão de vida para milhóes de brasileiros que ainda são tratados como cidadãos de segunda classe (governo Executivo).

O deputado Iran Barbosa (PT-SE), responsável pela coordenação dos trabalhos do seminário, finalizou a sessão dizendo da importância de abrir "as portas da Casa do Povo" para os debates que aconteceram ao longo daquela semana e parabenizou o movimento LGBT do Brasil:

Não podemos silenciar diante desse debate, precisamos apresentar respostas. Não podemos apenas debater, devemos também apresentar respostas: respostas por meio de leis, por meio de investimentos, por meio de posiçóes e por meio de enfrentamento, de luta [...] sabemos que o fato de as portas desta Casa terem sido abertas foi resultado da ação organizada das entidades que representam a classe. O fato de o Brasil hoje ter políticas públicas voltadas especificamente para esse segmento é resultado, sim, de um processo de organização e de luta da própria população. Os direitos são conquistados, eles não são dádivas que caem do céu, são conquistas sociais. Portanto, quero finalizar este seminário parabenizando todos aqueles que militam nesse importante movimento por justiça, por direito, que é o Movimento LGBT do nosso pais.

Os convidados do seminário eram parlamentares e lideranças do movimento, que articularam o discurso da política com depoimentos pessoais sobre experiências de violência e discriminação. As exposições ainda trouxeram pesquisas e pesquisadores que legitimam a denúncia de desamparo e comprometem-se com a luta contra o preconceito e a discriminação.

Da série de eventos observados ao longo da pesquisa, a razão para destacar os aqui expostos diz respeito ao tipo de mobilização nacional que envolvem. Sediados em Brasília, pretendem ter impacto direto sobre os Poderes Legislativo e Judiciário e reunir parte da representação nacional do que seria o movimento LGBT, uma vez que as principais figuras do movimento mainstream circulam por eles. 
Especialmente para o caso dos eventos realizados em Brasília, tendo como espaço o Congresso Nacional e a Esplanada dos Ministérios, colocar pautas "controversas" em discussão produz efeitos pedagógicos em vários sentidos. Além de fomentar o debate sobre o tema em questão, reverbera a ação de ocupar esse espaço específico, de estar na "Casa do Povo" e de tirar a "foto oficial" com a bandeira do arco-íris todo ano na rampa do Congresso. ${ }^{23}$

Há também um ganho de expertise no sentido de como se comportar, fazer silêncio durante exposiçōes, solicitar a palavra em momentos oportunos, circular em Brasília, conhecer, ter acesso e interpelar parlamentares diretamente. Para uma dinâmica mais interna aos movimentos, os eventos que reúnem ativistas de todo o Brasil propiciam que as pessoas se encontrem e podem ser palco para que disputas internas se manifestem. E os bastidores também funcionam para trocar informaçōes, experiências e articular açóes conjuntas. Existe ainda uma pedagogia direcionada aos parlamentares. As falas dos ativistas não apenas fazem denúncias, mas também ensinam os termos corretos a serem usados (como reproduzido anteriormente), comunicam ações realizadas em estados e municípios e, por vezes, informam e sugerem os caminhos que aqueles que querem "apoiar a causa" devem percorrer.

Diversos trabalhos já apontaram as Paradas do Orgulho como estratégia bem-sucedida de visibilização massiva. ${ }^{24}$ As falas aqui reproduzidas apontam para o acionamento de outra tática. Com foco na violência, nos assassinatos, parecem querer ressoar outro tipo de mobilização e também de moralização, tendo em vista a pressão política. São formas de afirmação de legitimidade e ganho de solidariedade que buscam outro caminho além da já conhecida irreverência das Paradas.

Alguns pontos podem ser depreendidos de eventos-ato, como são as marchas contra a homofobia e outras manifestaçōes públicas. Esses eventos concorrem para coletivizar situaçôes que poderiam ser tidas

\footnotetext{
${ }^{23} \overline{\text { Ver anexo C31 (p. 388). }}$.

${ }^{24}$ Ver França (2006); Carrara e Simões (2007); Ferreira (2012), entre outros.
} 
como particulares e individuais. ${ }^{25}$ São também eventos que produzem fatos noticiáveis, que carregam consigo uma dimensão espetacularizada. Certa feita, um ativista me explicou que, para cada evento planejado, é preciso pensar um lead ${ }^{26}$ para a imprensa, algo noticiável, que crie um fato.

Não estive presente na III Marcha, realizada em 2012, mas pude acompanhar a sua repercussão. $\mathrm{O}$ manifesto divulgado dizia que a "III Marcha é mais um marco histórico", referindo-se ao "abraço no STF”, performatizado pela Marcha no ano anterior e a outras "manifestaçôes de luta pelos direitos humanos". Afirmava que "as imagens que circularam pelo mundo mostram que no Brasil consolidar a democracia é avançar no processo de inclusão da nossa comunidade". Nesse sentido, o manifesto reiterava o vocabulário de inclusão do Brasil numa determinada ordem democrática internacional, como visto nas três versôes do PNDH, no capítulo anterior. O manifesto também fazia alusão a outros acontecimentos do ano de 2011: o veto ao kit anti-homofobia nas escolas e os casos de agressão pública já mencionados: "o crescimento da violência homofóbica [...] diversas notícias de agressões físicas nas ruas [...] todo esse quadro é diretamente alimentado pelo discurso homofóbico de fundamentalistas homofóbicos e representantes do setor conservador".

Nos últimos anos, as manifestaçōes do movimento LGBT têm insistido em apontar e, consequentemente, alimentar a imagem do inimigo "fundamentalista religioso". A resistência de políticos religiosos de fato é fortemente organizada. Vital e Leite Lopes (2013) produzem uma interessante análise em que buscam esclarecer algumas das nuanças de como vem se dando a atuação de parlamentares evangélicos em temas que envolvem "direitos das mulheres e de LGBTs no Brasil”. Por meio de pesquisa de campo, análise de material veiculado pela mídia, entrevistas

\footnotetext{
${ }^{25}$ Valendo-se do instrumental analítico da antropologia dos rituais, Chaves (2002) empreende uma leitura exemplar da eficácia da Marcha Nacional dos Sem-Terra ocorrida no ano de 1997. Certamente os eventos enfocados aqui não têm a mesma dimensão e não reúnem os mesmos elementos, mas talvez sejam comparáveis em termos do efeito que se deseja provocar.

${ }^{26}$ Lead (ou lide) é, no jargão do jornalismo, aquilo que se destaca na notícia, que resume o seu tema.
} 
com parlamentares, lideranças religiosas, entre outros atores, os autores demonstram - sem desconsiderar a relação com os católicos nesse processo - como a Frente Parlamentar Evangélica vem se estruturando e ganhando espaço. ${ }^{27} \mathrm{O}$ trabalho descreve como a Frente capitaliza os seus interesses or meio da mobilização de argumentos que gravitam ao redor de questóes ligadas à economia, ao "direito à vida" e à "preservação da família”, utilizam os meios de comunicação, sobretudo a internet, ocupam posições estratégicas na cena parlamentar, jogam com alianças oportunas e manipulam "moedas de troca" em momentos calculados como propícios para a negociação e a articulação política.

Nesse processo, as investidas de políticos religiosos vêm ganhando espaço não só no Congresso Nacional, mas também na mídia. Gostaria de chamar a atenção para a relação produtiva e de constituição mútua contida nesse antagonismo colocado como radical. Muitos desses políticos alcançaram notoriedade nos últimos tempos justamente por suas provocações "homofóbicas", e muitos militantes contribuem para essa notoriedade quando reproduzem seus discursos visando a manifestar indignação. Ao mesmo tempo, ao se colocarem contra sujeitos LGBT, "os fundamentalistas” colaboram para a produção da imagem de uma coletividade que pode ser chamada "população LGBT", independentemente dos valores atrelados a ela.

A violência expressa em espancamentos e assassinatos é considerada algo que extrapola o aceitável ou justificável. Logo, existe a aposta de que contra esses fatos não há argumento (religioso ou não) que possa ser colocado. Ramos e Carrara (2006) fazem uma leitura crítica da ênfase que o ativismo, então chamado homossexual, imprimiu até o fim da década de 1990 à denúncia da violência letal, afastando uma abordagem "mais propositiva sobre a temática da violência".

Os autores apontam um momento de inflexão em relação à abordagem da violência contra homossexuais, como quando da experiência da implantação do Disque Defesa Homossexual (DDH),

\footnotetext{
${ }^{27}$ Ainda de acordo com os autores, a "bancada cristâ", contando evangélicos e católicos, equivale a quase um quinto dos deputados da Câmara Federal (Vital e Leite Lopes, 2013, p. 156).
} 
no Rio de Janeiro, em 1999. O DDH, criado na Secretaria de Segurança Pública do Rio de Janeiro, foi desenhado de maneira a não ser apenas um programa de denúncia de violências, mas também de defesa. Os autores interpretam o envolvimento de pesquisadores como crucial para que o serviço então concebido fosse também um centro de produção de dados, e não apenas de atendimento a vítimas. Até esse momento, os únicos dados existentes eram oriundos de notícias de jornais, em levantamentos organizados pelo GGB, enquanto os novos serviços forneciam material oriundo dos relatos das próprias vítimas. A análise desses dados descortinou dinâmicas bastante diversificadas de violência, revelando que a maior parte das denúncias versava sobre agressōes verbais, extorsōes, ameaças, agressōes físicas e queixas de discriminação ocorrida em contexto de relações próximas aos denunciantes, como a própria casa ou vizinhança. ${ }^{28}$

Proceder a uma análise aprofundada a respeito da violência relacionada a orientação sexual ou identidade de gênero escapa ao escopo deste livro, mas é pertinente fazer uma pequena consideração. Ainda que possam incidir críticas que apontem as limitações da vitimização, não é possível ignorar a sua eficácia para justificar a reunião de pessoas em um mesmo grupo que sofre violência motivada por igual tipo de preconceito. Como visto neste capítulo, as denúncias sobre a vitimização e a violência letal são ainda muito utilizadas para angariar atenção e solidariedade durante o processo de demanda de ações de combate à homofobia. Em parte, para usar os termos de Efrem Filho (2013), são essas imagens que garantem o "preenchimento semântico" e emprestam sentido à categoria "homofobia". ${ }^{29}$

\footnotetext{
${ }^{28}$ A análise de Ramos e Carrara (2006) destaca a produçấo de Carrara e Vianna (2001) a partir de processos de justiça de crimes letais cujas vítimas eram homossexuais e também os surveys realizados nas Paradas do Orgulho, já destacados anteriormente. Para os autores, a experiência do DDH, descontinuada poucos anos após a sua implantação, inaugurou um novo tipo de relação entre ativismo e academia para a formulação de políticas públicas nessa seara. No capítulo 5 , volto a discutir mais detidamente a repercussão da experiência do DDH e a relação produtiva entre "ativismo" e "academia" na implementação de políticas LGBT na atualidade.

${ }^{29}$ Roberto Efrem Filho (2013) vem desenvolvendo uma análise bastante instigante a respeito da maneira como "o recurso discursivo à brutalidade" concorre para conformar pautas políticas e emprestar uma identidade ao movimento LGBT. O autor procura explorar especialmente como as imagens da violência brutal performatizam os corpos das vítimas, bem como as estratégias e as
} 
O campo de estudos que trata da "violência contra a mulher" 30 já faz, há alguns anos, a crítica aos limites da perspectiva vitimizadora e à abordagem da violência por meio do par mulher-vítima e homem-algoz. ${ }^{31}$ O trabalho pungente de Gregori (1993a, 1993b) demonstrou que esse tipo de dualidade contribui para a produção da vítima como um "não sujeito", enquanto a figura do agressor é preenchida pelo "homem" como uma espécie de categoria genérica que cumpre a função de reiterar o papel de subordinação da mulher. Essa perspectiva não só naturaliza "o homem" e "a mulher" como categorias analíticas, como também falha ao não considerar a dimensão relacional da violência. Ao instituir um agressor ativo e uma vítima passiva, pode corroborar mais do que ajudar a superar estruturas violentas de relação, uma vez que congela papéis e desconsidera os contextos mais amplos que as envolvem. Como chama a atenção Sarti (2009), esse tipo de leitura pode acabar por cristalizar a "vulnerabilidade" como uma característica constitutiva da identidade de certas "vítimas". 32

Creio que, para o campo que se estrutura a partir da violência correlata ao preconceito motivado por orientação sexual ou identidade de gênero, ou simplesmente "violência homofóbica", as consequências, os alcances e os limites dessa forma de ênfase na vítima ainda estão por ser investigados. Minha intenção não é sugerir que a crítica que incide sobre a área de "violência contra a mulher" possa ser fácil e diretamente transposta para cá. No entanto, as indicaçôes levantadas

negociações em torno da materialidade dos crimes - e dos corpos - envolvidas nas disputas entre o movimento e as esferas do governo. Ver também Efrem Filho (2017).

${ }^{30}$ Debert e Gregori (2008) discutem a denominação dessa área de estudos e os desafios e as nuances envolvidas no uso de expressōes como "violência contra a mulher", "violência conjugal", "violência doméstica", "violência familiar" e "violência de gênero": "trata-se de saber o que significa o emprego de cada uma dessas noçôes, sua rentabilidade em termos analíticos, bem como as limitaçōes e os paradoxos que elas apresentam" (p. 167).

${ }^{31}$ Paula Lacerda (2006) analisa como a dualidade vítima/algoz aparece em notícias sobre o assassinato de gays e travestis em jornais do Rio de Janeiro, entre 1980 e 2000.

32 Sarti (2009) oferece um bom exemplo para pensar nesse sentido. A autora discute o caso de um homem que chega a um serviço de atendimento apresentando-se como vítima de violência sexual e é dispensado pela funcionária, que explica que aquele era um serviço destinado ao atendimento de mulheres. Nessa situação, "o homem é visto como agressor, e não como objeto da violência. Não é o ato em si que configura a violência, mas a definição prévia de quem é a vítima. Um mesmo ato pode ser considerado violência ou não, conforme a representação que se tem da vítima" (Sarti, 2009, p. 96). 
por esses estudos são proveitosas para a reflexão, uma vez que guardam algumas semelhanças quanto à maneira como o campo que articula demandas por políticas públicas vem se estruturando. Além disso, também nessa arena, as "hierarquias sociais acionadas em relaçōes violentas vão de encontro ao jogo entre um conjunto de atributos relativos à masculinidade, à feminilidade e aos diferentes conteúdos associados a cada um desses termos" (Gregori, 1993a, p. 177).

Se, para a "violência contra a mulher", a dimensão representada como "doméstica" é a que fica sob holofotes e a extensão mais abrangente de relações de desigualdade de poder é obliterada (Debert e Gregori, 2008), para a "homofobia”, o que ocorre é o oposto. A face brutal da violência pública e "espetacularizável” ganha destaque em detrimento dos conflitos em âmbito doméstico e dos confrontos que se imiscuem em relações cotidianas e de proximidade das vítimas. Estes ainda são pouco reconhecíveis para a face política visibilizada.

Se a "figura da vítima" se tornou central como elemento que "assegura inteligibilidade ao sofrimento de segmentos sociais específicos, assegurando legitimidade moral às suas reivindicaçôes" (Sarti, 2011, p. 54), os modos como a violência relacionada à homofobia será delimitada, classificada, coletada, interpretada e negociada politicamente importam desde o princípio, evitando-se o risco de que um "efeito vitimizador" restrinja possibilidades reflexivas e de construção de ações políticas de enfrentamento. ${ }^{33}$

Seguindo essa reflexão, parece interessante atentar para a relação entre a produção da vítima, a inteligibilidade da violência e a dos próprios sujeitos correlatos a essa operação. Ao abordar a "violência relacionada à homofobia”, Gail Mason sugere que ela se infiltra não só no cotidiano desses sujeitos, mas também nos sistemas de

${ }^{33}$ Debert e Gregori (2008) retomam a revisão crítica conduzida por Gregori (1993a) da literatura sobre a questáo da violência contra a mulher na década de 1980, para indicar que, naquele momento, a autora já apontava a tendência dos estudos do período em reproduzir a estrutura assimétrica constitutiva das relaçōes violentas. Nesse sentido, a autora alertava para o "efeito vitimizador" localizado em "convençôes explicativas e descritivas presentes no tratamento político e acadêmico da violência contra a mulher" (p. 176). 
conhecimento por meio dos quais nós construímos e reconhecemos identidades sexuais:

I suggest that the statements that violence makes cannot be confined to the insults that are hurled during an attack. Homophobia-related violence also marks the bodies of lesbians and gay men with signs of vulnerability and victimhood; signs that name the category of homosexuality as being 'in danger' of hostility. [...] This is not so much because violence is something that we observe, but, more, because violence is a mechanism through which we distinguish and observe other things. In other words, violence is more than a practice that acts upon individual subjects to inflict harm and injury. It is, metaphorically speaking, also a way of looking at these subjects (2002, pp. 10-1).

Se um mapa mais abrangente e qualificado do tipo de violência que poderia ser enquadrado sob o guarda-chuva da "violência homofóbica" ainda está por ser feito, é fundamental não perder de vista a dimensão relacional das situações denunciadas, assim como as diferentes variantes conectadas à classe, à cor/raça, à religião etc. Mas, ainda há que se atentar para o fato de que a "vítima" também é produzida pela performatividade política dos movimentos sociais, pelos discursos acadêmicos sobre o tema, pelas políticas institucionalizadas por governos e também pela construção retórica daqueles que se opõem à sua institucionalização.

$\mathrm{Na}$ próxima seção, veremos que, se a violência como uma linguagem de legitimação tem sido privilegiada para a construção de "políticas LGBT”, este não é o único caminho estratégico argumentativo adotado, ainda que permaneça sempre sendo articulado em algum nível. 
No âmbito do Poder Legislativo Federal, um dos principais obstáculos para o avanço de propostas feitas na área de direitos relacionados a pessoas LGBT é o fato de a Constituição brasileira não abordar diretamente a discriminação por orientação sexual. Um dos principais canais de mobilização do ativismo vem sendo o projeto de lei que propõe a inclusão da orientação sexual e da identidade de gênero na lei que coíbe a discriminação por motivo de raça, cor, etnia, religião ou procedência nacional.

Existem, ainda, outros projetos em tramitação relativos à união entre pessoas do mesmo sexo, à regulamentação da adoção conjunta por casais homossexuais e à alteração do registro civil para travestis e transexuais. Entretanto, a dificuldade de articular o lobby parlamentar necessário para o andamento de propostas sobre as proposições controversas e a resistência de parte das bancadas religiosas fazem com que esses projetos não caminhem. Quanto à proposta de criminalização da discriminação (homofobia), líderes religiosos do Congresso alegam que o projeto "cercearia a liberdade de expressão ou opiniāo" (no caso, a condenação pública da homossexualidade com base em crenças religiosas). Sobre as propostas de regulamentação da união civil entre pessoas do mesmo sexo, uma das principais resistências relaciona-se com o não reconhecimento desse tipo de parceria como entidade familiar. A argumentação dos opositores se prende a uma determinada concepção de "família natural", na qual não haveria espaço para os pares homossexuais.

Para certa parte do movimento LGBT, mesmo que nada seja aprovado no âmbito do Legislativo, é muito importante manter a

\footnotetext{
34 Parte das ideias desenhadas nesta seção devo à participação no GT 01 - Instituiçōes estatais e "famílias": práticas de gestão, moralidades e estratégias, realizado durante a $27 .{ }^{a} \mathrm{RBA}$, em 2010 , e no GT38 - Famílias e açōes estatais de gestão: práticas, moralidade e estratégias, realizado durante a $28 .{ }^{2}$ RBA, em 2012. Agradeço a todos os participantes desses grupos pelas contribuiçōes recebidas e, em especial, às suas coordenadoras: Adriana Vianna e Maria Gabriela Lugones.
} 
pressão sobre a discussão dos projetos por conta da visibilidade que a questão ganha, ainda que envolva algum risco. Ao propor dispositivos que explicitamente regulam as relações entre pessoas do mesmo sexo, as discussões sobre o tema provocam reações contrárias extremamente hostis e combativas no sentido de limitar a concessão de direitos. Nesse processo, aparecem projetos de lei propondo a proibição da adoção por casais homossexuais, por exemplo. ${ }^{35}$

De outra parte, o oposto desse tipo de resistência vem sendo verificado no Poder Judiciário, no qual diversas decisões favoráveis concernentes à "população LGBT" têm sido aprovadas. Em torno de direitos sociais relacionados à previdência social, por exemplo, cabe citar rapidamente um caso ilustrativo. Em 1999, o Grupo Nuances, grupo ativista do Rio Grande do Sul, entrou com uma ação civil pública contra o INSS por violação de direitos humanos em razão do indeferimento de pedidos de pensão previdenciária para companheiros do mesmo sexo, e ganhou a causa. Hoje, consta da Instrução Normativa do INSS: "o companheiro ou a companheira homossexual de segurado" como "integrante do rol de dependentes", reconhecendo, portanto, a constituição de uma entidade familiar nesse tipo de vínculo (reconhecimento que não é alcançado no Legislativo). ${ }^{36}$

Em relação à adoção, em 2009, um caso bastante noticiado na mídia foi o da decisão tomada pela Justiça de Catanduva (SP), que abriu precedente ao conceder o direito de dois homens colocarem seus nomes na certidão de nascimento da filha adotiva. A juíza que decidiu o caso alegou que "o bem-estar da criança está acima de tudo". Dessa maneira, garantem-se direitos como herança e pensão e também

\footnotetext{
${ }^{35}$ Em 2010, o Projeto de Lei 7.018/10 (de autoria do deputado Zequinha Marinho, do PSC-PA) visava a proibir a adoção de crianças e adolescentes por casais do mesmo sexo. Outros dois exemplos mais recentes: o PDC (Projeto de Decreto Legislativo) 232/2011 (de autoria do deputado André Zacharow, do PMDB-PR), que foi apresentado após a decisão favorável do STF, propõe a realização de um plebiscito questionando a opinião do eleitorado sobre o posicionamento contrário ou favorável à união civil entre pessoas do mesmo sexo; e o PDC 234/2011 (de autoria de João Campos, do PSDB-GO), conhecido como "projeto da cura gay", que visava a suspender a Resolução do Conselho Federal de Psicologia que estabelece normas de atuação para os psicólogos em relação a questōes envolvendo a orientação sexual.

${ }^{36}$ Ver Golin et al. (2003).
} 
o direito de guarda em caso de morte de um dos pais. ${ }^{37}$ Em 2011, ocorreu a já mencionada decisão do Supremo Tribunal Federal, que reconheceu a figura jurídica de união estável entre pessoas do mesmo sexo, igualando-a em direitos e deveres a uniōes estabelecidas "entre o homem e a mulher", tal qual inscrito atualmente na Constituição Federal, e garantindo o seu estatuto como unidade familiar. ${ }^{38} \mathrm{Em}$ maio de 2013, o Conselho Nacional de Justiça (CNJ), "considerando a eficácia vinculante à administração pública e aos demais órgãos do Poder Judiciário", da decisão do STF, aprovou uma resolução segundo a qual todos os cartórios do Brasil ficam impedidos de recusar pedidos de conversão de união estável em casamento ou de celebração de casamento civil entre pessoas do mesmo sexo. ${ }^{39}$

Temos então, na incidência da pressão do movimento social nas diferentes esferas de poder, um cálculo de custos e benefícios em jogo todo o tempo: entre a estratégia de tentar criar dispositivos reguladores no âmbito do Poder Legislativo e a busca para reinterpretar e adaptar os já existentes por meio do Poder Judiciário (ainda que nesse âmbito se fique à mercê das decisões dos juízes).

Mesmo que a denúncia da violência e a criminalização da homofobia venham sendo os focos privilegiados de atenção do movimento LGBT, ou aquelas que têm mais visibilidade em eventos públicos, como visto no item anterior, existem outras estratégias concomitantes em circulação e, muitas vezes, em disputa. Para pensar essas estratégias, proponho aqui o exercício de olhar para as argumentações contrárias e a favor que circundam duas outras tentativas de regulação jurídica, já mencionadas no capítulo 1: a Proposta de Emenda Constitucional (PEC) que versa sobre o casamento civil entre pessoas do mesmo sexo e o anteprojeto de lei que visa à criação do Estatuto da Diversidade Sexual.

\footnotetext{
${ }^{37}$ Para uma análise sobre adoção e homossexualidade, além da abordagem do debate a respeito de "novos arranjos familiares" e da relação entre família e homossexualidade, ver Uziel (2007).

${ }^{38}$ Disponível em: http://oglobo.globo.com/politica/stf-reconhece-por-unanimidade-uniao-civil-entrepessoas-do-mesmo-sexo-2773524. Ver anexo C8 (p. 353-354).

${ }^{39}$ Resolução n. ${ }^{\circ} 175$, de 14 de maio de 2013, aprovada durante a 169. a Sessão Plenária do Conselho Nacional de Justiça (CNJ). Ver anexo C7 (p. 352).
} 
Especialmente após a decisão do STF favorável à união estável, em maio de 2011, o reconhecimento de relacionamentos entre pessoas do mesmo sexo como entidade familiar vem ganhando corpo. Assim, faz-se oportuna uma reflexão sobre a relação entre diferentes estratégias de regulação de direitos LGBT, o seu diálogo com distintas concepçôes de família circuladas nesse debate e o porquê desse acionamento específico. Podemos notar como "a família" é evocada, por vezes, como ponto de partida para mobilizações e, por outras, surge como uma resposta estratégica para determinadas provocaçōes. Também é possível perceber que "a família" aparece aqui ora como instituição modelar ideal acionada em argumentaçôes de ordem moral, ora como figura ou forma jurídica cuja significação vem sendo disputada por diferentes atores. É óbvio que esses planos estão profundamente imbricados, mas promovo aqui uma separação para fins analíticos.

Tanto na PEC do casamento civil quanto no Estatuto da Diversidade, é possível localizar uma determinada concepção de família entre os seus argumentos centrais, mas veremos que, mesmo não sendo sempre explicitamente mencionada, a entidade familiar também circunda discursos a respeito da criminalização da homofobia. Essas três proposiçóes - que apresentarei em ordem mais ou menos cronológica, de acordo com os períodos em que ganham mais visibilidade pública (2006, 2007, 2010, 2011 e 2012) - estão inseridas em um campo mais amplo de disputas que mobiliza diferentes representaçóes do movimento social, distintas estratégias de reivindicação de direitos e distintas entradas nos aparatos jurídico-legislativos da administração estatal.

Começaremos pelo PLC 122/2006, mais conhecido como projeto de criminalização da homofobia. Este ccomeçou a tramitar na Câmara dos Deputados em 2001, onde permaneceu durante cinco anos até ser aprovado na forma de um substitutivo; daí foi enviado para o Senado Federal, onde permaneceu parado. ${ }^{40}$ Desde o início da tramitação,

\footnotetext{
${ }^{40}$ PLC 122/2006: "Altera a Lei n. ${ }^{\circ} 7.716$, de 5 de janeiro de 1989, o Decreto-Lei n. ${ }^{\circ} 2.848$, de 7 de dezembro de 1940 (Código Penal), e o Decreto-Lei n. ${ }^{\circ}$ 5.452, de 1 . $^{\circ}$ de maio de 1943 (Consolidação das Leis do Trabalho - CLT), para definir os crimes resultantes de discriminação ou preconceito
} 
o projeto de lei já passou por diversas comissóes na Câmara e no Senado, já esteve na mão de diferentes relatores e foi foco de debates e de algumas audiências públicas promovidas no Congresso Nacional. Como já dito, aos parlamentares que também são lideranças religiosas é creditada a responsabilidade pelo fato de o projeto ter avançado muito pouco no sentido de uma aprovação ao longo de todo esse tempo. Além de considerações propriamente religiosas e aquelas que se fixam em termos de "natureza" e "normalidade", os opositores têm se baseado no argumento de que a proposta fere o princípio da liberdade de expressão, alegando que, uma vez aprovado, qualquer tipo de manifestação contrária à homossexualidade passaria a ser criminalizada. E nessas argumentaçōes que defendem uma suposta limitação à liberdade de expressão subjaz a ameaça a um determinado modelo de família e sociedade.

Destaco a seguir alguns trechos de argumentações favoráveis e contrárias ao PLC 122/2006 proferidas em alguns dos debates públicos de que foi alvo em diferentes momentos de sua trajetória. Quando ainda tramitava na Comissão de Constituição e Justiça da Câmara dos Deputados, em 2003, um voto em separado do deputado José Divino (PMDB-RJ), contrário à aprovação da proposta, apresentou a seguinte argumentação:

A orientação sexual, a meu ver, é uma opção, e não um gênero de vida, raça e cor. Trata-se de uma escolha humana para um determinado comportamento, assim como a orientação religiosa, política [...] A opção sexual não é nativa; o ser humano não nasce hetero ou homossexual, ele opta pela vida intima que levará a partir de um determinado periodo [...]. Portanto [...] não cabe [m] [...] puniçôes por não aceitação de uma orientação sexual, cujos parâmetros fogem das orientaçóes familiares e sociais, por não se tratar de preconceito, e sim de opção de vida [...] Vale enfatizar que homossexualismo não é uma cultura; os optantes não vivem em culturas diferenciadas, eles convivem nas diversas classes sociais

de gênero, sexo, orientação sexual e identidade de gênero. Estabelece as tipificaçōes e delimita as responsabilidades do ato e dos agentes" (Disponível em: http://www.senado.gov.br/atividade/ materia/detalhes.asp?p_cod_mate=79604). 
e culturais, não há como identificar um optante homossexual por sua cultura, raça ou cor [...]. ${ }^{41}$

A pauta da criminalização da homofobia opera no sentido de se fazer reconhecer "pessoas LGBT" como vítimas históricas de preconceito e discriminação em busca de proteção do estado. Sendo assim, é frequente a analogia com dispositivos legais antidiscriminação já existentes, como os relacionados à raça, à população indígena ou a pessoas com deficiência. Esse tipo de analogia encontra resistência entre aqueles que consideram a homossexualidade uma "opção", algo passível de escolha, ou um comportamento desviante ("que foge das orientaçôes familiares e sociais"), passível de correção, como fica claro na fala do deputado citado.

Em 23 de maio de 2007, quando o projeto de lei já estava tramitando no Senado em audiência pública convocada para instruí-lo, além de parlamentares, alguns convidados da "sociedade civil" foram chamados para o debate. A partir da ata da audiência convocada pela Comissão de Direitos Humanos e Legislação Participativa, temos acesso a algumas falas que trouxeram "família" para a discussão. ${ }^{42} \mathrm{Um}$ desses convidados foi um representante da Academia Evangélica de Letras do Brasil, reverendo Guilhermino Cunha:

É verdade sim [...] que todos são iguais perante a lei sem distinção de qualquer natureza. Portanto, é inviolável a liberdade de consciência, de crença e a manifestação do pensamento. Não apoiamos a violência contra os homossexuais, ainda que discordemos da sua opção. Épreciso proteger a integridade fisica daqueles sem prejudicar a liberdade das familias de ensinarem os princípios biblicos, da Igreja de pregá-los com a coragem profética e fidelidade biblica. A liberdade de culto e de liturgia é consagrada [...].

\footnotetext{
${ }^{41}$ Voto apresentado à Comissão de Constituição e Justiça da Câmara dos Deputados em 18 de setembro de 2003. Ver anexo C9 (p. 355-356). (Disponível em: http://www.camara.gov.br/proposicoesWeb/ prop_mostrarintegra? codteor $=171353 \&$ filename $=V T S+1+\mathrm{CCJC}+\% 3 \mathrm{D} \% 3 \mathrm{E}+\mathrm{PL}+5 / 2003$. Acesso em: maio 2011).

${ }^{42}$ Audiência Pública convocada pela Comissão de Direitos Humanos e Legislação Participativa do Senado Federal, realizada em 23 de maio de 2007 (Disponível em: http://www.senado.gov.br/ publicacoes/diarios/ pdf/sf/ 2007/08/07082007/suplemento/00082.pdf. Acesso em: maio 2011).
} 
$\mathrm{Na}$ mesma audiência e ainda contra o projeto, falou o deputado Takayama (PAN-PR):

Temos garantia pelo Estado de direito à tranquilidade àqueles que buscam viver uma vida simples do lar, que levam em alta conta os valores da familia, o matrimônio, como venerado, respeitado e digno de honra entre todos. Aos que são apenas marido, mulher e filhos, esta épara nós a ordem natural e não pode ser simplesmente desconsiderada. Homofobia não. Quem defende a si mesmo, quem valoriza o matrimônio e considera a origem sagrada da familia não é homofóbico, não está atacando ou execrando quem quer que seja, mas agindo de maneira legitima e natural.

Nessa ocasião, a única argumentação favorável ao projeto, que de alguma forma trouxe a entidade familiar para a discussão, veio da cineasta Tizuka Yamasaki, que iniciou a sua explanação questionando qual teria sido o motivo para estar naquela audiência. Depois de uma digressão sobre uma possível maior abertura e aceitação da homossexualidade no mundo do cinema, chega à conclusão de que estava ali por ter um filho gay:

[...] Eu pensei assim: eu vou aceitar falar aqui na frente porque eu tenho filho homossexual, entendeu? E acho que a mulher talvez tenha uma possibilidade mais fácil de chegar e entender esse problema da discriminação, porque quando se tem um filho homossexual, você não gosta ou desgosta do filho porque of filho é homem ou porque of filho é mulher ou porque é homossexual. A gente gosta porque é filho da gente.

Temos aqui um exemplo bastante tímido que traz a entidade familiar para uma argumentação favorável ao projeto por meio do depoimento da mãe de um homossexual. O que procuro apontar é o fato de a família aparecer, até então, com mais (e muita) frequência na voz daqueles que têm como objetivo atacar a suposta anormalidade dos que se engajam em relaçōes ou práticas homossexuais. De maneira geral, a estratégia dos que militam para que a criminalização da discriminação por orientação sexual e identidade de gênero 
seja inscrita na letra da lei tem sido denunciar casos de violação de direitos e apontar estatísticas de assassinatos por meio de dados produzidos pelas poucas pesquisas existentes e da apresentação de depoimentos-testemunhos de sobreviventes de agressōes homofóbicas. Entretanto, mais recentemente, começou a aparecer com mais força outra estratégia: o acionamento de mães (e, por vezes, de outros familiares) de lésbicas, gays, bissexuais, travestis e transexuais para darem os seus depoimentos.

Argumento que, em 2010, a presença das mães ganhou outra dimensão nessa cena, e um ponto marcante foi essa presença nos eventos realizados no Congresso Nacional no mês de novembro, explicitados na seção anterior. Retomo, então, alguns elementos de destaque daquela ocasião. O ponto alto de comoção do evento ficou por conta do depoimento de uma mãe cujo filho, Alexandre Ivo, de 13 anos, apenas cinco meses antes, fora brutalmente espancado e assassinado por ser ou parecer ser gay.

Eu, na condiçấo de mãe e de cidadä, tenho de vir a esta Casa pedir que sejam aprovadas leis que deem segurança, porque assim como eu perdi meu filho, outros adolescentes livres acham que podem expor a sua liberdade, porque adolescente não mede consequências... [choro]. Eles acham que sua liberdade náo incomoda, que sua alegria não incomoda. Mas, no caso do meu filho, incomodou, incomodou ao extremo de ser tirada a vida dele [choro]. Então, é esse o relato, é essa a minha luta. Eu não tive tempo de viver o meu luto, porque eu tenho de brigar por justiça, porque hoje os assassinos do meu filho estâo esperando o julgamento em liberdade. ${ }^{43}$

$\mathrm{Na}$ mesma ocasião, outra mãe que não estava inserida na programação oficial do seminário foi chamada para dizer algumas palavras. Seu filho, de 18 anos, sobreviveu a um tiro na barriga disparado por um soldado do Exército durante uma "dura" realizada

\footnotetext{
${ }^{43}$ Reprodução das notas taquigráficas do evento seminário Assassinatos Praticados contra a População LGBT, realizado em 24/11/2010, disponibilizadas em: www.camara.gov.br.
} 
entre rapazes que confraternizavam no parque do Arpoador após a Parada do Orgulho LGBT, no Rio de Janeiro, em outubro de 2010:

Resolvi fazer isso não só pelo meu filho, que é o grande amor da minha vida, mas também por aqueles que, a exemplo do Alexandre, não tiveram chance de se defender, por aqueles com quem, de repente, pode vir a acontecer o mesmo, pelos amigos do meu filho, pelos amigos dos amigos e por toda a classe-e eu me considero da classe, por ser mäe de um homossexual.

As mães, como encarnação da família por excelência, trazem para si o sofrimento da discriminação, do preconceito e da violência cometida contra seus filhos. A estratégia, então, é a de conquistar solidariedade. Lésbicas, gays, bissexuais, travestis e transexuais fazem parte de uma família, têm pai e mãe, irmãos e tios. E as mães também sofrem a homofobia quando os seus filhos são vitimados. Seguindo o argumento de Vianna e Farias (2011, p. 90), as mães

tanto acionam o caso particular (quando o discurso é preenchido por 'meu filho') quanto coletivizam e relacionam o seu sofrimento ao de outras mães efamiliares nos momentos que correspondem à 'dessingularização' do caso, afinal, é a condição de 'máe' que conecta aquela mãe que faz o discurso às outras máes e demais familiares de vitimas que ali estão sendo representados.

Estrategicamente, a mobilização das mães responde ao argumento da homossexualidade como uma ameaça à "família, base da sociedade". 44

Em junho de 2011, como reação à aprovação pelo STF da união civil entre pessoas do mesmo sexo, uma Marcha pela Família foi organizada pelo pastor Silas Malafaia e reuniu diversas lideranças evangélicas

\footnotetext{
${ }_{44}^{4}$ A maternidade é articulada como instrumento fundamental para a luta política em uma série de outros campos. Para algumas análises, além de Vianna e Farias (2011), ver Catela (2001); Freire (2002); Birman e Leite (2004); Araujo (2008); Soares et al. (2009); Movimento Mães de Maio (2011); Lacerda (2012), entre outros.
} 
em Brasília, inclusive alguns parlamentares. ${ }^{45}$ Cerca de dois ou três meses após esses eventos, surgiu a articulação Mães pela Igualdade, impulsionada por uma organização internacional chamada All Out. O grupo reúne "mães de LGBT" em geral e, em especial, "mães que perderam filhos em crimes homofóbicos" e difunde "uma mensagem simples e poderosa: A igualdade é um valor da família”. O lançamento público de uma campanha mobilizando essa ideia, juntamente com uma exposição de fotos das mães com seus filhos, foi feito no Senado Federal como parte de um seminário chamado Famílias pela Igualdade, promovido pela Frente Parlamentar Mista pela Cidadania LGBT, em 29 de setembro de $2011 .^{46}$

Da argumentação que evoca a "família" primordialmente como ponto de articulação de moralidades concorrentes, podemos passar para aquela centrada na "família" como categoria de normatização jurídica, em torno da qual se organizam elementos de proteção estatal e distribuição de direitos.

O deputado federal Jean Wyllys ${ }^{47}$ tem um posicionamento crítico em relação aos encaminhamentos dados ao PLC 122 no Congresso Nacional. No que seria referente a uma pauta LGBT, o deputado investe os esforços do seu mandato na PEC que trata da regulamentação do casamento civil entre pessoas do mesmo sexo. A proposta da PEC é alterar o artigo 226 da Constituição: "A família, base da sociedade, tem especial proteção do Estado", alterando o parágrafo $3 .^{\circ}$, no qual passaria a constar que: "Para efeito da proteção do Estado, é reconhecida a união estável entre duas pessoas, sejam do mesmo ou de diferente sexo, como entidade familiar, devendo a lei facilitar sua conversão em casamento". ${ }^{48}$

\footnotetext{
${ }^{45} \mathrm{Na}$ época, foi noticiada a presença de vinte a trinta mil pessoas. Ver anexo C10 (p. 357-358) e disponível em: http://g1.globo.com/politica/noticia/2011/06/lei-nao-pode-criar-terceiro-sexo-dizmagno-malta-em-marcha-em-brasilia.html. Acesso em: 01 jun. 2011.

${ }^{46}$ Disponível em: http://www.allout.org/pt/maespelaigualdade.

${ }^{47}$ Eleito deputado federal pelo PSOL-RJ para o mandato 2011-13.

${ }^{48}$ Texto atual: $\$ 3 .^{\circ}$ - Para efeito da proteção do Estado, é reconhecida a união estável entre o homem e a mulher como entidade familiar, devendo a lei facilitar sua conversão em casamento.
} 
Em 2011, o VIII Seminário LGBT da Câmara dos Deputados, ${ }^{49}$ que antecedeu a II Marcha Nacional contra a Homofobia, foi organizado pelo deputado e então coordenador da Frente Parlamentar Mista pela Cidadania LGBT e teve como tema "Quem ama tem o direito de casar - pela aprovação da PEC do casamento civil entre homossexuais". Na abertura, Jean Wyllys explicou que a ideia de o seminário ter um tema central foi da deputada Manuela d'Ávila (PCdoB-RS), naquele momento, presidente da Comissão de Direitos Humanos. Então ficou decidido: "que o tema seria o casamento civil entre homossexuais, porque acreditamos que, além da luta pela criminalização da homofobia, precisamos de uma agenda proativa, uma agenda que assegure direitos". A essa explicação ainda integrou o esclarecimento de que naquele ano havia sido tomada uma decisão estratégica de "divisão de tarefas": a Frente Parlamentar ficou responsável pelo seminário, e a "ABGLT e os movimentos representantes de diferentes segmentos" ficaram responsáveis pela Marcha contra a Homofobia. Em suas palavras: "nós tratamos do tema do casamento aqui na Câmara, e o movimento trata da criminalização da homofobia lá fora, numa parceria que nunca pode se desfazer".

A proposta da PEC já vinha sendo articulada havia algum tempo pelo deputado, mas foi lançada como uma campanha nacional em abril de 2012, com o título de "Casamento civil igualitário". ${ }^{50}$ Para Jean Wyllys, essa seria a pauta de direitos afirmativos que deveria ser seguida pelo movimento social. Segundo o deputado, com a garantia do Casamento Igualitário, "o Estado vai ter que proteger

\footnotetext{
49 O seminário foi uma iniciativa organizada em conjunto pela Comissāo de Legislação Participativa, a Comissão de Educação e Cultura, a Comissão de Direitos Humanos da Câmara dos Deputados e a Frente Parlamentar pela Cidadania LGBT no Congresso Nacional e contou com o apoio da Associação Brasileira de Lésbicas, Gays, Bissexuais, Travestis e Transexuais.

${ }^{50}$ Por meio de vídeos gravados com personalidades, a campanha divulga e busca assinaturas de apoio popular para a PEC, que propõe alterar o artigo 226 da Constituição. Para ser protocolada na Câmara, a PEC precisa da assinatura de 172 parlamentares. Em abril de 2013, o site da campanha informava que "O projeto já foi assinado por deputados e deputadas de quase todos os partidos, da base governista e da(s) oposiç(ōes). Mas, até termos a assinatura número 172, é melhor não publicar a lista para evitar as pressōes que os fundamentalistas de sempre vão tentar exercer contra aqueles que já assinaram [...]" (Disponível em: www.casamentociviligualitario.com.br. Acesso em: nov. 2013).
} 
a família [...] resolvemos fazer campanha da sociedade civil, para que os deputados não se sintam inibidos de votar". ${ }^{11}$ De acordo com o seu raciocínio, o direito ao casamento provocaria uma "transformação cultural" mais ampla por meio da garantia de direitos relacionados à família e, em médio prazo, garantiria também o enfrentamento da homofobia. Para o deputado, a decisão do STF não encerra a pauta, pois nem todos teriam acesso ao sistema de justiça. Destaco a seguir um pequeno trecho do texto de justificativa da PEC exposto no site da campanha:

A nossa luta pelo casamento, portanto, é também pelo reconhecimento social e politico da dignidade e da condição humana das pessoas homossexuais. É uma luta cultural e simbólica. Nos paises onde o Estado reconheceu o casamento civil entre pessoas do mesmo sexo, as novas geraçóes crescem e se educam sabendo que gays e lésbicas não são melhores ou piores que os heterossexuais, mas apenas diferentes, e que nossas famílias valem o mesmo que as familias de origem heterossexual e merecem o mesmo respeito e reconhecimento.

A lei também serve para educar.

O casamento civil igualitário, além de garantir direitos específicos, garante a igualdade perante a lei, a cidadania plena e o reconhecimento simbólico do Estado - e também vai ser, quando aprovado, um pedido de desculpas a gays e lésbicas por tantos séculos de discriminação. ${ }^{52}$

Em suma, essa estratégia aposta que o caminho para o reconhecimento pleno como sujeitos de direitos pelo estado viria por meio do reconhecimento pleno como família, constituída pelo casamento civil ou pela possibilidade de se constituir via casamento civil. Seria também uma medida de reparação e uma ação de abrangência pedagógica mais ampla, que igualaria homossexuais e heterossexuais.

\footnotetext{
${ }^{51}$ A campanha pelo casamento igualitário vem sendo construída nos moldes da campanha na Argentina, onde o casamento civil entre pessoas do mesmo sexo foi aprovado em julho de 2010. O mandato do deputado Jean Wyllys conta inclusive com um assessor que trabalhou na campanha daquele país.

52 Disponível em: www.casamentociviligualitario.com.br/casamento-igualitario/.
} 
Outro tipo de argumentação que aposta no reconhecimento como família é a proposta do Estatuto da Diversidade Sexual. Este investe tanto no reconhecimento de "direitos de LGBT" como vítimas de discriminação e violência quanto na afirmação de direitos, porém aposta em um vocabulário próprio de justificativa de demandas, relacionadas ao surgimento de um alegado "novo ramo do direito", o "direito homoafetivo".

A desembargadora Maria Berenice Dias, que se apresenta como a responsável por cunhar o termo homoafetividade, explica-o nos seguintes termos:

Não adianta procurar no dicionário, não está lá, ainda [...] Há palavras que carregam o estigma do preconceito. Assim, o afeto pela pessoa do mesmo sexo chamava-se 'homossexualismo'. Reconhecida a inconveniência do sufixo 'ismo', que está ligado à doença, passou-se a falar em 'homossexualidade', que sinaliza um determinado jeito de ser. Tal mudança, no entanto, não foi suficiente para pôr fim ao repúdio social ao amor entre iguais [...].

A marca da discriminação resta evidente na omissão da lei em reconhecer direitos aos homossexuais. A negativa do legislador revela nitida postura punitiva, pois condena à invisibilidade os vinculos afetivos envolvendo pessoas da mesma identidade sexual.

Ao denunciar esta evidente afronta à dignidade humana e aos princípios constitucionais da liberdade e da igualdade, acabei por cunhar o neologismo 'homoafetividade. ${ }^{53}$

O Estatuto da Diversidade Sexual segue os moldes de outros estatutos já existentes (como o do idoso e o da igualdade racial), aposta em "regras protetivas diferenciadas" e pretende reunir em uma

53 "Homoafetividade: um novo substantivo" (Disponível em: http://www.mariaberenice.com.br/ uploads/30_-_homoafetividade_-_um_novo_substantivo.pdf. Acesso em: abr. 2011). 
legislação única "todas as questões envolvendo diversidade sexual". ${ }^{4}$ Vejamos um trecho do seu texto:

\section{Disposiçóes gerais:}

Art. 1. ${ }^{\circ}$ - O presente Estatuto da Diversidade Sexual visa promover a inclusão de todos, combater a discriminação e a intolerância por orientação sexual ou identidade de gênero e criminalizar a homofobia, de modo a garantir a efetivação da igualdade de oportunidades, a defesa dos direitos individuais, coletivos e difusos.

Art. 2. ${ }^{\circ}-E$ reconhecida igual dignidade juridica a heterossexuais, homossexuais, lésbicas, bissexuais, transexuais, travestis, transgêneros, intersexuais, individualmente, em comunhão e nas relaçóes sociais, respeitadas as diferentes formas de conduzirem suas vidas, de acordo com sua orientação sexual ou identidade de gênero.

Art. 3. ${ }^{\circ}-E^{\prime}$ dever do Estado e da sociedade garantir a todos o pleno exercício da cidadania, a igualdade de oportunidades e o direito à participação na comunidade, especialmente nas atividades politicas, econômicas, empresariais, educacionais, culturais e esportivas.

Em trabalho desenvolvido anteriormente, ${ }^{55}$ pudemos localizar os "usos do afeto" no debate que circundou o Projeto de Lei 2.285, conhecido como Estatuto das Famílias e desenvolvido por um grupo em grande parte coincidente com aquele que desenvolvia o Estatuto da Diversidade Sexual. ${ }^{56}$ O projeto que tramitava desde 2007 no

\footnotetext{
${ }^{54}$ Entrevista com a desembargadora aposentada e presidente da Comissão da Diversidade da OAB, Maria Berenice Dias, publicada em 23 de agosto de 2011. Disponível em: http://www.ibdfam.org. $\mathrm{br} /$ ?clippings\&clipping=5053.

${ }^{55}$ Aguião e Barbosa (2010).

${ }^{56}$ Ambos os projetos foram desenvolvidos por um grupo ligado ao Instituto Brasileiro de Direito de Família (IBDFAM), cuja atual vice-presidente é a ex-desembargadora Maria Berenice Dias. De acordo com o seu site na internet, o IBDFAM "é uma instituição científica, sem fins lucrativos, criada em 1997, reconhecida pelo Ministério da Justiça como Utilidade Pública Federal pela portaria 2.134, de 27/05/2013, possuindo representação em todos os estados da federação". O seu objetivo é "produzir e divulgar conhecimentos e ideais de uma nova ordem jurídica, adequada à realidade
} 
Congresso Nacional, em sua formulação original, pretendia regular temas como a adoção e a união entre pessoas do mesmo sexo. Aqui e lá, uma das estratégias empreendidas é o deslocamento da ênfase na "sexualidade" para a "afetividade" presente nessas relaçōes.

No Estatuto das Famílias, o projeto era justificado em termos da necessidade de abarcar novos arranjos e composiçōes familiares no sentido de buscar a resolução de conflitos e demandas "a partir de novos valores jurídicos como o afeto, o cuidado, a solidariedade e a pluralidade" (IBDFAM, 2007, p. 4). Naquele momento, em resposta aos que eram contrários à proposta e a atacavam com termos como "malvado projeto de lei", "estatuto da desconstrução da família", "algozes da família natural", ${ }^{57}$ seus defensores a valorizavam ressaltando "a afetividade, os sentimentos e as emoçōes" presentes nos "laços familiares" estabelecidos entre pessoas do mesmo sexo. Parte da argumentação da proposta do Estatuto da Diversidade Sexual caminha no mesmo sentido, e os seus propositores defendem a ampliação do conceito de família tomando o "afeto" como o seu princípio básico.

Esse tipo de ênfase esboça um processo de "dessexualização" das relaçôes estabelecidas por pessoas do mesmo sexo e é uma estratégia que visa a deslocar a discussão do campo dos direitos sexuais para o campo do direito de família, com ganhos e perdas correlatos. Por um lado, isso ajudaria a legitimar o reconhecimento da união civil, mas, por outro, deixaria de fora exercícios da sexualidade que não sejam caracterizados por afeto ou por parcerias estáveis e monogâmicas.

A Constituição atualmente reconhece três formas de arranjos familiares: o fundado no casamento civil, o oriundo da união estável

da sociedade contemporânea, no campo do Direito de Família, Direito das Sucessōes e Direito da Criança e do Adolescente" (Disponível em: http://www.ibdfam.org.br. Acesso em: nov. 2013).

${ }^{57}$ Palavras do pastor da Assembleia de Deus Abner Ferreira, um dos convidados da audiência pública que discutiu o referido projeto na Câmara dos Deputados, em audiência pública realizada em maio de 2010. Para o pastor, o projeto de lei contraria "os usos, costumes e tradição da família brasileira" e desconfigura a "família natural", que para ele seria definida como "união de um homem e uma mulher, através do casamento, para partilhar amor e alegria, gerar filhos, suprir sua educação moral, construir uma base doméstica vital de produção e cosumo, oferecer segurança em tempos de dificuldades e unir as geraçōes. Todas as outras formas de família são incompletas e falsificaçōes do Estado" (Notas taquigráficas da audiência. Comissão de Constituição e Justiça. Audiência 12/05/2010. Departamento de Taquigrafia, Revisão e Redação. Câmara dos Deputados). 
e o da reunião de qualquer dos pais e seus descendentes (família monoparental). O texto do Estatuto parece inaugurar uma nova modalidade de categoria familiar: a "família homoafetiva". Alguns excertos do texto do anteprojeto:

\section{Direito à convivência familiar}

Art. 18 - A lei do País em que a família homoafetiva tiver domicilio determina as regras do Direito das Famílias.

\section{Direito à educação}

Art. 63-Os professores, diretores, supervisores, psicólogos, psicopedagogos e todos os que trabalham em estabelecimentos de ensino têm o dever de evitar qualquer atitude preconceituosa ou discriminatória contra alunos filhos de familias homoafetivas.

\section{Direito à moradia}

Art. 76 - Os agentes financeiros públicos ou privados devem assegurar acesso às entidades familiares homoafetivas para a aquisição da casa própria.

Para Roger Raupp Rios (2011), esse tipo de uso da "afetividade" tem função "anestésica e acomodadora da diversidade sexual às normas da heterossexualidade compulsória", promove a "higienização da orientação sexual”, transformando-a em uma condição assimilável. $\mathrm{O}$ autor indica os riscos de limitar a discussão à "moldura jurídica" do direito de família. Essa abordagem limitaria a "compreensão do conteúdo jurídico dos direitos sexuais à convivência familiar”. Esse tipo de aproximação operaria justamente no mesmo sentido das formas que se busca enfrentar, não repensaria padrões, não traria novos termos para o debate. Rios trata essa abordagem como "assimilacionismo familista", em que o primeiro termo se refere à tendência "na qual grupos subordinados ou tidos como inferiores adotam padrões oriundos de 
grupos dominantes, em seu próprio detrimento", e o segundo termo designa a "tendência a subordinar o reconhecimento de direitos sexuais à adaptação a padrōes familiares e conjugais institucionalizados pela heterossexualidade compulsória" (Rios, 2011, p. 108).

Todas essas discussões acionam a "família" em argumentaçōes de ordem sobretudo moral. Nos debates a respeito da criminalização da homofobia, pelo lado de seus detratores, há os que se identificam com uma dada ordem "natural" de moral religiosa que ronda a instituição familiar. Do lado favorável, temos a exposição do sofrimento das mães como exemplar do sofrimento que a homofobia ocasiona a toda a "família", acionada como um contra-argumento moral poderoso e valorizado em face dos "fundamentalismos" que impedem a regulação de direitos para a "população LGBT". Já na proposta do Casamento Igualitário, o reconhecimento como "família" é a via mais eficaz de garantia de igualdade plena e proteção estatal, implicando a pedagogia de uma moral que reconhece a "dignidade e a condição humana das pessoas homossexuais". Com o Estatuto da Diversidade, a "família homoafetiva", domesticada, seria a resposta final, articulada por uma concepção que produz uma nova figura jurídica de família, ao mesmo tempo que a inclui na ordem de uma boa e desejável moral.

Podemos pensar todas essas propostas como imbuídas da crença de uma pedagogia legal apaziguadora. Essas "novas famílias" não representariam a desnaturalização de um suposto antigo modelo, mas a normalização de outras naturezas, o que produziria o efeito de reafirmar a existência de uma "família normal". Permaneceriam inabaláveis as crenças na vida familiar organizada em torno da conjugalidade, nesse tipo de vida familiar, como "base da sociedade" e como componente mais profundo da constituição da subjetividade dos sujeitos. Os argumentos trazem a "família" na frente dos sujeitos. São sujeitos reconhecidos como tal porque fazem parte de uma "família".

No entanto, a proposição de regulação do casamento pode ser compreendida como normalizadora e "familista", por um lado, mas iguala direitos e não reconhece apenas vítimas historicamente violadas, por outro. Ao comentar as consequências da decisão de efeito vinculante do Supremo Tribunal Federal, que reconheceu 
a união estável entre pessoas do mesmo sexo, Rios (2011, p. 103) relaciona os ganhos relativos aos direitos adquiridos em decorrência desse reconhecimento: "inclusão em planos de saúde, previdência, associação como dependente em clubes e sociedades, dever de alimentos em caso de necessidade, divisão de bens adquiridos na constância da união, direitos à herança, usufruto dos bens do falecido e acompanhamento de parceiro em instituições hospitalares". O autor faz outra ponderação interessante ao analisar a argumentação do voto do relator do julgamento e considera que o tribunal expressou claramente "a abrangência do conceito constitucional de 'sexo' para as hipóteses de discriminação por orientação sexual” (p. 105). Esta poderia ser uma interpretação feita por extensão ou analogia dos termos já contidos no artigo $3 .^{\circ} \mathrm{da}$ Constituição, que explicita como um dos "objetivos fundamentais" da República "promover o bem de todos, sem preconceitos de origem, raça, sexo, cor, idade e quaisquer outras formas de discriminação".

Em artigo no qual refletem sobre cerimônias coletivas em que casais formalizaram a união estável pouco tempo após a aprovação do STF, Uziel et al. (2012) apontam para uma discussão interessante sobre como o reconhecimento pelo estado do contrato firmado entre duas pessoas pode ter o efeito de convertê-las em sujeitos políticos, ao afetar a percepção dos próprios sujeitos como possuidores de direitos. As autoras indicam que o fato de "ser homossexual não é em si mesmo transgressor ou subversivo", não implica necessariamente a recusa "de todas e quaisquer normas ou construçôes sociais”. Em diálogo com Eric Fassin (2004, p. 375), ${ }^{58}$ os autores nos lembram que homossexuais compartilham do mesmo sistema simbólico que heterossexuais, no qual ideais de "complementaridade e amor romântico" podem ser valorizados.

\footnotetext{
${ }^{58}$ Eric Fassin (2004, p. 192) aponta o casamento como uma forma de coming out, como uma linguagem pública para sentimentos e práticas privadas: "Marriage (and the lesser forms of partnership and cohabitation) cannot be understood merely as a practical arrangement, designed in terms of its legal consequences. Rather, this renewed institution should be apprehended as a symbol of gay and lesbian coming out, undermining the hierarchy of sexualities. Therefore, this other logic results in a social gesture, not simply private, as it is a claim for legitimacy, nor merely individual, as it reclaims the form of the couple".
} 
Um dos pontos centrais da argumentação de Butler (2003) ao tratar do Pacto de Solidariedade Civil francês incide sobre se queremos de fato limitar ao estado os termos ou os critérios de legitimação de certo tipo de relaçóes íntimas - no caso, o casamento homossexual - com a consequência de nos submetermos a um novo processo de normalização e ampliação de poder sobre "os corpos e os prazeres":

Ser legitimado pelo Estado é aceitar os termos de legitimaçāo oferecidos e descobrir que o senso público e reconhecivel da pessoalidade é fundamentalmente dependente do léxico dessa legitimação. Dessa forma, a delimitação da legitimação ocorrerá somente através de uma exclusão de um certo tipo, embora não evidentemente dialética. A esfera da aliança intima legitima é estabelecida graças à produção e à intensificação de zonas de ilegitimidade. Todavia, ocorre aqui uma oclusão ainda mais fundamental. Compreendemos mal o campo sexual se considerarmos que o legitimo e o ilegitimo esgotam todas as suas possibilidades imanentes (p. 226).

O que pode virtualmente se tornar legítimo (formatos determinados de união estabelecidas entre duas pessoas do mesmo sexo) produz imediatamente aquilo que não está imbuído dessa virtualidade, ou seja, aquilo que não poderá ser legitimado. Então, onde ficariam as práticas sexuais que não aparecem imediatamente nos léxicos de legitimação disponíveis? Butler aborda aquilo que escapa do binarismo legítimo/ ilegítimo, evocando "zonas intermediárias e formaçōes híbridas" e um tipo de política na qual seja possível operar com aquilo que pode ser do campo da imponderabilidade. Nesse sentido, o debate que ancora esse tipo de reconhecimento estaria circunscrito à lógica segundo a qual "a sexualidade é pensada em termos de casamento e o casamento é pensado em termos de aquisiçãao de legitimidade" (Butler, 2003, p. 227).

Entretanto, outras interpretaçôes, como a desenvolvida por Vale de Almeida (2007, p. 162), advogam que "o casamento em si não é nem um conteúdo nem uma relação. É uma das formas contratuais que podem recobrir ou não determinados conteúdos relacionais". 
Assim, "transformar" os significados simbólicos depositados nesse tipo de contrato seria algo que pode ser feito desde o seu interior. ${ }^{59}$

O conjunto de argumentos expostos nessas tentativas de regulação de direitos pode ser lido a partir do acionamento de diferentes moralidades que incidem sobre regimes de gestão da sexualidade. Carrara (2013) propõe revisitar o dispositivo da sexualidade delineado por Foucault (1988) e questionar se continuamos sob o mesmo tipo de "regulação físico-moral" ou se observamos um processo de atualização ou transformação que deslocaria a sexualidade como ponto de articulação de uma "biopolítica das populaçôes" e de uma "anatomopolítica dos corpos". ${ }^{60}$

Ao refazer o percurso de formação do regime secular da sexualidade ao longo do século XIX e parte do XX, o autor argumenta que a assunção de um novo regime deve ser considerada a partir da emergência dos direitos sexuais. O que permitiria essa nova configuração seria um deslocamento na fronteira que distingue "o bom e o mal sexo". Se os parâmetros, antes, estavam relacionados à (boa) reprodução (da espécie da raça, da população, da nação), nessa nova configuração, "a promoção do bem-estar individual e coletivo através do bom uso dos prazeres" está baseada na gestão responsável do consentimento. Assim, desde que não envolva risco a terceiros, todos os sujeitos - ou "quaisquer manifestaçôes da sexualidade" - têm direito à cidadania.

Teríamos então a passagem de uma linguagem centrada em concepções biomédicas para outra progressivamente centrada em um vocabulário sóciojurídico, e, correlatos a essa transição, diferentes corpora morais entrariam em cena. Ainda acompanhando os desenvolvimentos do autor, estaríamos vivendo um momento no qual "diferentes regimes

\footnotetext{
59 Para uma análise a respeito de conjugalidades e parentalidades entre pessoas do mesmo sexo em Portugal, França e Espanha, ver Vale de Almeida (2010). O autor reflete sobre o debate público a respeito do tema nos três países, ao mesmo tempo que explora a sua própria experiência de pesquisa e de atuação política como militante e deputado.

${ }^{60}$ Foucault apresenta dois polos de desenvolvimento da nova forma de poder sobre a vida desenvolvida durante os séculos XVII e XVIII: o "corpo como máquina" - "anátomo-política do corpo humano" - e o "corpo-espécie" - "biopolítica da população". O primeiro é caracterizado por procedimentos de disciplina, e o segundo, por controles reguladores: "temos pois duas séries: a série corpo-organismodisciplina-instituiçôes; e a série populaçäo-processos biológicos-mecanismos regulamentadores-Estado" (Foucault, 2002, p. 298).
} 
da sexualidade colidem e provocam, de tempos em tempos, abalos mais ou menos intensos" (Carrara, 2013).

As três propostas recortadas aqui - a PEC do casamento civil, a criminalização da homofobia e o Estatuto da Diversidade - funcionam como bons artefatos políticos de articulação de diferentes valorações morais. Quando novas fronteiras entre o "bom e o mau sexo" garantem a possibilidade de que "sujeitos LGBT" pleiteiem direitos, a "família" entra no debate como reação aos ataques fundamentados na religião, mas também porque é assumida como um valor inquestionável. A centralidade da "família" nas argumentaçōes mobilizadas tanto pela produção discursiva pró- "direitos LGBT" quanto por seus opositores em certo plano faz lembrar a antiga permutação entre os dispositivos da aliança e da sexualidade postulados por Michel Foucault. ${ }^{61}$ Nas argumentaçóes expostas, não podemos facilmente isolar uma nova moral, colocada de um lado, e uma "antiga", de outro, pois, nesse embate, traços dessas distintas moralidades se interpenetram. ${ }^{62}$

Toda essa discussão reflete (e é refletida por) diferentes caminhos de compreensão de mecanismos jurídicos de reconhecimento de direitos e sujeitos e também distintas moralidades imiscuídas nas distintas demandas, denúncias ou controvérsias. Independentemente da possibilidade de aprovação dessas proposições, da incorporação ou não às normas legislativas, já concorrem para a produção de convençōes de entendimento que são chave tanto para a compreensão quanto para a manutenção da

${ }^{61}$ A família aparece como central na análise de Foucault (1988), pois surge como permutadora dos dois dispositivos centrais: o da sexualidade e o da aliança. É em torno dela que se desenvolvem, e é ela que constitui o seu suporte: "saúde, progenitura, raça, futuro da espécie, vitalidade do corpo social, o poder fala da sexualidade e para a sexualidade; quanto a esta, não é marca ou símbolo, é objeto e alvo" (p. 138).

62 Trabalhando com outro contexto, Debert (2006) chama a atenção para o modo como propostas e açōes políticas de movimentos, "que pretendem ser progressistas e defensores de direitos humanos", têm dado lugar à família" como instituiçāo privilegiada para garantir a boa sociedade". A autora trata do modo como uma reconceitualização em curso tem convertido as Delegacias de Defesa da Mulher em delegacias de defesa de crimes contra a família, e da tendência dos Juizados Especiais Criminais em operar com uma lógica que privilegia a "defesa da família", despolitizando e desvinculando, dessa forma, a violência contra a mulher no âmbito dos seus direitos e reinscrevendo a questão na seara das relaçōes privadas. Nesse sentido, aponta que "a família passa a desempenhar um novo papel nas políticas públicas, transformando-se num aliado imprescindível no tratamento que as agências governamentais oferecem à cidadania malograda" (p. 34). 
correlação de forças que movimenta esse campo de produção de sujeitos e direitos.

Enquanto argumentos seguem disputados em um plano desse processo - que podem ser chamados de "legislativo" e "judiciário" -, algumas ações são institucionalizadas no plano "executivo". O período em que desenvolvi a pesquisa de campo coincidiu com aquele em que muitas iniciativas começaram a ser implementadas no plano administrativo governamental. É disso que trato no capítulo a seguir. 


\section{CAPÍTULO 4 OS DESAFIOS DOS ENQUADRAMENTOS ADMINISTRATIVOS E DAS CLASSIFICAÇÕES IDENTITÁRIAS}

Cena 5 - Maio de dois mil e onze

Sede da Secretaria de Direitos Humanos, Brasília. Local de uma reunião de "Gestores LGBT" com duração de dois dias.

A reunião começou depois de dois outros eventos de público mais amplo - o VIII Seminário LGBT do Congresso Nacional e a II Marcha Nacional contra a Homofobia - e dois dias antes da

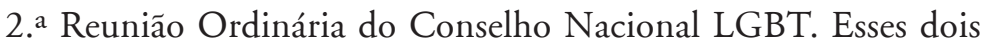
dias de encontro de gestores foram chamados pela Coordenação LGBT da Secretaria de Direitos Humanos por meio do próprio site da $\mathrm{SDH}$ e, a pedido da $\mathrm{SDH}$, o convite para a reunião também circulou em algumas listas de e-mails populares entre pessoas, grupos e organizaçōes envolvidas com movimentos LGBT. Segundo esse e-mail, os gestores interessados em participar da reunião deveriam entrar em contato com a SDH. Essa introdução é pertinente, pois o primeiro dia de reunião começou com uma 
reclamação contundente por parte dos cerca de trinta gestores e gestoras presentes direcionada ao coordenador LGBT da SDH.

A reclamação, enunciada por um gestor, mas acordada em consenso entre todos em conversa prévia, tratava do não recebimento de um "ofício" ou "convite oficial" da SDH para a participação na reunião. Os presentes postulavam que "nós, gestores estaduais e municipais que recebemos e executamos a demanda, [...] ficamos sabendo da reunião através de listas de discussão do movimento social, [...] nós não somos movimentos social". ${ }^{1}$ A reclamação trazia embutido um tom de crítica ao modo "não profissional" como a SDH vinha conduzindo o processo, sem "ofícios" e outras documentações que formalizassem o encontro. Diante disso, o coordenador nacional LGBT procurou esclarecer que, com as mudanças de governo, a SDH não sabia exatamente quem eram os secretários aos quais deveria enviar um convite formal, tampouco existia uma lista de contatos atualizada dos "gestores LGBT". Por isso, pensou que a circulação do convite nas listas dos movimentos sociais produziria um efeito de divulgação satisfatório e que, a partir do contato dos próprios gestores, os "ofícios" necessários poderiam ser encaminhados. Essa explicação não satisfez os reclamantes. Cabe pontuar que o coordenador nacional LGBT havia tomado posse há poucos meses e, naquele momento, parecia ser esse o seu primeiro cargo de gestão governamental. Durante a reunião foram frequentes as falas dos gestores que buscavam ensinar a melhor maneira e os trâmites burocráticos mais adequados a serem seguidos por um "gestor de governo".

Além da ausência de "ofícios", os gestores municipais e estaduais ali reunidos ainda expuseram outro incômodo: o fato de não terem assento no Conselho Nacional LGBT em momento considerado particularmente importante, pois o Conselho deliberava sobre a organização da II Conferência Nacional, evento cuja execução

1 Falas reconstruídas a partir de anotações do diário de campo. 
seria de responsabilidade dos gestores. Diante disso, foi a vez de a Coordenação da SDH esclarecer que não teria gerência sobre as decisões do Conselho. Assim, os próprios gestores deveriam se organizar para pleitear essa vaga e, enquanto isso não acontecia, procurar elaborar um documento formalizando as suas reivindicaçóes em relação à organização da Conferência e entregá-lo diretamente no dia da reunião do Conselho. No encerramento da reunião, quando encaminhamentos relativos à produção desse documento estavam sendo feitos, uma das duas transexuais presentes pediu a palavra para uma "questão de ordem", já que teria que deixar o encontro antes dos demais: "Nós, que somos as únicas mulheres trans aqui, as únicas transgestoras, e não estaremos presentes na reunião do Conselho amanhã, vamos conversar diretamente, ainda hoje, com a nossa presidenta [da ANTRA, com assento como membro efetivo do Conselho] e pedir que haja sensibilidade e compreensão para as nossas questôes".

Nesse momento, a separação entre movimento social e gestão pública foi posta de lado, pois se colocava a necessidade de articulação de lobby para questóes de interesse político. O que aconteceu foi o manejo e o acionamento de identidades particulares, bem como de redes pessoais vinculadas ao movimento social e não à gestão pública, que inúmeras vezes durante a reunião teve destacado o seu caráter "profissional”, de oficializar meios de comunicação e troca de informação entre gestores.

\section{"O TRIPÉ DA CIDADANIA": A RELAÇÃO ENTRE DEMANDAS E FORMATOS DA ADMINISTRAÇÃO ESTATAL}

A situação reconstruída acima é ilustrativa dos tipos de desafios e disputas que envolvem a constituição e a gestão de organismos voltados para a "população LGBT". Nos últimos anos, é notável a criação de instâncias administrativas nos níveis estaduais e municipais direcionadas 
a oferecer serviços e promover "direitos LGBT". Nessa cena, destaco um ponto que ganhou progressiva relevância durante o trabalho de campo: a disputa entre as técnicas administrativas com que opera a gestão pública e certo modus operandi praticado pelo movimento social.

Vale mencionar que, na situação descrita, quase todos os gestores presentes tiveram uma carreira anterior mais ou menos atuante em organizaçóes de militância LGBT ou de mulheres. Parece haver um processo de conversão burocrática (no sentido weberiano) da lógica de funcionamento mais pessoalizada, tida como própria de algumas organizaçôes de movimento social, para um caminho de crescente rotinização administrativa característica das repartições públicas (Weber, 1974). A crença no estado burocratizado, ou "na ideia abstrata e 'objetiva' das 'razões de Estado"”, apostaria que um "sistema de razões racionalmente debatíveis se oculta atrás de cada ato da administração burocrática" (Weber, 1974, p. 256). Em torno desse tipo de convicção, estabelecem-se disputas a respeito de quem é mais profissional, eficaz e competente.

O "tripé da cidadania" é a fórmula que vem sendo utilizada para expressar uma das principais revindicações do movimento LGBT na atualidade e se refere à implantação de três medidas nas esferas municipais e estaduais de governo: coordenadorias LGBT, conselhos LGBT e planos de combate à homofobia nos níveis locais. Outro aparato que vem se multiplicando nos últimos anos são os centros de referência. Em 2005, a Secretaria de Direitos Humanos (SDH) lançou um edital para [o] desenvolvimento de atividades de Prevenção e Combate à Homofobia, por intermédio da implantação e manutenção de Centros de Referência em Direitos Humanos que contemplem o combate à discriminação e à violência contra o segmento de gays, lésbicas, travestis, transexuais e bissexuais - GLTB. Podiam se candidatar à chamada 'instituições públicas, de âmbito federal, estadual e municipal, bem como as organizações não governamentais sem fins lucrativos, legalmente constituídas'. ${ }^{2}$

2 Em janeiro de 2013, o edital ainda podia ser visualizado no endereço: www.mj.gov.br/sedh/ct/ edital_homofobia.doc. 
Segundo Mello et al. (2012)3 , no ano de 2005, foram instalados 15 centros de referência e, no ano de 2006, outros 30 centros. Também em 2006, os projetos foram estendidos para universidades, com o investimento na implementação de "Núcleos de Referência em Direitos Humanos e Cidadania Homossexual (NRDHCH) em oito instituições públicas de ensino superior". Entretanto, os autores revelam certo ceticismo em relação à efetividade dessas ações. Em novembro de 2008, foi realizado pela SDH um seminário de Capacitação dos Centros de Referência em Direitos Humanos de Prevenção e Combate à Homofobia e dos Núcleos de Pesquisa e Promoção da Cidadania LGBT. De acordo com os autores, nesse encontro foi feita uma tentativa de avaliação das atividades conduzidas pelos núcleos e centros e "a tônica dos discursos de representantes dos diversos estados foi a descontinuidade dos trabalhos, tendo em vista a escassez de recursos e a dificuldade de sustentabilidade dos projetos, sem o apoio financeiro da SDH ou dos governos estaduais e municipais" (p. 297).

Um relatório sobre o monitoramento do Plano Nacional LGBT, divulgado pela SDH no $1 .^{\circ}$ semestre de 2010 , apontou a implantação de 29 Centros de Referência no final daquele ano. Não existem informaçōes sistematizadas e atualizadas periodicamente sobre a existência de coordenadorias, conselhos, centros de referência ou planos de promoção de direitos LGBT nos níveis estaduais ou municipais. ${ }^{4}$

Da reunião em que estive presente, em maio de 2011, destaco de maneira resumida como alguns dos gestores presentes expuseram, com mais ou menos detalhes, as iniciativas existentes nos estados e nos municípios que ali representavam. Certamente essa não é uma visão

3 Mello et al. (2012). O conteúdo do artigo faz parte do relatório da pesquisa "Políticas públicas para a população LGBT no Brasil: um mapeamento crítico preliminar”, desenvolvida pelo Sertão - Núcleo de Estudos e Pesquisas em Gênero e Sexualidade e financiada pela Secretaria de Direitos Humanos da Presidência da República (SDH/PR). Os resultados da pesquisa podem ser encontrados em: http://www.sertao.ufg.br/politicaslgbt/.

${ }^{4}$ Um levantamento não muito aprofundado de políticas existentes na época pode ser encontrado no texto-base da II Conferência Nacional LGBT, sob o subtítulo "Diagnóstico das Políticas Públicas". E uma exceção mais recente foi a Pesquisa de Informações Básicas Estaduais (Estadic) realizada pelo IBGE, referente ao ano de 2012, que verificou que cinco estados possuíam Conselhos voltados a direitos LGBT: Pará, Mato Grosso do Sul, São Paulo, Rio de Janeiro e Goiás (Disponível em: http:// www.ibge.gov.br/home/ estatistica/economia/estadic/estadic2012/. Acesso em: maio 2013). 
abrangente de todas as ações existentes naquele momento nos estados e municípios em questão, mas as exposiçōes feitas nos deixam antever alguns formatos possíveis para a construção de políticas. Em geral é comum que representantes de estados e municípios comecem a apresentação dizendo quais elementos do "tripé da cidadania" a sua região "já" implementou ou "ainda não". Reproduzo as informaçôes registradas em caderno de campo na ocasião:

Paraíba - 'Gerência LGBT' localizada na Secretaria da Mulher e da Diversidade Humana do governo do estado. Segundo a gestora presente, naquele momento, estava para ser inaugurado um Centro de Referência LGBT e Combate à Homofobia.

Alagoas - Gerência ligada à Secretaria de Estado da Mulher, da Cidadania e de Direitos Humanos. Segundo o gestor representante de $A L$, também existiria um centro de referência, mas não pude saber se especificamente para 'LGBT' ou se seria um centro de direitos humanos em geral que atenderia 'LGBT'.

Campinas (SP) - Centro de Referência LGBT funciona desde 2003 (foi o primeiro do Brasil e já esteve ligado a diferentes instâncias) e desde 2010 existe a Coordenadoria de Politicas para a Diversidade Sexual, estrutura ligada à Secretaria Municipal de Cidadania, Assistência e Inclusão Social.

São Paulo e SP - Políticas existentes no âmbito do estado: Coordenação de Políticas para a Diversidade Sexual (CDS) ligada à Secretaria da Justiça e da Defesa da Cidadania desde 2009. Conselho Estadual LGBT instituido em 2010, mas até aquela data não havia sido composto. Plano Estadual de Combate à Homofobia. Em 2009 foi inaugurado o Ambulatório de Saúde Integral de Travestis e Transexuais, ligado ao Programa Estadual de DST- 
AIDS. Lei antidiscriminação promulgada em 2001. ${ }^{5}$ No âmbito municipal: CADS - Coordenadoria de Assuntos de Diversidade Sexual, compondo a estrutura da Secretaria de Participação e Parceria da Prefeitura, CCH - Centro de Combate à Homofobia. Possui conselho em âmbito municipal de Atenção à Diversidade Sexual. Um dos gestores citou ainda a DECRADI - Delegacia de Crimes Raciais e Delitos de Intolerância.

Mato Grosso - Centro de Referência LGBT de Combate à Homofobia. Foi criado em 2005 com o apoio da SDH e hoje integra a estrutura da Secretaria de Estado de Justiça e Direitos Humanos. Segundo um dos gestores presentes, o Centro 'também é gestor de politicas', além de atender a usuários, ao que o outro gestor completou explicando que existe um termo de cooperação com a Defensoria Pública. Desenvolvem açôes de prevenção e atuam junto à segurança pública, com atividades nos presidios e capacitação de oficiais da PM, além da atuação na educação, através de projetos em escolas.

Goiânia e Goiás - Gerência de Politicas para a Diversidade dentro da estrutura da Secretaria de Estado de Politicas para Mulheres e Promoçáo da Igualdade Racial. O gestor presente mencionou a existência de um centro de referência que atende LGBT, mulheres, idosos e negros. Desde 2009 existe o Conselho Estadual de LGBT do Estado de Goiás.

Santo André (SP) - Segundo o gestor presente, uma assessoria de gênero existente na prefeitura começou a trabalhar a 'questão $L G B T$ ' em 2009, e a questão da diversidade sexual foi incluida no Conselho da Mulher (para mulheres lésbicas e bissexuais).

Acre - Existe um centro de referência alocado na Secretaria de Direitos Humanos e Justiça. De acordo com o gestor presente, existe ainda uma

5 Lei 10.948/01 define em seu artigo $10^{\circ}$ - "Será punida, nos termos desta lei, toda manifestação atentatória ou discriminatória praticada contra cidadão homossexual, bissexual ou transgênero". 
'divisão que trata de politicas públicas para LGBT' na secretaria e um núcleo de combate à homofobia ligado à universidade.

Belo Horizonte e Minas Gerais - Um centro de referência iniciou as atividades através do financiamento da SDH, com o fim do convênio ficaram inativos, mas naquele momento voltariam a funcionar como parte de uma estrutura da prefeitura. No âmbito do estado: Centro de Referência LGBT do Estado de Minas Gerais, ligado à Secretaria de Estado de Desenvolvimento Social (estaria sendo preparada para breve uma campanha de combate à discriminação por raça e sexualidade).

João Pessoa (PB) - O gestor presente explicou que existe uma Assessoria de Diversidade Humana' alocada na estrutura da Secretaria de Desenvolvimento Social e lá seriam desenvolvidas politicas para 'negros, LGBT e outras minorias vulneráveis.

Recife (PE) - Na estrutura da Secretaria de Direitos Humanos e Segurança Cidadã existe a Gerência de Livre Orientação Sexual, criada em 2005, com advogados, assistentes sociais e psicólogos.

Fortaleza e Ceará - A gestora presente explicou que uma assessoria de politicas públicas LGBT foi criada em 2007, no mesmo ano em que foram estabelecidas assessorias para mulher, pessoas com deficiência, juventude e idosos. As assessorias teriam sido transformadas em coordenadorias, com orçamento próprio em 2010. As politicas desenvolvidas no estado incluem um programa de qualificação profissional para travestis e transexuais, uma campanha Ceará Sem Homofobia e a existência de grupos de trabalho para traçar politicas LGBT em todas as secretarias, bem como delegados e destacados da defensoria pública especialmente para acompanhar crimes correlatos de homofobia. Possui lei municipal antidiscriminação.

Rio Grande do Sul-Coordenadoria Estadual de Diversidade Sexual criada em 2011. Não possui um conselho LGBT e, segundo o gestor 
presente, o governo disse que não iria compor um conselho naquele ano por questão financeira. Estaria para ser lançado o programa Rio Grande Sem Homofobia. Também não existe centro de referência, mas o gestor informon que a deputada Manuela D'Ávila e o senador Paulo Paim se comprometeram a colaborar.

Palmas (TO) - Segundo o gestor presente, existe o programa Palmas Sem Homofobia e uma coordenadoria com status de Secretaria.

Babia - Dentro da Secretaria de Direitos Humanos existe um núcleo que trata de questôes $L G B T$, com orçamento que supera as questóes do idoso e do indígena'. De acordo com o gestor presente, são priorizadas a instalação de núcleos e centros de referência em lugares de 'transbordo' e estaria para ser lançado um programa de combate à homofobia.

Durante a reunião, os gestores explicaram que a implementação das açôes depende muito da "vontade política" dos governos locais. O governo federal pode incentivar algumas açôes, mas não pode intervir, pois precisa respeitar o Pacto Federativo definido pela Constituição. O coordenador LGBT perguntou aos demais gestores se achavam válido que a SDH fizesse algum tipo de pressão junto aos estados que não têm uma coordenadoria LGBT ou organismo equivalente em sua estrutura. Os gestores responderam que isso não seria papel da Coordenação Nacional LGBT, mas do Conselho LGBT, pois esta seria a instância responsável por pressionar e "fiscalizar" as ações empreendidas pelo governo.

Não atualizei nenhuma dessas informaçôes que foram passadas pelos gestores em 2011, ${ }^{6}$ o que significa que neste momento pode haver mais ou menos políticas funcionando nessas regiōes, pois meu interesse é atentar para a relação entre as demandas e os

6 Para uma análise e levantamento não exaustivo, porém mais sistemático, do estado da arte da implantação de políticas LGBT até o ano de 2010, ver Mello et al. (2012a, 2012b) e também: http:// www.sertao.ufg.br/politicaslgbt/ index.php. Acesso em: maio 2013. 
formatos administrativos que as políticas adquirem. ${ }^{7}$ No trecho reconstruído anteriormente é interessante notar em que instâncias estão "penduradas" tais políticas e as diferentes formas como açōes voltadas para LGBT são efetivadas em cada localidade. Algumas iniciativas aparecem atreladas a organismos do governo do estado, outras, do município. Muitas são adicionadas como um novo braço de atuação em instâncias que já trabalhavam com outras questōes "específicas", como mulheres, jovens e idosos, e em algumas localidades são criadas novas estruturas independentes de outras questôes. Notamos que, com mais frequência, as iniciativas para LGBT estão ligadas a secretarias relacionadas a direitos humanos, assistência social, cidadania e justiça, realçando uma concepção que atrela direitos humanos e justiça à assistência social e, com menor frequência, aparecem instâncias de outra ordem, tais como "diversidade humana" e "livre orientação sexual".

Toda essa movimentação em torno da criação de novas estruturas de administração governamental fez surgir mais uma figura nesse campo: os "gestores LGBT". Por ocasião dessa reunião, em Brasília foi divulgado um informe sobre a criação do Fórum Nacional de Gestoras e Gestores LGBT (FONGES). ${ }^{8}$ Diante desse anúncio, o representante LGBT da SDH pediu explicações do porquê de a Coordenação Nacional não ter sido convidada para integrar esse Fórum. A resposta de um dos gestores presentes foi de que seria "um fórum só nosso, de gestores estaduais e municipais, separado". A resposta não satisfez à Coordenação Nacional, que pediu que o seu interesse em participar nesse Fórum ficasse registrado. Nessa situação, apesar de todos serem

7 Em fevereiro de 2013, a SDH lançou um edital para: "Contratação de consultor especializado para a identificação dos órgãos e das instituições componentes de um sistema de defesa e promoção de direitos humanos da população LGBT em cada estado, articulação desses órgãos e entidades para atuar em rede quando do recebimento de denúncias provenientes do Disque Direitos Humanos, assim como capacitar os profissionais envolvidos para lidar com as denúncias recebidas e fomentar a necessidade de retorno das informaçôes para favorecer o monitoramento dos casos" (Edital 001/2013 - Projeto PNUD BRA/07/019. Disponível em: http:// www.sdh.gov.br/assuntos/atuacaointernacional/editais/pdfs-dos-editais/edital-001.2013).

8 A criação do Fonges foi formalizada em reunião realizada em 20 de junho de 2011, em São Paulo, com o nome completo: Fórum Nacional de Gestoras e Gestores Estaduais e Municipais de Políticas Públicas para a População de Lésbicas, Gays, Bissexuais, Travestis e Transexuais. Ver anexo C11 (p. 359-361). 
"gestores LGBT", esboçou-se um antagonismo entre a gestão federal e as gestōes estaduais e municipais."

Ao longo do desenvolvimento da pesquisa de campo foi possível notar entre diversos atores um progressivo aprendizado do funcionamento administrativo do governo e, consequentemente, a colocação de demandas de acordo com o que se entende que sejam os formatos institucionalizados possíveis e corretos para cada propósito. Em seminários, encontros e reuniōes, várias vezes ouvi variaçōes da assertiva: "temos que estar antenados em como funciona o Estado administrativamente". Esse investimento em compreender morfologias da administração já acontece há alguns anos. O Projeto Aliadas, por exemplo, mencionado no capítulo 2, foi um importante signo desse esforço em "aprender a língua do Estado". A dubiedade dessa espécie de "empoderamento" reside no fato de que se aprende a operar com a mesma linguagem de poder que supostamente se pretende superar. Ou seja, adquire-se competência em linguagens e modos de operação que dificultam o acesso daqueles que não são muito bem "entendidos" na "máquina pública" e que não transitam nas redes de contato e influência. Mas não se faz muito para que esses modos e linguagens sejam transformados. Nota-se, ao contrário, uma verdadeira pedagogia em relação à adequação a procedimentos tradicionais da política.

O Conselho Nacional LGBT, espaço disputado na cena 5, reproduzida anteriomente, pode ser considerado como um dos locais

9 Em 08 de abril de 2013, a Secretaria de Direitos Humanos da Presidência da República disponibilizou para consulta pública o "documento-base" do Sistema Nacional de Enfrentamento à Violência Contra LGBT: "O sistema tem como objetivo incentivar a instalação de Conselhos e Coordenadorias estaduais, distritais e municipais LGBT em todo o país” (Disponível em: http://portal.sdh.gov.br/ clientes/sedh/sedh/2013/04/08-abr-13-sistema-nacional-de-enfrentamento-a-violencia-lgbt-entraem-consulta-publica). Cerca de 3 meses depois, em 3 de julho de 2013, a Portaria n. 766 instituiu o referido Sistema com a finalidade de "organizar e promover políticas de promoção da cidadania e direitos de LGBT, compreendidas como conjunto de diretrizes a serem observadas na ação do Poder Público e na sua relação com os diversos segmentos da sociedade". Segundo a Portaria, os integrantes do Sistema Nacional de Enfrentamento à Violência Contra LGBT seriam: "executores de políticas LGBT", "Conselhos LGBT" de nível nacional, estadual e municipal, "Comissão Intergestores da Política LGBT" e "Conferências LGBT". Outra Portaria, datada do mesmo dia, de n. ${ }^{\circ} 767$, instituiu o "Comitê Nacional de Políticas Públicas LGBT, no âmbito da Secretaria de Direitos Humanos da Presidência da República". Entre as suas "competências" consta a articulação das ações do Sistema Nacional (as duas portarias podem ser encontradas no anexo C12 e C13, p. 363 e 364). 
privilegiados para o exercício - e a exibição - desse aprendizado administrativo. O Conselho é também considerado a ferramenta principal de "controle social e participação", ambos indispensáveis ao modelo de democracia que o estado brasileiro vem se empenhando em produzir. Nesse sentido, contribui para agregar uma marca moral bastante valorada e significativa a um "Estado" que administra em parceria com a "sociedade civil". ${ }^{10}$

Acompanhei algumas das reuniōes do Conselho. Na primeira, um dos integrantes da "sociedade civil" brincou: "esse é o controle social do controle social", referindo-se ao fato de o encontro, sediado na SDH em Brasília, estar sendo transmitido pela internet em tempo real. Em outra reunião, um representante da Secretaria de Participação Social apontou o desconhecimento que as pessoas têm de distintas conferências que não sejam aquelas mais diretamente relacionadas ao seu interesse: "é preciso que haja articulação entre os conselhos [...] para somar forças e não elaborar políticas repetidas”. Em outra ocasião, um conselheiro do governo federal brincou dizendo que o nível de compreensão entre governo e sociedade civil era alto ali: "acho que apanhamos pouco".

De volta à cena 5 , outro momento interessante da reunião foi a apresentação dos dados acumulados até então pelo Disque 100 . O Disque Direitos Humanos (ou Disque 100) é um serviço da Ouvidoria da SDH para a denúncia de violações de direitos. ${ }^{11}$ Naquela ocasião, um coordenador do Disque 100 apresentou como o sistema funcionava, como os dados eram registrados, quais eram as formas de

${ }^{10}$ O Decreto n. ${ }^{\circ} 7.388$, de 9 de dezembro de 2010, que ajustou o formato do Conselho Nacional de Combate à Discriminação para que passasse a atuar no "combate à discriminação e promoção dos direitos LGBT", dispōe sobre sua competência "de natureza consultiva e deliberativa", com a finalidade de, "respeitadas as demais instâncias decisórias e as normas de organização da administração federal, formular e propor diretrizes de ação governamental, em âmbito nacional". O Conselho é composto por trinta membros, quinze representantes de Ministérios e Secretarias da Presidência da República e quinze da "sociedade civil".

${ }^{11}$ O Disque existe desde 2004 para denúncia de violações de direitos de crianças e adolescentes. Em fevereiro de 2011, foi lançado oficialmente um módulo específico destinado ao recebimento de denúncias de violação de direitos de lésbicas, gays, bissexuais, travestis e transexuais. Na mesma época também foram acrescentados módulos específicos para "idosos, pessoas com deficiência e populaçāo em situação de rua". Em abril de 2013 foi anunciada a possível inclusão de mais um módulo destinado à "população cigana" (Disponível em: http://www.sdh.gov.br/disque100/ouvidoria-disque-100). 
encaminhamento de denúncias, bem como alguns dados computados até ali. Quando existem estruturas montadas nos níveis de estados e municípios cuja atribuição específica cubra o atendimento de "questões LGBT", o serviço encaminha as denúncias recebidas para que sejam processadas localmente. Esse era o caso de algumas das instâncias representadas pelos "gestores LGBT" presentes na reunião.

A esse respeito, um dos gestores se manifestou dizendo que o sistema era ótimo, mas havia aumentando muito "a demanda”, e questionou como faria para dar conta das denúncias encaminhadas, inclusive financeiramente. Foi dado um exemplo. A ouvidoria envia faxes para os organismos locais com os dados das denúncias recebidas, "mas quem paga as resmas de papel?”. Alguns se manifestaram dizendo que era preciso aumentar a divulgação sobre o Disque 100, pois talvez este fosse o motivo da diferença notada entre a quantidade de denúncias recebidas entre diferentes estados e municípios - um reflexo do baixo conhecimento do serviço entre a população. Já outros interpretaram que a divulgação do Disque da SDH causaria um problema. Algumas regiōes possuem os próprios serviços telefônicos de denúncia, e uma divulgação maior do Disque 100 faria com que as pessoas passassem a acioná-lo ao invés dos canais locais (inclusive em razão de o número ser mais fácil de decorar). Então, a longo prazo, uma maior divulgação "enfraqueceria os serviços locais". Um dos gestores presentes, demonstrando ser "mais experiente", dirigiu-se aos demais "ensinando" que eles precisariam fazer pressão para que os recursos de que necessitam constem dos PPA dos seus estados, pois não seria possível "ficar esperando só do governo federal".

Outras discussões ocorreram sobre como estabelecer formatos e "rotinas para a emissão de relatórios gerenciais". Alguns manifestaram a preocupação de que denúncias estariam "caindo no limbo" ao serem encaminhadas, pois não existiria muito controle sobre a forma como isso vinha sendo feito ou de como estariam sendo recebidas. Por fim, para haver mais "agilidade", decidiu-se que seria criado um "e-mail oficial" especialmente para encaminhamentos da SDH às gestões locais. Para tal, foi solicitado que a SDH enviasse um "ofício" 
pedindo formalmente a criação de um e-mail para as respectivas instâncias administrativas locais competentes.

A expectativa para com o Disque 100 é de que, a partir dele, seja efetivamente possível construir e monitorar um "mapa nacional de violação de direitos humanos LGBT". Para isso seria preciso trabalhar com cuidado as categorias a partir das quais as informações são registradas. Esse foi um ponto de especial atenção entre os presentes na reunião. O entendimento, em particular, sobre a categoria "identidade de gênero" foi um ponto de controvérsias. De acordo com a exposição feita pelos responsáveis pelo Disque 100, o "sujeito LGBT" seria localizável nos registros por meio das seguintes categorias: "identidade" - "heterossexual, homossexual ou bissexual"; "sexo biológico" - "(F) feminino ou (M) masculino"; e "identidade de gênero" - "(F) feminina ou (M) masculina”. Os gestores se esforçaram para explicar aos presentes que "identidade de gênero" não poderia ser preenchida simplesmente pelas variáveis " $F$ " ou "M", pois a categoria incluiria "travestis" e "transexuais" e, ainda segundo um dos gestores, "F" ou "M" seria "gênero" e não "identidade de gênero".

Com as categorias preenchidas da maneira como foram apresentadas pelos responsáveis pelo Disque 100, travestis e transexuais de fato não seriam identificáveis. Durante a discussão, alguém chegou a propor a inclusão da categoria "identidade sexual" no sistema, mas a ideia não teve adesão. Por fim, ficou acertado que alguma nova implementação seria feita para que pudessem efetivamente capturar registros relacionados a travestis e transexuais. Essa passagem deixa evidente o quanto sistemas burocráticos de classificação têm dificuldade de incorporar categorias que escapam da concepção binária do dismorfismo sexual.

Em 2012, a SDH divulgou o primeiro "Relatório sobre Violência Homofóbica no Brasil”, incluindo as denúncias registradas pelo Disque 100 ao longo do ano de 2011. Especificamente sobre a informação da "identidade de gênero" para a composição do "perfil da vítima", o levantamento registra que, em 18,6\% das denúncias, o dado não foi informado. A interpretação para essa porcentagem, considerada alta, é a de que a categoria "não é corrente no senso comum, tornando-se seu entendimento um obstáculo para a resposta” (Brasil, 2012, p. 22). O relatório divulgado para os casos denunciados no ano de 2012 também 
traz considerações sobre o alto índice de registros "não informados" sobre "identidade de gênero": "Categorias como 'orientação sexual' e 'identidade de gênero', bem como suas diferenciaçôes, não são amplamente conhecidas entre a população, desinformação que se torna um obstáculo para a denúncia” (Brasil, 2013, p. 23).

A categoria "identidade de gênero" voltará a ser discutida na próxima seção. Por ora, considero relevante registrar como o episódio anteriormente citado ressaltou a importância de classificar sujeitos para a produção posterior de dados e igualmente a dificuldade dessa tarefa, sobretudo quando o que se está a classificar escapa de enquadramentos mais ordinários ou de categorias de apreensão mais convencionais.

O fazer cotidiano das políticas implica a compreensão dos modos de funcionamento administrativo do estado, ao mesmo tempo que a construção contínua das populações que são o objeto da administração. As dinâmicas produzidas pela interação desses novos agentes (gestores) com uma também "nova população" permitem vislumbrar como negociações cotidianas são imprescindíveis. A fabricação da necessidade de "ofícios", ou a miríade de formalizações e institucionalizaçōes burocráticas das quais os "ofícios" são um grande signo, as disputas por espaços de poder, a produção de enquadramentos, as fixações em "papel" e as disputas por enunciações legítimas são filigranas que vão constituindo políticas e sujeitos para essas políticas.

A noção de "trama institucional" articulada por Gregori (2000, p. 166) é bastante útil aqui, "na medida em que supõe a existência de uma rede formada por uma gama de instituiçôes e atores" não desprovida de conflitos. Não é possível olhar para a trama institucional que vem constituindo "sujeitos LGBT" no plano governamental brasileiro sem considerar as disputas e os rearranjos internos que envolvem os sujeitos que se reúnem sob esse coletivo. Tais movimentações condicionam e, ao mesmo tempo, são condicionadas por essa trama ou por essa malha de relações. Esse será o aspecto abordado na próxima seção. 


\section{"ATRÁS DO SILICONE TAMBÉM BATE UM CORAÇÃO"12 - TRAVESTIS, TRANSEXUAIS E ALGUNS DESLOCAMENTOS OU DESESTABILIZAÇÕES}

Uma discussão pormenorizada e detida sobre travestis e transexuais não é o foco deste livro. Contudo, é impossível refletir sobre o processo de construção de uma "população LGBT" sem considerar as inflexōes particularmente relacionadas ao $\mathrm{T}$ desse coletivo. Observei duas áreas de tensão que apareceram mais explicitamente durante o meu trabalho de campo. Notadamente, as maneiras como os sujeitos que se pretende reunir sob esse " $T$ " imprimem distensōes: i) no interior do próprio movimento organizado, quando funcionam para personificar o alvo da homofobia ou "a cara do movimento" e ao mesmo tempo desestabilizam a "homossexualidade" como categoria englobante do coletivo; ii) as relaçôes controversamente produtivas que estabelecem com as políticas de saúde. O que pretendo destacar é a maneira como essas distensōes reverberam "perturbaçōes de gênero" que desordenam convençōes ${ }^{13}$ refletidas em disputas por categorias de enunciação e classificação que percorrem determinadas "tramas institucionais".

Ainda nesse sentido, é bastante instigante para a reflexão a desestabilização ou a desnaturalização da categoria mulher provocada por travestis e transexuais que se definem como mulheres (independentemente do desejo de realização de cirurgia de transgenitalização), ou que procuram se aproximar de organizaçóes feministas, oscilando entre uma identificação com o movimento de mulheres e o movimento LGBT. ${ }^{14}$ Vianna (2009) destaca as "provocaçōes ruidosas" e as "dissidências

$12 \mathrm{O}$ enunciado completo diz: "não, não, não à discriminação, atrás do silicone também bate um coraçãa".

13 Utilizo convençôes aqui no sentido desenhado por Gregori (2011) que, em diálogo com Roy Wagner (2010 [1981]), assume, para além do significado presente no dicionário, a relação dialética entre convenção e invenção: "a convenção tem a ver com o ponto de vista coletivo, com a orientação da cultura, com o modo como as pessoas aprendem a experienciar, agir e comunicar; as convençóes sofrem mudanças, e novas inflexōes são inventadas, a partir de operaçôes de diferenciação e particularização, no marco de contextos anticonvencionais" (p. 21).

${ }^{14}$ Cf. Vianna e Carrara (2007) e Machado (2008). Em março de 2009, pela primeira vez, transexuais puderam participar oficialmente do XI Encontro Feminista Latino-Americano e do Caribe, realizado no México. 
inscritas no e pelo gênero" que surgem com a entrada em cena de travestis e transexuais que reivindicam o tratamento de seus relacionamentos afetivo-sexuais como relações heterossexuais. Dessa forma, provocam a "matriz de inteligibilidade" que pressupõe a coerência linear e encadeada entre sexo anatômico, performance de gênero e orientação sexual (Butler, 2008). ${ }^{15}$

Entre os materiais reunidos para esta análise, o uso do termo "identidade de gênero", forjado especialmente para "incluir" sujeitos que se definiriam mais pelos atributos de gênero incorporados ou desempenhados do que pela orientação sexual, parece ter ganhado corpo progressivamente a partir de 2005. Por volta dessa época, "homossexualidade" como termo englobante começa a dar lugar ao composto "orientação sexual e identidade de gênero". Por meio de alguns documentos podemos ter uma visão desse processo.

A expressão identidade de gênero não aparece no Brasil Sem Homofobia, de 2004, mas no relatório do I Congresso da ABGLT realizado no ano seguinte. Naquela época, o "T" da sigla significava transgêneros, e a introdução do conceito de "identidade de gênero" aparece mencionada em relação a ações de advocacy nacionais e internacionais para a inserção de "pessoas transgêneros e transexuais". ${ }^{16}$ Em alguns momentos, a expressão ainda surge atrelada ao termo "homossexual", como em um item específico intitulado "Identidade de gênero e orientação homossexual".

Já, nos anais do II Congresso da ABGLT de 2006, a fórmula a ser utilizada para se referir às açóes indica a consolidação do par

\footnotetext{
${ }^{15}$ De acordo com Judith Butler, "gêneros inteligíveis são aqueles que, em certo sentido, instituem e mantêm relações de coerência e continuidade entre sexo, gênero, prática sexual e desejo". Sendo assim, "a própria noção de 'pessoa' se veria questionada pela emergência cultural daqueles seres cujo gênero é 'incoerente' ou 'descontínuo', os quais parecem ser pessoas, mas não se conformam às normas de gênero da inteligibilidade cultural pelas quais as pessoas são definidas" (p. 38).

${ }^{16}$ Como nos trechos: "Nesse trabalho de advocacy devemos também solicitar a introdução e uma menção mais explícita sobre o direito das pessoas Transgêneros e Transexuais, introduzindo, além da Orientação Sexual, a dimensão da Identidade de Gênero, protegendo com isso as(os) Transgêneros e Transexuais"; e "Introduzir a discussão da Identidade de Gênero na Resolução Brasileira visando à proteção das pessoas Transgêneros e Transexuais, através de discussão com a Secretaria Especial de Direitos Humanos e com o Ministério das Relaçōes Exteriores" (Associação Brasileira de Gays, Lésbicas e Transgêneros - ABGLT. Resoluçōes do I Congresso da ABGLT: avanços e perspectivas, 2005. Curitiba, 2006).
} 
orientação sexual e identidade de gênero. No mesmo congresso também foi aprovada uma proposta para que a ABGLT alterasse o seu Estatuto nos seguintes termos:

Que, no próximo Encontro da $A B G L T$, o secretário geral peça como pauta a mudança do Estatuto no que se refere à sigla 'transgênero' e que possa se referenciar às categorias 'travestis e transexuais', para com essa mudança poder dar visibilidade aos transexuais.

Se, como no capítulo 2, percorremos alguns documentos, podemos compreender termos e expressōes a partir dos parâmetros que o próprio campo vai estabelecendo ao longo do tempo. O Brasil Sem Homofobia (2004) tem uma seção chamada "dúvidas frequentes", na qual algumas definições são apresentadas:

\section{O que é identidade sexual?}

É o conjunto de características sexuais que diferenciam cada pessoa das demais e que se expressam pelas preferências sexuais, sentimentos ou atitudes em relação ao sexo. A identidade sexual é o sentimento de masculinidade ou feminilidade que acompanha a pessoa ao longo da vida. Nem sempre está de acordo com o sexo biológico ou com a genitália da pessoa.

\section{O que é orientação sexual?}

Orientação sexual é a atração afetiva elou sexual que uma pessoa sente pela outra. A orientação sexual existe num continuum que varia desde a homossexualidade exclusiva até a heterossexualidade exclusiva, passando pelas diversas formas de bissexualidade. Embora tenhamos a possibilidade de escolher se vamos demonstrar, ou não, os nossos sentimentos, os psicólogos não consideram que a orientação sexual seja uma opçáo consciente que possa ser modificada por um ato da vontade. 
Transgêneros: Terminologia utilizada que engloba tanto as travestis quanto as transexuais. É um homem no sentido fisiológico, mas se relaciona com o mundo como mulher..$^{17}$

Transexuais: São pessoas que não aceitam o sexo que ostentam anatomicamente. Sendo o fato psicológico predominante na transexualidade, o individuo identifica-se com o sexo oposto, embora dotado de genitália externa e interna de um único sexo.

Então, em 2004, as “Dúvidas mais frequentes” se voltavam para identidade sexual, orientação sexual, transgêneros e transexuais. Identidade de gênero não aparece no texto em nenhum momento. Já no documento que resulta do I Congresso da ABGLT de 2005 não vemos mais nenhuma menção à identidade sexual e volta-se a definir orientação sexual e transgêneros. A definição de transexuais é a mesma do BSH, e há outras em acréscimo, como travesti, gênero e identidade de gênero. O glossário contido no documento define:

Gênero: É uma categoria analitica desenvolvida recentemente nas Ciências Humanas e se origina das discussóes e lutas feministas em seu esforço para desnaturalizar a situação e o lugar social de homens e mulheres na sociedade. Gênero náo significa o mesmo que sexo, pois este se refere às características biológicas de uma pessoa, enquanto gênero remete à construção social, histórica e cultural, envolvendo relaçóes de poder, identidades, papéis e funçóes sociais, imagens e significados associados a cada um dos sexos.

Identidade de gênero: Refere-se à maneira como alguém se sente e se apresenta para si e para os demais como homem ou mulher, ou ainda uma mescla de ambos, independentemente do sexo biológico. Trata-se de uma dimensão fundamental da existência humana, não devendo, portanto, constituir motivo para a discriminação. As pessoas

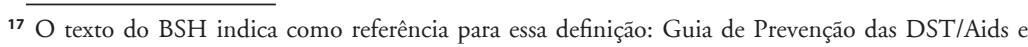
Cidadania para Homossexuais, PN-DST/AIDS. 
transgêneros - travestis e transexuais - são aquelas que constroem sua maneira de ser, de se expressar e de agir sem seguir estritamente as regras e os valores socialmente impostos a cada sexo. Devido à sua visibilidade, são tratadas com as piores formas de desprezo, abuso e violência.

Orientação Sexual: É a direção espontânea do desejo afetivo e erótico, que pode ter como objeto pessoas do sexo oposto (heterossexual), pessoas do mesmo sexo (homossexual) ou de ambos os sexos (bissexual). $O$ objeto do desejo sexual não é uma opção consciente da pessoa, pois é uma construção individual a partir da leitura e da vivência que cada um faz dos elementos disponibilizados pelo meio social: família, escola, vizinhança, mídia, entre outros. Nesta Tese, Orientação Sexual não significa Educação Sexual.

Transgêneros: Terminologia utilizada para descrever pessoas que transitam entre os gêneros. São pessoas cuja identidade de gênero transcende as definiçóes convencionais da sexualidade. Estão entre os(as) transgêneros: as (os) travestis, as(os) transexuais, os transformistas, as Drag Queens, as Drag Kings, os Cross Dressers, os intersex.

Transexuais: São pessoas que não aceitam o sexo que ostentam anatomicamente. Sendo o fator psicológico predominante na transexualidade, o individuo identifica-se com o sexo oposto, embora dotado de genitália externa e interna de um único sexo.

Travestis: As travestis, apesar de aproximarem seu corpo das formas femininas através das roupas e dos adereços, assim como de alteraçóes físicas, nâo deixam de obter prazer com seu pênis. Uma travesti normalmente não tem a intenção de alterar seu sexo biológico. Essas características costumam aparecer na puberdade e intensificam-se na adolescência. Ela se sente e se expressa publicamente de forma feminina, mas sem abrir mão de alguns atributos masculinos em algumas relaçóes que estabelece com a sociedade. 
Entre 2004 e 2005 nota-se como gênero ganha preponderância ou recebe mais atenção. Poderíamos interpretar aqui que identidade de gênero seria o gênero que precisa ser nomeado e afirmado quando em desacordo com o convencionalmente associado ao sexo biológico (ou às "regras e a os valores socialmente impostos a cada sexo"). Nesse caso, há uma associação entre esse sentido e as "pessoas transgêneros", aquelas que "transcendem as definiçôes convencionais". Por sua vez, entre transgêneros, temos a diferenciação entre travestis - pessoas que aceitam e "não deixam de obter prazer" com o "sexo biológico" - e transexuais - que "não aceitam o sexo que ostentam anatomicamente". Se em 2004 evocam-se formulações da psicologia, em 2005, o campo de referência é ampliado para as "ciências humanas". À psicologia mesclam-se concepçõos oriundas de "discussões e lutas feministas" para afirmar a "construção social, histórica e cultural" do gênero e da sexualidade.

Dando um salto para 2008, ${ }^{18}$ como já mencionado nos capítulos 1 e 2, o primeiro painel da I Conferência Nacional LGBT consistiu em uma apresentação didática a respeito dos conceitos de orientação sexual e identidade de gênero, e o "texto-base" da conferência, apresentado pela Comissão Organizadora na ocasião, trouxe um glossário bastante extenso. Vejamos alguns dos verbetes:

Transexual: pessoa com identidade de gênero que se caracteriza por uma afirmativa de identificação, solidamente constituida e confortável nos parâmetros de gênero estabelecidos (masculino ou feminino), independente e soberano aos atributos biológicos sexualmente diferenciados. Esta afirmativa consolidada pode, eventualmente, se transformar em desconforto e estranheza diante destes atributos, a partir de condiçóes socioculturais adversas ao pleno exercício da vivência dessa identidade de gênero constituída. Isto pode se refletir na experiência cotidiana de autoidentificação com o gênero feminino - no caso das mulheres que vivenciam a transexualidade, que apresentam órgãos

\footnotetext{
${ }_{18}$ Para exemplificar com outro documento anterior, o Plano Nacional de Enfrentamento da Epidemia de Aids e das DST entre Gays, HSH e Travestis do Ministério da Saúde, lançado em 2007, também utiliza o par orientação sexual e identidade de gênero.
} 
genitais classificados como masculinos no momento em que nascem - ou com o gênero masculino - no caso de homens que vivenciam a transexualidade, que apresentam órgãos genitais classificados como femininos no momento em que nascem. A transexualidade também pode, eventualmente, contribuir para que o individuo que a vivencia objetivar alterar cirurgicamente seus atributos físicos (inclusive genitais) de nascença para que os mesmos possam ter correspondência estética e funcional com a vivência psicoemocional da sua identidade de gênero.

Travesti: pessoa que nasce do sexo masculino ou feminino, mas que tem sua identidade de gênero oposta ao seu sexo biológico, assumindo papéis de gênero diferentes daquele imposto pela sociedade. Muitas travestis modificam seus corpos através de hormonioterapias, aplicaçóes de silicone elou cirurgias plásticas, porém vale ressaltar que isto náo é regra para todas.

Gênero: o conjunto de normas, valores, costumes e práticas através das quais a diferença entre homens e mulheres é culturalmente significada $e$ hierarquizada. Envolve todas as formas de construção social das diferenças entre masculinidade e feminilidade, conferindo sentido e inteligibilidade social às diferenças anatômicas, comportamentais e estéticas. Contemporaneamente se compreende que não há linearidade na determinaçāo do sexo sobre o gênero e sobre o desejo, sendo o gênero uma construção individual, social e cultural que sustenta a apresentação social da masculinidade elou feminilidade por um individuo.

Identidade de gênero: nos Princípios de Yogyakarta está definida como a profundamente sentida experiência interna e individual do gênero de cada pessoa, que pode ou não corresponder ao sexo atribuido no nascimento, incluindo o senso pessoal do corpo - que pode envolver, por livre escolha, modificaçâo da aparência ou funçâo corporal por meios médicos, cirúrgicos ou outros - e outras expressóes de gênero, inclusive vestimenta, modo de falar e maneirismos. 
Orientaçáo sexual: nos Princípios de Yogyakarta está definida como uma referência à capacidade de cada pessoa ter uma profunda atração emocional, afetiva, ou sexual por individuos de gênero diferente, do mesmo gênero ou ambos, assim como ter relaçôes intimas e sexuais com essas pessoas. Modernamente, as orientaçôes sexuais são distinguidas em 'heterossexualidade' (quando o interesse afetivo-erótico-sexual da pessoa se dirige em direção a pessoas do sexo oposto), 'homossexualidade' (quando esse interesse se expressa por pessoas do mesmo sexo) e 'bissexualidade' (interesse por pessoas de ambos os sexos).

A partir daqui, a definição de transexualidade abandona a ênfase na não aceitação dos "atributos biológicos sexualmente diferenciados" ou "órgãos genitais classificados como masculinos ou femininos ao nascer", deixando assim em aberto o desejo de realização de "cirurgia para alteração de seus atributos genitais de nascença”, e surge a possibilidade de "homens vivenciando a transexualidade", ausente até então. A diferenciação entre travestis e transexuais é menos enfática aqui. $O$ verbete transexual menciona a cirurgia facultativa e o que se refere a travestis descreve a possibilidade do uso de hormônio e/ou silicone, mas, nos dois casos, a questão central se volta para a não correspondência entre o sexo biológico e a identidade de gênero assumida. Esse glossário parece ser mais cauteloso quanto a definiç̧óes muito fechadas.

As definiçōes para orientação sexual identidade de gênero reproduzem em parte os termos contidos nos Princípios de Yogyakarta. ${ }^{19}$ Aqui, a orientação sexual é uma "capacidade" do indivíduo; lá, no documento

19 A tradução de Os Princípios de Yogyakarta sobre a aplicação da Legislação Internacional de Direitos Humanos em relação à orientação sexual e identidade de gênero foi lançada no Brasil em agosto de 2007, por meio da Secretaria de Direitos Humanos, como uma ação do Programa Brasil Sem Homofobia. Os "Princípios" foram originalmente elaborados por um grupo de especialistas em direitos humanos e direito internacional de vários países, na cidade de Yogyakarta, na Indonésia, em reunião presidida por Sonia Onufer Corrêa e Vitit Muntarbhorn, e foram apresentados na IV Sessão do Conselho de Direitos Humanos da ONU, em março de 2007. Os Princípios de Yogyakarta formam um conjunto de normas que versa sobre a legislação internacional de direitos humanos e sua aplicação "a pessoas de diversas orientaçôes sexuais e identidades de gênero". Partem do pressuposto de que "Todos os seres humanos nascem livres e iguais em dignidade e direitos. Todos os direitos humanos são universais, interdependentes, indivisíveis e inter-relacionados. A orientação sexual e a identidade gênero são essenciais para a dignidade e a humanidade de cada pessoa e não devem ser motivo de discriminação ou abuso". Ver, respectivamente, Guia del activista para usar los Principios de Yogyakarta (Dreilinden 
de 2005, aparecia como "uma direção espontânea" (mais próxima do impulso), talvez pelo esforço também expresso de afastar a ideia de "opção" de direcionamento do desejo sexual. A identidade de gênero não mais está explicitamente vinculada a transexuais ou travestis. E note-se também que, em 2008, o termo transgênero parece praticamente sair de circulação. No Plano Nacional LGBT, de 2009 - apesar de não conter nenhum glossário - percebemos que o sentido dos termos articulados é mais ou menos o mesmo desse documento de 2008.

Cabe mencionar que gays, lésbicas e bissexuais também constam como verbetes nesses documentos, mas as definições variam quase nada ao longo do tempo e são bem mais simplificadas. Cito apenas duas nuances mais significativas. Em 2005, para Bissexuais, tivemos: "São pessoas que se relacionam sexual e/ou afetivamente com ambos os sexos. Alguns assumem as facetas de sua sexualidade abertamente, enquanto outros vivem sua conduta sexual de forma fechada”. Definição que claramente deixa pairar sobre pessoas bissexuais uma suspeita ou acusação de viverem "no armário". Em 2008, a definição muda para: "Bissexual: pessoa que tem desejos e práticas sexuais e relacionamento afetivo-sexual com homens e mulheres".

A outra nuance curiosa tem a ver com uma característica que envolve todo o glossário apresentado em 2008: nele não se fala em sexo, mas apenas gênero (com a exceção das definições para travesti e transexual, reproduzidas anteriormente):

Homossexual: pessoa que tem desejos e práticas sexuais e relacionamento afetivo-sexual com pessoas do seu mesmo gênero.

Heterossexual: pessoa que tem desejos, práticas sexuais e relacionamento afetivo-sexual com pessoas do gênero oposto.

Gay: pessoa do gênero masculino que tem desejos, práticas sexuais e relacionamento afetivo-sexual com outras pessoas do gênero masculino.

Gesellschaft fur gemeinnutziges Privatkapital. Hivos: Fund for global Human Rights, 2010) e http:// www.yokyakartaprinciples.org. 
Lésbica: pessoa do gênero feminino que tem desejos, práticas sexuais e relacionamento afetivo-sexual com outras pessoas do gênero feminino.

Fica claro, enfim, que termos e categorias para se referirem a sujeitos específicos vão sendo construídos e reconstruídos, compreendidos e assimilados de forma diferente ao longo do tempo. ${ }^{20}$ Esse processo guarda relaçôes cada vez mais próximas com os desenvolvimentos de teorias e pesquisas da área de estudos de gênero e sexualidade e acompanha a tendência de progressivamente afastar o peso contaminado da natureza do sexo e enfatizar o caráter de construção sociocultural. No entanto, são formulaçôes também determinadas pela relação com táticas e estratégias características do movimento social, tidas como mais ou menos propícias para a relação com os formatos dados da burocracia jurídico-governamental.

Se todo esse esforço vem sendo feito para encontrar a categoria mais adequada para significar (ou representar) esse determinado conjunto de pessoas que se reúne entre "travestis e transexuais", a sua apresentação como vítimas exemplares do preconceito e da discriminação não variou.

\section{"NÓS SOMOS A CARA DO MOVIMENTO"}

Retratada como a população "mais estigmatizada e mais vulnerabilizada", as travestis e as transexuais ${ }^{21}$ de fato perfazem o maior número de vítimas de discriminação e preconceito contabilizadas nos levantamentos existentes sobre a violência que acomete "pessoas LGBT", ao mesmo tempo que apresentam os menores índices de escolaridade. ${ }^{22} \mathrm{E}$, como protagonistas das estatísticas de violência, as travestis e as transexuais cumprem um papel importante de visibilidade e mobilização para o movimento LGBT. Mas não sem que esse seja um

\footnotetext{
${ }^{20}$ É digna de nota a total ausência de intersexuais ou da intersexualidade nessa cena, incorporada já há algum tempo em movimentos da Europa e outras partes das Américas, tanto ao norte quanto ao sul

${ }^{21}$ Por ora estou me referindo apenas "às" transexuais"; mais à frente no texto, "os" transexuais entram no quadro.

${ }^{22}$ Ver Carrara e Ramos (2005) e Carrara et al. (2006).
} 
ponto de conflito e foco de disputas internas. Durante o trabalho de campo, em situações variadas, pude perceber e presenciar desacordos, discussōes e brigas envolvendo travestis e transexuais que acusam o próprio movimento LGBT de discriminá-las.

Mario Carvalho (2011) aborda especificamente o discurso de militantes travestis e transexuais em relação às demandas e às proposiçóes de políticas públicas de saúde no Brasil. Para o desenvolvimento do trabalho, o autor realizou entrevistas com uma série de lideranças do movimento de travestis e transexuais brasileiro, nas quais indagou sobre agenda prioritária, formas de organização, trajetórias pessoais, transformaçôes corporais, entre outras questōes. Recorro a algumas de suas entrevistadas para dar ênfase ao que nos interessa abordar aqui:

[No] nascimento da primeira instituição de travestis e transexuais do Brasil, a gente enfrentou muito problema com o próprio grupo... com eles que diziam que não tinham necessidade, eles que tentavam de todas as formas sempre cercear a nossa participação na parcela de recurso... disponibilizada para a população LGBT em geral. Mas a nossa... a organização do movimento de travestis e transexuais foi... também se deu por conta do preconceito, da homofobia do próprio movimento... que na época era movimento GLS. [...] E foi por conta dessas coisas todas que a gente decidiu criar um movimento... e que tem hoje grandes lideranças gays e lésbicas que estão aliadas a nós, mas que no passado nos desacreditavam, não nos davam espaço, mas que hoje viram a nossa força, a nossa capacidade... [E]les sabem que nós é que somos a cara do movimento. Se vai ter uma parada, são as travestis que têm que estar liderando. Se vai ter uma manifestação, são as travestis... é que todos os holofotes estão virados para as travestis... nós somos a ponta de lança, nós somos a cara do movimento. [...] Agora... nós sofremos muito preconceito... ainda sofremos dentro do próprio movimento LGBT. [...] A gente não consegue explicar, mas 
algumas coisas... as pessoas que nos discriminam deixam escapar. Eles nos chamam de homens de peito [...]. ${ }^{23}$

A travesti era protagonismo do trabalho dos outros em prol da cidadania dela, e achava que era protagonista. O protagonismo [não] é a minha miséria, ser a fundamentação da campanha ou do projeto, mas que eu diga como isso vai ser feito, que eu possa estar executando essa política ou essa ação. Aí sim, eu acredito em empoderamento. Empoderamento é quando você tem um projeto [...]. ${ }^{24}$

Para Carvalho (2011), narrativas como as mencionadas nos depoimentos anteriores denotam "uma certa manipulação política das travestis". O autor menciona a situação da I Marcha Contra a Homofobia em Brasília quando travestis foram o "abre-alas" do ato, carregando uma faixa com os dizeres: "De Luto Contra a Transfobia. E você?" (descrita na cena 4 do capítulo 3 ), como exemplo de como "são tomadas como elementos visuais importantes em diversas manifestações do movimento". Entretanto, também nota que somente "três travestis discursaram no carro de som durante a concentração da Marcha, e nenhuma delas fez uso do microfone durante o trajeto pela Esplanada dos Ministérios" (p. 48). As entrevistadas pelo autor demonstram insatisfação diante das dificuldades em alcançar espaços de direção no movimento mais amplo e acusam a falta de atenção direcionada para questôes que seriam específicas de travestis e transexuais. Ao indagar sobre os termos "homofobia" e "transfobia", se o primeiro poderia englobar o segundo, uma das suas entrevistadas respondeu:

\footnotetext{
${ }^{23}$ Jovana Baby, em entrevista concedida a Mario Carvalho em 18/06/2010, ênfase do original. Fundadora da Astral (Associação de Travestis e Liberados do Rio de Janeiro), primeira ONG de travestis do Brasil. No momento da entrevista, Jovana era a presidente da Antra (Carvalho, 2011, p. 47).

${ }^{24}$ Majorie Marchi, em entrevista concedida a Mario Carvalho em 16/08/2010 (Carvalho, 2011, pp. 130-1). À época da entrevista, Majorie era presidente da Astra-Rio (Associação de Travestis e Transexuais do Rio de Janeiro), vice-presidente da Antra e vice-presidente do Conselho Estadual LGBT do Rio de Janeiro. No momento dessa pesquisa, trabalhava para um equipamento do governo do estado voltado para o atendimento à população LGBT.
} 
A chamada homofobia que engloba tudo; como engloba tudo se eu não me sinto englobada? Tiram as travestis da frente. Por que as travestis não estão na frente [da sigla LGBT]? Quem é que leva a palavra homofobia nas costas? Nas justificativas de morte, exclusão, violência, em todas as pesquisas realizadas, a não ser as pesquisas sobre travestis, são pesquisas sobre violência, violação dos direitos, há um protagonismo absoluto, enorme [...]. ${ }^{25}$

Outro ponto de conflito fala sobre as pautas priorizadas pelo movimento LGBT mais amplamente. Durante o meu trabalho de campo, algumas vezes deparei com reclamações de travestis e transexuais que diziam que a sua pauta não poderia ser apenas união civil e criminalização da homofobia. As entrevistas realizadas por Carvalho também refletem esse incômodo. A mesma entrevistada prossegue:

Ao mesmo tempo em que ela [a homofobia] tem isso e tem toda essa visibilidade para legitimar sua causa, quando você se remete [à] política e pega o movimento LGBT, o movimento todo não luta por uma bandeira das travestis. O movimento como um todo luta pela união civil e pela criminalização da homofobia. Imagina esses dois aprovados hoje? Eu, enquanto travesti, o que é que muda para mim? A minha união civil será como homem, me unir como numa relação homossexual, que náo sou. Vou me casar com nome de homem. [...] Mas para mim não faz diferença [...] Vou casar como? Vai ser Felipe casado com Marcelo? Porque a Majorie não existe, a Majorie não tem documento. O que me dá mais tristeza é que a grande maioria das travestis não tem essa percepção. Ficam falando sobre homofobia, PLC 122, união civil [...]. A questão é esclarecer socialmente o que é homofobia e o que é transfobia, o que causa homofobia, o que causa transfobia, onde se dá e onde pode se dar a homofobia e a transfobia, $e$

${ }^{25}$ Majorie Marchi, em entrevista a Mario Carvalho concedida em 20/09/2010. 
mostr [ar] que são dois fatores totalmente diversos. Mas no imaginário coletivo é tudo uma coisa só. ${ }^{26}$

$\mathrm{O}$ preconceito e a discriminação que são dirigidos às travestis e às transexuais teriam algumas nuances de diferenciação em relação ao que atinge gays e lésbicas, pois, entre outras particularidades, as primeiras não poderiam "passar por". Ainda que as transformaçōes na aparência permitam que sejam percebidas como mulheres, existiria um limite para esse passing, como na hora de mostrar os documentos, por exemplo, nos quais a maioria permanece com o nome masculino de registro civil. Além disso, o mundo social convencional excluiria com mais frequência travestis e transexuais de espaços como a escola e a família, o que contribuiria para limitar suas possibilidades de inserção no mercado de trabalho, desembocando na prostituição como meio compulsório de subsistência. E estar nas ruas as tornaria também alvos mais fáceis para a violência. Outra fala que ouvi algumas vezes durante o trabalho de campo, relacionada com "ser a cara do movimento", dizia: "travestis e transexuais são boas para justificar projetos". Por conta da relação com as políticas de prevenção da Aids e também porque, com frequência, as travestis aparecem como as mais pobres, as mais pretas, as menos escolarizadas, por vezes são acionadas como uma espécie de ícone de "vulnerabilidade".

Podemos dizer que a organização política mais autônoma do movimento "T" é mais ou menos recente, se comparado ao que já foi chamado Movimento Homossexual Brasileiro. A primeira organização de travestis foi fundada em 1992. A Associação de Travestis e Liberados do Rio de Janeiro - Astral - surge em resposta à violência policial que reprimia a prostituição nas ruas. Naquela época, o grupo contou com o apoio do Iser, por meio de um projeto de prevenção às DSTs/Aids chamado "Saúde na Prostituição". Em 1993 aconteceu o primeiro "Encontro Nacional de Travestis e Liberados". Segundo Carvalho (2011), esse encontrou contou com 95 participantes de cinco estados e

\footnotetext{
${ }^{26}$ Majorie Marchi, em entrevista concedida a Mario Carvalho em 20/09/2010 (Carvalho, 2011, pp. 130-1).
} 
foi importante para dar início à formação de outros grupos. A partir de 1996, em sua quarta edição, o encontro passou a ter o financiamento do então Programa Nacional de DST/Aids (PN DST/Aids) ${ }^{27}$ e a chamar-se Encontro Nacional de Travestis e Liberados na Luta Contra a Aids - Entlaids. No ano de 2000, surgiu a primeira organização de nível nacional, a Associação Nacional de Travestis e Transexuais a Antra. ${ }^{28}$ No dia 29 de janeiro de 2004, o Ministério da Saúde, por intermédio do PN DST/Aids, lançou a primeira campanha voltada exclusivamente para travestis. O desenvolvimento da campanha foi feito junto com o movimento organizado e é considerado um grande marco para o movimento, tanto que, desde então, o dia 29 de janeiro entrou para o calendário como Dia Nacional da Visibilidade Trans. ${ }^{29}$

A organização do movimento de travestis e transexuais esteve desde sempre relacionada às políticas de saúde. E essa relação significa mais do que apenas o financiamento de organizaçóes ou de outras ações. Ao analisar a intervenção realizada por meio das políticas de prevenção das DSTs/Aids entre travestis que se prostituem, Larissa Pelúcio (2009) chamou de "SIDAdanização" a lógica que ancora o processo de "conversão" dessa "população-alvo" em "cidadãs". Essa "conversão" implicaria a "adesão a princípios tipicamente modernos, como a

${ }^{27}$ Atual Departamento de DST, Aids e Hepatites Virais (www.aids.gov.br).

${ }^{28}$ Mario Carvalho interpreta essa trajetória como uma espécie de "empoderamento tutelado", por meio do qual, progressivamente, a organização do movimento de travestis e transexuais busca atuar de maneira mais autônoma: a "incorporação de travestis e transexuais ao movimento LGBT se dá inicialmente num processo paradoxal de 'empoderamento tutelado', uma vez que os elementos discursivos e a práxis política na construção dessas militantes foi possibilitada por uma trama de relações que envolvem diversos atores, como as lideranças gays e lésbicas, agências governamentais e profissionais de saúde envolvidos em programas de prevenção de DST e AIDS" (Carvalho, 2011, p. 46). Para uma versão mais pormenorizada sobre o processo de inclusão de travestis no então chamado Movimento Homossexual Brasileiro, ver também Carvalho e Carrara (2013).

${ }^{29}$ Majorie Marchi, em entrevista para o site do CLAM publicada em 30/01/2007: "No dia 29 de janeiro de 2004, 27 ativistas trans adentraram o Congresso Nacional para o lançamento da campanha "Travesti e respeito". Essa foi uma ação pioneira, tratando-se de travestis e transexuais. Acredito que esse evento mostrou para o grande público o real poder de articulação do movimento social organizado. Foi também nesse dia que fundamos a Associação de Travestis, Transexuais e Transgêneros do Rio de Janeiro (Astra-Rio). Por isso, o dia 29 de janeiro será o marco histórico para simbolizar a luta por cidadania e igualdade de direitos desses segmentos altamente discriminados" (Disponível em: http://www.clam.org.br/publique/cgi/cgilua.exe/sys/ start.htm?infoid=2287\&sid=51. Acesso em: mar. 2013). 
'individualização' e a 'racionalização'”, mobilizando aspectos como a "potencialização da autoestima" e o "desenvolvimento de uma nova consciência política". ${ }^{30}$ A autora alerta para o fato de que o objetivo de politização desses indivíduos pode ser visto "como uma estratégia de controle bastante sutil, centrada na responsabilização dos sujeitos diante das questões de saúde” (p. 110-1). Podemos daí depreender que, seguindo um determinado modelo de "empoderamento", as travestis são incluídas por intermédio das políticas de saúde não como sujeitos integrais, mas como sujeitos preventivos: "até porque tem sido nos espaços das unidades especializadas em DST/Aids que elas têm encontrado possibilidades de serem ouvidas, vistas e, assim, experimentando uma cidadania possível, ainda que esteja associada a doenças sexualmente transmissíveis e à Aids" (Pelúcio, 2009, p. 132).

Somada a essa relação, o foco nas travestis como público-alvo da prevenção está diretamente vinculado à sua associação como trabalhadoras da prostituição, o que rende a acusação, feita pelo movimento, de que não são lidas como sujeitos per se pelas políticas de saúde, mas apenas como uma via de transmissão do HIV, diretamente, para os homens com quem se relacionam e, indiretamente, para suas esposas.

\section{"HOMENS E MULHERES TÊM GÊNERO, MAS TRANS}

\section{TEM IDENTIDADE DE GÊNERO"}

Em 2007, o Ministério da Saúde lançou o Plano de Enfrentamento da Feminização da Aids e outras DSTs, trazendo na capa o título Mulheres contra DST e Aids. Nesse plano, foram especificadas todas as mulheres a quem ele se destinava e suas estratégias, devendo contemplar: "gestantes; mulheres vivendo com HIV e Aids; adolescentes e jovens; lésbicas, bissexuais e outras mulheres que fazem sexo com mulheres; transexuais, negras; indígenas; mulheres em situação

\footnotetext{
${ }^{30}$ A elaboração de Pelúcio é inspirada nas discussōes realizadas por Duarte et al. (1993) a respeito de processos de "cidadanização" ou "conversão à cidadania" em camadas populares.
} 
de prisão; profissionais do sexo; trabalhadoras do campo e da cidade; mulheres em situação de violência sexual e doméstica; portadoras de deficiência; mulheres no climatério e as mulheres idosas". ${ }^{31}$ A outra iniciativa semelhante, lançada em 2008, foi o Plano Nacional de Enfrentamento da Epidemia de Aids e das DST entre Gays, Homens que Fazem Sexo com Homens (HSH) e Travestis. Vemos aí como o " $T$ " oferece certa resistência às classificações formuladas. Por que travestis são postas ao lado de homens, e transexuais ao lado de mulheres nos planos lançados? Talvez exista uma relação com a lógica da saúde que historicamente procurou enfatizar o sexo anatômico no enfrentamento da epidemia de Aids, o que vem sendo questionado mais recentemente. Outra explicação para tal, que ouvi durante o campo, dizia que estar junto com os homens seria uma escolha das próprias travestis, pois esse plano teria um orçamento maior do que o voltado para a "feminização" da epidemia.

Em março de 2010 acompanhei o Seminário Transexualidade, Travestilidade e Direito à Saúde, organizado pela Comissão de Cidadania e Reprodução - CCR..$^{32} \mathrm{O}$ evento, com duração de dois dias, reuniu pesquisadores, ativistas, médicos e outros profissionais que exercem atividades em serviços públicos de saúde que prestam atendimento a travestis e transexuais. Convidada do seminário, Larissa Pelúcio disse que era a primeira vez que era chamada para falar sobre travestilidade em um evento não relacionado diretamente à Aids. A "cidadania para além da saúde" foi um ponto tocado diversas vezes durante o seminário.

Esse seminário discutiu o direito ao acesso amplo aos serviços de saúde, o aconselhamento médico para hormonização e uso de

\footnotetext{
${ }^{31}$ Para uma análise a respeito da construção discursiva do "corpo lésbico" como vulnerável às DSTs/ Aids e consideraçōes sobre sua "invisibilidade" diante do SUS, ver Almeida (2005).

${ }^{32}$ O Seminário Transexualidade, Travestilidade e Direito à Saúde ocorreu em São Paulo, no Centro Universitário Maria Antônia, durante os dias 24 e 25 de março de 2010. Alguns textos e a relatoria do encontro podem ser encontrados em Arrilha et al. (2010) e no site da CCR. A CCR foi fundada em 1991 e está sediada no Cebrap (Centro Brasileiro de Análise e Planejamento), em São Paulo. Define-se como "uma entidade civil de âmbito nacional e sem fins lucrativos que tem o objetivo de promover e defender os direitos reprodutivos segundo os princípios das Declarações da ONU, em especial aqueles da Convenção pela Eliminação de Todas as Formas de Discriminação Contra a Mulher" (www.ccr.org.br).
} 
silicone, independentemente da entrada em programas do processo transexualizador, entre outros assuntos. Durante a programação, discussões que giraram em torno do processo transexualizador foram o ponto principal de atenção e de tensão. A inclusão do processo no Sistema Único de Saúde (SUS) em $2008^{33}$ foi celebrado como uma grande conquista. No entanto, essa "vitória" vem atrelada a certas concepções biomédicas sobre gênero e sexualidade, que hoje são o que garante a "transexuais" o acesso à realização da cirurgia de redesignação sexual pelo sistema público de saúde. Para acessar a cirurgia é preciso que a pessoa seja diagnosticada como portadora de "transtorno de gênero", ${ }^{34}$ ou seja, o reconhecimento que passa por uma patologização muitas vezes não desejada revela como os sujeitos não têm autonomia sobre os próprios corpos e tampouco sobre as relações que estabelecem com eles e por meio deles. O processo também exige obrigatoriamente a submissão a um período mínimo de dois anos de terapia psicológica antes que qualquer modificação corporal seja realizada. Além disso, o sujeito ainda deve provar que vive (por meio do uso de vestimentas adequadas, entre outros aspectos) de acordo com a "identidade" para a qual ele deseja fazer a transição. Sendo assim, não basta declarar-se transexual, é preciso "convencer” os responsáveis pelo diagnóstico. ${ }^{35}$

${ }^{33}$ Instituído no SUS pela Portaria n. ${ }^{\circ}$ 1.707, de 18 de agosto de 2008. Uma reconstrução do percurso dos debates políticos e acadêmicos que envolveram a publicação da Portaria pode ser encontrado em Arán et al. (2008) e Murta (2011).

${ }^{34}$ Para uma leitura crítica da emergência da noção de "transtorno de gênero" na psiquiatria e na psicanálise, ver Arán (2006) e Arán e Murta (2009). Para a relação entre essa noção usada como meio de acesso ao sistema de saúde pública no Brasil e a problematização de seus possíveis efeitos para a constituição de subjetividades, ver Arán et al. (2008).

${ }^{35} \mathrm{O}$ texto da portaria que regulamenta o processo diz: "Diretrizes de Assistência ao Indivíduo com Indicação para a realização do Processo Transexualizador: O CID-10 - Classificação Estatística Internacional de Doenças e Problemas Relacionados à Saúde - define, em seu capítulo F64 Transtornos da Identidade Sexual, F64.0 -, Transexualismo como "um desejo de viver e ser aceito enquanto pessoa do sexo oposto. Este desejo se acompanha em geral de um sentimento de mal-estar ou de inadaptação por referência a seu próprio sexo anatômico e do desejo de submeter-se a uma intervenção cirúrgica ou a um tratamento hormonal a fim de tornar seu corpo tão conforme quanto possível ao sexo desejado. Reconhecendo então que esta situação é determinante para um processo de sofrimento e de adoecimento a que estão sujeitos os transexuais e a necessidade de distinguir transexualismo dos demais transtornos da identidade sexual, o que possibilitaria erros incorrigíveis no atendimento a estas populaçôes, estabeleceram-se diretrizes, as quais buscam garantir a equidade 
A mobilização em torno da despatologização é um movimento crescente nos últimos anos. Entretanto, não existe exatamente um consenso sobre quais seriam os melhores termos e condiçôes para que o processo continue sendo garantido pelo Sistema Único de Saúde sem a exigência de um diagnóstico. ${ }^{36}$

Bento e Pelúcio (2012b) ${ }^{37}$ discutem os termos por meio dos quais a transexualidade é arrolada como um transtorno mental tanto no Manual Diagnóstico e Estatístico de Transtornos Mentais - DSM - quanto no Código Internacional de Doenças - CID, ${ }^{38}$ bem como os argumentos favoráveis ao fim do "diagnóstico de gênero". Para tal, mencionam a campanha internacional "Stop Trans Pathologization", que surgiu em 2007 justamente visando à retirada dos termos que patologizam a transexualidade nesses manuais. Até janeiro de 2013, entre América Latina, América do Norte, Europa, Ásia e Oceania, a campanha contava com a adesão de mais de 360 grupos. ${ }^{39}$

As autoras concentram a sua elaboração na desconstrução de quatro argumentos em que o "diagnóstico de gênero" se sustentaria. O primeiro seria a "diferença natural entre os gêneros", ancorado na ideia da "diferença sexual natural" - "ou se nasce homem, ou se nasce mulher”. O segundo argumento é nomeado pelas autoras como "a visão suicidógena". Esta se trata do discurso que se apoia na irreversibilidade do processo para afirmar que qualquer flexibilização

do acesso e orientar as boas práticas assistenciais, primando pela humanização e pelo combate aos processos discriminatórios como estratégias para a recuperação e a promoção da saúde". Portaria n. ${ }^{\circ}$ 1.707, de 18/08/2008, Ministério da Saúde.

${ }^{36}$ Do Plano Nacional LGBT consta uma ação sobre a questão. Nele é possível ler a indicação de despatologização, ainda que de maneira não explícita: "Implantação e implementação do Processo Transexualizador no SUS, garantindo atenção integral às pessoas que busquem os Centros de Referência credenciados, sejam transexuais ou travestis, assegurando que o diagnóstico diferencial não seja fator de exclusão de usuários desses serviços.

${ }^{37} \mathrm{O}$ artigo faz parte de um dossiê que reúne a contribuição de diversos pesquisadores a respeito de "vivências trans". O conjunto dos trabalhos oferece ainda um convite ao questionamento e à reflexão sobre as limitaçóes e os incômodos dos pesquisadores que enveredam por etnografias nesse campo, em que as experiências alargam alguns dos limites convencionados para a "normalidade" (cf. Bento e Pelúcio, 2012a).

${ }^{38}$ Elaborados pela Associação Norte-Americana de Psiquiatria (APA) e pela Organização Mundial de Saúde (OMS), respectivamente.

${ }^{39} \mathrm{O}$ site da campanha internacional disponibiliza informações em sete línguas diferentes: http://www. stp2012.info/old/pt. 
ou a retirada do caráter obrigatório da terapia psicológica incorreria em risco de vida para os sujeitos que pleiteiam a transição. O terceiro argumento trataria de "concessões estratégicas" e estaria embasado no entendimento de que, se o caráter de "doença” for retirado, o acesso ao Processo deixará de ser justificável no âmbito dos serviços públicos de saúde. As autoras interpretam que é justamente essa concepção de que o estado estaria desobrigado a oferecer acesso à saúde integral, caso o "diagnóstico de gênero" seja desmontado, que precisa ser combatida:

Se, para o Estado, os/as normais de gênero são aqueles/las que têm uma correspondência entre genitália, performance e práticas eróticas e se essa definição gera um modus operandi que exclui sujeitos que estão nos seus marcos, estamos diante de uma contradição com a sua própria definição universalizante (Bento e Pelúcio, 2012, p. 577).

O quarto e último argumento articulado por Bento e Pelúcio seria "a autoridade científica" que, de certa maneira, é muito simples: a inscrição em manuais compreendidos como repositórios de "verdades científicas" basta para assegurar essa "verdade do gênero". O DSM e o CID representariam, pois, a materialização de uma visão hegemônica e heteronormativa de gênero que, numa espécie de profecia que se cumpre por si mesma, é garantida pela articulação retórica que assegura a "cientificidade" de seus conteúdos. ${ }^{40}$

Destaco ainda algumas argumentações debatidas no Seminário Transexualidade, Travestilidade e Direito à Saúde, de 2010. Muitas falas se direcionaram para a crítica à maneira como a concepção das políticas em saúde - mas também grande parte de outras políticas levadas a cabo de maneira mais geral - está atrelada a uma visão binária de gênero.

\footnotetext{
${ }^{40}$ É importante destacar que a regulamentação do Processo Transexualizador pelo SUS é uma conquista bastante valorada. Mas isto não significa que os serviços oferecidos não padeçam de profundas carências ou que não sejam insuficientes diante das demandas existentes. São apenas quatro os hospitais credenciados para a realização da cirurgia em todo o Brasil e as condições de seu funcionamento parecem estar longe de serem as ideais. Para uma visão elaborada a partir de uma experiência neste tipo de serviço, ver Almeida (2010).
} 
Meu esforço aqui é revelar como a saúde - e sou uma defensora do SUS - éo setor de governo que mais avançou na garantia dos direitos $L G B T$ no geral, [...] por exemplo, em relação à política de enfrentamento da Aids. Mas o que eu gostaria de discutir hoje é que, ao mesmo tempo em que avançamos em termos de políticas públicas, a lógica do binarismo de gênero comparece nessa formalização da política pública, comparece na forma com que o movimento social vem reivindicando seus direitos sexuais e de gênero, e penso que é sobre tais aspectos que devemos pautar nosso debate, nosso esforço crítico em relação ao modo como fizemos as coisas até agora. Os debates travados durante o seminário questionaram a relação normativa constitutiva entre corpo sexuado e identidade, ou entre a forma do corpo e a identidade, e chamaram a atenção para a inexistência de outro vocabulário para dialogar com as politicas de governo voltadas para travestis e transexuais que não seja profundamente marcado por termos médico-psico-biologizantes. 'Se insistirmos que transexualidade não é doença, que um diagnóstico não é o que define a sua existência, quem é o sujeito de direito trans?', 'Há espaço nas agendas politicas para essa desconstrução?', 'Como desmantelar o controle do Estado sobre os nossos corpos?' (trecho da exposição de Tatiana Lionço). ${ }^{41}$

Podemos considerar que um dos efeitos da ampliação da discussão sobre o processo transexualizador é a multiplicação de sujeitos que passam a adotar essa identidade. A entrada do processo no SUS e o debate daí ocasionado por si sós ampliam o conhecimento dessa possibilidade de identificação, mas não apenas. $\mathrm{O}$ fato de não ser um serviço franqueado a travestis ou a quaisquer outros sujeitos que queiram passar por processos de hormonização, realizar implantes de silicone ou retirada de mamas, por exemplo, e ser um serviço destinado única e exclusivamente a transexuais diagnosticados como

\footnotetext{
${ }^{41}$ Alguns trabalhos que destacam essa relação "médico-psico-biologizante": Zambrano (2003); Bento (2006, 2008); Vianna e Carrara (2007); Arán e Murta (2009); Leite Jr. (2011). Outras contribuiçōes para o debate sobre a despatologização das transexualidades no Brasil, considerando a garantia de acesso à saúde integral pelo Sistema Único de Saúde, podem ser encontradas em Almeida e Murta (2013).
} 
tal pode provocar a adesão a essa categoria identitária como uma chave de acesso aos serviços. ${ }^{42}$ Mas um efeito de migração de outras identidades para a transexualidade pode também estar relacionada ao desejo de um reconhecimento pelo feminino:

Se você conversar com dez, quinze travestis, verá que hoje elas estão com a cabeça atordoada, pensando em fazer cirurgia, sem sequer saber se de fato são transexuais, porque a diferença é muito pouca, as diferenças são aquelas que não estão em conformidade com seu sexo biológico e que querem fazer a cirurgia e aquelas travestis que realmente estão satisfeitas com seu sexo biológico, com o pênis que ajeitam no meio das pernas, mas que querem e lutam pelo direito de serem reconhecidas como femininas' e terem reconhecido seu nome social. (trecho da exposição de Fernanda Benvenutty ${ }^{43}$ no Seminário Transexualidade, Travestilidade e Direito à Saúde).

Assim, essa escolha identitária não pode ser analisada apenas pragmaticamente como uma forma de acessar um serviço. Poderíamos dizer que os debates em torno do Processo Transexualizador dão novos contornos e teor discursivo à diferenciação entre travestis e transexuais. Bruno Cesar Barbosa $(2011,2013)$, por meio de trabalho etnográfico realizado em reuniōes chamadas "Terças Trans", sediadas no Centro de Referência da Diversidade de São Paulo - CRD -, ${ }^{44}$ localizou uma miríade de categorias que as pessoas usavam para se identificarem e dedicou-se a percorrê-las, seguindo as formas como eram enunciadas. $\mathrm{O}$ autor discorre sobre a produção performática de tais categorias e

\footnotetext{
42 Em trabalhos que acompanharam a experiência de pessoas transexuais, tanto Bento (2006) quanto Teixeira (2009) apresentam de maneira bastante sensível como sujeitos manejam as expectativas de equipes de médicos e psicólogos adequando-se a elas em relação à "transexualidade verdadeira". Constroem, assim, narrativas e performances de acordo com o que se espera como padrão de comportamento e subjetividade para receberem o "diagnóstico" que permita a inclusão em programas nos quais poderão ter acesso a procedimentos de transformação corporal.

${ }^{43}$ Apresentada, no momento do seminário, como "ex-presidente e atual relaçóes públicas" da Associação de Travestis da Paraíba - Abrapa.

${ }^{44}$ As reuniōes eram organizadas pela Secretaria de Travestis e Transgêneros da Associação da Parada do Orgulho LGBT de São Paulo (APOGLBT). O CRD é um equipamento público da prefeitura de São Paulo que se localiza no centro da cidade.
} 
sobre o acionamento de elementos como cor/raça, classe, geração, que se interseccionam na produção dos significados e dos sentidos que distinguem travestis e transexuais.

A diferenciação entre os termos tem um histórico traçado pela medicina psiquiátrica: travestis como fetichismo e transexualidade como transtorno. ${ }^{45}$ Mas, no dia a dia do campo político observado, são termos que ganham significação justamente na diferenciação entre si e espelhados na projeção do que seria a "mulher heterossexual natural", o "cume da feminilidade", para usar expressões localizadas pela pesquisa de Barbosa (2013). Algumas definições observadas pelo autor durante as reuniōes das Terças Trans foram: "as travestis seriam 'menos' mulheres que transexuais" ou estariam no "campo do indefinido", pois não desejam realizar a cirurgia. A diferenciação entre travestis e transexuais é situada conforme um espectro que gradua "o desconforto com o órgão genital". Transexuais estão idealmente localizadas do lado extremo do desconforto, e travestis, do outro.

Barbosa localizou uma série de expectativas "convencionalizadas" para o comportamento de travestis e transexuais entre o público das Terças Trans. Além de gênero e sexualidade, essas convenções intersectam aspectos relacionados a estilos de classe, cor/raça e geração. De travestis, espera-se uma composição de elementos e estilos corporais exagerados, como uso de silicone em grandes quantidades, formas escrachadas de expressão, "um esforço pelo feminino que beira o exagero", por isso mesmo, malsucedido. Já entre transexuais, o gestual seria comedido, o esmero na depilação de pelos faciais e outros ocultamentos de marcas corporais consideradas masculinas são indispensáveis, os cabelos bem tratados e ajustados e as transformações cuidadosamente construídas para serem "naturais". Nesse caso, não há necessidade de "fazer esforço para parecerem mulheres, são naturalmente femininas" (Barbosa, 2011, p. 37). O autor nota que travestis são, de uma maneira geral, localizadas em um "gradiente de cor da pele mais escura", são mais pobres e menos escolarizadas. As características de raça/cor aqui podem estar relacionadas à sensualidade e a certa provocação que

${ }^{45}$ Ver Leite Jr. (2011). 
remetem ao universo da prostituição. Entretanto, o autor faz a ressalva de que esses elementos não podem ser tomados de forma absoluta, mas devem ser encarados a partir de uma perspectiva fundamentalmente relacional. ${ }^{46}$

Cabe, por fim, destacar que o trabalho de campo realizado por Bruno Cesar Barbosa encontrou também pessoas que oscilavam situacionalmente, identificando-se ora com um, ora com outro termo, ou que não se identificavam com nenhum deles. Além de "travestis" e "transexuais", apareceram "trans", "transex", "mulher que vive a transexualidade", "mulher", entre outras categorias.

[...] Essas confusóes de identidade dos Ts... é só nos $T s$, viu? Onde tiver um $T$, tem uma confusão, porque sempre tem uma que não é mais transexual, a outra que não é mais travesti, a outra que... ai tem uma história de transgênero que, graças a Deus, deu muita confusão $e$ as pessoas deixaram de lado, mas sempre está aparecendo alguém que não se enquadra [...] (Fernanda Benvenutty, no Seminário Transexualidade, Travestilidade e Direito à Saúde).

[A] travestilidade é uma coisa que é muito fortemente desenvolvida no nosso contexto, na nossa realidade brasileira. Você não vê a travesti como ela é conceituada aqui no Brasil numa Holanda, numa Rússia, numa China ou num país da África por questóes sociais e culturais de cada lugar. Aqui existe uma diferença dentro da própria população na forma como ela se autopercebe. Concordo com a Fernanda, também tenho essa visão de que é a mesma coisa, como dizem: 'negros e brancos são todos iguais. Mas a questão é que existem diferenças de autopercepção; [...] elas se digladiam, essa população, porque existe esse estigma carregado com a palavra travesti e a maioria da população transexual não quer

${ }^{46}$ Barbosa aciona o exemplo de Tina para ilustrar este ponto. Tina se identifica como "mulher transexual", "mulher vivendo a transexualidade" e como "negra", adotando cabelos cuidadosamente arranjados em estilo "afro/black" e vestimentas que "denotavam interesse por tendências de moda associadas a estilos de classe mais elevados". Seu timbre de voz é feminino, sua silhueta é magra e "sem exageros de silicone". Mesmo tendo a pele mais escura, não pairam suspeitas sobre a "transexualidade" de Tina, pois outros elementos de diferenciação articulados ganham preponderância nesse contexto (2011, p. 41). 
estar inserida. Existe a questäo da travesti, a Fernanda é uma travesti que se considera mulher, mas a nossa experiência mostra que a grande maioria da população travesti, por diversos motivos, não se autopercebe enquanto mulher e acaba por discriminar a transexual por se reconhecer enquanto mulher, então fica essa guerra (Carla Machado, no Seminário Transexualidade, Travestilidade e Direito à Saúde).

Até aqui me referi mais enfaticamente às travestis e às transexuais. Vimos que, nos documentos percorridos, a referência a homens transexuais aparece pela primeira vez em 2008. ${ }^{47}$ Guilherme Almeida (2012) expõe mais alguns dos matizes em torno da transexualidade ao refletir sobre "homens trans": ${ }^{48}$ uma categoria identitária em "ascensão" no Brasil nos últimos anos; ainda que estejam representados em número reduzido no interior da movimentação política, oferece uma outra perspectiva interessante para a compreensão do campo.

A busca do acesso às modificaçóes corporais tem tido o efeito colateral de produzir uma identidade social radicalmente distinta para além das paredes hospitalares. Na minha percepção tal identidade vem se construindo menos em função do diagnóstico psiquiátrico e mais na suposição de uma completa adesáo aos signos corporais e aos comportamentos sociais que constituem as masculinidades, principalmente em seu 'modelo convencional' (Almeida, 2012, p. 516).

O autor enfatiza que a experiência da transexualidade para esses sujeitos pode se dar de maneiras muito distintas, como o recurso a vestimentas e outros acessórios, faixas torácicas para ocultar os seios, o uso de hormônios e a realização de cirurgias. No mesmo sentido de diversidade de vivências, Almeida faz questão de destacar como

\footnotetext{
${ }^{47}$ Apenas em 2010, uma resolução do Conselho Federal de Medicina retirou o caráter experimental da cirurgia de redesignação do sexo feminino para o masculino.

${ }^{48} \mathrm{O}$ autor esclarece que, para as reflexōes realizadas, considera "como equivalentes as categorias empíricas 'homem transexual', 'homem trans', 'trans-homem', 'transman', 'FTM' ou 'transexual masculino". E escolhe utilizar o termo "homem trans" no sentido de "condensar a experiência da transexualidade masculina" (Almeida, 2012, p. 513).
} 
características de classe, cor/raça, geração, origem e orientação sexual concorrem para imprimir os contornos dessas experiências. Ele registra ainda a "reabilitação do termo transexualidade, apreendido como descritor de vivências particulares, e não como patologia” (2012, p. 518).

É interessante como o autor nota que a transexualidade não é adotada como uma categoria identitária total por esses sujeitos, mas como um adjetivo, sempre precedida pelo substantivo "homem". Para alguns, a identidade trans se configura como uma condição temporária, uma ferramenta de acesso institucional. ${ }^{49}$ Essa recusa se daria não necessariamente por seu caráter patologizante, mas pelo desejo de se identificarem e serem reconhecidos plenamente como homens: "há alívio diante do encontro com uma unidade semântica capaz de oferecer inteligibilidade a suas trajetórias pessoais até então inomináveis e, por isso mesmo, mais abjetas" (Almeida, 2012, p. 517).

Outra dimensão fundamental trabalhada por Guilherme Almeida está diretamente relacionada às políticas de identidade e representação, tal como vêm sendo articuladas na atualidade. Trata-se da relativamente rápida capacidade de passing que homens trans conseguem desempenhar. Almeida reconhece que esses sujeitos, por meio da bem-sucedida e elaborada construção corporal de signos reconhecidos como masculinos, em especial após a realização da mastectomia e do uso continuado de testosterona, conseguem o "desconhecimento social da condição FTM" ${ }^{50}$

Em outras palavras, o uso da testosterona no caso dos homens trans, ao contrário do que ocorre com as mulheres trans, torna-os bastante próximos fisicamente às expectativas sociais de como deve parecer um homem, o que contribui para invisibilizá-los. Essa invisibilidade adquirida com frequência a duras penas significa para a maior parte um agradável momento de trégua na estressante e contínua batalha por respeito à identidadelexpressão de gênero. Por esse motivo, não sei se homens trans desejam comunidades reais e muito menos formar

\footnotetext{
49 Ao processo transexualizador, por exemplo.

${ }^{50}$ A sigla FTM (female to male) indica a transição feita do feminino para o masculino, e a sigla MTF (male do female) indica a transição de masculino para o feminino.
} 
grupos politicos, ou se a necessidade de encontrar pares se basta nesses encontros pontuais elou virtuais de socialização. É possivel que o desejo predominante seja de fato o de sumir na multidão, o 'direito à indiferença'. Este é facilitado pelo fato de que o passing, como dito, é obtido com facilidade (Almeida, 2012, p. 519).

Essa "invisibilidade" dos homens trans concorre diretamente com a "visibilidade" massiva tomada como estratégia de afirmação política privilegiada pelos movimentos sociais.

Não ficamos na saúde da mulher, não ficamos na saúde do homem, aí vem o Plano de Enfrentamento da Aids e também não estamos, em nenhum dos Planos, nem no Plano de Feminização, nem no Plano de HSH, gays e travestis, também não pegamos Aids, não nos infectamos.

A questão dos homens trans é complicada e não tenho muito a falar. As outras demandas säo as mesmas que têm as mulheres trans e, algumas vezes, as mesmas das travestis. Acho que a pior de todas pra nós é realmente a invisibilidade, em todos os sentidos (Trechos da exposição de Alexandre Santos [Xande], no Seminário Transexualidade, Travestilidade e Direito à Saúde).

Em junho de 2012, em um evento realizado em São Paulo, foi fundada a primeira Associação Brasileira de Homens Trans (ABHT), contando naquele momento com a participação de 17 "homens trans" de diferentes locais do Brasil. Essa associação nasceu se posicionando mais claramente a respeito da despatologização da sua identidade. Por ocasiāo do I Encontro de Homens Trans do Norte e Nordeste, em junho de 2013, foi aprovada uma "Moção sobre a reformulação da Portaria do Processo Transexualizador no SUS e a despatologização das transidentidades". Nessa moção, os participantes do encontro manifestaram-se muito claramente exigindo a retirada da obrigatoriedade do diagnóstico como condição para modificaçôes corporais e pelo fim da compulsoriedade da psicoterapia pelo 
período de dois anos, sem, entretanto, desconsiderar a importância do acompanhamento terapêutico como escolha e direito dos sujeitos. ${ }^{51}$

$\mathrm{Na}$ Conferência Nacional GLBT e nas etapas que a antecederam, quando se colocaram cotas de participação por gênero, travestis e transexuais foram incluídas na cota de gênero feminino. Em 2008 ainda não existiam homens transexuais visivelmente no campo, mas na Conferência de 2011 estiveram presentes e foram incluídos na cota de gênero masculino. Uma mulher lésbica não pode se identificar com o gênero masculino sem assumir uma identidade "trans", e o mesmo ocorre com homens que queiram se identificar com o gênero feminino, mas não como travestis e transexuais. Claramente, nessa esfera de negociação e ocupação de um espaço político, não se rompeu com o binarismo.

"Homens e Mulheres têm gênero. Travestis e transexuais têm identidade de gênero". Esta frase, dita de forma irônica e provocativa por um participante do Seminário discutido acima, é um forte signo dos limites da linguagem e das políticas colocadas em curso. A assunção da identidade de gênero como nova categoria, "por entender que gênero não atende a todas as questôes de gênero", me parece um sinal de que a política (ainda?) compreende gênero como uma outra maneira para falar de sexo (anatômico). Procura-se resolver a limitação de uma categoria por meio da utilização de outra, por sua vez, não menos limitada. ${ }^{52}$ O esforço de produzir novas categorias, seguido pelo esforço de produção de diferenciação entre elas (realizado pelo campo biomédico, pelas

\footnotetext{
51 Trecho da moção: "A exigência de um diagnóstico de nossas transidentidades invalida nossa capacidade de decisão sobre nosso próprio corpo, submetendo esta decisão a uma equipe de profissionais da saúde e ferindo nossa dignidade. Repudiamos e solicitamos a imediata retirada do diagnóstico. [...] Consideramos ilegítimo o estabelecimento de prazo de dois anos para que seja feito este diagnóstico junto a uma psicoterapia compulsória, tendo em vista que a realidade de nossas vidas não se reflete dentro de um período de tempo universal, e nem se resume a estereótipos estanques de gênero. Coerentes com a realidade, demandamos do Ministério da Saúde que não haja tempo preestabelecido, que este seja negociado entre paciente e equipe, respeitando a individualidade da pessoa trans".

${ }^{52}$ Cabe fazer a ressalva: aqui, refiro-me ao sentido que vem sendo veiculado pelos atores que compóem a cena da "política LGBT" ora apresentada, e não ao sentido da "identidade de gênero" forjada pelo discurso das ciências psi, embora os significados remanescentes dessa origem não possam ser desprezados. Para uma aprofundada e acurada leitura sobre "a invenção das categorias travesti e transexual no discurso científico", ver Leite Jr. (2011).
} 
políticas de governo, pelos próprios "nativos" e pelos pesquisadores do campo), explicitam a fragilidade dessas mesmas diferenciações. $\mathrm{O}$ "T" coloca em xeque não apenas a estabilidade das outras letras que compõem o coletivo, mas também as categorias "homem", "mulher", "heterossexualidade" e "homossexualidade", forçando as fronteiras do binarismo.

Vianna (2012) comenta uma situação etnográfica do trabalho de Flávia Teixeira (2009) em que uma travesti, a partir de uma transação financeira, travestiu-se de homem e casou-se com uma mulher para obter um visto de permanência no exterior. E assim, por meio desse "arranjo matrimonial" heterossexual, foi possível continuar vivendo do trabalho na prostituição. Em verdade, esse arranjo é algo frequente na trajetória de travestis acompanhadas por Teixeira. A situação provoca deslocamentos variados e desmonta categorias identitárias tão cuidadosamente construídas. Ou, nas palavras de Adriana Vianna: "o fascinante dessa situação debochada é que seu potencial subversivo está na exacerbação das próprias regras e da nossa crença nelas" (2009, p. 243).

Nesse caso, as regras centradas nos sistemas sexo-gênero-desejo podem ser manipuladas, reassaltando a fragilidade dessa estabilização. Em outro sentido, para travestis e transexuais, as políticas voltadas à (homo)sexualidade podem ser limitadoras ou, simplesmente, não lhes dizem respeito, como no caso da união civil destacado na fala de Majorie Marchi, algumas páginas atrás. ${ }^{53}$ Situações como essas desorganizam a coerência e a estabilidade do gênero, dos corpos e de normas reguladoras construídas como um efeito naturalizado de "práticas significantes", para usar uma expressão Judith Butler.

\footnotetext{
${ }^{53}$ Reproduzo o trecho: "Eu, enquanto travesti, o que é que muda para mim? A minha união civil será como homem, me unir como numa relação homossexual, que não sou. Vou me casar com nome de homem. [...] Mas para mim não faz diferença [...] Vou casar como? Vai ser Felipe casado com Marcelo? Porque a Majorie não existe, a Majorie não tem documento".
} 


\section{"NÃO SOMOS UM SIMPLES CONJUNTO DE LETRINHAS" - "SEGMENTOS", DISPUTAS E REARRANJOS DA POLÍTICA}

Cena 6 - Vinte e nove de outubro de dois mil e onze

Era outubro de 2011. No auditório do Hotel Jaraguá, centro de São Paulo, acontecia a II Conferência Estadual LGBT. Estávamos em plenária e era o momento de decidir como seria a composição de chapas para a eleição de delegados para a etapa nacional da conferência. Eu estava sentada no fundo do salão junto de outras pessoas (mulheres) quando uma menina nos abordou com uma proposta. Dizendo-se preocupada com a possibilidade de mulheres lésbicas e bissexuais serem "invisibilizadas" por conta da maioria de homens gays, travestis e transexuais presentes, nos apresentou a proposta de que a eleição não fosse feita por meio de chapas, mas por "segmento", ou seja, a composição teria que ter necessariamente uma lésbica representando lésbicas, um gay representando gays, uma travesti... Outra justificativa que apresentou era de que as chapas normalmente seriam formadas por pessoas ligadas a grupos/ organizaçôes dominantes e, por "segmentos", isso obrigatoriamente teria que ser mais diversificado.

A proposta foi apresentada à plenária com a explicação de que cada "segmento" deveria votar em seu representante individual por segmento: gays, lésbicas, travestis e transexuais. Não mencionaram bissexuais e, diante dos protestos que se seguiram a isso, explicaram que não seria necessário que bissexuais fossem representados especificamente, pois já estariam representados por gays ou lésbicas.

Terminada a apresentação, a representante do Conselho Nacional LGBT interveio e disse que a composição de chapas por segmentos feria o regimento nacional que estabelecia a proporção de $60 \%$ de gênero feminino e $40 \%$ de gênero masculino para a composição da delegação. 
Novamente, os proponentes da eleição por "segmento" se manifestaram, dizendo que a proporção de gênero seria respeitada. No total de 27 delegados a serem eleitos, estariam dez lésbicas e bissexuais, sete travestis e transexuais e dez gays. Uma das proponentes justificou: "eu, mulher bissexual e feminista, não me sinto à vontade para falar pelos homens gays e pelas trans, assim como não aceito que homens gays falem por mim. Então, a proposta é manter a proporcionalidade, mas por segmento".

Outros participantes ainda se manifestaram contra: "O movimento é para todos, não somos um simples conjunto de letrinhas"; "As travestis e transexuais são o segmento mais vulnerável, é injusto que tenhamos menos vagas. Além disso, são dois segmentos em um, não dá pra ser 3,5 transexuais e 3,5 travestis". E a proposta de "segmentação" perdeu.

A discussão dessa proposta foi um dos momentos de ebulição da II Conferência Estadual LGBT de São Paulo. As plenárias, como visto no capítulo 1, são espaços privilegiados para que as distensōes existentes se coloquem a descoberto. Nessa situação, a comoção pode ter sido gerada pelo alegado absurdo da obrigatória representação identitária de delegados, ou por esse formato de eleição dificultar a junção de grupos que já estariam pré-acordados em compor, ou por alguma resistência relacionada especialmente às pessoas que fizeram a proposta. Em cada discussão encenada nesse espaço podemos perceber níveis diferentes de disputa e negociação.

Atentando para atos de fala e enunciações de posicionamento, temos de volta aqui questōes já apontadas no capítulo 1, relativas a enfrentamentos por representação. Quem pode representar o quê e qual a representação mais legítima são definiçôes passíveis de compreensão apenas em relação ao jogo político encenado. Jogo que se faz produzindo diferenciaçôes e selecionando quais são os mais e os menos inseridos, quais incorporam melhor as marcas consideradas legítimas, e quais são os que melhor as articulam retoricamente ou expressam as conexões e as alianças tidas como mais rentáveis para 
a disputa. As plenárias são palco de disputas pessoais tanto quanto de disputas por espaço público político.

$\mathrm{Na}$ cena anterior, por exemplo, a exclusão de bissexuais dos "segmentos" expõe o entendimento, por parte de alguns, de que bissexualidade não definiria uma identidade per se. Se uma mulher é bissexual e se relaciona com outra, automaticamente poderia ser representada por uma lésbica e o processo correlato aconteceria com homens bissexuais.

Ainda na mesma conferência, outra cena revela esse tipo de questão de modo bastante claro: era o momento de eleição das vagas de delegados para a conferência nacional. Quatro chapas foram compostas para essa eleição, apresentando as suas candidaturas em plenária. Foram elas:

\section{Chapa 1: 'Aliança feminista contra a homofobia'}

A apresentação da chapa foi feita por uma 'mulher, lésbica e negra' que conclamou a representaçáo da 'periferia'. A chapa se colocou como representativa das religióes de matrizes africanas, pastores, 'pessoas que estão na academia estudando as questóes da comunidade LGBT', da Marcha Mundial das Mulheres, de organizaçóes do interior e da Aliança Paulista. ${ }^{54}$ 'A aliança está comprometida com o processo, com o feminismo'. Apesar de não se identificar assim, a chapa foi lida como composta por pessoas ligadas ao PT.

\section{Chapa 2: 'Independência ou morte'}

A apresentação da chapa 2 foi feita por uma mulher transexual: 'além de transexual, eu sou india, eu sou mãe de santo'. A chapa se colocou como a de maior representatividade [em quantidade] de travestis e transexuais, mencionou a defesa do PLC 122 e a despatologização da

\footnotetext{
${ }^{54}$ De acordo com o blog Aliança Paulista LGBT, o fórum é constituído pelas "seguintes entidades: 1. Visibilidade LGBT - São Carlos; 2. Corsa - São Paulo; 3. Diversitas - Taboão da Serra; 4. GESC Presidente Prudente; 5. A REDE de Cidadania - Jales; 6. ONG Primavera - Sertãozinho; 7. Grupo Diversidade em Ação - Jandira; 8. CAD - Limeira; 9. Movimento LGBT de Rio Claro - Rio Claro; 10. Triunfo da Razão de Viver - Jandira; 11. Somos - Araras; 12. Núcleo LGBT da Associação São Jorge - Guarulhos (Em: http://aliancapaulistalgbt.wordpress.com/about/. Acesso em abril de 2013).
} 
transexualidade. Alguns trechos do discurso da responsável pela defesa da chapa: 'o crime contra travestis e transexuais é muito pior, porque as pessoas não nos veem como mulheres, mas como homens vestidos de mulher. [...] chega de negociar a nossa identidade por kit homofobia que nem foi aprovado. O nosso movimento náo é partidário, é politico-social. [...] nos unimos como travestis e transexuais e depois procuramos parceiros, para visibilizar a posição de travestis e transexuais [...] essa é a realidade do Brasil, de travestis e transexuais que morrem todos os dias [...] nós queremos ir para Brasilia mostrar a nossa cara [...] nós não precisamos nos esconder'. Um número realmente grande de travestis e transexuais participantes da conferência integrou essa chapa, que também foi vista como composta por militantes do PSDB.

\section{Chapa 3: 'Democracia e pluralidade'}

A apresentação da chapa foi feita por um homem gay, que expôs como parte da composição as seguintes redes ou grupos: Conexão Paulista LGBT; Fórum Paulista de Travestis e Transexuais; Rede Afro LGBT, Conexão Jovem LGBT, CUT, UNE, ABL, União Juventude Socialista. Alguns trechos do discurso do responsável pela defesa da chapa: 'temos diferenças, mas temos que construir aquilo que nos unifica. [...] a conquista no Supremo é importante, mas o Congresso tem que aprovar essa lei [da união civil]. Nos orgulha a presença de todos os segmentos que poderiam estar representados, homens trans, travestis [...] mandato de delegado não é cheque em branco, tem que se comprometer. Pela construção mais ampla, mais democrática, mais plural'.

\section{Chapa 4: 'Rabo Solto' ('vai de quatro com o rabo solto')} A apresentação da chapa foi feita por uma travesti. Reproduzo alguns trechos do seu discurso: '[...] quem me conhece sabe o meu posicionamento, desde quando eu me assumi, eu náo consigo me enquadrar dentro de alguns parâmetros. Será que estamos fazendo de fato o que deveria ser feito? Somos representantes de uma população. São gays, lésbicas, travestis que estão lá fora. Nós tentamos até o último momento fazer uma chapa única de travestis e transexuais. Algumas pessoas acham que a gente vale ouro, para mim isso é massa 
de manobra. [...] ai a gente vai pra Brasilia e volta para a violência na Paulista, e náo só na Paulista, é na periferia. [...] Apresentando o nome da chapa, eu não preciso dizer mais nada. O que vamos fazer em Brasilia mesmo? Vamos questionar ou não? Vote com consciência, não pense só em garantir a sua estadia em Brasilia por uma semana'.

Os discursos de apresentação dos próprios candidatos nos permitem antever uma série de elementos que concorrem para a conformação desse campo interno de disputas. Todos são "sujeitos LGBT", mas se faz necessário o acionamento de outros marcadores ou posicionamentos, para além da orientação sexual e da identidade de gênero - a lésbica negra de periferia ou a transexual, índia e mãe de santo - que agregam valor aos que almejam ser a representação mais legítima do coletivo, oferecendo "múltiplos lugares de solidariedade" (Vianna, 2012). E, assim, apesar da exacerbação de diferenciações (ou especificidades) internas, expóem o esforço de expressar uma unidade constitutiva: "temos que construir aquilo que nos unifica", "chega de negociar a nossa identidade”.

Cena 7 - Trinta de outubro de dois mil e onze

A votação foi secreta, feita por meio de cédulas, e a Chapa 1 foi anunciada como a mais votada. Ao anúncio do resultado, um dos integrantes e principais articuladores da Chapa 1, Julian Rodrigues, pediu a divulgação do número de votos de todas as chapas. Dos 272 votos válidos: chapa 1 - 106 votos; chapa 2 - 57 votos; chapa 3 81 votos; chapa $4-28$ votos. Imediatamente após a divulgação, Julian comemorou o resultado em plenária aberta e de maneira bastante entusiástica. Ato contínuo, houve uma confusão, algumas pessoas correndo para o fundo do auditório, outras se afastando, enquanto uma aglomeração se formava no fundo da sala. Tudo ficou suspenso e todas as atençôes se voltaram para a cena. Alguns minutos depois, 
fiquei sabendo que Aghata Lima, integrante de uma das chapas de menor votação, deu um tapa na cara de Julian Rodrigues.

Recorro aqui a relatos feitos a mim durante o evento e às versóes postadas em sites dos grupos ligados às duas partes da contenda. Segundo me disseram, quando do anúncio da votação, Agatha Lima (que se identifica como mulher transexual) teria se dirigido aos componentes da chapa 1 , dizendo algo que condicionava a vitória à sua ligação com o PT. Julian teria então respondido com algo provocativo, que relacionava Agatha ao PSDB, e a essa altercação teria se seguido o tapa na cara.

O blog da Aliança Paulista LGBT, fórum ao qual Julian Rodrigues se filia, divulgou uma "nota de repúdio" ${ }^{55}$ relacionada ao episódio, na qual, sem mencionar o nome de Agatha, dizia que em momento de comemoração, Julian "recebeu covardemente um tapa na cara", e explica que o ato teria "na verdade por intenção 'desmoralizar' o conjunto de forças que compôs a chapa Aliança Feminista". Alguns trechos da nota:

Nota de Repúdio da Aliança Paulista LGBT

A Aliança Paulista LGBT - rede que congrega grupos e ativistas que lutam diariamente contra a homofobia, provenientes de vários pontos do estado de São Paulo - vem a público manifestar sua total perplexidade e rechaço diante das violentas agressóes fisicas ocorridas ao final da II Conferência Estadual LGBT no último fim de semana. [...]

Julian Rodrigues, que liderou a formação da chapa Aliança Feminista contra a Homofobia', que obteve quase $40 \%$ dos votos na eleição da delegação paulista à II Conferência Nacional LGBT, recebeu covardemente um tapa na cara [...]. Ao reagir instintivamente contra a agressäo descabida, Lula Ramires segurou o braço da agressora para detêla e esta, totalmente enfurecida, ameaçou revidar, sendo então protegido por Lucia Castro, que o abraçou por trás e o puxou. Ao perceberem o

55 Disponível em: http://aliancalgbtsp.wordpress.com/2011/11/02/nota-de-repudio-da-aliancapaulista-lgbt/. Acesso em: mar. 2013. 
ocorrido, Fernanda Estima - também integrante da chapa vitoriosa-e sua companheira Juliana Lora de Sá acorreram para defender Julian, no que receberam empurróes e tapas de lésbicas de outra chapa, que provocaram vários ferimentos em seus braços. O mesmo ocorreu com Mariana Rodrigues, também eleita delegada pela chapa. Mais tarde, outras ameaças foram feitas a Phamela Godoy, cabeça da chapa, e a mesma teve que sair escoltada do local do encontro.

Ao repudiarmos veementemente esta lamentável violência fisica que, atingindo a três companheiras e um companheiro de nossa articulaçâo politica, tinha na verdade por intenção 'desmoralizar' o conjunto de forças que compôs a chapa 'Aliança Feminista'. É inaceitável que pessoas que se dizem defensoras da população LGBT, tão humilhada por constantes atos de discriminação cotidiana, se valham das mesmas atitudes para com outras e outros militantes da mesma causa. Com esse gesto, sai perdendo a nossa comunidade como um todo.

A Aliança Paulista LGBT se esforça com vistas à organização dos segmentos mais fragilizados que exigem de nós um olhar diferenciado, até por estarmos cientes das vulnerabilidades resultantes da classe social, da bagagem cultural e da escolaridade. Estamos e sempre estaremos abertos ao diálogo e à construção coletiva, com espírito democrático e ético. [...]

Articulando a luta contra o machismo e o racismo (e temos muito orgulho de ver nossa chapa sendo apresentada por uma lésbica negra da periferia), enfrentamos a homofobia sem perder de vista que a sociedade nova que pretendemos construir pressupóe a justiça, a igualdade, a liberdade e a solidariedade. Só assim, TODAS as formas de violência e privação de direitos serão superadas.

Aliança Paulista LGBT [publicada em 02 de novembro de 2011]. 
Para o que seria o outro lado da história, recorro a dois textos divulgados pelo site Diversidade Tucana. ${ }^{56} \mathrm{Um}$ deles exprime que o conflito que resultou no tapa na cara teve início em disputa anterior, quando se discutia a maneira como seriam eleitos os componentes do Conselho Estadual LGBT. A contenda estava dividida entre os proponentes de eleições diretas e os de eleição realizada por meio de "entidades representativas", ou seja, por indicação de ONGs ou grupos. Julian era defensor da segunda proposta, que perdeu a votação. Assim, o episódio da eleição das chapas de delegados seria uma espécie de "troco à derrota política" anterior. De acordo com essa versão, após a divulgação do resultado da votação, "Julian Rodrigues resolveu provocar as travestis e transexuais - mais especificamente, Agatha Lima - pelo fato de esta não ter sido eleita como delegada. Essas provocações se deram por meio de insultos e agressóes verbais contra a militante". ${ }^{57}$

O outro texto, divulgado no site Diversidade Tucana, apresenta uma nota de "Posição Oficial" a respeito do ocorrido. ${ }^{58} \mathrm{O}$ seu conteúdo é bastante interessante, pois afirma que a contenda particular entre Julian e Agatha é apenas a "ponta do iceberg" de questôes mais profundas, envolvendo o movimento LGBT local. Sem se deter muito nos pormenores do atrito entre as duas pessoas, o texto discorre sobre outros acontecimentos que perpassaram o evento:

Posição Oficial do Diversidade Tucana sobre acontecimentos da II Conferência Estadual LGBT de São Paulo

O Diversidade Tucana repudia qualquer forma de violência - seja física, seja verbal. Atuamos e acreditamos no debate de ideias, visóes de mundo, propostas, ações. Também não pretendemos julgar as diferentes versöes do episódio e definir vítimas e algozes. Porém, acreditamos ser necessário

\footnotetext{
${ }^{56}$ Núcleo de Diversidade Sexual do PSDB fundado em São Paulo em 2006. Disponível em: http:// www.diversidadetucana. blogspot.com.br/2010/05/diversidade-no-psdb.html.

57 Texto assinado por Dario Neto e publicado no blog Diversidade Tucana. Disponível em: http:// diversidadetucana.blogspot.com.br/2011/11/violencia-de-quem-cara-palida.html. Acesso em: mar. 2013.

${ }^{58}$ Texto disponível em: http://www.diversidadetucana.blogspot.com.br/2011/11/posicao-oficial-dodiversidade-tucana.html. Acesso em: mar. 2013.
} 
desmitificar os acontecimentos da II Conferência Estadual LGBT de São Paulo [...].

O machismo foi a tônica da atuação de diversos militantes da sociedade civil desde antes da abertura da conferência. E se já é inaceitável o machismo que parte de homens e pessoas de identidade de gênero masculina, o que dizer quando ele parte de mulheres? O que dizer quando alguns militantes ainda insistem em rejeitar a união do Movimento LGBT, querendo substitui-la por uma atuação segmentada, em que lésbicas não lutam junto a gays, em que gays não reconhecem a luta de travestis e transexuais, e em que ninguém realmente se importa com a invisibilidade de bissexuais?

O Movimento LGBT paulista há anos sofre recorrentes crises protagonizadas sempre pelas mesmas pessoas. [...]

Ainda assim, essas mesmas pessoas não titubearam em puxar vaias aos representantes do governo do estado e até mesmo ao video enviado pelo governador Geraldo Alckmin exclusivamente para a conferência, afirmando de forma inquestionável o compromisso de sua gestão com o combate à homofobia. Curioso olhar os militantes que vaiavam os aliados presentes como se fossem inimigos e, ao mesmo tempo, lembrar que as lideranças politicas chamadas de aliadas por esses militantes estavam ausentes. Mais uma prova de que, para essas pessoas, não é a atuação o que conta, mas apenas a filiaçâo partidária. [...]

O episódio que envolveu a mulher Agatha Lima e Julian Rodrigues $e ́$, portanto, apenas a ponta de um iceberg que, em nossa opinião, o Movimento LGBT Paulista precisa reconhecer e discutir. Ou buscamos uma agenda comum de união do nosso movimento ou aprofundaremos uma espiral autofágica que há anos já vem consumindo a atuação de nossa militância. E, em nossa opinião, o primeiro ponto dessa discussáo deve necessariamente ser o verdadeiro reconhecimento e a visibilidade das demandas de travestis e transexuais, para que possamos sair do discurso demagógico e paternalista que tomou conta 
deste movimento e possamos avançar verdadeiramente em espaços de protagonismo para as Travestis e Transexuais.

[...] Acreditamos em uma nova relação da militância LGBT com seus atores partidários, de simbiose e não de subjugação. Somos um grupo partidário que luta por um Movimento LGBT independente de partidos e governos, forte, unido e com o compromisso único com a vida e os direitos de lésbicas, gays, bissexuais, travestis e transexuais do Brasil.

\section{Diversidade Tucana - Secretariado de Diversidade Sexual do PSDB} [nota publicada em 04 de novembro de 2011].

$\mathrm{Na}$ época do episódio, o governo do estado e a prefeitura de São Paulo funcionavam sob a gestão do PSDB. Assim, as políticas voltadas para a "diversidade sexual" nos dois âmbitos eram conduzidas por pessoas ligadas ao partido. Em janeiro de 2013, um governo do PT, com Fernando Haddad, tomou posse na Prefeitura de São Paulo, e Julian Rodrigues foi nomeado para a coordenação da CADS Coordenadoria de Assuntos de Diversidade Sexual, órgão inserido na estrutura municipal do governo. ${ }^{59}$

Ao reproduzir extensamente as notas das duas partes, não pretendo avaliar quaisquer dos lados como mais ou menos coerentes em suas justificativas, entretanto creio que a contenda possa ser tomada como profundamente ilustrativa de algumas tensōes significativas, e não restritas a esse grupo de pessoas particularmente envolvidas. $\mathrm{Se}$, aqui, os relatos apontam para uma dimensão circunscrita, que seria o movimento LGBT paulista, creio que eles desenhem uma dinâmica que possa ser tomada como mais ampla do campo das políticas LGBT no Brasil. Esse tipo de conflito não é novidade em São Paulo, assim como pode acontecer, com outras variações e outros elementos, em

\footnotetext{
${ }^{59}$ Em certa ocasião, durante o trabalho de campo, ainda no início de 2011, conversava com uma ex-contratada da Prefeitura de São Paulo sobre a minha dificuldade em encontrar alguém disposto a me receber para uma entrevista. Ela me disse que era "assim mesmo", pois "eles acham que gente da academia é do PT, logo vai ser contra o governo do PSDB”.
} 
todos os locais em que exista acúmulo de militância e de construção de políticas relacionadas ao tema.

Essas cenas falam sobre cisões que podem estar personificadas em determinadas figuras do campo, sobre a formação e a dissolução de redes e alianças. Quando em situações desse tipo, todo o campo é movimentado e chamado a se posicionar. No caso em questão, por exemplo, muitas discussóes a respeito de formas de violência que circulam no interior do próprio movimento foram feitas. Talvez essa seja uma dinâmica própria do percurso de um movimento social que nasce e se expande a partir de cisões internas e da multiplicação de arranjos, inclusive institucionais. ${ }^{60}$ Esse percurso envolve trajetórias pessoais, partidos políticos e diferentes tipos de gestão governamental, que amplificam os conflitos produzidos pelas políticas de identidade que contribuem para a multiplicação das "especificidades". Se no evento acima, realizado em São Paulo, aparece a lésbicalgay/travestil transexual negra e de periferia, nos eventos que acompanhei no Rio de Janeiro, o personagem correspondente é a lésbicalgay/travesti/transexual morador(a) de favela.

As "especificidades" surgem com uma eficácia bastante produtiva e mobilizadora em termos de enunciação e atração de solidariedades, mas, na prática, no cotidiano da aplicação das políticas, podem se transmutar apenas em categorias descritivas. Para dar um exemplo nesse sentido, durante um seminário que acompanhei em 2009, em uma das mesas, estavam presentes gestores de governo relacionados à área da saúde, que trataram, entre outras questóes, das políticas de prevenção às DST/ Aids. No momento do debate, direcionei aos expositores uma questão: Diante da existência de um plano de "feminização" da epidemia, de outro, voltado para "homens, travestis e HSH", de uma política especificamente voltada para a "população negra", um projeto orientado para "populações de terreiro" (todos esses mencionados durante o evento), como se daria a gestão desses direcionamentos ou o cruzamento dessas "especificidades" no cotidiano dos serviços?

\footnotetext{
${ }^{60}$ Dinâmica já enfatizada desde MacRae (1990) e abordada novamente sob outro ângulo por Facchini (2005).
} 
O conjunto das respostas foi interessante. Uma das pessoas respondeu que "um plano pega ou não pega", "o cruzamento não acontece". De acordo com essa expositora, "os gestores são chamados para discutir em cada fórum separadamente, mas não acontece a liga”. Outra pessoa, envolvida no movimento social, disse que "os planos vêm do movimento, e o movimento caminha em bloco mesmo". Já a terceira expositora, ao responder, destacou "a perspectiva pedagógica dos planos". De acordo com ela, os planos são "uma estratégia para forçar a gestão a olhar para o problema", uma vez que "todo mundo disputa o SUS”. E o que estaria em jogo não seria “apenas o cruzamento das demandas, mas tambéma colocação das demandas para o SUS" . ${ }^{61}$

Um sentido produtivo e interessante para se pensarem as "especificidades" pode ser lido em situações como a relatada na reflexão de Leite Lopes (2011), justamente sobre o processo de criação do grupo responsável pelo seminário mencionado no parágrafo anterior: o Grupo Conexão G da favela da Maré, no Rio de Janeiro. O autor nota que a ênfase na "especificidade" da experiência como "LGBT morador de favela" é feita destacando o contraste em relação ao "gay classe média", que comporia a maioria do movimento LGBT institucionalizado. Essa distinção por oposição tem eficácia não apenas como um mecanismo de mobilização e formação da identidade do novo grupo, mas também no sentido de ganhar um espaço próprio. No contexto das disputas internas que marcam o movimento, tomar para si o domínio da experiência do "LGBT favelado" empresta legitimidade e garante a delimitação de um lugar no campo. O Conexão G é o primeiro e, até o momento, o único grupo LGBT formado por moradores de favela e sediado nesse espaço.

Como visto na seção anterior, travestis e transexuais disputam entre si os significados das categorias que as identificam. Ao mesmo tempo, podem se unir na acusação de que são usadas para dar "a cara do movimento" quando conveniente, enquanto as suas demandas particulares são preteridas. Assim, acusam o movimento LGBT

${ }^{61}$ Essas falas foram registradas em caderno de campo durante o seminário Refletindo sobre Políticas Públicas para a População LGBT Moradora de Favelas, promovido pelo Grupo Conexão G, durante os dias 5 e 6 de novembro de 2009, no Rio de Janeiro. 
mais amplo de discriminá-las. A mesma acusação também é feita por mulheres lésbicas que, por vezes, podem se unir a travestis e transexuais em uma acusação uníssona de machismo por parte da maioria de homens gays que compõem o coletivo. Outras vezes são lésbicas e travestis que brigam entre si, em disputas internas desse feminino, como na situação reproduzida na cena 3 do capítulo 1. Assim como abordado nesta, a contenda que se desdobra a partir da cena 7 é também construída com base na relacionalidade que envolve, além das identidades, outros marcadores, como classe e cor/raça. Logo, também é relevante considerar que subjaz a essas disputas uma imagem do homem-gay-branco-classe média que serve de modelo standard por meio do qual a produção discursiva das outras identidades que compõem o coletivo é forjada, em relações de oposição e espelhamento.

Esses embates entre as "letrinhas" descortinam disputas por legitimidade, retóricas e estratégias políticas de visibilidade e reivindicação e evidenciam a potência contida na instabilidade dessa unidade, uma vez que é justamente essa suposta fragilidade que vem fazendo com que o campo se movimente não apenas para fora, mas também internamente. Se seguirmos as sugestões de Butler (2008), essas dinâmicas de produção e afirmação de identidades por oposição apontam para o "processo ilimitável de significação", que deve ser o ponto de partida para pensar as "identidades como efeito", não como "fundantes e fixas", mas como parte de "estruturas políticas generativas".

Os processos aqui apontados podem deixar mais claros os limites e os alcances das políticas em curso e, assim, estimular reflexôes a respeito de como uma nova população é gestada e gerida pelos formatos dados da administração governamental. Pensando nessa perspectiva, o próximo capítulo acompanha parte dos processos que envolvem a implantação de uma política específica, o Programa Rio Sem Homofobia. 


\section{PARTE III DA PROPOSIÇÃO À EXECUÇÃO OU DOS APRENDIZADOS DA GESTÃO}

Esta terceira parte aborda a dimensão local de implantação de uma política voltada para a "população LGBT". Em 2010, fiz a escolha de que um dos focos de atenção privilegiada da pesquisa de campo seria acompanhar uma iniciativa específica no Rio de Janeiro. Dois fatores principais contribuíram para essa escolha. Um deles refere-se à minha proximidade com redes de ativismo e de pesquisadores na cidade, e o outro está relacionado à inauguração de um serviço que, desde antes de sua abertura, vinha sendo divulgado e celebrado como uma espécie de modelo de implementação e gestão de "políticas públicas LGBT".

Em termos metodológicos, a observação detida da implantação de uma política permitiu o acompanhamento de um processo em andamento. De demandas até então pronunciadas em termos de tornar visiveis sujeitos articulados politicamente como uma população específica, passou-se à formulação de propostas de ação, até o ponto em que se constituiu em uma instância governamental na qual essa população precisa ser efetivamente gerida cotidianamente. 
Por meio desse tipo de observação mais detida, encarei a proposta de olhar para o estado como administração pública. Para isso, procurei seguir a proposta de Souza Lima (2002) ancorada no gestar e no gerir, que remetem a funções constitutivas e pedagógicas de coletivos e sua correlata gestão administrativa cotidiana (p. 16). O acompanhamento dos processos de rotinização dos serviços prestados pelo Centro de Referência LGBT do Rio de Janeiro manteve como questionamentos mais amplos: Quais são o papel e a função de um centro de referência? Como é definida a sua "população-alvo"? Quais são as demandas que devem ser enquadradas sob o guarda-chuva da violência relacionada à orientação sexual e/ou identidade de gênero? O cotidiano da administração produz classificações, enquadramentos e disputas a respeito de quem é a autoridade sobre o assunto, imbricados em decisões técnicas e administrativas e estratégias político-simbólicas. Mantendo as questões em perspectiva, procuro descrever a experiência de implantação dessa política específica, enfatizando o envolvimento de uma universidade no referido processo.

Cena 8 - Dia primeiro de julho de dois mil e dez

"Antigamente meu endereço era a delegacia pra ir presa, hoje eu tenho um endereço para nossos problemas, hoje temos nosso espaço. Esse espaço.”

"Um lugar para chamar de seu."

"Acredito que um Centro como esse vai passar a ser copiado em nível nacional por outros estados."

"A militância saiu do público-alvo de pesquisa, objeto de estudo, e mostra que pode propor, desenhar politica e dar pontapé na criação de um novo estado [...]. A sociedade civil deu um passo atrás para aprender com o governo como tornar demandas exequíveis, e o 
governo deu um passo atrás para aprender com o terceiro elemento, que é a sociedade civil.”

"A relação [entre governo e sociedade civil] tem que ser de diálogo e tensão, não é de troca de favores ou do Estado como canal de veiculação da sociedade civil."

"Burocracia é uma máquina de triturar nossos sonhos e esperanças."

“A lei só confirma aquilo que já está acontecendo na sociedade.”

Essas assertivas foram proferidas por diferentes pessoas, inseridas no movimento social e em cargos administrativos de governo, durante a cerimônia de lançamento de um conjunto de serviços lotados num equipamento público do governo estadual do Rio de Janeiro. Os trechos aqui reproduzidos resumem um pouco o tom e as expectativas suscitadas pelo evento.

Os serviços que tiveram a inauguração anunciada em $1^{\circ}$ de julho de 2010 foram:

- Centro de Referência de Promoção da Cidadania LGBT;

- Disque Cidadania LGBT;

- Comissão Processante para o Cumpra-se de Leis Antidiscriminação: Lei 3.406/00, que pune a discriminação contra LGBT, e Lei 3.559/01, que pune a discriminação de pessoas vivendo com HIV/Aids;

- Núcleo de Monitoramento de Crimes contra LGBT;

- Núcleo do Programa Rio Sem Homofobia;

- Centro de Documentação e Informação LGBT;

- Conselho Estadual dos Direitos da População LGBT;

- Centro de Referência de Promoção da Liberdade Religiosa e Contra a Intolerância, defesa e apoio jurídico, psicológico e social; 
- Centro de Referência de Promoção dos Direitos Humanos em DST/Aids e outras doenças, defesa e apoio jurídico, psicológico e social;

- Centro de Formação de Cidadania e Diversidades. 


\section{CAPÍTULO 5 SOBRE UMA POLÍTICA (QUE SE QUER) MODELO}

A cerimônia descrita na cena 8 consistiu em uma solenidade organizada para celebrar a inauguração de um conjunto de dez serviços a serem oferecidos pela Superintendência de Direitos Individuais, Coletivos e Difusos da Secretaria de Estado de Assistência Social e Direitos Humanos do Rio de Janeiro. Parte das atividades recebeu o apoio do governo federal por meio da SEPPIR e da SDH. A SuperDir funciona no prédio da Central do Brasil, no Centro do Rio de Janeiro. O espaço foi cedido no início de 2009 pela Secretaria Estadual de Segurança Pública, que se localiza no mesmo prédio. Todo o amplo espaço, que inclui salas, escritórios e um grande auditório, estava fechado e inutilizado há quase dez anos, tendo sido totalmente reformado para que pudesse abrigar a estrutura dos serviços. A verba para a reforma, $\mathrm{R}$ \$ 1,5 milhão, foi liberada pelo governo do estado. ${ }^{1}$

Na mesa oficial da solenidade de abertura esteve presente o secretário deAssistência Social e Direitos Humanos, o superintendente da Secretaria

1 Antes desse espaço no prédio da Central do Brasil, a SuperDir ocupou uma sala no Palácio da Guanabara, sede do governo do estado do Rio de Janeiro (entre 2007 e 2008) e um espaço no prédio do Detran (em 2009). 
de Direitos Individuais, Coletivos e Difusos, a subsecretária de Direitos Humanos da Presidência da República, o secretário Estadual de Segurança Pública, um representante do reitor da Universidade do Estado do Rio de Janeiro e um representante de cada área coberta pelos serviços, ou seja, uma representante "LGBT", uma representante da diversidade religiosa e uma representante de ONG/Aids. ${ }^{2}$ As falas da mesa de abertura foram ao encontro da maneira como o evento foi divulgado, ressaltando o pioneirismo do estado do Rio de Janeiro e o caráter de "vanguarda" dos serviços que estavam sendo inaugurados para a "luta pela cidadania sem distinção de credo, raça, orientação sexual e identidade de gênero". Alguns dos presentes enfatizaram que este deveria ser um modelo de serviço a ser replicado em todo o Brasil. Outro ponto destacado durante algumas das falas foi o de que os serviços seriam fruto de uma resposta governamental em face de uma demanda dos movimentos sociais.

Onze meses depois, o mesmo espaço abrigaria outra cerimônia que teve novamente o seu caráter pioneiro como grande destaque. Dessa vez, o evento seria o lançamento da campanha publicitária Rio Sem Homofobia.

Cena 9 - Dezesseis de maio de dois mil e onze

A entrada do edifício da Central do Brasil foi enfeitada com balóes nas cores do arco-íris. Na portaria - que também funciona como acesso para as instalações da Secretaria de Segurança Pública, para as instalações da Secretaria Estadual de Assistência Social, entre outros equipamentos -, chamava a atenção dos passantes, além dos balóes, a circulação de travestis e transexuais “montadas", entre

2 Segundo um boletim divulgado em 2007, a "Superdir iniciou suas ações de combate à discriminação e à promoção da cidadania junto à população GLBT (gays, lésbicas, bissexuais, travestis e transexuais); pessoas discriminadas por estado de saúde (HIV-Aids, tuberculose e hepatite); comunidades de religiōes de matrizes africanas; comunidade judaica e outras populaçōes discriminadas em razão de sua nacionalidade, origem, religiosidade, além das intolerâncias correlatas e das múltiplas formas de discriminação". 
outros personagens não tão frequentes ali. Ainda colaborava para o estranhamento a intensa circulação dos fotógrafos encarregados de registrar o momento.

Lá em cima, no amplo auditório do sétimo andar, o salão foi organizado de maneira a garantir um espaço reservado para as "autoridades" presentes entre o público. Telóes dispostos nas laterais do pequeno palco montado em uma das extremidades do auditório mostravam fotos de outros eventos e ações promovidas pela SuperDir, enquanto o público chegava e ia se acomodando.

Com alguns minutos de atraso, foi anunciado o início da cerimônia. Foram convidadas as "autoridades" para compor a mesa de abertura: o governador do estado, Sérgio Cabral, o secretário de Assistência Social e Direitos Humanos, Rodrigo Neves, e o superintendente de Direitos Individuais, Coletivos e Difusos, Cláudio Nascimento, que surgiram no fundo do salão e atravessaram o corredor formado entre os dois conjuntos de cadeiras da plateia, caminhando até o pequeno palco. $\mathrm{O}$ pequeno percurso se deu sob muitos aplausos e foi seguido por muitas luzes das câmeras de foto e vídeo que os acompanhavam. A quantidade de fotógrafos e cinegrafistas realmente impressionava. Dessa maneira também outras “autoridades" foram recebidas, como a senadora Marta Suplicy e a delegada Marta Rocha. Uma travesti, Jane di Castro, interpretou o Hino Nacional. A cantora Elza Soares, no palco, recitou uma poesia e cantou à capela. Ainda antes do início dos discursos, muitas fotos foram tiradas. $\mathrm{O}$ superintendente, de mãos dadas e erguidas com o governador e o secretário, em pose de vitória.

Lideranças de movimentos LGBT da capital e de outros municípios do estado, o secretário de Administração Penitenciária, deputados, representantes da Defensoria Pública, das secretarias estaduais de Saúde e Educação foram algumas das autoridades que tiveram presença registrada. No palco e na plateia. 
Os discursos ressaltaram a "vanguarda" do estado do Rio de Janeiro no que tange à garantia de "direitos LGBT".

Um representante da Secretaria Nacional de Direitos Humanos disse: "Rio de Janeiro, vocês são demais! Porque é tanta ação simbólica! [...] vocês realmente são vanguarda e têm feito avançar os direitos e o respeito aos cidadãos".

O vice-governador do estado, Pezão: "O Rio volta a ser a caixa de ressonância para todo o país [...].”

O governador, Sergio Cabral: "Hoje já fizemos uma catarse de mudanças e desejos [...] Vocês são corajosos, a Parada Gay mais charmosa é na Avenida Atlântica, com perdão Martha, você que é a grande prefeita de São Paulo [...] fomos o primeiro estado a reconhecer os companheiros do mesmo sexo [...] hoje é um dia em que estamos implementando mais políticas públicas".

Após os discursos, assistimos ao vídeo da peça publicitária da campanha e, para encerrar a cerimônia, travestis, transexuais, lésbicas e gays superproduzidos entregaram flores aos convidados.

Solenidades como as descritas anteriormente não são simples lançamentos, mas atos públicos que envolvem a montagem de uma cena, reunindo elementos específicos a serem utilizados na produção de uma determinada imagem para a política. E essa parece ser uma especialidade de como a "política LGBT" vem sendo constituída no Rio de Janeiro, em que determinados tipos de evento costumam seguir um mesmo script. Quase sempre Jane Di Castro é chamada para interpretar o Hino Nacional e outras cançôes. ${ }^{3}$ Nenhuma mesa de abertura se faz sem "autoridades". Todos os eventos são produzidos como "marcos".

${ }^{3}$ Em uma dessas ocasiōes, o superintendente explicou: "Jane di Castro canta o hino em todas as nossas cerimônias públicas para mostrar o lugar que queremos que todas as travestis e transexuais ocupem, um lugar de protagonismo, de agência, de cidadãs". 
A presença das "autoridades" é tida como importante por agregar legitimidade: se o próprio governador está presente, isso garante que a política seja compreendida como um compromisso do estado. Ao se referir a outras cerimônias organizadas pela SuperDir que contaram com a presença do governador, entre outras figuras de destaque na gestão do governo, Cláudio Nascimento diz:

[Essas grandes cerimônias], todas elas tiveram a presença do governador e de secretários importantes. Isso foi para quê? Para demarcar que a politica pública de combate à homofobia no estado, em função dos direitos da população LGBT, era uma politica que fazia parte de uma agenda prioritária, não era um penduricalho. Então, isso foi importante, do ponto de vista simbólico e político, para reafirmar esse lugar institucional dentro da gestâo. ${ }^{4}$

A campanha foi alardeada como a primeira do tipo na América Latina, mais uma vez investindo na imagem de "vanguarda". Orçada em $\mathrm{R}$ \$ 4 milhōes, as peças publicitárias contavam com cartazes, inserçôes em rádio, TV e mídia impressa, além de materiais promocionais, como bolsas, bonés, camisetas, chinelos, cadernos e barracas de praia. O investimento nessa campanha aponta para uma preocupação com comunicação, divulgação e boa relação com a imprensa em sentido mais amplo. Não basta fazer a política bem feita, é preciso fazer e investir para que a política apareça bem feita. Esse tipo de orientação diz algo sobre as formas por meio das quais o "Estado" representa a si mesmo. O espetáculo e a cerimônia da afirmação política - rituais encenados como parte da tecnologia de administração do poder - produzem um modelo exemplar, que pode ser tomado em dois sentidos: como a representação de um modelo irrepreensível e como mais um exemplar da simulação de um "Estado" idealizado. 5

${ }^{4}$ Entrevista realizada em outubro de 2011 no âmbito do projeto Retratos da Política LGBT no Estado do Rio de Janeiro, coordenada pelo LIDIS/UERJ (ver Carrara et al., 2017).

${ }^{5}$ Essa disposição poderia ser aproximada de um modo livre a algo semelhante ao investimento moral e estético e à relação entre o poder e a sua dramatização, tal como no Estado-teatro elaborado por Geertz (1991). 
A retórica que exalta o "pioneirismo" e a "vanguarda" reveste a imagem construída para essa política e é utilizada para falar de todo tipo de "primeira vez". O release divulgado logo após o evento de lançamento da campanha destacava o Hino Nacional cantado por Jane di Castro, ela mesma uma pioneira: "Uma das fundadoras da Parada Gay no Rio de Janeiro e primeira travesti do país a cantar o Hino Nacional em eventos e locais públicos, como o Congresso Nacional e a Assembleia Legislativa do Estado do Rio de Janeiro (Alerj) $[\ldots . . .]^{\prime}{ }^{6}$

Ainda nessa mesma ocasião, foi lançado o "Caderno de Ações e Metas do Programa Rio Sem Homofobia" - com 125 ações previstas para serem executadas por diferentes secretarias do estado - e foi anunciada a assinatura do decreto que garantiria o uso do nome social para travestis e transexuais no âmbito da administração pública estadual. Este só seria efetivamente publicado no Diário Oficial alguns meses depois, em 8 de julho de 2011, 7 quando mais um release foi liberado para a imprensa:

A pessoa transexual ou travesti poderá solicitar inclusäo do nome social nos registros dos sistemas de informação, cadastros, fichas, requerimentos, formulários, prontuários e congêneres. Essa é mais uma vitória histórica e marcante para esta população, que há muito vem sendo violada em seus direitos humanos. O Rio de Janeiro é um exemplo para o país!", orgulha-se o superintendente de Direitos Individuais Coletivos e Difusos da Secretaria de Estado Assistência Social e Direitos Humanos, Cláudio Nascimento. ${ }^{8}$

6 Uma leitura particular poderia ser feita a respeito da execução do Hino Nacional, realizada não só em eventos chamados por instâncias do governo, mas também em seminários e outros eventos organizados pelo movimento social e nas Paradas do Orgulho. O hino, na imensa maioria das vezes, é cantado por uma travesti/transexual, e a realização reiterada desse "ato cívico" evoca um apelo de inclusão e reconhecimento como cidadãos. $\mathrm{O}$ release completo de lançamento da campanha pode ser encontrado no anexo C14 (p. 364-6)

7 Decreto n. ${ }^{0} 43.065$, de 08 de julho de 2011. "Art. 1. ${ }^{\circ}$ - Fica assegurado às pessoas transexuais e travestis capazes, mediante requerimento, o direito à escolha de utilização do nome social nos atos e procedimentos da Administração Direta e Indireta do Estado do Rio de Janeiro".

8 Release divulgado pela Secretaria de Assistência Social e Direitos Humanos em 08/07/2011 (grifo meu). Disponível no anexo C15 (p. 367). 
Durante o período em que realizei a pesquisa de campo, muitos outros eventos "históricos" aconteceram no espaço do auditório da SuperDir. O lançamento da campanha foi feito alguns dias depois da decisão do STF que reconheceu a união entre pessoas do mesmo sexo. Um mês depois, o espaço sediaria "a maior cerimônia de casamento gay da história":

Programa Rio Sem Homofobia vai unir 50 casais no próximo dia 22 de junho

O Rio de Janeiro reafirmará, mais uma vez, seu pioneirismo na luta pela igualdade de direitos a gays, lésbicas e transexuais no Brasil. No dia 22 de junho, o Programa Rio Sem Homofobia promove o maior casamento gay coletivo do mundo, unindo 50 casais. Dois terços das unióes estáveis homoafetivas serão celebradas entre mulheres. ${ }^{\text {? }}$

Uziel et al. (2012), em artigo que analisa justamente essa primeira celebração coletiva de uniões - outras aconteceriam depois -, notam a cobertura midiática que o evento recebeu nos principais jornais do país e comentam a estratégia de projeção, com vistas à diminuição da homofobia que cercou a ação da Superintendência. ${ }^{10}$

A atuação da SuperDir em relação aos "direitos LGBT" teve início em 2007. O órgão tomou para si a tarefa de "combate à homofobia e promoção da cidadania LGBT no estado do Rio de Janeiro”. Em reflexão sobre o conjunto de cerimônias realizadas durante um período de mais ou menos cinco anos de funcionamento, o superintendente avalia:

Então, pra você ver, em quatro anos, cinco anos, nós tivemos sete ou oito cerimônias grandes, importantes, de marcação de lugar de

9 Ver "Rio celebra maior casamento gay coletivo do mundo" (Diário Oficial do Estado do Rio de Janeiro). Ver anexos C16 e C17 (p. 368 e 369).

${ }^{10}$ Como já discutido no capítulo 3, outra interessante discussão apresentada pelas autoras trata de como o reconhecimento do contrato firmado entre duas pessoas do mesmo sexo pode ter como efeito convertê-las em sujeitos políticos, ao afetar a percepção dos próprios sujeitos como detentores de direitos antes não acessados (Uziel et al., 2012). 
visibilidade pública da agenda $L G B T$ no estado. Se você pensar, fora as duas conferências, pode contar ai uns dez grandes eventos; fora as conferências regionais que a gente fez; somando tudo, dá em torno de vinte grandes eventos; fora a campanha [de divulgação do Programa Rio Sem Homofobia], em que foram 15 lançamentos regionais. Então, mostra o volume realmente da presença do estado, inclusive, fora da capital $[\ldots]^{11}$

Para compreender um pouco como a "presença do estado", identificada pelo lugar de "visibilidade pública da agenda LGBT", tornou-se possível no Rio de Janeiro, cabe retomar parte da trajetória dessa política.

\section{UM HISTÓRICO BREVE}

É preciso voltar um pouco no tempo para falar da experiência que possivelmente foi a precursora da retórica do "pioneirismo" da "política LGBT" do Rio de Janeiro. Trata-se da criação do Centro de Referência Contra Violência e Discriminação ao Homossexual - CERCONVIDH - e do Disque Defesa Homossexual - DDH -, serviços que foram lançados oficialmente em junho de 1999 e sediados na Subsecretaria de Pesquisa e Cidadania da Secretaria de Segurança Pública do Estado do Rio de Janeiro.

De acordo com um relatório do DDH, o centro de referência coordenava "iniciativas de formação, sensibilização e capacitação das polícias civil e militar", entre outras ações de enfrentamento à homofobia. As principais razões para a criação do serviço foram:

i. o reconhecimento da inexistência de uma política de segurança que atendesse às necessidades e especificidades da população homossexual;

\footnotetext{
${ }^{11}$ Entrevista realizada em outubro de 2011 no âmbito do projeto Retratos da Política LGBT no Estado do Rio de Janeiro, coordenada pelo LIDIS/UERJ.
} 
ii. a necessidade de estabelecer canais diretos entre a comunidade homossexual e os órgãos de segurança;

iii. a importância de aumentar os registros de ocorrência de crimes contra homossexuais, para diminuir sua incidência;

iv. experiências localizadas positivas (como em visitas das entidades a Batalhóes da Polícia Militar e em encontros com Delegados de Polícia) que indicavam que uma aproximação entre a comunidade homossexual e os órgãos de segurança era possivel, sendo preciso ultrapassar tabus e desobstruir os mecanismos de comunicação. ${ }^{12}$

Cláudio Nascimento destaca que a experiência do DDH significou um importante aprendizado de como lidar com a implantação desse tipo de política. Ele pondera que, apesar de nunca ter sido "gestor público", a participação no processo de criação do $\mathrm{DDH}$ configurou-se como uma importante experiência em termos de "liçôes aprendidas" e especialmente do que "não deveria ser feito".

A criação, em 1999, do serviço de Disque-Defesa Homossexual, no CERCONVIDH, Centro de Referência de Combate à Violência Homossexual [...], na época, foi um serviço importante, tinha presença, por conta da orientaçấo de como tratar na segurança pública a questão da cidadania, com a entrada do Luiz Eduardo Soares no Governo Garotinho. Na época, o PT estava também na relação, a esquerda também, parte da esquerda que foi eleita, que apoiou aquela famigerada aliança com o Garotinho. Teve então esse espaço do Luiz Eduardo Soares, que pôde contar com a presença da Silvia Ramos, da Lúcia Xavier, da Barbara Soares [...]. ${ }^{13}$

\footnotetext{
${ }^{12}$ Segundo o relatório do primeiro ano de atividades do DDH, durante o período foram atendidos 382 casos. "1 Relatório do Disque Defesa Homossexual - DDH, 2000" (Disponível em: http://www. ucamcesec.com. br/wordpress/wp-content/uploads/2011/06/Relatorio-1ano-DDH.pdf. Acesso em: maio 2012).

${ }^{13}$ Entrevista realizada em outubro de 2011 no âmbito do projeto Retratos da Política LGBT no Estado do Rio de Janeiro, coordenada pelo LIDIS/UERJ.
} 
No trecho acima, Cláudio Nascimento refere-se ao contexto político da época, crucial para a compreensão do processo de instalação do serviço. O foco da campanha eleitoral para o governo do estado naquele momento, na qual o vencedor foi Anthony Garotinho (PDT), era a promessa de renovação das políticas de segurança pública, área cuja condução vinha sendo alvo de incisivas críticas dos governos anteriores. Nesse cenário, a figura do antropólogo e cientista político Luiz Eduardo Soares destacou-se como de importância fundamental. Convidado a coordenar o plano de segurança pública da campanha de Garotinho, após a eleição, tornou-se subsecretário de Pesquisa e Cidadania da Secretaria de Segurança Pública do estado, espaço no qual seria implantado o DDH.

Martins (2002), ao analisar parte desse mesmo processo, aponta o contexto político daquele momento, compreendido como favorável à implantação de "um projeto pioneiro em toda a América Latina". $\mathrm{O}$ DDH fazia parte de um conjunto de açôes que iriam significar uma nova proposta de políticas de segurança pública para o estado:

[E]ra um programa, entre outros, de um governo 'moderno' e atento às necessidades das ditas 'minorias' e, por isso, poderia representar uma imagem mais 'liberal', mesmo que algumas dividas pairassem em relação às alianças politicas e ao comprometimento religioso desse mesmo governo (p. 66). ${ }^{14}$

A política de segurança juntamente com outros programas do governo, como os Restaurantes Populares oferecendo refeiçōes ao custo de R \$ 1,00 e a construção do Piscinão de Ramos, funcionavam como uma vitrine de grande apelo popular e catalisavam a atenção midiática para as iniciativas da nova gestão do estado.

Foram três as iniciativas de organizaçôes não governamentais que desembocaram no Disque Defesa Homossexual (DDH): o "Disque-

\footnotetext{
${ }^{14}$ Aqui, o autor se refere ao governador Anthony Garotinho, de religião evangélica, e que, em um episódio, chegou a declarar ser "contra o homossexualismo". Ver "Garotinho pede desculpas e aceita projetos de homossexuais”. Jornal O Globo, 12/11/2001. Ver anexo C18 (p. 370).
} 
-Violência/Disque Aids", iniciativa do Grupo Atobá, ${ }^{15}$ as denúncias de assassinatos realizadas por meio dos levantamentos do Grupo Gay da Bahia (GGB) e da exposição crescente dos casos na mídia, ${ }^{16} \mathrm{e}$ as "campanhas de conscientização, como o alerta sobre o "boa-noite cinderela', do Grupo Arco-Íris, realizado em 1997”. Essas açōes teriam chamado a atenção para a "necessidade de um acompanhamento mais eficaz dos casos de violência contra o público gay" (Martins, 2002, p. 61). Foi também fundamental para que o projeto tomasse forma a articulação com a Alerj, por intermédio do mandato do deputado Carlos Minc, e a parceria com pesquisadores do Instituto de Estudos da Religião (Iser), do Centro de Estudos de Segurança e Cidadania da Universidade Cândido Mendes (CE-SeC/Ucam) e do Instituto de Medicina Social (IMS/UERJ).

A Secretaria de Segurança cedeu o espaço físico, a linha telefônica e o salário de poucos funcionários alocados na Subsecretaria e o do gerente do $\mathrm{DDH}$, mas o cotidiano do atendimento ficava a cargo de voluntários recrutados dos grupos de militância e da colaboração dos parceiros envolvidos no projeto.

Ao recuperar o trajeto de implantação do DDH, Larvie (2001) relembra que o projeto costumava ser mencionado como uma realização de "custo quase zero" e que aquele governo tomava a "parceria com a sociedade civil como uma medida de baixo custo para aumentar a eficácia de políticas públicas e a eficiência do seu provimento" (p. 29). Entretanto, essa avaliação sobre os custos só foi possível graças ao tempo e à experiência de trabalho que os voluntários do atendimento e outros colaboradores cediam para que o serviço pudesse funcionar. Esse valor agregado não era contabilizado entre os custos do projeto. Apesar disso, as análises sobre a experiência do $\mathrm{DDH}$ avaliam a parceria entre movimentos sociais e a administração

\footnotetext{
${ }^{15} \mathrm{O}$ atual Grupo Atobá - Movimento de Afirmação Homossexual, foi fundado em 1985 com o nome de Atobá - Movimento de Emancipação Homossexual, tendo sede no bairro de Realengo, na Zona Oeste do Rio de Janeiro.

${ }^{16}$ Cf. Mott e Cerqueira (2001). E para uma análise de como casos de assassinatos de homossexuais eram tratados pela mídia durante o período 1980-2000, ver o trabalho de Lacerda (2006), já citado no capítulo 3.
} 
pública como extremamente positiva, em especial no que tange às políticas de segurança. Esse tipo de esforço conjunto ajuda a "garantir que as estratégias adotadas sejam coerentes em termos conceituais e viáveis em sentido prático" (Larvie, 2001, p. 24). ${ }^{17}$

O serviço, inaugurado oficialmente em junho de 1999, foi afetado por uma crise mais ampla, que atingiu a Secretaria de Segurança em março do ano seguinte, resultando na demissão de Luiz Eduardo Soares e, consequentemente, na saída da equipe que o acompanhava. ${ }^{18}$ De acordo com Martins, a sustentação desse projeto no governo se concentrava nesse conjunto de pessoas. Com a sua saída, tornou-se evidente a "falta de interlocução entre a Secretaria [...] e a coordenação do DDH", que "só se sustentava pela intervenção direta de Luiz Eduardo e sua equipe, e não numa parceria entre o governo e grupos comunitários" (Larvie, 2001, p. 82). Luiz Eduardo relata que muito tempo foi despendido em persuadir o governador para que os "projetos ganhassem vida própria”:

A única forma de defender nossa politica era colocá-la em prática e torná-la real, visivel, socialmente reconhecida e aprovada, antes que desse na telha de Garotinho inventar uma ideia qualquer incompativel com nossos programas e com a sequência lógica de sua implantação. Isso me levou a colocar na rua vários projetos ainda insuficientemente amadurecidos e insuficientemente negociados com as policias, o que reduziu sua qualidade, suas chances de êxito e desgastou minha liderança junto às corporaçóes (Entrevista publicada em Steil et al., 2001, p. 269). ${ }^{19}$

\footnotetext{
${ }^{17}$ Análises sobre a experiência do Disque Defesa Homossexual realizadas pelo grupo de pesquisadores envolvidos no processo podem ser encontradas em "Violência e minorias sexuais". Comunicaçöes do Iser, Rio de Janeiro, ano 20, n. 56, 2001.

${ }^{18}$ Com a justificativa de que havia uma ligação entre Luiz Eduardo Soares e o cineasta João Moreira Salles que, por sua vez, forneceria uma "mesada" para o traficante Marcinho VP, naquele momento procurado pela polícia, o governador demitiu o subsecretário ao vivo, durante a transmissão de um programa de TV. Para a versão do próprio Luiz Eduardo Soares sobre o episódio, ver Soares (2000).

${ }^{19}$ Nessa entrevista, Luiz Eduardo Soares fala sobre o episódio de sua demissão do governo e reflete sobre a relação entre a sua formação como antropólogo e cientista político e a prática na atuação administrativa, em especial sobre a experiência na Secretaria de Segurança Pública do Rio de Janeiro.
} 
O investimento em comunicação, no relacionamento com a mídia e com a opinião pública era uma das estratégias valorizadas pelo então subsecretário para consolidar uma nova política de segurança pública para o estado. Uma aposta que envolvia a "performance pública e a construção midiática das persone dos gestores”: seria esse o espaço em que "a gestão política intervém na esfera das percepções públicas, das interpretaçôes sobre os eventos da vida cotidiana [...]" (Soares, 2002, p. 22).

Do ponto de vista de Cláudio Nascimento, o ponto fraco naquele momento estava de fato relacionado à falta de estrutura do projeto:

Uma das fragilidades naquele momento é que não haviamos conseguido ainda um acúmulo de forças para que a politica que se iniciava tivesse uma consistência maior, do ponto de vista inclusive de sua estruturaçâo. No sentido de ter uma equipe técnica estruturada para a ação, de estar dentro da estrutura da Secretaria, de não ser algo conduzido pelo movimento, que na época foi o que aconteceu. A Secretaria deu o espaço, deu o telefone e era a sociedade civil que dirigia o serviço. Na época, a compreensão de parte do movimento era de que isso era bom, então, poucos divergiram; o Grupo Arco-Íris, um ou outro militante, em separado, mas a maioria dizia: 'concordamos que esse é o caminho que a gente quer agora, e que a gente tem que acumular'. O Arco-Íris continuou participando com uma atitude crítica pública, masparticipou. Na época, [...] primeiro foi o Atobá que coordenou com o Fábio, depois foi a Yone Lindgren, pelo Movimento D'Ellas, eu participava pelo Arco-Iris, a Jussara Bernardes. Nós tínhamos uma critica muito forte, havia uma reflexão muito grande que a gente estava enxugando gelo, tentando fazer uma coisa que náo conseguia ter resposta, que, internamente, ficava no favor [...]. E como também não era reconhecido dentro da estrutura, então você não tinha como mandar um ofício para um outro órgáo cobrando uma determinada questão, porque era visto como um serviço da sociedade civil, apoiado pelo governo, mas não necessariamente havia obrigação de setores do poder público de dar resposta para aquilo, principalmente setores de segurança, que eram, e ainda são, os mais resistentes a esse tipo de questão. Então, nós aprendemos, por exemplo, que era preciso estar 
dentro da agenda pública, era preciso ser algo assumido pelo governo do estado, algo que estivesse dentro da agenda da Secretaria, algo que tivesse a presença de diversos órgãos [...].20

Martins (2002) reproduz a fala de um "militante"21 a respeito do progressivo enfraquecimento do Disque Defesa Homossexual (DDH) após a demissão do subsecretário:

[A]gora nós temos problemas sérios, que aí é uma discussão sobre o $D D H$, não só sobre o DDH, mas sobre políticas públicas voltadas para a minoria dos setores discriminados na SSP [Secretaria de Segurança Pública], que dá pra pensar o que é política de Estado e o que é politica de Governo. Isso é um grande problema hoje, porque, por exemplo, o DDH, num primeiro momento, ficou mais como politica de governo, que na verdade é uma política da Secretaria e, à medida que sai o secretário, esvazia, há uma tentativa de esvaziamento total do serviço [...] e ai é que vem o problema que é não só do governo atual, mas também preocupações para nós enquanto organizaçôes e também implementadores de politicas. Porque na politica do governo, o governo sai, e sai a política também [...] (p. 80).

Uma vez que a gestão foi trocada, os laços e as alianças que contribuíam para o andamento do projeto foram perdidos, e a política, desestruturada. Como não existia nenhum estatuto formal

${ }^{20}$ Entrevista realizada em outubro de 2011 no âmbito do projeto Retratos da Política LGBT no Estado do Rio de Janeiro, coordenada pelo LIDIS/UERJ.

${ }^{21}$ Para o desenvolvimento de seu trabalho a respeito do processo de implantação do Disque Defesa Homossexual, Martins (2002) utiliza como recurso analítico a distinção dos atores envolvidos no projeto em "três categorias: os militantes, os executores [aqueles que gerenciavam o serviço] e os pesquisadores", como no trecho: "Correndo o risco de ser simplista, eu poderia dizer que a violência tinha para cada participante do projeto um significado: como dado a ser colhido e relativizado (pesquisadores), um problema a ser administrado (executores) e uma fonte de exposição na mídia para certas reivindicações e fortalecimento da 'luta política' e um certo discurso de 'vitimização' (militantes)" (p. 16-7). Para o autor, naquele momento entre tais categorias "havia uma disputa, nem sempre velada, pelo controle do serviço e pela definição do seu 'verdadeiro' papel” (p. 75). Como será visto logo adiante, apesar de ter encontrado uma distinção semelhante entre três categorias de sujeitos durante a minha pesquisa de campo, não poderia dizer que a minha interpretação sobre as relaçôes estabelecidas entre elas seja semelhante à do autor. 
estabelecendo o serviço, seu funcionamento ficava vulnerável às vontades da administração responsável. ${ }^{22}$

Os então "homossexuais" não foram a única "minoria" priorizada pelo programa desenhado pela equipe multidisciplinar da Subsecretaria de Segurança. Centros de Referência de Proteção de Minorias foram criados com ênfase na violência contra a mulher, negros, crianças e adolescentes. Silvia Ramos, que na época ocupava a posição de subsecretária adjunta, explica que a proposta era "de incorporação de conhecimentos, cultura, prioridades e potencialidades de comunidades delimitadas pela vulnerabilidade específica à violência”. Os centros de referência visavam a:

i. romper o círculo vicioso de desconfiança, ressentimento, medo e intolerância, de parte a parte, na relação entre polícia e minorias;

ii. aproximar segmentos fragilizados diante da violência, que nunca ou raramente tinham sido incluidos nas prioridades de politicas de segurança;

iii. aproveitar a parceria desses setores e desenvolver programas de cooperação em relação às tarefas de sensibilização e capacitação dos profissionais de segurança e de outros funcionários do estado em relação aos direitos das minorias e à valorizaçâo das diferenças;

iv. usar o conhecimento e o potencial de mobilização desses grupos para desenvolver politicas de prevenção à violência mais eficientes, compreensivas e inteligentes (mimeo, $\mathrm{s} / \mathrm{p}$ ).

De acordo com Ramos, o centro de referência de combate à violência contra homossexuais, do qual o $\mathrm{DDH}$ fazia parte, foi o primeiro a ser implantado e, assim, serviu de modelo para os demais,

\footnotetext{
${ }^{22}$ Em março de 2000, o deputado Carlos Minc chegou a protocolar uma proposta de lei (Projeto de Lei n.o 1.370/2000) que objetivava transformar o projeto do DDH em um serviço permanente da Secretaria de Segurança Pública do Estado do Rio de Janeiro. De acordo com o site da Alerj, o último movimento de tramitação do projeto data de 2008.
} 
sempre envolvendo protagonistas dos respectivos movimentos sociais e organizações que já tratassem dos temas. As atividades começaram com aulas para policiais, ministradas por integrantes do então chamado "movimento homossexual", e visitas de grupos de travestis a batalhões da Polícia Militar.

A ênfase na produção de dados, é importante notar, era uma orientação ampla e geral das políticas pensadas pela equipe coordenada por Luiz Eduardo Soares, que, não por coincidência, estava alocada na Subsecretaria de Pesquisa e Cidadania. Em relação à violência contra homossexuais, até aquele momento, os únicos dados existentes provinham das notícias de jornal contabilizadas pelo GGB e, em sua maioria, tratavam de assassinatos. Sendo assim,

a primeira providência ao criar o Disque Defesa Homossexual (DDH) - linha de atendimento direto à população homossexual dentro da Secretaria de Segurança - foi a criação de um banco de dados com registros detalhados dos casos atendidos pelos voluntários do movimento gay (Ramos, mimeo., s/n).

Um dos diferenciais da implantação do DDH foi o envolvimento de pesquisadores na articulação, decisivo para que o serviço não funcionasse apenas para o atendimento de vítimas. Cada atendimento gerava uma ficha de cadastro que alimentava diretamente um banco de dados. Havia o entendimento de que, além de aprofundar a compreensão dos tipos e das formas de violência que acometem "homossexuais", para usar os termos da época, os dados poderiam funcionar como instrumento de pressão para o fomento de políticas direcionadas a estes. Outro diferencial do atendimento, correlato a esse primeiro, era o fato de os dados coletados partirem diretamente das vítimas, e não de notícias de jornal, o que permitiu que dinâmicas variadas de discriminação e agressão relacionadas à homofobia fossem vislumbradas para além dos assassinatos veiculados pelos jornais (Ramos, 2001).

Em artigo no qual percorrem o tipo de conhecimento produzido nas relaçôes entre ativismo LGBT e academia, Silvia Ramos e Sergio Carrara (2006) debruçaram-se sobre dados produzidos pelo GGB, 
pelo DDH e pelos surveys aplicados nas Paradas do Orgulho LGBT. Os autores destacam o final da década de 1990 como um momento de inflexão que marca a conversão da denúncia em ação. Os autores argumentam que o movimento homossexual, em contraste com o movimento negro ou as mobilizaçôes contra a "violência de gênero", foi lento em dar início à proposição de ações efetivas, fixando-se "durante muito tempo num modelo estereotipado de "violência contra homossexuais' (os assassinatos)" (Ramos e Carrara, p. 198).

Como já comentado no capítulo 3, a análise dos dados levantados por meio do $\mathrm{DDH}$ revelou a "intensidade de dinâmicas cotidianas e silenciosas de homofobia": a maioria das denúncias se referia a agressões verbais e físicas, a discriminações vivenciadas em locais de comércio, trabalho, escola, família e vizinhança, revelando em grande dimensão a ocorrência de "crimes não espetaculares e não letais, gerados e vividos em escala microssocietária, na esfera da família e de conhecidos. Uma criminalidade, em geral, "sem fins lucrativos", em que vítimas e agressores compartilham das mesmas redes sociais (Ramos, 2001, p. 193). Essa dinâmica viria a ser corroborada pelos levantamentos dos diversos surveys aplicados nas Paradas do Orgulho até o presente momento. ${ }^{23}$ Então, uma outra compreensão da violência associada à homofobia surgiu a partir da reunião de novos dados, tendo como consequência a possibilidade da assunção de novas formas de ação:

As experiências do tipo do DDH e as pesquisas desenvolvidas a partir da década atual passaram a demonstrar que, em contraste com as dinâmicas de violências de gênero e de racismo (que por serem mais homogêneas permitem respostas focalizadas), a homofobia opera com muitas variáveis e engloba fenômenos dispares, que vão desde discriminaçóes na esfera doméstica a crimes com fins de lucro. Por

\footnotetext{
${ }^{23}$ A título de exemplo, a última pesquisa realizada na Parada do Rio de Janeiro, em 2012, revelou que $70 \%$ dos entrevistados já haviam sofrido algum tipo de discriminação relacionada à orientação sexual/ identidade de gênero. Entre "homens homossexuais", 62\% das situações de discriminação ocorreram em contextos que envolvem relações sociais de proximidade, como família, amigos e vizinhos. Para "mulheres homossexuais", a porcentagem de discriminaçōes no mesmo contexto foi de $40 \%$ (Pesquisa Mobilizaçâo, Violência e Políticas LGBT- Parada Orgulho, Rio 2012. Ver Carrara et al., 2017).
} 
essa razão, as estratégias de enfrentamento desses fenômenos e os discursos produzidos pelo movimento homossexual têm que reconhecer essa complexidade e mobilizar demandas especificas para diferentes violências (Ramos e Carrara, 2006, p. 198).

A experiência do DDH disparou, na época, a implementação de outras iniciativas semelhantes em Belo Horizonte, Brasília e Goiânia. O Centro de Referência e o DDH continuaram a funcionar de forma bastante enfraquecida até 2006. Durante esse período, houve algumas tentativas de reestruturação, mas a sistematização dos dados foi descontinuada.

As análises sobre tal experiência "pioneira”, realizadas por alguns dos responsáveis pelo projeto, conferem importância também ao significado simbólico de criar estruturas no plano governamental especificamente voltadas para o combate desse tipo de violência. Luiz Eduardo Soares, em avaliação dos efeitos das ações por ele capitaneadas, enfatiza especialmente três políticas que, segundo a sua visão, ocuparam lugares simbolicamente "desestabilizadores" no sentido de refundar valores e padrões: "a Campanha de Desarmamento, o Centro de Referência contra a Discriminação Homofóbica e os projetos contra a violência doméstica”.

[C]olocávamos em xeque a matriz em que se articulava a constelação semiológica dominante, em cuja sintaxe combinavam-se poder enquanto afirmação falôcentrica, armas de fogo e estigmatizaçôes homofóbicas e misóginas. Essa conexão triádica produzia um enunciado latente de natureza sexista, discriminatória e intrinsecamente subordinado à violência que, supostamente, destina-se a combater ou controlar. Em sintese, esse triângulo simbólico enunciava a mensagem: a ordem, os atores e os instrumentos que a produzem são masculinos, não havendo lugar, em sua estrutura, para a diferença, cuja integração imporia uma inflexão radicalmente democrática e pacífica ao conceito e às práticas da segurança pública (Soares, 2002, pp. 29-30). 
Com sentido semelhante, Silvia Ramos avalia que as ações propiciavam um novo repertório de amplo alcance de imagens e representações sobre homossexualidade e direito à diferença:

O impacto provocado por esse tipo de atividade revelou que essas iniciativas podem ter um alcance maior do que apenas as próprias populaçóes diretamente beneficiadas (as minorias). Elas mobilizam extraordinário interesse da midia, despertam outros setores da sociedade sobre o potencial de mudanças que podem ocorrer no âmbito da segurança (por exemplo, estimula a participação de associaçóes de moradores) e, por extensão, como num círculo virtuoso, as açóes atingem de volta a própria policia, que pode descobrir numa 'aula' com um professor do movimento gay ou do movimento negro - pela valorização que a atividade recebe na televisão, na família ou entre os colegas - uma oportunidade para desidentificar-se dos estigmas da incivilidade e para aderir a signos da urbanidade e da modernidade (Ramos, mimeo, s/p).

Ainda de acordo com essa autora, o interesse e o respeito com que a mídia veiculou dados e ações do $\mathrm{DDH}$ foram fundamentais nesse processo de "construção de experiências" e tiveram repercussão nas relações estabelecidas entre "militância, órgãos de governo, mídia e sociedade". Silvia Ramos destaca especialmente o impacto midiático de um primeiro encontro entre militantes e policiais:

No caso do Rio de Janeiro, o tratamento que a midia deu a uma aula (apenas uma, mas com enorme significado simbólico) que o secretário geral da ABGLT, Cláudio Nascimento, ofereceu à policia civil antes da implantação do DDH expressa essa dinâmica curiosa de reversão de expectativas, em que um grande preconceito pode se converter em um simbolo de modernidade para uma instituiçáo policial que quer parecer nova e se identificar com o profissionalismo (2001, p. 64). ${ }^{24}$

\footnotetext{
${ }^{24}$ Ver anexos: "Policiais se preparam para atendimento modelo", jornal $O$ Globo, 2 de março de 1999; "Política do rosa-choque muda a relação dos policiais com homossexuais no Rio", jornal $O$ Globo, 27 de junho de 1999; "Homossexuais sofrem extorsōes", jornal $O$ Globo, 9 de setembro de 2000;
} 
Essas avaliaçōes do sentido simbólico de uma política falam sobre implicaçōes que se estendem para além do cotidiano de um serviço ou projeto. E aqui, mais especificamente, permitem-nos indagar a respeito de como as relaçōes de gênero, intricadas com concepções a respeito de sexualidade, podem provocar perturbaçōes e atribuir características específicas a gramáticas de formulação e implantaçăo de políticas governamentais. Volto mais adiante a tratar do que diz respeito às interpelaçōes de gênero que esse tipo de política pode imprimir em determinadas instituiçôes e sujeitos. Por ora, gostaria de destacar o profundo investimento em uma nova perspectiva que recobria um conjunto de iniciativas, entre as quais o Disque Defesa Homossexual e o Centro de Referência de Combate à Violência contra Homossexuais.

Há certa continuidade entre o processo precursor de fins da década de 1990 e a história mais recente da "política LGBT" no Rio de Janeiro: o pioneirismo, a inovação, o investimento na relação com a mídia e, como será visto a seguir, a articulação entre pesquisadores, ativismo e executores de políticas envolvidos no esforço de "fazer do tema da violência contra os homossexuais um problema de Estado" (Martins, 2002, p. 95).

Apesar de tais processos guardarem certas semelhanças, a SuperDir e seus serviços na capital, ainda que estejam fisicamente localizados no mesmo prédio que a Secretaria de Segurança Pública, estão institucionalmente estruturados na Secretaria de Assistência Social e Direitos Humanos. Tal fato pode provocar o deslocamento da concepção das atividades desenvolvidas. Seria possível argumentar que a assunção de outra compreensão, mais ampliada, sobre a violência homofóbica, vislumbrada por meio de levantamentos como os compilados pelo DDH e, mais tarde, nas Paradas do Orgulho, tenham ampliado também as possibilidades ou a necessidade de respostas para o problema, que claramente não se restringe a uma questão de polícia ou segurança pública. Esse deslocamento descortinou a necessidade de

\footnotetext{
"Violência no reduto de defesa homossexual", jornal O Globo, 29 de junho de 2003. Ver anexos: C19, C20, C21, C22, C23, C24 (p. 371 a 376).
} 
ações em outros âmbitos, mobilizando redes de assistência e proteção mais amplas do que a policial.

Olhar para iniciativas no plano administrativo governamental implica reconhecer que os "jogos da política” estão atrelados a conexões pessoais, "climas favoráveis”, negociações e arranjos políticos de variadas ordens. Avançando no tempo, alguns antecedentes mais imediatos da implantação da política Rio Sem Homofobia remontam a uma carta-compromisso assinada em 10 de outubro de 2006 pelo então candidato ao governo do estado, Sergio Cabral (PMDB). A carta "Compromissos por um Rio Sem Homofobia" consistiu em um documento acordado com lideranças do movimento local ${ }^{25} \mathrm{e}$ articulado pela deputada federal Cida Diogo (PT) e pelo deputado estadual Carlos Minc (PT), envolvendo dez "compromissos" em troca de apoio. Um pequeno trecho da carta:

\section{Compromissos por um Rio Sem Homofobia}

Na qualidade de candidato ao Governo do Estado do Rio de Janeiro acompanho com preocupação a questão do preconceito, da discriminação contra o segmento de gays, lésbicas, travestis, transexuais e bissexuais (GLTB) em nosso estado e reconheço a necessidade de implementação de politicas para o combate à homofobia e promoçáo da cidadania de GLTB. Sendo assim, caso seja eleito governador do Estado do Rio de Janeiro, assumirei o compromisso de incorporar, nas realizaçóes do governo, o seguinte:

\footnotetext{
${ }^{25}$ Segundo um informe divulgado pelo Grupo Arco-Íris na época, "estiveram presentes no encontro Cláudio Nascimento, membro do Grupo Arco-Íris de Conscientização Homossexual e secretário de ações para os direitos humanos da ABGLT; Julio Moreira, diretor do Grupo Arco-Íris de Conscientização Homossexual; Majorie Marchi, presidenta da Associação de Travestis e Transexuais do Rio; Katia Jones, diretora da Associação de Travestis e Transexuais do Rio; Vera Couto, diretora do Movimento D’Ellas e da equipe Técnica do Centro de Referência contra a Discriminação a Homossexuais do Estado do Rio; Renato Marques, presidente do Grupo Diversidade Niterói; Victor de Wolf, diretor do Grupo Diversidade Niterói; e Rosangela Castro, coordenadora do Grupo Felipa de Souza. Também participaram da reunião a deputada estadual Cida Diogo e o deputado estadual Carlos Minc, que articulou o encontro". O informe bem como a íntegra da carta-compromisso encontram-se no anexo C26 (p. 380-382). Ver também "Cabral participa de reunião com grupos gays". Jornal O Globo, 10/10/2006 (anexo C25, p. 377-379).
} 
1. Apresentar, nos primeiros dois meses de governo, um plano detalhado para a aplicação da Lei 3.406 de 2000, com (A) capacitação do pessoal da área de fiscalização; (B) divulgação da lei; (C) criação da Coordenadoria de Defesa, Promoção e Garantia de Direitos de GLBT na Secretaria Estadual de Direitos Humanos para sua aplicação; (D) criação do fundo contra a violência, para acolher os valores advindos das multas cobradas aos estabelecimentos penalizados, com a devida participação da sociedade civil no acompanhamento da aplicação desses recursos em açöes especificas. Todos esses itens foram definidos na regulamentação e até hoje não foram cumpridos. (grifo meu).

2. Conceder imediatamente todos os pedidos de pensão para companheiros do mesmo sexo de funcionários públicos estaduais cuja uniäo for devidamente comprovada conforme prevê a Lei 3.786 de 2001. Hoje são mais de 50 pedidos de pensäo que se encontram engavetados no Instituto de Previdência do Estado do Rio de Janeiro por preconceito e discriminação.

3. Criar até o quarto mês de governo o Programa Rio Sem Homofobia, açôes governamentais de combate à discriminação contra GLBT e promoção de sua cidadania, nas diversas pastas do Executivo. Para isso criará no primeiro mês de trabalho uma Comissáo Técnica para Elaboração do Programa, com a participação de entidades de defesa dos direitos GLBT. O governo dotará o Programa de verbas para a implementação de açôes nos municípios do estado e no apoio às iniciativas das organizaçôes GLBT. (grifo meu).

Vemos que entre os compromissos do então candidato constavam a criação de um organismo na esfera de governo para lidar com a "promoção e garantia de direitos LGBT", a concepção do Programa Rio Sem Homofobia, além de outros "compromissos" que tratavam da elaboração de um "centro de referência contra a discriminação a 
homossexuais" e um "Disque Defesa Homossexual". Sérgio Cabral iniciou o seu mandato em 2007 e foi reeleito em 2010.

Cabe lembrar que, anos antes, Sérgio Cabral, então deputado estadual, e o também deputado Carlos Minc haviam conduzido uma iniciativa importante ao proporem o Projeto de Lei 2.385/2001. O projeto visava a equiparar à "condição de Companheira ou Companheiro" os parceiros do mesmo sexo de servidores públicos estaduais que mantivessem relacionamentos de união estável, estendendo a eles(elas) benefícios previdenciários e direitos civis, como "os preceitos legais incidentes sobre a união estável entre parceiros de diferentes sexos". O Projeto de Lei foi vetado pelo então governador Anthony Garotinho (PDT), sob a justificativa de "vício de inconstitucionalidade" formal e material, além de "subverter o princípio de separação entre os poderes". ${ }^{26}$

Em maio de 2007, durante cerimônia realizada no jardim de inverno do Palácio da Guanabara, Sérgio Cabral, já governador do estado, sancionou a Lei 5.034/07, que, nos moldes do projeto anteriormente vetado, prevê a concessão de benefícios para parceiros de mesmo sexo de servidores públicos. ${ }^{27}$ Nessa mesma cerimônia, respondendo a um convite de Benedita da Silva, então secretária da SEASDH, Cláudio Nascimento foi empossado como superintendente de Direitos Individuais, Coletivos e Difusos. Ele conta que as conversas sobre o convite começaram no fim de 2006 e que, a princípio, ele se sentiu "receoso" em aceitar, mas seguiu dialogando com "os setores do movimento" até se sentir seguro quanto à proposta. Naquele momento, Cláudio era um dos diretores do Grupo Arco-Íris e um dos secretários da ABGLT. A SuperDir já era uma estrutura existente na secretaria do governo, mas não estava em atividade:

\footnotetext{
${ }^{26}$ Segundo a justificativa, o projeto contrariava o disposto no $₫ 3 .^{\circ}$ do artigo 226 da Constituição, no qual a união estável é definida como aquela formada entre homem e mulher, incorrendo, portanto, em "vício de constitucionalidade material". Além disso, a Constituição fluminense define que matérias envolvendo servidores públicos só podem ser de iniciativa do Poder Executivo e, por ser proposta dos deputados, o Projeto de Lei incorreria em "vício de inconstitucionalidade formal" (ver Diário Oficial do Estado do Rio de Janeiro, Poder Legislativo, 7 de janeiro de 2002, Ano XXVIII, n. ${ }^{\circ}$ 4, Parte II, p. 3).

${ }^{27}$ Ver anexos C27 e C28 (p. 383 e 384).
} 
Quando a Benedita veio colocar o convite, eu disse para ela e para o governador, para eles dois, que tinha que deixar claro quais eram as açōes prioritárias nessa superintendência, que eu achava até melhor que não fosse Superintendência de Direitos Individuais, Coletivos e Difusos, pois era um nome muito amplo, que fosse algo mais especifico, mas já havia essa estrutura vaga e eles acharam que dava para trabalhar o tema dentro dessa superintendência. Eu disse, então, tudo bem, mas priorizando os eixos: a gente estava priorizando como eixo de atuação a questão LGBT, a intolerância religiosa e a discriminação por estado de saúde - três áreas que a gente abarcou. ${ }^{28}$

Segundo um boletim divulgado em 2007,

[A] Superdir iniciou suas açōes de combate à discriminação e promoção da cidadania junto à população GLBT (gays, lésbicas, bissexuais, travestis e transexuais); pessoas discriminadas por estado de saúde (HIV-Aids, tuberculose e hepatites); comunidades de religioos de matrizes africanas; comunidade judaica e outras populaçôes discriminadas em razão de sua nacionalidade, origem, religiosidade, além das intolerâncias correlatas e das múltiplas formas de discriminação.

O novo superintendente assumiu o cargo tendo como meta a criação de um programa de combate à homofobia no estado. Cerca de um mês após a posse, celebrando o 28 de junho, Dia Mundial do Orgulho LGBT, outra grande cerimônia foi realizada no Palácio da Guanabara para a assinatura do decreto que criou a Câmara Técnica para a elaboração do Programa Rio Sem Homofobia, o primeiro do tipo a ser implantado por um estado do Brasil.

De acordo com o decreto, sob a coordenação da SuperDir, a Câmara Técnica seria composta por "especialistas acadêmicos" e organizaçôes da sociedade civil "de renomada expertise e trabalho sobre promoção da cidadania e combate à homofobia”, parlamentares

\footnotetext{
${ }^{28}$ Entrevista realizada em outubro de 2011 no âmbito do projeto Retratos da Política LGBT no Estado do Rio de Janeiro, coordenada pelo Lidis-UERJ.
} 
estaduais e representantes de governo da administração pública estadual. ${ }^{29}$ Mais dois meses se passaram, e uma resolução da SEASDH-RJ, publicada em 14 de agosto de 2007, designou nominalmente os 28 membros a comporem o grupo de elaboração do Programa Rio Sem Homofobia. ${ }^{30}$

A Câmara Técnica trabalhou durante seis meses, reunindo representantes das secretarias do estado e representantes de grupos de militância. De acordo com Cláudio Nascimento, as primeiras reuniōes tiveram como objetivo o "nivelamento de informaçôes" e valeram-se em grande medida dos dados oriundos dos surveys realizados durante as Paradas do Orgulho:

Primeiro era necessário a comunidade e os movimentos conhecerem a secretaria, os seus projetos, suas açóes existentes e o que já estava planificado em linhas gerais, como pode-ria ser entáo encaixado ou como as propostas poderiam dialogar com as politicas gerais existentes, os programas. Além disso, era preciso que a secretaria entendesse quais eram as demandas da comunidade, as questóes identitárias, nomenclaturas, todas essas questóes, e também analisar quais eram as principais necessidades da comunidade. Para isso, foi muito importante contar com as pesquisas e com o apoio da UERJ e do CESeC. Essas duas pesquisas, de 2003 e 2004, foram base importante para orientar o diagnóstico da política pública estadual [...], o principal dado era aquele que ainda perdura, que menos de $8 \%$ das pessoas procuravam os órgãos de defesa dos direitos, portanto, mostrava uma situação de orfandade muito grande da comunidade em face da proteção das suas situaçóes de violação. ${ }^{31}$

Do trabalho realizado durante esse conjunto de encontros da Câmara Técnica, foi elaborado um relatório que serviu de base para

\footnotetext{
${ }^{29}$ Decreto 40.822, de 26 de junho de 2007. Ver anexo C29 (p. 385).

${ }^{30}$ Resolução SEASDH-RJ n. ${ }^{\circ}$ 032, de 14 de agosto de 2007. Ver anexo C29 (p. 385).

${ }^{31}$ O entrevistado refere-se a Carrara et al. (2003) e Carrara e Ramos (2005). Entrevista realizada em outubro de 2011 no âmbito do projeto Retratos da Política LGBT no Estado do Rio de Janeiro, coordenada pelo LIDIS/UERJ.
} 
o "caderno de propostas", contendo "metas", "eixos", "diretrizes" e "propostas de ação", apresentado para alimentar as discussōes durante o processo das conferências realizadas no estado do Rio de Janeiro, previamente à I Conferência Nacional LGBT de 2008. As propostas buscavam envolver todas as Secretarias do governo do estado.

O decreto que estabeleceu a realização da conferência estadual foi publicado em 28 de fevereiro de 2008. Entre as finalidades do evento aclaradas em seu texto, constava "avaliar e propor estratégias para implantar o Rio Sem Homofobia”. O processo das conferências regionais, oito no total, transcorreu entre os meses de março e abril de 2008, e a conferência estadual aconteceu entre os dias 16 e 18 de maio do mesmo ano, nas dependências da UERJ.

De acordo com o relatório produzido pela SuperDir, as conferências regionais, que elegeram os delegados para a etapa estadual, reuniram aproximadamente cem participantes cada uma, com exceção da conferência da capital, que contou com a participação de cerca de quatrocentas pessoas. Já a conferência estadual mobilizou 341 delegados (263 da "sociedade civil" e 78 do "poder público") e mais 351 participantes registrados como "observadores" ou "convidados".

As conferências regionais aconteceram em municípios determinados, mas a responsabilidade pela coordenação dos trabalhos ficou a cargo da Superintendência do governo do estado. Durante a preparação para os eventos locais, a Superintendência precisava mobilizar grupos de trabalho regionais, e não foi em todas as cidades que os coordenadores encontraram o "Movimento LGBT local", como preconizado no decreto que as convocou, ${ }^{32}$ e as relações foram estabelecidas de maneiras variadas:

Então, tem lugares que você tem a presença da sociedade civil organizada em grupos, associaçóes e entidades; tem lugares que tem a sociedade civil, mas pessoas que são ativistas independentes, que ainda

\footnotetext{
${ }^{32}$ Segundo o decreto que convocou a conferência estadual, uma das finalidades das etapas regionais era "discutir a interiorização e a ampliação da participação de Movimento LGBT local e gestores públicos locais e eleição dos delegados para a Conferência Estadual" (Decreto n. ${ }^{\circ} 41.196$, de 28 de fevereiro de 2008; ver anexo C1, p. 339).
} 
não estão se construindo no coletivo, no movimento, mas que são até muito orgânicos enquanto atuação LGBT na sua cidade, na sua região. A gente encontrou muitos lugares assim, principalmente no interiorzão, que tem sempre uma pessoa que é uma figura representativa; às vezes é uma figura exótica, ou uma figura muito politica, mas todos com um papel de influência, de alguma forma, na cena local. [...] Tem lugar que náo tem grupo gay, mas tem organizador de parada; tem lugar que tem organizador de festa, mas não sabe nada das questóes de direitos de $L G B T$, mas tem interesse; tem lugar que tem grupos organizados; tem lugar que tem LGBTs que são servidores públicos, de carreira, inclusive, estatutário, e que queriam tratar desse tema também na sua cidade. Com isso, a gente conseguiu talvez uma coisa importante: gerar uma maior capilaridade da cena LGBT dentro do estado [...]. [H] oje eu posso contar com pessoas em pelo menos cinquenta municipios; antigamente, a gente não sabia exatamente... ${ }^{33}$

Essa forma de organização das conferências ressalta o seu papel produtor de sujeitos politicamente mobilizados para a questão. Nota-se que a preparação do encontro, coordenada por uma instância de governo e originada por um decreto, alimenta a produção de movimentos sociais e políticos, envolve distintos sujeitos e instrumentaliza discursos.

A conferência estadual contou com a presença de Benedita da Silva, então secretária de Assistência Social e Direitos Humanos do Governo do Estado. Na ocasião, a secretária se comprometeu a criar um serviço telefônico de atendimento para "orientar, acolher e encaminhar LGBT para a rede de proteção social”, centros de referência para o apoio de vítimas de homofobia, o conselho estadual de direitos de LGBT, entre outras ações, todas propostas pela Câmara Técnica do Programa Rio Sem Homofobia. Assim, destaca Cláudio Nascimento, "a conferência de 2008 foi importantíssima para dar a tônica de qual era a agenda, quais eram as prioridades".

\footnotetext{
${ }^{33}$ Entrevista realizada em outubro de 2011 no âmbito do projeto Retratos da Política LGBT no Estado do Rio de Janeiro, coordenada pelo LIDIS/UERJ.
} 
Outro "marco" destacado como um dos resultados da conferência de 2008 foi a "Carta Compromisso da Universidade do Estado do Rio de Janeiro por um Rio Sem Homofobia". O documento, assinado pelo reitor, contemplava sete itens, entre os quais: apoiar a implantação do Programa Rio Sem Homofobia; criar um laboratório de políticas públicas LGBT na universidade; estabelecer atos administrativos, permitindo o uso de banheiros femininos por travestis e transexuais e do nome social; estabelecer resolução punindo atos homofóbicos nas instalações da Universidade e no Hospital Universitário Pedro Ernesto (HUPE/UERJ); e a permissão de acompanhamento em consultas, exames e internações de companheiros/as do mesmo sexo de usuários do HUPE.

Em abril de 2009 foi publicado o decreto que criou o Conselho LGBT do Estado do Rio de Janeiro, vinculado à Superintendência de Direitos Individuais, Coletivos e Difusos. De acordo com o decreto, o Conselho é composto por quarenta integrantes, $40 \%$ do "poder público" e $60 \%$ da "sociedade civil". No poder público estão 12 representantes de secretarias do estado e representantes do Ministério Público Estadual (MPE), da Assembleia Legislativa do Estado do Rio de Janeiro (Alerj), da Defensoria Pública Geral do Estado do Rio de Janeiro (DPGE) e da Ordem dos Advogados do Brasil (OAB-RJ), um para cada órgão, configurando um total de 16 integrantes. As 24 vagas destinadas à "sociedade civil", segundo o decreto, ficam distribuídas entre "organizações LGBT" (18 vagas), "organizaçôes de Direitos Humanos" (três vagas) e "Especialistas e acadêmicos de renomada expertise e trabalho sobre promoção da cidadania LGBT e combate à homofobia" (três vagas).

De caráter "deliberativo", o Conselho foi criado com a finalidade geral de: "elaborar, acompanhar, monitorar, fiscalizar e avaliar a execução de políticas públicas para lésbicas, gays, bissexuais, travestis e transexuais". O decreto de sua criação indica ainda 11 "competências" específicas para o Conselho, todas definidas em termos de "estimular", "apoiar", "propor", "fiscalizar" ações, leis, propostas e iniciativas visando a assegurar ou 
promover direitos para a "população LGBT" e combater a discriminação por orientação sexual/identidade de gênero. ${ }^{34}$

Outro "marco" ou "conquista" do ano de 2009 foi realizado junto à Chefia de Polícia Civil do Estado do Rio de Janeiro. A partir de junho daquele ano, os Registros de Ocorrência lavrados em delegacias do estado permitem assinalar "homofobia" como "motivo presumido" da ocorrência. ${ }^{35}$

Assim, desde o início de seu funcionamento, a Superintendência de Direitos Individuais, Coletivos e Difusos esteve envolvida com a elaboração do Programa Rio Sem Homofobia, com a organização das conferências LGBT e, eventualmente, com o encaminhamento de denúncias de homofobia que chegavam de maneira não sistematizada ao seu conhecimento. Mas, foi somente a partir de 2010, com a estrutura física de funcionamento e o orçamento garantido, que os centros de referência começaram a funcionar, sendo preciso lidar com um novo tipo de estruturação burocrático-administrativa inerente à gestão desse tipo de serviço.

De acordo com uma publicação do Programa Rio Sem Homofobia, de junho de 2012, até essa data, os centros de referência já teriam realizado mais de 8 mil atendimentos. ${ }^{36}$ Os centros funcionam por projetos. Então, a cada 12 meses, toda a estrutura montada e as ações planejadas correm virtualmente o risco de serem desmanteladas simplesmente por falta de verba ou "vontade política". Para remediar essa situação, o esforço feito é o de comprometer parceiros, envolver outras secretarias e promover muita visibilidade para as açôes. Espera-se, assim, que a falta de apoio ocasionada por uma eventual troca de gestão, que não seja exatamente apoiadora ou comprometida com "a causa",

\footnotetext{
${ }^{34}$ Tal qual nos exemplos: "IV - estimular, apoiar e desenvolver o estudo e o debate das condições em que vive a população LGBT urbana e rural, propondo políticas públicas, objetivando eliminar todas as formas identificáveis de discriminação; $\mathrm{V}$ - propor e estimular políticas transversais de inserção educacional e cultural, com o objetivo de preservar e divulgar o Patrimônio Histórico e Cultural da População LGBT" (Decreto n. ${ }^{\circ} 41.798$, Rio de Janeiro, 02 abril de 2009. Ver anexo C30, p. 386-387).

${ }^{35}$ De acordo com uma publicação do Rio Sem Homofobia, entre junho de 2009 e setembro de 2012, foram lavrados 1.397 registros, constando homofobia como motivo presumido. Revista Rio Sem Homofobia, ano 1, n. 1, jun. 2012.
}

${ }^{36}$ Revista Rio Sem Homofobia, ano 1, n. 1, jun. 2012. 
inviabilize a descontinuidade dos serviços, diante do constrangimento que seria causado à população atendida, ao movimento social e a outros gestores e parceiros envolvidos.

O superintendente Cláudio Nascimento comenta o processo de estruturação que visa a transformar uma "política de governo" em uma "política de Estado" e ressalta o papel das parcerias envolvidas:

Eu acho que é um processo também de construção do LGBT, o Centro de Referência, o Disque, todos esses serviços ainda estão em processo de consolidação, [...] eu acho que vai precisar de um tempo para essa politica ir se estruturando até 2014. Eu acho que aí, mesmo que entre em outra gestão, ela simplesmente não poderá varrer a existência desse serviço, ela pode questionar o formato, mudar uma coisa ou outra na estrutura, mas tirar totalmente é complexo, porque não é como era anteriormente, um projeto com a sociedade civil, que era só acabar o convênio ou acabar a relação, 'me dá a sala porque preciso da sala e tchau'. Não, envolve uma universidade também, envolve outros órgãos públicos na rede de proteção, então modifica a relação (grifo meu).<smiles>[CH]1[CH]CC1</smiles>

Então eu acho que é um pouco isso, se me perguntarem hoje se as politicas existentes estão mais para políticas de governo ou politicas de Estado, eu vou dizer que todas elas ainda estáo como política de governo. Mas em processo de entrar numa atmosfera de transição para política de Estado. Iniciando ainda muito devagar, porque politica pública precisa levar dez, quinze anos para se estruturar de fato, tem que passar pelo menos por duas ou três gestóes diferentes pra aquilo se consolidar como algo que não é mais de alguém, que não é mais porque aquele projeto, aquele politico, aquele gestor apoia, por mais que precise disso para iniciar, mas é necessário que ela se consolide. ${ }^{37}$

\footnotetext{
${ }^{37}$ Cláudio Nascimento, em entrevista realizada em outubro de 2011, no âmbito do projeto Retratos da Política LGBT no Estado do Rio de Janeiro do Laboratório Integrado em Diversidade Sexual e de Gênero, Políticas e Direitos - Lidis-UERJ.
} 
Outra estratégia de consolidação do serviço passa pelo reforço do enfoque no combate à violência, mais do que na "promoção de direitos”. Dessa forma, acredita-se que seja mais fácil lidar com possíveis oposições, como aquela encarnada em algumas lideranças religiosas:

Uma coisa é impressionante, você pode analisar. Até hoje o Silas Malafaia e todos esses evangélicos batem na lei anti-homofobia, mas não batem no Rio Sem Homofobia. Pode reparar, não tem uma matéria falando contra o Centro de Referência, contra o Disque. [...] Eu acho que ai houve um acerto da politica, com a participação da sociedade civil, com o poder público, de focar conceitualmente a estratégia de criação do serviço na questão do combate à violência [...]. Foi uma coisa muito pensada antes. Silvia Ramos, Sergio Carrara, Julio Moreira, eu, Marcio Caetano sentamos e discutimos isso, vamos focar. Cabral falava disso também, 'Minc, vamos focar na violência, porque aí como esses setores que dizem que defendem o direito à vida vão concordar que a pessoa seja assassinada?'. ${ }^{38}$

O primeiro Centro de Referência foi inaugurado em Nova Friburgo. Em seguida, foi aberto o da capital, em 01 de julho de 2010, junto com o lançamento do Disque Cidadania LGBT. O seguinte foi inaugurado em Duque de Caxias, em agosto de 2011 e, em junho de 2012, foi estabelecido o Centro de Niterói. E a perspectiva de expansão e abertura de novos centros é sempre destacada. Quanto mais equipamentos instalados, maior é a dimensão da política, não só no sentido estrutural, mas também no simbólico.

As ações do programa Rio Sem Homofobia lograram desdobramentos interessantes. Além da possibilidade de apontar o "motivo presumido" como homofobia em registros de ocorrência, articulado junto à polícia civil, e o uso do nome social em estabelecimentos públicos do estado, já mencionados anteriormente, foi realizada uma parceria com a Acadepol para a formação de 1.200 agentes da polícia civil.

${ }^{38}$ Cláudio Nascimento, em entrevista realizada em outubro de 2011, no âmbito do projeto Retratos da Política LGBT no Estado do Rio de Janeiro do Laboratório Integrado em Diversidade Sexual e de Gênero, Políticas e Direitos - Lidis-UERJ. 
A ação chamada "Jornada Acadepol de Formação para a Promoção da Cidadania LGBT, da Liberdade Religiosa e Direitos Humanos" é parte de um projeto maior que visa à formação de mais de 7.000 profissionais da segurança pública do estado do Rio de Janeiro. Outra ação, realizada em articulação com a Defensoria Pública do estado do Rio de Janeiro, foi a criação do Núcleo de Defesa da Diversidade Sexual e Direitos Homoafetivos - Nudiversis. E aqui várias outras iniciativas poderiam ser mencionadas. ${ }^{39}$

Cláudio Nascimento explica como a comunicação foi considerada uma área estratégica para o sucesso da política, um caminho para dialogar com a "conjuntura", produzir "climas favoráveis" e ter um grupo de interlocutores preparado e qualificado para lidar com negociaçôes entre diferentes setores, ainda que muitas dessas experiências sejam liçôes que têm por base táticas de advocacy utilizadas há muito tempo pelo movimento de mulheres:

A gente chegou à conclusão de que era importante, no início do programa Rio Sem Homofobia, anunciar primeiro e fazer depois, dar um tiro de costas para frente, para sentir como aquilo iria repercutir na sociedade de apoio e, ao mesmo tempo, para ter um espelho para refletir para dentro do próprio governo. Então, você pode olhar, desde 2007 pra cá, boa parte das coisas até 2010, primeiro a gente anunciava e depois lutava pela sua implementação internamente [...], a gente fazia uma combinação de comunicação com implementação, pra servir esse lugar também de consulta [...] E ai tem gente que confunde isso com politicagem de governo, para aparecer, só que na verdade essa é uma estratégia no sentido de gerar uma incidência, porque todas as estratégias de votos politicos trabalham assim com três elementos importantes: 1) criação de climas sociais favoráveis, comunicação; e ai entra outro, 2) a comunidade mobilizada no sentido da política; e 3) um grupo de interlocutores qualificados para lidar com a agenda numa determinada

\footnotetext{
${ }^{39}$ Todas as ações do programa são divulgadas no site: http://www.riosemhomofobia.rj.gov.br/.
} 
negociação. E foi um pouco nesse sentido, utilizando a experiência das mulheres. ${ }^{40}$

O investimento na visibilidade e na comunicação da política não é feito apenas por meio da montagem planejada em eventos como os já tratados anteriormente, ou da sua campanha publicitária. O Rio Sem Homofobia e as ações da Superdir são assessoradas por uma equipe de comunicação especialmente contratada para tal. Essa equipe atua em diálogo com a Subsecretaria de Comunicação Social do governo e trabalha para pautar matérias publicadas na imprensa oficial no estado do Rio de Janeiro, bem como se dedica a conseguir espaço em outras mídias de alcance nacional.

Diferentemente de outras estruturas do governo do estado, o Programa possui um site próprio, que procura usar uma linguagem "mais próxima da comunidade":

[...] o governo morre de medo de comunicação descentralizada, a comunicação de todas as secretarias tem uma conta única, para todos os órgáos, mas nós fizemos, temos as nossas próprias contas. A superintendência tem suas próprias contas. Isso também nos deu uma capacidade, inclusive em 2010. Diz um estudo interno do governo que a nossa ata foi uma das que mais apareceram na agenda pública do estado, 2010 e 2011, um estudo da Casa Civil, eles fazem um estudo de quantas vezes apareceu, por centimetragem, aquele órgáo de governo, o quanto ele influencia na sociedade, na opinião pública. Só que são relatórios que eles fazem para o governador, não é uma coisa pública para todo mundo, não, porque é de mais interesse de como caminha a política do governo e tal. Isso tem a ver com essas estratégias. Caramba, você pega o site do Rio Sem Homofobia, 8 mil seguidores, para um site de governo! Talvez porque soubemos alimentar essa forma de linguagem com a comunidade. ${ }^{41}$

\footnotetext{
40 Cláudio Nascimento, em entrevista realizada em outubro de 2011, no âmbito do projeto Retratos da Política LGBT no Estado do Rio de Janeiro do Laboratório Integrado em Diversidade Sexual e de Gênero, Políticas e Direitos - LIDIS/UERJ.

${ }^{41}$ Idem.
} 
Os Centros de Referência de Combate à Violência e Promoção da Cidadania LGBT representam o esforço na criação de uma nova estrutura administrativa no âmbito governamental. Portanto, precisam se adequar a todos os arranjos administrativo-financeiros que incidem sobre uma estrutura como essa, ao mesmo tempo que necessitam lidar com os "efeitos de produção de um aparato institucional" desse tipo em relação ao público que se pretende atingir:

Então, também eu acho que o papel de uma gestão pública que trabalha com direitos humanos é entender que só se fazem direitos humanos e promoção da cidadania se tiver políticas de gastos [...] tanto elaborando a proposta como avaliando se ela está seguindo o caminho correto [...]. Então, às vezes, você pensa um caminho, dois anos depois você olha para trás e pensa que náo era a melhor estratégia. É um pouco diferente da ideia de planejamento que se tem, por exemplo, para a área mais de obras públicas, de planejamento estratégico, de urbanização, onde você pode fazer um planejamento estratégico mais físico, orçamentário. [...] É preciso compreender e construir, e avaliar também esse processo fenomenológico diante da estruturação dos próprios movimentos. Uma agenda que era prioridade da comunidade LGBT em 2007 não é a mesma agenda de 2009, que não será a mesma de 2012. Então, logo esses planejamentos também precisam ser readaptados seguindo uma nova perspectiva [...].

[...] agora, assim, não ter outra superintendência para poder balizar, comparar, será que o que a gente tá fazendo tá certo, tá correto? Não tem, eu não tenho hoje no Estado brasileiro, ou em outro estado, uma estrutura aberta que eu possa dizer assim, entendeu? Qual é? A gente tá fazendo certo, tá fazendo errado, tá fazendo pouco, tá fazendo muito? Então, é pra mim um caminho no escuro também, um caminho de gato no escuro.

A relação de proximidade entre movimentos sociais e governo vem sendo crescentemente notada nos últimos anos, e, sem dúvida, foi essa proximidade que possibilitou tantas ações consideradas bem- 
sucedidas. Mas, como expõem Vianna e Carrara (2007), ao mesmo tempo se indaga se tal proximidade, uma atuação da sociedade civil que muitas vezes passa mesmo pelo interior de esferas administrativas governamentais, também não teria como consequência a redução de seu potencial crítico. Essa aproximação pode ser notada com o surgimento de centros de referência, coordenadorias e programas diversos voltados para "população LGBT", deixando transparecer conflitos inerentes ao processo de criação e à condução de políticas públicas. Possivelmente, são efeitos do deslocamento de posições de poder e, em consequência, das relações que se estabelecem por meio delas.

Aprofundando uma angulação dessa dimensão, a seguir procuro refletir sobre parte das relações estabelecidas entre movimento social, governo e universidade no processo de implantação dos centros de referência do Rio de Janeiro.

\section{UMA EXPERIÊNCIA NO EXERCÍCIO DA ADMINISTRAÇÃO COTIDIANA DE "NOVOS" SUJEITOS}

[...] state does not simply handle clients or employ staff but produces state subjects, as bureaucratized, dependent, disciplined, and gendered [...] state does not simply address private needs or issues but configures, administers, and produces them (Brown, 2006, p. 203).

Em dezembro de 2010, um convênio de cooperação técnica foi firmado entre a Universidade do Estado do Rio de Janeiro (UERJ) e a SEASDH-RJ para, entre outras ações, apoiar a implantação dos Centros de Referência de Combate à Homofobia e Promoção da Cidadania LGBT (CR LGBT).

O convênio acordado cumpria a função prática de ser uma forma de repasse financeiro para a execução de parte das ações do Programa Rio Sem Homofobia. Por meio desse convênio, a UERJ passava a ser a gestora de recursos para pagamento de pessoal e demais ações do 
projeto. Em um primeiro momento, a verba veio do governo federal, por intermédio da Secretaria de Direitos Humanos, e, depois, do próprio governo do estado.

Esse convênio provocou a criação do Laboratório Integrado em Diversidade Sexual e de Gênero, Políticas e Direitos (Lidis) na UERJ. Pensando na articulação dessa iniciativa com o meu tema de pesquisa, aproximei-me dos pesquisadores do Lidis e passei a participar de algumas de suas atividades como pesquisadora-colaboradora e a acompanhar as ações de apoio à implantação do CR LGBT. A proposta desse convênio apresentou-se como um espaço-chave para a realização do trabalho de campo, uma vez que estabeleceu uma parceria entre atores localizados na universidade e na gestão pública, em colaboração com o ativismo social, visando à implantação de uma política governamental específica, direcionada à "população LGBT". E ainda por ter permitido um tipo de inserção bastante privilegiada e particular no campo da pesquisa, por meio de um grupo de pessoas que vêm sendo as responsáveis pela construção de "políticas LGBT" no estado do Rio de Janeiro na atualidade.

Desde então, acompanhei de maneira sistemática esse processo, participando diretamente das conversações entre o Laboratório da UERJ e a SuperDir, em ações voltadas para a implantação, o monitoramento e a avaliação dos CR LGBT e de algumas outras atividades vinculadas ao Programa Rio Sem Homofobia.

Voltando à cena 8, apresentada algumas páginas atrás, a partir da inauguração desse conjunto de serviços direcionados à "população LGBT", passei a acompanhar essas movimentações no estado do Rio de Janeiro. Para tal, participei de reuniōes com a equipe da SuperDir e também tive acesso a alguns documentos-base do projeto.

Os objetivos do termo de cooperação firmado em 2010 (e que em 2013 chegou ao seu terceiro ano de renovação) entre a secretaria de governo e a universidade do estado abarcavam:

i. Apoiar, no periodo do Convênio, a SEASDH/Superdir na complementação da equipe técnica para a implementação e o monitoramento do Programa Rio Sem Homofobia e os serviços do 
Centro Metropolitano de Referência no Combate à Homofobia e Promoção da Cidadania LGBT;

ii. Apoiar, no periodo do Convênio, a SEASDH/Superdir na avaliação da implantação do Programa Rio Sem Homofobia, bem como os resultados do impacto social em todos os serviços na população beneficiada do estado do Rio de Janeiro;

iii. Apoiar a criação de sistema de informação e coleta de dados interligados entre todos os serviços de atendimento da SEASDHI Superdir, nas áreas de promoçâo da cidadania LGBT e combate à homofobia;

iv. Criação/implantação de programa de estágio com objetivo de contribuir para a formação profissional de estudantes das mais diversas áreas de conhecimento dentro dos serviços de atendimento da SEASDH/ Superdir;

v. Parceria com os Programas de Iniciação Cientifica e de Bolsas de Extensão da UERJ, com o objetivo de contribuir para a formação acadêmica de estudantes das mais diversas áreas de conhecimento e desenvolvimento de pesquisas dentro dos serviços de atendimento da SEASDH/Superdir.

Durante a minha observação e participação nas ações do convênio, durante os meses de dezembro de 2010 e janeiro de 2011, acompanhei o processo de formulação do edital e seleção da primeira equipe de profissionais que compôs o CRLGBT. Ao longo desse processo, foi interessante perceber quais eram as características de formação pessoal e profissional consideradas desejáveis para a seleção da equipe de trabalho do serviço, como, por exemplo, que a equipe fosse diversa em termos de sexo, orientação sexual e cor/raça, inclusive uma tentativa de que na seleção houvesse uma reserva de vagas de trabalho para travestis e transexuais, o que se mostrou juridicamente inviável. 
Durante o mês de fevereiro de 2011 participei do seminário de formação da equipe enfim selecionada; entre abril e outubro do mesmo ano estive presente em alguns dos encontros de supervisão e formação da equipe de profissionais que atuavam no serviço (advogados, assistentes sociais e psicólogos, em sua maioria). Participei também de reuniōes das comissōes de trabalho responsáveis por elaborar um sistema informatizado que deveria contemplar todos os Centros de Referência LGBT a serem estabelecidos no estado do Rio de Janeiro e também um protocolo de fluxo e de rotina de atendimento para todos os Centros.

Nesse processo, várias questōes curiosas se apresentaram, como, por exemplo, discussōes sobre como deveriam aparecer definiçōes e classificaçôes por cor/raça, identidade de gênero, sexo e orientação sexual nos documentos e nos protocolos oficiais de funcionamento do serviço; ou sobre como a população a ser atendida pelos Centros de Referência poderia ser identificada ou definida; como o próprio atendimento deveria ser classificado; ou como demandas diversas poderiam ser encaminhadas aos aparelhos de proteção social básica do estado do Rio de Janeiro.

O dia a dia de como lidar com essas questóes e de como criar consenso entre as pessoas da equipe sobre a melhor forma de conduzir encaminhamentos e atividades não se mostrou de simples execução. Contribuía, nesse sentido, o fato de a grande inauguração do serviço (descrita na cena 8) ter acontecido sem que o formato prático de condução das atividades tivesse sido efetivamente discutido ou estruturado internamente.

Dessa forma, o processo guarda semelhanças com a descriçãa feita por Gregori (1993a) a respeito das origens do SOS-Mulher de São Paulo, na década 1980. A autora descreve que, naquele momento, a pressa e a ansiedade para que os atendimentos começassem a ser feitos impediram uma discussão prévia aprofundada sobre a definição de formas de atuação, ou sobre como o público seria mobilizado e atendido, ou mesmo sobre o que era compreendido como "violência contra a mulher". O que era consenso consistia na expectativa de que os trabalhos fossem logo iniciados e que produzissem "visibilidade 
pública imediata". Acreditava-se também que, entrando em contato com os relatos e as histórias das mulheres atendidas, seria possível definir mais claramente o formato do atendimento (Gregori, 1993a, pp. 34-5). No caso dos Centros de Referência LGBT, havia uma definição ampla sobre quais eram os seus objetivos, mas não de como os procedimentos necessários para que esses objetivos fossem atendidos e encaminhados. O que havia era a expectativa de que, com a contratação de pessoal e a partir da assessoria oriunda do convênio forjado com a universidade, a estruturação do serviço poderia ser feita de forma concomitante com $o$ início de seu funcionamento.

Os objetivos definidos para os centros, em termos gerais, reuniam-se em torno de dois pontos: i) oferecer um serviço de "acolhimento" e "encaminhamento" por meio de "atendimento interdisciplinar (jurídico, social, psicológico)"; e ii) funcionar como um centro produtor e irradiador de informaçóes úteis para a mobilização de políticas públicas "de combate à homofobia e promoção da cidadania LGBT". Um pôster que anuncia o serviço diz o seguinte:

\section{Centro de Referência da Cidadania LGBT}

A gente cuida de Você

\section{O que é o CR LGBT?}

Precisa de informaçóes sobre seus direitos? Orientaçóes de como agir judicialmente em relação aos mais variados problemas? Quer perguntar sobre saúde? Cirurgia de readequação de sexo ou hormonioterapia? E as unióes estáveis homoafetivas? Sabe tudo sobre elas? Sente-se sozinho? Ou depressivo?

O governo do Estado do RJ coloca à disposição para você, seus amigos e familiares um espaço para chamar de seu. 


\section{Objetivos}

- Atender LGBT, familiares e amigos vítimas de discriminação e violência homofóbica;

- Orientar LGBT e sociedade em geral sobre direitos civis;

- Sensibilizar e capacitargestores públicos e segmentos da sociedade local sobre homofobia e cidadania LGBT;

- Formar e adequar políticas públicas pró-LGBT;

- Formar banco de dados estadual sobre homofobia e rede de apoio.

A equipe dos Centros de Referência é composta por psicólogos, assistentes sociais e advogados, responsáveis pelo atendimento aos "usuários". Completam a equipe os estagiários dessas três áreas disciplinares e o corpo administrativo de funcionários. Além do atendimento direto ao público que a procura, a equipe dos Centros de Referência também se envolve em açōes externas, como oficinas, palestras e atividades de formação.

Os "usuários" podem chegar ao serviço a partir das ligações feitas para o Disque Cidadania LGBT, que mantém sua linha de atendimento funcionando 24 horas por dia; encaminhados por outros serviços e instituiçôes; ou acessando diretamente os equipamentos, que funcionam de segunda a sexta-feira, em horário comercial. Existe também um canal de comunicação no site http://www.riosemhomofobia.rj.gov.br/, no qual é possível esclarecer dúvidas e solicitar atendimento. Por fim, os Centros recebem denúncias encaminhadas pelo Disque 100, o serviço da Ouvidoria de Direitos Humanos da Secretaria de Direitos Humanos da Presidência da República.

A partir do convênio de cooperação acordado com a universidade, os pesquisadores e os professores reunidos no Laboratório Integrado em Diversidade Sexual e de Gênero, Políticas e Direitos (Lidis-UERJ) comprometeram-se com a condução de uma série de atividades, tais como: a supervisão acadêmica e técnica de parte da equipe de psicólogos, assistentes sociais e advogados responsáveis pelos atendimentos nos Centros de Referência; a seleção e o acompanhamento de estagiários para essas três áreas; a organização e a participação em encontros, seminários, entre outras atividades relacionadas ao Programa Rio Sem 
Homofobia. Outra consequência da cooperação foi a formação de uma "comissão de monitoramento e avaliação", reunindo membros da superintendência, os professores e os pesquisadores da UERJ para o acompanhamento do processo de implantação dos Centros de Referência. Esse acompanhamento se deu basicamente em forma de reunióes.

Durante o primeiro ano da parceria, parte da pauta dessas reunióes girava em torno de discussões como as melhores maneiras de formatar rotinas de atendimento, fichas de cadastro, atribuiçôes de cada cargo da equipe de profissionais dos centros etc., ou seja, questôes práticas que emergiam do cotidiano dos serviços.

Durante a discussão dessas questões foi possível notar que se desenhava uma disputa no interior da cadeia de comando da administração dos Centros de Referência e que, em parte, havia sido alimentada pela maneira como os quadros profissionais e administrativos do serviço foram compostos. Algumas das pessoas que trabalham no dia a dia do CRLGBT - incluindo todos os que ocupam cargo de gerência e coordenação, portanto, uma posição hierarquicamente superior na estrutura - foram indicadas para o trabalho a partir de relações pessoais, de redes de movimento social e militância LGBT. Outros contratados chegaram até o serviço por meio de um processo de seleção pública conduzido pela UERJ. Todos esses com algum tipo de experiência acadêmica mais ou menos aprofundada e não necessariamente com passagem por organizações LGBT ou outros movimentos sociais. Outro ponto a ser levado em consideração é que alguns daqueles imbuídos da função de gerência e coordenação chegaram ao serviço antes da equipe composta para realizar os atendimentos diretos.

Essa forma de conduzir a seleção de profissionais criou uma configuração interna particular. Os profissionais contratados para o atendimento aos "usuários" - psicólogos, advogados e assistentes sociais - figuram como aqueles investidos do saber "técnico", sendo esta uma categoria êmica para tratar o saber oriundo da sua formação acadêmico-científica. Já os profissionais encarregados da gerência e da coordenação das atividades dos Centros são aqueles que, a despeito 
de também possuírem formação acadêmica, em alguns casos, têm a legitimidade de sua atuação garantida em termos do saber oriundo de sua experiência e prática prévias na militância política do movimento social.

Assim, entre "técnicos" e "políticos" distribuíam-se reclamações. Os investidos do saber "político" diziam que os "técnicos" estariam vivendo pela primeira vez o contato com o cotidiano da populaçáo "LGBT" atendida pelos centros. Essa falta de experiência faria com que não compreendessem muito bem os modos mais apropriados de conduzir o trabalho, pois esse não seria um aprendizado a ser garantido nas salas das universidades, mas apenas na experiência prática da vida. Enquanto isso, os "técnicos" queixavam-se de não terem a sua competência valorizada e de serem desinvestidos pela coordenação da autonomia necessária para que o seu trabalho fosse conduzido a contento.

Antes da entrada da equipe selecionada pela universidade, o Centro já fazia alguns atendimentos, e estes eram realizados pelos que agora ocupavam os cargos de comando na estrutura do serviço (os dotados de "experiência política"). Podemos dizer que, se não existiam regras escritas ou formalizadas sobre o modo como esse tipo de trabalho deveria ser conduzido, mas um modo de fazer baseado em "regras derivadas da experiência" (Lugones, 2009), ou seja, mesmo que não contassem com qualquer tipo de "protocolo" ou manual que guiasse a ação, a experiência acumulada era instrumentalizada como um guia para atuação.

Após o acordo de cooperação com a universidade e a entrada da nova equipe, foi preciso dar uma forma mais institucionalizada para as atividades, a qual era esperada para um serviço oferecido pelo governo do estado e prevista como um dos itens do convênio firmado. ${ }^{42}$ Então, a chegada de novos atores ao serviço provocou o questionamento dos modos de fazer postos pelos que já estavam lá, e a falta de formalização das atividades passou a ser discutida e disputada. Os debates a respeito da melhor maneira de conduzir tais processos constituíram um cenário propício para a emergência de conflitos por lugares de

\footnotetext{
42 "Objetivo iii) Apoiar a criação de sistema de informação e coleta de dados interligados a todos os serviços de atendimento da SEASDH/Superdir nas áreas de promoção da cidadania LGBT e combate à homofobia."
} 
autoridade: $\mathrm{O}$ que contaria mais, a competência acadêmica ou a prática política?

Outro personagem nessa composição é "a gestão", forma também êmica de designar os atores ligados mais diretamente à superintendência responsável pelo gerenciamento dos Centros de Referência e do Programa Rio Sem Homofobia. Todas as questões envolvendo a rotinização administrativa do serviço, como a atribuição de funções e atividades de cada profissional, a distribuição de horários de trabalho, a padronização e os modos de preenchimento das fichas de atendimento, o formato e a periodicidade para a feitura de relatórios, precisavam passar pelo crivo e a aprovação dessa "gestão". Então, outro nível da disputa emergia entre os profissionais das equipes dos Centros de Referência e a "gestão" da superintendência, que insistia em ter o controle absoluto sobre todas as decisões referentes à rotina de trabalho do serviço.

Essa tentativa de dar conta das tarefas necessárias para organizar o dia a dia de um serviço que visa a atender a uma população específica (ainda que os termos dessa especificidade nem sempre sejam claramente definidos), por meio da construção de dinâmicas de rotinização burocrática das atividades, era considerada uma forma de transição necessária. Apesar dos conflitos inerentes, essa transição era desejada por todos e tida como um processo natural para um serviço que teve sua concepção e sua origem forjadas pelo movimento social, mas agora atingia outro estatuto, estabelecendo-se como um equipamento do governo do estado.

Os professores e os pesquisadores ligados ao convênio com a universidade entraram nesse cenário fazendo uma espécie de mediação. Como parte dos membros da universidade lidava com o trabalho de assessoria e supervisão dos profissionais ligados aos centros, essa posição se convertia em canal de comunicação entre a equipe e a superintendência responsável pela gestão destes. As questões e os problemas levantados eram levados pela universidade para as reunióes de "monitoramento e avaliação" previstas no convênio, mas, na maioria das vezes, as decisões tomadas não eram encaminhadas, voltando na reuniāo seguinte. E, assim, como se estivessémos presos numa espécie 
de ritual infinito, percebíamos que as reuniōes funcionavam apenas para agendar outras reuniōes e que um possível papel de mediação nunca se concretizava de fato. Volto a tratar desses conflitos adiante.

Com o tempo, a pauta dessas reunióes de "monitoramento" foi se alterando e passaram a girar mais em torno de encaminhamentos burocráticos, como contrataçôes, pagamentos, acertos sobre a participação em eventos, apresentações e outras reunióes de interesse para o Rio Sem Homofobia, em que os professores da UERJ eram solicitados a representar a "cara da universidade".

Ainda que o encaminhamento prático dessas questões nos afligisse e parecesse nunca ser concluído a contento, aos poucos ficava claro que, enquanto discutíamos a organização de um serviço, tentando dar soluçôes ainda que provisórias aos problemas que se colocavam no dia a dia, categorias iam sendo forjadas, conceitos substancializados e a "população" à qual ele se destinava progressivamente ganhava forma e substância. A constituição de um serviço de atendimento passa também por constituir os problemas ou as questões específicas que serão seu objeto de atendimento, o que concorre para a produção ou a definição da "população" que será atendida.

Uma constatação da equipe que trabalha no serviço foi a de que a violência física não era a principal demanda, em termos numéricos, com a qual era preciso lidar. $\mathrm{O}$ maior empenho era na direção da "garantia de direitos", o que fez com que outra compreensão sobre os sentidos da violência tivesse surgido, associada à violação do princípio de acesso a direitos e imiscuída em práticas cotidianas diversas. E novamente se chegou à conclusão semelhante àquela que já tinha vindo à tona com a experiência do $\mathrm{DDH}$ há mais de uma década.

Os centros recebem denúncias de diferentes formas de violência e discriminação, mas, sobretudo, lidam com "demandas" relacionadas à união estável - tanto para a sua realização quanto para a sua dissolução - conversão de uniōes em casamento, retificação de registro civil, readequação sexual, depressão, ansiedade, mães buscando ajuda para lidar com filhos e filhas "LGBT" e professores para lidar com seus alunos e abordar temas como "diversidade sexual". Muitas das 
“demandas" recebidas não estão necessária ou obviamente relacionadas à orientação sexual ou à identidade de gênero, como o aconselhamento sobre direitos trabalhistas ou previdenciários, promoção de inserção no mercado de trabalho etc. Os casos em geral são encaminhados para outros equipamentos da rede pública de assistência e saúde (hospitais, UPAs, abrigos, CAPS, CRAS e CREAS etc.); ${ }^{43}$ no caso de denúncias criminais, para delegacias, com o incentivo para que o registro de ocorrência com o "motivo presumido" homofobia seja lavrado; já questôes jurídicas são encaminhadas para a Defensoria Pública e, eventualmente, para escritórios-modelo de universidades.

Existe ainda muita procura por informação, especialmente nas ligações recebidas pelo Disque Cidadania LGBT, desde aquelas sobre datas de Paradas do Orgulho e outros eventos LGBT e locais de distribuição de preservativos até pessoas que ligam apenas para saber do que trata essa linha e estudantes que procuram informaçóes e dados para escrever trabalhos de curso. Porém, parte da resposta ao que é trazido pelo "usuário" se encerra no real atendimento, no que os profissionais dos centros costumam chamar de "acolhimento" e "escuta", e não obrigatoriamente acontece um encaminhamento externo ao serviço.

$\mathrm{O}$ envolvimento entre a universidade e a gestão dos centros, de diferentes formas, incentiva a produção de reflexões sobre as ações empreendidas. A equipe de pesquisadores da UERJ também desenvolve pesquisas individuais que, de alguma forma, aproveitam o espaço dos CR LGBT como campo de investigação, assim como alguns dos profissionais envolvidos com o atendimento nos centros realizam trabalhos acadêmicos. Parte dos estagiários aproveitou a experiência no serviço para produzir suas monografias de conclusão de curso. ${ }^{44}$ Esses

\footnotetext{
${ }^{43}$ UPA - Unidade de Pronto Atendimento; CAPS - Centro de Apoio Psicossocial; CRAS - Centro de Referência de Assistência Social; CREAS - Centro de Referência Especializado de Assistência Social.

${ }^{44}$ Podemos citar alguns exemplos deste tipo de produção reflexiva. Em novembro de 2012, a equipe dos Centros de Referência realizou, em parceira com o Lidis e nas dependências da UERJ, o seminário "Diversidade sexual e identidade de gênero: refletindo sobre as práticas voltadas ao adolescer". Em agosto de 2013 aconteceu outro seminário, também na UERJ, dessa vez sobre as monografias produzidas a partir da experiência dos estagiários nos Centros de Referência. Durante o ano de 2013, o convênio entre o governo do estado e a UERJ, por intermédio do Lidis, passou a
} 
últimos trabalhos, produtos da experiência dos estagiários que entraram em contato com a temática pela primeira vez em sua prática profissional, representam produções interessantes por conjugarem a reflexão sobre as experiências de atuação e a urdidura de considerações sobre gênero e sexualidade a partir da visão dos seus cursos de formação. Destaco, a seguir, algumas dessas reflexões.

Tendo como fonte as fichas de atendimento do CR LGBT da capital, Isabela Scheufler Pereira ${ }^{45}$ debruçou-se sobre casos caracterizados como agressão e ameaça de agressão com "motivação homofóbica", na tentativa de traçar um perfil do agressor. Em sua análise, notou alguns problemas nas fichas de registro dos atendimentos feitos pelo Centro de Referência. As informações coletadas dos casos funcionariam mais para a quantificação do que para a caracterização dos atendimentos realizados e havia pouquíssima informação a respeito do agressor. A autora aponta inconsistências nos registros de orientação sexual e identidade de gênero e nota, ainda, que quase não há registros de cor/raça, religião ou outras informaçôes que seriam relevantes para traçar um perfil dos casos de discriminação e violência acompanhados pelo centro.

Nas fichas analisadas por Pereira (2013), os "usuários" apareciam classificados por sua orientação sexual, "heterossexual, bissexual, gay e lésbica”, sem que fosse apurada a distinção entre a orientação sexual e a identidade de gênero, presumindo, por exemplo, que todo gay teria uma identidade de gênero masculina ou que toda lésbica teria uma identidade de gênero feminina (p. 59-60). Já as identidades de gênero

destinar parte de sua frente de trabalho para o desenvolvimento de um projeto de pesquisa que, entre outros objetivos, se propunha a fazer um levantamento crítico a respeito dos dados produzidos pelos CR LGBTs e da relação entre as "demandas" trazidas por seus "usuários" e o seu impacto nas redes de proteção de assistência do estado. No âmbito de pesquisas individuais, Aureliano Lopes acompanha açōes nas quais se podem depreender os sentidos que o investimento em "cultura" tem sido tomado na execuçâo de "políticas LGBT"; Vanessa Leite desenvolve sua pesquisa de doutorado a respeito da legitimação da "juventude LGBT", tendo a política Rio Sem Homofobia como um dos campos de investimento de sua pesquisa; e Adriana Shad Balthazar, que, a partir do trabalho de campo realizado em dois dos Centros de Referência existentes no estado do Rio, elaborou a sua dissertação de mestrado sobre "o lugar que o silêncio ocupa na narrativa de pessoas que sofreram violência homofóbica” (Balthazar, 2012; Leite, 2014; Lopes, 2016; Carrara et al., 2017).

45 Trata-se de uma monografia de conclusão do curso de graduação em Assistência Social. A autora realizou o estágio disciplinar obrigatório para a conclusão do curso no Centro de Referência LGBT da capital do Rio de Janeiro, sob a orientação do professor Guilherme Almeida (FSS-UERJ). 
"que aparecem para o serviço são apenas as de travestis e transexuais" e, nesse caso, o que "fica invisibilizado para o serviço é a orientação sexual, pois o pressuposto em vigor é que travestis e transexuais são necessariamente heterossexuais" (p. 60).

Outra monografia foi produzida a partir de "grupos de conversa" que reuniam a equipe que trabalhava com o atendimento de casos nos Centros de Referência. Elisa Oliveira $(2013)^{46}$ procurou discutir as maneiras como esses profissionais compreendiam o fenômeno da homofobia. Em uma dessas discussões surgiram algumas reflexões dos profissionais a respeito dos sentidos da discriminação com que lidam no seu dia a dia de trabalho:

Em um dos grupos de conversa houve um debate acerca das açóes dos CRLGBTs: seria a ação deles somente pela via do combate à discriminação? No início do debate um dos participantes classificou cem por cento dos casos atendidos como casos de homofobia. No entanto, a discussão se encaminhou de certa forma que a questão girou em torno das açóes outras que os CRLGBTs também atuam, como, por exemplo, a elaboração de um contrato de união estável homoafetivo, que se configura, na fala de uma das advogadas, como uma ação de garantia de direitos e náo de combate à homofobia. Entretanto, a necessidade de elaboração de um contrato de união estável, haja vista a náo existência do casamento civil entre pessoas do mesmo sexo (salvo por decisóes judiciais), não se configuraria como uma forma de homofobia? Uma forma de homofobia mais institucionalizada, mas que de certa forma discrimina no sentido de que náo garante os mesmos direitos para casais homossexuais e heterossexuais? O fato de ir a um espaço público voltado para um segmento especifico numa tentativa de garantir direito já náo implica a não garantia desse direito a priori? (2013, p. 33).

\footnotetext{
${ }^{46}$ Monografia de conclusāo do curso de graduação em Psicologia. A autora realizou o estágio disciplinar do curso no Centro de Referência LGBT da capital do Rio de Janeiro, sob a orientação da professora Anna Paula Uziel.
} 
Outra discussão interessante realizada pela autora versa sobre os efeitos que a existência de um equipamento como os Centros de Referência LGBT - "espaço público voltado para a especificidade de sua identidade de gênero e orientação sexual" - podem ter sobre os seus "usuários". Para Oliveira, toda a "diversidade de demandas" recebidas pelos Centros se dirige para um mesmo ponto:

A diversidade de demandas converge em um ponto único e comum: a legitimação daquele usuário enquanto sujeito. As intervençóes dos CRs legitimam enquanto sujeito de direito, enquanto sujeito de desejo, enquanto ser no mundo. Com um encaminhamento impresso realizado por nós, por exemplo, usuários relatam que são mais bem recebidos, que se sentem respaldados e assegurados do que nos outros serviços, que muito comumente não estão preparados para receber o LGBT. Em sua dimensáo psíquica e emocional, ousaria dizer que a criação de um espaço voltado para lésbicas, gays, bissexuais, travestis e transexuais pode ter um efeito muito positivo. A possibilidade de falar abertamente sobre sua sexualidade - e muitas vezes, pela primeira vez na vida - se mostra para alguns usuários como uma experiência de libertação e alívio (p. 34).

A proposta dos Centros de Referência é de que funcionem como um dispositivo de "combate à homofobia e promoção da cidadania". Nesse sentido, a violência associada à homofobia pode compreender um espectro de sentido bastante amplo, inclusive o suposto de que o desconhecimento, a dificuldade ou o impedimento de acesso a algum serviço ou direito tenha como causa anterior e persistente o preconceito e a discriminação vivenciados por determinados sujeitos ao longo de suas vidas.

Nas interpretaçóes sobre os sentidos da homofobia e sobre os "efeitos" positivos dos centros para os "usuários" destacados por Oliveira, também podemos perceber algo sobre outro aspecto que sobressai da montagem dessa política: uma disposição que pode ser depreendida do slogan do CRLGBT: "A gente cuida de você”. Esse anúncio diz algo sobre a forma como alguns dos envolvidos na criação dos centros os 
conceberam. A política se destina a uma "população desamparada", nunca antes assistida por políticas públicas e que finalmente ganhou "uma porta onde pode bater". Essa imagem é comumente utilizada por alguns profissionais para falar dos "usuários" que chegam ao serviço. Nesse sentido, o CRLGBT deveria estar preparado para "acolher" e encaminhar, da melhor forma possível, qualquer tipo de "demanda" trazida por seu público.

Em mais um trabalho que reflete sobre os atendimentos do CR LGBT, Carolina Salles $(2012)^{47}$ chama a atenção para os "efeitos micropolíticos" de ações como as empreendidas pelos Centros de Referência. Para isso, desenvolve a sua reflexão por meio de um caso de denúncia de homofobia na escola recebida por um CR LGBT.

No caso por ela analisado, constatamos que Dimitri, de 43 anos, aluno de uma escola para jovens e adultos, procurou o Centro de Referência para relatar que passava por constrangimentos decorrentes de insinuações sobre a sua orientação sexual feitas por sua professora. Dimitri mencionou grande desconforto com isso, pois afetava a sua relação com os demais alunos, e também afirmou já ter vivenciado situaçôes semelhantes no passado, que acabaram por afastá-lo de outras instituições de ensino. Os profissionais do Centro de Referência proporcionaram a Dimitri alguns atendimentos para discutir os caminhos possíveis do desdobramento do caso. Segundo relata Salles (2011), uma possibilidade seria a via judicial. Dimitri poderia registrar uma ocorrência por discriminação em uma delegacia, acionar o Ministério Público e uma Coordenadoria Regional de Educação e denunciar a professora. Outra possibilidade seria buscar dialogar com a escola "com o objetivo de criar uma estratégia de orientação, responsabilização e sensibilização, tanto nos docentes quanto nos discentes" (p. 29). A equipe que atendeu Dimitri assumiu como prioridade a sua continuidade na escola, uma vez que já havia um histórico de evasão, e, após avaliar as possibilidades junto com o interessado, decidiu-se que a equipe do Centro de Referência entraria

\footnotetext{
${ }^{47}$ Monografia de conclusão do curso de graduação em Psicologia. A autora realizou o estágio disciplinar do curso no Centro de Referência LGBT da capital do Rio de Janeiro, sob a orientação da professora Anna Paula Uziel.
} 
em contato com a direção e a coordenação pedagógica da escola para discutir sobre algum tipo de ação de intervenção.

Após conversas e negociações, foi acordada a realização de uma ação na escola em questão, envolvendo alunos e professores de todas as turmas. Em parceria com o Grupo Arco-Íris, a equipe do Centro de Referência conduziu uma oficina de reflexão sobre estereótipos, e os integrantes do Grupo Arco-Íris apresentaram um esquete teatral baseado no Teatro do Oprimido. As atividades renderam um longo e profícuo debate com o envolvimento ativo de todos os participantes. O caso teve um desfecho satisfatório e, meses depois, Dimitri entrou em contato com a equipe para contar que continuava na escola e que havia ficado feliz com os desdobramentos do seu caso. ${ }^{48}$

A análise dessa ocorrência chama a atenção para o fato de o encaminhamento realizado não ter sido a simples denúncia da discriminação e também para as ações capilares que se desenrolam a partir da alternativa encontrada:

Conclui a partir dessa atividade que, quando os profissionais do CR saem do seu espaço físico de trabalho e se deslocam, entrando no ambiente onde se vivenciou o conflito/homofobia para discutir o 'problema', se cria um diálogo aberto, nos possibilitando intervençóes mais diretas, e de forma capilar naquele ambiente. O 'problema' pode se transformar em uma problemática que atravessa o cotidiano de todos nós (Salles, 2011, p. 36).

Uma das análises possiveis é a comparação entre uma ação focada no indivíduo professora, através do processo jurídico, e uma ação mais coletivizada, sem culpabilizaçôes individuais, buscando promover reflexão, debate e transformaçôes na comunidade escolar (p. 37).

A análise feita por Salles e a sua participação nos desdobramentos do atendimento falam sobre uma dimensão "micropolítica", como define

\footnotetext{
48 Dimitri é um nome fictício atribuído pela autora. Para mais detalhes sobre os atendimentos realizados, o percurso do caso e a atividade realizada na escola, ver Salles (2011, pp. 29-36).
} 
a autora, que escapa, em análises apressadas, dos possíveis efeitos de um serviço como o prestado pelos CR LGBTs.

Outro caso de atendimento feito pelo Centro de Referência LGBT da capital do Rio de Janeiro, dessa vez analisado por Amanda Moura (2013), ${ }^{49}$ traz mais alguns pontos interessantes. O caso escolhido pela autora é tido como marcante por vários membros da equipe, tanto pela complexidade de suas "demandas" - que passaram pelo atendimento da Psicologia, do Serviço Social e do Direito - quanto por ser um dos mais antigos, uma vez que a "usuária" nunca deixou de frequentar o serviço, chegando a ele há quase três anos. Trata-se de Mabel, transexual, "negra, pobre, de aparência frágil, mas com olhar doce, jeito meigo, fala mansa, delicada e determinada". De acordo com a autora, esse é um caso sempre muito discutido nas reuniōes de equipe do CR LGBT, pois ajuda os seus integrantes a pensarem sobre as limitações de sua atuação.

A primeira "demanda" de Mabel no CR LGBT foi por abrigamento. Duarte nos revela aos poucos o percurso de Mabel ao longo de sua análise, talvez porque tenha sido assim durante a trajetória da "usuária" no serviço. Mabel está inserida há quatro anos no programa do processo transexualizador do Hospital Universitário Pedro Ernesto (HUPE), onde recebe o tratamento de hormonização, atendimento psicológico e psiquiátrico. Além de abrigamento, Mabel recebeu auxílio do CR para dar entrada na sua retificação de registro civil e para lidar com outras situaçôes de discriminação vivenciadas, como aquela em que estava internada em uma clínica psiquiátrica, devido à ingestão de muitos medicamentos de uma só vez. Ela, então, telefonou para o centro para denunciar que havia sido posta na ala masculina e estava sendo obrigada a cortar as unhas e o cabelo. Por meio do percurso reconstruído por Duarte, ficamos sabendo que Mabel não é "usuária" apenas dos serviços oferecidos pelo CRLGBT e pelo HUPE, ela também é acompanhada pela equipe de um hospital psiquiátrico, além de outras instituições.

\footnotetext{
${ }^{49}$ Monografia de conclusāo do curso de graduação em Psicologia. A autora realizou o estágio disciplinar do curso no Centro de Referência LGBT da capital do Rio de Janeiro, sob a orientação da professora Anna Paula Uziel.
} 
O trânsito pelas instituiçóes foi se configurando de forma gradual e com um aspecto de rede: a partir do contato com o primeiro local que frequentou foi conhecendo os outros e à medida que tinha suas demandas sanadas, passa a se desligar da instituição ou não, como no caso da nossa, com a qual ela permanece vinculada. A moça mantém laços institucionais com diversos órgãos públicos do município. E estes espaços se configuram como as unicas redes que possui. Mabel não tem amigos, nem colegas na cidade, quando questionada como era essa situação em sua cidade natal, relata que sempre teve poucos amigos, desde a infância. A jovem é acompanhada pelo nosso Centro de Referência, por uma instituição psiquiátrica do Estado, onde tem acompanhamento psiquiátrico, psicológico, social e frequenta um bazar organizado pela instituição, realiza eventualmente atividades numa oficina de teatro de uma outra instituição psiquiátrica, frequenta uma $O N G$ que se propóe a elaborar projetos que assegurem a cidadania LGBT, além de ter passado por um projeto de capacitação profissional de travestis e transexuais da cidade (Moura, 2013, p. 43).

A autora destaca uma ocasião em que a equipe do CRLGBT promoveu uma oficina de fotos com Mabel. O objetivo era "criar um campo de afirmação de sua identidade feminina” e servir como embasamento para o processo jurídico de retificação de registro civil (p. 25). Esse tipo de atividade explicita o papel do centro na produção de gênero e de identidades para os sujeitos que o acessam, como visto com Oliveira (2013), mas também fala sobre outros efeitos.

O percurso de Mabel talvez seja um exemplo extremo de sujeito que se constitui nas e por meio das instituições, de aparatos administrativos que "acolhem", reconhecem e coetaneamente constituem as suas identidades - identidades essas reforçadas pelas instituições e que correm o risco de se esfacelarem fora delas.

Nestes trabalhos desenvolvidos a partir da experiência de estudantes que completaram a sua formação profissional na primeira turma de estagiários dos serviços promovidos pela política Rio Sem Homofobia, transparece a forma de funcionamento de um serviço que não nasce com a estrutura e o método de funcionamento definidos, mas primeiro "abriu 
as portas" e vem se construindo no processo, aos poucos "se modelando segundo o perfil da população usuária”. E essa é uma via de mão dupla, pois a "população usuária" também vem se modelando de acordo com o "perfil do serviço". As atividades relatadas pelas monografias citadas podem ser compreendidas também por meio de certas expectativas pedagógicas como um efeito para dentro dos CR LGBTs, para as outras instituiçóes envolvidas de alguma forma com essa política e para a própria "população usuária" ${ }^{50} \mathrm{~A}$ "promoção da cidadania" de que fala a política ensinaria a ter direitos. E esses são efeitos de difícil mensuração por meio da produção de indicadores quantitativos, que parecem ser os mais valorizados pelos gestores da política ou pela linguagem de estado com a qual dialogam.

Olhar para iniciativas no plano administrativo governamental implica reconhecer que essa é uma ação que também produz sujeitos, identidades, necessidades e normatizações. A administração burocratizada que pretende gerir sujeitos definidos a partir do gênero e da sexualidade não dá conta de abarcar os sentidos das "demandas" trazidas pelos "usuários". Talvez essa seja uma explicação possível para a dificuldade dos profissionais em estabelecer um registro padronizado e sistematizado de "identidade de gênero" e "orientação sexual", ou talvez esse campo do cadastro não receba tanta atenção porque, no fim das contas, não é o que mais importa no imediatismo do dia a dia dos atendimentos. Ou ainda porque esse tipo de registro importe mais para a produção de dados e para a gestão das atividades a longo prazo, o que não é feito pelas mesmas pessoas que lidam diariamente com aqueles que chegam ao serviço. A experiência do atendimento muitas vezes leva os profissionais responsáveis pelo trabalho a questionarem a cristalização de identidades, mas, ao mesmo tempo, reconhecem a necessidade instrumental de sua existência. Entretanto, os instrumentos e os mecanismos da rotinização das atividades existentes não deixam muito espaço para que relatem e reflitam sobre essa experiência, ou isso

\footnotetext{
${ }^{50}$ Gregori (1993a) menciona as expectativas das feministas em transformarem as mulheres atendidas pelo SOS-Mulher em militantes. Debert (2006) aponta intenção parecida relacionada à criação de delegacias especiais daqueles que compreendem essas iniciativas como um movimento de "politização da justiça".
} 
não é solicitado ou tido como relevante para os relatórios exigidos pela gestão. Estes, em geral, são pensados para comprovar a relevância e a premência da existência do serviço em termos numéricos, resultando na produção de tabelas, gráficos, números de atendimento e ofícios encaminhados, quantificação de notícias na mídia e eventos públicos realizados.

Retomando as disputas entre "técnicos" e "políticos" e as questôes e as "acusações" trocadas relativas à organização do trabalho, poderíamos dizer que existe certa resistência - de ambos os lados - para o encaminhamento prático de possíveis soluções para os problemas surgidos no cotidiano das atividades dos centros. Não pretendo sugerir que essas disputas sejam a origem do problema, porque esse de fato não é o caso, mas que a sua manutenção serve a alguns propósitos. Por exemplo, o formato das fichas de atendimento é criticado tanto pela falta de espaço para o preenchimento de questóes relevantes quanto pela maneira incompleta como são preenchidas. $\mathrm{O}$ resultado disso, como aponta o trabalho de Pereira (2011), é que informações consideradas importantes para o desdobramento dos casos, tanto práticas quanto analíticas, são perdidas. Mas, ainda que sejam incompletas e mal preenchidas, as fichas têm funcionado para que o trabalho seja quantificado e fornecem os números considerados satisfatórios para os propósitos políticos de afirmação da necessidade de manutenção e incremento da política. ${ }^{51}$

Daí o fato de que serem mal preenchidas é culpa dos “técnicos" que não fazem o trabalho como deveria ser feito. Mas, se acompanharmos a visão destes, observaremos que fichas ruins permitem apontar para a fragilidade da gestão política dos serviços, que não implementa fichas melhores e não dá a autonomia necessária para que o façam. Se o resultado final é ruim, é porque estão impedidos de fazê-lo como a sua formação qualificada permitir-lhes-ia. Por meio dessa acusação, os membros da equipe podem reafirmar o seu potencial e a sua competência, e que não são valorizados pelos que só estariam

\footnotetext{
${ }^{51}$ Segundo uma publicação do Programa Rio Sem Homofobia, em pouco menos de dois anos apenas o Centro de Referência localizado na capital teria realizado 6.506 atendimentos (Revista Rio Sem Homofobia, Ano 1, n. 1, junho 2012).
} 
preocupados com os rendimentos políticos decorrentes da existência do serviço. Além disso, fichas mal preenchidas ou com poucos dados aproveitáveis significam que os dados completos que lá deveriam constar ficaram retidos com o profissional que fez o seu preenchimento, ou seja, se não consta no papel, só aqueles que podem realmente saber o que aconteceu são os "técnicos". O correlato disso é óbvio e não exatamente uma novidade em organizaçóes burocrático-administrativas: a retenção da informação é uma forma de barganhar poder; se a pessoa sai, leva as informações junto com ela.

Parte da dificuldade em resolver os problemas apresentados também se explica pela convicção de que existiria uma forma exemplar de organização burocrática que deveria ser alcançada para que tudo, enfim, começasse a funcionar perfeitamente, aspecto que remete à crença na racionalidade burocrática das repartiçôes públicas, já apontada no capítulo 4. Como essa rotinização ideal não é atingida e nem poderia sê-lo, torna-se possível dizer que não funciona agora, mas funcionará um dia, quando tudo estiver perfeitamente organizado. Essa dimensão também pode ser relacionada ao reforço na crença das institucionalidades estatais, abordada mais diretamente no capítulo 1 .

Se existe uma falha na condução das atividades do serviço, não é porque o que se propõe seja de difícil enquadramento e implementação, ou porque o objetivo de sanar qualquer problema posto pelos sujeitos que o acessam seja impossível de ser cumprido. A demanda de ter a "atenção do Estado" foi conquistada, sujeitos historicamente negligenciados agora estão sob a proteção de um aparato montado especialmente para tal: "um lugar para chamar de seu". E se existe algum tipo de falha nessa proteção, ela não pode mais ser localizada no estado, mas naqueles que administram a política e falham em conduzir o processo da maneira como deveria ser. Ainda podemos pensar que a constante falta ou insuficiência das políticas é congruente com a forma como o campo se organiza e movimenta: para haver política, tem que haver cobrança e para haver cobrança, tem que haver a falta.

Por fim, é pertinente pensar em qual seria o lugar da universidade nessa composição. $\mathrm{O}$ convênio firmado entre a Superintendência e a 
UERJ, ambas partes do aparato do estado, envolvia a Universidade em basicamente duas frentes: i) "o apoio, a implantação, o monitoramento e a avaliação" da política; e ii) "contribuir para a formação acadêmica de estudantes", tornando o Centro um possível espaço de estágio para graduandos, e "estimular a produção acadêmica sobre o tema".

Para as duas instituições implicadas, essa cooperação trazia proveitos. $\mathrm{O}$ respaldo acadêmico empresta legitimidade para a política, reforçada pelo envolvimento de especialistas reconhecidos na área em que a política se propóe a intervir. A parceria com a universidade representa ainda um signo positivo de um governo atento à forma como o conhecimento acadêmico-científico pode ser investido em boas práticas da administração pública, sendo capaz de produzir, assim, mais conhecimento a ser reinvestido. Para a Universidade, a parceria significava mais do que apenas um novo campo para a produção de pesquisas e formação de alunos, ou um simples incremento da sua produção acadêmica. Estabelecer parceria na construção de políticas públicas também a reveste de certo prestígio e transmite a imagem de uma instituição comprometida para além da comunidade universitária, que compartilha o saber engajando-se na construção de políticas. Além disso, demonstra o seu compromisso com uma pauta atualmente em alta na agenda de direitos humanos. ${ }^{52}$

Entretanto, nesse cenário em que todos tinham algo a ganhar, a universidade foi recebida pela gestão do serviço de forma contraditória. O respaldo da academia era bem-vindo e, em certa medida, considerado necessário, mas, ao mesmo tempo, suas tentativas de intervenção nas açōes da política eram vistas com reticências e, muitas vezes, não eram levadas adiante. Nesse sentido, ainda que operando de maneira diferente, o conflito colocado entre "técnicos" e "políticos" nos Centros de Referência também estava presente na relação entre a "universidade" e a "gestão". À medida que os envolvidos na "gestáo" também tinham uma trajetória de envolvimento com o movimento social LGBT,

\footnotetext{
52 Cabe apontar que a Universidade do Estado do Rio de Janeiro já tem a reputação de se envolver com a agenda de direitos humanos e de promover projetos de extensão que visam a atingir um público externo à universidade. Parte dessa reputação também é creditada hoje ao seu pioneirismo na implantação de cotas raciais no seu processo seletivo.
} 
essa resistência ecoava a permanência de uma velha desconfiança ou "prevenção contra a academia". ${ }^{3}$

Temos então que as dinâmicas provocadas pelo convênio acabaram por explicitar três categorias reificadas, nas quais os sujeitos vão sendo constantemente posicionados, "A Universidade ou A Academia" e "O Poder Público ou O Gestor Público", duas categorias que se constituem por oposição entre si e por oposição a uma terceira categoria, também não menos reificada, que é "O Movimento Social ou O Ativismo". À "Universidade" caberia o saber acadêmico, mais reflexivo, e também o saber técnico concernente às áreas específicas de formação dos profissionais que atuam nos Centros de Referência, mais instrumental e operativo. Já ao "Poder Público/Gestor Público" caberia o saber político-administrativo, de cunho mais pragmático e resolutivo. A nenhum dos dois competiria aquilo que é considerado, não menos estereotipadamente, como característico dos movimentos sociais: a mobilização apaixonada, a impulsividade e a improvisação livre diante dos imprevistos que, por ventura, se apresentam no dia a dia de uma instituição. Refiro-me aqui a reificações no sentido de que certas características são atribuídas como inerentes a essas esferas, como se o pertencimento a tais espaços pudesse determinar formas de agir e pensar que retroalimentam a produção desses tipos de ficções institucionais estanques.

Essa forma de relação não pode ser considerada exatamente como uma novidade. Gregori (1999), ao comentar a formação do campo de estudo de gênero no Brasil e a sua "capilaridade com o desenvolvimento do feminismo como movimento social” (p. 226), descreve relação parecida envolvendo pesquisadoras e feministas no contexto da década de 1980. A autora nos conta que, durante a pesquisa de campo realizada no SOS-Mulher, junto com Heloísa Pontes, ambas eram tratadas como “'as acadêmicas', com toda a distância e comedimento que o rótulo implica” (Gregori, 1999, p. 228). Quanto a esse contexto, talvez a originalidade da situação aqui focalizada seja a introdução de

\footnotetext{
53 A expressão é utilizada por Heloisa Pontes (1994) ao descrever a resistência com que foi recebida quando propôs a realização de sua pesquisa junto às militantes do SOS-Mulher em 1982.
} 
um terceiro elemento: as disputas semelhantes que se dão agora no interior das malhas do governo.

Como visto, a história da política LGBT do Rio de Janeiro, desde a experiência precursora do $\mathrm{DDH}$, fez-se com uma relação de diálogo muito próxima entre implementadores de políticas de governo, organizações do movimento social, pesquisas e pesquisadores. ${ }^{54}$

Na última década foi notável o incremento da produção acadêmica a respeito de gênero e sexualidade. Ramos e Carrara (2006) mencionam que uma busca no Currículo Lattes das palavras "homoerotismo", "homossexualidade", "gay", "lésbica", "queer" trouxe o retorno de 1.420 pesquisadores em junho de 2006. A busca apenas da expressão "homossexualidade" em janeiro de 2013 apontou 3.589 pesquisadores envolvidos com o tema.

Parte dessa produção, com o aumento da circulação de pesquisadores e a multiplicação de núcleos em universidades e de pesquisas na área, é feita com o financiamento da Secretaria de Direitos Humanos. $\mathrm{O}$ incentivo para a realização de pesquisas e levantamentos de dados que colaborem para o "combate à violência e a promoção de direitos LGBT" esteve presente desde o PNDH II (2002) e também no Brasil Sem Homofobia (2004) e no Plano Nacional LGBT (2008). ${ }^{55}$ A

\footnotetext{
${ }^{54}$ É interessante notar que se a trajetória do que veio a se tornar o movimento LGBT no Brasil é contada a partir da sua relação com as políticas de saúde, no caso particular do Rio de Janeiro, essa trajetória primordial está mais ligada às políticas de segurança pública.

${ }^{55}$ Exemplo de propostas do PNDH II investidas com este sentido: "Promoção de pesquisas e coleta de informaçōes sobre a situação sociodemográfica dos GLTTB [...] assim como violência e discriminação praticadas em razão da orientação sexual"; "incentivar ações que contribuam para a preservação da memória e fomento à produção cultural da comunidade GLTTB no Brasil"; "promover campanha junto a profissionais de saúde e do direito para o esclarecimento de conceitos científicos e éticos relacionados à comunidade GLTTB" (PNDH II). Além de estar presente em um dos três princípios do Brasil Sem Homofobia, o estímulo à pesquisa aparece ainda em cinco de um total de 53 propostas de ação: "A produção de conhecimento para subsidiar a elaboração, a implantação e a avaliação das políticas públicas voltadas para o combate à violência e à discriminação por orientação sexual, garantindo que o governo brasileiro inclua o recorte de orientação sexual e o segmento GLTB em pesquisas nacionais a serem realizadas por instâncias governamentais da administração pública direta e indireta" (Brasil, 2004, p. 12). E, ainda, um trecho do Plano Nacional LGBT: "O Estado deve se comprometer a incentivar pesquisas acadêmicas e das organizaçôes da sociedade civil no sentido do esclarecimento das reais condiçôes de vida da população LGBT, bem como utilizar o conhecimento já acumulado. Essas pesquisas são essenciais para que as políticas públicas sejam construídas de acordo com as reais necessidades dessa população (Brasil, 2009, p. 17). Sobre o lugar e a importância das pesquisas
} 
Secretaria de Direitos Humanos tem lançado editais de apoio a núcleos de pesquisa, contratação de consultorias e apoio a eventos, seminários e encontros de pesquisadores e, desde 2011, começou a divulgar dados oficiais sobre homofobia, com base nos registros feitos pelo Disque 100 , trabalhados com a consultoria de pesquisadores. Na Conferência LGBT de 2011, uma pequena reunião improvisada foi promovida com os pesquisadores presentes no evento, cerca de quarenta pessoas, atores que podem ser lidos como representativos dos fios de uma trama que vem sendo formada por agendas mutuamente constituídas de pesquisa e intervenção.

O formato da experiência de implantação de uma política nos moldes da que foi descrita neste capítulo pode ser tomada como uma consequência desses desdobramentos ocorridos na última década. E é um exemplo da trama relacional que se forma em torno de sujeitos constituídos no cruzamento entre demandas dos movimentos sociais, aparatos governamentais e produção acadêmica.

qualitativas e quantitativas nas investigaçóes que envolvem sexualidade nas arenas da política e dos direitos humanos, sociológica e epidemiológica, ver Moutinho et al. (2005). 


\section{CONSIDERAÇÕES FINAIS OU NOTAS SOBRE UMA SITUAÇÃO ELOQUENTE}

Como visto no primeiro capítulo, as conferências estaduais, além de discutirem propostas locais, têm como um de seus objetivos a eleição dos delegados que representam o estado na conferência nacional. Para tal, a metodologia é a seguinte: os participantes da reunião podem se inscrever em duas categorias: como delegados, que têm voz e voto em plenária e podem ser eleitos como representantes para a etapa nacional; ou observadores, que podem até ter voz, mas nunca voto durante a reunião. Os delegados, por sua vez, são subdivididos em "poder público" ou "sociedade civil", conforme a sua inserção institucional. Na plenária final, por meio de chapas compostas pelos credenciados como delegados, são eleitos aqueles que irão assumir a representação na próxima etapa da conferência.

Até então, em todas as conferências das quais eu já havia participado, o meu crachá sempre foi de observadora. Mas nesse evento não foi assim. Durante a pré-conferência realizada na capital, cumprindo uma das etapas que antecederam a reunião estadual, minha posição no campo foi alterada. Nesse nível do processo das conferências, todos os presentes estão aptos a se reunirem em chapas para disputar uma vaga como delegação, ou não. 
Eu e outras pessoas ligadas ao Laboratório da UERJ estávamos participando da conferência e contribuindo em diferentes grupos de trabalho, mas não estávamos particularmente interessados em nos credenciar como delegados para a próxima etapa, a conferência estadual, pois estávamos certos de que poderíamos estar presentes e contribuir da mesma forma, continuando no nosso papel de observadores. No entanto, no momento de composição das chapas, fomos persuadidos a nos credenciar como "poder público", uma vez que todos tínhamos vínculo, como professores ou estudantes, com universidades públicas. Além disso, estávamos colaborando para a implantação de uma política pública no governo do estado.

Naquela pré-conferência, o número de vagas disponíveis para delegados era grande e foi montada uma chapa única reunindo "poder público" e "sociedade civil", logo, não haveria qualquer disputa. Todos os dispostos nas chapas seriam automaticamente eleitos delegados, bastando, para tanto, que a plenária referendasse a chapa montada.

Nós, da Universidade, discutimos um pouco sobre se aquele era o nosso lugar, "o poder público". Não era assim que nos enxergávamos a princípio. Se tivéssemos que escolher lados, provavelmente o primeiro impulso seria o de nos colocarmos ao lado da "sociedade civil". Mas acabamos por admitir que os argumentos eram convincentes. Mesmo que esse não fosse o lugar mais confortável para o pesquisador, era o que éramos instados a assumir naquele contexto. Entendemos que os gestores do governo, que seriam os demais integrantes da chapa, compreendiam que o apoio da Universidade era importante e, afinal, estávamos de fato envolvidos em um trabalho de parceria estreita com o governo do estado para a implantação de parte da política Rio Sem Homofobia.

Assim, dois meses depois, ao chegarmos à II Conferência Estadual LGBT do Rio de Janeiro, eu e os outros pesquisadores ligados à Universidade recebemos o crachá de "poder público". Não nos preocupamos mais com isso durante a conferência, até que percebemos que havia chegado o momento de formação das chapas para a eleição de delegados para a etapa nacional da reunião. E essa discussão começou a aparecer pelos corredores. 
A essa altura já sabíamos que, além da nossa situação, havia um entendimento geral naquela conferência de que as universidades ali presentes (UERJ e UFRJ), por serem órgãos públicos, e outras entidades como a OAB, ou Conselhos regionais e federais de psicologia ou serviço social estavam sendo entendidos como "poder público", portanto, pessoas vinculadas a essas instituições receberam o respectivo crachá, diferentemente de outros eventos, nos quais pesquisadores ou professores de universidades públicas receberam o crachá de observadores ou convidados. ${ }^{1}$

O fato é que se formaram duas chapas de "poder público", uma composta por pessoas inseridas na instância de governo com a qual a UERJ trabalhava em parceria (entendidos como "os da situação") e outra de pessoas não ligadas ao governo do estado e com alguns posicionamentos bastante críticos em relação às ações levadas a cabo por essa gestão (entendidos como "de oposição"). E, então, as duas chapas nos abordaram com um convite para composição e ficamos, nós, os "pesquisadores da academia" (nesse momento, subsumida como "A UERJ”), numa "saia justíssima”. Localizados nessa situação como "poder público", éramos pressionados a nos posicionar de um lado ou de outro. Não queríamos compor nenhuma das duas chapas, mas o que significava politicamente uma recusa ou uma aceitação para qualquer um dos lados, ou mesmo o que significava ficar "em cima do muro" e não assumir nenhum dos lados?

Considero essa uma situação eloquente, na medida em que oferece uma miríade de leituras possíveis. Entretanto, irei aqui abordá-la brevemente, retomando as principais questóes situadas nas três partes que estruturam este livro.

A primeira delas pode ser pensada acerca da delegação e da representação. O que significava nessa conjuntura a Universidade representar o "poder público"? Por que isso nos causava estranheza? Como essa delegação nos comprometia?

1 Ou em outras situaçōes, como, por exemplo, o Conselho Estadual LGBT do Rio de Janeiro, no qual os pesquisadores que na conferência estavam definidos como "poder público" ocupavam a vaga de "sociedade civil". 
Essa situação fala sobre o traçado artificial de determinadas fronteiras ou da justaposição de domínios tidos como idealmente distintos - inclusive por nós mesmos, muitas vezes, "os acadêmicos". E, nessa cena, a nossa resistência diante do crachá de "poder público" é sintomática, uma vez que a distinção entre nós e eles torna-se borrada. Porém, a situação fala também sobre um processo de conversão ou "colonização" a que estão sujeitos pesquisadores coagidos a se engajarem e a se comprometerem política e moralmente com os seus objetos de estudo. A ação de "comprometer-se" envolvida nessa circunstância aponta para os dois sentidos que podem ser atribuídos à palavra: "obrigar por compromisso", "responsabilizar" e "expor (alguém ou a si próprio) a situação constrangedora ou perigosa", "empenhar ou arriscar (palavra, honra, patrimônio etc.)". ${ }^{2}$ Essa situação nos forçou a sair da trincheira de qualquer fantasia remanescente de neutralidade que eventualmente ainda pudesse existir e nos obrigou a assumir os riscos de um determinado posicionamento no campo político, riscos estes já previstos desde muito antes daquele acontecimento.

A segunda questão a ser retomada versa sobre o que essa situação nos diz a respeito dos conflitos e das disputas que envolvem esses "sujeitos em processo". A "academia" surge como um ator de peso nessa cena não apenas por conta dos significados que produz ou (re)afirma por meio de pesquisas, mas também por ser ator ativo no fazer das políticas e nas "respostas do Estado". A situação explicita a inclusão desses atores também no que muitas vezes é considerado um campo de disputas internas dos seus objetos de estudo. Outro ângulo a ser considerado, diretamente relacionado a este, é a "academia" ou o "saber acadêmicocientífico" como um marcador social da diferença, que, como qualquer outro marcador, pode atribuir qualidades positivas ou negativas aos sujeitos que constitui, a depender de relaçôes e contextos contingentes.

E a terceira questão, que agora pode parecer bastante óbvia, é que a "academia" é parte dos processos que compõem a nossa imaginação de "Estado". Não apenas porque está atrelada a uma instituição pública, mas também porque os seus modos de funcionamento e a legitimidade

${ }^{2}$ Verbete "Comprometer". Dicionário Caldas Aulete. 
atribuída à sua "produção científica" também constroem os modelos ideais a partir dos quais produzimos essa imaginação.

Divisôes entre academia, ativismo ou movimento social, governo ou estado falam sobre disputas de território e espaço no campo, sobre competiçôes por financiamentos, sobre a produção e o deslocamento de hierarquias, entre outras coisas. O que importa não é definir o que essas categorias significam exatamente, mas compreender como elas são mutuamente produzidas e de que maneira são manejadas em cada contexto. Ao começar esta pesquisa, eu tinha o palpite de que deveria olhar para essas três arenas: a produção acadêmica sobre gênero e sexualidade, as movimentações do ativismo "LGBT" e as políticas levadas a cabo no plano governamental. De fato, elas apareceram com força no campo da pesquisa, e eu pude continuar operando com elas. Mas, meu próprio posicionamento e papel no campo, intencionalmente ou não, mostrou-me como essas arenas, entendidas como categorias de reflexão, são facilmente desmontáveis ou idealizadas. Pode-se atribuir tais deslocamentos, por sua vez, tanto às estratégias desenvolvidas no interior da arena política para colocar o pesquisador em determinada posição quanto a táticas assumidas por este no sentido de aceitar a posição na qual foi colocado ou buscar definir-se como pertencente a um ou a outro lugar.

No que foi dito até aqui, é perceptível que os significados de "campo" se misturam: o campo político (como aquele tratado por Bourdieu) e o campo da pesquisa (de que fala o jargão antropológico). Creio que essa oscilação de sentido reflete a dimensão colocada entre participar da produção de um campo político ao mesmo tempo que se produz o campo tomado como um objeto de pesquisa. Ou, nesse caso, colaborar para a implantação de uma política pública do governo do estado, que resulta de imediato na produção justamente do campo que se toma como objeto de estudo.

A relação entre movimento social, governo e academia, como acompanhada ao longo da pesquisa, ecoa o conceito de "tríade" elaborado por George Simmel (1950). Ainda que não se enquadre exatamente na tipologia traçada pelo autor, podemos considerar a relação entre os elementos segundo o seu modelo de tríade sociológica, 
pois carrega os traços de uma relação imanente/persistente entre os elementos. As configurações que operam entre a tríade excluem a possibilidade de um absoluto contraste entre os seus elementos, ainda que, ocasionalmente, uma parte seja contrastada à outra e que alianças permanentes ou temporárias estejam sempre sendo formadas.

Souza Lima e Castro (2008) apostam na superação da separação entre mundos de "ONGS" e "universidades", "militantes" e "pesquisadores" que foram construídos como separados, em grande parte como um aspecto do "efeito de Estado" presente em nossa percepção da vida social, sobretudo quando lidamos com e de dentro da administração pública:

Ao invés de um conjunto de estereótipos sobre o seu fazer profissional, a atitude do antropólogo em trabalhos 'aplicados' deve ser a de um humilde 'profissional do estranhamento', atento à permanente reinvenção de assimetrias, que exercerá uma atitude dialógica, seja no interior da administração pública, seja debatendo com uma comunidade [...] Cremos que ai está o plano inicial para a ponte entre mundos separados e para um assenhoreamento de nosso papel quando atuamos 'fazendo Estado', seja como produtores de conhecimento el ou ideologias, seja no exercício executivo de processos de intervenção: criar os mecanismos para mudar da mera sensação de estar 'implicado' numa situação para a consciência de que, de um modo ou de outro, nunca estamos fora do campo da produção para o 'aplicado' (p. 378).

Pensando novamente no modelo da tríade desenvolvido por George Simmel, é a própria relação que sustenta o equilíbrio entre os elementos engajados na interação, ainda que seja um equilíbrio instável.

Sustentar o processo de reconhecimento pelo "Estado" requer manter o equilíbrio das tensóes que ocorrem nas fímbrias dessa trama de relações. As contradições e as instabilidades mencionadas, por sua vez, devem ser pensadas como inerentes a tal formação política. O que torna "sujeitos LGBT" possíveis como uma "população" a ser administrada é o fato de conseguirem se produzir fazendo sentido no interior de uma determinada morfologia de estado como população 
“imaginável”, modelável e adaptável dentro de uma gramática, cujas regras e limites são mais ou menos elásticos.

Nos limites deste livro procurei dar conta de algumas das dimensões desse processo, e elas certamente não foram esgotadas aqui. Outros caminhos para o aprofundamento dessas dimensões são possíveis e necessários para a compreensão das dinâmicas políticas que permitem a produção e a articulação entre sujeitos, formatos de administração governamental e a constituição de direitos. 


\section{REFERÊNCIAS}

ABRAMS, Philip. "Notes on the difficulty of studying the State". Journal of Historical Sociology, v. 1. n. 1, pp. 58-89, 1988 [1977].

ADORNO, Sergio. "História e desventura: o 3. ${ }^{\circ}$ Programa Nacional de Direitos Humanos". Revista Novos Estudos Cebrap, n. 86, mar. 2010. AGUIÂO, Silvia. Raça e sexualidade em Rio das Pedras: Percepçôes e Classificaçōes (monografia-graduação). Universidade do Estado do Rio de Janeiro, 2004. . "Aqui nem todo mundo igual!": cor, mestiçagem e homossexualidades

numa favela do Rio de Janeiro (dissertação). Universidade do Estado do Rio de Janeiro, 2007.

- "Cenas da circulação: fragmentos de uma etnografia sobre homossexualidade, gênero, cor e mestiçagem em uma favela do Rio de Janeiro”. Sexualidad, Salud y Sociedad - Revista Latinoamericana, n. 9, dez. 2011.

e BARBOSA, Bruno Cesar. "Moralidades, convençôes e direitos

LGBT: estratégias retóricas de legitimação”. Paper apresentado no GT 01 Instituições estatais e "famílias": práticas de gestão, moralidades e estratégias. Coordenação: Adriana Vianna (UFRJ) e Maria Gabriela Lugones (UN). 27. a Reunião Brasileira de Antropologia - Brasil Plural: Conhecimentos, Saberes Tradicionais e Direitos à Diversidade. Belém, Pará, 2010. 
ALMEIDA, GuilhermeS. de. Da invisibilidade à vulnerabilidade: percursos do "corpo lésbico" na cena brasileira face à possibilidade de infeç̧ão por DST e Aids (tese). Universidade do Estado do Rio de Janeiro, 2005.

. "Reflexões iniciais sobre o processo transexualizador no SUS a partir de uma experiência de atendimento". In ARRILHA, Margareth et al. (orgs.). Transexualidade, travestilidade e direito à saúde. São Paulo: Oficina Editorial, 2010.

. "Homens trans: novos matizes na aquarela das masculinidades". Revista Estudos Feministas, v. 20, n. 2, maio-ago. 2012.

e HEILBORN, M. L. "Não somos mulheres gays: identidade lésbica na visão de ativistas brasileiras". Revista Gênero, v. 9, n. 1, $2 .{ }^{\circ}$ sem. 2008.

e MURTA, Daniela. "Reflexões sobre a possibilidade da despatologização da transexualidade e a necessidade da assistência integral à saúde de transexuais no Brasil". Sexualidad, Salud y Sociedad - Revista Latinoamericana, v. 1, 2013.

ALTMANN, Helena. "Orientação sexual nos Parâmetros Curriculares Nacionais”. Revista Estudos Feministas, v. 9, n. 2, pp. 575-85, 2001. ANDERSON, Benedict. Comunidades imaginadas: reflexóes sobre a origem e a difusão do nacionalismo. São Paulo: Companhia das Letras, 2008. ARÁN, Márcia. "A transexualidade e a gramática normativa do sistema sexo-gênero”. Revista Ágora, v. IX, n. 1, jan.-jun. 2006.

e MURTA, Daniela. "Do diagnóstico de transtorno de identidade de gênero às redescrições da experiência da transexualidade: uma reflexão sobre gênero, tecnologia e saúde”. Revista Physis, v. 19, n. 1, 2009.

et al. "Transexualidade: corpo, subjetividade e saúde coletiva". Psicologia \& Sociedade, v. 20, n. 1, pp. 70-9, 2008.

et al. Transexualidade e saúde pública: acúmulos consensuais de propostas para atenção integral. Disponível em: http://www.ccr.org. br/uploads/ eventos/seminariomar10/transexualidade\%20-\%20 ac\%C3\%BAmulos\%20consensuais.pdf . Acesso em: maio 2013.

ARAUJO, Fabio A. "Falta alguém na minha casa: desaparecimento, luto, maternidade e política”. In LIMA, Roberto Kant de (org.). Antropologia e Direitos Humanos V. Brasília: Booklink, 2008. 
ARRILHA, Margareth et al. (orgs.). Transexualidade, travestilidade e direito à saúde. São Paulo: Oficina Editorial, 2010.

AUSTIN, John Langshaw. How to do things with words. Oxford: Oxford University Press, 1962.

BALTHAZAR, Adriana S. (2012). O lugar do silêncio na violência homofóbica: o dizivel o o indizivel nas narrativas do sofrimento (dissertação). Universidade do Estado do Rio de Janeiro, 2012.

BARBOSA, Bruno César. Nomes e diferenças: uma etnografia dos usos das categorias travesti e transexual (dissertação). Universidade de São Paulo, 2012.

. "Doidas e putas': usos das categorias travesti e transexual". Sexualidad, Saludy Sociedad - Revista Latinoamericana, n. 14, ago. 2013. BENTO, Berenice. A reinvenção do corpo: sexualidade e gênero na experiência transexual. Rio de Janeiro: Garamond, 2006.

. O que é transexualidade. São Paulo: Brasiliense, 2008. (Coleção Primeiros Passos).

e PELÚCIO, Larissa. "Vivências trans: desafios, dissidências e conformaçōes. Apresentação". Revista Estudos Feministas, v. 20, n. 2, maio-ago. 2012a.

$\mathrm{e}$

"Despatologização do gênero: a politização das identidades abjetas". Revista Estudos Feministas, v. 20, n. 2, maio-ago. 2012b. BIRMAN, Patrícia e LEITE, Márcia Pereira (orgs.). Um mural para a dor: movimentos cívico-religiosos por justiça e paz. Porto Alegre: Editora da UFRGS, 2004.

BLÁZQUEZ, Gustavo. "Celebraciones escolares y poéticas patrióticas: la dimensión performativa del Estado-Nación”. Revista de Antropologia, USP, v. 55, n. 2, 2012.

BOURDIEU, Pierre. O poder simbólico. Lisboa: Difel; Rio de Janeiro: Bertrand Brasil, 1989.

. Razóes práticas: sobre a teoria da ação. Campinas: Papirus, 1996. . "A delegação e o fetichismo político". Coisas ditas. São Paulo: Brasiliense, 2004.

BRAH, Avtar. "Diferença, diversidade, diferenciação". Cadernos Pagu, v. 26, jan.-jun. 2006. 
BRASIL. Conselho Nacional de Combate à Discriminação da Secretaria Especial de Direitos Humanos/Ministério da Saúde. Brasil Sem Homofobia: Programa de Combate à Violência e à Discriminação contra GLTB e Promoção da Cidadania Homossexual. Comissão Provisória de Trabalho do Conselho Nacional de Combate à Discriminação da Secretaria Especial de Direitos humanos. Brasília: Ministério da Saúde, 2004 .

Ministério da Saúde. Projeto Somos - Desenvolvimento Organizacional, Advocacy e Intervenção para ONGs que trabalham com GAYS e outros HSH/Ministério da Saúde, Secretaria de Vigilância em Saúde, Programa Nacional de DST e Aids. Brasília: Ministério da Saúde, 2005. Disponível em: http://bvsms.saude.gov.br/bvs/ publicacoes/ projeto_somos.pdf. Acesso em: jan. 2013.

Ministério do Planejamento, Orçamento e Gestão. Secretaria de Planejamento e Investimentos Estratégicos - SPI. Relatório de Avaliação do Plano Plurianual 2004-2007: exercício 2008 - ano base 2007.

- Secretaria Especial dos Direitos Humanos da Presidência da República. Plano Nacional de Promoção da Cidadania e Direitos Humanos de LGBT. Programa Brasil sem Homofobia, Brasília-DF, 2009. Disponível em: http://www.mj.gov.br/sedh/homofobia/planolgbt.pdf. Acesso em: jun. 2009.

- Presidência da República. Secretaria Especial de Políticas para as Mulheres. Segurança Pública: Outros olhares, novas possibilidades. Editado por Aparecida Gonçalves, Ana Teixeira da Cruz. Organização João Trajano Sento Sé. Brasília: SPM, 2009a.

. Secretaria Especial dos Direitos Humanos da Presidência da República. Programa Nacional de Direitos Humanos - PNDH3. Brasília: SEDH/PR, 2010.

Secretaria de Direitos Humanos. Relatório sobre Violência Homofóbica no Brasil: Ano de 2011/Secretaria de Direitos Humanos; Priscila Pinto Calaf, Gustavo Carvalho Bernardes e Gabriel dos Santos Rocha (orgs.). Brasília: Secretaria de Direitos Humanos, 2012.

. Secretaria de Direitos Humanos. Relatório sobre Violência Homofóbica no Brasil: Ano 2012. Brasília: Secretaria de Direitos Humanos, 2013. 
BRITES, Jurema e FONSECA, Claudia (orgs.). Etnografias da participação. Santa Cruz do Sul: Edunisc, 2006.

BROWN, Wendy. "Finding the man in the State". In SHARMA, Aradhana e GUPTA, Akhil (eds.). The anthropology of the state: a reader. Oxford: Blackwell Publishing, 2006.

BUTLER, Judith. Excitable speech: a politics of the performative. New York: Routledge, 1997.

. "O parentesco é sempre tido como heterossexual?". Cadernos Pagu, v. 21, Núcleo de Estudos de Gênero - Pagu/Unicamp, 2003.

. Problemas de gênero: feminismo e subversão da identidade. 2 ed. Rio de Janeiro: Civilização Brasileira, 2008.

CÂMARA, Cristina. Cidadania e orientação sexual: a trajetória do Grupo Triângulo Rosa. Rio de Janeiro: Academia Avançada, 2002.

CAMARGO JR, Kenneth e MATTOS, Ruben. "Looking for sex in all the wrong places: the silencing of sexuality in the world bank's public discourse". In PARKER, Richard et al. (orgs.). Sex politics: reports from the front lines (e-book), 2007.

CARDOSO, Ruth C. L. "Movimentos sociais na América Latina”. Revista Brasileira de Ciências Sociais, v. 3, n. 1, 1987.

CARRARA, Sergio. "Políticas e direitos sexuais no Brasil contemporâneo". Revista Bagoas, n. 5, UFRN, 2010.

. "O dispositivo da sexualidade revisitado". Trabalho apresentado durante o 37. ${ }^{\circ}$ Encontro Anual da Anpocs, Águas de Lindoia/SP, 23 a 27 de setembro de 2013.

"Negociando fronteiras, negociando nas fronteiras: a antropologia e o processo de cidadanização da homossexualidade no Brasil”. Comunicação apresentada em 17 de outubro de 2013. Palestra promovida pelo NuSEX - Núcleo de Estudos em Corpos, Gêneros e Sexualidades Dissidentes. Museu Nacional/UFRJ, 2013.

AGUIÃO, Silvia; LOPES, Paulo Victor L.; TOTA, Martinho. Retratos da politica LGBT no Estado do Rio de Janeiro: CEPESC, 2017. e RAMOS, Silvia. "Política, direitos, violência e homossexualidade". Pesquisa 9. "Parada do Orgulho GLBT - Rio 2004. Rio de Janeiro: Cepesc, 2005. 
e SIMÕES, Julio. "Sexualidade, cultura e política: a trajetória da identidade homossexual masculina na antropologia brasileira”. Cadernos Pagu, v. 28, Unicamp, 2007.

e VIANNA, Adriana. "A violência letal contra homossexuais no município do Rio de Janeiro: características gerais”. In CÁCERES, Carlos F. et al. (orgs.). Ciudadanía Sexual en América Latina: abriendo el debate. Lima: Universidad Peruana Cayetano Heredia, 2004. e "Os direitos sexuais e reprodutivos no Brasil a partir da “constituição cidadā”". In OLIVEN, R. G. et al. (orgs.). A Constituição de 1988 na vida brasileira. São Paulo: Aderaldo \& Rothschild/Anpocs, 2008. et al. "Política, direitos, violência e homossexualidade". 8. a Parada do orgulho GLBT - Rio 2003. Rio de Janeiro: Pallas, 2003.

et al. Política, direitos, violência e homossexualidade. Rio de Janeiro: Cepesc, 2006.

CARVALHO, Mario. Que mulher é essa? Identidade, politica e saúde no movimento de travestis e transexuais dissertação). Universidade do Estado do Rio de Janeiro, 2011.

eCARRARA, Sergio. "Em direção a um futuro trans? Contribuição para a história do movimento de travestis e transexuais no Brasil". Sexualidad, Saludy Sociedad - Revista Latinoamericana, n. 14, ago. 2013. CASARES, Adolfo Bioy et al. Antologia da Literatura Fantástica. São Paulo: Cosac Naify, 2013.

CASTRO, Mary Garcia e SILVA, Lorena Bernadete da. Respostas aos desafios da AIDS no Brasil: limites e possibilidades. Brasília: Unesco/ Ministério da Saúde, 2005.

CATELA, Ludmila. Situação-limite e memória: a reconstrução do mundo dos familiares de desaparecidos da Argentina. São Paulo: Hucitec/Anpocs, 2001. CHAVES, Christine deAlencar. "A marcha nacional do sem-terra: estudo de um ritual político". In PEIRANO, M. (org.). O dito e o feito: ensaios de antropologia dos rituais. Rio de Janeiro: Relume Dumará, 2002. CLIFFORD, James. A experiência etnográfica: antropologia e literatura no século XX. Org. José Reginaldo Gonçalves. Rio de Janeiro: Editora da UFRJ, 1998. 
COELHO, Maria Claudia. "Lágrimas com farinha: percepções femininas da violência em Belém do Pará". In SENTO-SÉ, João Trajano (org.). Segurança Pública-outros olhares, novas possibilidades. Brasília: SPM, 2009. COMERFORD, John. Fazendo a luta: sociabilidade, falas e rituais na construçâo de organizaçóes camponesas. Rio de Janeiro: Relume-Dumarál Núcleo de Antropologia da Política, 1999.

"Reuniōes camponesas, sociabilidade e lutas simbólicas". In PEIRANO, M. (org.). O dito e o feito: ensaios de antropologia dos rituais. Rio de Janeiro: Relume-Dumará, 2002.

CORRÊA, Sonia. "Cruzando a linha vermelha: questôes não resolvidas no debate sobre direitos sexuais". Horizontes Antropológicos, ano 12, n. 26, jul.-dez. 2006.

DAGNINO, Evelina. "Sociedade civil, participação e cidadania: de que estamos falando?”. In MATO, Daniel (org.). Politicas de ciudadania y sociedade civil en tiempos de globalización. Caracas: Faces/Universidad Central de Venezuela, 2004.

DANILIAUSKAS, Marcelo. Relaçôes de gênero, diversidade sexual e políticas públicas de educação: uma análise do Programa Brasil Sem Homofobia (dissertação). Universidade de São Paulo, 2011.

DEBERT, Guita Grin. "Delegacias de Defesa da Mulher: judicialização das relações sociais ou politização da justiça?”. In CORREAA, Mariza (org.). Vida em familia: uma perspectiva comparativa sobre "crimes de honra". Cadernos Pagu/Unicamp, 2006.

DEBERT, Guita Grin e GREGORI, Maria Filomena. "Violência e gênero: novas propostas, velhos dilemas". Revista Brasileira de Ciências Sociais, v. 23, n. 66, fev. 2008.

DOIMO, Ana Maria. A vez e a voz do popular: movimentos sociais e participação política no Brasil pós-70. Rio de Janeiro: Relume-Dumarál Anpocs, 1995.

DUARTE, Luiz Fernando D. et al. "Das vicissitudes e limites da conversão à cidadania nas classes populares brasileiras”. Revista Brasileira de Ciências Sociais, ano 8, n. 22, jun. 1993.

EFREM FILHO, Roberto. "Corpos brutalizados: conflitos e materializaçôes nas mortes de LGBT”. Paper apresentado no SPG15 - Sexualidade e gênero: 
espaço, corporalidades e relações de poder. 37. Encontro Anual da Anpocs, Águas de Lindoia, SP, 23 a 27 de setembro de 2013.

- Mata-mata: reciprocidades constitutivas entre classe, gêneto, sexualidade e território. Tese (Doutorado em Ciências Sociais). IFCH/ Unicamp, 2016

ELIAS, Norbert. "Processos de formação do Estado e construção de nações". Escritos \& ensaios 1: Estado, processo, opiniáo pública. Rio de Janeiro: Jorge Zahar, 2006.

EWALD, François. Foucault, a norma e o direito. Lisboa: Vega, 1993.

FACCHINI, Regina. "Movimento homossexual no Brasil: recompondo um histórico". Cadernos AEL, v. 10, n. 18/19, 2003.

Sopa de letrinhas? Movimento homossexual e produção de identidades coletivas nos anos 90. Rio de Janeiro: Garamond, 2005. (Seção Garamond Universitária).

. Entre umas e outras: mulheres, (homos)sexualidades e diferença na cidade de São Paulo (tese). Unicamp, 2008.

e FRANÇA, Isadora Lins. "De cores e matizes: sujeitos, conexões e desafios no Movimento LGBT brasileiro". Sexualidad, Saludy Sociedad - Revista Latinoamericana, v. 3, 2009.

FASSIN, Eric. "Sociological question: an epilogue to more or less together". In WAALDIJK, Kees (ed.). More or less together - levels of legal consequences of marriage, cohabitation and registered partnerships for different-sex and same-sex partners: an comparative study of nine European countries. Paris: Institut National d'Etudes Démographiques, 2004.

FELTRAN, Gabriel. "Vinte anos depois: a construção democrática brasileira vista da periferia de São Paulo". Revista Lua Nova, n. 72, pp. 83-114, 2007.

FERNANDES, Felipe Bruno Martins. A agenda anti-homofobia na educação brasileira (2003-2010) (tese). Universidade Federal de Santa Catarina, 2011.

FERREIRA, Glauco B. Arco-Íris em disputa: a "Parada da Diversidade" de Florianópolis entre políticas, sujeitos e cidadanias (dissertação). Universidade Federal de Santa Catarina, 2012. 
FERREIRA, Letícia Carvalho M. Uma etnografia para muitas ausências: o desaparecimento de pessoas como ocorrência policial e problema social (tese). Universidade Federal do Rio de Janeiro, 2011.

FOUCAULT, Michel. História da sexualidade I: A vontade de saber. Rio de Janeiro: Graal, 1988.

- Em defesa da sociedade. São Paulo: Martins Fontes, 2002.

. Segurança, território, população: curso dado no Collége de France (1977-1978). São Paulo: Martins Fontes, 2008.

FRANÇA, Isadora Lins. Cercas e pontes: o movimento GLBT e o mercado GLS na cidade de São Paulo (dissertação). Universidade de São Paulo, 2006. . Consumindo lugares, consumindo nos lugares: homossexualidade, consumo e subjetividades na cidade de São Paulo. Rio de Janeiro: Eduerj, 2012. FREIRE, Jussara. "Quando as emoções dão formas às reivindicações". In COELHO, Maria Claudia e REZENDE, Claudia Barcellos (orgs.). Cultura e Sentimentos - Ensaios em antropologia das emoçôes. Rio de Janeiro: Contra Capa, 2010.

GALVÃO, Jane. AIDS no Brasil: a agenda de construção de uma epidemia. Rio de Janeiro: ABIA; São Paulo: Ed. 34, 2000.

GEERTZ, Clifford. Negara: o Estado Teatro no século XIX. Lisboa: Difel; Rio de Janeiro: Bertrand Brasil, 1991.

GOLIN, Celio. "Orientação sexual e novos sujeitos de direito". In FONSECA, Claudia et al. (orgs.). Antropologia, diversidade e direitos humanos: diálogos interdisciplinares. Porto Alegre: Ed. da UFRGS, 2004. GOLIN, Celio et al. A justiça e os direitos de gays e lésbicas: jurisprudência comentada. Porto Alegre: Sulina, 2003.

GREEN, James. Além do carnaval: a homossexualidade masculina no Brasil do século XX. São Paulo: Editora Unesp, 2000.

GREGORI, Maria Filomena. Cenas e queixas: um estudo sobre mulheres, relaçôes violentas e a prática feminista. São Paulo: Paz e Terra/Anpocs, $1993 \mathrm{a}$.

. "As desventuras do vitimismo". Revista Estudos Feministas, Florianópolis, UFSC, n. 1. pp. 143-9, 1993 b.

. "Estudos de gênero no Brasil (comentário crítico)". In MICELI, Sergio (org.). O que ler na ciência social brasileira (1970-1995). Sociologia, v. II. São Paulo: Sumaré/Anpocs; Brasília: Capes, 1999. 
Viração: experiências de meninos nas rua. São Paulo: Companhia das Letras, 2000.

. Prazeres perigosos: erotismo, gênero e limites da sexualidade (tese). Universidade Estadual de Campinas, 2011.

IBDFAM - Instituto Brasileiro de Direito de Família. Estatuto das Famílias - Projeto de Lei n. ${ }^{\circ}$ 2.285/2007, Porto Alegre, 2007.

JACCOUD, Luciana (org.). Questão social e políticas sociais no Brasil contemporâneo. Brasília: IPEA, 2005.

LACERDA, Paula. O drama encenado: assassinatos de gays e travestis na imprensa carioca (dissertação). Universidade do Estado do Rio de Janeiro, 2006.

. O "caso dos meninos emasculados de Altamira": polícia, justiça e movimento social (tese). Universidade Federal do Rio de Janeiro, 2012. LARVIE, Patrick. "Violência contra homossexuais e organizações comunitárias". Violência e Minorias Sexuais. Comunicações do ISER, ano 20, n. 56, Rio de Janeiro, 2001.

LEITE JR., Jorge. Nossos corpos também mudam: a invenção das categorias "travesti" e "transexual" no discurso cientifico. São Paulo: Annablume, 2011. LEITE LOPES, Paulo Victor. Sexualidade e construção de si em uma favela carioca: pertencimentos, identidades, movimento (dissertação). Universidade Federal do Rio de Janeiro, 2011.

LEITE, Vanessa et al. "Política sexual no Brasil contemporâneo: a trajetória da criminalização da homofobia no Legislativo Federal". Anais do XI Congresso Luso-Afro-Brasileiro de Ciências Sociais, Salvador, 2011.

LEITE, Vanessa J. Impróprio para menores? Adolescentes e diversidade sexual e de gênero nas politicas públicas brasileiras contemporâneas. (Tese de Doutorado). Instituto de Medicina Social, Universidade do Estado do Rio de Janeiro, Rio de Janeiro, 2014.

LOPES, Aureliano. Linda, doce, fera: a construção de corporalidades politicas no concurso de beleza Miss T Brasil. (Tese de Doutorado). Instituto de Medicina Social, Universidade do Estado do Rio de Janeiro, Rio de Janeiro, 2016. LUGONES, Maria Gabriela. Obrando em autos, obrando em vidas: formas e fórmulas de Proteção Judicial dos tribunais Prevencionais de Menores de Córdoba, Argentina, no começo do século XXI (tese). Universidade Federal do Rio de Janeiro, 2009. 
. "Nuevos impulsos de la reflexión antropológica: confluencias en torno de las políticas de infancia". Paper apresentado no GT03 - Agendas de investigación, agendasdeintervención: diálogosytensionesenlaproducción del conocimiento antropológico. IX Reunião de Antropologia do Mercosul, Curitiba, 10 a 13 de julho, 2011.

MACHADO, Lia Zanotta. Comunicação apresentada no workshop "Regulações Internacionais, Direitos Diferenciados e Políticas de Reconhecimento", LACED-MN- UFRJ, Porto Seguro, 30 de maio, 2008. MACRAE, Edward. A construção da igualdade: identidade sexual e politica no Brasil da abertura. Campinas: Editora Unicamp, 1990.

MARTINS, Hildeberto Vieira. Basta um telefonema? O Disque Defesa Homossexual e a militância homossexual no campo da violência (dissertação). Universidade do Estado do Rio de Janeiro, 2002.

MASON, Gail. The spectacle of violence: homophobia, gender and knowledge. London/New York: Routledge, 2002.

MATTOS, Ruben A. et al. "As estratégias do Banco Mundial”. Politicas Públicas e AIDS, n. 1. Rio de Janeiro: ABIA, 2001. (Coleção ABIA).

MELLO, Luiz et al. "Por onde andam as políticas públicas para a população LGBT no Brasil”. Revista Sociedade e Estado, v. 27, n. 2, 2012a.

et al. "Políticas públicas para a população LGBT no Brasil: notas sobre alcances e possibilidades". Cadernos Pagu, n. 39, 2012b.

MESQUITA NETO, Paulo de. "Programa Nacional de Direitos Humanos: continuidade ou mudança no tratamento dos direitos humanos no Brasil”. Revista CEJ, v. 1, n. 1, jan.-abr 1997.

MITCHELL, Timothy. "Society, economy and the State effect". In SHARMA, Aradhana e GUPTA, Akhil (orgs.). The anthopology of the State: a reader. New Jersey: Blackwell Publishing, 2006.

MOURA, Amanda Duarte. Mabel e o trânsito dos corpos: um estudo sobre transexualidade (monografia - graduação). Universidade do Estado do Rio de Janeiro, 2013.

MOTT, Luiz e CERQUEIRA, Marcelo. Causa mortis: homofobia. Salvador: Editora GGB, 2001. 
MOUTINHO, Laura. Razão, cor e desejo: uma análise comparativa sobre relacionamentos afetivo-sexuais "inter-raciais" no Brasil e África do Sul. São Paulo: Editora Unesp, 2004.

. "Negociando com a adversidade: reflexões sobre 'raça', (homos) sexualidade e desigualdade social no Rio de Janeiro". Revista Estudos Feministas, Florianópolis, v. 14, n. 1, jan.-abr. 2006.

et al. (orgs.). Sexualidade e comportamento sexual no Brasil: dados e pesquisas. Rio de Janeiro: Cepesc-UERJ, 2005.

MOVIMENTO MÃES DE MAIO. Mães de Maio: do luto à luta. São Paulo: Movimento Mães de Maio, 2011.

MURTA, Daniela. Os desafios da despatologizaçâo da transexualidade: reflexóes sobre a assistência a transexuais no Brasil (tese). Universidade do Estado do Rio de Janeiro, 2011.

OLIVEIRA, Elisa Beatriz Alvares. Pensando dentro da nossa caixinha: discutindo homofobia nos CRLGBTS (monografia - graduação). Universidade do Estado do Rio de Janeiro, 2013.

OLIVEIRA, Rosa M. R. Isto é contra a natureza? Decisóes e discursos sobre conjugalidades homoeróticas em tribunais brasileiros (tese). Universidade Federal de Santa Catarina, 2009.

PARKER, Richard. A construção da solidariedade, AIDS, sexualidade e politica no Brasil. Rio de Janeiro: Relumé-Dumara/ABIA/UERJ, 1994.

(org.). Políticas, instituiçôes e Aids: enfrentando a epidemia no

Brasil. Rio de Janeiro: ABIA/Jorge Zahar Editor, 1997.

PECHENY, Mario et al. (orgs.). Todo sexo es político: estudios sobre sexualidad en Argentina. Buenos Aires: Libros del Zorzal, 2008.

PEIRANO Mariza. "Rituais como estratégia analítica e abordagem etnográfica”. In - (org.). O dito e o feito: ensaios de antropologia dos rituais. Rio de Janeiro: Relume-Dumará, 2002.

PEREIRA, Isabela Scheufler. Virando a lente da homofobia: consideraçóes sobre as características dola "homofóbicola" a partir de dados coletados num CRLGBT (monografia - graduação). Universidade do Estado do Rio de Janeiro, 2013.

PINHEIRO, Paulo Sergio e MESQUITA NETO, Paulo de. "Programa Nacional de Direitos Humanos: avaliação do primeiro ano e perspectivas". Revista Estudos Avançados, v. 11, n. 30, ago. 1997. 
PIRES, Roberto e VAZ, Alexander. Participação social como método de governo? um mapeamento das "interfaces socioestatais" nos programas federais. Rio de Janeiro: IPEA, 2012. Disponível em: http://www.ipea. gov.br/portal/index.php?option=com_content $\&$ view=article\&id=15116. Acesso em: abr. 2013.

PONTES, Heloísa. "Inventário sob forma de fichário. Paixão e compaixão: militância e objetividade na pesquisa antropológica”. Revista de Antropologia, USP, v. 36, 1994.

RAMOS, Silvia. "Disque Defesa Homossexual: narrativas da violência na primeira pessoa”. Violência e Minorias Sexuais. Comunicaçóes do Iser, Rio de Janeiro, ano 20, n. 56, 2001.

. "O papel das ONGs na construção de políticas de saúde: a Aids, a saúde da mulher e a saúde mental". Ciência \& Saúde Coletiva, v. 9, n. 4, out.-dez. 2004.

"Minorias e prevenção da violência", 2011 (mimeo). Disponível em: http:/www.ucamcesec.com.br/wordpress/wp-content/ uploads/2011/06/Silvia-Ramos_Minorias-e-prevencaoviol\%C3\% AAncia.pdf. Acesso em: jun. 2013.

e BORGES, Dorian. "Disque Defesa Homossexual: números da violência”. Violência e Minorias Sexuais. Comunicaçóes do Iser, Rio de Janeiro, ano 20, n. 56, 2001.

e CARRARA, Sergio. "A constituição da problemática da violência contra homossexuais: a articulação entre ativismo e academia na elaboração de políticas públicas". Physis, Revista de Saúde Coletiva, v. 16, n. 2, 2006.

RIOS, Roger Raupp. "Para um direito democrático da sexualidade". Horizontes Antropológicos, ano 12, n. 26, pp. 71-100, Porto Alegre, jul.dez. 2006.

. "Desenvolver os direitos sexuais - desafios e tendências na América Latina". In CORNWALL, Andrea e JOLLY, Susie (orgs.). Questóes de sexualidade: ensaios transculturais. Rio de Janeiro: ABIA, 2008. . "Direitos humanos, direitos sexuais e homossexualidade". In POCAHY, Fernando (org.). Políticas de enfrentamento ao heterossexismo: corpo e prazer. Porto Alegre: Nuances, 2010. 
. "Direitos sexuais, uniōes homossexuais e a decisão do Supremo Tribunal Federal (ADPF no 132-RJ e ADI 4.277)". In —— et al. (orgs.). Homossexualidade e direitos sexuais: reflexóes a partir da decisão do STF. Porto Alegre: Sulina, 2011.

. "Direito à diferença ou direito geral de igualdade?". In SOUZA LIMA, A. C. (coord. geral). Antropologia e direito: temas antropológicos para os estudos jurídicos. Rio de Janeiro/Brasília: Contra Capa/Laced/ABA, 2012. SALLES, Carolina Motta Cardoso. Experiência no Centro de Referência e Cidadania LGBT (monografia - graduação). Universidade do Estado do Rio de Janeiro, 2012.

SARTI, Cyntia. "Corpo, violência e saúde: a produção da vítima". Sexualidad, Salud y Sociedad - Revista Latinoamericana, n. 1, 2009.

. "A vítima como figura contemporânea". Caderno CRH, Salvador, v. 24, n. 61, jan.-abr. 2011.

SZASZ, Yvonne e SALAS, Guadalupe. Sexualidad, derechos humanos y ciudadanía: diálogos sobre un proyecto en construcción. México: El Colegio de Mexico, 2008.

SILVA, Cláudio Roberto da. Reinventando o sonho: história oral de vida política e homossexualidade no Brasil contemporâneo (dissertação). Universidade de São Paulo, 1998.

SIMMEL, Georg. "The Triad". In WOLFF, Kurt H. (ed.). The sociology of Georg Simmel. Nova York/Londres: The Free Press/Collier MacMillan Publishers, 1950.

SIMŌES, Júlio A. e FACHINNI, Regina. Na trilha do arco-iris: do movimento homossexual ao LGBT. São Paulo: Editora da Fundação Perseu Abramo, 2009.

SOARES, Barbara Musumeci. "A antropologia no executivo: limites e perspectivas”. In CORREAA, Mariza (org.). Gênero e cidadania. Campinas: Pagu - Núcleo de Estudos de Gênero, Unicamp, 2002. (Coleção Encontros).

et al. (orgs.). Auto de resistência: relatos de familiares de vítimas da violência armada. Rio de Janeiro: 7Letras, 2009.

SOARES, Luiz Eduardo. Meu casaco de general: quinhentos dias no front de segurança pública do Rio de Janeiro. São Paulo: Companhia das Letras, 2000. 
"A eficácia pragmática da sensibilidade antropológica e a inversão do modelo defensivo: observaçoes sobre o lugar do simbólico na política pública de segurança. Gênero e cidadania”. In CORRÊA, Mariza (org.). Gênero e cidadania. Campinas: Pagu - Núcleo de Estudos de Gênero, Unicamp, 2002. (Coleção Encontros).

SOUZA LIMA, Antônio Carlos de (org.). Gestar e gerir: estudos para uma antropologia da administração pública no Brasil. Rio de Janeiro: Relume-Dumará, 2002.

SOUZA LIMA, Antonio Carlos de. "Apresentação: Dossiê Fazendo Estado". Revista de Antropologia, São Paulo, v. 55, n. 2, 2012.

SOUZA LIMA, Antonio C. e CASTRO, João P. M. "Políticas Públicas". In SANSONE, Livio ePINHO, Osmundo (eds.). Raça:novasperspectivas antropológicas. Brasília: ABA; Salvador: EDUFBA, 2008.

STEIL, Carlos Alberto et al. "Entrevista com Luiz Eduardo Soares". Horizontes Antropológicos, Porto Alegre, ano 7, n. 15, pp. 239-70, jul. 2001. TATAGIBA, L. "Os conselhos gestores e a democratização das políticas públicas no Brasil”. In DAGNINO, E. (org.). Sociedade civil e espaços públicos no Brasil. São Paulo: Paz e Terra, 2002.

TEIXEIRA, Ana Claudia (org.). Os sentidos da democracia e da participação. São Paulo: Polis, 2005.

TEIXEIRA, Flávia do Bonsucesso. "L'Italia dei Divieti: entre o sonho de ser europeia e o babado da prostituição”. Cadernos Pagu, v. 31, jul.-dez. 2008. - Vidas que desafiam corpos e sonhos: uma etnografia de construir-se outro no gênero e na sexualidade (tese). Unicamp, 2009.

UZIEL, Anna Paula. Homossexualidade e adoção. Rio de Janeiro: Garamond, 2007.

et al. "A luta pelo amor e o amor pela luta: notas sobre a cerimônia coletiva de uniōes homoafetivas no Rio de Janeiro". Revista Sociedade e Cultura, v. 5, n. 2. pp. 369-77, Goiânia, dez. 2012.

VALE DE ALMEIDA, Miguel. "O casamento entre pessoas do mesmo sexo. Sobre 'gentes remotas e estranhas' numa 'sociedade decente'". In GROSSI, Miriam et al. (orgs.). Conjugalidades, parentalidades e identidades lésbicas, gays e travestis. Rio de Janeiro: Garamond, 2007.

- A chave do armário: homossexualidade, casamento, família. Florianópolis: Ed. da UFSC, 2010. 
VENTURI, Gustavo e BOKANY, Vilma (orgs.). Diversidade sexual e homofobia no Brasil. São Paulo: Editora Fundação Perseu Abramo, 2011. VIANNA, Adriana. Limites da menoridade: tutela, familia e autoridade em julgamento (tese). Universidade Federal do Rio de Janeiro, 2002. VIANNA, Adriana. "(Trans)posiçôes: notas sobre políticas de reconhecimento em sexualidade”. Comunicação apresentada no Seminário Territórios Sensíveis: Diferença, Agência e Transgressão, PPGAS/MS/ UFRJ e New York University, Rio de Janeiro, 15 e 16 de junho, 2009. . "Atos, sujeitos e enunciados dissonantes: algumas notas sobre a construção dos direitos sexuais”. In MISKOLCI, Richard e PELUCIO, Larissa (orgs.). Discursos fora da ordem: sexualidades, saberes e direitos. São Paulo: Fapesp/Anablume, 2012.

"Introdução: fazendo e desfazendo inquietudes no mundo dos direitos". In (org.). O fazer e o desfazer dos direitos: experiências etnográficas sobre política, administração e moralidades. Rio de Janeiro: Epapers/Laced, 2013.

e CARRARA, Sergio. "As vítimas do desejo: os tribunais cariocas e a homossexualidade nos anos 1980". In PISCITELLI, Adriana et al. (orgs.). Sexualidade e saberes: convençôes e fronteiras. Rio de Janeiro: Garamond, 2004. e . "Sexual politics and sexual rights in Brasil: a case study". In PARKER, Richard et al. (orgs.). SexPolitics - Reports from the front lines (e-book), 2007. e

. "Os direitos sexuais e reprodutivos no Brasil a partir da 'Constituição Cidadâ”'. In OLIVEN, Ruben et al. (orgs.). A Constituição de 1988 na vida brasileira. São Paulo: Aderaldo \& Rothschild/Anpocs, 2008. e FARIAS, Juliana. "A guerra das mães: dor e política em situações de violência institucional”. Cadernos Pagu, v. 37, jul.-dez. 2011. e LACERDA, Paula. Direitos e políticas sexuais no Brasil: o panorama atual. Rio de Janeiro: Clam/IMS, 2004.

VILLELA, Wilza Vieira. "Das interfaces entre os níveis governamentais e a sociedade civil”. In PARKER, R. et al. (orgs.). Saúde, desenvolvimento e politica: respostas frente à AIDS no Brasil. Rio de Janeiro: ABIA; São Paulo: Ed. 34, 1999. 
VITAL, Christina e LEITE LOPES, Paulo Victor. Religião e política: uma análise da atuação de parlamentares evangélicos sobre direitos das mulheres e de LGBTs no Brasil. Rio de Janeiro: Fundação Heinrich Böll/Instituto de Estudos da Religião - Iser, 2013.

WAGNER, Roy. A invenção da cultura. São Paulo: Cosac Naify, 2010. WEBER, Max. Ensaios de sociologia. 3 ed. Rio de Janeiro: Zahar, 1974. ZAMBRANO, Elizabeth. Trocando os documentos: um estudo antropológico sobre a cirurgia de troca de sexo (dissertação). Universidade Federal do Rio Grande do Sul, 2003. 
A linha do tempo a seguir é composta por eventos de dimensão nacional e de dimensão local, abrangendo Rio de Janeiro e São Paulo. Aqui constam lançamentos de documentos e eventos tidos como marcos tanto para diretrizes da administração pública de nível federal quanto para o movimento LGBT em nível nacional. As aspas são utilizadas para "em contrução", pois assumo a dimensão processual na tentativa de compreender a maneira como uma população é constituída. Nesse sentido, à Linha sempre poderão ser acrescentados novos eventos à medida que adquiram relevância no tempo ou que outros objetivos analíticos estejam em jogo.

\section{3}

- I Encontro Nacional de Travestis e Liberados, com apoio do Programa Nacional de DST/Aids 
1995

- IV Conferência Mundial sobre a Mulher: Igualdade, Desenvolvimento e Paz, em Beijing, China

- VIII Encontro Nacional de Gays e Lésbicas

- Fundação da Associação Brasileira de Gays, Lésbicas, Bissexuais, Travestis e Transexuais (ABGLT)

- Realização, no Rio de Janeiro, da reunião da International Gay and Lesbian Association (ILGA), com apoio financeiro do governo federal por meio do Programa Nacional de DST/Aids. Foi o primeiro encontro da associação realizado na América Latina

- 1. a Parada Gay do Rio de Janeiro, realizada durante o encontro da ILGA

\section{6}

- I Conferência Nacional de Direitos Humanos

- Lançamento do primeiro Programa Nacional de Direitos Humanos (PNDH I)

- IV Encontro Nacional de Travestis e Liberados na Luta contra a Aids (ENTLAIDS)

- No Rio de Janeiro, Lei 2.475/96 pune administrativamente estabelecimentos comerciais e públicos que discriminarem pessoas em razão de sua orientação sexual

- II Conferência Nacional de Direitos Humanos

1998

- III Conferência Nacional de Direitos Humanos

1999

- Início do segundo mandato do governo FHC 
- IV Conferência Nacional de Direitos Humanos

- "Em dezembro: iniciativa dos grupos Arco-íris e Atobá reivindica a revogação da Portaria n. ${ }^{\circ}$ 1.376/93, do Ministério da Saúde, que regulamenta a doação de sangue, a qual impede que pessoas dos chamados 'grupos de risco' doem sangue” (Simões e Fachinni, 2009)

- Implantação do Disque Defesa Homossexual e do Centro de Referência contra Violência e Discriminação ao Homossexual, pela Subsecretaria de Pesquisa e Cidadania da Secretaria de Segurança Pública no Rio de Janeiro

\section{0}

- V Conferência Nacional de Direitos Humanos

- Assassinato de Edson Néris, crime emblemático da violência contra homossexuais e que abriu precedentes no judiciário ao ser caracterizado como "crime de ódio"

\section{1}

- III Conferência Mundial das Nações Unidas contra o Racismo, Discriminação Racial, Xenofobia e Intolerância Correlata, em Durban, África do Sul

- Criação do Conselho Nacional de Combate à Discriminação (CNCD)

- VI Conferência Nacional de Direitos Humanos

2002

- VII Conferência Nacional de Direitos Humanos

- Lançamento do II Programa Nacional de Direitos Humanos (PNDH II)

\section{3}

- Início do primeiro mandato do governo Lula 
- Criação da Secretaria Especial dos Direitos Humanos da Presidência da República

- Criação da Secretaria Especial de Políticas para as Mulheres

- Criação da Frente Parlamentar Mista pela Livre Expressão Sexual, posteriormente renomeada como Frente Parlamentar Mista pela Cidadania LGBT, no Congresso Nacional

- VIII Conferência Nacional de Direitos Humanos

- Inauguração do primeiro Centro de Referência LGBT do Brasil, em Campinas (SP)

\section{4}

- I Conferência Nacional de Políticas para as Mulheres

- Lançamento do I Plano Nacional de Políticas para Mulheres

- IX Conferência Nacional de Direitos Humanos

- Lançamento do programa federal Brasil Sem Homofobia

- Portaria n. 2.227 GM-MS, de 14 de outubro de 2004, cria o Comitê Técnico de Saúde da População de Gays, Lésbicas, Transgêneros e Bissexuais

\section{5}

- Decreto 5.397, de 22 de março de 2005, institui que o CNCD conte com "quinze representantes de entidades e organizações não governamentais das populações negra, indígena e do segmento de Gays, Lésbicas, Transgêneros e Bissexuais - GLBT"

- Criação da Rede Afro LGBT, durante o 1. ${ }^{\circ}$ Encontro Nacional de Ativistas LGBT Afrodescendentes, em Brasília

- II Seminário Nacional GLBT: Gays, Lésbicas, Bissexuais e Transexuais, realizado na Câmara dos Deputados pela Comissão de Lesgilação Participativa, em parceria com a Comissão de Direitos Humanos e Minorias, com a Comissão de Educação e Cultura e com a Frente Parlamentar Mista pela Livre Expressão Sexual, no dia 28 de junho 
- Lançamento do edital para seleção de projetos de prevenção e combate à homofobia (SDH)

- Lançamento do Programa Estratégico de Ações Afirmativas: População Negra e Aids

- Criação da Coordenadoria para Assuntos da Diversidade Sexual na estrutura da prefeitura de São Paulo

\section{6}

- Conferência Regional das Américas (Brasília, 26, 27 e 28 de julho)

- X Conferência Nacional de Direitos Humanos

- Criação da Delegacia de Crimes Raciais e Delitos de Intolerância na cidade de São Paulo

- Inclusão da representação de Lésbicas, Gays, Bissexuais, Travestis e Transexuais, juntamente com a dos estudantes e das populações negra, do campo e da floresta, no Conselho Nacional de Saúde

\section{7}

- Lançamento do Plano Integrado de Enfretamento da Feminização da Epidemia de Aids e outras DSTs

- No Rio de Janeiro, Lei 5.034/07 concede o benefício de pensão para parceiros do mesmo sexo de servidores do estado (da contestação dessa lei deriva o julgamento pelo Supremo Tribunal Federal da $\mathrm{ADPF} 132$ e da $\mathrm{ADI}$ 4277, que reconheceu a união estável entre parceiros do mesmo sexo em maio de 2011)

- I Seminário Nacional de Segurança Pública e Combate à Homofobia, promovido pela Secretaria Nacional de Segurança Pública e pela ABGLT, no Rio de Janeiro, entre os dias 10 e 13 de abril

\section{8}

- I Conferência Nacional de Gays, Lésbicas, Bissexuais, Travestis e Transexuais 
- Lançamento do Plano Nacional de Enfrentamento da Epidemia de Aids e das DSTs entre Gays, HSH e Travestis

- XI Conferência Nacional de Direitos Humanos

- Portaria n. ${ }^{0} 1.707$, de 18 de agosto de 2008, regulamenta o chamado "processo transexualizador" no SUS

- Lançamento da campanha Não Homofobia, promovida pelo Grupo Arco-Íris, em Brasília, durante o II Seminário de Advocacy e Aliadas

\section{9}

- Conferência de Exame de Durban (Conferência Mundial contra o Racismo, Discriminação Racial, Xenofobia e Intolerância Correlata, 2001), entre 20 e 24 de abril, em Genebra

- Em São Paulo, Decreto Estadual n. ${ }^{0} 54.032$ cria a Coordenação de Políticas para a Diversidade Sexual do Estado de São Paulo

- Portaria do Ministério da Saúde n. ${ }^{\circ} 1.820$, de 13 de agosto de 2009, que estabelece "os direitos e deveres dos usuários da saúde", entre outras disposiçôes, determina direito de atendimento livre de qualquer discriminação "em virtude de idade, raça, cor, etnia, religião, orientação sexual, identidade de gênero, condiçōes econômicas ou sociais, estado de saúde, de anomalia, patologia ou deficiência”. Além disso, a mesma portaria garante a identificação do usuário pelo nome social, independentemente do registro civil

- Lançamento do Plano Nacional de Promoção da Cidadania e Direitos Humanos de LGBT

- Criação da Coordenação-Geral LGBT, compondo a estrutura da Secretaria de Direitos Humanos da Presidência da República

- Lançamento do III Plano Nacional de Direitos Humanos (PNDH III)

- No Rio de Janeiro, Decreto n. ${ }^{\circ} 41.798$, de 2 de abril de 2009, cria o Conselho dos Direitos da População de Lésbicas, Gays, Bissexuais, Travestis e Transexuais do estado do Rio de Janeiro

- Aprovação da Política Nacional de Saúde Integral de Lésbicas, Gays, Bissexuais, Travestis e Transexuais (Política Nacional de Saúde Integral LGBT) no Conselho Nacional de Saúde 


\section{0}

- Reunião da ILGA-LAC é realizada em Curitiba (PR)

- Criação de Grupo de Trabalho para acompanhar a implementação do Programa Brasil sem Homofobia e do Plano Nacional de Promoção da Cidadania e dos Direitos Humanos de Lésbicas, Gays, Bissexuais, Travestis e Transexuais no âmbito do Ministério da Educação. Publicado no Diário Oficial da Uniáo de 12 de abril de 2010

- 1. ${ }^{a}$ Marcha contra a Homofobia é realizada em Brasília

- Fica determinado, por decreto presidencial, o dia 17 de maio como o Dia Nacional de Combate à Homofobia

- Criação do Conselho Nacional LGBT

- 25. ${ }^{a}$ Conferência da ILGA é realizada em São Paulo

- II Encontro Nacional da Rede Afro LGBT realizado em São Paulo

\section{1}

- Início do governo Dilma

- 1. ${ }^{\text {a }}$ Reunião Ordinária do Conselho Nacional LGBT

- Lançamento do módulo LGBT do Disque 100 da Secretaria de Direitos Humanos da Presidência da República

- Aprovação da união estável e reconhecimento da união entre pessoas do mesmo sexo como entidade familiar pelo Supremo Tribunal Federal (no dia 5 de maio)

- Intensa controvérsia a respeito do programa Escola sem Homofobia, que culminou com o veto da presidenta à produção e à distribuição do material educativo (mais conhecido como "kit gay" ou "kit anti-homofobia”) previsto nas ações daquele programa

- II Marcha Nacional contra a Homofobia é realizada em Brasília

- VIII Seminário LGBT no Congresso Nacional

- Primeira conversão de união estável entre pessoas do mesmo sexo em casamento civil

- Criação do Fórum Nacional de Gestoras e Gestores LGBT

- No Rio de Janeiro, em ofício protocolado em setembro de 2011, a SuperDir/SEASDH-RJ solicita a inclusão do nome social de travestis 
e transexuais nos registros e boletins de ocorrência da polícia do Rio de Janeiro. O pleito foi atendido em 29 de janeiro de 2012

- Portaria n. ${ }^{\circ} 2.837$, de $1 .^{\circ}$ de dezembro de 2011, redefine o Comitê Técnico de Saúde Integral de Lésbicas, Gays, Bissexuais, Travestis e Transexuais (Comitê Técnico LGBT), instituído pela portaria 2.227, de 14 de outubro de 2004

- II Conferência Nacional LGBT

\section{2}

- III Marcha Nacional Contra a Homofobia é realizada em Brasília.

- IX Seminário LGBT, no Congresso Nacional, com o tema "Sexualidade, papéis de gênero e educação na infância e na adolescência”.

\section{3}

- Lançamento do Sistema Nacional LGBT 


\begin{tabular}{|c|c|c|c|}
\hline & & Data & Local \\
\hline 1. & $\begin{array}{c}\text { Pré-Conferência de Políticas Públicas } \\
\text { para GLBT da Capital da Cidade do } \\
\text { Rio de Janeiro }\end{array}$ & $\begin{array}{l}5 \text { de abril } \\
\text { de } 2008\end{array}$ & $\begin{array}{l}\text { Rio de Janeiro, } \\
\text { UERJ }\end{array}$ \\
\hline 2. & $\begin{array}{l}\text { I Conferência de Políticas Públicas para } \\
\text { GLBT do Estado do Rio de Janeiro }\end{array}$ & $\begin{array}{l}16,17 \text { e } 18 \\
\text { de maio de } \\
2008\end{array}$ & $\begin{array}{l}\text { Rio de Janeiro, } \\
\text { UERJ }\end{array}$ \\
\hline 3. & $\begin{array}{c}\text { I Conferência Nacional de Políticas } \\
\text { Públicas para Gays, Lésbicas, Bissexuais, } \\
\text { Travestis e Transexuais }\end{array}$ & $\begin{array}{l}6,7 \text { e } 8 \text { de } \\
\text { junho de } \\
2008\end{array}$ & $\begin{array}{c}\text { Brasília, Centro } \\
\text { de Convenções } \\
\text { Brasil } 21\end{array}$ \\
\hline 4. & $\begin{array}{c}\text { Seminário do Grupo Conexão G- } \\
\text { Refletindo sobre Políticas Públicas } \\
\text { para a População LGBT Moradora de } \\
\text { Favelas }\end{array}$ & $\begin{array}{l}5 \text { e } 6 \text { de } \\
\text { novembro } \\
\text { de } 2009\end{array}$ & Rio de Janeiro \\
\hline 5. & $\begin{array}{l}\text { Seminário Transexualidade, } \\
\text { Travestilidade e Direito à Saúde, } \\
\text { organizado pela Comissão de } \\
\text { Cidadania e Reprodução }\end{array}$ & $\begin{array}{c}24 \text { e } 25 \text { de } \\
\text { março de } \\
2010\end{array}$ & São Paulo \\
\hline
\end{tabular}




\begin{tabular}{|c|c|c|c|}
\hline 6. & $\begin{array}{l}\text { Seminário UnB Fora do Armário: } \\
\text { Rumo a } 1 .^{a} \text { Marcha Nacional LGBT }\end{array}$ & $\begin{array}{l}17 \text { e } 18 \text { de } \\
\text { maio de } \\
2010\end{array}$ & Brasília, UnB \\
\hline 7. & $\begin{array}{l}\text { VII Seminário de Lésbicas, Gays, } \\
\text { Bissexuais, Travestis e Transexuais } \\
\text { no Congresso Nacional - Direitos } \\
\text { Humanos de LGBT: cenários e } \\
\text { perspectivas. }\end{array}$ & $\begin{array}{l}18 \text { de maio } \\
\text { de } 2010\end{array}$ & $\begin{array}{l}\text { Brasília, } \\
\text { Câmara do } \\
\text { Deputados }\end{array}$ \\
\hline 8. & $\begin{array}{l}\text { 1. a Marcha Nacional contra a } \\
\text { Homofobia e } 1 .^{\circ} \text { Grito Nacional } \\
\text { pela Cidadania LGBT e Contra a } \\
\text { Homofobia }\end{array}$ & $\begin{array}{l}19 \text { de maio } \\
\text { de } 2010\end{array}$ & $\begin{array}{l}\text { Brasília, } \\
\text { Esplanada dos } \\
\text { Ministérios }\end{array}$ \\
\hline 9. & $\begin{array}{l}\text { Mesa - pirâmide da discriminação - } \\
\text { Ciclo de Debates: Diversidade em Pauta }\end{array}$ & $\begin{array}{l}17 \text { de junho } \\
\text { de } 2010\end{array}$ & São Paulo \\
\hline 10. & $\begin{array}{l}\text { Inauguração do Centro de Referência } \\
\text { contra a Homofobia, a Intolerância } \\
\text { Religiosa e a Discriminação de } \\
\text { Pessoas Vivendo com HIV/Aids } \\
\text { - Superintendência de Direitos } \\
\text { Individuais, Coletivos e Difusos } \\
\text { (SuperDir-SEASDH-RJ) }\end{array}$ & $\begin{array}{l}1 .^{\circ} \text { de julho } \\
\text { de } 2010\end{array}$ & Rio de Janeiro \\
\hline 11. & $\begin{array}{c}\text { 3. } .^{\circ} \text { Seminário Estadual de } \\
\text { Travestilidade e Transexualidade - } \\
\text { Travestis e Transexuais Unidas por um } \\
\text { Rio Sem Transfobia }\end{array}$ & $\begin{array}{l}13 \text { de } \\
\text { agosto de } \\
2010\end{array}$ & Rio de Janeiro \\
\hline 12. & $\begin{array}{l}\text { II Seminário Estadual de Lésbicas e } \\
\text { Mulheres Bissexuais "Unindo Esforços, } \\
\text { Ampliando Conquistas" }\end{array}$ & $\begin{array}{l}27 \text { e } 28 \text { de } \\
\text { agosto de } \\
2010\end{array}$ & Rio de Janeiro \\
\hline 13. & $\begin{array}{l}\text { Oficina de apresentação da Pesquisa } \\
\text { sobre Homofobia nas Escolas }\end{array}$ & $\begin{array}{c}4 \text { de } \\
\text { outubro de } \\
2010\end{array}$ & $\begin{array}{l}\text { Rio de Janeiro, } \\
\text { SuperDir }\end{array}$ \\
\hline 14. & $\begin{array}{c}\text { I Encontro Nacional de Pesquisa em } \\
\text { Diversidade Sexual e Direitos Humanos }\end{array}$ & $\begin{array}{l}9 \text { e } 10 \text { de } \\
\text { outubro }\end{array}$ & Campinas \\
\hline
\end{tabular}




\begin{tabular}{|c|c|c|c|}
\hline 15. & $\begin{array}{l}\text { Ato LGBT pelo Estado Laico e } \\
\text { Criminalização da Homofobia }\end{array}$ & $\begin{array}{c}20 \text { de } \\
\text { outubro de } \\
2010\end{array}$ & $\begin{array}{l}\text { Rio de Janeiro, } \\
\text { Cinelândia }\end{array}$ \\
\hline 16. & $\begin{array}{c}\text { II Seminário Nacional de segurança } \\
\text { Pública para LGBT: pela Defesa da } \\
\text { Dignidade Humana }\end{array}$ & $\begin{array}{c}8 \text { a } 11 \text { de } \\
\text { novembro } \\
\text { de } 2010\end{array}$ & Rio de Janeiro \\
\hline 17. & $\begin{array}{l}\text { Ato Protesto contra a Homofobia na } \\
\text { Avenida Paulista }\end{array}$ & $\begin{array}{l}21 \text { de } \\
\text { novembro } \\
\text { de } 2010\end{array}$ & São Paulo \\
\hline 18. & Seminário Escola Sem Homofobia & $\begin{array}{l}23 \text { e } 24 \text { de } \\
\text { novembro } \\
\text { de } 2010\end{array}$ & $\begin{array}{l}\text { Brasília, } \\
\text { Câmara dos } \\
\text { Deputados }\end{array}$ \\
\hline 19. & $\begin{array}{c}\text { Entrega do Prêmio Educando para a } \\
\text { Diversidade Sexual }\end{array}$ & $\begin{array}{l}23 \text { e } 24 \text { de } \\
\text { novembro } \\
\text { de } 2010\end{array}$ & $\begin{array}{l}\text { Brasília, } \\
\text { Câmara dos } \\
\text { Deputados }\end{array}$ \\
\hline 20. & $\begin{array}{l}\text { Audiência Pública "Bullying } \\
\text { Homofóbico nas Escolas" }\end{array}$ & $\begin{array}{l}23 \text { e } 24 \text { de } \\
\text { novembro } \\
\text { de } 2010\end{array}$ & $\begin{array}{l}\text { Brasília, Senado } \\
\text { Federal }\end{array}$ \\
\hline 21. & $\begin{array}{c}\text { Seminário sobre os Assassinatos de } \\
\text { LGBT }\end{array}$ & $\begin{array}{c}23 \text { e } 24 \text { de } \\
\text { novembro } \\
\text { de } 2010\end{array}$ & $\begin{array}{l}\text { Brasília, } \\
\text { Câmara dos } \\
\text { Deputados }\end{array}$ \\
\hline 22. & $\begin{array}{l}\text { II Encontro Nacional da Rede Afro } \\
\text { LGBT }\end{array}$ & $\begin{array}{l}3 \text { a } 5 \text { de } \\
\text { dezembro } \\
\text { de } 2010\end{array}$ & São Paulo \\
\hline 23. & 25. ${ }^{a}$ Conferência Mundial ILGA & $\begin{array}{l}4 \text { a } 9 \text { de } \\
\text { dezembro } \\
\text { de } 2010\end{array}$ & São Paulo \\
\hline 24. & $\begin{array}{c}\text { Seminário Interno de Treinamento da } \\
\text { Equipe Rio Sem Homofobia }\end{array}$ & $\begin{array}{c}22 \text { a } 25 \text { de } \\
\text { fevereiro de } \\
2011\end{array}$ & Rio de Janeiro \\
\hline 25 . & $\begin{array}{l}\text { I Reunião do Conselho Nacional LGBT } \\
\text { (transmissão on-line) }\end{array}$ & $\begin{array}{l}30 \text { e } 31 \text { de } \\
\text { março de } \\
2011\end{array}$ & Brasília, SDH \\
\hline
\end{tabular}




\begin{tabular}{|c|c|c|c|}
\hline 26. & $\begin{array}{c}\text { Lançamento da campanha Rio Sem } \\
\text { Homofobia }\end{array}$ & $\begin{array}{l}16 \text { de maio } \\
\text { de } 2011\end{array}$ & Rio de Janeiro \\
\hline 27. & $\begin{array}{l}\text { Semana de Combate à Homofobia e } \\
\text { VIII Seminário LGBT no, } 17 \text { de maio }\end{array}$ & $\begin{array}{c}17 \text { a } 20 \text { de } \\
\text { maio de } \\
2011\end{array}$ & $\begin{array}{l}\text { Brasília, } \\
\text { Congresso } \\
\text { Nacional }\end{array}$ \\
\hline 28. & $\begin{array}{c}\text { II Marcha Nacional Contra a } \\
\text { Homofobia }\end{array}$ & $\begin{array}{l}18 \text { de maio } \\
\text { de } 2011\end{array}$ & $\begin{array}{c}\text { Brasília, } \\
\text { Esplanada dos } \\
\text { Ministérios }\end{array}$ \\
\hline 29. & Reunião de Gestores LGBT & $\begin{array}{c}18 \text { e } 19 \text { de } \\
\text { maio de } \\
2011\end{array}$ & Brasília, SDH \\
\hline 30. & $\begin{array}{c}\text { 2. }{ }^{a} \text { Reunião Ordinária do Conselho } \\
\text { Nacional LGBT }\end{array}$ & $\begin{array}{l}20 \text { de maio } \\
\text { de } 2011\end{array}$ & Brasília, SDH \\
\hline 31. & $\begin{array}{l}\text { Reunião do Conselho Municipal de } \\
\text { Atenção à Diversidade Sexual }\end{array}$ & $\begin{array}{c}28 \text { de } \\
\text { junho de } \\
2011\end{array}$ & $\begin{array}{c}\text { São Paulo, } \\
\text { Secretaria de } \\
\text { Participação e } \\
\text { Parceria }\end{array}$ \\
\hline 32. & $\begin{array}{c}\text { Pré-Conferência LGBT da capital - Rio } \\
\text { de Janeiro }\end{array}$ & $\begin{array}{c}18 \mathrm{de} \\
\text { setembro } \\
\text { de } 2011\end{array}$ & $\begin{array}{l}\text { Rio de Janeiro, } \\
\text { ACADEPOL- } \\
\text { Academia de } \\
\text { Polícia Civil do } \\
\text { Rio de Janeiro }\end{array}$ \\
\hline 33. & $\begin{array}{l}\text { 2. }{ }^{\text {a Conferência Estadual LGBT de São }} \\
\text { Paulo }\end{array}$ & $\begin{array}{c}29 \text { a } 30 \text { de } \\
\text { outubro de } \\
2011\end{array}$ & $\begin{array}{l}\text { São Paulo, } \\
\text { Hotel Jaraguá }\end{array}$ \\
\hline 34. &  & $\begin{array}{c}18 \mathrm{de} \\
\text { novembro } \\
\text { de } 2011\end{array}$ & $\begin{array}{c}\text { Rio de Janeiro, } \\
\text { prédio da Bolsa } \\
\text { de Valores }\end{array}$ \\
\hline 35. & $\begin{array}{l}\text { 6. a Reunião do Conselho nacional } \\
\text { LGBT (transmissão on-line) }\end{array}$ & $\begin{array}{c}22 \text { de } \\
\text { novembro } \\
\text { de } 2011\end{array}$ & Brasília, SDH \\
\hline 36. & II Conferência Nacional LGBT & $\begin{array}{c}15 \text { a } 18 \text { de } \\
\text { dezembro } \\
\text { de } 2011\end{array}$ & Brasília \\
\hline
\end{tabular}


ANEXO C

ALGUNS DOCUMENTOS

(DECRETOS, PORTARIAS E MATERIAL VEICULADO PELA MÍDIA) 


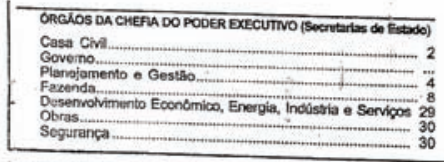

\section{ATOS DO PODER EXECUTTVO}

DECRETO N 41.195 DE 28 DE FEVEREIRO DE 2008 DECLARA DE UTILIDADE PÜLICA INTERESSE SOCIAL, PARA FINS DE MENCIONA, SITUADO NO MUNICIPIO DONCIONA, SITUADO

OSO GOVERADOR DO ESTADO DO RIO DE JANEIRO, no a conferida pelo art. $8^{\circ}$, do Decreto-l e legais, em especia processo administrativo $n^{\circ}$ em vista. 1422015 disposto nos autos do DECRETA:

Art. $1^{\circ}$ - Com fundamento no art. $5^{\circ}$, allnea " $e^{*}$ e $\%$ do Deort. 2 , v. da Le 4132 de lunho de 1941 , combinado com declarados de utilidade pública e setembro de 1962 , ficar de desapropriaça, os seguintes interesse social, para fins Geral de imóveis: a) Lote $17 / 18$ do PAL 6122, da Rua Saint Roman, matricula b) Lole 16 do PAL 6122, da Rua Saint Roman, matricula
212 ,

Art. $2^{2}$ - Incluem-so na presente declaraçăo de utilidade poveis a que se refere o artigo anterior, existentes nos imó-

Art $3^{\circ}$ - Fica autorizada a alegaçăo de urgêncla no processe posse.

Art. 4. Esta, Este Decreto entrará em vigor na data de sua puRio de Jaheiro, 28 de fevereiro de 2008

$$
\text { SÉRGIO CABRAL }
$$

DECRETO N 41.196 DE 28 DE FEVEREIRO DE 2008 CONVOCA A I CONFERENCIA ESTADUAL DE POLITICAS PUBLICAS PARA GAYS, LESBICAS, BISSEXUAIS, TRA. VESTIS E TRANSEXUAIS (GLBT) DO RIO DE JANEIRO, E DA OUTRAS PRO

O GOVERNADOR DO ESTADO DO RIO DE JANEIRO, NO vista o constante do processo ncionals e legais, e lendo em DECRETA:

Art. 10. Fica convocada a I Conferencia Estadual de PollTransexuais (GLara Gays, Lessicas, Blssexuais, Travestis Transexuais (GLBT) do Rio de Janeiro em conformidade com a I Conferéncia Nacional de Gays, Lesbicas, Blsene convoca vestis e Transexuais e da outras providencias a realizar-eo dos dias 21 a 23 de marco de 2008 , sob a coordenackio da Secretaria de Estado de Assistencla Social e de Direitos Hu manos - SEASDH, através da Superintendêncla de Direitos Indin

Art. $2^{*}$ - A I Conferencla Estadual de Politicas Públicas para Gays, Lésbicas, Bissexuais, Travestis e Transexuais, (GLPT) do Rio de Janeiro, doravante denominada I CE-GLBT, tem por finalidade:

1- discutir e propor as diretrizes para a implementaça de politicas publicas e o plano nacional e estadual de promocaba da cidadania e direitos humanos de gays. lésbicas, bisso-

Ë- avaliar e propor estratégias para Implantar o Programa III - avaliar e propor estratégias para fortalecer o Programa

NV - eleger os delegados do Estado do Rio de Janeiro para Conferência Nacionat

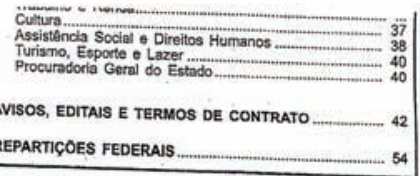

Art. $3^{\circ}$ - A I CE-GLBT será presidida polo Superintendente membros da Comissá. Organizadora Estadugil nomeará os

membros com a participaçano dos seouintes composta por 26 13 membros de organizaches GLBT seguintes representantes: qajos do opoverno no ambito da Administraçato Pública Esta.
dual, sendo:

1- Secretarla de Estado da Casa Civil - CASACIVIL

- Secretaria de Estado do Governo - SEGOV

PLAG

V : Secretaria de Estado de Seguranca - SESEC

DEC Secretaria de Estado de Saúde e Defesa Civil - SES-

Vil- Secretaria de Estado de Educachlo - SEEDUC

VII - Secretaria de Estado do Trabalho o Renda - SETRAB

X. - Secretaria de Estado de Cultura - SEC Estado de Turísmo, Esporte e Lazer - SE

IE

XI.-Defensoria Pública Geral do Estado do Rio de Janeiro -

XII - Assembléla Legislativa - ALERI

Humanos - SEASDH Estado de Assistencia Social e Dirottos Art. $5^{\circ}$ - No prazo do 15 dlas a Secretaria do Estado de As. Ststencia Social e Direitos Humanos, com o Estado de As. reguriamenterá, por Rireitos Individuais, Coletivos e Difusos cenda os atos, por Resolucắa, o presente Decreto, estabele. Organizadora da Conferíncia Eara a compcsigalo da Comissto

reallzaça Comissäo Organizadora Estadual tem por funçâo a abordados nas 9 (nove) e definiçato dos temas que serâ realizadas em nove regibes do Estado do gionais, a serem na Conferencia Estadual.

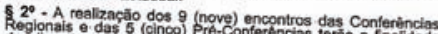
de discutir a Interiorizaça e ampliaçáa teráo a finalidad Movimento GLBT local a gestores publicos participaçào de dos delegados para a Conteréncia Estadual, conforme Régi-
mento interno da CE-GLBT. $53^{\circ}$ - A delegacalo da Conferéncia Estadual de Politicas P0 blicas para GLBT do Rlo de Janeiro será eleita nas 9 (nove regiao a ser definido no Regimento Interno da CE-GLB' cadá
de Janeiro.

4. - O Regimento Intemo da I CE-GLBT obedecera son nal de Politicas para GLBT, dspondo sobre: - processo de escolth de delegadas o dele II - a operacionalizaçăo dos debates, tendo como base o to$855^{\circ}$ - Os integrantes da Comissta tuida, nab farbo jus a qualquer remuneraciac, sendo as as suas Art. $6^{\circ}$ - Este Decreto entrará em vigor na data de sua puRio de Janeiro, 28 de fevereiro de 2008 SERGIO CABRAL

DECRETO N* 41.197 DE 23 DE FEVEREIRO DE 2009 AUTORIZA A PRORROGACÁAO DA CONTRA. TACAOO DE PROFISSIONAIS PELA SECRETA. RIA DE ESTADO DE TRABALHO E RENDA E DÁ OUTRAS PROVIDENCIAS.

- GOVERNADOR DO ESTADO DO RIO DE JANEIRO, nO uSO de suas atribuicoes legais, - tendo em vista o que consts do Procesese $n^{*}$ E-22:152200

DECRETA:

Art. $1^{\circ}$ - Fica autoritada a promogacaco da contrataça de profissionais, a partir de 29 de levereiro de 2008 , att o quantitasivo permitido no Anexo da Lei $n^{3} 4.990$, do 27 de fevereico de 2007 , e nos Imitos servico pútifico prestado no Estado, atros manutençato do relevarte de Trabaho e Renda, mo atendimento a da Secretarla de Estado Unila Federal. 
$\mathrm{C} 2$

\section{ESTADÃO.COM.BR/Nacional}

Para salvar Palocci, Dilma cede e suspende kit anti-homofobia

Bancada evangélica ameaçou apoiar ida do ministro ao Congresso caso cartilha continuasse sendo produzida

25 de maio de 2011 | $17 \mathrm{~h} 52$

BRASÍLIA - Assustado com a ameaça feita na noite desta terça-feira, 24, no plenário, de convocação do ministro-chefe da Casa Civil, Antonio Palocci, caso o governo não retire de circulação o chamado "kit anti-homofobia", o governo decidiu receber as bancadas religiosas no Planalto e anunciar a suspensão de divulgação de qualquer material sobre o tema. Essas decisões foram anunciadas nesta quarta-feira, 25, pelo ministro-chefe da Secretaria Geral da Presidência, Gilberto Carvalho, logo depois do encerramento de uma conversa com parlamentares das bancadas evangélica, católica e de defesa da familia.

Veja Também:

- Caixa: Palocci foi responsável por vazamento de dados do caseiro

- Carvalho nega fim do casamento com PMDB por derrota no Código

- CCJ adia votação de pedido de convocação de Palocci

-FT: Caso Palocei é primeiro teste político para Dilma

Sob forte pressão da oposição, Palocci vem sendo cobrado a dar explicações sobre a rápida evolução do seu patrimônio, que se multiplicou por 20 nos quatro anos em que o ministro exerceu mandato de deputado federal.

Gilberto Carvalho anunciou que a presidente Dilma Rousseff determinou a suspensão da produção de vídeos e cartilhas contra a homofobia e mandou suspender a divulgação do que já havia sido distribuído. Os ministros da Educação, Fernando Haddad e da Saúde, Alexandre Padilha, serão chamados ao Planalto para conversar sobre o caso.

"A presidente assistiu ao vídeo, não gostou e vai conversar com os ministros. Ela achou que o vídeo era impróprio para o seu objetivo. Não se trata de uma posição só de aparências. A presidente tem as suas convicções e acha que o material é inadequado. Ela foi muito clara nesse sentido e determinou que esse material não circule oficialmente por parte do governo", declarou Gilberto Carvalho, confirmando a informação dos deputados evangélicos. Abaixo, um dos vídeos que fariam parte do material:

Os parlamentares evangélicos já haviam transmitido a indignação da presidente Dilma sobre o material que trata de homofobia. Os deputados Anthony Garotinho (PR-RJ), Ronaldo Fonseca (PR-DF), e o líder do PR na Câmara, Lincoln Portela (MG) consideraram que o material se tratava de "uma apologia ao homossexualismo". Disseram que "trazia cenas e desenhos de sexo anal e oral", com "uma didática muito agressiva" e se mostraram "preocupados com a maneira virulenta com que esse material está sendo apresentado".

Apesar da pressa do Planalto em receber os parlamentares e atender ao pedido de suspensão das publicaçôes e dos vídeos, Gilberto Carvalho disse que "não houve recuo" do governo em relação à política de discussão sobre homofobia e que "não tem toma lá, dá cá".

Para o ministro, os parlamentares das bancadas religiosas anunciaram que não iriam mais promover a convocação do ministro Palocci porque acharam que essa era a atitude mais conveniente, e não por terem sido atendidos pelo governo. "Nós oferecemos o diálogo. Eles que tomassem a atitude que achassem consequente. Foram eles que decidiram suspender aquela história de que estavam falando (de convocar o Palocci ao Congresso)", reagiu. Os parlamentares, na saída do Planalto, no entanto, avisaram que não iriam mais ajudar a convocar Palocci, pelo atendimento do pleito sobre o corte na divulgação do material sobre homofobia. Abaixo, o segundo vídeo, "Torpedo", que também faria parte do kit 
Debate amplo. Gilberto Carvalho informou, ainda, que a presidente convocou os ministros da Educação, Fernando Haddad, e da Saúde, Alexandre Padilha, para conversar sobre a produção de material que trate de questões de costumes e informá-los que qualquer coisa sobre este tipo de tema terá de passar por um debate mais amplo e pelo crivo presidencial. "É importante que esse material, para ser produtivo, para atingir o seu objetivo, seja fruto de uma ampla consulta na sociedade, para não gerar esse tipo de polêmica que acaba prejudicando a causa para o qual foi destinado. Qualquer outro material, daqui para frente, editado pelo governo sobre a questão de costumes passará pelo crivo amplo da sociedade e das bancadas interessadas", avisou.

O ministro da Secretaria Geral insistiu que "não se trata de retrocesso" na discussão do tema, mas que o governo entende que o assunto tem de ser tratado de outra forma e mais amplamente discutido. "O governo está aprofundando o diálogo. Se você produz um material que sofre uma tamanha contestação, o objetivo para o qual está destinadoé prejudicado. É preferivel produzir um material com mais diálogo para atingir o objetivo. Não se trata de recuo, mas de um processo mais aprofundado de diálogo", avaliou.

Segundo Carvalho, "o governo mantém sua posição clara contra qualquer tipo de homofobia, $\mathrm{e}$ as bancadas também se declararam contra a homofobia. Mas o governo achou prudente não editar esse material que estava sendo preparado no MEC. A presidente decidiu a suspensão desse material e do vídeo produzido por uma ONG. O governo decidiu também suspender a distribuição desse material", declarou Gilberto, falando em nome do governo, depois de receber os parlamentares no Planalto.

Ameaças. Os próprios parlamentares reconheceram que o material não está sendo distribuído nas escolas, embora o ministro Fernando Haddad, na semana passada, tenha admitido que isso seria feito. Mas reiteraram que querem a suspensão de todo e qualquer material sobre o tema e ameaçaram criar problemas no Congresso em votações, além da convocação de Palocci e de apoiar mobilização pela instalação de uma CPI contra o Ministério da Educação. O vídeo e o material impresso, entretanto, vazaram para a internet, provocando a ira dos parlamentares da bancada religiosa.Abaixo, o último vídeo da série, "Encontrando Bianca": 
---- Original Message -----

From: ABGLT - Presidência

To: Undisclosed-Recipient::

Sent: Friday, October 26, 2007 6:02 PM

Subject: INFORME PROJETO ALIADAS - CONGRESSO x GLBT

\section{INFORME PROJETO ALIADAS - www.abglt.org.br/aliadas}

Brasília-DF, 22 a 25 de outubro.

\section{PLC 122/2006, Orçamento da Uniáo e outras notícias de interesse GLBT.}

\section{Conferencia Nacional GLBT no PPA 2008/2011}

A ABGLT/Projeto Aliadas garantiu esta semana na Comissão de Direitos Humanos do Senado Federal (CDH), uma nova ação no Plano Plurianual (PPA) 2008/2011, trata-se da Conferencia Nacional GLBT. A emenda foi articulada junto à senadora Fátima Cleide (PT/RO) que apresentou a emenda da Conferência e outras ações já existentes para o Programa Brasil Sem Homofobia (BSH). A ABGLT/Projeto Aliadas articulou com os/as parlamentares da $\mathrm{CDH}$ para aprovação das emendas sugeridas. Durante a reunião da $\mathrm{CDH}$ realizada na quarta-feira (24/10) o Senador Paulo Paim anunciou que das doze sugestôes de novas emendas apresentadas de diversos segmentos foram selecionadas cinco emendas para: igualdade racial, idosos, crianças e adolescentes, mulheres e GLBT.

Para efetivar esta ação a ABGLT começou a negociar emendas a Lei Orçamentária Anual (LOA)/2008 a fim de garantir orçamento para a SEDH realizar a Conferência Nacional GLBT.

Outras sugestōes de emendas para o programa BSH foram apresentadas pelo Projeto Aliadas nas comissóes de Cultura e Orçamento. O relatório com as emendas ao PPA serão postadas no site www.abglt.org.br/aliadas na segundafeira (29/10). 


\section{LOA 2008 - Orçamento GLBT}

O presidente da ABGLT, Toni Reis, foi convidado pela Comissão de Direitos Humanos do Senado Federal (CDH), a participar na ultima quarta-feira (24/10) de uma audiência pública sobre a Lei Orçamentária Anual (LOA) de 2008. A mesa da audiência foi composta por representantes da Secretaria Especial de Políticas para Mulheres (SPM), Secretaria Especial de Políticas de Promoção da Igualdade Racial (SEPPIR), Conselho Nacional dos Direitos da Pessoa Portadora de Deficiência (CONADE), Conselho Nacional dos Direitos dos Idosos (CNDI) e pela Associação Brasileira de Gays, Lésbicas, Bissexuais, Travestis e Transexuais (ABGLT).

Toni Reis apresentou a ABGLT e defendeu a importância de incorporar recursos no orçamento da União para as políticas públicas pró GLBT. Entre as prioridades da LOA/2008 o presidente da ABGLT destacou a importância de alocar orçamento para a Conferência Nacional GLBT. Os prazo para apresentação de emendas à LOA abre no dia 31/10 e encerra no 08 de novembro.

As ONGs podem enviar sugestão e articular emendas individuais para os/ as parlamentres de seus estados. O projeto Aliadas dará orientação para as organizaçōes interessadas.

\section{Orçamento de 2007 - liberaçáo de recursos}

A ABGLT articulou durante toda a semana na tentativa de descontigenciar recursos da LOA 2007 destinadas ao Ministério da Educação e à Secretaria Especial de Direitos Humanos. No total são R \$ 7 milhões e duzentos mil reais contigenciados, esses recursos foram alocados no orçamento da União de 2007 através de ações de advocacy do projeto Aliadas da ABGLT.

A presidência da ABGLT fez diversas reuniōes com autoridades e enviou ofícios pedindo a imediata liberação dos recursos para a execução do programa Brasil sem Homofobia.

Para o descontigenciamento, a presidência da ABGLT e a coordenação executiva do Projeto Aliadas reuniram-se com autoridades estratégicas, entre elas:

- Senadora Ideli Salvati (PT/SC) - líder do bloco de apoio ao governo no Senado.

- Deputado Henrique Fontana (PT/SC) - vice-líder do governo na Câmara dos Deputados. 
- $\quad$ Deputada Cida Diogo (PT/RJ) - Coordenadora da Frente GLBT

- $\quad$ Rogério Sotili - secretario executivo da SEDH.

- $\quad$ André Lazaro - secretario executivo do MEC.

Se liberados os recursos devem ser repassados ainda este ano.

\section{PLC 122/2006 - Audiência com o presidente do Senado Federal.}

Foi grande a movimentação na terça-feira (23/10) no Senado Federal, em torno do Projeto de Lei da Câmara (PLC) 122/2006. Deputados e Senadores da Frente Parlamentar Evangélica, acompanhados de pastores dos estados de Rondônia e Espírito Santo visitaram diversos gabinetes no Senado Federal, e no fim da tarde os adversários do projeto de lei foram recebidos pelo presidente do Senado Tião Viana (PT/AC). Na seqüência o presidente da ABGLT, Toni Reis solicitou às senadoras Ideli Salvati (PT/SC) e Fátima Cleide (PT/RO) que Tião Viana recebesse a ABGLT. A líder do PT e do bloco de apoio ao governo no Senado, Ideli Salvati garantiu rapidamente a audiência. Foi a primeira vez que um presidente do senado e do congresso nacional recebeu lideranças do movimento GLBT. Tião Viana, afirmou que dará prioridade para a votação do PLC 122/2006 quando o mesmo chegar até o Plenário. Os opositores anunciaram que fariam uma manifestação com dez mil pessoas contrarias ao PLC/122 em frente ao Senado Federal durante a 45a reunião da $\mathrm{CDH}$ a ser realizada no dia seguinte pela manhã. Nenhuma manifestação foi registrada pela Policia legislativa. O senador Magno Malta declarou para a imprensa que pretende ser o relator do PLC 122/2006 na Comissão de Cidadania e Justiça CCJ.

\section{PLC 122/2006 - Votação}

$\mathrm{Na}$ quarta-feira $(24 / 10)$ na pauta da $45^{\mathrm{a}}$ reunião da $\mathrm{CDH}$ estavam apenas dois itens: na $1^{\text {a }}$ parte a apresentação do parecer do relatório da senadora Fátima Cleide; e na $2^{\text {a }}$ parte a audiência pública sobre a LOA com a participação da ABGLT na mesa.

Já no inicio da reunião o senador Marcelo Crivela (PRB /RJ) pediu que o parecer do PLC 122/2006 fosse retirado de pauta alegando que os componentes da $\mathrm{CDH}$ não receberam com dois dias de antecedência o parecer para se instruírem. O pedido foi aceito pelo presidente da $\mathrm{CDH}$ 
senador Paulo Pain (PT/RS), baseado no artigo no 108 do regimento do Senado. A relatora Fátima Cleide solicitou à presidência se ela pudesse ler o parecer para a comissão. Magno Malta ( PR/ES) manifestou-se afirmando que foi na reuniāo para pedir vistas ao processo mas com o descumprimento do artigo 108, o parecer deveria sair de pauta. Raramente o artigo do regimento do senado é usado, mas por se tratar de matéria polêmica os parlamentares contrários utilizaram o regimento e derrubaram a pauta. A senadora Fátima Cleide lembrou aos senadores opositores que sempre esteve à disposição para debater a matéria e que realizou reuniōes com um grupo de trabalho com participação de aliados e adversários do PLC 122/2006.

A votação foi remarcada para a próxima reunião da comissão que acontecera na próxima quinta-feira dia 01 de novembro.

Mesmo com item fora de pauta o senador Flávio Arns (PT/PR) pediu que as partes interessadas na matéria entrassem em um acordo. Em seu pronunciamento o senador paranaense, disse que a discriminação contra GLBT não pode ser admitida. Com o pedido de Arns e a pedido do senador Crivela, a senadora Fátima Cleide marcou para a manha seguinte uma reunião com os opositores, a frente parlamentar evangélica teria uma proposta de alteração do projeto.

\section{PLC 122/2006 - A proposta da Frente Parlamentar Evangélica}

$\mathrm{Na}$ quinta-feira às 10 horas da manhã no gabinete do senador Marcelo Crivela representantes da Frente Parlamentar Evangélica e da Frente Parlamentar pela Cidadania GLBT reuniram-se para receber a proposta da frente evangélica e Frente Parlamentar da Família e Apoio à Vida. O senador e vice presidente da frente GLBT, Geraldo Mesquita (PMDB/AC) junto com a senadora Fátima Cleide, na presença do presidente da ABGLT - Toni Reis, Dr. Ivair dos Santos da SEDH, o representante do minstro Justiça Pedro Abramoway e assessores de parlamentares das duas frentes, receberam o documento dos opositores entregue pelo Deputado Bispo Rodovalho (DEM /DF), que na ausência dos senadores Crivela e Magno Malta prefiram não debater a proposta e remarcaram a reunião para segunda-feira (29/10). Cinco pastores do RO e ES e dos deputados da frente evangélica também estavam presentes na reunião. $\mathrm{O}$ documento entregue à frente GLBT foi assinado pelos deputados federais: Henrique Afonso (PT/AC), José Linhares (PP/CE), Pastor Manoel Ferreira (PSB/PB), Bispo Rodovalho (DEM /DF), Pastor Miguel Martini (PHS/MG), pelos senadores Magno Malta e Marcelo Crivela e pelo deputado estadual de Rondônia Valter Araujo . 
Dia 01 novembro será lido o parecer da Senadora Fátima Cleide. É fundamental a participaçáo de todas e todos. A ABGLT/Projeto Aliadas estará presente.

\section{O DOCUMENTO}

A proposta entregue descaracteriza totalmente o PLC 122/2006, a frente evangélica quer retirar os termos orientação sexual e identidade gênero, e sugerem a seguinte redação: art.20 "... define os crimes resultantes de discriminação ou preconceito de raça, cor, etnia, religião, procedência nacional e sexo". Com a redação proposta a lei que criminaliza a homofobia deixa de existir.

Em uma reunião com a senadora Fátima Cleide, Toni Reis afirmou que a ABGLT não negociará esta proposta. "Esta sugestão desrespeita a comunidade GLBT e as mulheres, não negociaremos em hipótese alguma" afirmou o presidente da ABGLT.

O documento dos opositores foi assinado por sete parlamentares, e cinco pastores. O projeto Aliadas e a Frente Parlamentar pela Cidadania GLBT começaram ontem a recolher assinaturas de parlamentares da frente GLBT, pedindo à $\mathrm{CDH}$ do senado o voto favorável ao parecer da senadora Fátima Cleide. Até o final da tarde de ontem já contávamos com a assinatura de 19 aliados.

\section{Informaçóes adicionais:}

Toni Reis - Presidente da ABGLT e coordenador geral do projeto Aliadas 4196028906 presidencia@...

Igo Martini - Coordenador executivo do projeto Aliadas - (41) 96025984 -(61) 81232695 aliadas@...

www.abglt.org.br/aliadas 


\title{
FOLHA DE S.PAULO
}

$14 / 11 / 2010-13 h 30$

\section{Grupo usou barra de lâmpadas em agressão a jovens na avenida Paulista}

\author{
GUILHERME REED \\ COLABORAÇÃO PARA A FOLHA
}

Atualizado às $14 \mathrm{~h} 03$.

O grupo de cinco rapazes --entre eles quatro menores-- que agrediu jovens em dois ataques na avenida Paulista, na manhã deste domingo, usou barras de lâmpadas brancas como arma.

Acompanhe a Folha no Twitter

Conheça a página da Folha no Facebook

Mãe de agressor diz que filho teve 'atitude infantil'

Primeiro, o grupo atacou dois rapazes que saiam de uma festa na altura do número 459 da Paulista --uma das vitimas conseguiu fugir e outra teve que ser internada devido aos ferimentos. Em seguida, os agressores foram em direçăo a um grupo de outros três jovens, já na altura do número 700 da avenida, e atacaram um deles com um golpe na cabeça.

A policia investiga se os ataques têm motivaçăo homofóbica -inicialmente, a PM informou erroneamente que os presos eram skinheads. Segundo o boletim de ocorrência, durante a agressão os rapazes diziam coisas como "suas bichas" e "vocês são namorados".

O delegado Alfredo Jang, do $5^{\circ} \mathrm{DP}$ (Aclimação), informou os menores serão transferidos para a Fundação Casa hoje à noite, e o maior será encaminhado para o $2^{\circ} \mathrm{DP}$. Jang indicou que eles devem responder por formação de quadrilha, porque eram cinco, e lesão corporal gravissima tentada. Além disso, afirmou que, "no minimo", eles estavam alcoolizados.

A mãe de um dos menores, de 16 anos, disse à Folha que o filho teve uma "atitude infantil". "Recebi a ligação quando ele já estava detido. Foi uma atitude infantil. Ele sai sempre com os amigos e nunca aconteceu absolutamente nada. É um garoto que tem boas notas. Estou constrangida pela situação."

Ela contou ainda que os rapazes detidos estudam juntos em um colégio do ltaim Bibi, bairro nobre da região oeste de São Paulo.

\section{OS ATAQUES}

À reportagem, João*, 20, contou que ele e Marcos *, 19, tinham acabado de sair de uma 
festa e esperavam um táxi quando viram o grupo de cinco rapazes atravessando a rua em direção a eles. Segundo João, estavam bem vestidos, usando roupas de marca, conversando e rindo. "À primeira vista, pareciam inofensivos. Quando passaram pela gente, um deles me agrediu na cabeça com um soco", conta.

Cada uma das vítimas fugiu para uma direção. João conta que correu para uma estação de metrô. "Apanhei até entrar no metrô. Ainda tropecei e caí na escada."

Quando estava seguro, ligou para o celular de Marcos, e uma mulher atendeu. Ela relatou que o rapaz estava no chão, sangrando, muito machucado e precisando de ajuda.

Socorrido no pronto-socorro Vergueiro, ele foi transferido depois para o hospital Oswaldo Cruz.

"É um trauma, nunca se espera que vá acontecer isso, tão de repente. É inacreditável", lamenta Joăo.

Após esse primeiro ataque, os cinco rapazes continuaram caminhando pela avenida Paulista, levando barras de lâmpadas nas mãos, quando cruzaram com outros três jovens saindo de uma lanchonete.

Desta vez, Bruno*, 23, foi o único agredido. Segundo o boletim de ocorrência, os jovens bateram com a barra de lâmpada na cabeça dele. Quando Bruno estava curvado, recebeu uma segunda pancada no rosto, relatou, e depois vieram socos no tronco e na cabeça.

Uma testemunha presenciou a segunda agressão e chamou a policia. Os cinco jovens foram detidos.

\section{* Os nomes são fictícios.}

\section{Endereço da página:}

http://uww1. folha.uol.com. br/cotidiano/830530-grupo-usou-barra-de-lampadas-em-agressao-a-jovens-naavenida-paulista.shtmi

\section{Links no texto:}

Acompanhe a Folha no Twitter http://twitter.com/folha_com

Conheça a página da Folha no Facebook http://www.facebook.com/folhadesp

Mãe de agressor diz que filho teve 'atitude infantil' http://unw1. folha.uol.com. br/cotidiano/830526-mae-de-agressor-diz-que-filho-teve-atitude-infantil-grupoatacou-3-na-av-paulista.shtm

mãe de um dos menores, de 16 anos, disse $\mathrm{http}$ //www1 fol ha uol com br/cotidiano/830526-mae-de-agressor-diz-que-filho-teve-atitude-infantil-grupoatacou-3-na-av-paulista.shtm!

Copyright Folha de S. Paulo. Todos os direitos resenados. É proibida a reprodução do conteúdo desta 


\section{ESTADÃO.COM.BR/São Paulo}

Jovem é baleado após Parada Gay do Rio e acusa militares

D., de 19 anos, disse que beijava o namorado quando três agentes do Exército apareceram e começaram a agredi-los

16 de novembro de 2010 | oh od

Marcelo Auler / RIO - O Estado de S.Paulo

O jovem D.I.M.L., de 19 anos, foi ferido com um tiro na barriga no Arpoador, zona sul do Rio, na noite de domingo, após a Parada Gay na orla de Copacabana. Ele acusa três militares do Exército de abordarem ele e seu namorado quando estavam "dando beijos". Inquérito vai apurar tentativa de homicídio e crime de discriminação por preconceito.

Os três militares, segundo depoimento do jovem ao delegado Alessandro Thiers, apareceram no Parque Garota de Ipanema - separado por uma grade do Forte de Copacabana - no momento em que um grupo de pessoas usava a área para sexo ou simples namoro, como disse ser seu caso. "Eles estavam com roupa camuflada, aquela meio azulada, agruparam cerca de 15 pessoas e começaram a tocar o terror psicológico. Começaram a ofender, a xingar, dizendo que se pudessem matavam cada um de nós com as próprias mãos. Humilharam e bateram, entre outras coisas", disse o jovem, aluno do ensino médio, após ser atendido no Hospital Miguel Couto e liberado. O ferimento foi superficial.

Segundo D., como seu acompanhante estava sem RG, os militares os retiveram no local após liberar os demais. "Ao ficarmos só nós dois, eles nos agrediram verbalmente e fisicamente. Foi quando um deles me empurrou, eu caí sentado e ele atirou na minha barriga", contou. Depois, o militar ainda lhe deu um chute. Ele foi socorrido por PMs,

O Comando Militar do Leste pela manhã divulgou nota afirmando que "nenhum militar do Forte de Copacabana disparou arma de fogo esta madrugada no Arpoador" e negando que militares façam ronda na área externa ao forte. À tarde, encaminhou dois oficiais à delegacia para ajudar no esclarecimento do caso. Os 30 militares em serviço no domingo serão levados à delegacia. 


\section{C6}

\section{Mackenzie divulga nota contra Lei da Homofobia; OAB fala em "postura da Idade Média"}

Rafael Targino

En Sà Paulo 16/112010 1 tohas

A Universidade Presbiteriana Mackenzie divilgou em seu site, na útima semana, uma nota em que se dizia contra a Lei da Homofobia. De acordo com o comunicado. assinado pelo chanceler [reitor] Augustus Nicodemus Lopes, "ensinar e pregar contra a prática do homossexualismo (sic) năo é homofobia, por entender que uma lei dessa natureza maximiza direitos a um determinado grupo de cidadăos." A lei torna crime manifestaçđes contrárias aos homossexuais.

\footnotetext{
Leia a integra da nota do Mackenze sobre a Lei da Homofobia

(http //educacao.uol.com.br/ulthot/2010/11/16/leia-a-integra-da-nota-do-mackenzie-sobre-alei-da-homofobia. 3 tm
}

Segundo o Mackenzie, "as Escrituras Sagradas, sobre as quais a breja Presbiteriana do Brasil [controladora da instituiçăo] firma suas crenças e práticas, ensinam que Deus criou a humanidade com uma diferenciaçăo sexual (homem e mulher) e com propósitos heterossexuais especficos que envolvem o casamento, a unidade sexual $e$ a procriaçăo".

O texto foi retirado do ar durante o feriado da Proclamaçăo da República. A assessoria de imprensa do Mackenzie nâo disse o motivo pelo qual ele nâo está mais disponivel no site.

\section{NOTA OFICIAL. DO MACKENZE}

"O pronunciamento sobre o PL. 122 e da kreja Presbiteriana do Brasil, Associada Vitallicia do Mackenzie, feito em 2007, e se encontra em seu site. O Mackenzie se posiciona contra qualquer tipo de violência e descriminaçào (sic) feitas ao ser humano, como tambem se posicion contra qualquer tentativa de se tolher liberdade de consciéncia e de expressão garantidas pela Constituiçăo."

Nota da redaçbo: A palawa "descriminaçao", utilizada pela assessoria do Mackenzie, significa, de acordo com o Dicionário Aulete, "ecklo cu ato de descriminar, de retirat a imoutacab de crime a alog: descriminolsacilo" Chitte-llaulate ud com. brisite. pho?

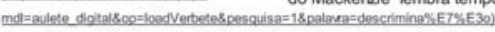

\section{Indignação}

Nesta terça (16), a assessoria de imprensa da instituiçẫo enviou ao UOL Educaçâo outra nota em que afirma que "o pronunciamento sobre o PL 122 [Lei da Homofobia] é da igreja Presbiteriana do Brasil, Associada Vitalicia do Mackenzie, feito em 2007, e se encontra em seu site." No entanto, no comunicado emitido no site do Mackenzie na última semana, o chanceler afirma que "o manifesto presbiteriano sobre a homofobia (...) serve de orientaçăo â comunidade acadêmica.

A nota indignou grupos de defesa de direitos dos homossexuais e especialistas na área. Para o presidente da Comissäo Nacional de Direitos Humanos da OAB (Ordem dos Advogados do Brasil), Jayme Asfora, a postura do Mackenzie "lembra tempos da Idade 
Média". "[A universidade está] Formando seus

alunos na base do preconceito, da discrminaçâo, indo de encontro à Constituiçầo Federal. Ela prega, como um dos seus maiores principios, a isonomia, a igualdade. Todos săo iguais perante a lei", afima.

Para o presidente do GGB (Grupo Gay da Bahia), Marcelo Cerqueira, essa é uma postura "esperada" do Mackenzie. "É uma questăo de consciência. O que move essa questâo do Mackenże é uma posiçăo reacionária", afirma. No comunicado, a universidade utiliza o termo "homossexualismo", que deixou de ser usado por se referir a homossexualidade como doença.

O Mackenzie, na nota enviada ao UOL, diz tambèm que "se posiciona contra qualquer tipo de violéncia e descriminaçăo (sic) feitas ao ser humano, como tambèm se posiciona contra qualquer tentativa de se tolher a liberdade de consciência e de expressão garantidas pela Constituiçăo:

O UOL Educaçäo pediu uma entrevista com o chanceler Augustus Nicodemus Lopes, mas o Mackenzie disse que iria se pronunciar por meio de nota.

\section{Criacionismo}

O Mackenzie, em 2008, assumiu oficialmente, nas aulas de ciências. a posiçăo criacienista (hitp//hmw1. folha. vol com.brifolha/ciencia/ut306u473446.shtml) -que defende que foi Deus quem criou o universo. A direçào da instituçăo, na época, afirmou que não negava os avanços da biologia vindos do darwinismo, mas que precisava também, mostrar que existe outra explicaçăo, de fundo religioso, para a origem das espécies.

\section{LEIAMAS}

Livros de ensino religioso em escolas publicas estimulam homofobia e intolerancla, diz estudo (http://educacao vol.com briulthot/2010/06/23/ivros-de-ensino-religioso-no-brasil-estimulamhomofobia-e-intolerancia-diz-estudo-da-unb.jhtm)

Escolas e colegas salo hostis a alunos e alunas homossexuais, aponta pesquisa (http://educacao.uol.com.br/ultnot/2010/10/04/escolas-e-colegas-sao-hostis-a-alunos-ealunas-homossexuais-aponta-pesquisa.jhtm)

Policia instaura inquérito para apurar homofobia em jornal de estudantes da USP (hitt:://educacao uol_combor/ultnoU/2010/04/27/policia-instaura-inquerito-para-apurarhomofobia-em-jornal-de-estudantes-da-usp.jhtm)

Faculdade abrita sindicancia para apurar jornal com incitaça à homofobia (http://educacao.uol.combrifultnot/2010/04/26/taculdade-abrira-sindicancia-para-apurarjornal-com-incitacao-a-homofobia. htm

Uustiça de SP determina abertura de processo contra publicaço que incitou homofobia na USP (http/leducacao vol,com.br/ultnot/2010/04/26/justica-de-5p-determina-abertura-deprocesso-contra-publicacao-que-incitou-homofobia-na-usp.jhtm)

Pesquisa revela que $87 \%$ da comunidade escolar tem preconceito contra homossexuais (http://educacao.uol.combriulthot/2009/07/24/ult105u8411.jhtm)

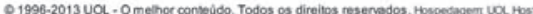


C7

\section{Presidência}

ENUNCIADO ADMINISTRATIVO No 14, DE 14 DE MAIO DE 2013

A realizaçẩo de concurso público, de provas e titulos, é medida que se impठ́e aos Tribunais imediatamente após a declaraçăo de vacância de serventias e órgăos prestadores de serviços notariais e de registro que atuem por delegaçăo do poder público ou oficializados, sob sua jurisdiçăo, nos exatos termos do $\S 3^{\circ}$ do art. 236 da Constituiçăo Federal.

Precedente: Procedimento de Controle Administrativo $n^{\circ}$ 0002328-10.2012.2.00.0000

\section{Ministro Joaquim Barbosa}

Presidente

\section{RESOLUÇĀO N` 175, DE 14 DE MAIO DE 2013}

sexo.

Dispōe sobre a habilitaçåo, celebraçăo de casamento civil, ou de conversão de uniåo estável em casamento, entre pessoas de mesmo

O PRESIDENTE DO CONSELHO NACIONAL DE JUSTIÇA, no uso de suas atribuições constitucionais e regimentais,

CONSIDERANDO a decisầo do plenàrio do Conselho Nacional de Justiça, tomada no julgamento do Ato Normativo no 0002626-65.2013-2.00.0000, na $169^{2}$ Sessăo Ordinária, realizada em 14 de maio de 2013;

CONSIDERANDO que o Supremo Tribunal Federal, nos acórdāos prolatados em julgamento da ADPF 132/RJ e da ADI 4277/DF, reconheceu a inconstitucionalidade de distinçăo de tratamento legal às uniठ́es estáveis constituidas por pessoas de mesmo sexo:

CONSIDERANDO que as referidas decisóes foram proferidas com eficacia vinculante à administraçăo pública e aos demais órgåos do Poder Judiciário:

CONSIDERANDO que o Superior Tribunal de Justiça, em julgamento do RESP 1.183.378/RS, decidiu inexistir óbices legais à celebraçăo de casamento entre pessoas de mesmo sexo:

CONSIDERANDO a competência do Conselho Nacional de Justiça, prevista no art. 103-B, da Constituiçăo Federal de 1988;

RESOLVE:

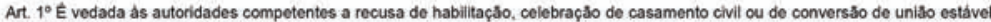
em casamento entre pessoas de mesmo sexo.

Art. $2^{\circ} \mathrm{A}$ recusa prevista no artigo $1^{\circ}$ implicará a imediata comunicaçåo ao respectivo juiz corregedor para as providèncias cabiveis.

Art. $3^{\circ}$ Esta resoluçăo entra em vigor na data de sua publicaçăo.

Ministro Joaquim Barbosa

Presidente

\section{Secretaria Geral}

\section{Secretaria Processual}




\title{
O GLOBO
}

\section{STF reconhece, por unanimidade, união civil entre pessoas do mesmo $\operatorname{sexo}$}

\begin{abstract}
Carolina Brigido
BRASILIA - Por unanimidade, o Supremo Tribunal Federal (STF) reconheceu legalmente na quinta-feira as uniōes entre pessoas do mesmo sexo. A partir desta sexta-feira, devem ser aplicadas a esse tipo de relaçăo as mesmas regras da uniâo estável heterossexual, prevista no Código Civil. A Corte năo relacionou os direitos que decorrem da decisāo. Mas, por analogia, os gays poderāo pleitear, por exemplo, a declaraçāo conjunta de Imposto de Renda, pensão em caso de morte ou separaçăo, partilha de bens e herança. A pessoa só precisa comprovar que integra uma "convivência pública, continua e duradoura", como diz a lei.
\end{abstract}

PROTESTO: Para CNBB, união entre homossexuais é a 'destruiçăo da familia'

COMEMORAÇÃO:Comunidade gay comenta julgamento do STF sobre uniẫo estável

INFOGRAFICO: Confira os direitos que os casais gays podem ganhar

MIDIAS SOCIAIS: Internautas comemoram decisão do Supremo

A regra deve ser aplicada pelos órgãos responsáveis, como o INSS, as operadoras de plano de saúde privado. empresas e governos. O cidadão que se sentir discriminado poderá entrar com açăo na Justiça. Diante do precedente do STF, a chance de vitória será alta. Em casos de separaçăo, se năo houver acordo entre as partes, também será necessário recorrer à Justiça.

Ficou decidido que as açōes devem ser julgadas, a partir de agora, individualmente pelos ministros, sem necessidade de ir a plenário, e sempre a favor dos homossexuais. A Corte também decidiu que cabe ao Congresso aprovar lei regulamentando as peculiaridades dos direitos decorrentes das unióes homoafetivas.

- É como que uma convocaçăo. A decisão da Corte implica que o Legislativo assuma essa tarefa de regulamentar a equiparaçăo - explicou o presidente do STF, ministro Cezar Peluso.Críticas à falta de decisôes sobre o tema no Congresso

A decisăo foi tomada no julgamento de duas açóes: uma proposta pelo governo do Estado do Rio, em 2008, e a outra, pelo Mnistério Público, em 2009. Há diferentes decisōes de tribunais e juizes sobre o tema. Com a decisão do STF, o entendimento fica unificado.

O principal argumento dos opositores da causa é que, ao tratar da familia, a Constituiçăo menciona apenas a relação entre homem e mulher. Para os ministros do STF, a falta de menção năo pode ser entendida como proibiçăo à uniấo de homossexuais. Eles lembraram principios constitucionais, como a dignidade, a igualdade, a vedação de discriminação por orientação sexual, a liberdade e a proteção da segurança juridica.

O relator, Carlos Ayres Britto, defendeu a exensâo de todos os direitos dos casais tradicionais às uniōes homoafetivas. Luiz Fux concordou com o relator. Votaram da mesma forma Cármen Lúcia, Ricardo Lewandowski, Joaquim Barbosa, Gilmar Mendes, Ellen Gracie, Marco Aurélio Mello, Celso de Mello e Peluso. José Antonio Toffoli nāo participou do julgamento, por ter dado parecer nas açōes quando era advogado-geral da Uniăo.

- Em casas onde nunca passaram um juiz ou um padre, há amor, há uma familia. O conceito de familia só tem validade conquanto privilegie a dignidade das pessoas que a compõe. A união homoafetiva enquadra-se no conceito de familia - argumentou Luiz Fux

- O Estado não pode adotar medidas nem interpretaçōes que provoquem a exclusão juridica de grupos minoritários - concordou Celso de Mello. - Com esse julgamento, o Brasil dá passo significativo contra a discriminaçâo.

Boa parte dos ministros lamentou que o STF tenha tido de tomar essa atitude no lugar do Congresso. 
- A ausência de aprovação dos diversos projetos de lei indica a falta de vontade coletiva quando à tutela juridica das uniőes homoafetivas - disse Marco Aurélio.

No julgamento, vários ministros mencionaram direitos que deveriam ser concedidos aos homossexuais. Ayres Britto, por exemplo, citou a adoção oficial de crianças por duas pessoas do mesmo sexo. Porém, a Corte preferiu năo definir como ficam esses detalhes. A ministra Maria do Rosário, da Secretaria dos Direitos Humanos, comemorou o resultado:

- Prevaleceram os direitos humanos, a igualdade, o principio constitucional de um pais que rejeita a discriminação. Este é um grande passo, porque todos os cidadăos brasileiros, homens e mulheres, independentemente de serem homossexuais ou heterossexuais, têm o mesmo valor - disse.

URL: http://glo.bo/xNJ8Mk

Noticia publicada em 5/05/11 - Oh00 | Atualizada em 3/11/11 - 22h32 | Impressa em 01/04/13 - 12h40 
COMISSÃO DE CONSTITUIÇÃO E JUSTÍÇA E DE REDAÇÃO

Projeto de Lei ${ }^{\circ} 5 / 2003$, que altera os arts. $1^{\circ}$ e 20 da lei $n^{\circ} 7716$, de 5 de janeiro de e $\circ \S 3^{\circ}$ do art. 140 do Código Penal, para incluir a punição por discriminação ou preconceito de gênero e orientação sexual.

Autor : Deputada Iara Bernardi

Relator: Deputado Aloysio Nunes

Ferreira.

Voto em Separado do Deputado José Divino.

O Projeto de Lei em referência foi distribuido as Coordenação de Comissões Permanentes (CCP), e de constituição Justiça e Redação (CCJR).

Ele pretende alterar os arts. $1^{\circ}$ e 20 da Lei $n^{\circ} 7716$, de 05 de janeiro de 1989 , e $\circ \S 3^{\circ}$ do art. 140 do Código Penal, para incluir a punição por discriminação ou preconceito de gênero e orientação sexual.

Nesta Comissão, a matéria recebeu parecer favorável do relator, pela constitucionalidade, juridicidade, boa técnica legislativa, apesar de ter consciência de que o PL 5/2003, tenha ignorado algumas normas da Lei Complementar 95/98, apresentando Emenda rejeitando o mérito.

A orientação sexual ao meu ver é uma opção, e não um gênero de vida, raça e cor. Trata-se de uma escolha humana para um determinado comportamento, assim como a orientação religiosa, política etc...

A opcão sexual não é nativa: o ser humano não nasce hetero ou homossexual, ele opta pela vida intima que levará apartir de um determinado periodo ao longo de sua existência.

Portanto Não me deterei em discorrer sobre o PL 5/2003, consciente que não cabe a inclusão na lei $n^{\circ} 7716$, e $\circ \S 3^{\circ}$ do art. 140 do Código Penal, punições por não aceitação de uma orientação sexual, cujo os parâmetros fogem das orientações familiares e sociais, não se tratar de preconceito e sim de opção de vida. 
Vale enfatizar que homossexualismo não é uma cultura; os optantes não vivem em culturas diferenciadas, eles convivem nas diversas classes sociais e culturais, não há como identificar um optante homossexual por sua cultura, raça ou cor.

Com relação a justificativa da autora do Projeto Lei, o enorme grau de violência praticado contra os homossexuais, é também praticado com a mesma gravidade contra : mulheres donas de casa, mulheres prostitutas, crianças e adolescentes usuários de drogas, negros, pobres e religiosos.

A vista do exposto, opinamos pela não aprovação deste Projeto, por entender que não cabe mudança na lei, ficando o mérito da questão prejudicado.

Sala das sessões, em 18 de setembro de 2003.

\section{JOSÉ DIVINO}

Deputado Federal - PMDB/RJ 


\section{$\boldsymbol{\top}$}

01/06/2011 17h27 - Atualizado em 01/06/2011 18h26

\section{Lei não pode criar 'terceiro sexo', diz Magno Malta em marcha em Brasília}

Parlamentares participaram de evento contra projeto que criminaliza homofobia. Manifestantes favoráveis ao PLC 122 fizeram 'contra-marcha' na Esplanada.

Do GI DF

imprimir

O senador Magno Maka (PR-ES) disse nesta quarta-feira (1), durame manifestaçấo em frente ao Congresso Nacional contra a aprovaçâo do projeto de Lei da Câmara (PLC) 122, que criminaliza a homofobia, que o Senado não tem poder para crár "um terceiro sexo" por meio de kegishạão.

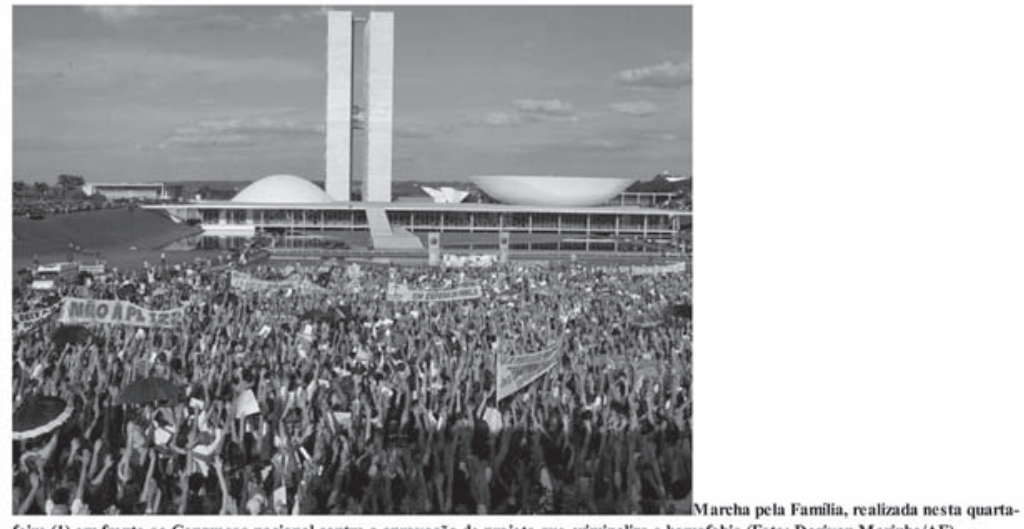
feira (1) em frente ao Congresso nacional contra a aprovação de projeto que criminaliza a homofobia (Foto: Dorivan Marinho/AE)

"Se Deus criou macho e fêmea, nào vai ser o Serndo que vai crỉu um terceiro sexo com uma le" disse, "É preciso que eles [homossexuais] entendam que o anseio grotesco de uma minorí nìo vai se faker engolir", afirmou.

O evento, batizado de Marcha peh Famfía, foi organizado pelo pastor Silas Mahafia e reuniu diversos parhmentares contránios ao projeto de kei em cima de carros de som - entre eles os depieados federais João Campos (PSDB-GO), Ronaldo Fonseca (PR-DF), Jair Bolsonaro (PP-RJ) e Arthony Garotinho (PR-RJ), e os senadores Marceb Crivelh (PR-RJ) e Walter Pinheiro (PT-BA). A PM estimou em até 20 mil pessoas os presentes na Marcha pela Familis.

Garotinho se manifestou contra a aprovaçào do projeto, 'Eles [os participantes da marcha] amma a todas as pessoas, só que nào concordam como pecado de algums", disse.

Em oposiçào ao evento,um grupo de integrantes de movimentos liģados a causas homossexuais fez uma espécie de contra-marcha à Marcha Peba Famila. Eles se reuniram em frente à Catedral de Brasilia às $15 \mathrm{~h}$ e seguiram até o Congesso, no mesmo local onde ocorria a Marcha pela Familia.

A policia formou um cordåo de isolamento para eviar conflitos entre os dois grupos. Um contingente de 110 policiais foi deslocado para o beal para 
acompanhar o evento.

Ainda assim, os dois grupoos se hostifraram Os defensores do projeto de kei chamnam os integrantes da Marcha pela Familia de "maxistas" $\mathrm{e}$ "fiscistas". O deputado Jair Bokaro rebateu as acusaçỏes. "Eles săo ridicubs. Até o que eles falam é ridicub", afimou.

Os manifestantes que defendem o PLC 122 carregivam faicas e entoavam paharas de ordem em fivor de uma "famila phural". Muitos se vestiram de roxo. A manifestaçî̀o foi organizada pela internet, mas nuitos chegaram ao local sem saber que havia um evento organirado.

"Eu viria de quakquer jeito, independentemente de ter um evento organizado ou nào", disse Crítiano Ferreira, 35, servidor público, Eke vine há 3 anos con um companheiro e defende o projeto de ki. 'O Estado é püblico e hico, e por isso não pode privilegiar o pensamento de uma religĩio para defender ume kgishação", afirmou 
C11

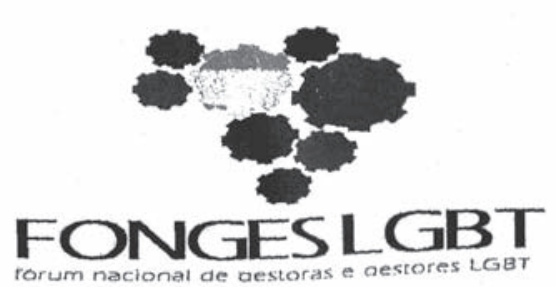

Brasilia, 15 de dezembro de 2011.

\begin{abstract}
À Comissāo Organizadora da II Conferência Nacional LGBT
Às delegadas e delegados, observadoras e observadores, convidadas e convidados presentes na II Conferência Nacional LGBT
\end{abstract}

Esta carta tem a intenção de apresentar as Vossas Senhorias, a criação, em 20 de junho de 2011, na cidade de Sáo Paulo - SP, do Fórum Nacional de Gestoras e Gestores Estaduais e Municipais de Políticas Públicas para População de Lésbicas, Gays, Bissexuais, Travestis e Transexuais - FONGES LGBT, uma entidade constituída pelo conjunto das gestoras e gestores responsáveis pela coordenaçáo e execuçẩo da politica LGBT em seu território, e cujos objetivos săo:

- Contribuir para a formulação de diretrizes básicas para o aprimoramento das políticas públicas voltadas à população LGBT;

- Defender e posicionar-se em favor dos interesses dos Municipios, Estados e Distrito Federal na garantia da execuçăo de politicas públicas e sociais para a populaçáo LGBT;

- Fortalecer a participação dos Municípios. Estados e do Distrito Federal, garantindo os direitos LGBT como Políticas de Estado;

- Promover o intercâmbio de experiências e ações que facilitam a operacionalizaçâo da politica para a populaçáo LGBT, respeitando as diversidades regionais:

- Articular junto aos poderes executivos e legislativos a ampliaçáo de recursos financeiros que viabilizem e garantam a sustentabilidade da politica pública para a população LGBT; 


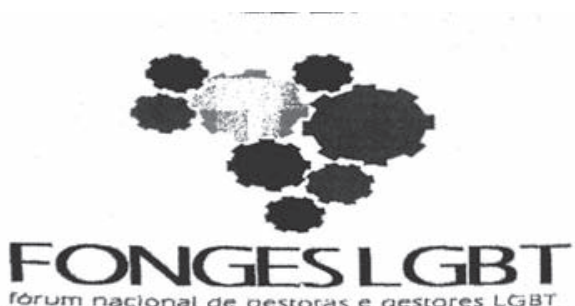

- Participar das instâncias de pactuaçăo, discussáo e de deliberaçăo da política para a populaçăo LGBT;

- Propor Estudos e Pesquisas que contribuam para o aperfeiçoamento da política para a populaçâo LGBT.

- Estimular a criaçăo de órgăos gestores da política pública para a populaçâo LGBT nos Estados, Distrito Federal e Municipios.

Nossa estrutura organizacional é composta pela Assembléia Geral. Coordenaçăo Geral, Comissōes e Câmaras Técnicas.

A Coordenaçáo Geral e sede atual do FONGES estâo sob responsabilidade do Governo de Mato Grosso do Sul. As Coordenaçóes Regionais foram definidas conforme segue:

Nordeste - Prefeitura Municipal de Fortaleza/CE;

Norte - Governo do Estado do Pará;

Sudeste - Prefeitura Municipal do Rio de Janeiro;

Sul - Governo do Estado do Rio Grande do Sul;

Centro-Oeste - Governo do Estado de Mato Grosso do Sul.

Além das Coordenaçōes Regionais o FONGES - LGBT possui, ainda, duas Comissōes instituidas:

1) institucionalizaçăo da Política Pública para a populaçáo LGBT - Governo do Estado do Ceará;

2) Jurídica e de Ética - Governo do Estado de Sâo Paulo.

Assim, multo embora sejamos um organismo novo, nos colocamos parceiros da sociedade civil organizada e do Governo Federal na construçăo das politicas públicas para a populaçåo LGBT, inclusive porque acreditamos viver um momento favorável, capaz de avançar na institucionalizaçâo $\theta$ capilarizaçâo das Politicas Públicas pró-LGBT. 


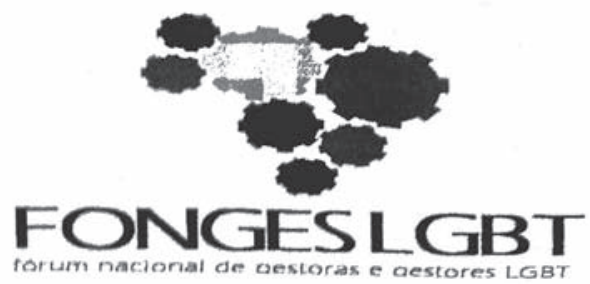

Ressaltamos, por fim, que empenhamos esforços e disponibilidade política para a realizaçáo das etapas municipais, regionais e estaduais que preconizaram esta II Conferència Nacional LGBT, garantindo o pleno sucesso das etapas locais visando à construçáo de novos rumos e de novas propostas de políticas públicas a serem debatidas nesta II Conferência Nacional.

Dessa forma, ao mesmo tempo em que cumprimentamos essa distinta plenárla, colocamo-nos à disposiçáo para, durante estes três dias, em especial, e nos demais dias do decorrer dos anos, a construçăo de um país livre da lesbofobia, transtobia e homofobia minorando a discriminaçáo, preconceito e violência pelas quals passam, cotidianamente, nossa população de lésbicas, gays, bissexuais. travestis e transexuais.

Atenciosamente,

\section{Coordenação Geral FONGES- LGBT}


(a)

PROCLRADORIA-GERAL FEDERAL

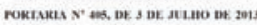

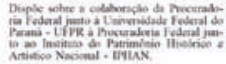

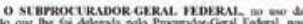

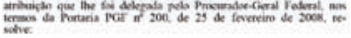

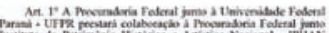

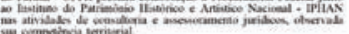



ANTONDO Ronento Dasso

SECRETARIA DE DIREITOS HUMANOS

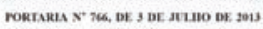

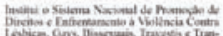

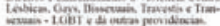



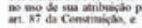

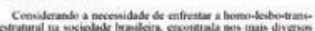



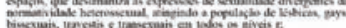

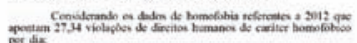

\begin{tabular}{|c|}
\hline $\begin{array}{l}\text { PRESIDÊNCIA DA REPÚBLICA } \\
\text { CASA CIVIL } \\
\text { IMPRENSA NACIONAL }\end{array}$ \\
\hline 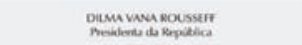 \\
\hline  \\
\hline 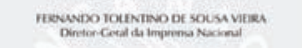 \\
\hline 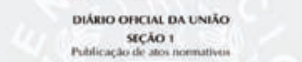 \\
\hline 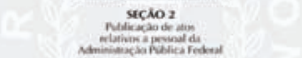 \\
\hline 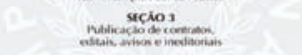 \\
\hline 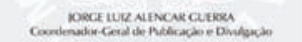 \\
\hline 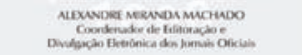 \\
\hline 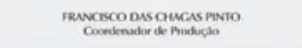 \\
\hline 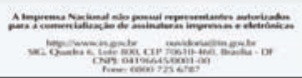 \\
\hline
\end{tabular}

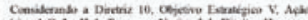

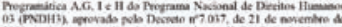

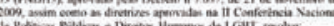

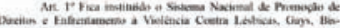

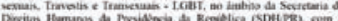

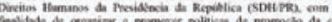

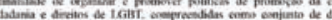

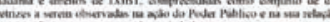

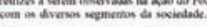

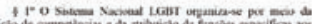

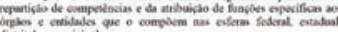
distriat e manicipal.

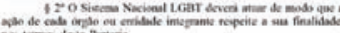

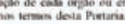

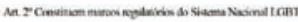

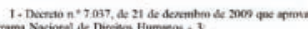
6 Pregama Naciotal de Direthen Hummes - 3

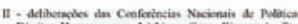

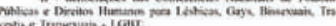

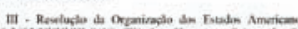

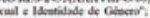

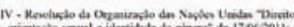

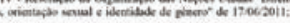

V. Portaria MroG or 233, de is de maio de 2010, que

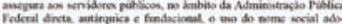

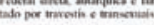

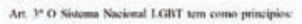

1. aniculaske iefrefolestisa:

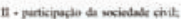

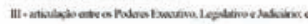

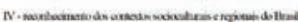

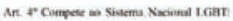

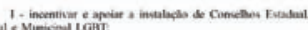

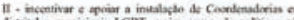

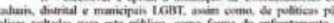

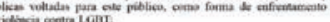

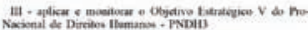

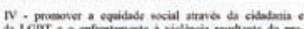

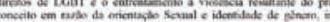

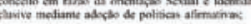

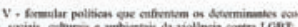



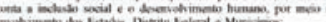

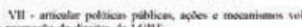

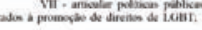

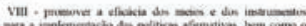

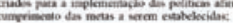

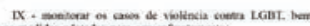

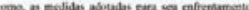

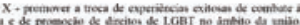

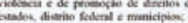

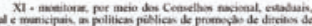

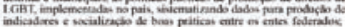

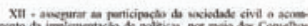

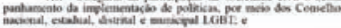

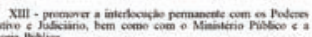 Deginlations of Juticion \\ An. 9 Intepant o Sistema Nasiveal LCBI. \\ 1. SOAPR,

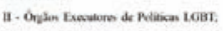

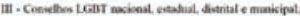

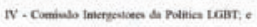 \\ V. Cinfanksias Loist.

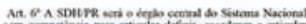

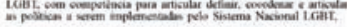

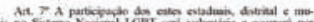

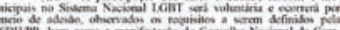

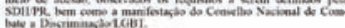

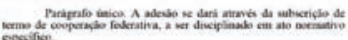

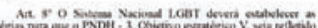

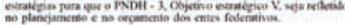

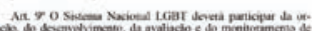

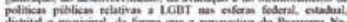

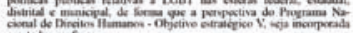

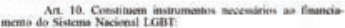

1. Nene Marimat de Cinerso (PPN)

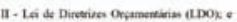

iti - Lei Ongescatirit Araul

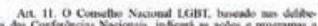

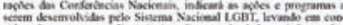

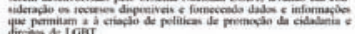

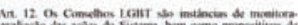

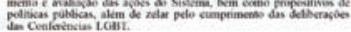

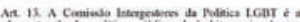

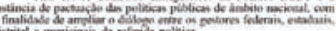

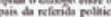

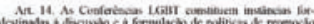

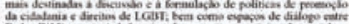

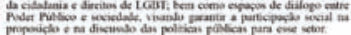

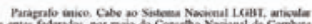

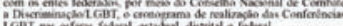

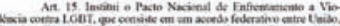

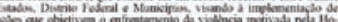

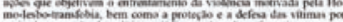

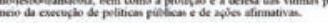

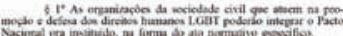

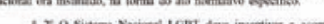

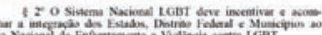

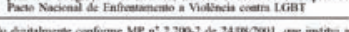




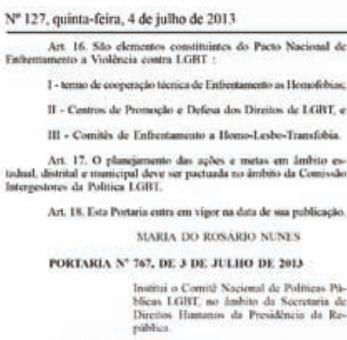

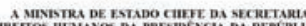

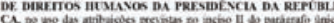



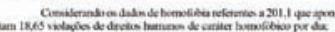

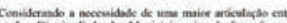



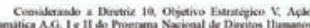

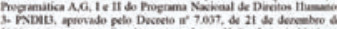

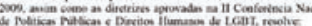

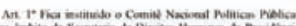

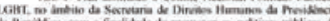

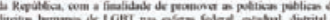
manicipail.

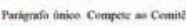

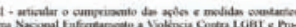
megito de Dirions:

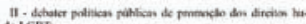

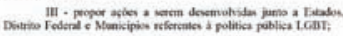

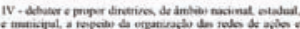

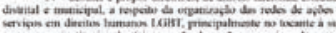

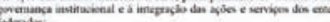

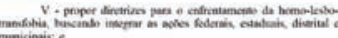

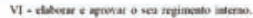

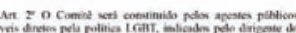

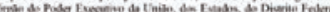

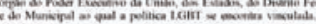

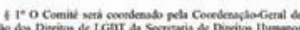

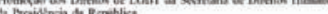

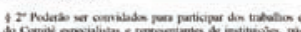

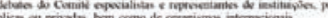

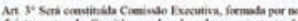

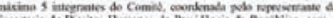

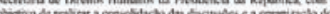
whathen do Cemite

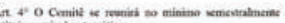
poderi mastitis exmiseles temitica.
Diário Oficial da Uniāo - Seçào 1

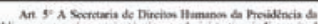

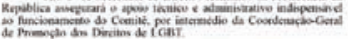

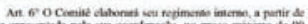

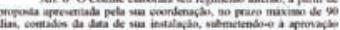

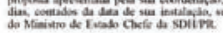

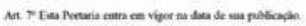
MARRL DO ROBARLO NETIS ке.micacio

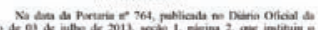

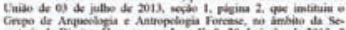

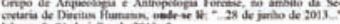

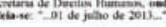

\section{SECRETARIA DE PORTOS}

AGẼNCIA NACIONAL DE TRANSPORTES AQUAVIARIOS

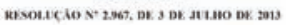

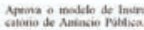

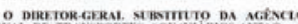

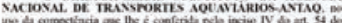

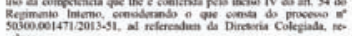

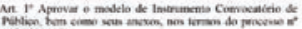
303000014712013.92.

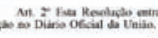

$$
\text { MDRo arito }
$$

SECRETARLA DE AVIACĊo CIVIL AGÉNCIA NACIONAL DE AVLACẢO CIVIL

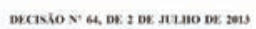

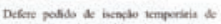

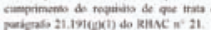

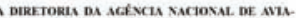
fio civil. - Avic, me erescicio de compelbcis ope the fir

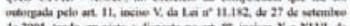

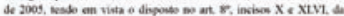

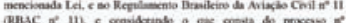

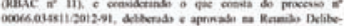

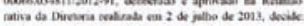

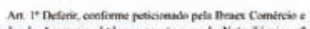

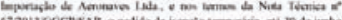
6.

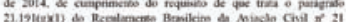

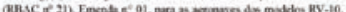

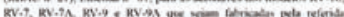

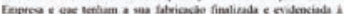
ANMC dengo dense prom

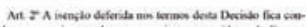

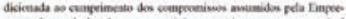

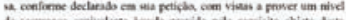

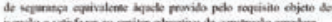

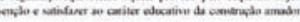

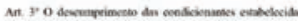

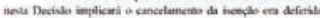

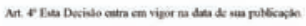

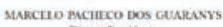

105V 1677.7042 3 केष

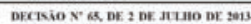

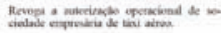

A DIRETORAS DA AGEVIA NACIONA. DE ANA

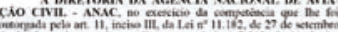

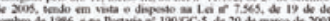

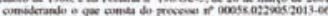

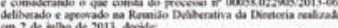
in 2 de gathe de 2013, destiter

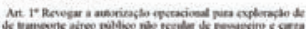

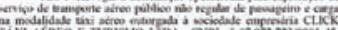

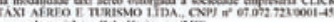

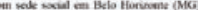

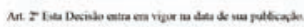

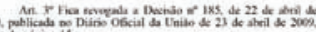
ento 1, piciea is

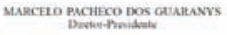

SUPERINTENDÉNCIA DE REGULACAO ECONOMICA E ACOMPANHAMENTO DE MERCADO

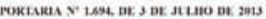

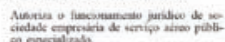

A STPFANTENDENTE DE REGTLAC̆́ ECONô. ICC E. ACOSiPs

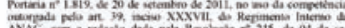

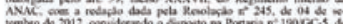

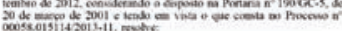

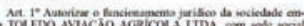

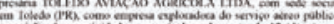

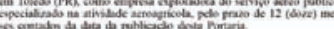

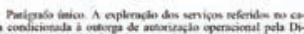

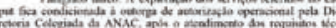
Heveryorition

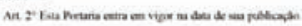

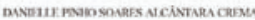

SUPERINTENDĖNCIA DE SEGURANCA

OPERACIONAL
GERÉNCIA DE FATORES HUMANOS NA AVIACX̃o E MEDICINA DE AVIACAAO

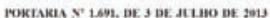

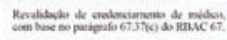

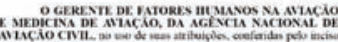

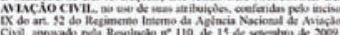

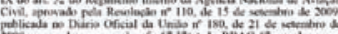

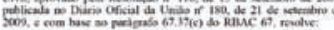

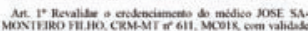

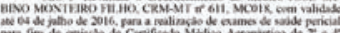

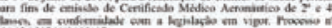
000690997482013.97

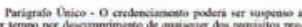

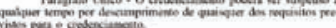

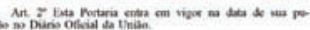
Dasme. Barra cames

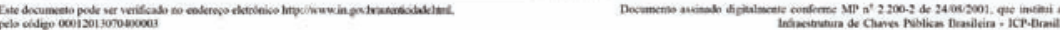


C14

\section{IMPRENSARJ NOTÍCIAS}

GOVERNADOR

\section{ESTADO LANÇA CAMPANHA RIO SEM HOMOFOBIA}

16/05/2011 - 12:48h - Atualizado em 16/05/2011 - 18:18h , Por Guedes de Freitas

Na ocasiăo, govemador autorizou policiais e bombeiros a participarem uniformizados da Parada do Orgulho Gay

O Governo do Estado lançou nesta segunda-feira (16/5) a Campanha Rio Sem Homofobia, que será veiculada por rádios, televisōes, cartazes, outdoors, busdoor, mobiliário urbano, folhetos, além de um site e itens promocionais, como camisetas, barracas de praia e blocos, para reforçar a luta do movimento GLBT (gays, lésbicas, bissexuais, travestis e transexuais) no Estado do Rio.

Assinada pela empresa de publicidade e propaganda Nova S/B, a campanha vai reforçar a mensagem contra a homofobia mostrando homossexuais como cidadăos comuns. As peças publicitárias văo destacar a atuaçăo inovadora do Programa Rio sem Homofobia, que combate a discriminaçăo e o preconceito contra LGBT, promovendo a cidadania desta populaçăo no Estado do Rio.

A campanha estará nas ruas a partir desta terca-feira (17/5), data em que, desde 1993, celebra-se o Dia Mundial de Combate à Homofobia. Este ano a data será comemorada em 102 paises, entre eles o Brasil, O governador Sérgio Cabral participou da solenidade, realizada no auditório do $7^{\circ}$ andar do prédio da Central do Brasil, ao lado do vice-govemador e secretário de Obras, Luiz Fernando Pezão, e da senadora Marta Suplicy, que representa a frente parlamentar LGBT no Congresso Nacional.

\section{Estado também lança o Caderno de Açōes e Metas}

Na mesma solenidade, aberta pela atriz e travesti Jane Di Castro interpretando o Hino Nacional e a cantora Elza Soares declamando a letra da música Monte Castelo, de Renato Russo, do grupo Legiåo Urbana, foi lançado o Caderno de Açes e Metas, do Programa Rio Sem Homofobia, que reúne 125 iniciativas para serem executadas nas áreas de administraçăo penitenciária, assistência social e direitos humanos, educaçăo, saúde, segurança pública e defensoria pública geral.

Depois de assinar o documento de lançamento do caderno, Cabral elogiou o trabalho desenvolvido pela Secretaria de Assistência Social e Direitos Humanos de uma forma geral e, no caso especifico do movimento LGBT, as politicas públicas de transformaçőes sociais. Depois, listou uma série de medidas que o Governo do Estado tomou, nos últimos anos, para diminuir a discriminaçăo que esse segmento da populaçăo sofre, citando, entre outras, a garantia de pensâo a companheiro ou companheira de funcionário público.

Cabral realçou a importância de se divulgar essas e outras açós da luta contra o preconceito e a favor da universalizaçáo dos direitos humanos e da liberdade individual. O governador pediu à equipe técnica para rodar as peças publicitárias feitas para o rádio e televisâo, que ele próprio ajudou a criar.

Por fim, o governador também autorizou os policiais militares e civis e bombeiros que se assumem gays a participarem uniformizados, se assim desejarem, da próxima Parada Gay, como se we em outras cidades onde essas marchas sâo populares, como Nova York, San Francisco e Paris. 
- Da minha parte, eståo todos liberados para sair na próxima passeata. Podem botar o carro do Corpo de Bombeiros, das policias. Nenhum problema. $\mathrm{O}$ amor nāo deve ser razăo de nenhum tipo de discriminação - garantiu.

\section{Luta agora é para aprovar lei de criminalizaçăo da homofobia}

Segundo o coordenador do Programa Rio sem Homofobia e presidente do Conselho Estadual dos Direitos da populaçăo LGBT, Cláudio Nascimento, também responsável pela Superintendència de Direitos Individuais Coletivos e Difusos, da Secretaria Estadual de Assistência Social e Direitos Humanos, a luta, agora, é fazer com que o Congresso Nacional aprove o projeto de lei 122/2006 que considera crime qualquer ato contra homossexuais. Segundo ele, esta agenda é da sociedade civil, mas conta com todo o apoio do Governo do Estado.

- Um passo importantissimo que demos foi a aprovaçāo, no Supremo Tribunal Federal (STF), da legalizaçâo da uniâo civil de pessoas do mesmo sexo. Uma vitória que foi conseguida por meio de uma açăo do Governo do Estado. Isso dá orgulho ao Rio de Janeiro, que sempre foi vanguarda na história das transformaçóes sociais do pais. A próxima etapa é fazer com que o Congresso saia da letargia, da sua covardia em relaçăo a esse debate, e assuma de forma objetiva e sincera que um setor da sociedade está excluido dos direitos plenos de cidadania. É preciso ter uma legislaçăo que torne crime a prática da homofobia - disse Nascimento.

O superintendente informou que, amanhă, sairâo caravanas de 27 estados para pressionar o Congresso Nacional a votar o projeto de lei. O governador acredita que, assim como os membros do Supremo Tribunal Federal (STF) legalizaram a uniâo civil de pessoas do mesmo sexo, o Senado vai aprovar o projeto de lei.

A senadora Marta Suplicy, que aponta o Estado do Rio como vanguarda nas conquistas sociais no Brasil, disse que há muitos parlamentares que concordam com a causa LGBT, mas temem se manifestar.

- Esta parcela dos parlamentares está de acordo com o casamento homoafetivo, com o combate à homofobia, mas nâo deixa a causa ir para frente. Conclamo as pessoas simpatizantes a auxiliarem esta parcela, que é mais numerosa, a vencer suas dificuldades em se pronunciar $e$, assim, podermos aprovar a lei no Senado - pediu Marta Suplicy.

O secretário de Assistência Social e Direitos Humanos disse que é a primeira vez na América do Sul que um governo estadual lança uma campanha de defesa da diversidade sexual. Segundo Rodrigo Neves, o lançamento da campanha vem no momento especial do movimento LGBT, logo após a decisẫo do STF. Por fim, Neves informou ainda que o Disque Cidadania LGBT (0800 0234567) vai atender 24 horas por dia, a partir de hoje.

Ele citou ainda açōes de órgăos fora de sua pasta a favor da causa LGBT, como a decisāo da Defensoria Pública Geral do Estado do Rio Janeiro de criar o núcleo de defesa da diversidade sexual, o primeiro no pais, e a disposiçăo da chefe da Policia Civil, Martha Rocha, também presente ao evento, de incrementar as investigaçōes e o combate aos crimes homofóbicos no Estado. $O$ secretário anunciou a inauguraçăo no segundo semestre dos centros de referencia do Programa Sem Homofobia nas cidades de Duque de Caxias, Sâo Gonçalo, Nova Iguaçu e Niterói.

- E, no dia 28 de junho, dia do meu aniversário, o governador vai assinar decrelo permitindo que traves tis e transexuais possam usar o nome social deles quando forem a uma repartição pública estadual $e$ assim năo sofram mais constrangimento - completou Neves.

Uma das fundadoras da Parada Gay no Rio de Janeiro e primeira travesti do pais a cantar o Hino Nacional em eventos e locais públicos, como o Congresso Nacional e a Assembleia Legislativa do Estado do Rio de Janeiro (Alerj), a atrize ativista do movimento LGBT Jane Di Castro relembrou os tempos dificeis para os homossexuais em todas as áreas de atividade no pais devido à

discriminação e violência. Nos anos 1960, ela trabalhava no musical Le Girls, em que todos os componentes eram transformistas. O musical só foi liberado pela censura da ditadura em 1966. Segundo Jane, graças às conquistas dos últimos tempos, a situaçâo do homossexual hoje é bem melhor. 
- E muito disso se deve ao Sérgio Cabral, que conheço desde garoto, pois sou muito amiga do pai dele. O fato de ele ser carioca, de ter uma cabeça carioca e amar o Rio, o movimento LGBT conquistou muita coisa aqui. Os governadores e prefeitos anteriores não tinham este espírito, não entendiam direito o Rio de Janeiro. Hoje me sinto honrada de ter um aliado como o governador Sérgio Cabral - frisou a transformista.

\section{FOTOS}

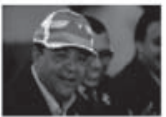




\section{ASSISTÊNCIA SOCIAL E DIREITOS HUMANOS \\ NOTÍCIAS}

\section{ESTADO ASSEGURA DIREITO DE TRAVESTIS E TRANSEXUAIS DE USAREM NOME SOCIAL}

selecione/selecione/selecione - selecione:selecioneh - Atualizado em 12/07/2011 - 11:01 h

Decreto assinado pelo governador Sérgio Cabral foi publicado no Diário Oficial do dia 11 de julho

Mais uma vezo estado do Rio de Janeiro legitima sua posiçâo democrática e garantidora dos direitos civis da populaçăo de lésbicas, gays, bissexuais, travestis e transexuais (LGBT). 0 governador Sergio Cabral assinou um decreto que assegura às pessoas transexuais e travestis capazes, mediante requerimento, o direito à escolha de utilizaçâo do nome social nos atos e procedimentos da Administração Direta e Indireta do Estado do Rio de Janeiro.

Entende-se por nome social o modo como as pessoas traves tis e transexuais saao reconhecidas. identificadas e denominadas na sua comunidade e meio social. Todos os registros do sistema de informaçăo, cadastro, programas, projetos, açōes, serviços, fichas, requerimentos, formulários prontuários e congêneres da Administraçăo Pública Estadual deverăo conter o campo "Nome Social" em destaque, fazendo-se acompanhar do nome civil, que será utilizado apenas para fins internos administrativos.

"A pessoa transexual ou travesti poderá solicitar inclusão do nome social nos registros dos sistemas de informaçăo, cadastros, fichas, requerimentos, formulärios, prontuários e congêneres. Isso é mais uma vitória his tórica e marcante para esta populaçăo, que há muito vem sendo violada em seus direitos humanos. O Rio de Janeiro é um exemplo para o paisf", orgulha-se o superintendente de Direitos Individuais Coletivos e Difusos da Secretaria de Estado Assistência Social e Direitos Humanos, Cláudio Nascimento.

As denúncias referentes â não utilizaçăo do nome social pela Administração Pública Direta deverăo ser encaminhadas para a Comissâo Processante criada pela Resoluçăo SEASDH n ${ }^{\circ} 310$, de 29 de dezembro de 2010, da Secretaria de Estado de Assistência Social e Direitos Humanos, em razão da Lei $3.406 / 2000$. 
C16

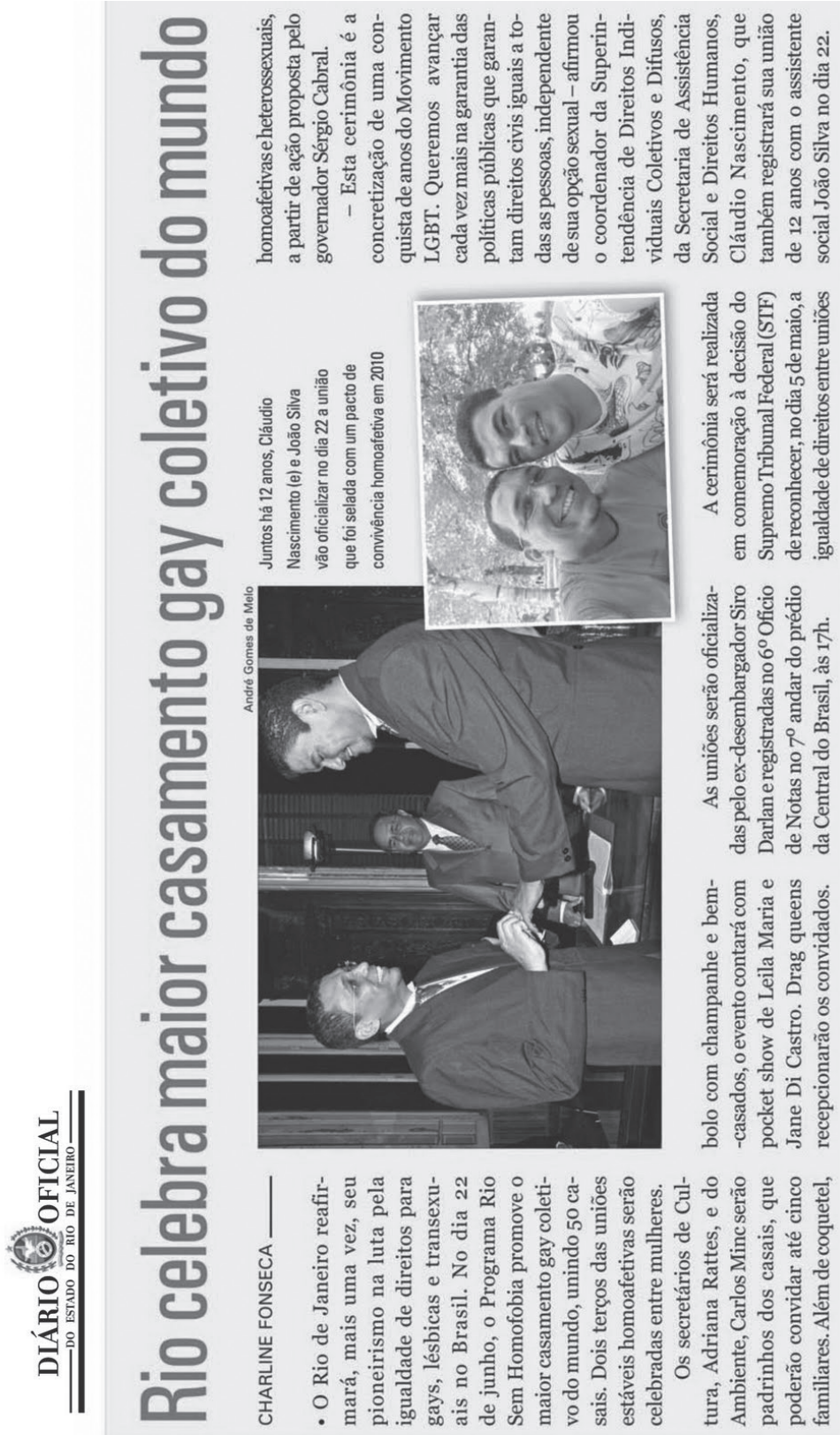




\section{IMPRENSARJ \\ NOTÍCIAS}

\section{ASSISTÊNCIASOCIAL}

\section{RIO DE JANEIRO CELEBRA MAIOR CERIMÔNIA DE CASAMENTO GAY DA HISTÓRIA}

18/06/2011 - 10:03h - Atualizado em 18/06/2011 - 17:42h

7. Por Charline Fonseca

\section{Programa Rio Sem Homofobia vai unir 50 casais no próximo dia 22 de junho}

O Rio de Janeiro reafirmará, mais uma vez, seu pioneirismo na luta pela igualdade de direitos a gays, lés bicas e transexuais no Brasil. No dia 22 de junho, o Programa Rio Sem Homofobia, promove o maior casamento gay coletivo do mundo, unindo 50 casais. Dois terços das uniōes estáveis homoafetivas serăo celebradas entre mulheres.

Os secretários de Cultura, Adriana Rattes, e do Ambiente, Carlos Minc serão padrinhos dos casais, que poderăo convidar até cinco familiares para o evento. Alèm de coquetel, bolo com champanhe $e$ bem-casados, o evento terá trilha sonora especial com pocket show de Leila Maria, que cantará cançōes próprias, e de Jane Di Castro, interpretando os maiores sucessos de Roberto Carlos. Drag queens caracterizadas com figurinos inspirados na Belle Époque recepcionarăo os convidados.

As unī̄es serăo oficializadas pelo ex-desembargador Siro Darlan e registradas no $6^{\circ}$ Oficio de Notas no auditório do $7^{\circ}$ andar do prédio da Central do Brasii, no centro, às $17 \mathrm{~h}$. Uma equipe do Núcleo de Direitos Humanos da Defensoria Pública, que também apóia o evento, estará presente para conceder isençăo àqueles que atestarem impossibilidade financeira de pagamento das taxas de cartório.

Acerimónia será realizada em comemoraçăo à decisăo do Supremo Tribunal Federal (STF) de reconhecer, no dia 5 de maio, a igualdade de direitos entre uniós homoafetivas e heterossexuais. a partir de aça proposta pelo governador do estado, Sérgio Cabral. Para o coordenador da Superintendéncia de Direitos Individuais Coletivos e Difusos, da Secretaria de Assistência Social e Direitos Humanos, Cláudio Nascimento, o casamento coletivo dará visibilidade aos direitos conquistados pelos homossexuais.

-Esta cerimônia é a concretizaçăo de uma conquista de anos do Movimento LGBT. Queremos avançar cada vez mais na garantia de nas politicas públicas que garantam direitos civis iguais a todas as pessoas, independente de sua opção sexual - afirma.

Segundo Clăudio, que também registrará sua uniẫo de 12 anos com o assistente social Joăo Silva no dia 22 - há um ano, o casal oficializou a uniâo como pacto de convivência homoafetiva - a superintendência pretende realizar cerimônias regionais para ampliar o acesso da populaçăo à informaçăo.

- A partir do segundo semestre, vamos visitar as nove regiōes do Estado, promovendo o mesmo evento em cidades-polo, incentivando os casais de gays, lésbicas e transexuais a registrarem suas uniōes, o que lhes confere mais segurança, principalmente ao construir um patrimonio comum adianta Cláudio. 


\section{Garotinho pede desculpas e aceita projetos de grupos homossexuais}

Governador regulamenta a lei estadual que pune a discriminaçăo


\section{PT teme herdar um governo falido}

Partido fará levantamento sobre problemas e falhas da gestăo Garotinho
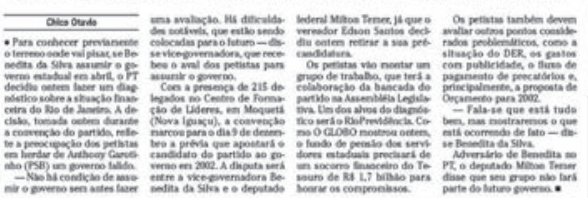

CPI gaúcha vai indiciar Diógenes e mais dez

Doaçóes a Clube de Cidadania podern ter servido para beneficiar o PT em Porto Alege
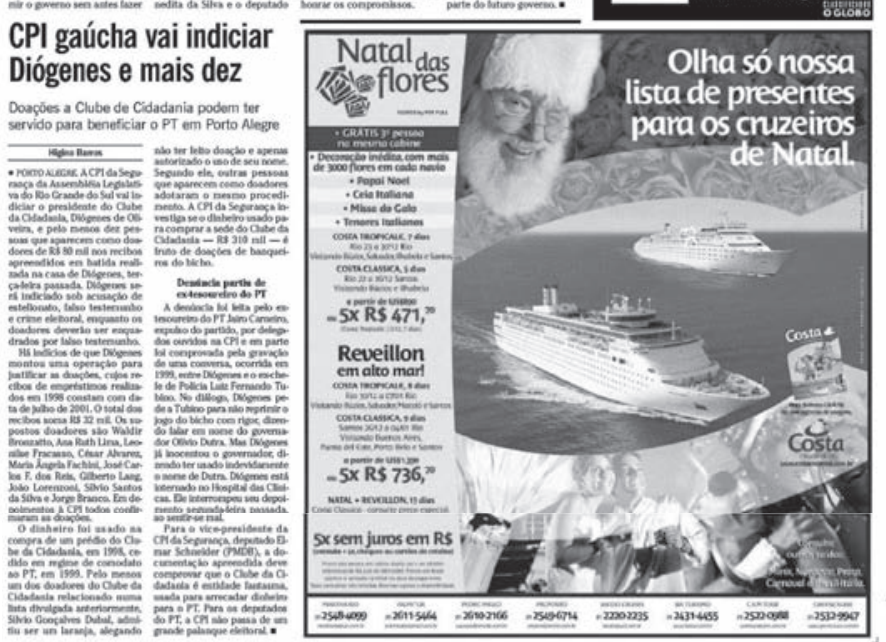

ZONA SUL. MELHOR ATÉ NO PREÇO.

Sempre as methores marcas. Sempre os methores preces. Essa só vale hoje: $12 / 11 / 01$

Filezinho de Peito de Frango Sadia lkg

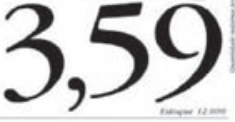

Nào perca: amanhà tem mais uma oferta exclusiva.



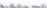

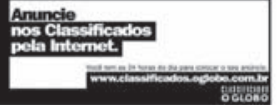



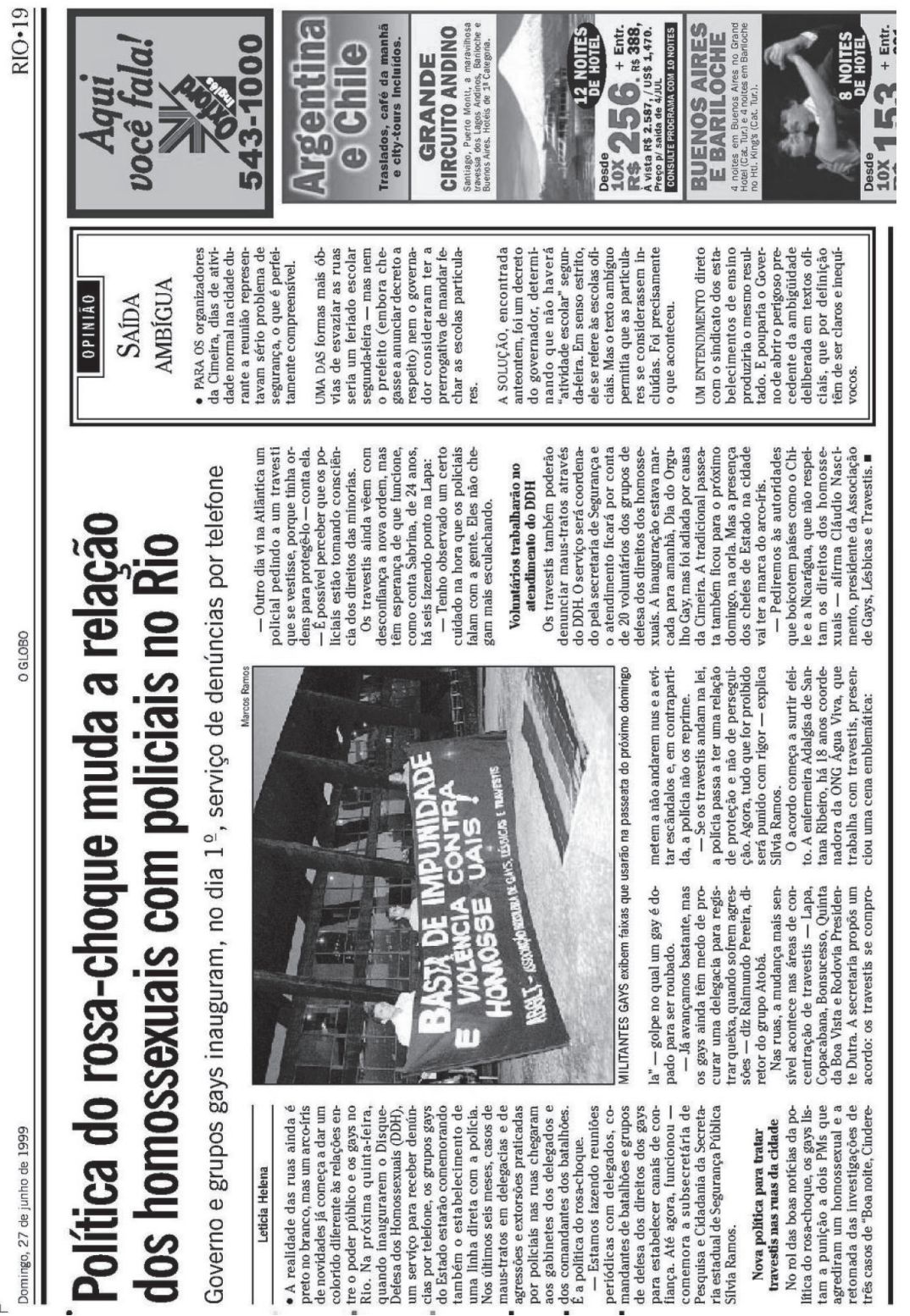
C20

Corregedoria pune dois policiais por preconceito sexual

PMs farão curso de boas maneiras para saber lidar com gays

Leticia Helena

- A discriminação a homossexuais rendeu dez dias de prisâo e um curso de boas maneiras para os PMs Marcos Antônio Brasil Couto e Nílton Rodrigues da Silva, lotados no $13^{\circ}$ BPM (Praça Tiradentes). Na madrugada do último dia 21, os policiais, chamados para socorrer três rapazes atacados por um bêbado, no Parque do Flamengo, agrediram verbalmente as vítimas insinuando que eles estavam ali para práticas homossexuais. Um dos rapazes, o estudante de engenharia química Severino Ramos Dias, procurou a Corregedoria-geral da PM, reconheceu os policiais e conseguiu que eles fossem punidos.

- Essa discriminação nâo pode existir na Polícia Militar, que é paga para proteger os cidadâos, independentemente da condição sexual deles - afirma Severino.

$\mathrm{Na}$ noite do dia 20 , Severino e dois amigos foram a uma feira de náutica na Marina da Glória. $\mathrm{Na}$ volta, foram abordados por um homem, que ofereceu cerveja. Eles tentaram se desvencilhar $\mathbf{e}$, na confusão, o desconhecido agrediu o estudante com uma cabeçada e um chute. Mesmo ferido, Severino deteve o agressor, que acabou sendo liberado pelos PMs. O estudante registrou queixa na $9^{3}$ DP (Catete) e procurou a corregedoria. Segundo o corregedor-geral da PM, Coronel Francisco de Paula Araújo, a puniçáo tem caráter educativo:

- Os policiais farão um treinamento para lidar com esse tipo de situaçâo, sem preconceitos. 


\section{PM assina convênio para iniciar projeto Telessalas $\mathbf{2 0 0 0}$ de educação à distância}

Já na primeira etapa do curso, 600 policiais poderão concluir o ensino médio

- A Polícia Militar do Rio é a primeira do país a ser atendida pelo projeto Telessalas 2000 - de educação à diståncia com aulas de ensino médio. Ontem, o governador Anthony Garotinho e o diretor-geral da Fundaçâo Roberto Marinho, José Roberto Marinho, assinaram convênio que, já na primeira fase, vai dar a chance a 600 PMs de concluir o ensino mé dio, antigo Segundo Grau. De acordo com o governador, mais que uma oportunidade para a ascensâo profissional dos PMs atendidos, a parceria representa um novo passo para a melhoria da segurança pública no estado.

- O policial bem preparadoé a peca-chave da nossa proposta de política de segurança pública eficiente e humana - disse Garotinho.

Nas 20 telessalas instaladas nos quartéis - há aulas em três turnos - os PMs terâo acesso a videos e materiais impressos sobre temas relacionados à sua formaça profissional e de interesse da comunidade, como direitos humanos, educaçâo para o trânsito e educaçâo ambiental. Concluído o ensino médio, os policiais poderão ingressar na Academia de Polícia Dom João VI, de onde saem oficiais.

Experiência poderá ser estendida a outros estados

Na solenidade de assinatura do convênio, no quartel General da Polícia Militar, José Roberto Marinho, destacou que a experiência iniciada ontem na PM do Rio poderá ser estendida à Policia $\mathrm{Cl}$ vil e a outros estados. Ele também destacou que os temas abordados no curso incentivam atitudes de cidadania e a prática solidária, e que a melhoria na qualificaçáo profíssional da PM deve resultar em melhores serviços à populaçâo.

- $O$ sucesso de todos vocês representa a paz e a tranqüilidade de todos nós e de nossas famílias - disse ele.

O secretário nacional de Formaçâo e Desenvolvimento Profissional, Nassim Mehedif também ressaltou que o projeto Telessalas 2000 na PM deve resultar na melhoria da segurança:

Dos 29 mil policiais militares do estado do Rio, cerca de 16.500 nâo têm o segundo grau completo. Cerca de 1.600 policiais se inscreveram para as primeiras 600 vagas das 20 telessalas nos quartéis da PM.

O projeto Telessalas 2000 é desenvolvido através de parceria entre o Ministério do Trabalho e Emprego, a Confederaçâo Nacional da Indústria, a Federaçâo das Indústrias do Estado de Sâo Paulo, o Canal Futura e a Fundaçâo Roberto Marinho.



\section{ONG GAY: Policiais se preparam para atendimento modelo}

- Pela primeira vez, uma platéia de 50 delegados e detetives assiste a uma palestra dada pelo representante de uma ONG de homossexuais, na Academia de Polícia Civil. Uma delegacia com atendimento modelo será inaugurada no
Centro no próximo dia 29. Enquanto Cláudio Nascimento Silva, secretário da Associaçào Brasileira de Gays, Lésbicas e Travestis e presidente do Grupo Arco-Iris falava, um rapaz distribuía panfletos cor-de-rosa na platéia. 


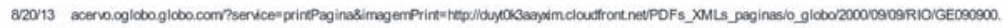

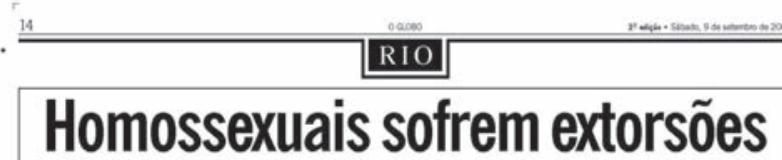

Acusações a policiais representam $12,6 \%$ das queixas no Disque-Defesa dos gays

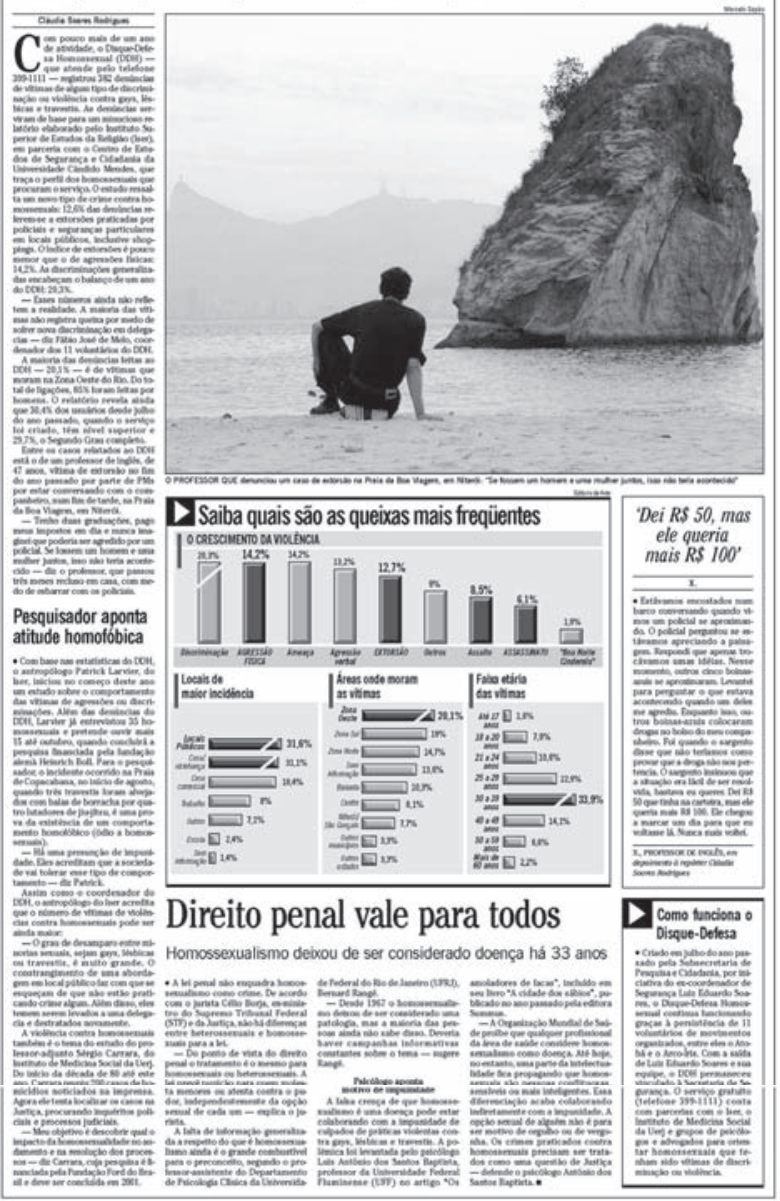




\section{Violência doméstica assusta homossexuais}

Dados do DDH indicam que quase metade das agressóes contra gays é praticada por parentes e até parceiros

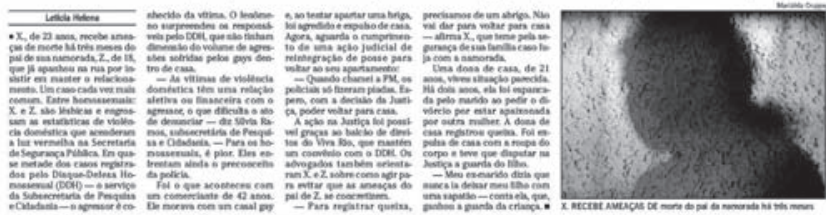

Para náo ter opcăio

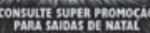

\section{FRETAMENTPS}

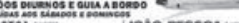

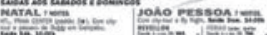
3.97:

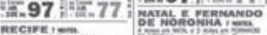

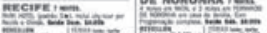
곰.97; :

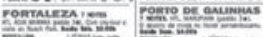
5-97 $12-76$

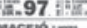

Maceno ;

207 : PORTO SEGURO

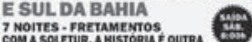
Somente a meilher Ostruterem estruterada

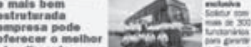

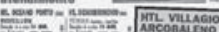
\%-87: 59 :

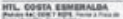

곤 $112:$ :

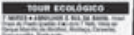
垔 근.118: HOTÉIS RESORT ${ }^{7 \text { homs }}$ Herrs exch man

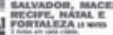

$1=$ 드.

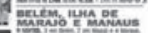
단 368 ! 곤 II $-368 i=160$ i o mruyor go sut

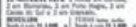
需.194:

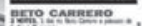
$=\ldots \ldots . . .51$ 整.97: mivnoo = 불 $97=$

\section{$2+2$}

(19)

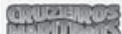

ine

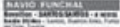

107r

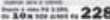

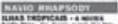
풀 NEW YORK NEW YOW PRomocilo

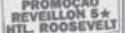
1드로:

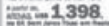
PISNEY PISNEY 2int 2625 cauroremia ini $-1698$ CANADA CANAOA aceitam maus tratos

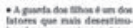

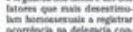

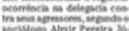

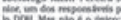

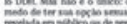

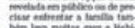
con

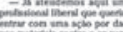

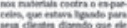

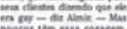

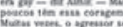

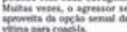
Pan tonta sacole

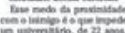

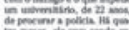

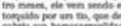

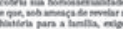
Yon

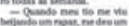


cis temba ile

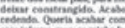

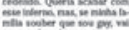

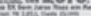

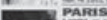

PAras $\frac{x-1255}{2}$ RomA. E. $y=1210$

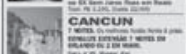
CANCUN $15-2=1330$. B N nuENOS AIRES

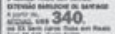
MCOS ANDINOS

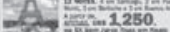

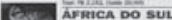
AFracA DO SUL int $=1530$

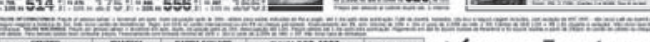

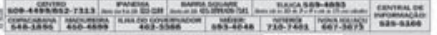

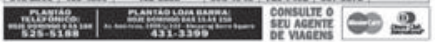




\section{Violência no reduto de defesa do homossexual}

Atendente do DDH é agredido por policial militar no prédio da Secretaria de Segurança Pública e nada é feito

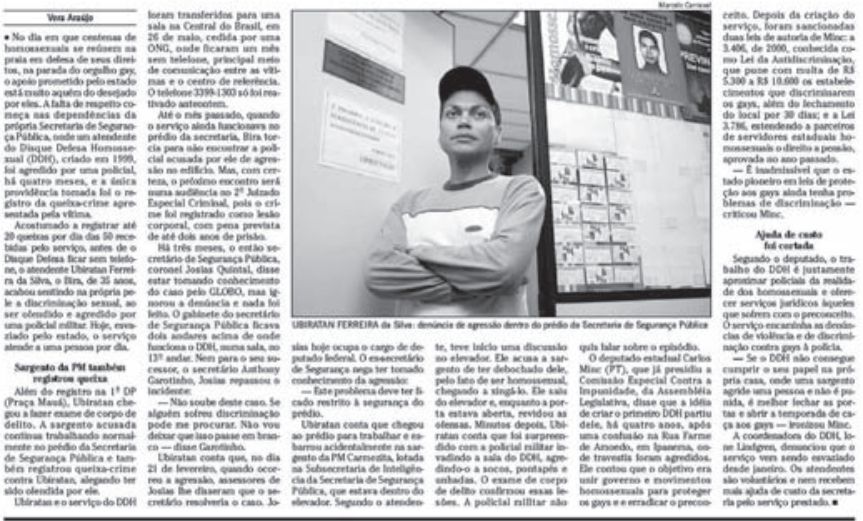

\section{0 baiano que incluiu 0 Rio no mapa das passeatas gays}

A Parada do Orgulho GLBT, hoje, em Copacabana, é a décima marcha comandada por Cláudio Nascimento
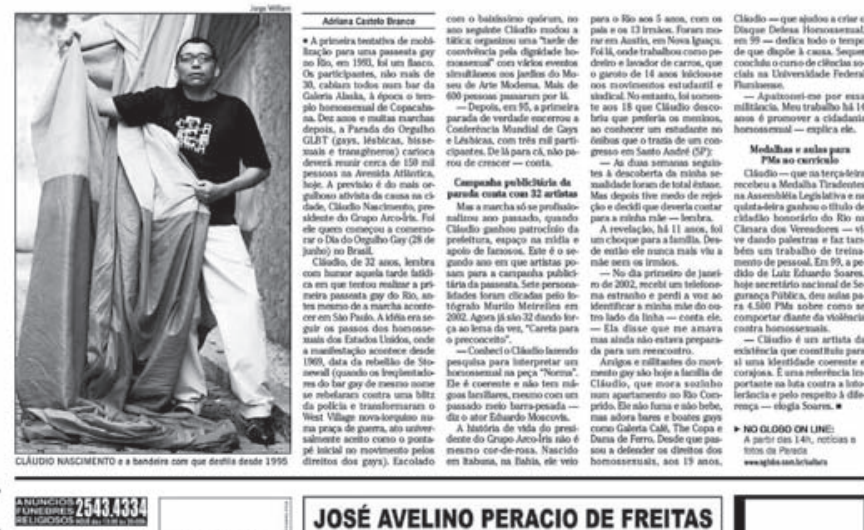

ASSIME SILVA KALIL
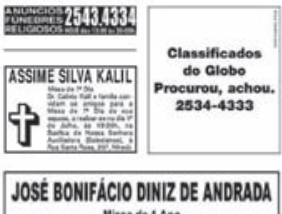
Missa de 1 Ano

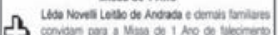

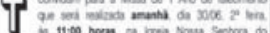

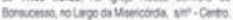
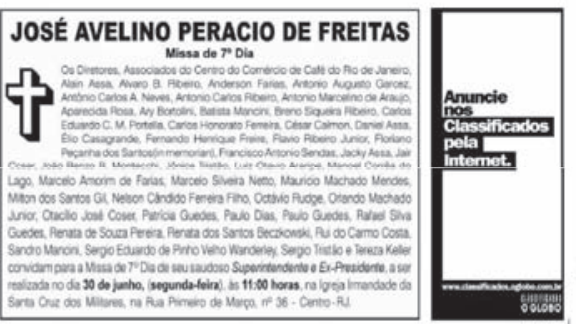
Nota do Grupo Arco-íris e Carta Compromisso 'Por um Rio Sem Homofobia.

\section{Sérgio Cabral assina Carta Compromisso Por um Rio Sem Homofobia}

Hoje, as 15 h, o senador Sérgio Cabral, candidato ao Governo do Estado do Rio de Janeiro se encontrou com representantes de organizações GLBT fluminenses. O encontro aconteceu na Barra da Tijuca na sede do Comitê Central da campanha de Sérgio Cabral.

Estiveram presentes no encontro Claúdio Nascimento, membro do Grupo Arco-Iris de Conscientização Homossexual e secretário de ações para os direitos humanos da ABGLT; Julio Moreira, diretor do Grupo Arco-Iris de Conscientização Homossexual; Marjori Machi, presidenta da Associação de Travestis e Transexuais do Rio; Katia Jones, diretora da Associação de Travestis e Transexuais do Rio; Vera Couto, diretora do Movimento Dellas e da equipe Técnica do Centro de Referência contra a Discriminção a Homossexuais do Estado do Rio, Renato Marques, presidente do Grupo Diversidade Niterói; Victor de Wolf, diretor do Grupo Diversidade Niterói; e Rosangela Castro, coordenadora do Grupo Felipa de Souza. Também participaram da reunião a deputada estadual Cida Diogo e o deputado estadual Carlos Minc, que articulou o encontro.

Houve dois momentos do encontro com o Senador Sérgio Cabral, o primeiro com os representantes do movimento GLBT e os parlamentares presentes e depois uma coletiva com a imprensa com o candidato, os representantes do Movimento GLBT do Rio e os parlamentares. Todos os principais órgãos de imprensa estiveram presentes: TV, Rádio, Jornais, Revistas, Sites e correspondentes internacionais.

No primeiro momento, o senador Sérgio Cabral falou do seu compromisso com os direitos humanos e com a causa dos direitos de GLBT, 
inclusive citando uma série de participações na ALERJ e no Senado. Explicou que o projeto de emenda constitucional de no. 70 - que propõe o reconhecimento do casamento entre pessoas do mesmo sexo - não havia conseguido adesões, inclusive do próprio Movimento Orgnaizado GLBT. Destacou que o movimento GLBT reivindica a legalização da união civil entre pessoas do mesmo sexo e não casamento. Cabral informou que o projeto não obteve parecer elaborado durante os quase três anos de tramitação no Senado e que ele apoiava a união civil entre pessoas do mesmo sexo. Falou ainda que o casamento é uma instituição religiosa e que isso não é parte da própria pauta do movimento GLBT. Admitiu que o senador Crivela fez o pedido pela retirada do projeto. Disse que já antes das eleiçôes havia pensado em retirá-lo, mas que não quis fazê-lo para não configurar como um abandono de bandeira que sempre defendeu. Destacou que de forma alguma permitirá em seu governo uma intromissão de outrem. Disse que um representante de sua campanha, já no primeiro turno, havia assinado a Carta Compromisso Por Um Rio Sem Homofobia e que naquele momento gostaria de ratificar o compromisso com a comunidade GLBT do Rio ao anunciar, explicar e assinar publicamente a Carta Compromisso.

O ativista Cláudio Nascimento, do Grupo Arco-Iris, foi escolhido pelos Grupos GLBT presentes como interlocutor no encontro. Nascimento disse que os ativistas ali presentes reconheciam a trajetória política do senador nas questóes de direitos humanos, especialmente os direitos de GLBT. A atuação de Cabral, quando ainda era deputado estadual e presidente da ALERJ, foi fundamental para a aprovação da Lei 3406 de 2000 - de autoria do deputado Carlos Minc, que proíbe a discriminação por orientação sexual no estado do Rio - articulando com parlamentares apoio a lei. Também quando da votação do projeto de lei 3786 de 2001 - sendo co-autor com o deputado Carlos Minc que assegura o direito a pensão a companheiros do mesmo sexo de servidores públicos estaduais - saiu da cadeira da presidência da ALERJ e foi para o plenário defender o projeto. A lei já em vigor não é cumprida pelo atual Governo. Citou outros momentos da trajetória 
do senador ligados ao tema, como por exemplo, a articulação junto com o Carlos Minc e o Grupo Arco-Iris para a derrubada do projeto de lei do deputado-pastor Edno Fonseca, que propunha a criação de programas, com recursos públicos, para mudança da orientação sexual de homossexual para heterossexual. Nascimento reconheceu que o PEC 70 não havia recebido a adesão do Movimento Organizado de GLBT e que ele não era parte da sua prioridade legislativa. Entretanto destacou que a retirada da PEC 70 num momento político eleitoral polarizado como esse, representou simbolicamante um aceno ao fundamentalismo religioso e um abandono das bandeiras por ele defendidas. Ressaltou porém, que gostaria de ver afirmada no candidato outra posição, a dos direitos humanos e a da defesa do princípio constitucional do laicidade do Estado. Nascimento destacou que o candidato precisava fazer um pronunciamento público reafirmando seu comprometimento e assumindo uma plataforma concreta para a cidadania de gays, lésbicas, travestis, transexuais e bissexuais do Rio.

$\mathrm{Na}$ sala com a imprensa foram ratificadas posições das partes, sendo feita uma declaração conjunta do candidato e de ativista do Grupo Arco-Iris Claúdio Nascimento. O candidato apresentou e explicou cada proposta de políticas públicas que assume junto ao Movimento Organizado de GLBT do Rio, caso seja eleito. Depois disso, o candidato ratificou com a sua assinatura a Carta Compromisso Por Um Rio Sem Homofobia. Cláudio Nascimento o presenteou com uma bandeira do arco-iris, símbolo mundial do Movimento GLBT.

Segue abaixo a Carta Compromisso por um Rio Sem Homofobia.

Grupo Arco-Iris de Conscientização Homossexual Informaçôes: 021 - 2208-2799 e 2238-8292

021-8192-5232 (Cláudio Nascimento)

Fonte: http://www.claudionascimento.blogspot.com.br/2006/10/ nota-do-grupo-arco-iris-em-10.html\#linksNota do Grupo Arco -Iris, em 10.10.2006 


\section{Compromissos por um Rio Sem Homofobia}

Na qualidade de candidato ao Governo do Estado do Rio de Janeiro acompanho com preocupaçáo a questáo do preconceito, da discriminaçáo contra o segmento de gays, lésbicas, travestis, transexuais e bissexuais(GLTB) em nosso Estado e reconheço a necessidade de implementaçáo de políticas para o combate a homofobia e promoçáo da cidadania de GLTB.

Sendo assim, caso seja eleito, Governador do Estado do Rio de Janeiro, assumirei o compromisso em incorporar, nas realizaçóes do governo, o seguinte:

1 - Apresentar, nos primeiros dois meses de governo, um plano detalhado para a aplicação da lei 3406 de 2000, com (A) capacitação do pessoal da área de fiscalização; (B) divulgação da lei; (C) criação da Coordenadoria de Defesa, Promoção e Garantia de Direitos de GLBT na Secretaria Estadual de Direitos Humanos para sua aplicação; (D) criação do fundo contra a violência, para acolher os valores advindos das multas cobradas aos estabelecimentos penalizados, com a devida participação da sociedade civil no acompanhamento da aplicação desses recursos em ações especificas. Todos esses itens foram definidos na regulamentação e até hoje não foram cumpridos.

2 - Conceder imediatamente todos os pedidos de pensão para companheiros do mesmo sexo de funcionários públicos estaduais cuja união for devidamente comprovada conforme prevê a lei 3786 de 2001. Hoje são mais de 50 pedidos de pensão que se encontram engavetados no Instituto de Previdência do Estado do Rio de Janeiro por preconceito e discriminação.

3 - Criar até o quarto mês de governo o Programa Rio Sem Homofobia, ações governamentais de combate a discriminação contra GLBT e promoção de sua cidadania, na diversas pastas do Executivo. Para isso criará no primeiro mês de trabalho uma Comissão Técnica para Elaboração do Programa, com a participação de entidades de 
defesa dos direitos GLBT. O Governo dotará o Programa de verbas para a implementação de ações nos municípios do Estado e no apoio as iniciativas das organizaçôes GLBT.

4- Incluir nos primeiros quatro meses o Centro de Referência contra a discriminação a Homossexuais do Estado do Rio e o Disque Defesa Homossexual na estrutura formal da Secretaria de Segurança Pública. O Centro deverá ser dotado de recursos humanos e financeiros para o efetivo cumprimento de suas funções de acolher, registrar, encaminhar e acompanhar os casos de violência contra GLBT nas delegacias de polícia e outros agentes de policia civil e militar. Isto tem o objetivo de resultar na efetiva investigação do caso e na melhoria do atendimento, visto que, na maioria das vezes, a vítima quando assume a sua orientação sexual ou relata a situação que visibiliza a sua sexualidade, há um total descaso ou mal atendimento, colaborando com a manutenção do ciclo de impunidade. Criado em 1999, o Centro de Referência hoje é mantido principalmente com o esforço de voluntários.

5- Criar na Polícia Civil o Núcleo de Investigação Especializada para crimes envolvendo a violência por discriminação racial, identidade de gênero e orientação sexual, com inspetores e delegados que já vem atuando no tema de segurança pública e violência contra GLBT. Essa medida possibilitará uma apuração adequada e efetiva, além de contribuir para a formação de dados sobre os tipos de violência e possíveis semelhanças nas investigaçôes.

6- Fortalecer a Assessoria Estadual de DST-Aids e Hepatites, com verbas do Estado para medicamentos, exames, camisinhas, gel lubrificante, pesquisas, prevenção e assistência. Com os recursos cada vez mais escassos, oriundos do Banco Mundial, o Estado do Rio de Janeiro precisa dotar-se de uma política responsável com a saúde pública, já que vem apresentando altos índices epidemiológicos em DST, Hiv/Aids e Hepatites. Investir em prevenção das DST, Hiv/Aids e assistência às pessoas com doenças Hiv/Aids e/ou Hepatites contribui 
para a economia dos recursos em saúde pública, especialmente nos gastos hospitalares.

7- Manter e fortalecer a Secretaria Estadual de Direitos Humanos como uma pasta de atuação transversal a todas as outras, garantindo o recorte de direitos humanos em todas as políticas governamentais. Para isso, será necessário dotá-la de orçamento adequado para que consiga cumprir suas funções no campo da prevenção, educação, correção e atenção.

8- Defender e garantir o princípio republicano da laicidade do Estado em todas as áreas de governo. Para isso o governo promoverá valores de respeito aos direitos humanos e e que combata, com ações efetivas e de caráter contínuo, a homofobia, o racismo, a discriminação de gênero, deficiência física e estado de saúde, além de afirmar a pluralidade cultural e religiosa de nosso povo.

9- Reconhecer e promover a participação de representantes de organizações GLBT nos espaços de formulação, acompanhamento e avaliação de políticas públicas, como nos Conselhos de Educação, de Cultura, Segurança Pública, Direitos da Mulher, Direitos Humanos e Juventude.

10 - Reconhecer o caráter cívico, cultural, educativo, cidadão, de reivindicação por direitos de GLBT, garantindo e apoiando a realização das Paradas do Orgulho GLBT do Estado do Rio Janeiro e demais manifestaçôes e açôes que promovam uma cultura de paz, de combate a homofobia e de celebração da diversidade sexual.

Rio de Janeiro, 10 de Outubro de 2006.

Sérgio Cabral Filho

Candidato ao Governo do Estado do Rio de Janeiro

PMDB - 15 Coligação 


\title{
O GLOBO
}

\section{Cabral participa de reunião com grupos gays}

\begin{abstract}
Ludimilla de Lima - O Globo
RIO - Depois da polêmica atitude de retirar do Senado o projeto que legalizava a uniâo civil de homossexuais, o candidato a governador Sérgio Cabral (PMDB) recebeu nesta terça-feira o apoio de movimentos de GLTB (gays lésbicas, travestis, transexuais e bissexuais). Integrantes da comunidade, que protestaram contra a açăo do candidato no Congresso, foram ao comitê da campanha de Cabral, que lá assinou documento com dez compromissos para o segmento. Entre eles, a concessão de pensōes a companheiros do mesmo sexo de servidores públicos estaduais, que já é previsto em lei mas nẵo é cumprido.
\end{abstract}

O ato público apagou um incêndio iniciado semana passada, com o acordo que garantiu o apoio do candidato derrotado Marcelo Crivella (PRB), bispo licenciado da Igreja Universal, à sua campanha. Em troca da aliança com o senador evangélico, Cabral tirou de tramitaçăo o projeto de emenda à Constituiçăo de sua autoria.

- O movimento tem um posicionamento contrário ao projeto; o que a gente reivindica è a questăo da união civil entre pessoas do mesmo sexo. No entanto, nós ponderamos com Cabral que esse evento (a retirada da PEC) ocorrer num segundo turno poderia parecer uma moeda de troca, um aceno ao fundamentalismo religioso disse o coordenador de articulaçăo politica do grupo Arco-lris, Cláudio Nascimento.

Cabral justificou a retirada dizendo que o projeto năo era adequado por incluir um capitulo denominado casamento. E que, por isso, atendeu a uma "ponderaçăo" do senador Crivella.

- O senador Crivella sabe sobre o meu posicionamento - disse Cabral, que se reuniu antes com a bancada do PT.

Enquanto Cabral conversava com representantes de GLTB, o deputado estadual Edino Fonseca (Prona), pastor evangélico, esperava para ser atendido pelo candidato.Ele, que apóia Cabral, é autor da proposta chamada de Tei para curar gays".

URL: http:/glo.bo/10EGJlx

Noticia publicada em 10/10/06 - 0h00 | Atualizada em 24/05/12 - 15h00 | Impressa em 14/05/13 - 01h10 


\section{Governo concede pensão a parceiros de servidores gays}

Foram quatro os beneficiados na solenidade desta terça (28).

Proxima medida deve punir estabelecimentos que discriminem gays.

Do Gt $\approx$ RDo

Dente ind contule

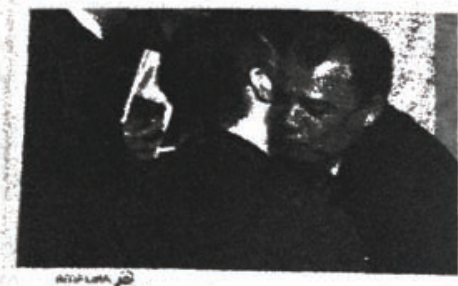

ansum is

O govemador Sergio Cabral cumprimenta um militante do movimento GLBT (Foto. Rafael Andrade Folha (magem)
O governador Sérgio Cabral concedeu, nesta terça-feira (28), em solenidade no Palácio Guanabara, as primeiras quatro pensōes a parceiros de servidores públicos homossexuais Os beneficiados pela Lei 5034/07, sancionada por Cabral no dia 31 de maio, foram Carlo Mascheroni, Cássia Florizia, Edgard Gabriel Filho e Toni Garrido Ferreira.

\section{Segundo o governador, a lei é} uma demonstraçăo do respeito à cidadania dos homossexuais. Durante a cerimónia, ele ressaltou a parceria com o secretário estadual de Ambiente. Carlos Minc, na luta pela defesa dos direitos civis

dos homossexuais, iniciada na Assembléia Legislativa do Rio.

Minc declarou na solenidade que a próxima iniciativa será buscar a puniçāo de estabelecimentos que discriminem os homossexuais e também as autoridades que se omitam nesses casos.

O representante da secretaria de Assistência e Direitos Humanos, Cláudio Nascimento, também militante do movimento GLBT (Gays, Lésbicas, Bissexuais e Transgêneros), informou que a nova lei beneficiara mais de 30 mil servidores estaduais e seus companheiros.

\section{Saiba mais}

- OAB apoia a luta de gays e lésbicas

URL- http://g1.globo.com/Noticias/Rio/0..MUL95092-5606,00.html 


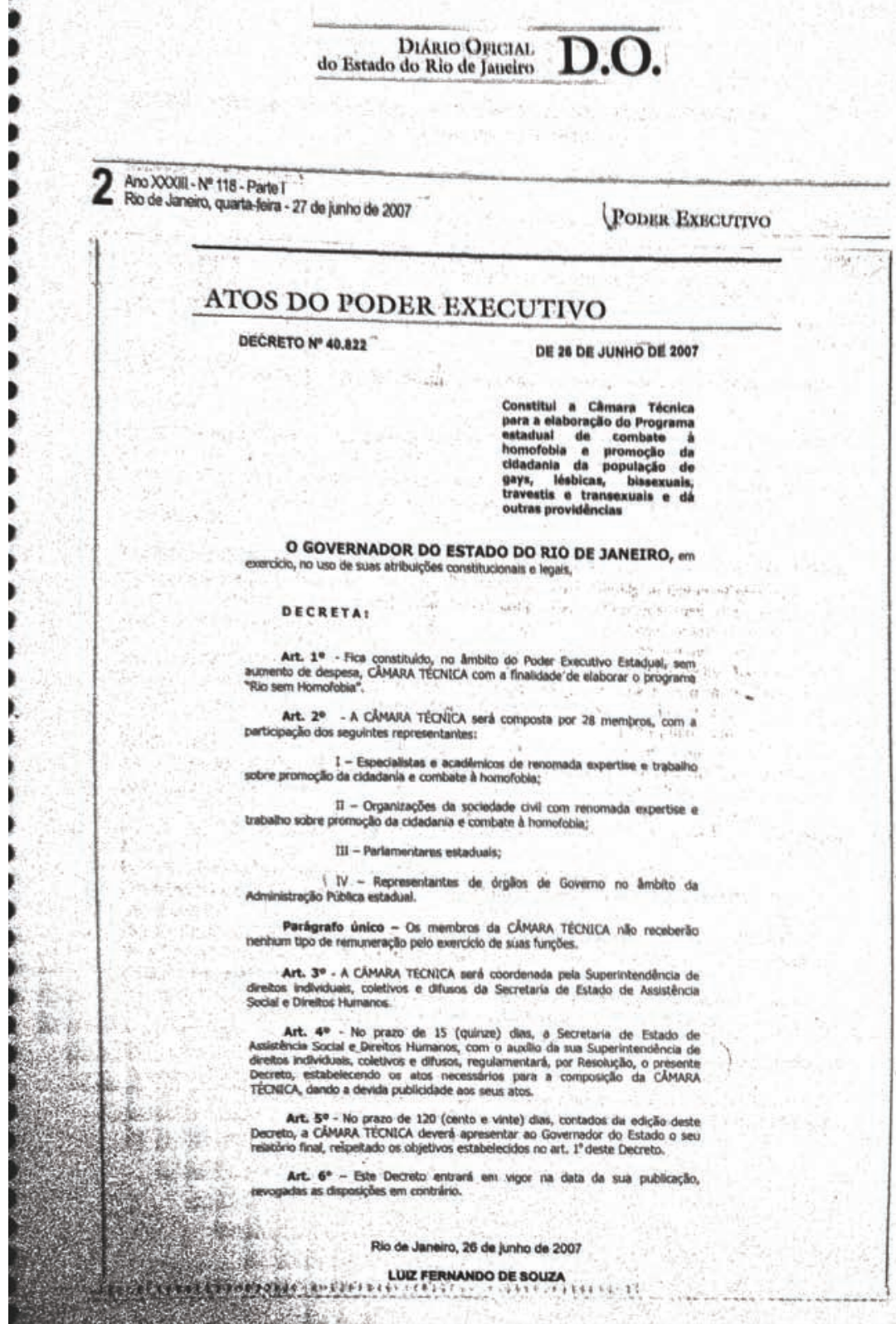




\section{DECRETO N 41.798 DE 02 DE ABRIL DE 2009}

CRIA O CONSELHO DOS DIREITOS DA POPULAÇĀO DE LÉSBICAS, GAYS, BISSEXUAIS, TRAVESTIS E TRANSEXUAIS DO ESTADO DO RIO DE JANEIRO E DÁ OUTRAS PROVIDÊNCIAS.

O GOVERNADOR DO ESTADO DO RIO DE JANEIRO, no uso de suas atribuiçōes constitucionais e legais, e tendo em vista as Resoluçōes da I Conferência Estadual de Politicas Públicas para GLBT do Rio de Janeiro, conforme Decreto $n^{\circ}$ 41.196, de 28 de fevereiro de 2008, e da Câmara Técnica para Elaboração do Programa Rio Sem Homofobia, na forma do Decreto $n^{\circ} 40.822$, de 26 de junho de 2007 , e o constante do Processo $n^{\circ} E-23 / 1344 / 2008$,

\section{DECRETA:}

Art. $1^{\circ}$ - Fica criado o CONSELHO DOS DIREITOS DA POPULAÇÄO DE LÉSBICAS, GAYS, BISSEXUAIS, TRAVESTIS E TRANSEXUAIS DO ESTADO DO RIO DE JANEIRO (CONSELHO LGBT - RJ), no âmbito do Poder Executivo Estadual, vinculado à Secretaria de Estado de Assistência Social e Direitos Humanos do Rio de Janeiro, coordenado pela Superintendência de Direitos Individuais, Coletivos e Difusos, de caráter deliberativo, com a finalidade de elaborar, acompanhar, monitorar, fiscalizar e avaliar a execuçăo de politicas públicas para lésbicas, gays, bissexuais, travestis e transexuais (LGBT) destinadas a assegurar a essa populaçăo o pleno exercicio de sua cidadania.

Art. $2^{\circ}$ - O CONSELHO DOS DIREITOS DA POPULAÇÃO DE LÉSBICAS, GAYS, BISSEXUAIS, TRAVESTIS E TRANSEXUAIS DO ESTADO DO RIO DE JANEIRO (CONSELHO LGBT - RIO), terá as seguintes competências:

I - desenvolver açăo integrada e articulada com o conjunto de Secretariais e demais órgăos públicos, visando a implementaçăo de politicas públicas comprometidas com a superaçăo das discriminaçŏes e desigualdades, devido à orientaçăo sexual e à identidade de gênero;

II - articular e definir politicas públicas de promoçăo da igualdade de oportunidades e de direitos para a populaçăo LGBT:

III - prestar assessoria ao Poder Executivo, emitindo pareceres, acompanhando, monitorando, fiscalizando e avaliando a elaboração e execução de programas de governo no âmbito estadual, bem como opinar sobre as questões referentes à cidadania da população LGBT;

IV - estimular, apoiar e desenvolver o estudo e o debate das condiçōes em que vive a população LGBT urbana e rural, propondo politicas públicas, objetivando eliminar todas as formas identificáveis de discriminaçăo:

V - propor e estimular politicas transversais de inserção educacional e cultural, com o objetivo de preservar e divulgar o Patrimōnio Histórico e Cultural da Populaçăo LGBT;

VI - fiscalizar e exigir o cumprimento da legislaçăo em vigor no que for pertinente aos direitos assegurados à populaçăo LGBT:

VII - propor e adotar medidas normativas para modificar ou derrogar leis, regulamentos, usos e práticas que constituam discriminações contra lésbicas, gays, bissexuais, travestis e transexuais:

VIII - propor e adotar providência legislativa que vise eliminar a discriminação por orientaçāo sexual e identidade de gênero, encaminhando-a ao poder público competente:

IX - propor e adotar intercâmbio e convênios ou outras formas de parceria com organismos nacionais e internacionais, públicos ou privados, com a finalidade de viabilizar ou ampliar as açóes e metas estabelecidas pelo CONSELHO LGBT - RJ;

X - manter canais permanentes de diálogo e de articulação com o movimento LGBT - a serem definidos pelo seu Regimento Interno - em suas várias expressōes, apoiando suas atividades, sem interferir em seu conteúdo e orientaçăo própria;

XI - receber, examinar e efetuar denúncias que envolvam fatos e episódios discriminatórios contra lésbias, gays. bissexuais, travestis e transexuais, encaminhando-as aos órgåos competentes para as providências cabiveis além de acompanhar e monitorar os procedimentos pertinentes.

Art. $3^{\circ}$ - A estrutura do CONSELHO DOS DIREITOS DA POPULAÇÃO DE LÉSBICAS, GAYS, BISSEXUAIS, TRAVESTIS E TRANSEXUAIS DO ESTADO DO RIO DE JANEIRO (CONSELHO LGBT - RJ), compor-se-á dos meios necessários para o exercicio de suas atribuiçōes de será definida por Resolução da Secretaria de Estado de Assistência Social e Direitos Humanos e regulamentada pelo Regimento Interno do CONSELHO LGBT - RJ. 
Art. $4^{\circ}$ - O CONSELHO LGBT - RJ será composto por 40 (quarenta) integrantes, sendo $60 \%$ da sociedade civil e $40 \%$ do poder público com mandato de 02 (dois) anos, com a possibilidade de recondução por mais 02 (dois) anos, sendo:

I-Secretaria de Estado da Casa Civil - CASA CIVIL (01 representante);

II - Secretaria de Estado de Governo - SEGOV (01 representante);

III - Secretaria de Estado de Planejamento e Gestão - SEPLAG (01 representante);

IV - Secretaria de Estado de Assistência Social e Direitos Humanos - SEASDH (01 representante);

V-Secretaria de Estado de Segurança - SESEC (01 representante);

VI - Secretaria de Estado de Administração Penitenciária - SEAP (01 representante);

VII - Secretaria de Estado de Saúde e Defesa Civil - SESDEC (01 representante);

VIII - Secretaria de Estado de Educação - SEEDUC (01 representante);

IX - Secretaria de Estado do Ambiente - SEA (01 representante);

X-Secretaria de Estado de Trabalho e Renda - SETRAB (01 representante):

XI - Secretaria de Estado de Cultura - SEC (01 representante);

XII - Secretaria de Estado de Turismo, Esporte e Lazer - SETE (01 representante);

XIII - Assembléia Legislativa - ALERJ (01 representante);

XIV - Ministério Público Estadual - MPE (01 representante);

XV - Defensoria Pública Geral do Estado do Rio de Janeiro - DPGE (01 representante);

XVI - Ordem dos Advogados do Brasil - OAB-RJ (01 representante);

XVII - Organizaçōes LGBT, registradas, sediadas e em funcionamento no Estado do Rio de Janeiro (18 representantes).

XVIII - Organização de Direitos Humanos, registradas, sediadas e em funcionamento no Estado do Rio de Janeiro e que contemplem em seu programa e/ou missão a defesa dos direitos civis e da promoção da cidadania de homens e mulheres independentes da orientação sexual e identidade de gênero ( 03 representantes)

XIX - Especialistas e acadêmicos de renomada expertise e trabalho sobre promoçăo da cidadania LGBT e combate à homofobia (03 representantes)

$\S 1^{\circ}$ - Os (as) Conselheiros (as) da sociedade civil serão escolhidos por fórum próprio e depois encaminhados para a nomeação por Resolução a ser publicada pela Secretaria de Estado de Assistência Social e Direitos Humanos no prazo de 30 (trinta) dias a contar da data da publicação deste decreto;

$\S 2^{\circ}$ - As funçōes de membro do CONSELHO LGBT - RJ serão consideradas como serviço público relevante e por isto não serão remuneradas.

Art. $5^{\circ}$ - A nomeação do (a) Presidente (a) do CONSELHO LGBT - RJ, observadas as indicações do Conselho Estadual da População LGBT, será ratificada pelo Governador por meio de Decreto.

Art. $6^{\circ}$ - O CONSELHO LGBT - RJ poderá solicitar ao Governador do Estado que sejam colocados à sua disposição servidores públicos estaduais necessários para 0 atendimento de suas finalidades.

Art. $7^{\circ}$ - Este Decreto entrará em vigor na data de sua publicação, revogadas as disposições em contrário.

Rio de Janeiro, 02 de abril de 2009

SÉRGIO CABRAL 
C31

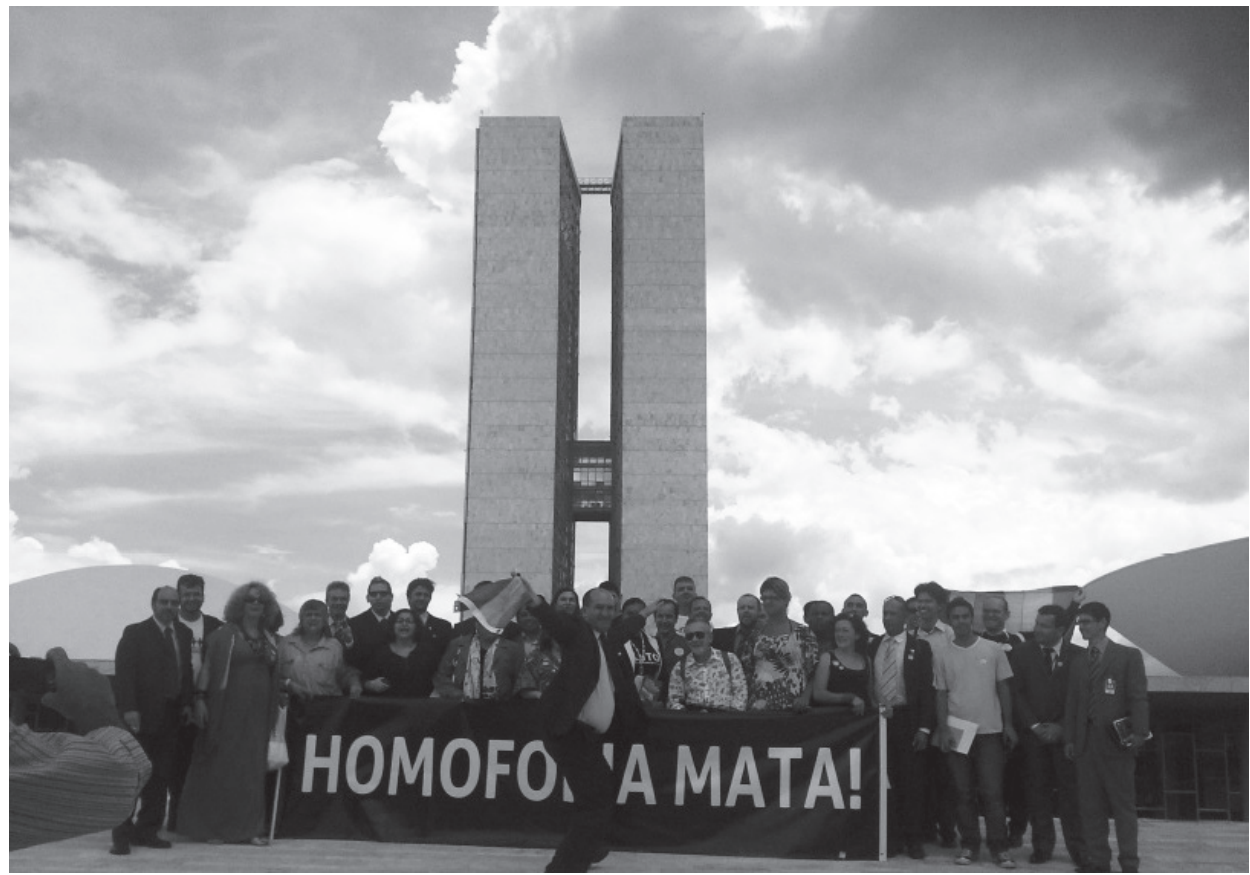

Foto: Silvia Aguião 


\section{SOBRE A AUTORA}

Silvia Aguiāo é graduada em Ciências Sociais pela Universidade do Estado do Rio de janeiro. Realizou o mestrado em Saúde Coletiva no Instituto de Medicina Social da Universidade do Estado do Rio de Janeiro, o doutorado em Ciências Sociais pela Universidade Estadual de Campinas e o pós-doutorado no Centro Brasileiro de Análise e Planejamento (CEBRAP). Desenvolve estudos e pesquisas na área de Antropologia, trabalhando a partir de uma perspectiva insterseccional com temas como sexualidade, gênero e raça em suas interfaces com sociabilidade, políticas e direitos, movimentos sociais e processos de Estado. 
Conheça os demais títulos da Coleção Sexualidade, Gênero e Sociedade publicados pela Editora Garamond:

\author{
Sexualidade e Gênero nas Ciências Sociais \\ A mulher no corpo: uma análise cultural da reprodução \\ Emily Martin \\ Uma interpretaçâo do desejo: ensaios sobre o estudo da sexualidade \\ John Gagnon
}

\title{
Homossexualidade e Cultura
}

Prazeres dissidentes

Maria Elvira Díaz-Benítez e Carlos Eduardo Fígari (orgs.)

O Rei Momo e o arco-íris: homossexualidade e carnaval no Rio de Janeiro

Fabiano Gontijo

Homossexualidade e adoção

Anna Paula Uziel

Conjugalidades, parentalidades e identidades lésbicas, gays e travestis

Miriam Grossi, Anna Paula Uziel e Luiz Mello (orgs.)

A reinvenção do corpo: sexualidade e gênero na experiência transexual

Berenice Bento

Toda feita: o corpo e o gênero das travestis

Marcos Benedetti

Novas famílias: conjugalidade homossexual no Brasil contemporâneo

Luiz Mello

Sopa de letrinhas? Movimento homossexual e produção de identidades coletivas nos anos 90

Regina Facchini

O homossexual visto por entendidos

Carmen Dora Guimarães

Dois é par: gênero e identidade sexual em contexto igualitário

Maria Luiza Heilborn 


\section{Sexualidade em Debate}

Sexualidade, familia e ethos religioso

Maria Luiza Heilborn, Luiz Fernando Dias Duarte, Clarice Peixoto e Myriam Lins de Barros (orgs.)

Novas legalidades e democratização da vida social: família, sexualidade e aborto Maria Betânia Ávila, Ana Paula Portella e Verônica Ferreira (orgs.)

Movimentos sociais, educação e sexualidades

Miriam Pillar Grossi, Simone Becker, Juliana Cavilha M. Losso, Rozeli Maria Porto e Rita F. Muller (orgs.)

Religiäo e sexualidade: conviç̧óes e responsabilidades

Emerson Giumbelli (org.)

Sexualidades e saberes: convençôes e fronteiras

Adriana Piscitelli, Maria Filomena Gregori e Sérgio Carrara (orgs.)

\section{Pela EdUERJ:}

\section{Sexualidades e Cultura}

A transexualidade no tribunal: saúde e cidadania

Miriam Ventura

Gays, lésbicas, transgenders: o caminho do arco-íris na cultura norte-americana Eliane Borges Berutti

Entre mulheres: etnografia sobre relaçōes homoeróticas femininas em segmentos médios urbanos na cidade de Porto Alegre

Nádia Elisa Meinerz

Consumindo lugares, consumindo nos lugares: homossexualidade, consumo e subjetividades na cidade de São Paulo

Isadora Lins França

Devir puta: políticas da prostituição na experiência de quatro mulheres militantes José Miguel Nieto Olivar

Trânsitos: brasileiras nos mercados transnacionais do sexo

Adriana Piscitelli

Sexualidade adolescente como direito? A visäo de formuladores de políticas públicas Vanessa Jorge Leite

Parentesco, Tecnologia e Lei na Era do DNA

Claudia Fonseca 
O monstro contemporâneo: a construção social da pedofilia em múltiplos planos Laura Lowenkron

\section{Sexualidade em Debate}

Feminilidades: corpo e sexualidades em debate

Anna Paula Uziel, Aureliano Lopes da Silva Junior, Daniele Andrade, Jimena de Garay Hernandez (orgs.) 